\title{
Beroepscodes : morele kanttekeningen bij een professionaliseringsaspect van de verpleging
}

Citation for published version (APA):

van der Arend, A. J. G. (1992). Beroepscodes : morele kanttekeningen bij een professionaliseringsaspect van de verpleging. [Doctoral Thesis, Maastricht University]. Datawyse.

https://doi.org/10.26481/dis.19920925av

Document status and date:

Published: 01/01/1992

DOI:

10.26481/dis.19920925av

Document Version:

Publisher's PDF, also known as Version of record

\section{Please check the document version of this publication:}

- A submitted manuscript is the version of the article upon submission and before peer-review. There can be important differences between the submitted version and the official published version of record.

People interested in the research are advised to contact the author for the final version of the publication, or visit the DOI to the publisher's website.

- The final author version and the galley proof are versions of the publication after peer review.

- The final published version features the final layout of the paper including the volume, issue and page numbers.

Link to publication

\footnotetext{
General rights rights.

- You may freely distribute the URL identifying the publication in the public portal. please follow below link for the End User Agreement:

www.umlib.nl/taverne-license

Take down policy

If you believe that this document breaches copyright please contact us at:

repository@maastrichtuniversity.nl

providing details and we will investigate your claim.
}

Copyright and moral rights for the publications made accessible in the public portal are retained by the authors and/or other copyright owners and it is a condition of accessing publications that users recognise and abide by the legal requirements associated with these

- Users may download and print one copy of any publication from the public portal for the purpose of private study or research.

- You may not further distribute the material or use it for any profit-making activity or commercial gain

If the publication is distributed under the terms of Article $25 \mathrm{fa}$ of the Dutch Copyright Act, indicated by the "Taverne" license above, 


\section{BEROEPSCODES}

morele kanttekeningen bij een professionaliseringsaspect van de verpleging 


\title{
Beroepscodes
}

\section{Morele kanttekeningen bij een professionaliseringsaspect van de verpleging}

\author{
PROEFSCHRIFT \\ ter verkrijging van de graad van doctor \\ aan de Rijksuniversiteit Limburg te Maastricht, \\ op gezag van de Rector Magnificus, Prof.Mr. M.J. Cohen, \\ volgens het besluit van het College van Dekanen, \\ in het openbaar te verdedigen \\ op vrijdag 25 september 1992 om 16.00 uur
}

door

Adrianus Jacobus Gerardus van der Arend geboren te Monster in 1950 


\section{Promotores}

Prof.Dr. P.J. Thung

Prof.Dr. H. Philipsen

\section{Beoordelingscommissie}

Prof.Mr. F.C.B. yan Wijmen (voorzitter)

Prof.Dr. H.A.M.J. ten Have (Katholieke Universiteit Nijmegen)

Prof.Dr. H. Huijer-Abu Saad

Prof.Dr. E. Schroten (Rijksuniversiteit Utrecht)

Dr. F.C.J. Stevens

1992 A.J.G. wam der Arend, Ulestraten

Produktie: Datawyse, Maastricht

Druk: Krips Repro, Meppel

Nicts uit deze uitgave mag worden verveelwoudigd en/of openbaar gemaakt door middel van druk, microIillm, fotokopie of op welke andere wijze ook zonder voorafgaande schriftelijke toestemming van de auteur. 


\section{WOORD VOORAF}

De plannen voor deze studie werden reeds lang geleden gesmeed. Het onderwerp leende zich goed voor een uitwerking vanuit mijn interessen en kwalificaties op het terrein van de ethiek en de verpleegkunde. Een neiging om voortdurend "ja" te zeggen tegen de vele interessante verzoeken uit de universitaire gemeenschap voor bijdragen aan met name het onderwijs in de Faculteit der Gezondheidswetenschappen heeft arbeidsvreugde gegeven, doch daarnaast ook telkenmale roet in het eten gegooid. Ook persoonlijke omstandigheden en activiteiten in het kader van de vakgroep zijn daar debet aan geweest.

Het is de verdienste van beide promotores dat zij mij aan de zuigkracht van andere activiteiten hebben weten te onttrekken en op het spoor gezet van het resultaat dat nu voor $U$ ligt. Beiden zijn in woord en geschrift een blijvende inspiratie. Professor Thung ben ik bijzondere dank verschuldigd voor het feit, dat hij met de beperkte tijd die hij voor de vakgroep beschikbaar had, destijds het initiatief nam om de begeleiding van mijn verdere wetenschappelijke ontwikkeling op zich te nemen. Ik heb de reis naar Leiden altijd met plezier gemaakt, in het vooruitzicht van opbouwende kritiek, serieuze discussies en een altijd goede ontvangst. Professor Philipsen heeft mijn worsteling met de materie allereerst begeleid doordat ik een discussie aanging met zijn publikaties, waaraan ik vruchtbare opvattingen en argumenten mocht ontlenen. In de persoonlijke contacten heeft hij me erwoor behoed van dit proefschrift een levenswerk te maken en was ik verbaasd over de snelheid waarmee hij tekorten en hiaten in de tekst feilloos wist op te sporen.

De vakgroep heeft mij een half jaar in de gelegenheid gesteld om een groot deel van het verzamelde gedachtengoed ongestoord aan het papier toe te vertrouwen. Zonder deze geste zou ik mijn energie ongetwijfeld weer in onderwijsactiviteiten hebben gestoken. Mijn dank gaat speciaal uit naar Ingrid, Ina en Elly die mij gedeeltelijk verlosten van het tijdrovende typewerk.

Tenslotte Marianne, Erik en Lieke. Hun naaldkunst, balvaardigheid en fluitspel bleven lange tijd onbeantwoord. De trouw en het geduld waarmee ze vele avonden en weekeinden wachtend op mij vulden, is niet vergeefs geweest. Als blindheid en doofheid mij kenmerkten, dan is dat nu voorbij. 



\section{INHOUDSOPGAVE}

Woord vooraf

Pagina

1 Inleiding

1.1 Het onderwerp van deze studie

11

1.2 Situering van het beroep van verpleegkundige

1.3 Normatieve en ethische aspecten van beroepscodes

2 Professie en professionalisering* uitgangspunten en ontwikkelingen

2.1 Inleiding

2.2 Historische aspecten

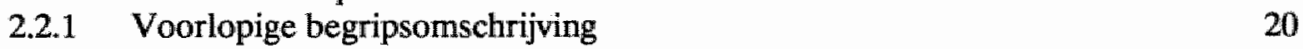

2.2.2 Ontstaan van het beroep, pre-industriële factoren $\quad 21$

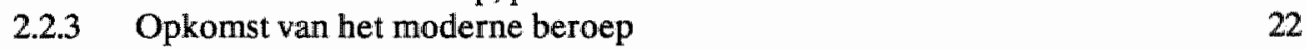

$\begin{array}{lll}2.3 & \text { Professie en professionalisering } & 23\end{array}$

2.3.1 Stand van zaken $\quad 23$

2.3.2 Van 'beroep' naar 'professie' $\quad \therefore \quad 24$

2.3.3 Institutionalisering en legitimering 25

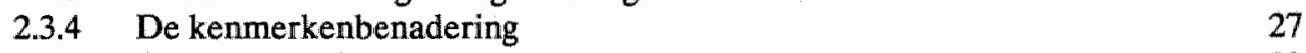

2.3.5 De functionalistische benadering $\quad 29$

2.3.6 Kritiek op kenmerkenbenadering en functionalisme 31

2.3.7 De procesbenadering $\quad 33$

$\begin{array}{lll}2.3 .8 & \text { Openstaande vragen } & 40\end{array}$

2.3.9 Professionalisering en bureaucratisering $\quad 42$

2.4 Professionalisering van het beroep van verpleegkundige 44

2.4.1 Karakterisering van het beroep van verpleegkundige 45

2.4.2 Verpleging en geneeskunde 46

2.4.3 Verpleging als vrouwenberoep $\quad 48$

2.4.4 De verpleging binnen de organisatie 49

2.4.5 De beroepsorganisatie(s) van verpleegkundigen 51

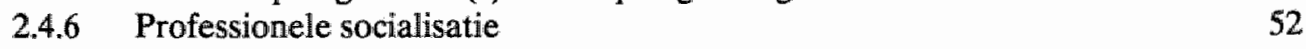

2.4.7 Macht en onmacht van de verpleging in Nederland 54

3 Normatieve aspecten van professionalisering

$\begin{array}{lll}3.1 & \text { Inleiding } & 59\end{array}$

3.2 Normativiteit $\quad 60$

3.2.1 Normativiteit in sociologisch perspectief 61

3.2.2 Normativiteit: verschillende denkwijzen en poging tot systematisering

3.2.3 Sociologie en ethiek: vergelijking van methoden en begrippen 75 
3.3 Normatieve aspecten van professionaliseringstheorieën $\quad 79$

3.4 Waarden en beroepscodes 84

3.4.1 Beroepscodes in de professionaliseringsliteratuur $\quad 85$

$\begin{array}{ll}\text { 3.4.2 Beroepscodes als vindplaats van waarden } & 91\end{array}$

3.4.3 Naar een vraagstelling voor verder onderzoek:

beroepscodes in moreel perspectief

\section{Beroepscodes voor verpleegkundigen}

4.1 Inleiding

4.2 Terminologische en historische context 100

4.2.1 De term 'code" 100

4.2.2 Beroepscodes in historisch perspectief :- 102

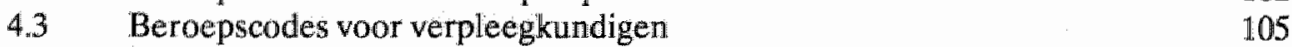

$\begin{array}{ll}\text { 4.3.1 Voorgeschiedenis en afbakening } & 106\end{array}$

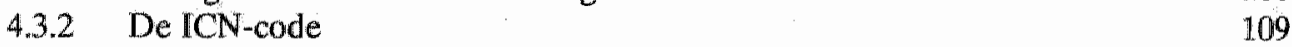

4.3.3 De ANA-code 111

$\begin{array}{lll}4.3 .4 & \text { De UKCC-code } & 114\end{array}$

4.3.5 De NMV-code $\quad 118$

4.4 Waardenoriëntaties in de beroepscodes 122

4.4.1 Het morele karakter van de beroepscodes $\quad 122$

4.4.2 Beroepscodes als etiquette? 124

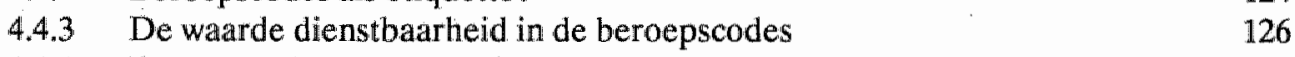

$\begin{array}{ll}\text { 4.4.4 Beroepscodes als ideologie } & 136\end{array}$

4.5 Functies van de codes 144

5 Ethiek, beroepscodes en professionalisering

$\begin{array}{lll}5.1 & \text { Inleiding } & 147\end{array}$

5.2 Ethiek, beroepsethiek en beroepscodes 148

$\begin{array}{lll}\text { 5.2.1 Meta-ethisch en normatief-ethisch kader } & 149\end{array}$

5.2.2 Superioriteit van beroepsgebonden morele claims 159

$\begin{array}{ll}5.2 .3 & \text { Legitimiteit van beroepsgebonden morele claims } \\ 5 & 165\end{array}$

$\begin{array}{ll}\text { 5.2.4 Morele status van beroepscodes } & 172\end{array}$

$\begin{array}{lll}5.3 & \text { Toepassingsproblemen bij beroepscodes } & 174\end{array}$

$\begin{array}{ll}\text { 5.3.1 Morele positie van verpleegkundigen } & 175\end{array}$

$\begin{array}{lr}\text { 5.3.2 Het probleem van de rationalisering } & 179\end{array}$

$\begin{array}{lll}5.3 .3 & \text { Het probleem van de uniformering } & 182\end{array}$

$\begin{array}{ll}\text { 5.3.4 Het probleem van de individualisering } & 186\end{array}$

$\begin{array}{ll}\text { 5.3.5 Het probleem van de sanctionering } & 190\end{array}$

$\begin{array}{ll}\text { 5.3.6 Nogmaals: de morele status van beroepscodes } & 198\end{array}$

5.4 Morele kanttekeningen bij professionalisering 200

6 Samenvatting en conclusies

$\begin{array}{lll}6.1 & \text { Vraagstelling } & 207\end{array}$

$\begin{array}{lll}6.2 & \text { Professionalisering } & 207\end{array}$

6.3 Het beroep van verpleegkundige 208

$\begin{array}{ll}6.4 & \text { Sociologie en ethiek } \\ \end{array}$ 
$\begin{array}{ll}6.5 & \text { Normatieve aspecten van professionalisering } 210\end{array}$

$\begin{array}{lll}6.6 & \text { Beroepscodes voor verpleegkundigen } & 210\end{array}$

6.7 Ethisch kader en status van beroepsethische noties 212

6.8 Superioriteit en legitimiteit van beroepsgebonden waarden $\quad 212$

$\begin{array}{ll}6.9 & \text { Toepassingsproblemen van codes } \\ 213\end{array}$

6.10 Morele status van de codes 214

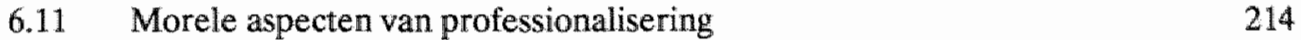

$\begin{array}{ll}6.12 & \text { Perspectief en aanbevelingen } \\ 215\end{array}$

$\begin{array}{ll}\text { Summary } & 217\end{array}$

Lijst van afkortingen en figuren $\quad 222$

$\begin{array}{ll}\text { Literatuurlijst } & 223\end{array}$

$\begin{array}{ll}\text { Index } & 232\end{array}$

$\begin{array}{ll}\text { Curriculum Vitae } & 237\end{array}$

$\begin{array}{lr}\text { Stellingen } & 238\end{array}$ 
$\because \quad$ 


\subsection{Het onderwerp van deze studie}

In deze studie wordt ingegaan op de ontwikkeling van het beroep van verpleegkundige. Deze ontwikkeling in Nederland volgend, raakt men gefascineerd door haar vele facetten: enkele, elkaar snel opvolgende generaties kritische verpleegkundigen hebben het beroep nieuw élan gegeven, het opleidingsstelsel en -niveau hebben een aantal opmerkelijke wijzigingen ondergaan, verpleegkundigen treden thans veelvuldig en nadrukkelijk in de openbaarheid en het aantal publikaties en het peil ervan zijn met sprongen omhoog gegaan. Dergelijke ontwikkelingen worden hier empirisch en in samenhang beschreven met behulp van een in de sociologie gangbaar instrument, namelijk dat van de professionaliseringstheorieën.

Daarnaast waren wij vooral geînteresseerd in het normatieve karakter van een aldus beschreven professionaliseringsproces van het beroep van verpleegkundige. In dit grensgebied tussen empirische en morele dimensies van professionalisering laat zich de centrale doelstelling van dit onderzoek plaatsen: het verwerven van een inzicht in de relatie tussen de ethische en sociale aspecten van de professionalisering van het beroep van verpleegkundige en in het ethisch fundament van professionalisering als zodanig. Voor een adequate verkenuning van dit probleem werd het noodzakelijk geacht een nauwkeurige analyse uit te voeren van vier beroepscodes voor verpleegkundigen. De ethische reflectie hierop bevat de kern van onze beschouwing. Daartoe werd als vraagstelling ontwikkeld: welke morele posities zijn te onderscheiden in door beroepsgroep(en) en beroepsorganisaties op het terrein van de verpleegkunde in de westerse samenleving gepubliceerde beroepscodes; hoe verhouden deze morele posities zich tot het professionaliseringsproces van de beroepsgroep in het bijzonder en tot maatschappelijke processen in het algemeen; en hoe dienen deze vanuit een normatief-ethisch perspectief te worden gewaardeerd?

In deze inleiding wordt nader ingegaan op de context van het bovenstaande en wordt een eerste beschrijving gegeven van de belangrijkste ontwikkelingen, concepten en begrippen die in het onderzoek aan de orde komen. 'Beroepscode." -andere gebruikte termen ziljn 'ethische code', of simpelweg 'gedragsregells' (vergelijk NRV 1988)- omschrijven wij hier als: een samenhangend geheel van (morele) principes en regels met betrekking tot de doeleinden en waarden van een beroep en de houding en het gedrag hiervoor vereist; de beroepscode dient ter ondersteuning van de positie en het handelen van beroepsbeoefenaren.

Beroepscodes blijken een nuttig en bruikbaar vehikel voor de beschrijving van de normatieve aspecten van professionaliseringsprocessen. Ze kunnen worden beschouwd als de samenvatting van de waarden en normen waaraan beroepsgroepen hun leden binden en waarmee ze zich aan de 'buitenwereld' presenteren. Gezien de doelstelling van dit onderzoek ligt dan een analyse van de inhoud en functies van beroepscodes op het terrein van de verpleging voor de hand. 
De normatieve aspecten van professie en professionalisering en hun toespitsing in het verschijnsel beroepscode kunnen uiteraard op vele manieren worden bestudeerd. Vanuit het empirisch onderzoek zijn echter nauwelijks resultaten in deze te melden. Hoogstens kunnen enkele gegevens worden ontleend aan studies op het terrein van de theorieën omtrent professie en professionalisering. Dit is een van de redenen waarom dit onderzoek start met een uiteenzetting van deze theorieën. Het kan er niettemin toe leiden dat bepaalde vraagstellingen, die zich lenen voor nader empirisch onderzoek, nauwkeuriger kunnen worden geformuleerd en in een rangorde van belangrijkheid kunnen worden geplaatst, al naargelang de invalshoek van waaruit vervolgstudies worden ondernomen. Hiermee is een gedeelte van het wetenschappelijk belang van onze bijdrage aangegeven. Ook zullen we trachten inzicht te verschaffen in de aard en samenhang van impliciet en expliciet geformuleerde waarden, zoals vanuit een professionaliseringsbelang door diverse beroepsgroepen naar voren gebracht bij de totstandbrenging van hun beroepscade. Dit kwalificeert het onderzoek als een interpretatief-theoretische studie van beschouwingen over beroepscodes.

Deze studie wordt ondernomen vanuit een normatief-ethische interesse. Het gaat daarbij niet alleen om het normatieve kader van zich professionaliserende beroepsgroepen en hun codes, maar ook en vooral om de ethische reflectie daarop. Met andere woorden: het is weliswar van belang op het spoor te komen van de waarden en doeleinden die door beroepsgroepen worden nagestreefd, maar in het verlengde daarvan ligt de vraag of deze waarden en doeleinden alsmede de wijze waarop ze worden nagestreefd, beantwoorden aan bepaalde morele principes die in de samenleving als belangrijk gelden en ethisch kurnen worden gerechtvaardigd. In deze optiek wordt het bestaan van een beroepseigen normatief kader en van beroepscodes opgevat als moreel probleem, dat kan worden geanalyseerd met behulp van het onderzoeksinstrumentarium van de ethiek. Hiertoe worden de aan het beroep eigen waarden en normen geconfronteerd met de normatief-ethische belangen van algemeen-maatschappelijke en/of sociaal-culturele aard. Tevens zal de morele status van beroepscodes in het kader van de ethische theorievorming aan de orde worden gesteld. Deze analyse wordt ondernomen op geleide van een ethische theorie waarin voor de concrete morele ervaring en waardenbeleving van actoren een prominente plaats wordt ingeruimd. Als belangrijkste wetenschappelijk belang van ons onderzoek kan dan ook gelden: een verheldering van het inzicht in de relatie tussen ethiek, beroepsethiek en beroepscodes.

\subsection{Situering van het beroep van verpleegkundige}

"De geschiedenis van het ziekenhuis is er een van de verpleging". Met deze bondige typering begint Verwey $(1981,7)$ een kort historisch overzicht van de ontwikkeling van het beroep van verpleegkundige in een studie over de stabiliteit in de personele bezetting van verpleegafdelingen.

$\mathrm{Zij}$ baseert dit historisch overzicht op gegevens, ontleend aan Querido's bekende geschiedschrijving van de ziekenverpleging in West-Europa "Godshuizen en gasthuizen" (1967). Zowel Querido als Verwey komen tot de conclusie, dat historisch gezien de verpleging in beginsel vele mogelijkheden bezat om uit te groeien tot de centrale beroepsgroep in de ziekenhuizen. Deze waren immers oorspronkelijk vooral bedoeld voor de 
zorg aan armen, behoeftigen en zieken. Die zorg makte in de eerste helft van de negentiende eeuw een krachtige bloei door onder invloed van het werk van Theodor Fliedner (1800-1864) die daarbij duidelijk steunde op de christelijke caritas-gedachte. Daarnaast werd in de tweede helft van de negentiende eeuw de genoemde bloei ondersteund door de oprichting van verpleegstersopleidingen. Hieraan is vooral de naam van Florence Nightingale (1820-1910) verbonden. Tot ongeveer 1880 bevonden zich nauwelijks artsen in de ziekenhuizen. Door de ontdekking van nieuwe medische onderzoeks- en behandelmethoden die alleen institutioneel konden worden toegepast, werd het pas na 1880 zinvol om in een ziekenhuis genezing te zoeken. Tenslotte moet het emancipatiestreven van vrouwen worden genoemd. In de negentiende eeuw was de verpleging een van de weinige mogelijkheden voor vrouwen uit de gegoede stand om een min of meer onafhankelijke positie in het maatschappelijk leven op te bowwen en te handhaven (Bakker-Van der Kooij 1983, 276).

Als we de situatie van nu met die van vóór 1880 vergelijken dan is duidelijk, dat de ver pleging slechts in geringe mate haar positie en rol bij de ontwikkelingen in de gezondheidszorg heeft verdedigd of heeft kunnen verdedigen. De centrale positie van artsen in de gezondheidszorg enerzijds en de maatschappelijk ongelijke positie van mannen en vrouwen anderzijds zijn onzes inziens de belangrijkste factoren die -waarschijnlijk in wisselwerking- hebben verhinderd, dat de verpleging uitgroeide tot het toonaangevende beroep in de gezondheidszorg (vergelijk Davies 1983, 185-186). Andere redenen staan hiermee in verband of zijn van ondergeschikt belang. Zonder volledig te willen zijn noemen. wij nog de volgende, veelal in samenhang voorkomende redenen: hoewel de maatschappelijke waardering voor het verplegingswerk sterk lijkt toe te nemen (indicatief zijn hier de toegenomen aandacht in de media en bij de overheid en hogere opleidingseisen), is het nog altijd vooral herkenbaar aan zijn harde structurele aspect van instrumentele, dat wil zeggen afgeleide verrichtingen waarvoor ogenschijnlijk geen hoge opleiding nodig is. Het behoeft geen verwondering te wekken dat een dergelijke beeldvorming een weinig positief, eerder negatief effect heeft op de toedeling van verantwoordelijkheid en op de hoogte van arbeidsloon en sociale status. Daarnaast dreigde steeds het gevaar van ütholling van het beroep. Aspecten van de beroepsuitoefening, die een specifieke deskundigheid gingen eisen, leidden aanvankelijk niet tot specialisaties binnen het beroep, maar tot geheel nieuwe beroepen (bijwoorbeeld diëtetiek, fysiotherapie). Identiteitskwesties zijn de gemoederen binnen de verpleging dan ook in toenemende mate gaan bezighouden (zie hiervoor Van der Arend 1983). Deze hangen tevens samen met het roepingsideaal dat de verpleging lange tijd heeft achtervolgd in haar streven naar erkenning als beroep onder andere beroepen. De aard van het werk alsmede zijn inbedding in de christelijke caritas en de daarmee gepaard gaande religieuze mystificering en bemoeienis (hier zij het werk van Theodor Fliedner in herinnering gebracht) hebben er op zijn minst in de publieke opinie, maar ook binnen de eigen gelederen voor gezorgd, dat roeping als belangrijke bepalende factor voor intrede in het beroep werd gezien. Ook nu nog kan deze atmosfeer van dienstbaarheid als een belemmerende factor worden beschouwd ten aanzien van een functionele opvatting van het werk van verpleegkundigen en hun institutionele inbedding en positie. Dit is overigens evenzo van toepassing op andere dienstverlenende beroepen, maar deze hebben zich klaarblijkelijk gemakkelijker kunnen ontworstelen aan de belemmeringen die hieruit voor hun functioneren en positie voortvloeiden. 
Deze historische erfenis en de eerder genoemde factoren vormen de achtergrond waartegen deze studie tot stand is gekomen. Met name een behoefte aan verduidelijking van de actuele maatschappelijke positie van de verpleging vormde de directe aanleiding tot deze studie.

Een vak dat zich vanaf het begin van deze eeuw met de maatschappelijke positie van beroepen en met het verschijinsel 'beroep' als zodanig heeft beziggehouden, is de sociologie. Er kan zelfs van een afzonderlijke subdiscipline worden gesproken: de beroepensociologie. De sociologische theorie(ën) betreffende de in deze paragraaf genoemde verschijnselen alsmede de implicaties hiervan voor het beroep van verpleegkundige en zijn relatie met het beroep van geneeskundige zijn onderwerp van bespreking in hoofdstuk 2. Daarbij geldt als uitgangspunt dat we niet spreken vanuit een triviaal begrip van 'beroep' en 'professie', maar vanuit een opvatting waarin beroepen en professies worden verbonden aan een gemiddeld tot hoog niveau van opleiding en competentie. Voorzover het processen van professionalisering betreft, zullen we daarbij tevens niet uit het oog verliezen dat een beroep of professie meestal in een georganiseerd verband wordt uitgeoefend. Ook processen van bureaucratisering dienen derhalve onze aandacht te hebben. Primair gaat deze echter uit naar professionaliseringsprocessen.

\subsection{Normatieve en ethische aspecten van beroepscodes}

Een bestudering van beroepen met behulp van de begrippen professie en professionalisering dient niet alleen een theoretisch belang. Een beschrijving van de posities van verschillende beroepen ten opzichte van elkaar levert nog geen volledig beeld op van de situatie waarin beroepen zich op een bepaald moment bevinden. Verder zijn van belang de totale sociale context waarin een beroep wordt uitgeoefend en de krachten die op de relatie tussen het beroep en zijn omgeving van invloed zijn. Met name wordt hier gedoeld op de verhouding tussen (de vertegenwoordigers van) een beroep en de samenleving als geheel. Een benadering van het beroep vamuit de begrippen professie en professionalisering kan de aspecten blootleggen waaronder deze verhouding nader kan worden bestudeerd.

Een bestudering hiervan is naar onze mening van betekenis voor de toekomst van het beroep als zodanig. De meeste beroepen konden zich slechts ontwikkelen en een zelfstandig arbeidsterrein claimen dankzij het feit dat in de samenleving een min of meer constante behoefte bestond aan het produkt dat of de dienst die werd geleverd of verleend. De verhouding tussen samenleving en beroep is er dus een van wederzijdse afhankelijkheid. Enerzijds is de samenleving afhankelijk van een groeiend aantal uiteenlopende beroepen voor de vervulling van taken, die een zodanige specialistische kennis en/of vaardigheid vereisen, dat het bezit ervan niet meer mag worden verwacht van de gewone burger. Anderzijds zijn de beroepen afhankelijk van de samenleving (dus ook van elkaar), omdat hun voortbestaan is gekoppeld aan de door hen bevredigde behoefte aan bepaalde, welomschreven produkten en diensten. Beroepsgroepen zullen er dan ook naar streven, dat aan de desbetreffende behoefte en de bevrediging daarvan door de samenleving een hoge waarde wordt toegekend. Zolang dat het geval is, hoeft een beroepsgroep niet te vrezen voor haar voortbestaan. Zij zal dat waarschijnlijk ook proberen veilig 
te stellen, bijvoorbeeld door de samenleving te confronteren met de gemaakte vorderingen in kennis en vaardigheid en hiervan het belang aan te geven voor de oplossing van als ernstig op te vatten problemen. Een andere mogelijkheid is, aan de samenleving getuigenis af te leggen van de integere wijze waarop het beroep wordt uitgeoefend en aldus te laten zien hoe zorgvuldig met een door de samenleving hooggeachte zaak wordt omgesprongen.

Indien het bovenstaande een reēel beeld van de werkelijkheid geeft, wordt de verhouding tussen beroep en samenleving dus onder andere gekenmerkt door een normatief aspect. Met andere woorden: hun interactie wordt mede bepaald door het streven de eigen doelstellingen bij de andere partij aanvaard te krijgen. Het is dit aspect, dat in de theorieën met betrekking tot professie en professionalisering steeds meer aandacht krijgt. Het zal in hoofdstuk 3 nader worden uitgewerkt.

Met de benoeming van dit aspect als normatief bevinden we ons bovendien in een overgangsgebied tussen sociologie en ethiek. In hoofdstuk 3 zal dan ook worden aangevangen met een nadere plaatsbepaling van het normatieve in ethiek en sociologie.

Het normatieve kader zal nader worden aangeduid als het proclameren, nastreven en realiseren van waarden die voor de positie en uitoefening van een beroep van belang worden geacht. Dit normatieve kader is pas recentelijk op de voorgrond getreden en daarom tot op heden nauwelijks sociologisch bestudeerd en onderzocht. Sinds de laatste decennia wordt echter steeds meer aandacht besteed aan de interactie tussen beroepsgroep(en) en samenleving en komen aldus meer gegevens beschikbaar over het normatieve kader waarbinnen een beroep wordt uitgeoefend. In de schaarse analyses hiervan speelt onder andere het begrip "macht" een centrale rol (vergelijk Larson 1979; Van der Krogt 1981; zie ook hoofdstuk 2).

In deze analyses wordt echter slechts marginaal aandacht besteed aan het meer ideëelnormatieve kader dat juist door de beroepsgroepen zelf, met name in de gezondheidszorg, al sedert lange tijd naar voren wordt gebracht. We bedoelen hier de beeldvorming met betrekking tot het beroep en de beroepsuitoefening en niet de concrete invloed die men tracht uit te oefenen op bijvoorbeeld het beleid ten aanzien van de gezondheidszorg. Voor een positieve beeldvorming is enerzijds van belang, dat een beroepsgroep zich presenteert conform het in de samenleving heersende verwachtingspatroon van na te streven waarden en doeleinden, en anderzijds dat er garanties zijn dat de beroepsbeoefenaren zich naar dat gepresenteerde beeld zullen gedragen. Welnu, vele beroepsgroepen huldigen de opvatting dat het formuleren en hooghouden van een zogenaamde beroepscode een belangrijke functie kan vervullen bij een positieve beïnvloeding vain de beeldvorming over het beroep en zijn beoefenaren. Een beroepscode zou enerzijds de samenleving ervan moeten overtuigen dat haar belangen met betrekking tot de door de beroepsgroep geleverde diensten worden veiliggesteld, maar anderzijds beroepsbeoefenaren een referentiekader moeten bieden waaraan zij hun handelen kunnen spiegelen. Dit gegeven maakt beroepscodes aantrekkelijk en relevant voor onderzoek naar de normatieve aspecten van professies en professionalisering. Een daartoe strekkende vraagstelling zal meer in detail worden ontwikkeld en toegelicht aan het slot van hoofdstuk 3 (de centrale vraagstelling werd reeds vermeld in 1.1).

De daarop volgende hoofdstukken zijn voornamelijk gewijd aan een nadere analyse en beschouwing van deze beroepscodes. Het focus zal daarbij vooral worden gericht op de 
gezondheidszorg en daarbinnen op de beroepsgroep van verpleegkundigen. Deze inperking van de vraagstellïng is niet toevallig. De gezondheidszorg wordt als specifieke sector van het maatschappelijk leven hoog gewaardeerd, verschaft werk aan vertegenwoordigers van velerlei beroepen waarvan sommige een hoog aanzien genieten en is als menselijke activiteit ten dienste van mensen een vindplaats en smeltkroes van vele (vaak tegengestelde) morele noties. Binnen de gezondheidszorg vinden we bovendien een groot aantal officiële beroepscodes en zich professionaliserende of reeds geprofessionaliseerde beroepsgroepen, zodat aan een primaire onderzoeksvoorwaarde (aanwezigheid van een onderzoeksobject) in relatie tot het gestelde doel wordt voldaan. Een laatste beperking wordt ingegeven door een specifiek aandachtsveld binnen de discipline en scholing van onszelf, namelijk de ethiek in verband met de verpleging en verpleegkunde. Dit is een terrein wan onderzoek en onderwijs dat nog nauwelijks in kaart is gebracht, maar al wel gonst van nieuwe ontwikkelingen en bedrijvigheid. Een reden om het onderzoek tot deze beroepsgroep te beperken is het feit, dat momenteel op het terrein van de verpleegkunde, internationaal gezien, reeds meer dan 20 beroepscodes zijn gepubliceerd en dat professionalisering tot de veelbesproken vraagstukken binnen de beroepsgroep behoort. Hierdoor kan het onderzoek aansluiten bij actuele discussies en de resultaten daarbij van voordeel doen zijn.

Beroepscodes zijn onderwerp van publiek debat. In 1988 werd door de Nationale Raad voor de Volksgezondheid (NRV) de "Nota bouwstenen voor "beroepscodes" en "gedragsregels"'t gepubliceerd. Deze gebeurtenis kan in het verlengde worden gezien van het Wetsontwerp beroepsuitoefening in de individuele gezondheidsżorg. Onderdeel hiervan zijn voorzieningen om voor vele beroepen, waaronder dat van verpleegkundige, tot een vorm van tuchtrecht te komen. Beroepscodes worden door de NRV -redenerend vanuit een professionaliseringstheoretisch standpunt- daartoe als een zinvol instrument beschouwd; reden om deze onder de aandacht van het publiek te brengen. Ook door middel van deze studie wordt aan het verschijnsel bekendheid gegeven. Daarnaast hopen we met ons onderzoek praktische aanwijzingen te verschaffen over de wijze waarop beroepscodes al dan niet voor de beroepsuitoefening kunnen worden aangewend.

Het grote aantal beroepscodes voor verpleegkundigen in aanmerking nemend, is de analyse beperkt tot de internationaal meest bekende en vooraanstaande (die van de American Nurses' Association, die van de International Council of Nurses en die van de United Kingdom Central Counsil of Nurses, Midwives and Health Visitors) alsmede die van de Nederlandse Maatschappij voor Verpleegkunde (nu Nieuwe Unie '91 geheten). De presentatie en analyse van deze vier codes beslaan het gehele hoofdstuk 4 . Een uitleg van de diverse functies die zij kunnen vervullen zal daarbij niet ontbreken.

Onze normatief-ethische interesse in het verschijnsel beroepscode krijgt vooral gestalte in hoofdstuk 5. Het kader daarvoor is in 1.1 geschetst, maar verdient nog enige toelichting in het licht van de opmerkingen die toen werden gemaakt. Deze betreffen met name de implicaties van een normatief-ethische beschouwing van beroepscodes voor enerzijds de te hanteren ethische theorie en anderzijds de verhouding tussen beroepsgroep en samenleving.

Een ethische theorie dient voldoende kritische massa te bezitten om de rechtvaardigingsgronden van een bepaald moreel verschijnsel op hun houdbaarheid te toetsen, maar moet tevens getuigen van realiteitszin, dat wil zeggen: ze moet de morele aspecten van 
beroepscodes kunnen plaatsen binnen de concrete functies die ze vervullen en de context waarbinnen ze functioneren. Langs het spoor van de ethische analyse en reflectie kont daarbij expliciet het spanningsveld aan de orde tussen het handelen van beroepsgroepen enerzijds en de wensen in dit opzicht vanuit de samenleving anderzijds. De ethiek kan aan de verheldering van dit spanningsveld een bijdrage leveren door de desbetreffende normatieve posities te analyseren en deze te onderzoeken op hun morele houdbaarheid. Op grond van het onderzoek kunnen dan wellicht uitspraken worden gedaan over de morele wenselijkheid van professionalisering, voorzover althans professionalisering wordt gerelateerd aan de waarden en normen die voortvloeien uit beroepscodes.

Een behandeling van genoemde kwesties kan tot relevante en actuele resultaten en aanbevelingen leiden. In de eerste plaats kan een gefundeerd oordeel worden gegeven over de morele betekenis van de huidige beroepscodes. Ten tweede kunnen aanbevelingen worden gedaan ten aanzien van de wenselijkheid van beroepscodes. Voorts kan een oordeel worden uitgesproken over de betekenis van beroepsethische discussies in het algemeen, waarvan beroepscodes een uitvloeisel zijn.

Dit laatste is van belang, wanneer de aandacht meer in het bijzonder wordt gericht op de beroepsgroep van verpleegkundigen. Haar streven om beroepscodes te formuleren dan wel de bestaande beroepscodes een grotere betekenis te verlenen voor beroepsbeoefenaren en samenleving, gaat gepaard met een vloed van geschriften die tot het domein van de beroepsethiek kunnen worden gerekend. Opvallend is echter, dat men zich daarbij in verregaande mate conformeert aan de ethische discussies die binnen de beroepsgroep van geneeskundigen gangbaar zijn. Voor andere (para-medische) vakgebieden kan vaak hetzelfde worden gesteld. Dit wettigt de vraag of het op den duur wel zinvol is om te spreken van een speciale beroepsethiek voor verpleegkundigen. Een voortgezet onderzoek naar de morele betekenis van beroepscodes kan indices voor een antwoord opleveren. Het is echter geenszins de bedoeling om in deze studie tot een ontwerp van een dergelijke beroepsethiek voor verpleegkundigen te komen.

De resultaten van het onderzoek worden in hoofdstuk 6 samengevat en van conclusies en commentaar voorzien. Daarbij zal de boven uiteengezette opbouw van de studie worden gevolgd.

Het is zinvol de opzet van deze studie nog eens samen te vatten in een schema. Dat is gebeurd in figuur 1.1. In dit schema zijn per hoofdstuk tevens de belangrijkste thema's vermeld alsmede de auteurs die daarbij centraal hebben gestaan. 
Figuur 1.1: Opbouw van deze studie en belangrijkste aangehaalde auteurs

\begin{tabular}{|c|c|}
\hline $\begin{array}{l}\text { (Van der } \\
\text { (Dingwall }\end{array}$ & $\begin{array}{l}\text { (t, 1981) } \\
\text { is, } 1983 \text { ) }\end{array}$ \\
\hline 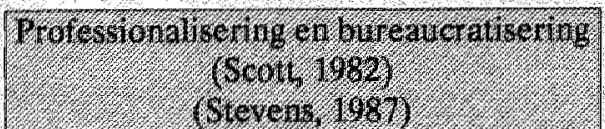 & $\begin{array}{l}\text { Profe-silonilinering van de verpleging } \\
\text { (geen specifieke auterin) }\end{array}$ \\
\hline
\end{tabular}

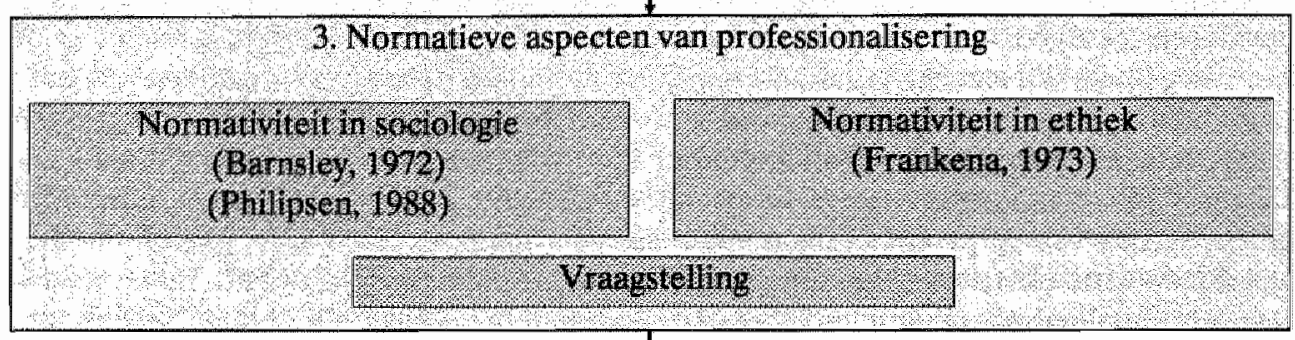

\section{Nornatieve aspecten van professionalisering}

minativiteditin et

(Frankena, 1973)

\section{Beroepscodes voor verpleegkundigen \\ (ICN, 1973; ANA, 1985) \\ (UKCC, 1983; NMV, 1990)

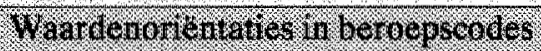 \\ (Kuilgen, 1088 )}

\section{Ethiek, beroepscodes en professionalisering}

(Vos, 1989)

(Philipsen, 1988)

\section{Ethiseh kader \\ (Vos 1989 )}

Morele status van beroepscodes.

(geer specifekle auteur)

\section{Morele kant telkeninger bif}

professionalisering

\section{Samenvatting en conclusies}




\section{UITGANGSPUNTEN EN ONTWIKKELINGEN}

\section{$2.1 \quad$ Inleiding}

De idealen en werkelijkheden waarmee een persoon tijdens de uitoefening van zijn beroep te maken heeft, worden niet uitsluitend ontleend aan individuele denkbeelden en activiteiten. Binnen de hulpverlening bijvoorbeeld spelen achtergronden en wensen van cliënten een wezenlijke rol bij de bepaling van de richting van het beroepsmatige handelen. Tal van activiteiten worden tevens bepaald door zowel impliciete als expliciete regels en normen, geldend binnen de groep van collega-beroepsbeoefenaren, soms zelfs gepaard gaande met (dreiging van) sancties bij overtreding van die regels en normen. Een goed voorbeeld van dit laatste is het medisch tuchtrecht. Uitoefening van een bepaald beroep heeft dan ook valk niet alleen gevolgen voor het soort activiteiten dat wordt verricht, maar ook voor het persoonlijk leven van beroepsbeoefenaren, in de zin van verwachtingen ten aanzien van de individuele levenswoering. Kortom, een beroep impliceert een bepaald rolmodel. In tijden dat ziekenzorg vooral een taak van religieuze kloosterlingen was, leverde dit bijvoorbeeld een rolmodel op van ongedeelde loyaliteit. De huidige verpleegkundige zall zich hier waarschijnlijk niet meer in thuisvoelen, terwijl dit door de aard en situatie van het beroep wellicht toch van hem wordt verwacht.

De uitoefening van een beroep vindt dus plaats in een sociale werkelijkheid die mede wordt beïnvloed door factoren, samenhangend met de houding, opvattingen en wensen ten aanzien van de beroepsgroep als geheel. Interacties met andere groepen in de samenleving zorgen er daarnaast voor dat deze houding, opvattingen en wensen een zekere kleur, intensiteit en status krijgen. Daarbij zal de beroepsgroep er soms veel aan zijn gelegen, dat haar stem wordt gehoord en haar idealen worden gerealiseerd. Dat lukt de ene beroepsgroep beter dan de andere.

De invloed van de belangen van de totale beroepsgroep op de beroepsuitoefening en het gedrag van haar leden en daarmee op belangrijke aspecten van het maatschappelijk ge. beuren is reeds lang geleden herkend in de sociologie. Vanaf het begin van deze eeuw heeft de zogenaamde 'beroepensociologie' een gestage ontwikkeling doorgemaakt tot een erkende specialisatie. Het beroep als begrip werd in een conceptueel kader geplaatst, van waaruit het verschijnsel nader kon worden bestudeerd en de positie van beroepen ten opzichte van elkaar kon worden bepaald.

De sociologische theorieën, die sindsdien op dit terrein zijn ontwikkeld en de inzichten die daaruit zijn ontstaan met betrekking tot beroepen als zodanig, zullen in dit hoofdstuk de achtergrond vormen voor een schets van de situatie waarin het beroep van verpleegkundige zich bevindt. Deze achtergrond en schets worden noodzakelijk geacht voor een verheldering van de normatieve aspecten van de verpleegkundige beroepsuitoefening -zowel collectief als individueel- en voor een ethische reflectie op die normatieve aspecten in hoofdstuk 3 en volgende. 
We beginnen dit hoofdstuk met een globale schets van enige relevante historische, culturele en conceptuele aspecten ten aanzien van het verschijnsel 'beroep'. In samenhang met bovenvermelde theorieën zal blijken dat daarvan een aparte klasse kan worden afgezonderd, namelijk die van 'professies'. Dit blijken beroepen met een zekere status op grond van hun vorderingen op het terrein van kennis en kunde alsmede vanwege de percepties in de samenleving ten aanzien van het nut ervan. We spreken dan over beroepen waarvoor een uitgebreide scholing nodig is en niet over bijvoorbeeld de schoenmaker of over magazijnwerk. Met betrekking tot de sociologische theorievorming over dit verschijnsel zal in de paragrafen 2.3 een aantal verschillende benaderingen aan de orde worden gesteld die min of meer ook in chronologische volgorde aanhangers kenden: de kenmerkenbenadering, de functionalistische benadering en de procesbenadering. Onderdeel van deze laatste is de machtsbenadering, die in 2.3.7 expliciet onze aandacht zal krijgen met het oog op onze analyse later. Het gaat ons primair om een beschrijving van een stand van zaken in de sociologie. We laten echter niet na enige woorden te wijden aan nog openstaande vragen. Verder zal de relatie worden beschreven tussen professionalisering en een verschijnsel dat hiermee vaak in verband wordt gebracht, namelijk bureatscratisering. In de paragrafen 2.4 tenslotte zullen diverse elementen uit het geschetste theoretisch kader worden toegelicht aan de hand van een beschrijving van het beroep van verpleegkundige, met name in de relatie ervan tot dat van geneeskundige. Daarin zal onder andere sprake zijn van een zekere onmacht die verpleegkundigen ervaren wanneer vanuit de machtsbenadering naar hun professionele status wordt gekeken.

\subsection{Historische aspecten}

\subsubsection{Voorlopige begripsomschrijving}

'Het' beroep is te kwalificeren als een sociaal verschijnsel. 'Beroep' vatten wij hier op als: "een bepaald deel van de maatschappelijke arbeidsverdeling dat een aantal mensen tegenover anderen beschouwt als het domein dat bij uitstek van hen is" en "waarop de beoefenaars een claim leggen" (Mok 1977, 222). 'Maatschappelijke arbeidsverdeling' kan hier worden omschreven als: "de verdeling van het maatschappelijke produktieproces over velerlei beroepen, functies, bedrijven en bedrijfstakken" (De Jager en Mok 1983, 276 en 394).

Ten aanzien van de maatschappelijke arbeidsverdeling wordt gewoonlijk een onderscheid gemaakt tussen een viertal sectoren: landbouw en visserij, nijverheid, maatschappelijke dienstverlening en de niet-commerciële dienstverlening. Tot de niet-commerciële dienstverlening, ook wel quartaire sector genoemd; behoort onder andere de verpleging. Vooral deze sector zal onze aandacht krijgen, maar dan wel uitsluitend die beroepen waarvoor een zekere scholing is vereist.

De groei van de verschillende sectoren is een gevolg van de industrialisatiegraad en het economisch draagvlak van een samenleving. Ook sociale structuren van een samenleving (bijvoorbeeld machtsverhoudingen) spelen een belangrijke rol. De groei van de quartaire sector heeft -evenals die van de tertiare sector (maatschappelijke dienstverlening)krachtige impulsen gekregen uit de ontwikkeling van de verzorgingsstaat (Hammenga 
1990, 346). Dit alles vergt enige historische toelichting. Een omschrijving van de belangrijkste begrippen volgt later (zie vooral de paragrafen 2.3 ).

\subsubsection{Ontstaan van het beroep, pre-industriële factoren}

De maatschappelijke arbeidsverdeling, waar het beroep een uitvloeisel van is, is een oud gegeven van onze samenleving en cultuur. We zouden kunnen zeggen, dat op het moment dat een bepaalde taakverdeling tussen mannen en vrouwen ontstaat en zich bepaalde hiërarchische verhoudingen tussen bezitters en bezitlozen manifesteren met dienovereenkomstige rechten en plichten, er al sprake was van een zekere arbeidsverdeling. Waarschijnlijk is het zelfs nog beter om in dit verband het ontstaan van beroepen te koppelen aan het moment dat zich grotere samenlevingsverbanden zoals nederzettingen vormen, maar zeker is dit geenszins. Geen auteur waagt zich dan ook aan een uitspraak over het precieze moment waarop in onze samenleving het beroep als zodanig zichtbaar wordt. Wel is iedereen het erover eens dat de ontwikkeling en differentiatie van beroepen essentieel werden beínvloed door de industriële revolutie. Vóór die periode was er echter al geruime tijd sprake van een aantal 'hogere' beroepen, bijwoorbeeld het beroep van geneeskundige, dat van rechtsgeleerde en het beroep van officier.

Voor een goed inzicht in de ontwikkeling van de beroepen in de negentiende en twintigste eeuw zijn volgens Larson (1979, 3-4) twee aspecten uit de pre-industriele periode van belang. Op de eerste plaats de sterke binding van beroepen aan de sociale stratificatie: "... for the ... professions, establishment and social standing were equivalent to their association with the elites and with the state." (Larson 1979, 3). Deze binding was zo sterk dat bijvoorbeeld binnen de geneeskunde geen uitwisseling van ideeën en kennis plaatsvond tussen degenen die wel en degenen die niet een universitaire scholing hadden genoten (Larson 1979, 4; Starr 1982). Desondanks maakten universitaire scholing of andere kwalificaties genezers niet superieur bij het publiek (Freidson 1970, 19).

In samenhang met het bovenstaande is nog een tweede aspect van belang, namelijk de verwevenheid van een beroep waarvoor een opleiding moest worden gevolgd ('learned profession') met kerk en universiteit. De opleiding was meer gericht op het doorgeven van de klassieke cultuur dan op de verwerving van praktische vaardigheden en deskundigheid. In de negentiende eeuw kwam de nadruk juist op de laatste te liggen, mede als gevolg van de opkomst van de natururwetenschappen en het ontstaan van afzonderlijke vakgebieden vanaf de zeventiende eeuw (Larson 1979, 4 en 44-45). Mede hierdoor, maar vooral door de aard van de sociale veranderingen ten tijde van de industriële revolutie, werd de sterke binding aan de oorspronkelijke sociale stratificatie (zie eerste aspect) doorbroken en konden binnen de maatschappelijke arbeidsverdeling verwante terreinen zich aaneensluiten tot-weliswaar ook intern gestratificeerde- beroepen in de moderne betekenis van het woord.

Tenslotte kan nog worden gewezen op de verschuiving van de plaats die het beroep innam in het persoonlijk leven van zijn beoefenaren. In de pre-industriële periode waren. beroepsuitoefening en persoonlijke levensvoering sterk met elkaar verbonden. In de negentiende eeuw werd het beroep een institutie die buiten de private sfeer was gelegen. Bovendien traden er verschillen op in de mate waarin beroepen fungeerden als rolmodel. voor het gedrag dat van beroepsbeoefenaren -ook in een ruimere sociale context- mocht 
worden verwacht. Met name bij de zogenaamde 'echte professies' zien we dan vervolgens een tegenstelling ontstaan. Deze professies schrijven een alomvattend en veeleisend rolmodel voor waaraan de moderne professional meestal niet wil of kan beantwoorden ( $\mathrm{Co}$ ser $1974,4-8)$. Onder geneeskundigen bijvoorbeeld zijn er tegenwoordig velen die hun beroep voornamelijk benaderen als een vak en minder als een soort levensinstelling.

\subsubsection{Opkomst van het moderne beroep}

De opkomst van het moderne beroep wordt vooral gekenmerkt door "a wave of association". Deze door Carr-Saunders gegeven typering houdt in, dat de stichting van krachtige (nationale) beroepsorganisaties als een belangrijk middel werd gezien om het marktaandeel te consolideren dan wel uit te breiden. Rond het midden van de negentiende eeuw werden er in de westerse landen dan ook vele opgericht (Larson 1979, 5).

Deze ontwikkeling is niet vanzelf gegaan. De verandering van een gemeenschapsgeoriënteerde in een marktgerichte samenleving tijdens de industriële revolutie heeft haar sporen nagelaten in die zin, dat ook de beroepen kenmerken gingen vertonen van het industriële kapitalisme, met name ten aanzien van de corporatieve aspecten ervan (Larson 1979, 6).

Pre-industriële aspecten blijven echter dit proces beînvloeden. De vernieuwing van de beroepen wordt geleid door de 'carriers of social structure', waarmee zij worden bedoeld die hoog op de ladder staan in de sociale stratificatie, mede als gevolg van opleiding en afkomst (Larson 1979, 5). Aristocratische of quasi-aristocratische elites controleerden nog steeds de markt (Larson 1979, 12). Een verschil met de pre-industriële periode is echter, dat beroepsgroepen formele beroepsorganisaties in het leven roepen die het nieuwe fundament van macht en eigendom vormen, de motor achter nieuwe beroepen en carrière-perspectieven zijn en derhalve de structurele contekst bieden voor ondersteuning van de samengaande sociale en economische veranderingen en voor de verdediging tegen de directe invloed van traditionele klassebelangen. Deze organisaties werden gevormd naar bureaucratisch model, dat wil zeggen: gebaseerd op de principes van functionele rationaliteit en toegepaste wetenschap en gelegitimeerd door hun deskundigheid. Uit dit bureaucratisch verschijnsel komt de structurele context voort waarbinnen beroepen zich voorspoedig konden ontwikkelen (Larson 1979, 145; zie ook 2.3 .9 hierna).

De ontwikkeling van deze beroepsorganisaties in spe ging niet in de richting van vakbondsvorming, maar van beroepsvorming. Dat wil zeggen: men zette zich minder in voor formele belangenbehartiging dan wel voor een collectief proces ter versterking van de functie van het beroep in de samenleving. Vakbondsvorming zou een bevestiging inhouden van ongelijkheden in de sociale stratificatie. Met beroepsvorming liep men dit gevaar veel minder, hetgeen gunstig werd geacht voor het imago van het beroep bij het publiek. Beroepsvorming kon niet alleen een barrière opwerpen tegen kwakzalverij en gezamelijk optreden tegenover derden mogelijk maken, maar ook een belangrijke bijdrage leveren aan het verdoezelen van structurele ongelijkheden in de sociale verbanden. Deze uit de pre-industriële periode stammende ongelijkheden (bijvoorbeeld tussen universitair en niet-universitair geschoolden, tussen genezers en publiek) deden ook daarna hun invloed gelden (Larson 1979, 156).

Naast een economische functie vervulde de beroepsorganisatie dus ook een ideologische functie. In die ideologische functie werd aangesloten bij een dominante waarde in de 
westerse samenleving (namelijk gelijkheid), hetgeen noodzakelijk werd geacht (en ook was) voor het verkrijgen van brede maatschappelijke erkenning. Alleen via deze maatschappelijke erkenning kon de superioriteit van het beroep en zijn beoefenaars worden bevestigd (Larson 1979, 157).

\subsection{Professie en professionalisering}

\subsubsection{Stand van zaken}

Onze schets van enkele historische aspecten, verbonden aan de ontwikkeling van het moderne beroep, laat een aantal belangrijke punten zien waarmee rekening moet worden gehouden bij een nadere beschrijving van de huidige situatie. Grofweg zijn op grond van de paragrafen 2.2 de volgende relevante ontwikkelingen te onderscheiden:

1. Op de eerste plaats een sterke verwevenheid van de ontwikkeling van het beroep en van de maatschappij. Enerzijds sloten beroepselites zich aan bij de gevestigde (economische) belangen van de toplaag in de sociale stratificatie. Anderzijds poogde men voortdurend de eigen belangen ideologisch te rechtvaardigen. Hiermee bleef men weliswaar in het spoor van dominante waarden in de samenleving, maar werden tegelijkertijd bestaande ongelijkheden toegedekt.

2. In samenhang met genoemde verwevenheid kan ten tweede worden gewezen op een proces van collectivisering en bureaucratisering binnen beroepsgroepen tijdens en na de industriële revolutie: door de krachten te bundelen in formele beroepsorganisaties konden eigen belangen veilig worden gesteid tegenover de zuigkracht en de dreiging die uitgingen van het industrieel-monopolitisch kapitalisme dat belangrijke sectoren van de maatschappij zozeer kenmerkte.

3. Op de derde plaats moeten de sterke differentiatie en specialisatie van arbeidstaken in de negentiende en twintigste eeuw worden vermeld. Deze luidden het ontstaan van talloze afzonderlijke beroepen in, overigens met dienovereenkomstige afbakeningsproblemen. In verband met de ontwikkeling van de verzorgingsstaat zou de grootste groei zich voordoen in de tertiaire en quartaire sector.

Collectivisering binnen beroepsgroepen enerzijds en differentiatie en specialisatie van arbeidstaken anderzijds lijken tegenovergestelde processen, maar zijn feitelijk van verschillende orde. Het eerste is een proces van groepsdynamische aard, waarbij onder andere wordt gewezen op de uniciteit van het beroep. Het tweede is grotendeels een proces van inhoudelijke aard, waarbij onderdelen van het beroepsterrein een zodanig specifiek karakter met dienovereenkomtig vereiste kwalificaties en competenties krijgen, dat daaruit als het ware een afzonderlijk beroep met specifieke taken voortvloeit. Beroepsgroepen waarbij dit laatste in grote mate plaatsvindt of heeft plaatsgevonden, zullen dan ook een claim leggen op een breed scala van activiteiten (bijvoorbeeld de notaris stelt niet alleen akten op, maar geeft ook voorlichting). Hoewel dit onherroepelijk tot segmentering binnen beroepsgroepen leidt, zijn de meest 'geslaagde' beroepsgroepen in staat gebleken eventuele tegenstellingen via het proces van collectivisering toe te dekken en de eenheid in de beroepsgroep als geheel te bewaren: de uniciteit werd gehandhaafd en tegelijk het terrein zo breed mogelijk gehouden. 
Voor een beschrijving van de huidige situatie ten aanzien van het beroep levert Van der Krogt -in aansluiting bij de drie hierboven genoemde ontwikkelingen en de bestaande literatuur op dit terrein samenvattend-nog de volgende aanwijzingen:

1. Voor de oplossing van de problemen van de moderne samenleving wordt steeds meer een beroep gedaan op gespecialiseerde deskundigen, die zich meestal graag als professionalls beschouwen.

2. De beheersbaarheid van de verzorgingsstaat hangt mede af van de structuren en processen van 'het maatschappelijk midden' (de term is van Van Doorn). Dit is een gebied van economische zelfstandigheid (bijvoorbeeld in de vrije beroepen), professionele autonomie en verzelfstandiging van formele en bureaucratische beroepsorganisaties, waarop de overheid in het algemeen weinig greep heeft en waarvan de gewone burger zich afhankelijk weet.

3. De sub 2 vermelde beheersbaarheid neemt af omdat in toenemende mate een discrepantie zichtbaar wordt tussen de ideologie van beroepsbeoefenaren en hun feitelijk handelen (bijvoorbeeld ten aanzien van het dienstbaarheidskarakter). Hierdoor groeit het publieke wantrouwen en wordt sociale controle steeds wenselijker. Inzicht in de structuren en processen van het maatschappelijk midden legt deze discrepantie bloot, toont de noodzaak tot verandering aan, maar leidt niet tot wijzigingen om redenen die in punt 1 en hierna in de punten 4 en 5 zijn verwoord.

4. Bepaalde beroepen slagen er steeds in hun relatief autonome positie ook in minder gunstige (sociaal-economische en/of politieke) omstandigheden te bewaren, terwijl onduidelijk is hoe deze gerechtvaardigd kan worden.

5. De beroepsgroepen in het algemeen, maar die binnen de gezondheidszorg, het welzijnswerk en het onderwijs in het bijzonder, zijn een politiek-relevante factor van het hoogste belang geworden (Van der Krogt 1981, 9-12).

In aanvulling op het eerste punt van Van der Krogt kan tenslotte nog worden gewezen op het eerder vermelde fenomeen, dat professionals tevens een claim leggen op een breed scala van activiteiten, onder handhaving van de uniciteit van het beroep of domein. Daarmee zullen ze zeer waarschijnlijk de grenzen van hun arbeidsterrein overschrijden, maar bovendien hun autonomie en invloedssfeer vergroten.

Het beroep is dus nog meer dan voorheen in het centrum van de maatschappij komen te staan. Het bedient zich als het ware nog van dezelfde ideologie als in de vorige eeuw. Maar het haalt zich daarmee in toenemende mate ook de kritiek van het publiek op de hals, dat de autonomie en macht van sommige beroepsgroepen en -beoefenaren graag ingeperkt ziet, mede tegen de achtergrond van een zich wijzigende dominantie van waarden en de partiële machteloosheid van de overheid.

\subsubsection{Van 'beroep' naar 'professie'}

Zoals aangegeven, is het beroep als sociaal verschijnsel een centrale factor in het functioneren van de maatschappij. Naarmate de sociologie zich als afzonderlijke wetenschappelijke discipline ontwikkelde werd dan ook meer aandacht besteed aan beroepsvorming en beroepsontwikkeling.

Deze belangstelling vanuit de sociologie was niet alleen gericht op de beschrijving van het beroep als samenhangend geheel van arbeidstaken of als het structurele kader waarin 
arbeid in de samenleving is geinstitutionaliseerd in de context van maatschappelijke arbeidsverdeling. $\mathrm{Zij}$ was ook gericht op een theorie-genererende ideaal-typische schets van het verschijnsel beroep als zodanig, dat wil zeggen: een rationele constructie, waarbij beroepen werden ontdaan van alle marginale kenmerken en eigenschappen om aldus de essentieel geachte over te houden en deze te laten gelden als criteria voor de beschrijving en evaluatie van beroepen die zich als zodanig presenteren. De beroepen die het meest met dit ideaal-type overeenkwamen, werden professies genoemd. Beroepen die op weg waren om de kenmerken van het ideaal-type te gaan vertonen, werden geacht zich te bevinden in een proces van professionalisering.

Voor de constructie van het ideaal-type gebruikte men vooral observaties van beroepen met een lange geschiedenis van onafhankelijkheid en hoog maatschappelijk aanzien, zoals het beroep van officier, arts, jurist en priester. Met behulp hiervan ontstond een socjologische theorie met betrekking tot de verschijnselen professie en professionalisering, waarmee in principe van elk beroep de positie kon worden bepaald op het continuum van beginnend beroep naar volwaardige professie.

Vooruitlopend op wat nog volgt, noodzaakt het bovenstaande voor een bepaling van de positie van het beroep van verpleegkundige niet alleen tot kennisname van de theorie omtrent professie en professionalisering. Het lijkt tevens zinvol om dit beroep te vergelijken met dat van arts, als beroep met een hoge graad van professionalisering enerzijds en aanpalend bij het beroep van verpleegkundige anderzijds.

\subsubsection{Institutionalisering en legitimering}

Vanuit een sociologische optiek wordt het beroepsvormingsproces gekenmerkt door twee belangrijke aspecten: institutionalisering en legitimering. In aansluiting op eerder ontwikkelde begripsomschrijvingen (zie onder andere 2.2.1) definiëren De Jager en Mok "beroep" dan ook als : "een geinstitutionaliseerd en gelegitimeerd kader rond een bepaald deel van de maatschappelijke arbeidsverdeling dat een aantal mensen tegenover andere mensen beschouwt als het domein dat hen toebehoort" $(1983,394)$. Andere auteurs sluiten zich hierbij aan (onder andere Van der Krogt 1981; Hammenga 1990, 347).

Met institutionalisering wordt bedoeld het ontstaan van een social kader voor een min of meer vast patroon van activiteiten. De desbetreffende actoren ontwikkelen vaste structuren rond hun activiteiten en probleemoplossingen, stellen doeleinden vast die zij in en door deze structuren willen bereiken en zoeken hiervoor steun in hun omgeving (Mok 1973, 104). De activiteiten en oplossingen van een beroep als institutie zijn naar buiten toe herkenbaar en naar binnen het referentiekader voor toekomstig handelen.

Hierbij kan een onderscheid gemaakt worden tussen domeininstitutionalisering en sociale institutionalisering. Met domeininstitutionalisering wordt bedoeld de mate waarin de omgeving een beroep toestaat bepaalde activiteiten en een consensus over waarden te ontwikkelen. Sociale institutionalisering is de mate waarin de omgeving een beroep toestaat een intern interactiepatroon te ontwikkelen met duidelijke grenzen ten opzichte van buitenstaanders en die patronen te gebruiken als middel tot normatieve integratie van beroepsgenoten (Mok 1973, 105-106).

Er is sprake van een legitimeringsproces wanneer beroepsbeoefenaren "streven naar erkenning en aanvaarding door andere beroepsgroeperingen, opdrachtgevers, afnemers en de samenleving als geheel van hun verklaring en zingeving van de werkelijkheid" (Mok 
$1973,104)$. Een dergelijke legitimering is een belangrijke voorwaarde voor institutionalisering van een betoep.

Het belang van institutionalisering en legitimering voor beroepsvormingsprocessen wordt door Van der Krogt onderschreven (1981, 123 e.v.). Hij werkt deze begrippen uit en geeft daaraan een uitbreiding in vergelijking tot de oorspronkelijke versie van Mok.

Zoals Mok hecht ook Van der Krogt veel waarde aan het onderscheid tussen domein- en sociale institutionallisering, omdat ten aanzien van diverse beroepen de mate van institutionalisering van beide vormen sterk kan verschillen. Domeininstitutionalisering beschouwt Van der Krogt hierbij als onderdeel van het beroepsvormingsproces op zichzelf. Sociale institutionalisering verwijst in zijn visie naar het collectiviseringsproces dat zich in een beroepsgroep kan voordoen.

Beide processen hebben volgens hem uiteindelijk tot doel "de instandhouding of creatie van geinstitutionaliseerde en gelegitimeerde machtsposities" (Van der Krogt 1981, 125), via welke de rol, functie en status van een beroep voor een belangrijk deel kunnen worden gewarborgd. Naast de genoemde vormen van institutionalisering onderscheidt hij derhalve nog een derde vorm: machtsinstitutionalisering (zie ook figuur 2.2 in 2.3.7).

In overeenstemming hiermee onderscheidt hij ook een derde vorm van legitimering, namelijk machtslegitimering. Deze definieert hij als. "het doen aanvaarden van de machtspositie van een beroepsgroep in een systeem, en het legitimeren van de beïnvloedingspogingen die vanuit die positie worden ondernomen". (Van der Krogt 1981, 131)

Verder kan volgens Van der Krogt, op basis van literatuurgegevens, bij alle drie vormen een onderscheid worden gemaakt tussen legitimeringsgronden en legitimeringsargumenten. Legitimeringsargumenten zijn kennisargumenten, dienstbaarheidsargumenten, en ethische argumenten (onder andere interne en externe controlemechanismen en ethische codes). Door middel van dergelijke argumenten worden het bestaan en de wijze van functioneren van een beroepsgroep uitgelegd en gerechtvaardigd. Legitimeringsgronden zijn de redenen waarom anderen de legitimering van de beroepsgroep aanvaarden. Deze kunnen dezelfde zijn als de legitimeringsargumenten (Van der Krogt 1981, 129-130). Het onderscheid tussen legitimeringsgronden en legitimeringsargumenten is van belang voor de in deze studie te ontwikkelen vraagstelling. In hoofdstuk 3 komen we hierop terug.

De legitimeringsargumenten tesamen vormen de ideologie van de beroepsgroep, hier gedefinieerd als "het geïntegreerde geheel van waarden, normen, feiten en inzichten, dat specifiek is voor een groep, en dat het bestaan en de wijze van functioneren van de groep legitimeert" (Van der Krogt 1981, 128). Van der Krogt tekent hierbij aan dat het gebruik van de ideologie (dus ook legitimering) zowel een externe als interne functie heeft: extern, omdat hiermee steun gezocht wordt in de omgeving (zie ook 2.3.1); intern, omdat zij een basis verschaft voor een 'unieke identiteit' onder de leden van de beroepsgroep en eveneens voor de bereidheid tot het opkomen voor groepsbelangen. Verschillen in ideologie tussen beroepsbeoefenaren kunnen daarentegen een belangrijke oorzaak zijn van segmentering bimnen beroepsgroepen, maar tevens een aanwijzing vormen voor op handen zijnde veranderingen in taak of functie en arbeidsomstandigheden. 


\subsubsection{De kenmerkenbenadering}

In het bovenstaande is het beroep casu quo het beroepsvormingsproces verbonden aan de beschrijving van enkele centrale begrippen uit het huidige sociologische denkkader. Dit mag echter niet verhullen dat het verschijnsel in de loop van de tijd op verschillende manieren en vanuit uiteenlopende sociologische optieken is bestudeerd en beschreven. Dit zal in de komende paragrafen duidelijk worden.

Hoewel de sociologische bestudering van het beroep diepgaand werd beinvloed door Parsons en Hughes, komt Carr-Saunders de eer toe als eerste een systematische studie aan dit thema te hebben gewijd. Dit wordt gesignaleerd in diverse bijdragen aan het overzichtswerk van Dingwall en Lewis (1983) en blijkt ook uilt beider literatuurlijst van bijna 500 titels op het terrein van de beroepensociologie in de Verenigde Staten en Engeland. Met Carr-Saunders' publikatie van "Professions: their organization and place in society" uit 1928 begon een tak van specialistische studie binnen de sociologie, die aanvankelijk geheel werd beheerst door de zogenaamde kenmerkenbenadering ('trait-approach').

In de kenmerkenbenadering worden professies beschouwd als "beroepen die een aantal basiskenmerken gemeen hebben, die hen van de andere (en dus niet-professionele) beroepen onderscheiden. Daarbij staat de auteurs veelal een of een zeer beperkt aantal 'volwaardige' professies voor ogen (...), dan wel een (...) ideaalbeeld van de 'volwaardige" professie" (Van der Krogt 1981, 39). Dit betekent een nadere inperking van het gestelde in 2.3.2.

Greenwood $(1957,45)$ noemt als voornaamste kenmerken van een professie:

1. Er is een basis van systematische theorie, mede gebruikt voor domeinafbakening.

2. De autoriteit van de professional wordt erkend door cliënten, wier behoeften tevens door de professional worden bepaald.

3. Deze autoriteit wordt door de samenleving goedgekeurd en gesanctioneerd.

4. Een ethische code reguleert de relaties van professionals met cliënten en met collega's.

5. Er is sprake van een professionele cultuur, ondersteund door formele beroepsorganisaties.

Deze ideaal-typische opsomming van Greenwood wordt door veel auteurs in het centrum geplaatst van hun bespreking van de kenmerkenbenadering (onder wie Van der Krogt 1981, 39; Dingwall 1983, 8; Toren 1969, 144). Tevens blijkt echter uit hun bespreking dat daarnaast in de literatuur nog vele andere basiskenmerken worden genoemd. De belangrijkste daarvan vormen een uitbreiding van het derde kenmerk van Greenwood en zijn een beroepsopleiding en wettelijke bescherming van het beroep. Ook wordt meermalen gerefereerd aan een 'roepingsidee' als essentiële voorwaarde van toetreding tot een pro* fessie. Lammers (1964) bijvoorbeeld onderscheidt een ideële binding naast een sociale en instrumentele binding aan een professie.

Genoemde kenmerken kunnen worden verdeeld in structüurkenmerken (onder andere opleidings- en toelatingscriteria) en houdingskenmerken (onder andere roepingsidee en gebruik van collega's als referentiegroep) (Hall 1972 in Van der Krogt 1981, 40). Ook is een verdeling mogelijk naar kernelementen (systematische theorie, dienstbaarheidsideaal) en afgeleide kenmerken (alle andere kenmerken) (Goode 1969, in Van der Krogt 1981,40 ). 'Autonomie in taakdefinitie en taakuitvoering" wordt algemeen als het belang- 
rijkste afgeleide kenmerk beschouwd, en daarom soms tot centraal kenmerk verheven (onder andere door Freidson 1970, 71). Larson $(1979, x)$ onderscheidt de kenmerken van een professie naar drie algemene dimensies: een cognitieve dimensie (kennis en kunde, opleiding), een normatieve dimensie (dienstbaarheidsoriëntatie, beroepsethiek) en een evaluatieve dimensie (vergelijking met andere beroepen op basis van afzonderlijke kenmerken, leidend tot een bepaalde mate van autonomie en prestige).

Afhankelijk van de probleemstelling die men als ingang kiest, kunnen binnen de kenmerkenbenadering twee varianten worden onderscheiden: de continuumbenadering en de ontwikkelingsbenadering. Bij de eerste dienen de basiskenmerken te worden opgevat als continua waarop de positie wan professies afzonderlijk kan worden aangegeven. Het karakteristieke van de ontwikkelingsbenadering is, dat een aantal stadia wordt aangegeven waarlangs het professionaliseringsproces van een beroep verloopt (Van der Krogt 1981, 41-42). Als voorbeeld van de laatste benadering brengt Van der Krogt de door Caplow in 1954 onderscheiden stadia naar voren:

1. Oprichting van een professionele vereniging.

2. Naamsverandering om los te komen van oude 'banden'.

3. Ontwikkeling van een ethische code.

4. Voortdurende druk op de politiek om het beroep beschermd te krijgen.

5. (Tegelijk met het vorige punt) ontwikkeling van opleidingsfaciliteiten.

In beide varianten kan professionalisering worden omschreven als het proces waarbij beroepen meer en/of intensiever de kenmerken van de (ideale) professie gaan vertonen.

Op grond van dit laatste is door enkele auteurs ook een onderverdeling of hiërarchie van beroepen opgesteld. Carr-Saunders (in Toren 1969, 143) onderscheidt:

1. Gevestigde professies, de professies in eigenlijke zin, wier praktijk is gebaseerd op theoretische studie en gebonden aan hechte groepsnormen (de jurist, geneeskundige, priester).

2. Nieuwe professies, ontwikkeld op basis van eigen fundamenteel onderzoek (onder andere de chemicus, accountant, en beoefenaars van natuur- en sociale wetenschappen).

3. Semi-professies, die zich meer baseren op de verwerving van technisch kunnen dan op theoretische studie (onder andere de verpleegkundige, optometrist, maatschappelijk werker).

4. 'Would-be'-professies, gefundeerd in de vertrouwdheid met moderne praktijken in de zakenwereld, administratieve sector en actuele conventies (onder andere de ziekenhuismanager, marketing-deskundige).

Etzioni $(1969, v)$ onderscheidt slechts twee categorieèn: professies en semi-professies. De laatste worden in vergelijking tot de professies gekenmerkt door een kortere opleiding, minder gelegitimeerde status, minder erkende geprivilegieerde communicatie, lager niveau van gespecialiseerde 'body of knowledge', en grotere afhankelijkheid van controle door anderen. Voor een bestudering van semi-professies dient volgens Etzioni in het sociologisch onderzoek ook aandacht te worden besteed aan organisatievormen, orndat bijna alle semi-professionals in dienstwerband werkzaam zijn, evenals aan demografische factoren, omdat verreweg het grootst aandeel wordt gevormd door vrouwen, en aan conflict-analyse, omdat "... the normative principles and cultural values of professions, organizations, and female employment are not compatible". (Etzioni 1969, vi; zie ook Toren 1969,144$)$. 
Semi-professies worden ook wel sub-professies of pseudo-professies genoemd (Etzioni 1969 , v). Freidson hanteert de aanduiding 'para-professies', maar reserveen de term hoofdzakelijk voor de para-medische professies. Dit zijn professies wier autonomie slechts partieel is en is afgeleid van en wordt beperkt door de dominante medische professie (Freidson 1970, 49 en 76). Autonomie als centraal kenmerk nemend, vermeldt Toren nog een andere aanduiding van semi-professies, namelijk heteronome professies", een concept dat afkomstig is van Weber: "Heteronomy (...) means that members of the profession are guided and controlled not only from within - that is, by internalized professional norms, expert knowledge, and the professional community - but also by administrative rules and by superiors in the organizational hierarchy" (Toren 1969, 153).

Voor een nadere duiding van geneeskunde als professie is volgens Freidson nog een ander onderscheid van belang, namelijk dat tussen dienstverlenende ('consulting") en wetenschappelijke ('scholarly or learned scientific') professies. Voor de laatste is overheidssteun of steun van ideële groeperingen voldoende ter verkrijging van een monopolie over hun werk. Dienstverlenende professies, zoals de geneeskunde, ondergaan daarenboven nog de test van praktische probleem-oplossingsmogelijkheden ten overstaan van hun lekencliëntele (Freidson 1970, 22): "Unlike science and scholarship, which create and elaborate the formal knowledge of a civilisation, practicing (e.g. consulting, AA) professions have the task of applying that knowledge to everyday life. Practicing professions are the links between a civilisation and its daily life and as such must, unlike science and scholarship, be in some sense joined to everyday life and the average man". (Freidson $1970,74)$.

\subsubsection{De functionalistische benadering}

Een eigenschap van de kenmerkenbenadering is haar exclusief descriptieve grondslag. Men zal tevergeefs zoeken naar een verklaring van de gepresenteerde kenmerken. In de functionalistische benadering wordt getracht in deze lacune te voorzien. Volgens Van der Krogt (1981, 47-48) verloopt de redenering daarbij als volgt: "De professionele beroepen in de maatschappij vervullen bepaalde functies, en wel juist die functies die in belangrijke mate verbonden zijn met de centrale waarden van de samenleving. Om het gevaar van uitbuiting van de samenleving door beroepsbeofenaren te voorkomen, moeten de professionele beroepen voldoen aan een aantal structurele vereisten".

Welke die centrale waarden en structurele vereisten zijn wordt vervolgens uitgelegd aan de hand van (een bespreking van) het werk van Parsons, die algemeen als een belangrijke, zo niet de belangrijkste vertegenwoordiger van het functionalisme in de beroepensociologie wordt gezien (Van der Krogt 1981, 48-51; zie ook Dingwall 1983, 1-12; Murray e.a. 1983, 197-198; Atkinson 1983, 225; Freidson 1970, 159; Larson 1979, xiii). Volgens Parsons is een goed functioneren van de professies van essentieel belang voor onze samenleving: "The professional type is the institutional framework in which many of our most important social functions are carried on (...) the maintenance of which is not an automatic consequence of belief in the importance of the functions as such but involves a complex balance of diverse social forces"t. (Parsons, geciteend in Van der Krogt 1981, 48). De belangrijkste aspecten van dit professionele (ideaal)-type zijn rationaliteit; functionele specificiteit en universalisme. 'Rationaliteit' duidt hier op een normatief patroon (de mens is niet "van nature' op rationaliteit gericht). 'Functionele specificiteit' verwijst naar 
de superieure technische competentie op een specifiek, begrensd gebied en de hiermee samenhangende autoriteit. "Universalisme" duidt op het benutten van maatstaven en criteria die worder ontleend aan algemeen geldig en toepasbaar geachte principes binnen het eigen domein en die dus onafhankelijk zijn wan de specifieke sociale relatie waarwoor ze zijn bedoeld (bijwoorbeeld de relative tussen arts en patiënt in het medisch "universum) (Van der Krogt 1981, 48-49; Dingwall 1983, 3).

Objectief succes en sociale erkenning, als individuele doeleinden van beroepsbeoefenaren, worden bereikt met behulp van een bepaalde set van geinstitutionaliseerde rollen (in de geneeskunde die van arts en zieke; vergelijk bijwoorbeeld Stari 1982). Om deze rollen goed te kunnen 'spelen' zijn affectieve neutraliteit en oriëntering op de beroepsgroep als geheel (collectiviteitsoriëntering) belangrijke vereisten voor de beroepsbeoefenaar. Rolafwijking en rolonaangepastheid worden gecorrigeerd met behulp van subtiele mechanismen, waardoor het algemene karakter van het professionele patroon in onze samenleving kan worden bewaard. Alleen dan gunt de samenleving de professies hun privileges. Zo geldt bijvoorbeeld in de geneeskunde: "De collectiviteitsoriëntering is de institutionalisering van de bescherming van de patiënt tegen uitbuiting" (Van der Krogt 1981, 49-50).

In de functionalistische benadering ligt een zwaar accent op het proces van sociale controle (Rueschemeyer 1983, 41) en op de socialisatie van professionals-in-opleiding (Atkinson 1983, 225). Alleen via dit socialisatieproces wordt verhinderd dat een tegenstelling ontstaat tussen het functioneren van het sociale systeem en de activiteiten van individuen in de samenleving. Op deze wijze wordt overeenstemming verzekerd tussen de normen en waarden binnen het systeem en de subjectieve bedoelingen van sociale actoren. Dingwall en Lewis wijzen er overigens op dat het bij dit socialisatieproces niet zozeer gaat om de verwerving van sociale strategieën ter hantering van werkervaringen, maar om de internalisatie van het normatieve kader van de professie $(1983,223)$. De gemeenschappelijke oriëntatie op 'succes' is hierbij van groot belang, overeenkomstig vigerencle normatieve maatstaven. Of dit nu materieel of immaterieel succes betreft, is van veel minder belang (Dingwall 1983, 3-4).

Indien professionalisering wordt beschouwd als een proces van sociale controle, rijst de vraag wie dan wel de professionele experts controleert in die situaties waarin bescherming tegen bijvoorbeeld incompetentie en uitbuiting is gewenst. Gezien de specifieke kennis van experts en hun autoriteitsrelatie ten opzichte van anderen zullen in het algemeen hun cliënten daartoe niet in staat zijn. Het antwoord van de functionalisten is zowel simpel als verbluffend: de professies zelf; "... the professions 'strike a bargain with society" in which they exchange competence and integrity against the trust of client and community, rellative freedom from lay supervision and inference (bedoeld is 'interference', AA), protection against unqualified competition as well as substantial remuneration and higher social status. As guarantees of this self-control they point to careful recruitement and training, formal organisation and informal relations among colleagues, codes of ethics, and professional courts or committees enforcing these codes." (Rueschemeyer 1983,41 ). Beheersing van het socialisatieproces van professionals-in-opleiding kan op grond van Rueschemeyers uitspraken derhalve worden gezien als een sociaal controlemiddel of -mechanisme.

Het bovenstaande citaat van Rueschemeyer laat tevens zien dat er ook in de functionalistische benadering aandacht is voor de kenmerken van professies. Maar, zoals gezegd, de functionalisten proberen, in tegenstelling tot de aanhangers van de kenmerkenbenade- 
ring, deze kenmerken te verklaren. Bovendien blijt hun aandacht beperkt tot die (elementen van) kenmerken die een functionele relevantie hebben voor de samenleving als geheel, of voor de relatie tussen professional en cliënt (vergellijk ook Van der Krogt 1981, 48). Professionalisering wordt in de functionalistische benadering dan ook gezien als "... een proces waarbij -doordat een beroep een taak gaat vervullen die essentieel wordt geacht in de samenleving- dit beroep bepaalde kenmerken gaat vertonen, die zorgen voor een goede vervulling van deze taken." (Van der Krogt 1981, 38).

\subsubsection{Kritiek op kenmerkenbenadering en functionalisme}

De kenmerkenbenadering en functionalistische benadering zijn niet zonder kritiek gebleven. Vooral de kenmerkenbenadering heeft het zwaar te verduren gehad. De kritiek op de functionalistische benadering loopt voor een gedeelte parallel aan die op de kenmerkenbenadering. Vandaar dat die kritiek in deze paragraaf voor beide benaderingen tegelijk wordt behandeld.

Tegen zowel de kenmerkenbenadering als de functionalistische benadering kan ten eerste worden ingebracht dat hier de eenmaal gegroeide maatschappelijke verhoudingen, zoals door de beroepsgroepen zelf gepercipieerd, als permanent gegeven worden gezien. De beschrijvingen die professies van zichzelf geven, worden eenvoudigweg overgenomen (Van der Krogt 1981, 13-14; Dingwall 1983, 7; Binnenveld 1982, 109). De eigenschappen van professies worden op deze wijze getransformeerd tot quasi-neutrale categorieën, die als zodanig door een oplettend toeschouwer in de werkelijkheid niet hoeven worden teruggevonden (Mungham en Thomas 1983, 136-137). Tevens wordt hiermee ook de ideologie van de desbetreffende beroepen overgenomen (Van der Krogt 1981, 45 en 56). Bovendien hebben de gegevens, waarop de uitspraken over professies in het algemeen zijn gebaseerd, slechts betrekking op enkele (vanouds toonaangevende) beroepen, met name de geneeskunde (Van der Krogt 1981, 14). Gezien vanuit de behoefte aan een omschrijving van 'professie' en 'professionalisering" die ook voor het moderne beroep van toepassing is (zie 2.3.2), kunnen we stellen, dat de hier gegeven definities een te geringe reikwijdte bezitten. De in beide benaderingen naar voren gebrachte kenmerken van professies overtuigen dan ook niet als objectief vast te stellen attributen waarmee professies kunnen worden onderscheiden van beroepen (Freidson 1970, xix en 83; Larson 1979, xi). De theoretische waarde van deze benaderingen is derhalve aan twijfel onderhevig. $\mathrm{Bo-}$ vendien is er onvoldoende sprake van een uitgewerkt kritisch-historisch kader.

Een tweede punt van kritiek betreft het statisch-deterministische karakter van zowel de kenmerken- als de functionalistische benadering. Dit hangt enerzijds samen met het eerste punt van kritiek, anderzijds komt het vooral tot uiting in een geringe aandacht voor de individuele kant van beroepsmatige arbeid. Wat het eerste betreft, er wordt vooral aandacht geschonken aan structurele en/of functionele aspecten met betrekking tot professies. Hoe deze structuren en functies zijn ontstaan en vooral van welke processen zij het gevolg zijn en welke storingen daarin optreden, wordt nauwelijks aan de orde gesteld. Dit. leidt tot een rigide toepassing van het kenmerkenschema en tot een soort van etikettering van beroepen, waarbüj andere eigenschappen en kenmerken worden gemarginaliseerd. Ten tweede wordt gemakshalve over het hoofd gezien, dat vormgeving en wijziging van de werkelijkheid een sociaal subject vooronderstellen, dat geen onveranderlijk abstractum is, maar verwijst naar individuele actoren, die voortdurend wisselen en 
zich ontwikkelen. Verschillen en constanten in individuele beroepsuitoefening en de aard daarvan kunnen niet worden verklaard met behulp van de formele kenmerken van een professie. Daardoor kan ook een professie (als verzamelling beroepsbeoefenaren) niet worden begrepen als een waststaande werkelijkheid, waarvan de eigenschappen een continu gegeven vormen (vergelik Freidson 1970, 83-84). Met name in de kenmerkenbenadering 'overkomt' professionalisering als het ware een beroep (Van der Krogt 1981, 14 en 47).

Een derde en laatste punt van gemeenschappelijke kritiek op de kenmerkenbenadering en functionalistische benadering betreft het gebrek aan aandacht woor de verschillende maatschappelijke rollen van beroepsgroepen. Dit hangt samen met het feit, dat het onderwerp te zeer als geisoleerd fenomeen is bestudeerd (Van der Krogt 1981, 14) en te weinig in de context van sociaal-economisch en sociaal-historisch bepaalde marktmechanismen (Larson 1979, xi; Dingwall 1983, 7), sociale (politieke) machtsrelaties (Van der Krogt 1981, 14) en sociale verantwoordelijkheid (Haug 1980, 61). De hierop gebaseerde processen in de samenleving vormen volgens recente beroepensociologische inzichten een duidelijker verklaring voor de rol van professies dan in de kenmerkenbenadering en functionalistische benadering tot uiting komt (zie de genoemde auteurs).

De specifieke kritiek op de functionalistische benadering concentreert zich vooral op de veronderstelde systeembehoeften en belangenoverlap. Volgens Van der Krogt (1981, 51) kunnen vraagtekens worden gezet bij de opvatting dat de adequate vervulling van maatschappelijke behoeften bepalend is voor de institutionele structuur en praktijken van beroepen, omdat onduidelijk blijft wie die maatschappij vertegenwoordigen en hoe bijvoorbeeld maatschappelijk welzijn moet worden gedefinieerd. Parsons tracht weliswaar de institutionalisering van de medische professie te verklaren vanuit de behoeften van het sociale systeem aan gezonde actoren voor de vervulling van relevante rollen, maar ziet daarbij de eigen behoeften en belangen van de medische beroepsgroep en haar individuele cliënten over het hoofd. Gezondheidsbehoeften kunnen bij een dure gezondheidszorg botsen met economische behoeften. Voorrang voor vervulling van economische behoeften en belangen van cliënten kan zeer nadelig zijn voor de behoeften en belangen van de medische professie. Belangentegenstellingen zijn in beginsel in elk sociaal systeem aanwezig, waardoor het bestaan van behoeften van het systeem als geheel (systeembehoeften) in twijfel kan worden getrokken. Van belangenoverlap zal dan ook meestal geen sprake zijn, tenzij een geduchte gezamenlijke vijand moet worden bestreden (bijyoorbeeld de ziekte AIDS).

Belangentegenstellingen zijn ook aanwezig binnen een beroepsgroep zelf. In 2.3 .1 is al gewezen op de grote mate van segmentering die binnen een beroepsgroep kan optreden. Verschillen in beloning en status zijn daarvan zowel oorzaak als gevolg. De typisch functionalistische notie van een professie als beroepsgemeenschap van leden met gemeenschappelijke waarden lijkt met dit gegeven in tegenspraak (Mok 1973, 52 en 61; Larson 1979, $\mathrm{xi}_{*}$ Van der Krogt 1981, 53-54).

Juister is echter orn de kritiek vooral te richten op het exclusieve karakter van deze notie in de functionalistische traditie. Bij 'geslaagde' professies kan zowel sprake zijn van sterke segmentering als van een sterke gemeenschappelijke oriëntatie op sociaal-culturele waarden. Deze functioneren immers als legitimeringsgrond. Daarnaast wordt Parsons verweten nogal vaag te zijn geweest over die gemeenschappelijke waarden, met name 
hun oorsprong en overdracht, en hun internalisatie als component van de wijze waarop het beroep wordt uitgeoefend (Dingwall 1983,7).

Kritiek is er ook op Parsons' zienswijze, dat de belangrijkste aspecten van het professionele ideaal-type ook van toepassing zijn op de geneeskunde. Volgens Freidson (1970, 168-170) wordt de medische praktijk -medisch onderzoek en medische wetenschap laat hij buiten beschouwing- eerder geleid door particularisme en functionele diffusiteit dan door universalisme en functionele specificiteit. De medicus-practicus is overtuigd van zichzelf en bovenal een pragmaticus (particularisme) en betreedt mede daardoor terreinen die buiten zijn competentie liggen (functionele diffusiteit). In tegenstelling tot Freidson $(1970,171)$ plaatst Johnson (aangehaald in Van der Krogt 1981, 53) bovendien vraagtekens bij Parsons' nadruk op de cognitieve rationaliteit bij professies. Hierdoor wordt het zicht verduisterd op aantoonbare machtsrelaties binnen beroepsgroepen en op de sociale selectie van patiënten en behandelingsmethoden. Overigens lijkt de kritiek van Freidson enigszins achterhaald door recent onderzoek, waarbij is aangetoond dat onder invloed van moderne, vooral technologische ontwikkelingen, de processen van professionalisering en bureaucratisering steeds meer hand in hand gaan en dus niet als tegengestelde mechanismen mogen worden beschouwd voor de oplossing van complexe problemen binnen organisaties (zie verder 2.3.9).

\subsubsection{De procesbenadering}

Op de bouwvalligheden van de kenmerkenbenadering en de functionalistische benadering trachtte men het gebouw van de professies en professionalisering opnieuw op te richten. Voorall sinds de jaren zeventig worden veel pogingen ondernomen tot hernieuw* de conceptualisering. Kenmerkend hiervoor is de voortdurende discussie die daarbij wordt gevoerd met het verleden. Om deze reden worden zij ook wel betiteld als antistructureel-functionalistisch (onder andere Van der Krogt 1981, 21).

Deze benaming is niet geheel juist. Telkens blijkt, dat in de nieuwe benaderingen gebruik wordt gemaakt van elementen uit vroegere of dat ze eigenlijk bestaan uit de oude in een ander jasje. Oude en nieuwe benaderingen sluiten elkaar dus niet geheel uit. Integendeel, vaak is er sprake van wederzijdse bevruchting. Elementen, die ook in de meeste nieuwe pogingen overeind blijven, zijn bijvoorbeeld de structureel-functionalistische uitgangspunten "... dat een eenmaal gecreêerde structuur een 'sociaal feit' is, dat als zodanig een beperking voor individuen vormt" en "... het belang van socialiseringsprocessen en het integratieve effect van gedeelde waarden en normen." (Van der Krogt 1981, 22).

Socialiseringsprocessen en normatieve integratie van collectiviteiten leveren min of meer stabiele sociale verbanden op. Maar de op basis hiervan bestaande beperkingen voor individuen, zowel binnen als buiten zo'n collectiviteit of sociaal verband, leiden tot weerstanden die moeilijk onder controle zijn te houden. Macht en conflict zijn elementen die nauw met vormen van institutionalisering en legitimering zijn verbonden (zie ook 2.3.3). Daarnaast worden zij gerealiseerd in een sociaal-culturele context die voortdurend aan verandering onderhevig is. Professies en professionalisering zijn verschijnselen die van deze invloeden niet ontheven zijn. Vandaar dat deze verschijnselen in toenemende mate als een dynamisch proces worden beschreven en vanuit een ontwikkelingsperspectief worden geïnterpreteerd. Beroepensociologische studies die in een dergelijk kader worden verricht, zouden wij willen vatten onder de algemene noemer van de 'procesbenade- 
ring'. 'Professionalisering', als proces-beschrijvende term, kreeg in deze studies meer aandacht dan het meer statische begrip 'professie'. De nadruk ligt op de beschrijving van historische condities en sociale processen. Momentopnamen worden minder relevant geacht.

In de procesbenadering -eigenlijk moeten we hier van een meervoud spreken-wordt gebruik gemaakt van allerlei elementen uit verschillende sociologische modellen. Van der Krogt noemt onder andere conflictmodellen, ruilmodellen, speltheoriemodellen, symbolisch interactionisme, symbolisch-structurele modellen. Alle zijn ontwikkeld of herontdekt als reactie op het structureel-functionalisme. Van der Krogt zelf ontwikkelt zijn professionaliseringsmodel vanuit een actie-sociologisch perspectief, waarbij vooral teruggegrepen wordt op het symbolisch interactionisme en vervolgens op de ruiltheorie en op elementen uit de structureel-functionalistische traditie. Zijn uitgangspunt ligt bij "de actor als primaire bron van handelen, inclusief de creatie van structuren" (Van der Krogt 1981, 21-22).

Ook Dingwall ziet het symbolisch interactionisme als een belangrijke inspiratiebron voor de hedendaagse professionaliseringsmodellen en -theorieën. Het steunt in hoofdzaak op het werk van de Amerikaanse sociologische school van Chicago ten tijde van de Tweede Wereldoorlog. Everett Hughes geldt als de voorman van deze sociologische stroming (onder zijn leerlingen bevonden zich bekende sociologen als Becker, Goffman, Strauss en Freidson; de laatste is in dit hoofdstuk al meermalen genoemd). Zij had een sterk empirische grondslag, naar voren komend in een combinatie van kwalitatief onderzoek en antropologische veldstudies die in de sociale smeltkroes van Chicago goed gedijden (Dingwall 1983, 4).

In Hughes' gedachtengang staan twee concepten centraal: bevoegdheid (license) en mandaat. Alle beroepen hebben een impliciete of expliciete bevoegdheid tot het uitvoeren van bepaalde activiteiten, die verschillen van de activiteiten van anderen. In ruil daarvoor worden geld, goederen en diensten ontvangen. Het is deze geformaliseerde ruilrelatie die werk doet verschillen van andere activiteiten. Indien daarnaast door de beoefenaars van een beroep gemeenschapszin wordt ervaren op basis van gedeelde werkervaringen zullen zij waarschijnlijk tevens een mandaat claimen om zelf te bepalen welk beroepsgedrag, welke technische inhoud, welke stijl van dienstverlening en vooral welke patronen van publieke vraag en aanbod aan de beroepsuitoefening moeten worden verbonden. Professies beschouwt Hughes als een duidelijke illustratie van de mogelijke wettelijke, intellectuele en morele reikwijdte van een mandaat: "Not only do professions presume to tell the rest of their society what is good and right for it: they can also set the very terms of thinking about problems which fall within their domain. They exemplify in an extreme form the role of trust in modern societies with an advanced division of labour." (Dingwall 1983,5).

Deze arbeidsverdeling is een belangrijk facet van zowel de functionalistische als de symbolisch-interactionistische benadering van het verschijnsel professionalisering, belangrijker nog dan het onderscheid tussen professies en andere beroepen. Maar terwijl de functionalisten professies nog primair zagen alls een speciale categorie van beroepen, wordt in het symbolisch interactionisme het onderscheid tussen beide vooral als van symbolische aard beschouwd. Het begrip vertegenwoordigt meer een claim dan een werkelijkheid. Arbeid, beroepsopleiding en beroepsideologie worden meer bepaald door de concrete arbeidsverdeling dan door de veronderstelde aard van het beroep. Het is in deze opvat- 
ting ook alleszins denkbaar, dat meer aandacht bestaat voor het individuele arbeidsproces dan voor eventueel aanwezige overkoepelende structuren en waarden- en normenpatronen. Binnen de symbolisch-interactionistische benadering worden veelvuldig studies aangetroffen naar de vraag hoe leden van bepaalde beroepsgroepen opereren en overleven temidden van conflicterende tendenzen en spanningen tijdens de uitoefening van hun beroep (Atkinson 1983, 226-227). Dit heeft overigens van diverse zijden kritiek opgeleverd. Er zou binnen de symbolisch-interactionistische benadering te weinig rekening zijn gehouden met de organisatorische aspecten van beroepsmatige arbeid en de wederzijdse beïnvloeding van individuele en collectieve factoren tijdens het proces van professionalisering (zie onder andere Van der Krogt 1981, 27; Dingwall 1983, 7; Atkinson 1983, 234; Rueschemeyer 1983, 39). Verschillende elementen uit het symbolisch interactionisme worden in latere beroepensociologische studies nader uitgewerkt, deels in het verlengde ervan, deels als reactie erop. We zullen hier slechts één studie citeren, namelijk die van Van der Krogt (1981). Voor deze keuze zijn verschillende redenen aan te geven:

1. Van der Krogt's studie bevat een discussie met de belangrijkste posities van en bezwaren tegen de symbolisch-interactionistische benadering.

2. Van der Krogt levert niet alleen interessant en zeldzaam empirisch materiaal omtrent de situatie in Nederland, maar plaatst dit tevens in een conceptueel raamwerk dat model kan staan als basis voor zowel praktische als theoretische studies in de toekomst. Dit neemt niet weg dat er nogal wat kritiek is geleverd op de wijze waarop hij zijn zogenaamde machtsbenadering empirisch heeft uitgewerkt. Met name Klinkert (1982, 113) heeft aangegeven dat documenten van beroepsgroepen als uitgangspunt voor de desbetreffende benadering problematisch zijn.

3. Zijn studie bevat een aantal elementen die van belang zijn bij de uitwerking van een vraagstelling voor de onderhavige studie. We komen daar nog op terug.

Zoals gezegd, bestaat de achtergrond van Van der Krogts model uit een symbolisch-interactionistisch geïnspireerd actiesociologisch perspectief. Het belangrijkste conceptuele element dat uit de symbolisch-interactionistische traditie wordt overgenomen is de actor als primaire bron van handelen, gekenmerkt door vrijheid en rationaliteit en handelend niet op basis van objectieve feiten en omstandigheden, maar op basis van de perceptie van die feiten en omstandigheden. Uit de ruiltheorie wordt overgenomen, dat het vooral de belangen van de actor zijn die het handelen kunnen verklaren. Verder wordt via de structureel-functionalistische traditie de lijn van Durkheim en de negentiende-eeuwse Franse sociologie voortgezet in de visie, dat een structuur als sociaal feit een beperking voor individuen vormt. Ook het belang van socialiseringsprocessen en de integratie van collectiviteiten op basis van gedeelde waarden en normen wordt onderschreven. Van der Krogt beschouwt de structureel-functionalistische elementen vooral als "een relativering van de 'overbewuste' actor uit het symbolisch interactionisme, en het 'hyperrationele' individu uit de ruiltheorie." (21-22).

Zoals andere aanhangers van de procesbenadering gaat ook Van der Krogt vooral in op het verschijnsel professionalisering. Hij legt daarbij een accent op de collectieve aspecten. Dat wil zeggen: voor professionalisering wordt het essentieel geacht dat een aantal individuele actoren de krachten bundelt en een door gezamenlijke actie gedragen proces in gang zet. Daar professionele beroepsgroepen een machtsfactor vormen, wordt deze collectieve actie tevens gekenmerkt door pogingen collectieve macht te verwerven (16). Zelf noemt Van der Krogt zijn procesbenadering een machtsbenadering (57). 
'Professionalisering' wordt door Van der Krogt gedefinieerd als "een proces waarbij leden van een beroepsgroep op collectieve wijze, vooral gebruik makend van kennismacht, trachten een collectieve machtspositie te verwerven en/of te verdedigen, met het doel de gebruiks- en ruilwaarde van het beroep te beheersen." (94). Aan de hand van deze definitie worden de diverse kernelementen van het model nader toegelicht.

Collectief gedrag wordt essentieel geacht voor professionalisering. Fundament van dit collectieve gedrag is echter het individuele gedrag van beroepsbeoefenaren: "... professionalisering is primair gebaseerd op de behoeften en belangen van de individuele beroepsbeoefenaar (...) en diens individuele machtspositie ..." (95). Voor een antwoord op de vraag welke deze behoeften zijn en of er een prioriteit in kan worden aangebracht doet Van der Krogt een beroep op Vrooms definitie van motivatie: "... een proces dat de keuze leidt die door personen (...) wordt gemaakt tussen alternatieve vormen van vrijwillige activiteit (...). De motivatie wordt (...) enerzijds bepaald door de verwachting dat het doel bereikt kan worden (...) en dat hier een beloning tegenover zal staan, en anderzijds door de sterkte van de voorkeur voor de beloning." (100). Van der Krogt vertaalt behoeften klaarblijkelijk in motieven.

In materiële zin kan een aantal motieven worden onderscheiden voor de uitoefening van een beroep. Van der Krogt bijvoorbeeld noemt de volgende:

1. Dienstbaarheid aan mens en samenleving.

2. Uitoefening van het vak op zichzelf.

3. Contraprestaties (101).

Ten aanzien van aankomend artsen somt Freidson $(1970,178)$ vier kernmotieven op:

1. Dienstbaarheid ('helping individuals').

2. Zelfontplooiïng ('intellectual investment').

3. Inkomen en prestige.

4. Onafhankelijkheid en autonomie.

Deze (en andere) motieven kunnen worden samengevat in het formele onderscheid tussen een expressieve beroepsoriëntatie en een instrumentele beroepsoriëntatie (De Jager en Mok 1983, 289-290), respectievelijk een 'vocational orientation' en een 'entrepreneurial orientation' (Larson 1979, 60-62). In een expressieve of 'vocational' oriëntatie wordt de uitoefening van een beroep vooral gezien als een middel tot zelfontplooiing en dienstbaarheid (ook wel de intrinsieke waarde van arbeid genoemd). In een instrumentele of 'entrepreneurial' oriëntatie ligt de nadruk op contraprestaties als inkomen, prestige, onafhankelijkheid en autonomie (extrinsieke waarde van arbeid). Uiteraard kunnen de meeste uit deze oriëntaties voortvloeiende behoeften ook buiten het beroep worden vervuld. Door deze en andere factoren zal de 'mix' van motieven van elke kandidaat-beroepsbeoefenaar weer een andere structuur en hiërarchie vertonen.

Professionalisering wordt behalve door de motieven van beroepsbeoefenaren ook bepaald door hun belangen. Deze zijn in zekere zin het complement van die motieven en worden door Van der Krogt omschreven als: "... het handhaven en vergroten van de behoeftenbevredigingscapaciteit van een beroep." (103). De gebruiks- en ruilwaarde van een beroep spelen hierin een belangrijke rol. Ten aanzien van het motief dienstbaarheid stelt hij bijvoorbeeld: "De behoefte aan dienstbaarheid aan mens en samenleving, kan door het werk worden vervuld indien mens en samenleving aan dit werk behoefte hebben, waarde aan dit werk toekennen. Hoe groter deze 'gebruikswaarde', des te meer kan de dienstbaarheidsbehoefte worden vervuld. Tevens kan echter de behoefte aan contra- 
prestatie meer worden vervuld. Dit is echter geen automatische relatie, waardoor het nastreven van een goede 'ruilwaarde" eveneens een belang is." (103). Andere belangen van de beroepsbeoefenaar zijn: "De mogelijkheid van beroepsuitoefening zoals gewenst ....", en -indien noodzakelijk- "... medewerking van de cliënt ..." (103). Het voorgaande kan dan in een schema worden samengevat zoals vermeld in figuur 2.1 .

Figuur 2.1: Oriëntatie op het beroep: motieven en belangen

\begin{tabular}{|c|c|c|}
\hline $\begin{array}{c}\text { expressieve/ } \\
\text { vocational } \\
\text { orièntatie }\end{array}$ & dienstbaarheid & gebruikswaarde \\
\hline $\begin{array}{c}\text { instrumentele/ } \\
\text { entrepreneurial } \\
\text { oriëntatie }\end{array}$ & zelfontplooiing & $\begin{array}{c}\text { beroepsuitoefening } \\
\text { als gewenst } \\
\text { inkomen/prestige } \\
\text { medewerking } \\
\text { consument/cliënt } \\
\text { onafhankelijkheid/ } \\
\text { autonomie }\end{array}$ \\
ruilwaarde \\
\hline
\end{tabular}

Behartiging van belangen moet de beroepsbeoefenaar zekerheid verschaffen over de beroepsuitoefening in de toekomst, dus "... vormen belangen even zovele onzekerheden voor de toekomst ..." en "... kunnen dus ook als onzekerheidsbronnen worden geformuleerd (...). Het omgaan met onzekerheidsbronnen is voor elke beroepsbeoefenaar een meer of minder groot probleem; het beheersen ervan een belang." (104-105).

Centraal in dit proces staan de gebruikswaarde en ruilwaarde van het beroep. Vergroting daarvan vermindert de onzekerheid van de beroepsbeoefenaar en is een belangrijke factor in het professionaliseringsproces. Voor een bepaling van de middelen die een beroepsbeoefenaar ter beschikking staan om dit te realiseren, introduceert Van der Krogt het begrip 'marktcapaciteit': "De marktcapaciteit verwijst naar de reeks eigenschappen die de individuele beroepsbeoefenaar relevant acht voor zijn beroepsuitoefening, en die hij als 'ruilobject' aanbiedt aan de afnemer van zijn diensten." (107). Als belangrijkste eigenschappen worden vervolgens vermeld: arbeidsbeschikbaarheid (universeel ruilobject) en kennis en kunde (specifiek, domeingebonden ruilobject) (109). De gebruikswaarde van een beroep wordt bepaald door de maatschappelijke behoefte aan de ingebrachte marktcapaciteit (dus vooral arbeidsbeschikbaarheid en kennis en kunde) en de waarde die eraan wordt toegekend. Kennisbeheersing heeft echter een relatief hoge gebruikswaarde, omdat zij voor de afnemer tevens een belangrijke mate van onzekerheidsbeheersing impliceert, iets dat voor arbeidsbeschikbaarheid op tal van terreinen in veel mindere mate geldt (109). Kennis en kunde zijn daarmee een belangrijke bron van macht voor de beroepsbeoefenaar (110).

Wat een machtsbron is, welke machtsbroninen kunnen worden onderscheiden en welke rol zij spelen in het professionaliseringsproces, laat Van der Krogt zien aan de hand van 
zijn beschrijving van de machtspositie van beroepsbeoefenaren. Bij een machtspositie is volgens hem sprake van "... een spiraalproces: een machtspositie komt tot stand op grond van bepaalde machtsbronnen waarna vervolgens, op grond van deze positie, de primaire machtsbronnen effectiever gebruikt kunnen worden, waardoor de machtspositie wordt verstevigd, etc." (112). De machtspositie van een beroepsbeoefenaar definieert hij als ".... een positie in een stelsel van relaties die vooral op basis van deskundigheidsmacht en normatieve macht verkregen is, en van waaruit de beroepsbeoefenaar invloed kan uitoefenen op de totstandkoming van beslissingen in het stelsel van relaties, en de uitvoering daarvan." (112). Naast deskundigheidsmacht (op grond van kennis en kunde) is dus ook de normatieve macht een belangrijke primaire machtsbron. Zij wordt "... ontleend aan het feit dat een doel wordt nagestreefd waaraan door de samenleving een hoge waarde wordt toegekend ..." (111). Daarnaast worden als machtsbronnen genoemd: onzekerheidsbeheersing, centraliteit (verbondenheid met andere delen van de organisatie), en onvervangbaarheid. Deze hangen echter sterk samen met de deskundigheidsmacht (alle genoemde bronnen) en/of de normatieve macht (centraliteit). Verder worden nog genoemd: sanctiemacht, legale macht en referentiemacht. Deze functioneren echter vooral als secundaire machtsbronnen, omdat zij pas tijdens het professionaliseringsproces worden verkregen (110-111). Voor het ontstaan van een collectieve machtspositie en dus voor professionalisering van een beroep zijn institutionalisering en legitimering van die positie van groot belang (96; zie voorall ook 2.3.3 hierboven).

Op grond van het bovenstaande ontwerpt Van der Krogt een basisschema van professionalisering (zie figuur 2.2). Hierin zijn tevens een aantal externe invloeden op het proces van professionalisering ingevuld.

Met behulp van dit schema kan een groot aantal professionaliseringsstrategieën worden onderscheiden, elk gericht op een of meer onderdelen van de machtspositie en machtsbronnen. Van der Krogt werkt 18 strategieën uit en lardeert ze met veel voorbeelden. We vermelden er hier één om de werking van het basisschema nader te verhelderen. Waar nodig zal in het vervolg van deze studie een nuttig gebruik worden gemaakt van het beschikbare materiaal.

Eén van de strategieën is gericht op vergroting van de centraliteit bij de onzekerheidsbeheersing (in het schema: vergroting van de gebruikswaarde van een beroep door middel van domeininstitutionalisering en -legitimering vanuit de collectieve machtspositie):

\footnotetext{
"Wanneer een behoefte of onzekerheidsbron wordt gedefinieerd waarvoor het eigen beroep de gehele, of een belangrijk deel van de oplossing biedt, is automatisch de centraliteit bij de behoeftevervulling of onzekerheidsbeheersing gewaarborgd. Maar ook wanneer het eigen beroep niet de oplossing van het probleem kan leveren, kan toch een centrale positie worden ingenomen. Deze situatie is te vinden in die gevallen dat een beroepsgroep bij een onzekerheidsbeheersing wordt ingeschakeld (zich zelf weet in te schakelen of ingeschakeld te houden), terwijl het eigenlijke werk door een ander beroep, weelal lager in de kennishiërarchie, wordt gedaan. Dit is bijvoorbeeld te zien in de relatie huisarts-fysiotherapeut. Op grond van zijn (veronderstelde) grotere kennis, wordt de huisarts beter in staat geacht eerst een diagnose te stellen, om te bezien of inschakeling van een fysiotherapeut noodzakelijk is, en hoe lang. De huisarts is een sluis, en de fysiotherapeut is afhankelijk van hem. Toch bezit de fysiotherapeut waarschijnlijk op zijn vakgebied meer kennis en zeer zeker meer kunde dan de huisarts. Maar de diagnose, of fysiotherapie dan wel een andere oplossing geïndiceerd is, wordt vanwege de bredere kenmis van de huisarts aan hem en niet aan de fysiotherapeut toevertrouwd.

Door handhaving van een centrale positie kan een beroepsgroep ook de gevolgen van het 'afbrokkelen" van het domein beperken. Zo hebben de tandartsen hun positie kunnen handhaven door te bewerkstelligen dat tandhygiënisten alleen onder leiding van tandartsen mogen werken.
} 
(Overigens is dit inmiddels achterhaald: er zijn ook vijigevestigde tandhygiênisten casu quo mondhygiënisten, AA).

Ook de creatie van een centrale positie bij nieuwe domeinen komt woor Nu er ten aanzien van de psychotherapie het een en ander geregeld gatat worden, is de kans groot dat de verwijzing naar een psychotherapeut door de huisarts moet geschieden. Verder pleiten de psychiaters erwoor, dat de 'intake bij instituten voor psychotherapie aan hen wordt voorbehouden." (138139).

Van der Krogt past het door hem ontwikkelde conceptuele model toe op de ontwikkeling van het beroep van huisarts na de Tweede Wereldoorlog in Nederland alsmede op het ontstaan en de ontwikkeling van het beroep van bijstandsmaatschappelijk werker. Ook deze case-studies zijn voorbeelden van de wijze waarop vanuit een conceptueel kader het concrete verloop van professionaliseringsprocessen (hier van twee zeer uiteenlopende beroepen) kan worden beschreven en het belang ervan kan worden aangeduid.

Figuur 2.2: Basisschema van professionalisering (Bron: Van der Krogt 1981, 126)

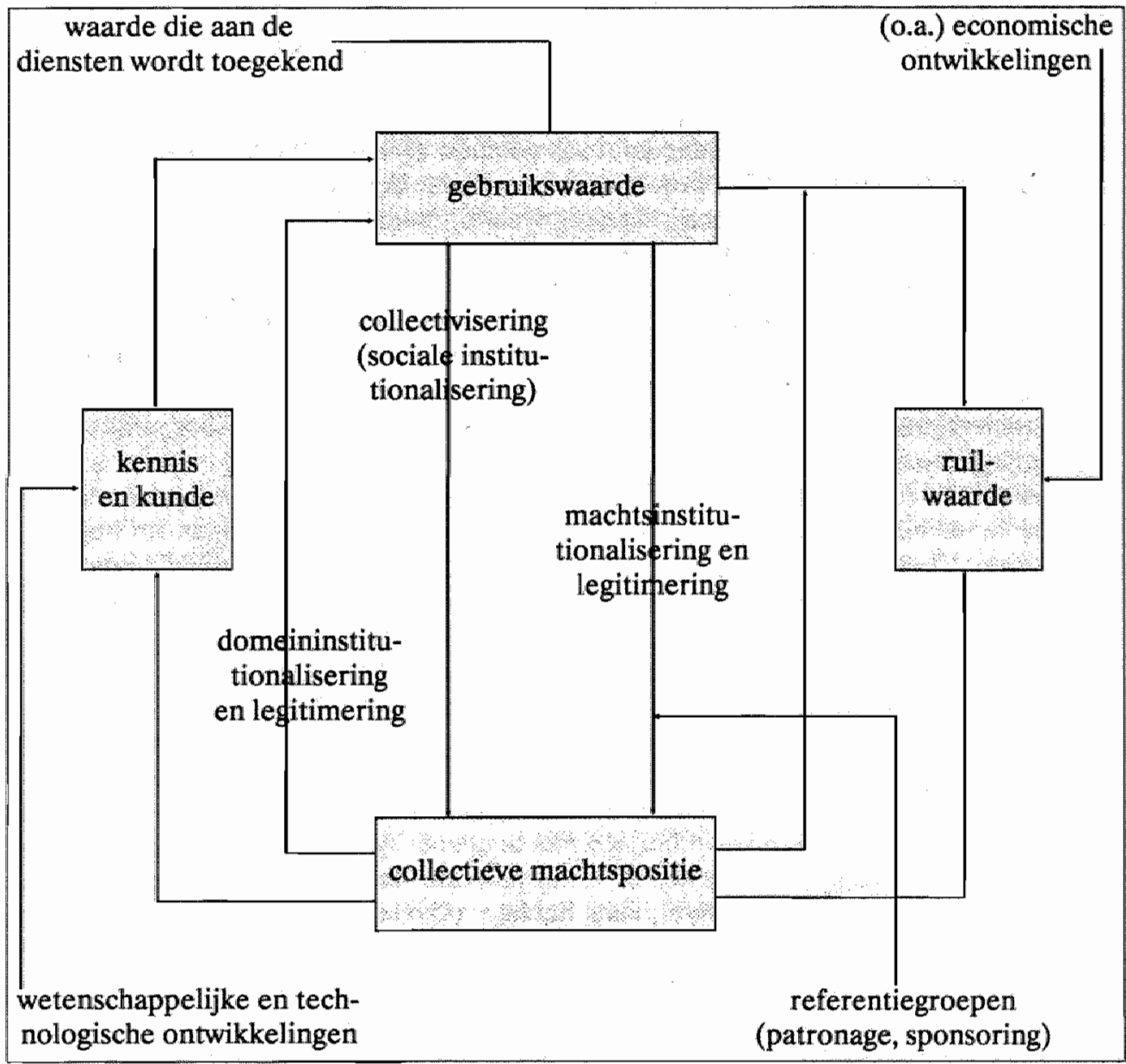




\subsubsection{Openstaande vragen}

De sociologie van het beroep heeft een gestage ontwikkeling doorgemaakt. Binnen dit onderzoeksspecialisme ontstonden talloze conceptuele modellen, waarbij voortdurend werd voortgebouwd op de verdiensten van eerdere modellen en werd getracht de feilen wan deze modellen in betere constructen op te vangen. Hoewel het in eerste instantie vooral ging om een adequater beschrijving en verklaring van de verschijnselen beroep, professie en professionalisering als zodanig, werd bovendien aansluiting gezocht bij de dominante theoretische stromingen binnen de sociologie als geheel. Omdat hedentendage nauwelijks van een duidelijk dominante stroming kan worden gesproken, betekent dit, dat in de meeste moderne conceptuele modellen elementen herkenbaar zijn uit versehillende theoretische stromingen. Zoals gezegd (zie 2.3.7), bekent Van der Krogt (1981) zich bijwoorbeeld zowel tot het functionalisme als tot het symbolisch interactionisme, zowel tot de actietheorie als tot de ruiltheorie.

Is met de veelheid aan conceptuele modellen, visies en empirisch onderzoek met betrekking tot beroepen, professies en professionalisering nu alles over deze verschijnselen naar voren gebracht en bekend? Volgens Dingwall (1983, 11-12) blijkt uit recente ontwikkelingen, dat onderzoekers op dit terrein het op drie punten in grote mate met elkaar eens zijn:

1. Allereerst is duidelijk geworden, dat de genoemde verschijnselen in een veel breder perspectief dienen te worden bestudeerd, met name in een historisch perspectief en op zowel individueel als collectief niveau. Daarbij moet professionele arbeid niet alleen worden bestudeerd in de context van arbeidsdeling, maar ook als onderdeel van het netwerk van sociaal-economische relaties.

2. Ten tweede moet nog groter belang worden gehecht aan de factor kennis. Arbeidsdeling impliceert ook verdeling van kennis, met dienovereenkomstige gevolgen van wederzijdse afhankelijkheid en kwetsbaarheid voor betrokkenen. Kennis is bovendien een sociaal product, hetgeen het ontstaan en instandhouden van een bepaalde sociale orde impliceert.

3. Als derde en belangrijkste punt van overeenstemming brengt Dingwall naar voren de urgentie van vergelijkend empirisch onderzoek. In dit verband wordt een strikte scheiding tussen beroepensociologie en sociologie van de professies een doodlopende weg genoemd. Van groter belang zijn gedetailleerde gevalsbeschrijvingen van arbeidssituaties en werk-settingen, hoewel ook deze dienen te worden gebaseerd op een breder begrip van structurele en culturele factoren dan voorheen het geval was.

Freidson (1983) sluit zich nadrukkelijk bij Dingwall aan, vooral bij diens eerste en derde punt. In een conceptuele analyse van het begrip 'professie' geeft hij een nadere schets van de 'state of the art' in de theorie van de professies. Op conceptueel niveau is er naar zijn mening in de jaren zeventig en tachtig nauwelijks iets veranderd, in die zin, dat verreweg de meeste auteurs vast blijven houden aan het generiek concept 'professie' in plaats van een generiek concept van 'beroepen' te formuleren, waarbinnen de als professies gelabelde afzonderlijke beroepen hun plaats hebben. (Overigens is een dergelijk concept wel uitgewerkt in de arbeids- en organisatiesociologie, maar daar richt onze aandacht zich nu niet op). Voor de ontwikkeling van een theorie van de professies is daarentegen noodzakelijk, dat het begrip wordt opgevat als een historisch bepaalde constructie, geldig 
binnen een beperkt aantal samenlevingen, en dat onderzoek wordt verricht naar de ontwikkeling, het gebruik en de gevolgen ervan in die samenlevingen, zonder dat meer dan bescheiden generalisaties worden nagestreefd (Freidson 1983, 20). De onderzoeksstrategie dient fenomenologisch van aard te zijn: "One does not attempt to determine what profession is in an absolute sense so much as how people in a society determine who is a professional and who is not, how they "make' or 'accomplish" professions by their activities, and what the consequences are for the way in which they see themselves and perform their work." (27). Als zodanig zijn case-studies van afzonderlijke (groepen) beroepsbeoefenaren van groot belang voor een sociaal relevante taxonomie (36),

Rueschemeyer (1983) gaat in op het onderwerp van de tweede conclusie of aanbeveling van Dingwall. Zijn standpunt betekent een herwaardering van de functionalistische positie ten aanzien van de sociale controle op deskundigheid. Door arbeidsdeling kon kennis een bepaalde bron van macht gaan vormen. Terwijl voor functionalisten de regulering van die macht gelegen was in handen van de beroepsgroepen zelf, wijst Rueschemeyer op het brede spectrum van oplossingen die in de geschiedenis voor dit probleem zijn gegeven, afhankelijk van de kenmerken van de verschillende samenlevingen waarin ze voorkwamen, van het evenwicht tussen beroepsgroepen, consumentengroepen en overheden en van de culturele vormen van kennis. Het onderzoek naar dit spectrum van oplossingen staat nog slechts in de kinderschoenen (47 en 54).

Ook het model van Van der Krogt lost alle problemen niet op. Het schept weliswaar duidelijkheid op conceptueel niveau en bezit ook een zekere zin-adequaatheid, maar veel gedegen empirisch onderzoek is nodig om bovendien de causale adequaatheid ervan aan te tonen (Van der Krogt 1981, 247). De centrale themata in zijn model -beĩnvloeding en machtsuitoefening- kunnen een zoveelste voorbeeld worden van een eenzijdige nadruk op bepaalde elementen uit de werkelijkheid die wordt aangeduid met de termen professie en professionalisering (Freidson 1983, 32). Het onderzoek naar beĭnvloeding en machtsprocessen noemt Van der Krogt ook het belangrijkste probleem van onderzoek naar professionaliseringsprocessen: "Dit onderzoek houdt reeds jaar en dag de wetenschappelijke gemoederen bezig. Zelfs de onderzoeksresultaten naar openlijke machtsuitoefening leidden al tot disputen (...). De latere nuanceringen van het machtsbegrip (...) maakten de onderzoeksproblemen alleen maar groter." (Van der Krogt 1981, 248). Voor het positivistisch georiënteerde onderzoek is de grens van het onderzoekbare bijna bereikt, volgens Van der Krogt. Zelf ontwerpt hij een onderzoeksprogramma waarbij gebruik wordt gemaakt van kwalitatieve methoden (in de lijn van de Weberiaanse traditie). Sleutelbegrippen hier zijn participerende observatie, diepte-interviews en case-studies. Deze verwoorden een tendens voor toekomstig onderzoek die ook de eerder genoemde auteurs in deze paragraaf voorstaan. De waarde ervan is echter geenszins aangetoond. Van der Krogt heeft ook nimmer een uitwerking gegeven aan zijn eigen onderzoeksprogramma. Bovendien is door anderen gewezen op het zelfbevestigende karakter van het onderzoek naar machtsprocessen. Volgens Hall (1983) levert dit onderzoek derhalve conceptueel verder weinig op en kan men zich beter concentreren op het onderzoek naar beroepsgroepen zelf. 


\subsubsection{Professionalisering en bureaucratisering}

In de inleiding werd reeds angekondigd, dat het focus in de onderhavige studie vooral is gericht op het onderscheid tussen beroep en professie en op het verschijnsel professionalisering, zoals omschreven en onderzocht in de beroepensociologie. Professionalisering en inschakeling van ptofessionals zijn echter slechts éen manier om complexe problemen in de samenleving en binnen organisaties tot een oplossing te brengen. Bureaucratisering daarentegen wordt in dat verband vaak voorgesteld als de tweede dominante wijze van probleem-oplossen. Het is om deze reden dat het verschijnsel bureaucratisering en zijn relatie tot professionalisering aparte aandacht verdient.

Het belang van bureaucratisering als verschijnsel wordt ook in de beroepensociologie onderkend. Volgens Larson $(1979,145)$ bijvoorbeeld kwam uit het bureaucratisch verschijnsel de structurele context voort waarbinnen beroepen zich voorspoedig konden ontwikkelen en een bepaalde professionele status konden verwerven (zie ook 2.2.3). Toren $(1969,153)$ noemde -overigens in navolging van Weber- bureaucratische controle een van de belangrijkste kenmerken van de zogenaamde semi- of heteronome professies; een kenmerk, dat deze deed onderscheiden van volwaardige professies (zie ook 2.3.4). Ook Van der Krogt $(1981,10)$ verwijst naar deze bureaucratisch-structurele context wanneer hij probeert het belang aan te geven van een intensieve bestudering van het verschijnsel professionalisering. Daarnaast zijn in een van de meest recente beroepensociologische bundels enkele studies gewijd aan het verschijnsel bureaucratie en de betekenis daarwan voor de taken en het functioneren van professionals (zie Dingwall en Lewis 1983; 177 220). Het verschijnsel als zodanig en zijn relatie tot professionalisering zijn echter vooral voorwerp van studie binnen de organisatiesociologie. Wij maken hiernaar een uitstapje om een en ander te verduidelijken.

Volgens Stevens en Philipsen zijn in een organisatie "... bureaucratie en professie te beschouwen als beheersformules om complexiteit te reduceren. In thet ene geval gebeurt dit door complexe taken onder te brengen bij specialisten, professionals genaamd. In het andere geval tracht men door middel van taakverdeling, hiërarchisering en standaardisering de complexiteit (van taken) te lijf te gaan." (Stevens en Philipsen 1988, 169). Als kenmerken van een bureaucratie worden verder genoemd:

"- een grote mate van arbeidsverdeling;

- onderverdeling in hiërarchissche niveaus;

- veelal schriftelijk vastgelegde regels en procedures;

- trapsgewijze loopbaanontwikkeling op grond van leeftijd en prestatie;

- salariëring naar positie in de hiërarchie." (170).

Vergelijken we deze kenmerken met de eigenschappen van een professie, dan lijken bureaucratisering en professionalisering tegengestelde processen te impliceren, die tot twee geheel verschillende structuren aanleiding geven waarin de inzet van professionals in organisaties wordt geregeld. Scott $(1982,213)$ onderscheidt dan ook een autonome professionele organisatie, een heteronome professionele organisatie, en een verenigde ('conjoint') professionele organisatie. Onder een professionele organisatie verstaat hij de organisatie waarin de primaire of belangrijkste taken worden uitgevoerd door professionals, zoals bijvoorbeeld een ziekenhuis. $\mathrm{Zij}$ is autonoom wanneer aan professionals delegatie heeft plaatsgevonden van de verantwoordelijkheid voor de formulering en ver- 
wezenlijking van de doeleinden, voor de bepaling van uitvoeringsmaatstaven en voor de bewaking van die maatstaven (214). Zij is heteronoom wanneer professionals duidelijk ondergeschikt zijn aan het administratief systeem en wanneer de antonomie die ze nog wel bezitten min of meer vastligt (223). Zij is verenigd ('conjoint') wanneer professionals en 'administrators' ongeveer gelijke macht bezitten, hun functies ongeveer even belangrijk zijn, en hun optreden wordt gekenmerkt door wederzijdse afhankelijkheid en beïnvloeding (230). Scott haast zich echter te vermelden, dat proces en resultaat geenszins samenvallen. In praktisch elke (grotere) organisatie is zowel sprake van professionalisering als bureaucratisering. De uiteindelijke organisatievorm die uit deze processen resulteert, is afhankelijk van velerlei factoren. Als zodanig kunnen worden genoemd:

1. De rationale achter genoemde processen.

2. De (interne en externe) 'support'-structuren die een bepaalde organisatievorm begunstigen.

3. De kenmerken van de organisatie.

4. De afweging van de voor- en nadelen die gepaard gaan met (de keuze van) een bepaalde organisatievorm (213-214).

Zo noemt Scott de groeiende inschakeling van paraprofessioneel en technisch personeel als onvervangbare bijdrage aan de medische zorg éen van de redenen waarom ziekenhuisorganisaties verschuiven van een autonome naar een heteronome professionele structuur (223).

Dit laatste is volgens Stevens $(1987,9)$ slechts ten dele waar. Op basis van onderzoek naar organisatiekenmerken, tijdsbesteding en taakopvatting onder medisch specialisten kwam hij tot de conclusie "... dat bij toename van complexiteit in de gezondheidszorg (...) bureaucratische en professionele beheersingsformules steeds meer samen zullen optreden". Verschuivingen in de organisatiestructuur zullen dan niet zozeer betrekking hebben op minder of meer bureaucratisering of professionalisering, maar op minder of meer bureaucratisering ên professionalisering (zie ook Van der Krogt 1981, 153). Een dergelijke ontwikkeling is ook geschetst door Van Ommen (1988, 226-238) in een onderzoek naar communicatiepatronen en besluitvorming in multidisciplinaire behandelteams in een psychiatrisch ziekenhuis. Er wordt zelfs gesteld, dat bureaucratisering en professionalisering elkaar versterkende processen zijn. Om die reden zijn bijvoorbeeld de meest specialistische professionele medische afdelingen in ziekenhuizen tevens de meest bureaucratische (Stevens 1987, 149; Stevens en Philipsen 1988, 175).

Deze onderzoeksresultaten doen het vermoeden rijzen, dat ontwikkelingen in organisaties met complexe doeleinden en taken vooral zullen plaatsvinden in de richting van een 'conjoint' professionele beheersingsstructuur. Complexe problemen lijken niet te kunnen worden opgelost met behulp van uitsluitend taakverdeling, standaardisering en formalisering (de bureaucratische beheersingsformule) noch met behulp van uitsluitend inschakeling van hooggespecialiseerde deskundigen, bijvoorbeeld ten behoeve van case-management (de professionele beheersingsformule). Het werk van moderne professionals is dan ook in toenemende mate geprogrammeerd en geprotocolleerd (Stevens 1987, 151).

Een vraag die naar aanieiding van het bovenstaande opdoemt is die naar de betekenis ervan voor processen van professionalisering en voor het onderzoek naar deze processen. Aan het thema kennis, dat een belangrijke rol speelt bij de legitimering en institutionalisering van professies, kan worden toegelicht dat bureaucratisering zowel een zegen als een vloek voor professionaliseringsprocessen kan zijn. Er kan namelijk een onderscheid 
worden gemaakt tussen kennisontwikkeling en kennistoepassing. Kennisontwikkeling typeert de volwaardige en autonoom functionerende professional. Het is bij uitstek het domein, dat hij tot het zijne kan noemen en waarop niemand anders competent is. Kennistoepassing echter is een terrein dat in principe via standaardisering en formalisering toegankelijk is voor een veel groter aantal beroepsbeoefenaren. Kennistoepassing en routinisering van kennis zouden derhalve aanleiding kunnen geven tot een de-professionaliseringsproces. Kennisontwikkeling vergroot evenwel het terrein van kennistoepassing. Professionalisering (in de betekenis van toegenomen autonome kennisontwikkeling) kan daarom hand in hand gaan met bureaucratisering (in de vorm van toegenomen gestandaardiseerde en geroutiniseerde kennistoepassing) (vergelijk Stevens en Philipsen 1988, 175).

Een geslaagd professionaliseringsproces zal aldus een hoge mate van kennisontwikkeling en waarschijnlijk een hoge mate van gebureaucratiseerde kennistoepassing te zien geven. Gebureaucratiseerde kennistoepassing die niet gepaard gaat met een hoog niveau van kennisontwikkeling, kan dan vervolgens een aanduiding zijn van een minder geslaagd professionaliseringsproces of zelfs van deprofessionalisering. Onderzoek naar het gebruik van bureaucratische beheersingsformules kan dus, in combinatie met andere factoren van zowel formele als materiële aard, nadere gegevens opleveren ten aanzien van de mate en aard van professionalisering wan een beroep. Dit betreft niet alleen het terrein van professionele kennis en kunde, maar ook thema's als taakverdeling en segmentering, waar al eerder naar werd verwezen.

De beroepensociologie kan worden verrijkt, indien het verschijnsel professionalisering meer in termen van bureaucratisering wordt beschreven en geanalyseerd. Een dergelijke verbreding van het theoretisch kader bergt echter het gevaar in zich dat de concepten professie en professionalisering zodanig worden uitgebreid dat ze als uitgangspunt van theorievorming en analyse niet meer voldoen. In de onderhavige studie is er voor gekozen deze verbreding vooralsnog buiten beschouwing te laten en slechts in deze paragraaf expliciet aandacht te schenken aan de verhouding tussen professionalisering en bureaucratisering. Niettemin zullen verwijzingen naar beider relatie niet geheel achterwege blijven, indien dit voor de beschrijving van specifieke verschijnselen noodzakelijk wordt geacht (zie bijvoorbeeld 5.3.2 en 5.4).

\subsection{Professionalisering van het beroep van verpleegkundige ${ }^{1}$}

Theorieên en conceptuele modellen van professie en professionalisering zijn, zoals ge-

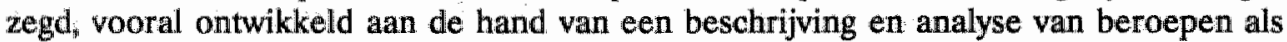
dat van officier, geneeskundige en jurist, aanvankelijk ook nog dat van kerkelijk ambtsdrager. In het vervolg van dit hoofdstuk richten wij het focus echter op het beroep van

1 Van 2.4 zjn de paragrafen $2.4 .1 \mathrm{t} / \mathrm{m} 2.4 .4$ een bewerking van onze bijdrage "De positie van verpleegkindigen en bun beroepsgroep" in Bergh-Braam, A.H.M. van den/Kooij, C.H. van der/Pasch, A.E.W.M. van de: Honderd jaar verplegen - een bijsluiter over gisteren met een opening naar morgen; De Tijdstroom; Lochem 1990, 275-288. 
verpleegkundige. In dat verband stoten we op een veelheid aan studies en geschriften die bij kunnen dragen aan een gedetailleerde beschrijving van het beroep van verpleegkundige. Maar slechts een uiterst gering deel daarvan kan worden geplaatst in de theorievorming inzake professie en professionalisering. Bovendien gaat het in deze laatste studies meer om een toepassing en vertaling van reeds eerder ontwikkelde theorieën en modellen op het beroep van verpleegkundige dan dat expliciet een poging wordt ondernomen tot nadere nuancering van die theorieën en modellen.

Niettemin is dit het materiaal, waarvan we in het kader van dit onderzoek in eerste instantie gebruik zullen maken. De desbetreffende studies hebben meestal betrekking op de situatie in de angelsaksische landen. Waar mogelijk zullen de gegevens hieruit worden aangevuld met gegevens over de situatie van het beroep in Nederland.

Eerst worden de kenmerken en functies van het beroep van verpleegkundige in algemene zin beschreven. De hierop betrekking hebbende thema's zullen in afzonderlijke paragrafen aan de orde worden gesteld. Tenslotte wordt de situatie van het beroep van verpleegkundige in Nederland beschreven langs de lijn van een recente professionaliseringstheorie, namelijk de machtsbenadering. De keuze voor deze benadering is in 2.3 .7 reeds toegelicht. Overigens hebben wij ten aanzien van de verpleging voornamelijk de intramurale sector op het oog, omdat verreweg het grootste aantal verpleegkundigen hierin werkzaam is. Met name wanneer het gaat om de mate van autonome beroepsuitoefening moet men bedenken dat daartoe in de extramurale sector aanzienlijk meer mogelijkheden aanwezig zijn. Dit feit op zichzelf geeft reeds aan, dat het beroep van verpleegkundige in zekere mate gesegmenteerd is.

\subsubsection{Karakterisering van het beroep van verpleegkundige}

De jaren zestig van deze eeuw laten een sterke toename zien van studies op het terrein van de geschiedenis, het ontstaan en de ontwikkeling van het beroep van verpleegkundige. De bekendste zijn voor Engeland: Abel-Smith 1960; voor de Verenigde Staten: Davis 1966, Bullough en Bullough 1979; voor Nederland: Dane 1985 (1966).

Voor de Verenigde Staten werd de actuele situatie met betrekking tot de verpleging in die periode, met gebruikmaking van genoemde studies, door Katz (1969) beschreven in het kader van de benadering van professies die op dat moment dominant was in de sociologie, dat wil zeggen de structureel-functionalistische benadering. Zijn anailyse maakt deel uit van een meeromvattend onderzoek naar de zogenaamde semi-professies (Etzioni 1969; zie ook 2.3.4). Overigens zullen verpleegkundigen zich bij een structuralistische en functionalistische benadering gewoonlijk goed thuisvoelen, omdat deze vanwege hun statische en harmonische karakter uitstekend kunnen dienen als beroepsideologie (Hammenga/Smits 1990, 414).

Katz beschrijft de situatie van de verpleging in de Verenigde Staten als volgt: "The modern nurse is caught in the throes of change. Medicine has increasingly made her into an administrative specialist, while her heritage is that of bedside care for the individual patient. From her leaders she is under pressure to become a professional, while the physician and she herself are apt to doubt her qualifications as a professional. She is a woman who finds herself in a work situation where the most prestigious positions routinely go to men. She ranks low in occupational prestige and financial rewards." (1969, 54). Hij vervolgt dan met de vraag welke positie de verpleging inneemt ten aanzien van 
de beheersing en toepassing van (vooral medische) kennis. Het onderzoek leidt tot de volgende conclusie. De verhouding tussen verpleegkundigen en artsen vertoont kasteachtige kenmerken (zie voor dit aspect ook Lammers 1967). Artsen worden beschouwd als de uiteindelijke beheerders van de kennis met betrekking tot gezondheid en ziekte van patiënten. Deze positie wordt zowel erkend door verpleegkundigen als door de instellingen waaraan ze zijn verbonden (59). Alleen functies die geen duidelijke plaats hebben in de geneeskunde worden overgelaten aan anderen. Voor verpleegkundigen zijn dat de (ver)zorgende functies: "It is as though the nurse receives the right to engage in her traditional tasks as a bonus for accepting second-class citizenship in the dominant medical system." (70-71). In die functies benadrukt de verpleegkundige de uniciteit van de patiënt en diens behoefte aan menselijke contacten met de omgeving. Deze zogenaamde 'tender loving care' wordt echter betaald in de slecht verhandelbare munt van tijdelijke positieve gevoelens van de kant van patiënten en niet in de sociale erkenning van een respectabel loon (66-67). Verpleegkundigen zijn er niet in geslaagd en hebben er vaak ook niet expliciet naar gestreefd deze 'tender loving care' in het formele jasje te steken van een gedragswetenschappelijke 'body of knowledge', als tegenwicht en/of aanvulling bij de formele kennis van de geneeskunde. Op grond hiervan zal de verpleging ook niet uitstijgen boven haar status van semi-professie (75).

Diverse thema's uit de studie van Katz worden later door andere auteurs opnieuw behandeld, deels met verwijzing naar Katz. De belangrijkste thema's zijn:

1. De verhouding tussen verpleegkunde en geneeskunde.

2. Verpleging als typisch vrouwenberoep.

3. Rol en positie van de verpleegkundige binnen de organisatie.

Daarnaast kunnen nog worden genoemd:

4. De rol van beroepsorganisaties.

5. De socialisatie van verpleegkundigen in spe.

Meestal worden meer van deze thema's in samenhang ter sprake gebracht en worden andere, hier niet vermelde thema's (zoals ten aanzien van de omvang en het niveau van het beroep van verpleegkundige) hieraan gekoppeld. Aan elk van de genoemde thema's wordt in het volgende een afzonderlijke paragraaf gewijd.

\subsubsection{Verpleging en geneeskunde}

De verhouding tussen verpleging en geneeskunde is een thema dat in bijna geen enkele verhandeling over de professionele status van het beroep van verpleegkundige ontbreekt. Deze verhouding is niet alleen het gevolg van een bepaalde arbeidsverdeling, maar wordt ook beïnvloed door de status van medische respectievelijk verpleegkundige kennis, wettelijke regelingen en typerende kenmerken van de beoefenaren van de desbetreffende beroepen.

Overeenkomstig Katz' conclusie kan worden gesteld, dat gegevens met betrekking tot de roldifferentiatie tussen verpleegkundigen en artsen verwijzen naar een gebrek aan duidelijkheid bij verpleegkundigen omtrent hun kennisdomein en op een publiek imago van verpleegkundigen als 'verlengde arm' van de arts. Tevens kan naar voren worden gebracht, dat deze twee groepen beroepsbeoefenaren een aantal activiteiten in de gezondheidszorg ook tot hun gedeelde verantwoordelijkheid rekenen. Daarbij gaat het vooral om activiteiten in het kader van gezondheidsvoorlichting- en opvoeding. Deze worden 
echter voor een belangrijk deel door verpleegkundigen uitgevoerd. Dat ze nog niet door verpleegkundigen zijn geclaimd als een exclusief verpleegkundig domein weerspiegelt de huidige status van de verpleging in de gezondheidszorg, gekenmerkt door weinig autonomie als vakgebied (Weiss 1983,139 ; Gruending 1985,553 ).

Wel is gepoogd de begrenzing van beide kennisdomeinen nader te specificeren aan de hand van de begrippen 'zorg' en 'genezing' ('care' en 'cure'). Dit is evenwel binnen de diverse beroepsgroepen en bij het publiek een slecht begrepen onderscheid gebleken. Met name de verpleging -die hierbij het meeste belang heeft- is er niet in geslaagd verschillen en relaties tussen beide begrippen duidelijk te maken (Hall 1980, 152; illustratief voor discussies in Nederland is De Jong 1982). Zorgtheorieën en -modellen zijn weliswaar reeds ontwikkeld, vooral in de Verenigde Staten, maar hun wetenschappelijke en praktische relevantie en bruikbaarheid moeten grotendeels nog worden bewezen.

Een probleem daarbij is, dat zorgfuncties in elke samenleving en voor elk individu tot het alledaagse leven behoren, dit in tegenstelling tot genezingsfuncties (zie bijvoorbeeld Oakley 1984, 26; De Jong 1982, 21). De verpleging zal dan ook moeten aangeven, waarin haar kennis en competentie zich onderscheiden van die in het alledaagse leven. Tot nu toe is zij daarin nauwelijks geslaagd (Hall 1980, 154; Dickinson 1982, 61; Van Gemert en Spijker 1983, 92). Anderzijds heeft Mok $(1968,773)$ reeds meer dan twee decennia terug gewezen op het gevaar van overprofessionalisering: te grote nadruk op een theoretischprofessionele oriëntatie bij verpleegkundigen kan er toe leiden, dat een kloof ontstaat tussen theorie en praktijk, en dat verpleegkundigen op de stoel van artsen gaan zitten. Dezen zullen dat zeker niet accepteren (zie ook Hadders 1990, 280; Pool 1982, 237).

De geneeskunde kan zich beroepen op haar natuurwetenschappelijk karakter. Haar kennisdomein wordt als dermate specifiek en specialistisch erkend, dat zij zich daarin duidelijk onderscheidt van de theoretische en praktische competentie die voor het dagelijks leven noodzakelijk wordt geacht (Oakley 1984, 26). Deze maatschappelijke erkenning komt onder andere tot uiting in een wettelijke bescherming van de geneeskundige beroepsuitoefening. Ook in dit opzicht bestaat er een groot onderscheid tussen verpleging en geneeskunde. Hoewel bijvoorbeeld in alle staten van de Verenigde Staten inmiddels zogenaamde Nursing Practice Acts aan verpleegkundigen bepaalde bevoegdheden verlenen, wordt uit de bepalingen in al deze Acts duidelijk, dat de beroepsuitoefening gekoppeld is aan en onder supervisie staat van de geneeskunde (McCloskey 1981, 42; als voorbeeld van de inhoud en totstandkoming van zo'n Act zie Storch et al 1984, 49-55). In Nederland is er alleen een wettelijke titelbescherming. Een daartoe strekkende wet kwam in 1921 tot stand. Deze werd gewijzigd in 1977, maar nog altijd werd alleen de titel beschermd en niet de beroepsuitoefening. De zogenaamde 'verlengde arm'-constructie bleef gehandhaafd, zodat ook in Nederland de verpleegkundige als het ware werkt onder de paraplu van de geneeskundige beroepsuitoefening. Hetzelfde zal wellicht gelden als de nieuwe Wet op de beroepen in de individuele gezondheidszorg (Wet BIG) zal zijn ingevoerd (Gunkel 1982, 349; zie vooral Van der Mijn 1989, 175 en 241).

De verhouding tussen verpleging en geneeskunde wordt verder bepaald door enige typische kenmerken van de beoefenaren van beide beroepen, mede in relatie tot de context waarin het beroep wordt uitgeoefend. Als belangrijke kenmerken kunnen worden genoemd:

1. Sekse.

2. Verwachtingen omtrent de beroepsuitoefening. 


\section{Aard van nagestreefde beloning.}

4. Geneigdheid tot collectieve actie.

De beroepsgroep wan werpleegkundigen bestaat in overgrote meerderheid uit vrouwen (in de Verenigde Staten meer dan $95 \%$ van de beroepsbeoefenaren). Deze hebben vóór intrede in het beroep verwachtingen die sterk zijn gebonden aan idealen als hulpbetoon en een warm menselijk contact met patiënten (Hutchinson 1982, 10). Hun arbeidsbevrediging is intrinsiek van aard, dat wil zeggen verbonden met de inhoud van het werk zelf (Austin 1978, 22; Oakley 1984, 26). En ze zijn weinig bereid tot gezamelijke actie met collega's ten behoeve van betere arbeidsomstandigheden en verbetering van de mogelijkheden tot beroepsuitoefening (Boyle 1984, 164; Pool 1982, 238). Daarentegen bestaat de beroepsgroep van artsen in de meeste westerse landen in overgrote meerderheid uit mannen. Hun verwachtingen richten zich veel sterker op de beroepsuitoefening zelf, dat wil zeggen het genezen van ziektes (Roberts 1980, 51; Oakley 1984, 26). Extrinsieke beloningen als inkomen en status bepalen in hoge mate de arbeidstevredenheid. En zij zijn veel sneiler geneigd zich aan te sluiten bij collega's om collectief hun belangen te laten behartigen (Pool 1982, 238). Gesteld wordt, met wisselende nadruk, dat deze verschillen grote invloed hebben op de statusverschillen tussen het beroep van verpleegkundige en dat van arts. Deze kenmerken worden weersplegeld in de publieke beeldvorming over beide beroepen en de beoefenaren daarvan (Krantzler 1986, 951). Ze zullen nader aan de orde worden gesteld in het kader van de andere thema's die we naar aanleiding van Katz' studie hebben genoemd.

\subsubsection{Verpleging als vrouwenberoep}

Zowel binnen als buiten de beroepsgroep zijn de achtergronden en implicaties van de verpleging als vrouwenberoep breed uitgemeten, bestudeerd en besproken. Veel auteurs beschouwen dit verschijnsel als de belangrijkste variabele ten aanzien van de verschillen in professionele status tussen professies en semi-professies in het algemeen, en tussen geneeskunde en verpleging in het bijzonder (Simpson en Simpson 1969, 199; Jacobs 1968, 780). Roberts stelt onomwonden vast: "... It is not possible to discuss the status of nursing seperately from the gender of its members." $(1980,35)$.

Het vrouwelijk imago van het beroep van verpleegkundige is niet alleen een gevolg van de getalssterkte van vrouwen in het beroep, maar heeft ook te maken met de sociaal-culturele inbedding van de inhoud van het beroep en de maatschappelijke rol van de vrouw (Krantzler 1986, 951). Oakley formuleert het alls volgt: "In many ways, history has defined a good nurse as a good woman." $(1984,24)$. Zij trekt een vergelijking tussen de traditionele taken van verpleegkundigen en de taken van vrouwen in het gezin. Deze bestonden (en bestaan) voor een groot deel uit de zorg voor een aangenaam fysiek en emotioneel klimaat, terwijl de man bepaalde wat werkelijk belangrijk is en hoe het moet worden uitgevoerd. Vrouwen, dus in het algemeen ook verpleegkundigen, worden gesocialiseerd naar een psychologisch patroon, waarbij de nadruk ligt op afhankelijkheid, passiviteit, dienstbaarheid en zorg voor andermans welzijn. Hoewel dit de verpleegkundige in hoog aanzien doet staan bij de patiênt, draagt het tevens bij aan een lage status van het beroep (Oakley 1984, 26; Watson 1981, 1489-1490).

Er is sprake van een vicieuze cirkel. Verpleegkundigen zijn steeds beschouwd als 'verlengde arm' van de arts en hebben geen eigen kennisdomein ontwikkeld, omdat de medi- 
sche professie gold als de primaire bron van kennis. Dit gemis van een eigen kennisdomein werd op zijn beurt beschouwd als een rechtvaardiging van de lage status van het beroep van verpleegkundige, een positie waarin de ontwikkeling van zo'n kennisdomein bijna onmogelijk is (Roberts 1980, 34; zie ook O'Reilly 1982, 19; Weinrich 1984, 2).

Deze impasse wordt nog versterkt doordat veel verpleegkundigen zich als vrouw sterk gebonden hebben aan hun traditionele rol van moeder en huisvrouw. Velen werken parttime. Voor velen is het inkomen van de partner bellangrijker dan wat ze zelf als verpleegkundige verdienen. De meeste verpleegkundigen rekenen als huisvrouw het huishouden en de zorg voor de kinderen tot hun exclusieve taak. Zij oriënteren zich dan ook minder op hun rol als professional dan op hun taak in het gezin. Daarnaast spelen zij als beroepsbeoefenaar in het contact met artsen ook nog een bepaalde erotiserende of sexuele rol, door Stein (1971, 129-137) een van de meest essentiële elementen van de 'doctor-nurse game' genoemd (zie ook Hutchinson 1982, 9). Dit alles illustreert de 'vrouwelijke' aspecten in de rol van de verpleegkundige en de daarmee gepaard gaande lage status van het beroep (Roberts 1980, 51).

\subsubsection{De verpleging binnen de organisatie}

De rol van de verpleegkundige binnen de organisaties waar het beroep wordt uitgeoefend, wordt voor de Verenigde Staten door Murphy als volgt beschreven: "... patients need care by the professional nurse, but the nurse's time is consumed in monitoring medical activities delegated by the physician and managing the auxiliary personnel on the ward." $(1978,4)$. Deze toestand wordt door Jacox onder meer toegeschreven aan de straffe bureaucratische organisatie van de huidige instellingen voor gezondheidszorg, waar volgzaamheid prevaleert boven autonoom optreden van verpleegkundigen: "Nurses' actions are so greatly determined by prescribed routines, policies, administrative directives, and physicians' orders that there is little freedom left for the exercise of professional judgment." $(1978,15)$. Hoewel deze constatering soms moet worden gerelativeerd met een verwijzing naar de huidige ziekenhuispraktijken, bijvoorbeeld ten aanzien van de acute en intensieve zorg, kan autonoom-professioneel optreden van verpleegkundigen nog steeds een niet geaccepteerde doorbreking betekenen van een reeds lang bestaande "opeenstapeling van strikt gescheiden horizontale lagen" (Mok 1968, 775; zie ook Hammenga 1990, 363).

Aldus tekent zich voor veel verpleegkundigen een conflict af tussen hun rol als beroepsbeoefenaar en hun rol als lid van een organisatie (Dean 1983, 536; Hadders 1990, 273; Hammenga 1990, 363; Van den Bergh-Braam 1982, 323). Dit conflict is kenmerkend voor de socialisatie van verpleegkundigen in het beroep (zie ook 2.4.5) en wordt niet opgelost via de opleiding (Gorman and Clark 1986, 134). Het conflict is ook kenmerkend voor het verschil tussen de positie van de verpleegkundige en die van de arts. De eerste is veelal werknemer in loondienst, de arts daarentegen lid van een in beginsel vrij beroep. De arts wordt in vele landen dan ook minder geplaagd door de nadelen van hiërarchische verhoudingen met meerderen (zie bijvoorbeeld Lurie 1981, 46). Bovendien behoort hij als lid van de medische staf tot een professie met een groot gezag ten aanzien van de inhoud van zowel medische als niet-medische zorgverlening (Singleton and Nail 1984, 128; Goudriaan en Hakkenberg 1982,620). Voor de situatie in Engeland moet bij dit alles wel een kanttekening worden geplaatst. De reorganisatie van de National Health Service in 
1974 heeft er toe geleid, dat in organisatorisch opzicht de verpleegkundige leiding dezelfde management-verantwoordelijkheden kreeg toegeschoven als bijvoorbeeld geneeskundigen (Dean 1983, 537).

Daarnaast bestaan er ook binnen de beroepsgroep van verpleegkundigen zelf bepaalde gezagsverhoudingen die wijzen op een lage professionele status. Gebonden als de verpleegkundige is aan diens rol als lid van een organisatie, bereikt deze in het algemeen geen carriëre en verhoging van status via optimale professionele zorg aan de patiënt, maar juitst door zich van het bed van de patiënt te verwijderen (Roberts 1980, 51). Het maken van carrière in het ziekenhuis wordt door beroepsgenoten soms zelfs met wantrouwen bekeken en als doorbreking van de gelijkheidsideologie ervaren. Het verplegen in stricte zin biedt pas sinds korte tijd enig carrière-perspectief door de mogelijkheid van specialisatie. De belangrijkste weg waarlangs men vooruit kan komen loopt echter nog steeds langs het management en het onderwijs (Dickinson 1982, 61).

In de Verenigde Staten (sinds de jaren vijftig), maar ook in Engeland (sinds de jaren zeventig), zien we bovendien een duidelijke tendens tot het afstoten van verpleegkundige taken naar lager gekwalificeerd personeel, de zogenaamde 'auxiliaries' (Dickinson 1982, 62; Chapman 1977, 53; McCloskey 1981, 41; Wirsing 1979, 8). Voor Nederland is een dergelijke beweging, als een van de strategieën tot statusverhoging van de professie, beschreven door Van Gemert en Spijker (1982, 163-164; zie ook Mok 1968, 775). Ook de discussies over 'het beroepsprofiel' in de jaren tachtig kunnen in dat licht worden bekeken, met name waar een onderscheid wordt geponeerd tussen verschillende niveau's van verpleegkundige beroepsuitoefening (NRV 1984; Bakker/Le Grand-Van den Boogaard 1988; Beroepsprofiel 1982).

Het resultaat is, dat verpleegkundigen uiteindelijk alleen nog maar coördinerende en andere organisatorische taken (zullen) vervullen en niet meer aan het bed van een patiënt zijn te vinden. Dit wordt wel een van de grootste problemen in de hedendaagse verpleging genoemd: "... we have created an administrative rather than a professional elite. Status and financial reward is given to those who occupy hierarchical positions which with rare exceptions are confined to management and education ..." (Tiffany 1982, 44; zie ook Austin 1978, 13).

Deze gegevens laten een nadere interpretatie toe vanuit de in paragraaf 2.3 .9 beschreven verhouding tussen professionalisering en bureaucratisering. Binnen organisaties wordt het werk van verpleegkundigen in grote mate bepaald door bureaucratische beheersingsformules. Er is sprake van geroutiniseerde kennis, meestal ontleend aan en toegepast op gezag van de geneeskunde. De ruimte voor autonoom-professionele beslissingen is beperkt. Ontwikkeling van (specialistische) kennis vindt nauwelijks plaats en staat duidelijk in functie van de bijdrage die zij levert aan de (ontwikkeling van) medische zorg. Mede in verband hiermee wordt het beroep van verpleegkundige, zoals dat van arts, nog steeds gekenmerkt door fragmentatie en segmentatie en door een soms ver doorgevoerde taakverdeling. Dit wordt onder andere duidelijk wanneer men de functies van wijkverpleegkundige en intensive care verpleegkundige met elkaar vergelijkt. De ontwikkeling van een gemeenschappelijke professionele identiteit heeft hiermee geen gelijke tred gehouden. Functiebenamingen verhullen dan ook een slechts geringe mate van autonomie binnen het beroep. Bovendien worden carrièreperspectieven niet ontleend aan de eigen rol als beroepsbeoefenaar of professional, maar aan de positie binnen de (hiërarchische structuur van de) organisatie. Aldus kan het beroep van verpleegkundige ook vanuit het 
perspectief van bureaucratisering worden getypeerd als een beroep met een lage graad van professionalisering. De aanwezige bureaucratische aspecten zijn immers minder het gevolg van ontwikkelingen binmen het deskundigheidsdomein dan wel van ontwikkelingen binnen organisaties als zodanig. Dit wijst er bovendien op dat de segmentering van het beroep van verpleegkundige van een andere aard is en/of andere achtergronden heeft dan de segmentering van het beroep van arts.

\subsubsection{De beroepsorganisatie(s) van verpleegkundigen}

De beroepsorganisaties voor verpleegkundigen hebben naast materiẻle belangenbehartiging vooral tot doel de beroepsontwikkeling te bevorderen (Mok 1983, 197). De koppeling van beide doelstellingen acht de Nederlandse Maatschappij voor Verpleegkunde (NMV, nu Nieuwe Unie '91 geheten), de grootste beroepsorganisatie van verpleegkundigen in Nederland, overigens een essentiële voorwaarde voor een optimaal functioneren binnen de Nederlandse verhoudingen (Vos 1990, 245-246). In Engeland zag de Royal College of Nurses (vanuit een soortgelijke optie als die van de NMV) zich zelfs wettelijk genoodzaakt om zich als vakbond te laten registreren om de belangen van verpleegkundigen ook op het terrein van de beroepsontwikkeling te kunnen behartigen (Bellaby and Oribabor 1980, 305).

De bevordering van de beroepsontwikkeling lijkt door deze beroepsorganisaties slechts gedeeltelijk te kunnen worden gerealiseerd (zie ook 2.4.4). In een vergelijkend onderzoek naar beroepsverenigingen van verpleegkundigen in België en de Verenigde Staten kwamen Brown en Claus tot de conclusie, dat "... the efficacy of any action by nurses" associations (...) is affected by the extant control of the medical community and the hospitall organizations:" $(1983,195)$. Overeenkomstig wat bij andere thema's werd beschreven, wordt ook de rol van beroepsorganisaties van verpleegkundigen in hoge mate bepaald door de (organisaties van) beoefenaren van andere beroepen en functionarissen (zie verder bij Bellaby en Oribabor 1980, die voor Engeland tot dezelfde conclusie komen als Brown en Claus). Vooral vanuit sociologische hoek wordt dit overigens vooralsnog ook een wenselijke situatie genoemd, omdat alleen op deze wijze professionalisering van het beroep van verpleegkundige haalbaar wordt geacht, daar dit afhankelijk is van het "sponsorship' van met name de geneeskunde (Mok 1983, 198).

De kracht van dergelijke beroepsorganisaties wordt verder bepaald door de mate waarin zij als spreekbuis kunnen fungeren voor alle verpleegkundigen in een bepaald land. Dit heeft te maken met de organisatiegraad van verpleegkundigen en met het aantal der desbetreffende beroepsorganisaties alsmede met de bereidheid tot samenwerking van die organisaties. Een en ander blijkt van land tot land sterk uiteen te lopen. Zo vertonen bijvoorbeeld de Verenigde Staten en Engeland een relatief hoge organisatiegraad onder verpleegkundigen in respectievelijk de American Nurses' Association en de National League for Nursing enerzijds en de Royal College of Nursing anderzijds, terwijl in Belgie en Nederland sprake is van een veel lagere organisatiegraad, van meer (deels verzuilde) beroepsorganisaties, en tot voor kort van een geringe bereidheid tot samenwerking tussen die organisaties (Brown en Claus 1983, 190-195; Bellaby and Oribabor 1980, 305; Yeager and Kline 1983, 48; Vos, 1990, 234-236; Hammenga 1990, 429-430; in 1989 nog werd door de $\mathrm{CFO}$, de op één na grootste belangenorganisatie van verpleegkundigen, de samenwerking met de Nederlandse Maatschappij voor Verpleegkunde formeel opge- 
zegd). De positie van de beroepsorganisaties in de Verenige Staten en Engeland is dan ook sterker dan die in België en Nederland. Hall $(1973,29-33)$ onderscheidt diverse gebieden waarop een beroepsorganisatie invloed dient te hebben indien zij professionalisering van het beroep beoogt. Deze betreffen de beroepsopleiding, de wettelijke registratie en bescherming van de beroepsuitoefening, het gezondheidszorgbeleid, het werkgelegenheidsbeleid, de organisatie van de verpleegkundige dienstverlening en de ontwikkeling van het specifieke kennisbestand van de beroepsgroep. Daarvan afgeleid zijn dan nog taken als: controle over de relaties met andere beroepsgroepen (vooral geneeskunde), over de economische hulpbronnen, over de personeelsvoorziening, over de consumentenbehoeften en over de ondersteunende diensten. Op al deze punten lopen de beroepsorganisaties in Nederland en België achter, soms ver achter, op hun collega's in de Verenigde Staten en Engeland.

Kenmerkend voor de situatie in Nederland is, dat de beroepsorganisaties van verpleegkundigen bijvoorbeeld niet waren uitgenodigd voor de uitgebreide hoorzittingen, die door de overheid in 1987 voor alle belangenorganisaties werden georganiseerd in het kader van de voorstellen van de 'Commissie Dekker' tot herstructurering van de gezondheidszorg. Pas na krachtig aandringen en een uitvoerige lobby hunnerzijds werden de organisaties van verpleegkundigen alsnog uitgenodigd voor een extra hoorzitting (Akties $1987,24)$. lets dergelijks is nadien nog enige malen voorgekomen bij de samenstelling van centrale onderzoekscommissies ten aanzien van thematiek die voor verpleegkundigen van belang is.

Voor de meeste landen geldt nog steeds, dat de beroepsorganisaties door externe belemmeringen weinig manoeuvreermogelijkheden worden geboden. Daarenboven kampen bijna alle beroepsorganisaties van verpleegkundigen met een gebrek aan voldoende en bekwame vertegenwoordigers (Dean 1983, 538), hoewel de leden van beroepsorganisaties, relatief gezien, een hogere opleiding hebben genoten dan niet-leden (Yeager and Kline 1983, 51).

\subsubsection{Professionele socialisatie}

Als laatste, maar zeker niet onbelangrijkste thema stellen we aan de orde de socialisatie van verpleegkundigen in spe. In dit kader zal ook uitgebreider worden ingegaan op een aspect dat al eerder meermalen werd vermeld, namelijk de opleidingssituatie.

Opleiding en training zijn wel de primair bepalende factoren genoemd van socialisatie in een professie. Daarnaast wordt nadruk gelegd op de effecten van situationele factoren in de werksetting (in de Becker-Freidson school) en op de interactie tussen de socialisant, het beroep waarvoor deze kiest en de andere actoren waarmee de socialisant te maken krijgt (de benadering van Light).

Lurie (1981) heeft op basis van deze drie benaderingen de resultaten van het socialisatieproces onderzocht bij verpleegkundigen die in de Universiteit van Californië tot 'nursepractitioner' werden opgeleid. Zij constateert dat, hoewel persoonlijke keuzes van de socialisant een rol spelen, een jaar na opleiding "... significant changes occurred in the attitudes toward patient care and toward relations with other staff and with physicians, selfperceptions as a nurse, and coping skills (...), and in the activities of basic care nursing, nursing leadership, nurse-practitioners' working relations with physicians ..." (39). 
De tijdens de opleiding aangeleerde rol van professioneel verpleegkundige bleek slechts zeer ten dele volgehouden te kunnen worden in de werksetting. De werkomstandigheden zelf waren hiervoor de belangrijkste oorzaak: "Limits on activities were usually not self-imposed but, rather, the result of organizational constraints." (Lurie 1981, 43; zie ook Ketefian 1985, 253; voor artsen is een soortgelijke conclusie verwoord door Strauss 1966).

Dat verpleegkundigen aan deze rolbelemmeringen toegeven, verklaart Lurie als volgt: "Since the work setting is mot the situation in which the essential professional knowledge and skills are transmitted, it can never be regarded as the primary determinant of socialization. But since the worksetting provides opportunity for professional employment, it is a more powerful determinant of socialization for those primarily dependent upon it.". Een feit is in elk geval dat "... almost all nurses must function as employees in order to function as professionals at all." (46). Anderen geven niet toe aan deze rolbelemmeringen en verkiezen uit het beroep te stappen. Dit zijn meestal tevens degenen die er hoge maatstaven op na houden ten aanzien van de (professionele) uitoefening van hun beroep en die daardoor de grootste moeilijkheden ondervinden met de organisatorische setting waarin de beroepsuitoefening plaatsvindt (Kramer/Baker 1971, 29). In samenhang met het gegeven dat de verpleging een typisch vrouwenberoep is, noemt Mok nog een aspect dat deze zogenaamde "burnout" in de kaart kan spelen. Hij vraagt zich af "... of het huwelijk niet dikwijls een sociaal aanvaarde vlucht uit het beroep (...) betekent." $(1968,776$; ruim twee decennia later zouden we overigens 'huwelijk' kunnen aanvullen met 'partnerrelatie' en/of 'ouderschap').

Er is echter meer aan de hand. Artsen hebben niet alleen grote invloed op het socialisatieproces van verpleegkundigen op de werkvloer, maar ook in de opleidingssituatie. Het feit bijvoorbeeld dat in Europa meer dan de helft van alle opleidingen tot verpleegkundige wordt geleid door een of meer artsen en de meeste opleidingen duidelijk medisch zijn georiënteerd, wordt wel als één van de belangrijkste oorzaken gezien van de onderontwikkeling van het verpleegkundig onderwijs en de verpleegkundige dienstverlening (Hall. 1980, 156; zie ook McCloskey 1981, 43). Ook tijdens de opleiding wordt de verpleegkundige in spe dus al gesocialiseerd in de richting van dienstverlening en onderhorigheid aan de geneeskunde.

Daarnaast hebben de meeste westerse landen te maken met een opleidingsstructuur die het best te vergelijken is met een bonte lappendeken. Er is een veelheid aan basisopleidingen met verschillende ingangseisen en eindniveau's. Ook kunnen verpleegkundigen een keus maken uit talloze specialisatiecursussen en bij- en nascholingsprogramma's. Van een goede afstemming tussen en coördinatie van deze opleidingsmogelijkheden is meestal weinig sprake. Dit wordt enerzijds veroorzaakt door onenigheid binnen de beroepsgroep over de wenselijke opleidingsstructuur en -inhoud, anderzijds door het feit, dat de beroepsgroep hierop geen directe controle kan uitoefenen door de gebondenheid ervan aan allerlei voorschriften en regels van overheidswege (Wirsing 1979, 10; Hadders 1990, 265-266 en 280). Overigens hebben ook overheden hiertoe in het verleden bijgedragen door te zeer een laissez-faire houding in deze materie aan te nemen (Prince 1984, 162).

Een dergelijke structuur leidt enerzijds tot ondoorzichtigheid in de kwalificaties en competenties van verpleegkundigen en is anderzijds een voedingsbodem voor al dan niet terechte claims met betrekking tot statuswerschillen tussen verpleegkundigen (Dickinson 
1982, 62; McCloskey 1981, 41 en 43; Chapman 1977, 51; zie ook 24.4). In Nederland bijvoorbeeld bestaan er alleen al vier verschillende basisopleidingen in de verpleegkunde op het eerste deskundigheidsniveau, een veelvoud daarvan aan vervolgopleidingen (waaronder de typische 'huisopleidingen') en zijn sinds enige jaren discussies gaande over een verdere niveau-differentiatie in de beroepsuitoefening, inclusief functie-aanduiding, op grond van de verschillen tussen de basisopleidingen (Hadders, 1990).

Hoewel het bovenstaande de opleiding tot verpleegkundige in het perspectief plaatst van een onduidelijk, of minstens meerduidig beroepsbeeld, lijkt dit van weinig invloed op het uiteindelijke resultaat van de socialisatie van verpleegkundigen in het beroep (zie ook Dassen 1989, 67 en 115-116).

Aspecten die ten aanzien van die socialisatie nog niet uitdrukkelijk aan de orde zijn geweest, betreffen de motivatie, attitude en (morele) grondhouding waarmee de gemiddelde verpleegkundige het beroep uitoefent en de daarmee samenhangende activiteiten uitvoert. Diens oriëntatie op dienstverlening -een belangrijk motief om het beroep van verpleegkundige te kiezen en een opleiding daartoe te gaan volgen (Lurie 1981, 32; Mok 1968, 772)- blijkt een relatief streng volgehouden houding te zijn (McCloskey 1981, 44; Pool 1978, 292).

Hoezeer deze houding een rol speelt op het niveau van de beroepsgroep als geheel en bij haar streven naar professionalisering, wordt door McCloskey als volgt geformuleerd: "The service motive of nurses has (...) included the willingness of the profession as a whole to be inadequately remunerated (...) and inadequately recognized as a major caring profession in terms of its unique role and function (...) and above all, the overemphasis on service has been the main deterrent to setting up an adequate educational system in nursing (...). The emphasis on service is the cause of the failure to establish a foundation of science." $(1981,44)$. De nadruk op dienstverlening heeft er dus toe bijgedragen, dat een aantal kenmerken en functies, geldend voor het beroep als een volwaardige professie, niet tot ontwikkeling werd gebracht.

\subsubsection{Macht en onmacht van de verpleging in Nederland}

In 2.3.7 werden de contouren geschetst van een benadering van de verschijinselen professie en professionalisering waarbij het begrip macht een centrale rol speelt. Hoewel bijvoorbeeld Glaser reeds in 1966 het beroep van verpleegkundige onder dit aspect beschreef (Glaser 1966, 42-55), geldt een dergelijke benadering als een van de recente verworvenheden in de beroepensociologie. Er wordt niet zozeer gekeken naar het beantwoorden van een bepaald beroep aan een aantal voorgeschreven kenmerken, wil het voor een professie doorgaan, maar veel meer naar de interactie van het beroep en zijn beoefenaars met hun omgeving, met de cliënten, met de cultuur. Ook wordt gekeken naar historische aspecten, relaties met andere beroepen, en naar de innerlijke dynamiek van het beroep en zijn beoefenaars. Om dit toe te lichten hebben we het conceptuele model bekeken zoals ontwikkeld door Van der Krogt (1981).

Professionalisering werd daarbij gedefinieerd als "een proces waarbij leden van een beroepsgroep op collectieve wijze, vooral gebruik makend van kennismacht, trachten een collectieve machtspositie te verwerven en/of te verdedigen, met het doel de gebruiks- en ruilwaarde van het beroep te beheersen". De centrale begrippen uit deze definitie werden in 2.3.7 nader toegelicht. Tevens werd gesteld, dat voor het verwerven van een col- 
lectieve machtspositie door een beroepsgroep ook de behoeften en belangen alsmede de machtspositie van de individuele beroepsbeoefenaar van belang zijn. Verder worden de gebruiks- en ruilwaarde van een beroep beïnvloed door de centrale processen van institutionalisering en legitimering.

In een analyse van het beroep van verpleegkundige past Hammenga $(1990,428-460)$ het model van Van der Krogt toe op de situatie in Nederland. Verschillende aspecten, genoemd in 2.4.1 tot en met 2.4.6 komen in deze analyse terug. Ze zullen dan ook slechts worden genoemd, miet uitgewerkt. Hetzelfde geldt voor wat we bij andere auteurs over deze aspecten aantroffen.

Hammenga beschrijft de huidige situatie van de verpleegkundige beroepsgroep in $\mathrm{Ne}$ derland als volgt (429-430): "De meeste verpleegkundigen zijn werkzaam in de lijnstructuur van een bureaucratische organisatie, waardoor ze nauwelijks. over een collectieve machtspositie beschikken. Daarnaast is er een groot machtsverschil ten opzichte van andere beroepsgroepen in de gezondheidszorg. Veell verpleegkundige werkzaamheden vloeien bijvoorbeeld voort uit de definities en opvattingen van andere beroepsgroepen. Bovendien zijn verpleegkundigen onderling sterker hiërarchisch geordend dan andere beroepsbeoefenaren. Functie-eisen gaan dan in de regel boven beroepseisen, die overigens nog in ontwikkeling zijn". Vervolgens verwacht hij dat hier maar weinig verandering in zal komen: "Individueel sturende activiteiten zijn vooral afkomstig van een beperkte beroepselite (auteurs in vaktijdschriften, docenten), terwijl van een collectieve aanpak nauwelijks sprake is. De organisatiegraad van het beroep is laag en zelfs bij overheidsmaatregelen die diep in het eigen vlees snijden is er weinig bereidheid om de belangen van het beroep te verdedigen". (De CAO-akties vanaf 1989 kunnen evenwel als een tegengestelde tendens worden beschouwd.) Als positieve ontwikkelingen ter mogelijke versterking van de machtspositie noemt hij verder nog de scholing in verpleegkundige zorgconcepties, nieuwe organisatiemodellen, minder hiërarchische interne verhoudingen, beginnende wetenschappelijke ondersteuning van de beroepsuitoefening en de belangstelling voor veranderingsstrategieën op het uitvoerend niveau.

Vergroting van de gebruiks- en ruilwaarde van het beroep van verpleegkundige vermindert onzekerheid bij verpleegkundigen, vergroot hun machtspositie en is daarmee een essentieel onderdeel van het professionaliseringsproces waarin het beroep zich bevindt. Om dit te realiseren introduceerde Van der Krogt het begrip 'marktcapaciteit'. Kennis en kunde enerzijds en arbeidsbeschikbaarheid anderzijds zijn daarvan de belangrijkste factoren. Hammenga (1990, 433-434) wijst ten aanzien van deze marktcapaciteit op een zekere innerlijke tegenspraak in de positie van de verpleging: terwijl verpleegkundigen proberen meer nadruk te leggen op de factor kennis en kunde (door middel van theorievorming, onderzoek, beroepsopleiding) geldt voor werkgevers en zorgontvangers de arbeidsbeschikbaarheid nog steeds als voornaamste factor. Tevens wordt gesteld, dat verpleegkundigen niet de machtspositie bezitten om hun kennis en kunde tot gelding te brengen. De status van deze kennis en kunde wordt grotendeels ontleend aan het gezag dat de arts inboezemt. Consequentie hiervan is ook "... dat verpleegkundigen veelal vanuit een 'zorgvreemd" model moeten werken" (434). Bovendien is de inhoud van de somtijds gepropageerde kennis en kunde van clien aard, dat ze niet slechts in de behoefte daaraan bij de afnemers voorzien, maar deze zelfs totaal wegnemen. Zo zijn zelfzorgtheorieën er expliciet op gericht de verpleegkundige in te wisselen voor de zorg van de afnemer voor zichzelf. De maatschappelijke behoefte is dus niet in overeenstemming met de behoefte van 
de beroepsgroep en haar leden. En dit leidt tot vraagtekens en ambivalentie ten aanzien van de gebruikswaarde van de verpleging. Wel wijst Hammenga erop, dat de genoemde aard van de kennis en kunde ook tot vergroting van de gebruikswaarde kan leiden, wanneer verpleegkundigen meer nadruk leggen op de educatieve waarde van hun beroep: "Verpleegkundigen maken hun zorgontvanger tijdelijk afhankelijk van iets dat deze beroepsgroep de zorgontvangers kan leren, namelijk voor zichzelf en anderen te zorgen." (437; zie ook 2.4.2).

Andere aspecten die de machtspositie van verpleegkundigen bedreigen casu quo verzwakken zijn volgens Hammenga de verpleegkundige optie op een holistische benadering en de segmentering van het beroep. Door zich te richten op de individuele afnemer als persoon loopt ze het risico geen generaliseerbare kennis te ontwikkelen en maatschappelijke factoren te verwaarlozen. Segmentering duidt op de splitsing van het beroep (alsmede de opleiding daartoe) in een aantal werkvelden met ieder zijn eigen belangen, hetgeen op gespannen voet staat met de verbondenheid aan het ene, onverdeelde beroep (439). Ook bestaande hiërarchische verhoudingen van verpleegkundigen ten opzichte van elkaar in de arbeidsorganisatie kunnen als een vorm van segmentering worden beschouwd (442-444; zie ook 2.4.4).

Samenwerking wordt door de leden van een beroepsgroep nuttig gevonden wanneer zij verwachten hun onzekerheidsbronnen daarmee beter te kunnen beheersen. In dat geval is sprake van een proces van collectivisering. Deze kan volgens Hammenga voor verpleegkundigen op twee wijzen gestalte krijgen: via de arbeidsorganisatie en via de beroepsgroep (440; zie ook Larson 1979, 185 en 55-56). Voor de beoefenaar van een beroep met professionaliseringsaspiraties ligt de laatste weg het meest voor de hand, maar deze wordt in de verpleging allerminst druk belopen: "De organisatiegraad van het verpleegkundig beroep heet een der laagste te zijn van alle beroepsgroepen" (440). Als redenen noemt Hammenga: beleving van het beroep als roeping, religieuze oorsprong van het beroep, het karakter van vrouwenberoep met dientengevolge een grote doorstroming, gerichtheid op hulpverlening en niet op de maatschappelijke situatie van het beroep, functiegerichte in plaats van beroepsgerichte scholing, vroegtijdige wegsocialisering van kritiek. Het verwerven van een collectieve machtspositie (het doel van collectivisering) wordt om deze redenen in sterke mate belemmerd; zodat ook de individuele machtspositie van verpleegkundigen nauwelijks wordt verbeterd.

De collectieve machtspositie van de verpleging kan als de resultante worden beschouwd van drie machtsbronnen: de gebruikswaarde van het beroep (op individueel niveau), de aantalsmacht en de referentiemacht. Ten aanzien van de gebruikswaarde levert Hammenga een goede samenvatting van het bovenstaande: de machtsbronnen van de verpleegkundige worden beperkt door diens plaats in de lijnstructuur van een arbeidsorganisatie; de beheerste onzekerheidsbronnen betreffen hoofdzakelijk huishoudelijke en assisterende functies; en de normatieve macht van verpleegkundigen is slechts afgeleide macht (voorall van artsen). In termen van arbeidsbeschikbaarheid (aantalsmacht) bezit de verpleging echter een kapitale machtsbron, welke evenwel nauwelijks wordt gebruikt. Hoewel zij de grootste beroepsgroep in de gezondheidszorg vormt wordt dit gegeven (uit vooral ethische motieven) nauwelijks benut om betere condities voor de beroepsuitoefening te scheppen. Tenslotte de referentiemacht: volgens Hammenga kan de relatieve gebruikswaarde van de verpleging aanzienlijk worden verhoogd, wanneer zij zich laat'sponsoren' door arbeidsorganisaties en/of artsenorganisaties. In ruil daarvoor zou de verple- 
ging af moeten zien van fundamentele hervormingen en de dominante (dat wil zeggen medische en of organisatie-)waarden en normen moeten aanvaarden (444). Bepaalde tekenem, hierboven genoemd, wijzen op het tegendeel, waardoor de eventueel beoogde professionalisering in termen van machtsverwerving gemakkelijk kan omslaan in een deprofessionaliseringsproces (hetgeen door sommige auteurs overigens ook bewust wordt nagestreefd; vergelijk Van den Bergh-Braam 1985, 206-207). Zoals in paragraaf 2.3.9 reeds aangegeven, is een dergelijk de-professionaliseringsproces ten aanzien van de status en positie van het beroep slechts aanvaardbaar, wanneer deze het gevolg is van een noodzakelijke toename van bureaucratische beheersing van kennistoepassing op grond van een hoog niveau van kennisontwikkeling.

Machtsposities van waaruit de gebruiks- en ruilwaarde van een beroep kunnen worden beinvloed, kunnen slechts tot stand worden gebracht en in stand gehouden, wanneer deze zijn geïnstitutionaliseerd en vooral gelegitimeerd. Voor het beroep van verpleegkundige vormden deze legitimering en institutionalisering tot voor kort geen enkel probleem. Zolang de verpleging (en de samenleving) de dominantie van de geneeskunde in de gezondheidszorg erkende, nam zij een grote vlucht in het kielzog van de medische ontwikkelingen en medicaliserende tendenzen (medische sponsoring). Via de opleiding werden verpleegkundigen in spe hier al vroeg mee vertrouwd gemaakt. Legitimeringsargumenten waren er in overvloed: hun kennis en kunde alsmede de controle over de beroepsgroep stond onder invloed van artsen en aan hun dienstbaarheid werd nimmer getwijfeld. Ook de legitimeringsgronden leverden geen probleem op dankzij de medische sponsoring en de aanvaarding daarvan door de beroepsgroep van verpleegkundigen. Mondigwording van de consument, kritiek op de geneeskunde en andere maatschappelijke twijfels, leidden echter tot een heroriëntatie op de gezondheidszorg, waarbij beroepen onder druk kwamen te staan, andere beroepen tot ontwikkeling kwamen (met name in de welzijnssector) en bestaande evenwichten en verhoudingen werden verstoord. Volgens Hammenga verkeert de verpleging momenteel in een situatie die haar dwingt tot een nieuwe bezinning omtrent het domein dat zij als werkterrein en object van kennis en kunde kan claimen. In de confrontatie met andere beroepen en met de gezondheidszorg als geheel zal zij zich veel moeite moeten getroosten om nieuwe legitimeringsargumenten te vinden en de oude legitimeringsgronden gewijzigd te krijgen. Immers: "Het beeld van de verpleegkundige in onze samenleving berust namelijk nog voor een belangrijk deel op de 'traditionele' verpleegkundige die onder patronage van de medicus werkt" (Hammenga 1990, 446). 


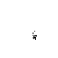




\section{PROFESSIONALISERING}

\subsection{Inleiding}

In voorgaand hoofdstuk is het kader geschetst vanwaaruit thans een vraagstelling voor verder onderzoek zal worden geformuleerd. Dit onderzoek wordt ondernomen vanuit een ethisch perspectief. Onder ethiek kan worden verstaan: de praktische wijsbegeerte die het vrije en verantwoordelijke handelen van de mens bestudeert onder het opzicht van goed en kwaad. Nadere uitwerking van de in dit onderzoek gehanteerde ethische positie zal plaatsvinden in hoofdstuk 5 .

De ethische invalshoek ten aanzien van het verschijnsel professionalisering laat zich omschrijuen als: de reflectie op de morele implicaties van de normatieve aspecten van professionalisering. Zoals we in hoofdstuk 2 hebben gezien is 'professionalisering' conceptueel te rangschikken onder de categorieèn van de beroepensociologie. Een vraag naar de normatieve aspecten van professionalisering is dan ook allereerst onder deze noemer te behandelen. We verbreden de vraag echter naar die met betrekking tot een sociologisch perspectief op de normatieve dimensie van de werkelijkheid als geheel. Hetzelfde zullen we doen met betrekking tot het ethisch perspectief. Beide perspectieven komen achtereenvolgens aan de orde in de paragrafen 3.2. Ze monden uit in een vergelijking van methoden en begrippen tussen sociologie en ethiek, wederom met het oog op de normatieve dimensie van de werkelijkheid. Daarbij zal blijken dat deze normatieve dimensie hecht verankerd is in het hart van beide disciplines zelf.

In $3.3 \mathrm{zal} \mathrm{het} \mathrm{onderzoek} \mathrm{weer} \mathrm{worden} \mathrm{toegespitst} \mathrm{op} \mathrm{het} \mathrm{verschijnsel} \mathrm{professionalisering.}$ Aangetoond zal worden dat de theorieèn met betrekking tot professionalisering niet alleen een aantal normatieve aspecten blootleggen van dit verschijnsel, maar ook zelf een niet onaanzienlijke normatieve dimensie bezitten. Vervolgens zullen in de paragrafen 3.4 de normatieve aspecten van professionalisering nader worden geduld in samenhang met het verschijnsel beroepscode. Gesteld wordt dat beroepscodes een belangrijk verschijnsel vormen waaraan de normatieve aspecten van professionalisering zowel sociologisch als ethisch kunnen worden geillustreerd en onderzocht. Allereerst zal in dat verband worden nagegaan wat er ten aanzien van beroepscodes wordt vermeld in de professionaliseringsliteratuur. Op geleide daarvan worden beroepscodes daarna gepresenteerd als vindplaats van waarden.

Aldus worden de normatieve aspecten van professionalisering geplaatst in een raamwerk van onderzoek naar waarden en normen, met beroepscodes als vehikel. Dit raamwerk leent zich goed voor een ethische reflectie op beroepscodes en via deze op de normatieve aspecten van professionalisering. Een daartoe strekkende vraagstelling vormt de afsluiting van dit hoofdstuk en het startpunt voor de hoofdstukken erna. 


\subsection{Normativiteit}

'Normatief' kan in zijn meest algemene betekenis worden omschreven als: een norm gevend of voorschrijvend. Daarbij wordt vaak gedacht in termen van het verstrekken van een taak of opdracht, of in termen van de criteria of voorwaarden waaraan een bepaalde handeling dient te voldoen. Het vermijden van een handeling als stelen kan bijvoorbeeld als een dergelijke norm worden beschouwd. Deze norm kan expliciet aan mensen worden voorgehouden. Maar zij kan ook impliciet verweven zijn in de benoeming van een bepaald handelen. Als een handeling wordt omschreven als diefstal dan wordt daarmee tevens gezegd dat een norm is geschonden. Met diefstal wordt immers niet bedoeld dat iets weggenomen is, maar dat iets onterecht is weggenomen. De norm "niet stelen' is hier niet gebruikt in de betekenis van opdracht, maar in de betekenis van beoordelingscriterium.

Veel termen in het dagelijks spraakgebruik bezitten een dergelijke normatieve lading, expliciet dan wel impliciet, als voorschrift dan wel als beoordelingscriterium. De normatieve lading van deze termen reikt echter verder. Opvolging of schending van een norm impliceert meestal een bepaalde reactie vanuit de omgeving, namelijk goedkeuring of afkeuring. Deze reactie kan worden beschouwd als nauw verbonden met de normatieve lading van de desbetreffende term. De invloed die de term uitoefent op het reactiepatroon van de omgeving kan aldus worden gerekend tot de normatieve lading van de term. Zijin normativiteit strekt zich uit tot de consequenties van zijn werking.

Niet alleen termen uit het dagelijks spraakgebruik bezitten een normatieve lading, maar ook wetenschappelijke termen. Dit kan zelfs het geval zijn met termen of begrippen die op het eerste gezicht een exclusief beschrijvende functie vervullen ofwel descriptief of reëel zijn gedefinieerd. Zo werd in de humane embryologie het begrip pre-embryo geïntroduceerd ter aanduiding van de vroegste fase in de biologische ontwikkeling van de bevruchte menselijke eicel. Daarnaast bestond echter een zeer restrictief beleid ten aanzien van de toelaatbaarheid van medische experimenten met embryo's. Door nu een gedeelte van de embryonale fase begripsmatig af te zonderen en een eigen status te geven is volgens sommige onderzoekers het restrictief beleid hierop in stricte zin niet meer van toepassing. De normatieve lading van het ogenschijnlijk beschrijvende begrip pre-embryo bestaat er in dit geval in, dat met de introductie van dit begrip een uitzonderingssituatie wordt gecreëerd waarin een 'verbodsvoorschrift' buiten werking wordt gesteld (vergelijk Spreeuwenberg 1989, 451-472).

Een soortgelijke redenering kan worden opgezet ten aanzien van het begripsmatige onderscheid tussen vroeggeboorte en abortus, ter aanduiding van de geboorte van een prematuur respectievelijk immatuur kind. Evenzo zal een natuurwetenschappelijk of sociaalwetenschappelijk onderzoeker in zijn keuze van een bepaald conceptueel model het normatieve perspectief verraden vanwaaruit deze (delen van) de werkelijkheid beoordeelt in termen van structuur en interactie. Dit mechanisme is in vele toonaarden beschreven (zie onder andere De Boer/Köbben 1974; Albert 1976; Kunneman 1983; Korthals 1986).

Het pre-embryo-voorbeeld maakt duidelijk, dat het normatieve -hier het buiten werking stellen van een norm- contextafhankelijk is voor wat betreft zijn kwalificatie als normatief. Dat geldt in zijn algemeenheid voor al het menselijk handelen. Intenties en doelein- 
den van personen alsmede omstandigheden waaronder het handelen plaatsvindt, zijn mede bepalend voor de vraag in welke mate en op welke wijze iets als normatief kan worden geïnterpreteerd.

Behalve dat uit de context kan worden afgeleid of de desbetreffende norm daadwerkelijk wordt gevolgd, dus een substraat in de werkelijkheid ornvat, bestaat ook nog de mogelijkheid dat normen worden voorgehouden in de betekenis van een ideaal. In het eerste geval kan tot een normatieve dimensie worden besloten op grond van een beschrijving van gedragingen. In het tweede geval bestaat het normatieve puur als gedachtengoed van een individu of groep.

Het menselijk bestaan lijkt aldus doordrenkt van normativiteit. Ook daar zijn normen werkzaam, waar er niet expliciet naar wordt verwezen. Dit heeft de filosoof Henderson $(1988,21)$ doen besluiten een normatieve dimensie toe te kennen aan de gehele werkelijkheid, zowel de humane als de non-humane werkelijkheid, en wel op grond van drie hoofdargumenten:

1. Al ons denken en doen impliceert een oordeel over of wordt beoordeeld op zijn gevolgen voor dingen, wezens, denkbeelden, andere mensen, verleden en toekomst. Dit op grond van de 'law of no non-effect'. Dat wil zeggen: alles wordt beïnvloed door en heeft invloed op alles, hoe indirect ook.

2. Niemand kan leven zonder het stellen van daden of handelingen.

3. Het identificeren en benoemen van zaken impliceert evaluaties van deels normatieve aard. Onderzoek van de (non-)menselijke omgeving is niet mogelijk zonder evaluatieve (dus normatieve) maatstaven.

Het normatieve wordt bij Henderson min of meer gelijkgesteld met de beïnvloedende en/of evaluerende werking van zaken en mensen. Als algemene en formele uitspraak over de werkelijkheid verschaft dit echter weinig voldoening. Dat de werkelijkheid een normatieve dimensie bevat levert nog geen inzicht op in de preciese aard ervan. Bovendien moet nog worden omschreven hoe de verhouding tussen de normatieve en de andere dimensies van de werkelijkheid er uitziet. Het zijn juist deze punten waarover verschil van mening blijkt te bestaan. Uit deze meningsverschillen komt naar voren dat het normatieve vanuit verschillende perspectieven en accentleggingen kan worden waargenomen en bestudeerd.

In het kader van deze studie zullen nu twee van deze perspectieven nader worden beschreven. Op de eerste plaats het sociologische perspectief op de normatieve dimensie van de werkelijkheid. Ten tweede het praktisch-filosofische perspectief op deze dimensie. Het sociologisch perspectief is van belang voor een interpretatie van de normatieve aspecten van professionalisering in het verlengde van hoofdstuk 2 . Het praktisch-filosofische perspectief wordt geboden tegen de achtergrond van de doelstelling van deze studie.

\subsubsection{Normativiteit in sociologisch perspectief}

Tot uitgangspunt van deze paragraaf hebben twee auteurs gediend die een uitgebreide sociologische studie hebben gewijd aan de normatieve dimensie van (een deel van) de werkelijkheid. De eerste, J. Barnsley, heeft in zijn boek "The social reality of ethics" (1972) een vergelijkende analyse neergelegd van conceptuele en empirische aspecten met betrekking tot de normatieve dimensie van het menselijk bestaan. Van belang is verder dat hij daarbij een discussie aangaat met gangbare opvattingen binnen de wijsgerige 
ethiek. De tweede auteur, H. Philipsen, heeft in zijn boek "Gezondheidszorg als project en bejegening" (1988) een programmatische schets geboden van conceptualisaties en methoden, die voor een onderzoek naar de normatieve dimensie van het menselijk bestaan vruchtbaar lijken. Daarnaast heeft hij deze in verband gebracht met opvattingen over ziekte, gezondheid en gezondheidszorg.

Beide auteurs bieden een samenvatting wan eigentijdse opvattingen over het normatieve, gezien door de bril van de socioloog. Opvallend is echter, dat -hoewel een kloof van zestien jaar het verschijnen van beide studies scheidt- beiden deels teruggrijpen op dezelfde sociologische bronnen. Dit kan samenhangen met beider mening (Barnsley 1972, 7, $17-$ 20, 89; Philipsen 1988, 7,39, 125), dat in dit onderdeel van de sociologie weinig vooruitgang wordt geboekt en men in het algemeen veel methodologische problemen ontmoet. Wellicht is dit de reden, dat een heroriëntatie op gezaghebbende auteurs uit het verleden plaatsvindt. Het vermoeden lijkt gewettigd, dat naast het werk van deze auteurs geen belangrijkere andere werken verschenen zijn en een weergave wordt geboden van de actuele stand van zaken in het vakgebied.

Barnsley (7-8) kent in zijn beschouwingen een centrale rol toe aan het begrip 'moral code'. Het doet bij hem dienst als analytische term ter beschrijving van individuele en groepsgebonden opvattingen over goed en kwaad, wenselijkheden en onwenselijkheden, alsmede van de hiermee samenhangende richtlijnen voor gedrag. Deze opvattingen maken deel uit van wat in een samenleving is geïnstitutionaliseerd als waarheid en als zodanig een onderdeel vormt van de 'objectieve' werkelijkheid.

Het begrip 'moral code' vervult volgens Barnsley drie essentiële functies:

1. Een brede interpretatieve functie: aan individuele ervaringen wordt door middel van onderscheidende en evaluerende criteria een bepaalde betekenis verleend, zowel ten aanzien van het eigen handelen als ten aanzien van het handelen van anderen.

2. Een praktische functie: de 'moral code' bevat aanbevelingen tot een bepaald gedrag.

3. Door het begrip wordt de aandacht gericht op het feit dat 'moralities' gewoonlijk bestaan uit minder of meer geïntegreerde systemen van voorschriften en waarden.

Deze morele voorschriften en waarden worden door Barnsley formeel gedefinieerd in termen van de superioriteit en legitimiteit die ervoor worden geclaimd (47). De vraag of ze ook in wijsgerig-ethische zin zijn gerechtvaardigd zondert hij uitdrukkelijk af wan het sociologische perspectief. Het gaat om de claim zelf, niet om de kwaliteit van de claim (42). Ten aanzien van de superioriteitsclaim maakt hij onderscheid tussen de autonomie en de prioriteit van morele voorschriften en waarden. Ze zijn autonoom in die zin, dat geen verdere rechtvaardiging ervan noodzakelijk wordt gevonden, als ze eenmaal zijn aanvaard. De prioriteit betreft hun voorrang op andere (niet-morele) aspecten van het gedrag (43).

De legitimiteit van morele voorschriften en waarden (= morele code) omvat drie met elkaar verbonden aspecten: rechtvaardigbaarheid, intersubjectiviteit, en realiteit-gebondenheid. 'Rechtvaardigbaarheid' verwijst naar de gegrondheid van een claim, de aanwezigheid van een bewijs of argument. 'Intersubjectiviteit' betreft het vereiste dat een claim bindend is voor degene die de claim naar voren brengt én voor anderen. Dit impliceert een bepaalde mate van belangeloosheid en generaliseerbaarheid van de claim. 'Realiteitgebondenheid' tenslotte betreft de eis, dat morele principes zijn gebaseerd op de ware aard der dingen. Dat wil zeggen, dat zij op een of andere wijze zijn afgeleid van iemands 
grondovertuiging, zijn opvatting inzake de menselijke natuur, inzake de wereld, of inzake de werkelijkheid in het algemeen (44-46).

Gezien bovenstaande kenmerken van morele claims is het niet verwonderlijk dat Barnsley morele codes een centrale rol toeschrijft in samenlevingen en in het leven van de leden daarvan (47). Met betrekking tot de elementen van een morele code wordt primair een onderscheid gemaakt tussen de processen van evaluatie en van voorschrijven. Het proces van evaluatie voltrekt zich in de context van waarden en idealen. Het voorschrijvende aspect betreft de eerder genoemde morele voorschriften, maar strekt zich uit tot allerlei andere onderdelen van het handelen zoals handelingsregels, gedragsnormen en morele adviezen. Kenmerk ervan is, dat zij het gedrag leiden. Morele evaluaties daarentegen worden gekenmerkt door observaties van de waardigheid of onwaardigheid van een handeling (of actor). Evaluaties, met andere woorden, betreffen dus de 'goedheid' van een handeling, terwijl voorschriften gericht zijn op de 'juistheid' ervan (49). Tot zover sluit hij aan bij het gebruikelijke sociologische onderscheid tussen waarden en normen als de bepalende elementen van een morele code.

Barnsley heeft echter kritiek op de nadruk onder sociologen op de zogenaamde 'doctrine of approbationism'. Hierin worden waarden beschouwd als de primair constituerende aspecten van een morele code. Voorschriften en normen zijn slechts een afgeleide daarvan (89). Tegenover deze opvatting betoogt hij, dat de primaire betekenis van de systematiek in morele codes bestaat in het feit, dat zij karakteristieke wijzen van moreel redeneren en morele rechtvaardiging bevatten (52). Dit kenmerk wordt naar zijn oordeel veelal onvoldoende belicht in bestaande typologieën en classificatieschema's van waarden en normen (67). Voorschriften kunnen niet rechtstreeks worden afgeleid uit evaluaties, maar slechts met een beroep op additionele assumpties (69). Bovendien lijkt een focus op normen of morele voorschriften zijns inziens voor de sociologie beter hanteerbaar dan een focus op waarden. Maatstaven voor de beoordeling van gedrag als juist of onjuist zijn gewoonlijk veel explicieter geformuleerd en 'objectiever' dan de maatstaven waarmee mensen een handeling evalueren als goed of kwaad. Waarden zijn slechts secundaire theoretische constructies. Ze zijn door middel van gevolgtrekkingen afgeleid uit de gegevens die ten aanzien van morele voorschriften zijn verzameld (51-52).

Met betrekking tot de wijzen van moreel redeneren onderscheidt Barnsley twee grondvormen:

1. Een rechtvaardiging van het morele voorschrift vanuit de goede of slechte consequenties die ten aanzien van de toepassing van een principe redelijkerwijs mogen worden verwacht (extrinsieke morele argumentatie).

2. Een rechtvaardiging van het morele voorschrift doordat het de belichaming vormt van een gekozen criterium van juistheid (intrinsieke morele argumentatie).

In overeenstemming met een in de wijsgerige ethiek gehanteerd onderscheid plaatst Barnsley de extrinsieke wijze van morele argumentatie binnen de teleologische theorieën en de intrinsieke wijze van moreel argumenteren binnen de deontologische theorieën (76; de genoemde theorieën worden in 3.2.2 nader uitgewerkt). Hij acht het om een aantal redenen van belang om het onderscheid ook in sociologische analyses op te nemen:

1. Veel situaties waarin basale morele dilemma's aan de orde worden gesteld, kunnen worden geanalyseerd overeenkomstig deze twee vormen van rechtvaardiging. De verschillen hebben meestal betrekking op het onderscheid tussen doeleinden en middelen. 
2. De nadruk op een bepaalde vorm van rechtvaardiging hangt samen met bepaalde sociale condities. Zo vergen acute situaties meestal een nadruk op een extrinsieke, instrumentele benadering:

3. Het voordeel van een onderscheid tussen beide vormen van rechtvaardiging bewijst zich ook in de context van moderne samenlevingen, waarin bijvoorbeeld de nadruk op economische groei leidt tot eenzijdig extrinsieke, instrumentele rechtvaardigingen $(77-81)$.

Philipsen (1988) plaatst het normatieve in een culturele context. Het normatieve aspect van de cultuur vat hij vervolgens samen onder de term 'waardenoriëntatie' (133). In navolging van Kluckhohn definieert hij 'waardenoriëntatie' als:

1. een gegeneraliseerd en systematisch geheel van opvattingen,

2. dat het gedrag beinnloedt;

3. en wel opvattingen over de natuur, de plaats van de mens daarin en de rellaties tussen mensen,

4. alsook opvattingen over het wenselijke en niet-wenselijke met betrekking tot de verhouding tussen mens en natuur en de onderlinge verhoudingen tussen mensen (134).

Duidelijk is, dat binnen deze waardenoriëntatie een plaats wordt toegekend aan bepaalde cognitieve aspecten van de cultuur en dat het normatieve meer in het bijzonder wordt aangeduid als opvattingen inzake waarden en normen. Dit laatste is vergelijkbaar met wat Barnsley hierboven samenvatte onder de term 'morele code'. Bovendien legt ook Barnsley een relatie tussen morele codes en de cognitieve aspecten van de cultuur. Deze komt naar voren in zijn eis van realiteit-gebondenheid als aspect van de legitimiteit van morele claims. Een zelfde relatie vinden we bij Philipsen terug in het tweede, derde en vierde onderdeel van zijn definitie.

'Waarden' omschrijft Philipsen als:

1. denkbeelden over 'zaken',

2. die voor goed en wenselijk worden gehouden,

3. volgens een verscheidenheid van criteria voor goedheid,

4. die deel uitmaken van de cultuur van de samenleving, en

5. alleen begrepen kunnen worden in samenhang met andere normen en waarden, alsook andere elementen van de cultuur (130).

Kortom: "Waarden zijn "zaken" of beter ideeën die nagestreefd dienen te worden en waarover in groeperingen overeenstemming bestaat." (18).

'Normen' omschrijft hij ideaal-typisch als "....kenmerken van gedrag en de beoordeling ervan in termen van gedragsregels ..." (212). De kenmerken van deze gedragsregels zijn:

1. Ze bevatten een feitelijke verwachting dat men in overeenkomstige situaties op dezelfde wijze zal handelen.

2. Niet-nakomen ervan wordt negatief beoordeeld (bijvoorbeeld als ongepast beschouwd).

3. (Niet-)nakomen ervan wordt sociaal gesanctioneerd door relevante anderen.

4. Nakomen ervan doet men uit zichzelf, zonder dwang.

5. Ze zijn geen geformaliseerde en gestandaardiseerde voorschriften, maar er is nuimte voor individuele toepassing.

6. Ze hebben geen betrekking op individuen als zodanig, maar op groepen of categorieën mensen onder bepaalde omstandigheden. 
7. Ze worden door groepen of categorieèn mensen gedeeld en zijn niet individueel van aard.

8. Ze staan niet op zichzelf, maar hangen samen met andere normen, inhoudelijk ook met bepaalde waarden, sociale functies of historische processen (121-122).

Philipsen vat het bovenstaande alsvolgt samen: "Normen zijn vanuit de waarden begrijpelijke regels voor vanzelfsprekend gedrag." (24). Gememoreerd zij hier, dat Barnsleys kritiek op het approbationisme zich richt tegen onder andere dit soort definities en ermee samenhangende uitwerkingen van normen als afgeleide van waarden.

Terwijl Barnsley de termen 'voorschrift' en 'norm' als synoniemen hanteert, onderscheidt Philipsen deze juist. In tegenstelling tot normen in stricte zin is bij voorschriften sprake van:

1. Een zekere formalisatie en standaardisatie.

2. Een bepaalde mate van (vooral juridische) dwang.

3. Geringere of zelfs afwezige internalisatie of 'deling'.

4. Geringe normatieve integratie (122-124).

Voorschriften zijn veelal operationeel van aard. Ze zijn soms normatief, voorzover ze aanwijzingen vormen voor onderlinge verhoudingen, omgangsvormen en uiterlijk (124). Barnsley nu betrekt operationele voorschriften uitdrukkelijk niet in zijn betoog, als zijnde voorschriften van niet-morele aard. Daarnaast dekt zijn gebruik van de term 'voorschrift' min of meer de omschrijving die Philipsen geeft van de term 'norm'.

Rekening houdend met dit verschil in nomenclatuur zien we dat tussen beide auteurs een verschil optreedt ten aanzien van de geschiktheid van voorschriften respectievelijk normen als primair object van onderzoek met betrekking tot normen en waarden. Barnsley legt duidelijk de nadruk op het domein van de voorschriften. Philipsen daarentegen betoogt, dat normen -althans binnen organisaties als de gezondheidszorg- veelal zijn verdrongen door voorschriften en reglementen, zeker op de gebieden die van strategisch belang zijn voor de verwezenlijking van de doeleinden (26). Zelfs in de samenleving als geheel vindt men ze nauwelijks: boven-individuele regels in de vorm van gedragscodes en omgangsvormen zijn zeldzaam (123). Philipsen legt dan ook meer nadruk op 'waarden' als primair object van onderzoek.

Naast het onderscheid tussen normen en voorschriften maakt Philipsen ook een onderscheid tussen zogenaamde 'eindwwaarden' en 'handelingswaarden' (hij volgt hierin Rokeach). Eindwaarden betreffen 'zaken' die een doel in zichzelf zijn, zoals geluk, efficiency en vrede. Hiervoor wil Philipsen het begrip 'waarden' in engere zin reserveren. Handelingswaarden zijn wijzen van handelen die als normatief juist worden beschouwd, zoals eerlijkheid, toewijding en zakelijkheid. Hiervoor reserveert hij de term 'deugden' (18). Tussen waarden in engere zin en doeleinden bestaat een nauwe relatie. Doeleinden zijn op te vatten als de institutionele verschijningsvorm van waarden. Veelal worden zij in organisaties omgezet in voorschriften, in veel mindere mate in gedragsregels als normen of in handelingswaarden als deugden (19-20).

Over de onderlinge relatie tussen waarden en deugden, normen en voorschriften en hun relatieve positie in een organisatie als de gezondheidszorg betoogt Philipsen het volgende: "Waarden en normen zijn constructies ,(...) nemen in het menselijk handelen een intermediaire plaats in. (...) In een organisatie worden waarden omgezet in doeleinden en in een statuut vastgelegd. Vanaf dat moment zijn waarden tot op zekere hoogte wel als entiteit in de objectieve werkelijkheid te beschouwen. Tot op zekere hoogte is een goede 
toevoeging omdat doeleinden gewoonlijk concreter en operationeler van aard zijn dan de waarden waarvan ze zijn afgeleid. Ook normen hebben een tegenhanger in de objectieve werkelijkheid van de formele organisatie: reglementen, procedures, voorschriften, gestandaardiseerde vaardigheden enzovoort. De relatie tussen normen en voorschriften is meer problematisch dan die tussen waarden en doeleïnden. Voorschriften worden eerder ontleend aan de doeleinden dan aan de normen." (24-25).

Normen spelen in de gezondheidszorg volgens Philipsen vooral een rol in de wederzijdse bejegening van actoren (27). De gezondheidszorg wordt daarbij opgevat als een bijzondere vorm van project (11). Zo'n project geldt "... als het meest typische voorbeeld van een systeem: gedurende een beperkte tijd (...) wordt op een nauw omschreven manier (...) een gedefinieerde begintoestand omgezet in een gedefinieerde eindtoestand ..." (9).

Het bijzondere aan de gezondheidszorg als project is, dat de aanwezigheid van de patiënt of cliënt interfereert met het projectmatig handelen. Dit wordt volgens Philipsen gekenmerkt door instrumentele rationaliteit (11) en denoterend denken. Het denoterend denken wordt beheerst door "... het werelldbeeld van de objectieve werkelijkheid van oorzaak en gevolg die door waarneming, theorie en methodiek gekend wordt en steeds beter gekend wordt." (19). Het is een denken, dat causale relaties blootlegt, deze in theoretische constructies probeert samen te vatten en te positioneren en op basis daarvan handelingsalternatieven ontwerpt. Wat niet in dergelijke relaties en constructies is onder te brengen, vormt voor het denoterend denken een probleem.

De patiënt is niet alleen object van het project en het denoterend denken, maar onttrekt zich daar als subject ook aan. Hij is zieke, niet alleen ziekte. Naast de aanvaarding van het project ten aanzien van zijn ziekte gelden voor hem ook waarden als geluk, zin van het leven, evenals dat voor hulpverleners het geval is. Hij zal zich mede laten leiden door het zogenaamde connoterend denken: "In dit connoterend denken overheerst het bewustzijn met zijn gewaarwordingen, waarbij de dingen niet louter zijn wat ze zijn, maar ook wat ze betekenen" (19). Dit impliceert, dat tot het denken andere zaken worden toegelaten dan uitsluitend die welke in causale relaties en theoretische constructies kunnen worden gevangen.

Dit connoterend denken komt tot uiting in de stijl van optreden, door Philipsen 'bejegening' genoemd: "Het is in de gezondheidszorg het gedrag dat niet direct gericht is op de specifieke doeleinden van medische behandeling, verpleging, verzorging, revalidatie, voorlichting en dergelijke." (13). Tussen project en bejegening bestaat steeds een spanning, waarbij de bejegening zich veelal schikt naar het project, zodat de ontmoeting meestal de kenmerken vertoont van een 'instrumentele ceremoniële orde' (15 en 17). Philipsen bedoelt hiermee, dat hulpverleningsrelaties in het algemeen primair zijn gericht op het oplossen van een hulpvraag met behulp van beproefde methoden en instrumenten volgens het wetenschappelijk referentiekader van de hulpverlener en niet op de eveneens aanwezige onzekerheden en zinvragen. Ook om deze reden zal men op problemen stuiten wanneer men op zoek gaat naar normen in de gezondheidszorg. Normen hangen immers nauw samen met een specifieke benadering van dergelijke zinvragen vanuit de waardenoriëntatie. Eerder werd al gewezen op de verdringing van deze normen door voorschriften.

In tegenstelling tot Barnsley gaat Philipsen niet in op de wijze waarop waarden en doeleinden, normen en voorschriften, project en bejegening, worden gerechtvaardigd. Zijn analyse beperkt zich tot een beschrijving van de genoemde verschijnselen. Wel heeft hij 
aandacht woor de verschillende wijzen van denken (denoterend en connoterend) op grond waarvan deze verschijnselen zijn wat ze zijn. Dit denken speelt dus meer een voorwaardelijke rol dan dat het dienst doet als rechtvaardiging.

\subsubsection{Normativiteit: verschillende denkwijzen en poging tot systemati-}

\section{sering in de praktische filosofie}

In de vorige paragraaf werd gesproken over normatieve aspecten van de werkelijkheid vanuit een sociologisch perspectief. We vervolgen hier onze beschouwingen met een uiteenzetting van die normatieve aspecten vanuit de praktische filosofie.

Onder deze term worden gewoonlijk alle pogingen gerangschikt die vanuit wijsgerig perspectief worden ondernomen om sociale verschijnselen in hun eenheid en verscheidenheid te duiden en om ze te plaatsen in een bepaalde denkwijze ten aanzien van het menselijk handelen. Als zodanig wordt de praktische filosofie met verschillende termen aangeduid: wijsgerige ethiek, sociale filosofie, sociale ethiek, wijsbegeerte van het maatschappelijk handelen, en andere. Iedere auteur hanteert als het ware zijn of haar eigen nomenclatuur en begrippenkader.

Wat hieronder schuilgaat lijkt dus op het eerste gezicht zeer divers. Bij nadere beschouwing worden echter samenhangen zichtbaar die zich lenen voor een poging tot systematisering. Deze poging wordt hier ondernomen langs twee varianten: die van de wijsgerige ethiek en van de sociale filosofie (zie figuur 3.1). De gepresenteerde systematiek levert een inzicht op in de diverse denkwijzen waarlangs het normativiteitsvraagstuk in de filosofie wordt benaderd. Zij is dus zowel achtergrond als nuttig bijproduct van de thematiek die hier aan de orde is:

Ook in de ethiek wordt het begrip 'normativiteit' gebruikt ter aanduiding van een kenmerk van sociale verschijnselen. Dit begrip ontleent zij meestal aan de sociale wetenschappen. Daarnaast wordt het echter gebruikt in het kader van eén van haar expliciete functies, namelijk die van een beoordeling van de wenselijkheid van die verschijnselen. 'Normativiteit' heeft in de ethiek dus een dubbele betekenis: een beschrijvende en een evaluatieve betekenis. Enerzijds heeft de ethiek er belang bij te weten welke normatieve aspecten in de werkelijkheid geldingskracht hebben (descriptief). Zij richt zich daarbij voornamelijk op het identificeren van feitelijk aanwezige of gevolgde waarden en normen in het menselijk handelen, in zijn meest brede betekenis. Anderzijds rekent zij het tot haar taak criteria te ontwikkelen ter beoordeling van die normatieve aspecten (evaluatief). De ethiek poogt dan een antwoord te formuleren op de vraag welke waarden en normen aanwezig zouden moeten zijn of gevolgd zouden moeten worden. Zij formuleert dat antwoord in de richting van een specifieke opvatting over datgene, dat de mens tot een goed mens maakt en dat de samenleving tot een goede samenleving maakt. Tot de ethiek behoort dan ook een nadere explicitering van 'het goede'. We komen hierop nog terug.

Analyses ten aanzien van feitelijk aanwezige of gevolgde waarden en normen vinden plaats in wat de descriptieve ethiek wordt genoemd. Deze vorm van ethiek beweegt zich op hetzelfde terrein als wat in de sociale wetenschappen wordt gepresenteerd als de resultaten van het onderzoek naar normen en waarden. Dït betreft niet alleen het sociologisch onderzoek waarvan in het bovenstaande sprake was, maar bijvoorbeeld ook het on- 
derzoek dat wordt ondernomen vanuit een (sociaal)psychologische, politicologische of cultureel-antropologische invalshoek. De resultaten van dit soort onderzoek, evenals van de descriptieve ethiek, geven inzicht in het morele verschijnsel als zodanig. Het 'morele verschijnsel' is de formele aanduiding van wat onder filosofen algemeen het 'ethos' of de 'moraal" wordt genøemd van een individu, groep of samenleving. 'Ethos' en 'moraal' zijn descriptieve predikaten. Het gebruik, door Barnsley en Philipsen hierboven, van termen als 'moral code', 'morality' en 'moreel' moet ook in deze beperkte betekenis worden opgevat. Tegelijkertijd wordt door bijvoorbeeld Philipsen nog een verdere beperking in de betekenis aangebracht door 'ethos' alleen te reserveren voor normatieve aspecten van waarneembaar collectief gedrag. Daarentegen wordt in de ethiek met 'ethos' tevens verwezen naar individueel gedrag en naar de al dan niet waarneembare gezindheid van personen. De betekenis die Barnsley hecht aan het begrip 'moral code" sluit hier bij aan.

Formulering van 'het goede' en van aanbevelingen inzake met dit goede overeenstemmende en nastrevenswalardige waarden en normen, vindt plaats in het kader van de zogenaamde normatieve ethiek: "Normative ethics is concerned with justifying and applying criteria of what is morally right and wrong, good and bad. These activities of normative ethics issue in normative moral rules and judgments, and these, in turn have direct implications for what human actions, characters, institutions, and ways of life should be like:" (Gewirth 1974, 990). De bepaling van deze criteria behoort tot de centrale vragen in de normatieve ethiek en is uiteindelijk van beslissende betekenis voor de aard van haar normativiteit.

Deze vraag is echter niet alleen kenmerkend woor de wijsgerige ethiek, maar ook voor de sociale filosofie (en daarmee voor de praktische filosofie als zodanig). Hoewel de vraag op verschillende manieren wordt benaderd, lijkt daarbij veelvuldig gebruik te worden gemaakt van wederzijds erkende zienswijzen. Zo onderscheidt de sociaalfilosofe Van Asperen bijvoorbeeld in navolging van de ethicus Frankena (1973) waardetheorieën, plichttheorieën en evaluatieve theorieën. In de waardetheorieën, ook wel axiologie genoemd, houdt men zich vooral bezig met de omschrijving van 'het goede'. Het nadenken over waarden wordt in de plichttheorie aangevuld met beschouwingen over de vraag hoe er zou moeten worden gehandeld. Deze prescriptiviteit en gerichtheid op de toekomst zijn kenmerkend voor de plichttheorie. (Volgens sommige ethici zijn deze kenmerken zelfs beslissend voor het bestaan van de ethiek als vakgebied überhaupt; vergelijk Nauta 1971, 20-24). Een evaluatieve theorie daarentegen is niet toekomstgericht, maar beoordeelt het handelen achteraf. $\mathrm{Zij}$ is retrospectief. Centraal in deze theorie staan de vraag naar de verantwoordelijkheid en overwegingen met betrekking tot de context van het handelen (Van Asperen 1978, 5).

Hoewel het bovenstaande, zoals gezegd, in de wijsgerige ethiek niet wordt ontkend noch bestreden, is er toch wel sprake van accentverschillen en van een andere terminologie en afwijkend begrippenkader. Toekomstgerichtheid en retrospectiviteit van een theorie worden in de normatieve ethiek meestal samengevoegd en genoemd als onderscheiden, maar niet te scheiden kenmerken van éen en dezelfde theorie. Met betrekking tot de gangbare theorieën wordt dan vervolgens een onderscheid gemaakt tussen deontologische en teleologische theorieën. De vraag naar de bepalende criteria van de normatieve ethiek wordt in deze theorieèn op verschillende wijze beantwoord (edoch formeel-analoog aan de sociale filosofie). Het belangrijkste verschil is volgens Gewirth, dat deontologische theorieën geen beroep doen op overwegingen ten aanzien van waarden bij de be- 
antwoording van de vraag naar de criteria van de normatieve ethiek. Daarnaast formuleert hij nog vijf additionele verschillen: "(1) Deontological theories advocate doing certain things on principle or because they are inherently right, whereas teleological theories advocate doing things because of their consequences. (2) Deantological theories set forth absolute obligations, whereas teleological theories set forth only conditional obligations. (3) Deontological theories set forth formal or relational criteria, such as equality or impartiality, whereas teleological theories set forth material or substantive criteria, such as pleasure or happiness. (4) Deontological theories set forth distributive criteria, concerning how goods or evills should be allocated or divided among men, whereas teleological theories set forth aggregative criteria, concerning the maximization of goods and minimization of evils. (5) Deontological theories set forth plural as well as unitary criteria, whereas teleological theories set forth only a unitary criterion, such as doing the greatest amount of good:" (Gewirth 1974, 990).

Deontologische theorieën vallen gedeeltelijk samen met wat Van Asperen hierboven plichttheorieën noemde. Echter, de exclusiviteit van het kenmerk 'toekomstgerichtheid' ontbreekt en uitsluitend morele plichten komen ter sprake (hierover later). Teleologische theorieèn zijn gebaseerd op waardetheorieèn (axiologie). Deze verbondenheid van deontologische theorieën met plichttheorieenn en van teleologische theorieèn met waardetheorieèn is meervoudig van aard. $\mathrm{Zij}$ vormen een nadere uitwerking van normatieve posities in de praktische filosofie, respectievelijk in wijsgerige ethiek en sociale filosofie. Ten tweede is er een verbondenheid op inhoudelijk gebied, indien men althans waarden en plichten van nonmorele aard voor het moment even buiten beschouwing laat. Zo wordt zowel binnen de teleologische ethiek als de waardetheorieën gebruik gemaakt van dezelfde hedonistische en antihedonistische opvattingen ten aanzien van de vraag wat als hoogste goed moet worden beschouwd. En zowel bij de deontologische ethiek als bij de plichttheorieën kan onderscheid worden gemaakt tussen formele en materiële posities en vervolgens ten aanzien van de laatste tussen pluralistische en monistische posities. Een nadere uitleg van deze posities volgt later nog in het kader van een bespreking van het morele karakter van waarden en plichten.

Allereerst wordt echter de 'brede' betekenis van het waardebegrip aan de orde gesteld. Deze komt wooral naar voren in de waardetheorieèn of axiologie. In de teleologische e-thiek treft men het begrip uitsluitend aan in zijn morele betekenis.

In een sociaalfilosofische context is het begrip 'waarde' een abstracte aanduiding voor alle vormen van kritische of pro- en contra-predikaten, in tegenstelling tot descriptieve predikaten of feiten. In een meer beperkte en concreter betekenis verwijst het naar hetgeen wordt gewaardeerd, hetgeen wordt geacht waarde te bezitten, hetgeen goed of wenselijk wordt genoemd.

Zowel ten aanzien van deze brede als ten aanzien van de meer beperkte betekenis kunnen twee soorten wijsgerige theorieën onderscheiden worden." normatieve theorieèn en metanormatieve theorieën: "Normative theories make value judgments of valuations; they tell us what is good or what has value, what is bad, and so on. Metanormative. theories analyze value, valuation, and good; they neither make value judgments in this way nor tell us what is good or has value. Instead, they define, what goodness and value are and what it means to say that something is good or has value." (Frankena 1967, 230). 
Voor de onderhavige beschouwing is vooral de beperkte betekenis van "waarde" van belang. 'Waarde" krijgt hier de betekenis van 'intrinsieke waarde': het goede of wenselijke als doel of in zichzelf (dit in tegenstelling tot bijvoorbeeld 'extrinsieke' of 'instrumentele waarde': het goede als middel tot een hoger goed). Normatieve theorieën, met als uitgangspunt deze betekenis van 'waarde' als 'intrinsieke waarde', concentreren zich dus rond de vraag wat het goede is, wat waarde heeft in zichzelf, wat kan worden beschouwd als het doel van ons streven of als criterium voor intrinsieke waarde. Sommige theorieën formuleren het doel of het goede als genot of plezier. Zij staan bekend als hedonistische waardetheorieën. Daarin wordt aangenomen dat alleen ervaringen intrinsiek goed kunnen zijn en dat zij alleen goed kunnen zijn wanneer zij plezierig zijn of genot opleveren. Daartegenover staan de anti-hedonistische theorieën waarin niet "plezier" maar andere 'zaken' als het hoogste goed worden beschouwd, soms zelfs meer 'zaken' tegelijk. In deze theorieën kan aan bijvoorbeeld kennis, zelfverwerkelijking, schoonheid, waarheid, deugd, harmonie of vriendschap intrinsieke waarde worden toegekend.

In metanormatieve waardetheorieën wordt niet zozeer het criterium of de inhoud van (intrinsieke) waarden of 'het goede' bepaald, maar wordt onderzocht wat de aard is van deze waarden en 'goedheid'. Hiertoe behoren ook de vraag naar de aard van ethische waarden en ethische oordelen en de vraag hoe deze zich onderscheiden van niet-ethische waarden en oordelen. Dergelijke vragen zijn zowel van belang voor de sociale fillosofie als voor de wijsgerige ethiek. In beide takken van wijsbegeerte worden daartoe dezelfde posities ingenomen en geldt Frankena als een gezaghebbend auteur. Deze posities kunnen in onze systematiek worden beschouwd als een dwarsverband tussen sociale filosofie en wijsgerige ethiek (als metanormatieve theorie respectievelijk meta-ethiek; zie figuur 3.1).

Ten aanzien van genoemde vragen formuleert Frankena $(1967,231-232)$ de volgende posities:

1. Naturalisten of cognitivisten beschouwen waarde-oordelen als descriptief of feitelijk in die zin, dat waarde-oordelen eigenschappen toeschrijven aan dingen. Deze eigenschappen zijn natuurlijk of empirisch en kunnen worden waargenomen en/of gedefinieerd en de toeschrijvingen kunnen worden gefalsifieerd.

2. Intuitionisten menen juist, dat waarde of goedheid een kenmerk is dat noch kan worden waargenomen noch ervaren noch object kan zijn van empirisch onderzoek. Tot deze groep behoren filosofen die menen, dat intrinsieke goedheid of waarde een ondefinieerbare niet-natuurlijke of niet-empirische kwaliteit of eigenschap is.

3. Noncognitivisten verdedigen het standpunt, dat waarde-oordelen niet een bepaalde eigenschap toeschrijven, maar een geheel andere functie of betekenis hebben. Onder hen bevindt zich een groep die waarde-oordelen beschouwt als uitingen van een attitude, emotie of wens. Anderen kwalificeren ze als instrument om soortgelijke uitingen of reacties op te roepen bij anderen. Weer een andere groep beschouwt waarde-oordelen als prescripties, aanbevelingen of eenvoudig als waarderingen (zie ook Brandt 1967, 7-8; Gewirth 1974, 980-990).

De grondvraag waar het in de metanormatieve theorieën orn gaat is echter die naar de rechtvaardiging van basale of zogenaamde nonderivatieve waarde-oordelen:

1. Intuitionisten menen, dat dergelijke oordelen niet argumentatief kunnen worden gerechtvaardigd, maar slechts intuïtief kunnen worden gekend of zelf-evident zijn. 


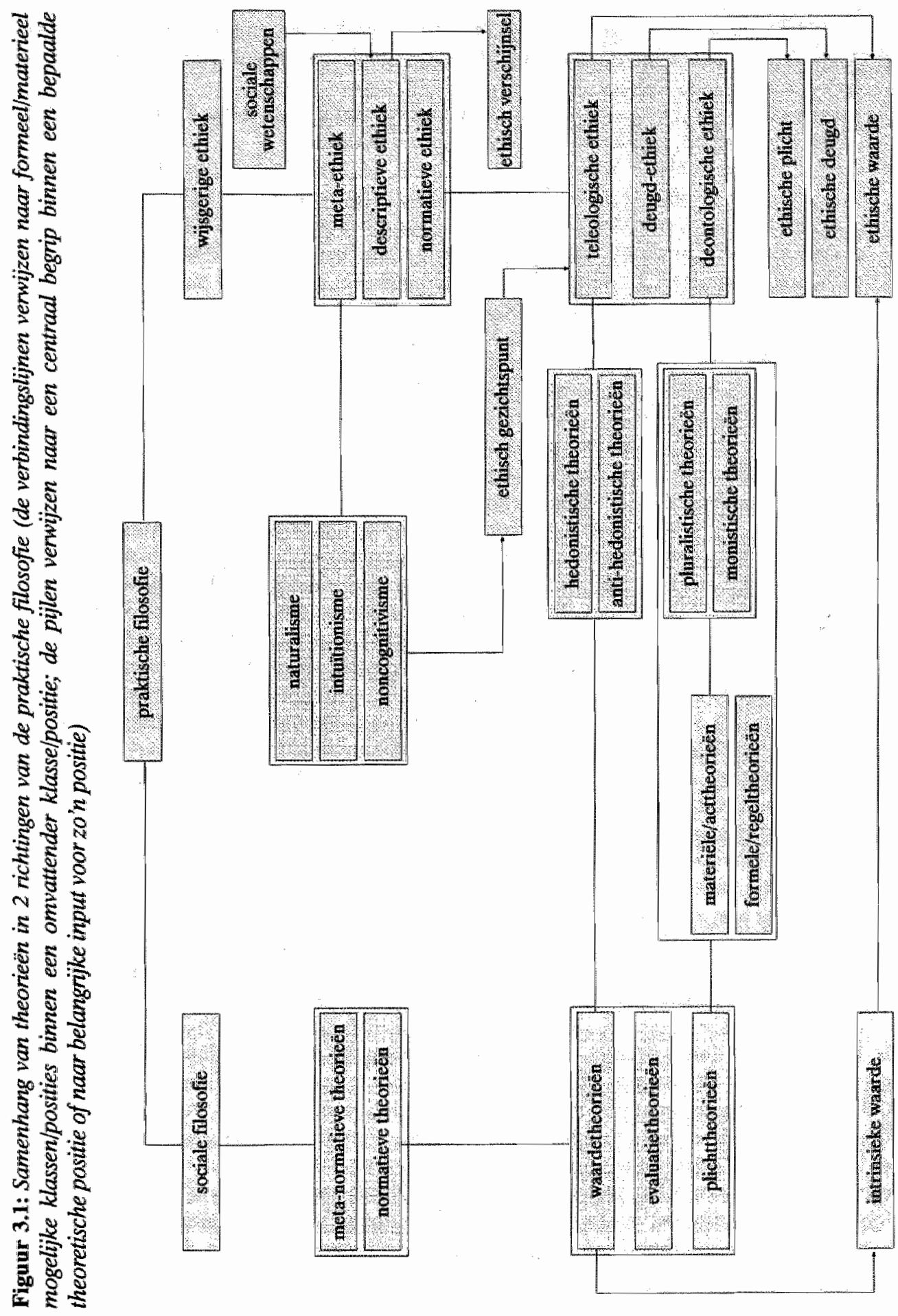


2. Naturalisten menen, dat een empirische bewijsvoering mogelijk is of dat waarde-oordelen worden bevestigd door de betekenis van de desbetreffende (analytische of gedefinieerde) termen.

3. Metafysisch cognitivisten verantwoorden waarde-oordelen met een beroep op metafysische argumenten, goddelijke openbaring of bij definitie.

4. Onder noncognitivisten wordt een breed scala aan 'rechtvaardigingen' aangetroffen, varierend van de onmogelijkheid tot rechtvaardiging vanwege het willekeurige en irrationele karakter van waarde-oordelen, via waarde-oordelen als intersubjectief valide conventies, tot waarde-oordelen als rationeel rechtvaardigbaar edoch niet inductief of deductief bewijsbaar (Frankena 1967, 232).

Zoals gezegd, vinden we bovenstaande posities terug in zowel de sociale filosofie als de wijsgerige ethiek. Hieronder wordt meer in stricte zin ingegaan op wijsgerig-ethische begrippen en posities. Met de boven gepresenteerde inzichten is immers nog steeds niet precies de vraag beantwoord wat bijvoorbeeld in de teleologische normatief-ethische theorieën een waarde tot een ethische waarde en een waarde-oordeel tot een ethisch oordeel maakt. Wel is reeds opgemerkt, dat in dergelijke theorieën het begrip 'waarde' veelal wordt opgevat in de betekenis van 'intrinsieke waarde' en dat ten aanzien van het criterium voor 'intrinsieke waarde' een aantal (hedonistische en anti-hedonistische) opvattingen bestaat. Verder moet nog worden vermeld, dat ook waarden van andere aard (nuts-, extrinsieke, inherente en contributieve waarden) in een normatief-ethische context een rol spelen. Ze worden dan echter meestal in een functioneel verband met intrinsieke waarden of intrinsieke goedheid geplaatst (onder andere Frankena 1973, 82).

Een waarde is een ethische waarde wanneer zij een persoon, motief, bedoeling, daad of karaktereigenschap betreft en op ethische gronden kan worden aanbevolen (Frankena $1973,62,70$ en 82). Deze ethische gronden kunnen -om niet in een cirkelredenering te vervallen-worden ontleend aan wat onder ethici in het algemeen als invulling van het zogenaamde 'ethisch gezichtspunt' wordt gehanteerd, namelijk dat:

1. We normatieve oordelen geven over handelingen, verlangens, disposities, bedoelingen, motieven, personen, karaktereigenschappen.

2. We bereid zijn om onze oordelen algemeen te laten gelden.

3. De redenen voor onze oordelen aangeven wat het beoordeelde in het bestaan van mens en dier teweegbrengt, geformuleerd in termen van het bevorderen en het verdelen van het niet-morele goed en kwaad.

4. In geval het oordeel onszelf of onze eigen handelingen betreft, onze redenen ook dan aangeven wat onze eigen handelingen en disposities in het bestaan van andere mensen en dieren als zodanig, zo die er door worden beïnvloed, teweegbrengen. (Frankena 1973, 113).

In het eerste en derde aspect van deze omschrijving ligt tevens besloten wat in teleologisch perspectief als een ethisch waarde-oordeel wordt beschouwd. Ethische waarde-oordelen geven een oordeel over de waarde van handelingen, personen, motieven en dergelijke voorzover deze niet-ethische waarden of het nonmorele goed (helpen) bevorderen en/of verdelen. Zo zijn de uitspraken "Jan is jaloers" en "jalouzie is een onwaardig motief" ethische waarde-oordelen, terwijl de uitspraken "dat is een goede auto" en "genotmiddelen zijn op zichzelf goed" niet-ethische waarde-oordelen zijn. In de eerste soort oordelen wordt gesproken van personen en motieven, in de tweede soort van dingen en ervaringen. Deze laatste krijgen pas een ethisch gehalte wanneer wij stellen dat het moreel aan- 
bevelenswaard is om ze na te streven. Het onderscheid tussen beide soorten oordelen is dus mede afhankelijk van een verschil in de gronden of redenen die wij met betrekking tot het desbetreffende waarde-oordeel aangeven. Zo zijn bijvoorbeeld waarde-oordelen, gebaseerd op instrumentele of esthetische waarden, altijd van nonmorele aard (Frankena $1973,62)$.

Naast een teleologische benadering kent men in de normatieve ethiek, zoals toegelicht, een deontologische benadering, ook wel plicht-ethiek genoemd. Deze laatste benaming mag niet worden verward met die van een plichttheorie in algemene zin. In tegenstelling tot de plicht-ethiek houdt men zich binnen de algemene plichttheorieën ook bezig met (de formulering van) zogenaamde nonmorele plichten. Daarnaast geldt, dat ook binnen teleologische benaderingen gebruik wordt gemaakt van plichttheorieën. Deze schrijven voor aan welke eisen handelingen moeten voldoen om een nonmorele waarde te realiseren. In de plicht-ethiek als deontologische theorie spelen nonmorele waarden geen rol van betekenis.

Deontologische theorieën ontkennen min of meer wat teleologische theorieën bevestigen. Het juiste, het verplichte, het ethisch goede staat niet in functie van het nonmoreel goede of van de maximalisatie van het overwicht van het goede over het kwade, maar heeft een ander fundament. Voor de deontoloog kan het criterium voor het verplichte of het ethisch juiste liggen in bepaalde eigenschappen van de handeling of in de handelingsregels zelf, bijvoorbeeld in het feit dat een belofte wordt ingelost (Frankena 1973, 15).

Afhankelijk van de invulling van dat criterium wordt onderscheid gemaakt tussen materieel-deontologische theorieën en formeel-deontologische theorieën: "Material theories hold that the criterion of the rightness or obligatoriness of actions consists in some feature either of the actions themselves or of the background of the actions, whereas formal theories hold that it consists rather in some logically necessary relation between the judgments or rules in accordance with which the actions are performed" (Gewirth $1974,9901-991$ ).

Onder de materiële theorieën vinden we zowel pluralistische als monistische theorieën, dat wil zeggen: theorieẽn waarin handelingen en hun achtergrond diverse kenmerken kunnen bezitten die die handelingen verplichtend doen zijn (bijvoorbeeld existentialisme en situatie-ethiek) respectievelijk theorieën waarin slechts én principe als criterium voor de juistheid van handelingen geldt (bijvoorbeeld de wil van God of menswaardigheid). Het belangrijkste probleem bij materiële theorieën houdt verband met de (onmogelijkheid tot) rechtstreekse rechtvaardiging van plichten uit de kenmerken van een handeling. Hier stelt zich het feit-waarde-probleem in volle omvang: uit feitelijke premissen kan nu eenmaal geen normatieve conclusie worden afgeleid.

In de formeel-deontologische theorieën daarentegen wordt een logisch noodzakelijke relatie aangenomen tussen ethische oordelen. Handelingen die niet in overeenstemming zijn met bepaalde oordelen zijn inconsequent en zelfcontradictoir. Bijvoorbeeld, als iemand een vraag wordt gesteld en het is rationeel zijn plicht om geen onwaarheden te vertellen, dan is het rationeel zijn plicht een waar antwoord te geven. Een logisch noodzakelijke relatie tussen ethische oordelen wordt verkregen door toepassing van het principe van universaliseerbaarheid: wat goed is voor éen persoon moet goed zijn voor alle vergelijkbare personen in vergelijkbare omstandigheden. Toepassing van dit principe 
vergt echter een beroep op minsțens één ander substantieel principe als noodzakelijke voorwaarde tot een fundering van wat ethisch verplicht is. 'Rechtvaardigheid' doet vaak dienst als een dergelijk principe (Gewirth 1974, 991-994).

Het onderscheid tussen materieel- en formeel-deontologische theorieën valt in grote lijnen samen met een ander veelgebruikt onderscheid, namelijk dat tussen act-deontologische theorieên en regel-deontologische theorieên. In de act-deontologische theorieën worden -zoals in de materiêle theorieën- de handeling en de kenmerken daarvan centraal gesteld. $\mathrm{Er}$ is geen norm voorhanden om vast te stellen wat in bijzondere gevallen verplichtend is. Alle algemene regels worden uit het bijzondere geval van de specifieke handeling afgeleid (met alle problemen vandien: zie boven). Regel-deontologen beweren -zoals de formeel-deontologen- dat het criterium voor het verplichtende bestaat uit één of meer regels. Deze kunnen tamelijk concreet zijn ("altijd de waarheid spreken") en/of nogal abstract (het universaliseerbaarheids- en rechtvaardigheidsprincipe) (Frankena $1973,17,23$ en 25). Overigens wordt het onderscheid tussen act- en regel-theorieën niet alleen bij deontologische theorieën gemaakt, maar bijvoorbeeld ook bij een teleologische theorie als het utilisme (zie verder bij Frankena 1973, 34-43).

Tot slot nog enige verduidelijking van de begrippen 'deugd' en 'deugd-ethiek'. Deze worden soms ten onrechte verward met 'plicht' en 'plicht-ethiek'. Het begrip 'plicht' verwijst naar een behoren, een moeten. Het verplichtende wordt in de plicht-ethiek afgeleid uit de kenmerken van een handeling of een algemene regel. Aan het verplichtende liggen principes ten grondslag die niet zijn verankerd in de persoon van de actor. Het begrip 'deugd' daarentegen verwijst naar een dispositie, gewoonte, hoedanigheid of karaktereigenschap van de persoon zelf. Een ethische deugd is dan een dispositie die beantwoordt aan de eerder genoemde uitgangspunten van het morele gezichtspunt. In de deugd-ethiek vormen deze ethische deugden de basis voor ethisch verantwoord handelen. Het bezit ervan zal door ieder persoon worden nagestreefd. Niettemin blijkt uit dit laatste al, dat een deugd-ethiek bijna onmogelijk is zonder aanvullende regels of principes te veronderstellen of te formuleren. Uiteraard kunnen deze deugden als zodanig wel in verband worden gebracht met bepaalde regels en principes. Frankena veronderstelt bijvoorbeeld een zekere complementariteit tussen plichten en principes enerzijds en deugden anderzijds. Bepaalde deontologische en teleologische oordelen zouden als deugden kunnen worden geherformuleerd. Zo kan worden gesproken van het principe van weldadigheid en de deugd van welwillendheid (Frankena 1973, 63-64). 'Rechtvaardigheid" zou zowel als principe als als deugd kunnen worden geformuleerd.

Bovenstaande beschouwing met betrekking tot de systematische aspecten van de praktische filosofie in het algemeen en van de sociale filosofie en wijsgerige ethiek in het bijzonder is nogal complex. Getracht is om in kort bestek de belangrijkste theoretische posities en terminologische verschillen aan de orde te stellen en te verduidelijken. Daarbij werd soms de algemene positie direct toegespitst op een specifieke categorie begrippen. Zo werden de meta-ethische posities toegelicht aan de hand van het begrip 'waarde', terwijl deze posities uiteraard ook consequenties hebben voor de aard en plaatsbepaling van begrippen als 'plicht' en 'deugd'.

Gezien de complexiteit van het geheel is in figuur 3.1 gepoogd de belangrijkste posities en begrippen in een schema samen te vatten en aan elkaar te relateren. Daarbij is ervoor 
gekozen deze toe te lichten aan de hand van twee varianten, waarin de praktische filosofie kan worden uitgewerkt, namelijk vanuit een sociaalfilosofisch perspectief en vanuit een wijsgerig-ethisch perspectief. Geconstateerd werd, dat er weliswaar een verscheidenheid aan begrippen tussen beide perspectieven bestaat, maar tevens een zekere eenheid in inhoudelijke (theoretische) stellingnames. In figuur 3.1 is getracht beide aspecten te visualiseren door de twee perspectieven begripsmatig te onderscheiden, maar ten aanzien van verwante en overeenkomstige theoretische posities dwarsverbanden te schetsen. Het gaat hier om het aangeven van verbanden tussen in de literatuur vaak uiterst dispers naar voren komende termen, waarvan de relatie meestal verhuld blijft. In de uitleg bij het schema is naar voren gekomen, dat verschillen tussen beide perspectieven vooral worden gevonden in de rol en positie van het morele domein. In dat opzicht kan bij de sociale filosofie gesproken worden van een bredere context en een ruimer perspectief, waarin sneller dan bij de wijsgerige ethiek wordt geabstraheerd van de individuele menselijke bestaanswijze en handelingssituatie. In de rest van het betoog zal echter vooral worden aangesloten bij het wijsgerig-ethisch perspectief. Daarbij zal meermalen naar het gepresenteerde schema worden terugverwezen.

\subsubsection{Sociologie en ethiek: vergelijking van methoden en begrippen}

Paragraaf 3.2 werd ingeleid met het vermoeden en de mening van sommige auteurs, dat het normatieve in de dagelijkse en wetenschappelijke praktijk alomtegenwoordig is. Dit vermoeden lijkt te worden bevestigd wanneer het normatieve in de meest brede betekenis wordt omschreven als "invloed hebbend op ...". Hierdoor ontstaat een beeld van de werkelijkheid als de volledige samenhang van alles met alles, inclusief de personen die van die werkelijkheid deel uitmaken.

Sociologie -onder andere in thaar toespitsing op culturele antropologie- en de praktische filosofie als wijsgerige ethiek hebben dat beeld zowel beperkt als genuanceerd. 'Beperkt', omdat het normatieve primair wordt geplaatst en bestudeerd in de context van de sociale werkelijkheid; de anorganische werkelijkheid wordt als het ware tussen haakjes gezet. 'Genuanceerd', omdat in verband met het normatieve een ingewikkeld netwerk van relaties tussen en conceptualisaties van geìdentificeerde onderdelen van die sociale werkelijkheid wordt opgebouwd. Daarbij zijn ook verschillen aan het licht gekomen met betrekking tot de aard van het normatieve in sociologie en wijsgerige ethiek en met betrekking tot de wijze waarop het normatieve wordt bestudeerd. Dit leidt tot de noodzaak enige ordening in terminologie en concepten aan te brengen ten behoeve van de nog volgende beschouwingen.

Het meest opmerkelijke verschil tussen sociologie en wijsgerige ethiek met betrekking tot de normatieve aspecten van de werkelijkheid is van methodologische aard. Beoefenaars van de sociologie stellen zich in het algemeen ten doel inzicht te verschaffen in bestaande sociale verhoudingen en daarin wetmatigheden aan te wijzen. Dit kwalificeert de sociologie als een empirische wetenschap, waarin observatie van sociale feiten zowel uitgangspunt als toets is voor de opbouw van kennis. Sociologische concepten zijn voornamelijk omschrijvingen of abstracties van het reële, tot stand gekomen door toepassing van reductie en selectieve waarneming. Hierdoor kunnen uitspraken over de toekomst niet anders dan via een kunstgreep geschieden, namelijk door extrapolatie vanuit het gekozen werkelijkheidsmodel en het resultaat als een premisse in een prognose binnen te 
voeren. Ook over de aanvaardbaarheid van die sociale werkelijkheid kan niet anders worden beslist dan met behulp van buiten de sociologie ontwikkelde criteria.

De ontwikkeling van deze criteria is daarentegen éen van de belangrijkste doelstellingen van de wijsgerige ethiek, voorall in haar toespitsing op de normatieve ethiek. Weliswaar wordt in de normatieve ethiek ook een vooraanstaande plaats toegekend aan het inzicht in de sociale werkelijkheid (vergelijk de vereisten van het ethisch gezichtspunt), maar uiteindelijk is het haar begonnen om een reflectie op die sociale werkelijkheid met het oog op de realisering van de goede mens en de goede samenleving. De kwaliteit van deze reflectie en de daaruit resulterende criteria wordt niet gemeten aan empirische, maar aan rationele maatstaven. Normatieve ethiek beweegt zich voornamelijk op het conceptuele niveau. $\mathrm{Zij}$ wordt als het ware bedacht. $\mathrm{Zij}$ wordt niet direct afgeleid uit de werkelijkheid (dit zou namelijk een naturalistische drogreden impliceren; overigens zullen we deze stellingname in 5.2.1 nuanceren). Deze werkelijkheid wordt onder kritiek gesteld. Naar aanleiding van in de normatieve ethiek ontwikkelde criteria voor ethisch verantwoord handelen kunnen uitspraken worden gedaan met betrekking tot de vraag hoe de toekomst er uit moet zien.

Deze verschillen in methodologie hebben tevens consequenties voor de omschrijving en plaats van het normatieve in sociologie en normatieve ethiek. Dit is een tweede belangrijk verschil tussen beide. Het normatieve wordt hier gemakshalve opgevat als het complex van waarden en normen, zoals dat door beide disciplines wordt bestudeerd. Doel en aard van de sociologie brengen met zich mee, dat waarden en normen aanwijsbare entiteiten dienen te zijn of abstracties daarvan. Bovendien dienen deze te worden gedragen door collectiviteiten, wil er sprake zijn van generaliseerbare onderzoeksresultaten. De methodologische problemen die dat oproept, hebben ervoor gezorgd, dat (het onderzoek naar) het complex van waarden en normen binnen de sociologie nog steeds als een, zij het interessant randgebied geldt, voorzover het althans gaat over dieptestructuren (bijvoorbeeld ten aanzien van het masculiene karakter van onze cultuur). Een dergelijk oordeel is in veel mindere mate van toepassing op studies naar institutionaliseringsprocessen, hoewel ook daaraan uiteraard tal van normatieve aspecten zijn verbonden.

Daarentegen raakt het onderzoek naar waarden en normen het hart van de normatieve ethiek. Daarbij wordt een specifieke relatie verondersteld tussen morele waarden en normen en nonmorele waarden en normen. De fundering hiervan is niet gebonden aan aanwijsbare entiteiten binnen collectiviteiten, maar is een rationele constructie op basis van expliciete criteria van morele goedheid. De realisering van morele waarden en normen kan strikt genomen een fictie blijken te zijn, in die zin, dat noch enig individueel gedrag noch enig collectief gedrag eraan beantwoordt. Dit ontkracht de normatieve ethiek hoogstens ten aanzien van de mate waarin zij aansluit bij condities binnen de sociale werkelijkheid, echter niet ten aanzien van haar geldigheid.

Wat de omschrijving van het normatieve betreft is thans het moment gekomen om enige afspraken te maken. In de voorafgaande beschouwing over het sociologische en ethische perspectief op het normatieve zijn vele begrippen en termen de revue gepasseerd. Daarbij werden reeds enige vergelijkingen gemaakt ten aanzien van de verschillende benamingen die auteurs hanteren voor hetzelfde fenomeen, alsmede ten aanzien van de verschillende fenomenen die door auteurs met eén begrip worden aangeduid. Het normativiteitsbegrip is de paraplu waaronder al deze benamingen en fenomenen nu hun plaats moeten krijgen. Meer expliciet kan bet normatieve worden gedefinieerd als: het 
geheel van waarden en normen, doeleinden en woorschriften, deugden en plichten en alle omschrijvingen daarvan, wier invloed zich doet gelden in de sociale werkelijkheid en aan de hand waarvan die sociale werkelijkheid wordt beoordeeld in termen van feitelijkheid en wenselijkheid.

Met "het geheel' wordt aangegeven, dat het hier een samenspel en onderlinge afhankelijkheid van genoemde componenten betreft. Met name Philipsen heeft daar ten aanzien van een sociologische optiek sterk de nadruk op gelegd. Ook voor de normatieve ethiek is dit een evidentie waar nauwelijks discussie over bestaat. Met 'sociale werkelijkheid" wordt het deel van de werkelijkheid bedoeld, dat wordt gevormd door het gedrag van de mensen die daar deel van uitmaken, alsmede door de daarin aanwezige instituties en gebruiken. 'Gedrag' moet daarbij in nime zin worden verstaan. Het betreft niet alleen waarneembare activiteiten, maar ook het nalaten daarvan alsmede disposities, attitudes, motieven en karaktereigenschappen van mensen, zowel op individueel als collectief niveau.

Het onderscheid tussen 'feitelijkheid en wenselijkheid' in bovenstaande omschrijving van. het normatieve duidt erop, dat het normatieve niet alleen als een analytische dimensie van de werkelijkheid moet worden beschouwd, maar via de kritische conceptualisaties daarvan ook als een rationeel-ideële dimensie. Deze laatste dimensie kan op conceptueel niveau een belangrijk hulpmiddel zijn voor begripsvorming en inzicht in de analytische dimensie. Zelfs kan zij zelf voorwerp van analyse worden. De analyses van Barnsley ten aanzien van de rechtvaardiging van 'moral codes' zijn hiervan een sprekend voorbeeld. Overigens zal het begrip 'morele code' in deze studie niet worden gebruikt conform de betekenis die Barnsley eraan hechtte. Nadere explicitering hiervan volgt later in dit hoofdstuk.

Ten aanzien van de begrippen 'waarde' en 'norm' wordt in de omschrijving van het normatieve uitgegaan van zowel de sociologische als de ethische betekenis. In de sociologische betekenis wordt hier, in aansluiting bij de omschrijving van Philipsen, onder 'waarden' verstaan: collectieve opvattingen over hetgeen goed, juist en derhalve nastrevenswaardig is. "Normen' zijn in deze context: collectieve verwachtingen ten aanzien van uit waarden begrijpelijke regels voor vanzelfsprekend gedrag. De kritiek van Barnsley op het zogenaamde approbationisme wordt dus afgewezen. Philipsen heeft betoogd, dat niet alleen normen, maar ook waarden kunnen worden geoperationaliseerd als specifieke kenmerken -zij het wellicht in abstractis- van sociale verschijnselen en zich in die hoedanigheid lenen voor sociologisch onderzoek.

Het geheel van waarden en normen, zoals voorkomend bijvoorbeeld in een beroepsgroep, wordt hier verder 'ethos' genoemd. Dit begrip zal echter niet alleen van toepassing zijn op collectiviteiten, maar ook op undividuele personen. Hiermee wordt aangesloten bij het begrippenkader van de normatieve ethiek, dat meer dan dat van de sociologie is toegesneden op een analyse en waardering van individueel gedrag. Philipsens begrippen 'eindwaarde' en 'handelingswaarde' zal men verder in deze studie nauwelijks aantreffen. $\mathrm{Zij}$ vallen -nu ontdaan van hun collectieve denotatie en aangevuld met de morele dimensie- samen met de begrippen 'intrinsieke waarde' respectievelijk 'deugd", zoals deze in ethisch perspectief reeds eerder werden gedefinieerd. In verband met de noodzaak tot helderheid en consistentie zullen deze begrippen steeds worden gehanteerd mét of zónder het voorvoegsel 'moreel' of 'ethisch', ter aanduiding van hun ethische respectievelijk sociologische betekenis. Dat geldt ook voor de overige hier gebruikte termen en 
begrippen. Het voorvoegsel 'ethisch' of 'moreel' duidt erop, dat het desbetreffende begrip steeds vanuit het perspectief van 'het ethisch gezichtspunt' wordt bekeken en derhalve is betrokken op personen, inclusief hun motieven, bedoelingen, handelingen en karaktereigenschappen. Daarbij gelden de bijvoeglijke naamwoorden 'ethisch' en 'moreel" als synoniemen.

Tenslotte de begrippen 'doeleinden', 'voorschriften' en 'plichten'. Vanuit een sociologisch perspectief werden 'doeleinden' door Philipsen beschouwd als de institutionele verschijningsworm van waarden (eindwaarden en handelingswaarden oftewel waarden in engere zin en deugden). 'Voorschriften' werden omschreven als operationalisaties van waarden en normen in het kader van organisaties en projecten. Het normatieve karakter van voorschriften werd in dat verband zeer gering geacht door hun uiterlijke, instrumentele aard en het niet vereist zijn van internalisatie. Daarentegen wordt hier geopteerd voot een ruimere omschrijving van 'doeleinden' en 'voorschriften'. Vanuit onze omschrijving van het normatieve wordt aan 'doeleinden' zowel als aan 'voorschriften' normatieve betekenis toegekend. Daarbij wordt voorgesteld om ook de niet-institutionele verschijningsvormen van waarden tot het domein der doeleinden te rekenen. Dit betekent dat ook particulier-rationele belangen als doeleinden in de komende beschouwingen kunnen worden betrokken.

Eenzelfde voorstel zou kunnen worden gedaan ten aanzien van het domein der voorschriften, voorzover ze beschouwd worden als operationalisaties van waarden en normen. Hier wordt echter geopteerd voor zowel een beperking als een uitbreiding van het begrip. De voorgestelde beperking houdt verband met het expliciete karakter en de zichtbaarheid van voorschriften. De uitbreiding van het begrip betreft zijn normatieve functie. Voorschriften worden enerzijds beschouwd als handelingsaanwijzingen, die op enigerlei wijze vastgelegd en waarneembaar zijn. Hier wordt dus sterker nadruk gelegd op formalisatie dan het geval was in de omschrijving van 'voorschrift' door Philipsen. Anderzijds wordt aan voorschriften een zwaarder normatieve werking toegerekend. In onze visie heeft een voorschrift normatief gewicht, omdat het als handelingsaanwijzing een duidelijke -hoewel nog te expliciteren- invloed op het gedrag van mensen heeft. Ook wordt niet uitgesloten, dat de voorgeschreven waarde of norm volledig wordt geïnternaliseerd. Het uitvaardigen van voorschriften heeft dit laatste ook vaak tot doel. Het voorschrift kan dan ook samenvallen met de norm, waar het oorspronkelijk de uitdrukking van was. In tegenstelling tot Philipsen maakte Barnsley dan ook geen onderscheid tussen de begrippen 'voorschrift' en 'norm'. Voorts moet het begrip 'voorschrift' ruim worden geïnterpreteerd. Het omvat alle handelingsaanwijzingen, zoals voorkomend in statuten, reglementen, procedures, protocollen, gedragsstandaarden, alsmede ethische codes, morele adviezen en besluitvormingsprocessen.

Het begrip 'plicht' sluit nauw bij dit alles aan. In aansluiting op hetgeen in de vorige paragraaf over plichten en plicht-ethiek alsmede in samenhang met hetgeen boven werd gesteld, wordt 'plicht" hier omschreven als: een in een norm of voorschrift tot uitdrukking gebracht(e) handelingskenmerk of handelingsregel met het oog op de realisering van een bepaald doel of goed. Zoals bij waarden en normen kennen we ook ten aanzien van doeleinden, voorschriften en plichten morele en nonmorele varianten. 


\subsection{Normatieve aspecten van professionaliseringstheorieën}

Met behulp van het geschetste begrippenkader en het geboden inzicht in een sociologisch respectievelijk ethisch perspectief op de sociale werkelijkheid wordt in het onderstaande getracht de verschijnselen professie en professionalisering op hun normatieve aspecten te analyseren (volgens onze definitie in 3.2.3). Daarbij kan op de eerste plaats onderscheid worden gemaakt tussen een conceptueel en een empirisch niveau. Het conceptuele niveau betreft de normativiteit van de elementen (ideeën, abstracties, kenmerken), waaruit theorieën met betrekking tot professie en professionalisering zijn opgebouwd. Het empirische niveau verwijst naar de normativiteit van de verschijnselen die met behulp van die theorieën worden beschreven. Het gebruik van het begrip 'macht' als onderscheidend kenmerk van professies en professionalisering kan op conceptueel niveau bijvoorbeeld vele waardegebonden elementen bevatten, die als zodanig kunnen worden bestudeerd. Op empirisch niveau kan met behulp van de operationalisaties van het begrip 'macht' de feitelijke invloed van werschijnselen worden beschreven, die worden geacht uitdrukking te zijn van die macht.

Bovendien kan blijken, dat een onderscheid moet worden gemaakt ten aanzien van de normatieve aspecten van de diverse professionaliseringstheorieën die in hoofdstuk 2 aan de orde zijn gesteld.

Een derde mogelijke onderscheiding volgt meer uitdrukkelijk de verschillende elémenten uit onze omschrijuing van het normatieve. $Z$ o zouden zowel op conceptueel als empirisch niveau waarden en doeleinden kunnen worden onderscheiden van normen en voorschriften enerzijds en van plichten en deugden anderzijds. Bijvoorbeeld het identificeren van bepaalde centrale waarden en doeleinden binnen een beroepsgroep kan worden geplaatst tegenover het antwoord op de vraag of deze waarden en doeleinden ook hebben geresulteerd in overeenkomstige gedragsnormen en -voorschriften en/of zijn vertaald in specifieke deugden en plichten.

Een vierde indelingscriterium tenslotte kan worden gevonden in het onderscheid tussen verschillende waarnemingsniveaus. Hiermee wordt bedoeld, dat de normatieve aspecten, zoals door diverse professionaliseringstheorieën zowel conceptueel als empirisch aan de orde gesteld, kunnen worden bestudeerd op het niveau van de individuele beroepsbeoefenaar, op het niveau van de beroepsgroep en op het niveau van de samenleving als geheel. Dit indelingscriterium wordt door Van der Krogt $(1981,47)$ een noodzakelijk vereiste geacht voor een adequate beschrijving van professionaliseringsprocessen.

Onderstaande beschouwing heeft echter niet tot doel een adequate beschrijving van professionalliseringsprocessen te geven. Daarentegen stellen we een speurtocht voor naar waarden en normen, doeleinden en voorschriften, zoals geïmpliceerd in de diverse professionaliseringstheorieën. Dan ligt een keuze voor het eerste en/of tweede indelingscriterium meer voor de hand dan een keuze voor het laatste criterium. Daarbij zal het onderscheid tussen conceptueel niveau en empirisch niveau enigszins worden veronachtzaamd door beide niet als aparte categorieën op te voeren maar door het betoog heen te weven. Hoewel epistemologisch van belang, zal een dergelijk onderscheid ons waarschijnlijk weinig verder brengen op weg naar de identificering van normatieve aspecten, mede gezien de geringe hoeveelheid empirisch materiaal dat inmiddels uit het beroepen- 
sociologisch onderzoek naar voren is gebracht, alsmede gezien de vragen die ten aanzien van dat onderzoek nog openstaan (zie 2.3.8). Niettemin zal, juist vanwege laatstgenoemde reden, hier expliciet worden stilgestaan bij de normatieve aspecten van theorievorming in verband met professie en professionalisering als zodanig.

Theorieën worden in de wetenschap gewoonlijk ontworpen met het oog op de presentatie van een systematisch overzicht van verschijnselen en een verklaring van de relaties daartussen. Die verschijnselen worden meestal beschreven met behulp van concepten. Concepten kunnen zeer concreet, maar ook zeer abstract zijn (bijvoorbeeld 'tafel' respectievelijk 'interieur'). Dergelijke zeer abstracte concepten worden ook wel constructen genoemd. Zij kunnen niet direct worden waargenomen. Om aan dit 'bezwaar' tegemoet te komen worden zij meestal beschreven in termen van beter observeerbare en meetbare concepten (zie het construct 'gezondheid' en alle diagnostische hulpmiddelen om het meetbaar te maken). Observeerbaarheid en meetbaarheid van concepten worden van belang geacht om binnen de theorie de relaties tussen de verschijnselen zo mogelijk causaal te beschrijven en de generaliseerbaarheid van de resultaten van studies, die op grond van die theorie worden ondernomen, zo groot mogelijk te doen zijn. Om deze reden worden ook in de sociale wetenschappen waarde-oordelen en waardegebonden aspecten zoveel mogelijk uit de concepten en de omschrijvingen daarvan geweerd. Lukt dit niet en moet de daaruit resulterende theorie worden gekwalificeerd als een normatieve theorie, dan wordt dit vaak als een diskwalificatie van de wetenschap beschouwd (zie voor een overzicht van deze en contraposities Phillips 1983).

Zoals eerder vermeld (zie 3.2), bevatten echter zelfs de meest descriptief of empirisch ogende wetenschappelijke activiteiten nog normatieve aspecten. Deze hangen samen met de context waarbinnen deze activiteiten plaatsvinden (vergelijk het eerder gegeven preembryo-voorbeeld). Deze context is om een aantal belangrijke redenen normatief voor de wetenschap:

1. $\mathrm{Zij}$ produceert als het ware het object van wetenschap door in de werkelijkheid bepaalde elementen te doen oplichten als voor de wetenschap interessante waarnemingseenheden, met uitsluiting van andere elementen (het afsterven van bossen roept bijvoorbeeld als het ware vanzelf de behoefte aan nader inzicht in dit proces op).

2. Zij indiceert de aard en inhoud van vraagstellingen, omdat bepaalde relaties tussen verschijnselen meer relevantie lijken te bezitten of evidenter zijn dan andere relaties (vergelijk bijvoorbeeld de eugenetische onderzoeksgolf in de eerste decennia van deze eeuw).

3. Er wordt grote waarde gehecht aan de productie van wetenschappelijke kennis en kunde, omdat deze een belangrijke functie wordt toegedacht bij de oplossing van maatschappelijke vraagstukken (vergelijk bijvoorbeeld het AIDS-onderzoek).

4. Daarnaast is de context -tezamen met de persoon van de wetenschapper- bepalend voor de presentatie van wetenschappelijke inzichten, met name ten aanzien van de vraag of en welke resultaten van onderzoek uiteindelijk naar buiten zullen worden gebracht en hoe dat moet gebeuren (vergelijk bijvoorbeeld de zogenaamde "affaire Buck').

In het algemeen zijn professie- en professionaliseringstheorieën een goede illustratie van het bovenstaande. Hun gebondenheid aan bepaalde uitingen van het menselijk handelen 
en aan door menselijke interventies ontstane instituties tekent hun context-afhankelijkheid en daarmee hun normatieve implicaties. Bovendien wordt uit de chronologie van theorieën duidelijk welke invloed op hun ontstaan is uitgegaan van de methodologische wijzigingen in het vakgebied sociologie als geheel. De professie- en professionaliseringstheorieenn werden achtereenvolgens geinspireerd door het structureel-functionalistische en het symbolisch-interactionistische perspectief op de sociale werkelijkheid. Een professionaliseringstheorie als die van Van der Krogt bouwt op deze perspectieven voort. Hij verbindt ze daarnaast onder andere met elementen uit de als reactie op genoemde stromingen ontstane ruiltheorie. Dit betekent, dat nu eens het collectief of de samenleving, dan weer de individuele actor en vervolgens de interactie tussen beide het primaire object van de professie- en professionaliseringstheorieën vormden. Impliciet dan wel expliciet bleven dus andere aspecten van de sociale werkelijkheid buiten beschouwing of speelden een ondergeschikte rol. Dit bracht ongetwijfeld en noodzakelijkerwijs eenzijdigheden met zich mee in de theorieën als verklaring voor de rol en functie van professies en professionals in de samenleving. De methodologische aspecten van deze theorieën hebben derhalve enerzijds invloed op de aard en inhoud van de concepten. Anderzijds moeten zij worden gerekend tot de context waarbinnen het wetenschappelijk onderzoek op het terrein van professies en professionalisering plaatsvindt en tot (presentatie van) resultaten leidt. De invloed van methodologische keuzes bepaalt in zekere mate de aard van het normatieve in de op basis van deze keuzes ontstane theorieën (elke theorie construeert als het ware zijn eigen werkelijkheid).

Deze normativiteit wordt evidenter wanneer theorieën niet alleen als verklaringsmodel, maar ook als evaluatie-instrument worden ingezet. Dit is bij de onderhavige theorieën duidelijk het geval. Voorzover bijvoorbeeld bij de kenmerkenbenadering (zie 2.3.4) kan worden gesproken van een theorie -er wordt immers geen verklaring geboden van de gepresenteerde kenmerken- wordt zij beschouwd als een nuttig instrument voor het opstellen van een hiërarchie van beroepen. Alleen al de term 'hiërarchie' verraadt de waardegebondenheid van de onderneming. Hoewel onderzoekers als Carr-Saunders en Etzioni pretenderen bij hun evaluatie van beroepen alleen empirische criteria te hanteren, worden de resultaten gepresenteerd in termen van bovenschikking en onderschikking. Dit komt tot uiting in een rangordening van beroepen als 'professies', 'semi-professies' en 'would-be-professies'. Beroepsgroepen kunnen aan de gepresenteerde ideale kenmerken en het geschetste belang ervan doelstellingen ontlenen tot gerichte activiteiten voor een 'betere' positie in de hiërarchie. Hoewel de kenmerkenbenadering haar vooraanstaande positie in de beroepensociologie reeds lang is kwijtgeraakt, volgen nog steeds veel beroepsgroepen een strategie tot versterking van de eigen mogelijkheden binnen de bestaande arbeidsdeling die in termen van de kenmerkenbenadering kan worden beschreven. $\mathrm{Zij} \mathrm{komt} \mathrm{in} \mathrm{handboeken} \mathrm{vaak} \mathrm{naar} \mathrm{voren.} \mathrm{In} 2.4$ gaven wij reeds het voorbeeld van de beroepsgroep van verpleegkundigen (zie vooral 2.4.7).

Overeenkomstig de eerder genoemde context-afhankelijke aspecten van theorieenn kunnen aan de kenmerkenbenadering voorts nog andere normatieve aspecten worden onderscheiden. De kenmerken van de ideale professie werden destijds ontleend aan een klein aantal beroepen, dat toentertijd in de sociale werkelijkheid op de voorgrond trad. Dat waren die van officier, geneeskundige, jurist en priester. Vandaar datt 'autonomie' en 'wetenschappelijke kennis en kunde' binnen de kenmerkenbenadering als belangrijke kenmerken en centrale concepten werden gepresenteerd. Op grond van deze selectieve 
waarneming worden nog steeds kenmerken als "zorgzaamheid' (verpleegkundige?) of 'vertrouwdheid met moderne praktijken in de zakenwereld' (bedrijfskundige, manager?) niet opgemerkt of als minder relevant terzijde geschoven. Daarnaast brengt een dergelijke praktijk sommige beroepen in conflict met de waarden en normen die hen in eigen ogen juist zozeer typeren.. De op grond van ideale kemmerken geschetste rangordening van beroepen en dienovereenkomstige doelstellingen ten behoeve van positieverbetering leidt bij hen tot een welhaast onoverbrugbare kloof tussen ideaal en werkelijkheid. Dit is een reden waarom bijwoorbeeld een aantal vooraanstaande verpleegkundigen opteert voot de-professionalisering in plaats van professionalisering van het beroep van verpleegkundige (zie 2.4.7)) . Het kan worden gezien als een duidelijk voorbeeld van de normatieve invfoed die van theorieen uitgaat op het denken en doen van beroepsgroepen en beroepsbeoefenaren op grond van de selecties dile binnen die theorieên plaatsvinden. Die normatieve invloed werkt bovendien blijkbaar in twee richtingen uit. Allereerst beïnvloeden theorieën het denken en doen van beroepsbeoefenaren in termen van de ervaringen die zij opdoen en de doeleinden die zij zich stellen. Ten tweede kunnen ze de effecten van die ervaringen en doeleinden zodanig beïnvloeden, dat de uiteindelijke resultaten zelfs contradictoir zijn aan de principes van de theorieën zelf. Dat doet zich voor op het moment, dat een beroepsgroep zichzelf voor de keuze plaatst te professionaliseren of juist te de-professionaliseren.

De normatieve invloed van selecties binnen de kenmerkenbenadering is nog om een andere reden van belang. Haar selectiviteit was niet alleen een gevolg van de waarneming van een zeer beperkt aantal beroepen, maar ook van de aard van die waarneming. In 2.3.6 werd als eerste en belangrijkste punt van kritiek op de kenmerkenbenadering naar voren gebracht, dat de onderzoeksresultaten niet zozeer waren gebaseerd op neutrale observatie, maar op een overname van beschrijvingen die professies van zichzelf prijs wilden geven. Aangenomen mag worden dat deze beschrijvingen werden gekleurd door beroeps(beoefenaar)gebonden voorstellingen, waarden en doelstellingen. Gesteld werd dan ook, dat de kenmerkenbenadering is gekleurd door de ideologie van de "waargenomen" beroepsgroepen. Hiermee staat de descriptieve grondslag van de kenmerkenbenadering duidelijk ter discussie en wordt haar normativiteit met het oog op positieverbetering van beroepsgroepen bevestigd. Overigens is bovenstaande kritiek ook van toepassing op de structureel-functionalistische benadering. Deze laten wij hier echter verder buiten beschouwing.

Een overwinning van deze kritiek kan als een sterk punt worden beschouwd van de procesbenaderingen in de beroepensociologie. Beroepen, beroepsgroepen, en beroepsbeoefenaren lijken meer in hun ware gedlaante te worden geobserveerd. Bovendien beperkt men zijn observatie niet tot een selectief aantal in het oog springende beroepen, maar heeft men deze in beginsel uitgebreid tot het gehele maatschappelijke veld van beroepsmatig verrichte arbeid. Met de overwinning van kritiek zijn de normatieve aspecten van de theorieën binnen de procesbenadering echter nog niet verdwenen. Dit wordt toegelicht aan het voorbeeld van de machtsbenadering van Van der Krogt (zie 2.3.6).

Ook bij Van der Krogt is de maatschappelijke context mede bepalend voor de normatieve aspecten van zijn theorie (over de methodologische context is boven al het een en ander gezegd). Hij presenteert zijn theorie uitdrukkelijk als een bijdrage aan het inzicht in het functioneren van het "maatschappelijk midden' (de term is uitgelegd in 2.3.1). Dit in- 
zicht wordt noodzakelijk geacht om bepaalde maatschappelijke problemen het hoofd te bieden. Die problemen hebben onder andere te maken met het voor de overheid beheersbaar en bestuurbaar houden van kennis- en invloedsstromen. De machtsbenadering is erop gericht via het bevorderen van inzicht een bijdrage te leveren aan de oplossing van deze problemen. Hoewel niet gepresenteerd als normatieve theorie, functioneert de machtsbenadering derhalve feitelijk wel als zodanig, doordat het handelen van relevante actoren er daadwerkelijk door zal worden beïnvloed. Bovendien vervult zij deze functie niet alleen voor de overheid, maar ook ten aanzien van de beroepsgroepen door welke die overheid mogelijk voor problemen wordt gesteld. Immers, in de opsomming van 18 strategieën ter vergroting van de invloed van beroepsgroepen (Van der Krogt 1981, 134150) worden evenzovele doelstellingen van maatschappelijke activiteiten van collectiviteiten aangeboden. Een paar van deze strategieën worden door hem zelfs volledig uitgewerkt. In deze expliciete vorm werden de normatieve aspecten van professionaliseringstheorieën nog niet eerder naar voren gebracht.

Daarnaast levert toepassing van de machtsbenadering op bestaande beroepen en beroepsgroepen conclusies op die op andere wijze bijdragen aan de normativiteit van de machtsbenadering. Van der Krogt vermijdt weliswaar waarde-oordelen uit te spreken over de positie van bepaalde beroepsgroepen. Maar evenals de kenmerkenbenadering leidt ook zijn benadering tot een hiërarchisering casu quo rangordening van beroepen en beroepsgroepen. Het meest geprofessionaliseerd zijn dan die beroepsgroepen, die er het best in zijn geslaagd een collectieve machtspositie te verwerven en deze geaccepteerd te krijgen. Zoals aangegeven, moet een op deze basis impliciet veronderstelde rangordening tot de normatieve aspecten van de desbetreffende benadering worden gerekend.

Interessant voor de onderhavige beschouwing is verder, dat de machtsbenadering niet alleen met normatieve aspecten is omgeven vanwege de (maatschappelijke en methodologische) context waarbinnen zij is ontwikkeld. Zij is dat ook niet uitsluitend door de implicaties ervan voor het handelen van individuen en collectiviteiten. Ook de sociale werkelijkheid van zich ontwikkelende beroepen zelf wordt binnen de machtsbenadering beschreven als een normatief proces. Dit komt onder andere tot uiting in de keuze en omschrijving van de centrale concepten. Begrippen als 'macht', 'institutionalisering' en 'legitimering' zijn alle uitdrukking van en worden door Van der Krogt ook omschreven als min of meer doelgerichte menselijke strevingen, waarbij waarden en normen een niet onaanzienlijke rol spellen. Deze waarden en normen worden in de machtsbenadering niet altijd als zodanig waargenomen en benoemd. Zo wordt vermeerdering van kennis en kunde tot de cognitieve elementen van het professionaliseringsproces gerekend. Zij kan echter evengoed als centralle waarde worden beschouwd en het streven ernaar derhalve als een normatief element in het professionaliseringsproces. Het laatste zou ook logischer zijn geweest als we bedenken dat de verwerving van kennis en kunde een van de belangrijkste onderdelen wordt genoemd van het streven naar een collectieve machtspositie door een beroepsgroep.

Het bovenstaande zou ons ertoe kunnen verleiden thans alsnog het in de aanhef van deze paragraaf vermelde derde indelingscriterium in stelling te brengen, ten einde het geheel van waarden en normen, geïmpliceerd in de machtsbenadering en andere benaderingen, te ontrafelen. Deze waarden en normen zouden vervolgens kunnen worden geconfronteerd met een axiologische taxonomie (een voorbeeld hiervan staat beschreven in Philip- 
sen 1988, 142-148). Bovendien kan worden gezocht naar de materiële verhouding tussen de aldus beschreven waarden en 'de' dominante waardenoriëntatie in 'de' samenleving (deze laatste kan worden ontleend aan de zojuist genoemde passage in Philipsen 1988). Verder zouden wij het tot onze taak kunnen rekenen de beschreven waarden axiologisch te identificeren als intrinsieke of als andere waarden om aldus op het spoor te komen van waarden die in ethisch-normatief opzicht kunnen worden geaccepteerd als een na te streven goed en welke niet. Dit zou immers een aanzienlijke reductie en vereenvoudiging van een eenmaal gepresenteerde waardenreeks kunnen betekenen. Al deze kwesties zijn in waardensociologisch en wijsgerig-ethisch opzicht relevant en interessant en derhalve een uitwerking waard. Wij kiezen er in het verdere verloop van dit hoofdstuk echter voor zo nauw mogelijk aan te sluiten bij een beroepensociologisch en beroepsethisch perspectief en stellen dan eerst de vraag naar de empirische bron waarin waarden op het niveau van de beroepsgroep het meest pregnant naar voren zouden kunnen komen. De beroepsgroep is daarbij als waarnemingseenheid gekozen, omdat zij onder andere als intermediair fungeert tussen de individuele beroepsbeoefenaar en de samenleving. Aan enkele van de eerder genoemde kwesties zal in hoofdstuk 5 aandacht worden geschonken.

\subsection{Waarden en beroepscodes}

In deze paragraaf zal op basis van het voorafgaande worden toegewerkt naar een vraagstelling voor verder onderzoek naar de normatieve aspecten van professionalisering. Aan het begin van het onderhavige hoofdstuk werd reeds aangekondigd, dat deze vraagstelling betrekking zal hebben op het verschijnsel beroepscode.

Hoewel het verschijnsel beroepscode nog nader moet worden geduid, levert een eerste verkenning ervan een aantal interessante aspecten op. Deze hebben betrekking op het profesionaliseringsdebat zowel in een sociologische als in een ethische context en zowel in een conceptueel als in een empirisch kader. Waarden lijken hierbij impliciet en/of expliciet een belangrijke rol te vervullen. Analyse en kritiek van beroepscodes alsmede beschouwingen over hun rol en functie in het doen en laten van beroepsgroepen zouden dus aangrijpingspunt kunnen zijn van een nadere verheldering van de normatieve aspecten van professionalisering, zowell in sociologisch als in ethisch opzicht.

De eerste verkenning van het verschijnsel beroepscode wordt in de eerste subparagraaf hieronder aangevangen met een opsomming van de uitspraken die in dit verband zijn gedaan door de auteurs aan de hand waarvan wij in hoofdstuk 2 het verschijnsel professionalisering hebben beschreven. Vervolgens zal worden getracht de normatieve implicaties van een en ander te schetsen door beroepscodes te kwalificeren als vindplaats van waarden. Dit vormt de overgang naar de slotparagraaf van dit hoofdstuk waarin het verschijnsel beroepscode vanuit een ethisch perspectief van een vraagstelling voor verder (ethisch) onderzoek zal worden voorzien.

Tenslotte nog een relativering van het gebruik van de term 'beroepscode'. Voor deze term is gekozen, omdat daarmee naar onze mening het best wordt aangesloten bij de herkomst en functie van de in het geding zijnde materie. In het algemeen gaat het bij een beroepscode om een verzameling richtlijnen en/of aanbevelingen, opgesteld door een beroepsgroep en bedoeld om het gedrag van beroepsbeoefenaren te reguleren. In de literatuur wordt hetzelfde verschijnsel ook wel aangeduid met termen als 'ethische code', 
"gedragscode" en 'gedragsregeis'. In de engelstalige literatuur corresponderen hiermee termen als respectievelijk professional code', 'ethical code' of 'code of ethics." "code of conduct' en 'rules of conduct'. Ook combinaties van deze termen treft men aan, bujwoorbeeld "ethische beroepscode" en 'protessional code of ethical conduct:. Deze samenstellingen hebben als madelen, dat in de toegevoegde bijvoegitike en zelfstandige naamwoorden betekenissen worden verleend die reeds in het hoofdwoord opgenomen zin en/of dat onterecht de suggestie wordt gewekt, dat we te doen hebben met een verbijzondering van de in het hoofdwoord geimpliceerde betekenis. In het volgende hoofdstuk zal nader op dergelijke etymologische kwesties worden ingegaan.

\subsubsection{Beroepscodes in de professionaliseringsliteratuur}

In het algemeen worden in de professionaliseringshiteratuur weinig verwijzingen aangetroffen naar het verschijnsel beroepscode. Bovendien duidt de context waarin uitspraken over beroepscodes worden geplaatst, op het gegeven, dat het welhaast nergens de bedoeling van de auteur is meer dan terloopse aandacht aan het verschijnsel te schenken. Fundamentele en/of uitputtende beschouwingen zijn dus niet beschikbaar. Ook naar bet door Philipsen benadrukte analytische onderscheid tussen beroepscodes als voorschrift en beroepscodes als norm (zie 3.2.1) zal men vergeefs zoeken. De context van de schaarse uitspraken over beroepscodes levert echter meestal wel een duidelijke indicatie op voor hun strekking. De desbetreffende uitspraken zijn dan ook vaak onvolledig of onbegrijpelijk, wanneer deze niet tevens in de context van de analyse of theorie van een auteur worden geplaatst.

Het is om laatstgenoemde reden dat in deze paragraaf in hoofdzaak wordt uitgegaan van de auteurs wier analyses en theorieen reeds in het voorgaande hoofdstuk naar voren werden gebracht. De context van hun uitspraken over beroepscodes mag dus enigszins als bekend worden verondersteld. Echter, waar nodig zal deze worden aangevuld. De auteurs waar het hier om gaat zijn Freidson (1970), Larson (1979), Van der Krogt (1981) en die in de bundels onder redactie van Etzioni (1969) en Dingwall en Lewis (1983). Daarnaast zal worden gerefereerd aan auteurs in de bundel van Blair en Rubin (1980). Deze kregen in het vorige hoofdstuk minder aandacht dan de eerstgenoemden, maar gezien het thema van de bundel -zelfregulering van professies- worden diverse uitspraken gedaan over beroepscodes die voor ons doel van belang zijn. De auteurs/bundels worden chronologisch behandeld naar hun jaar van publikatie.

In de bundel van Etzioni zijn vooral de bijdragen van Toren en Goode van belang. Volgens Toren $(1969,147)$ worden professies gekenmerkt door een hoge mate van onafhankelijkheid in de formulering en uitvoering van hun taak. Hierbij treden twee kernelementen op de voorgrond: systematische kennis en professionele normen. Het niet voldoen aan één van beide kernelementen plaatst een beroep in de sfeer van de semiprofessies (hij noemt als voorbeeld de verpleegkunde). De professionele normen worden doorgaans gebaseerd op een beroepscode ("code of ethics"). Van deze code wordt gezegd, dat hij:

1. Gericht is op een collectiviteit (147).

2. Een verwoording is van een dienstbaarheidsideaal (147).

3. Een belangrijke rol speelt in de socialisatie en training van beroepsbeoefenaren (171). 
4. Als geinternaliseerd geheell van waarden en normen van belang is voor de interne regulering van het gedrag van beroepsbeoefenaren binnen een beroepsgroep ( $p 152)$.

5. Qua toepassing door beroepsbeoefenaren zich minder leent voor controle door externe instanties dan bijwoorbeeld het geval is met financielle middelen (171).

Verder stelt Toren, in navolging van Carr-Saunders en Greenwood, dat de 'commitment' tot een beroepscode een expliciete eigenschap vormt van de klassieke gevestigde professies. Ook hier speelt het element 'onafhankelijkheid' een cruciale rol. Dat wordt duidelijk wanneer hij Carr-Saunders' opvatting overneemt (overigens zonder enige verklaring), dat de tendens binnen beroepsgroepen tot overgang van een zelfstandige beroepsuitoefening naar een gesalarieerd werknemerschap een factor is die de betekenis en invloed van beroepscodes sterk ondermijnt (143-144). Dit gesalarieerd werknemerschap is een kenmerk van beroepsbeoefenaren in de semiprofessies. Naast betekenisondermijning hebben codes bij deze semi-professies bovendien te lijden onder vaagheid en inconsistentie. Vaagheid en inconsistentie van codes worden zelfs als criterium gehanteerd om beroepen niet als professie, maar als semi-professie te kwalificeren (144).

Ook Goode (1969) sluit aan bij de kenmerken- en structureel-functionalistische benadering van professionalisering door de beroepscode ('code of ethics') tot de lijst van kenmerken van een professie toe te laten (276). Zoals Toren onderscheidt hij twee centrale elementen in professies: een geheel van abstracte kerinis en een dienstbaarheiddsideaal (277). Om dit dienstbaarheidsideaal werkelijkheid te laten worden is een beroepscode onmisbaar (280). Beroepscodes zijn bovendien explicieter, zowel in hun formele als informele formuleringen, naarmate de verwerkelijking wan het dienstbaarheidsideaal alsmede de beroepsuitoefening als geheel een intensiever contact tussen beroepsbeoefenar en cliënt impliceren en een grotere doordringing van de persoonlijkheidssfeer van de laatste door de eerste noodzakelijk maken (302). Dit betekent overigens niet, dat een code alleen de belangen wan cliënten dient of beschermt. Een code kan ook gezien worden als een weloverwogen plan ten dienste van de doeleinden van de professie (292). De onmisbaarheid van een beroepscode voor professies wordt door Gioode sterk afgezwakt. In een kritiek op Wilensky's ontwikkelingsmodel binnen de kenmerkenbenadering beschrijft hij enkele voorbeelden uit de klassieke professies. Zo bezat de Amerikaanse onde van advocaten vóór de Amerikaanse revolutie nog geen officieel gepubliceerde beroepscode, terwijl er wel sprake was van nauwgezette training in en controle op het gedrag van beroepsbeoefenaren. Evenzo publiceerde ook de geneeskundige beroepsgroep voór de twintigste eeuw geen formele beroepscode, terwijl toch reeds rond 1850 diverse medici op grond van hun onbetamelijk gedrag werden geroyeerd als lid van hun beroepsvereniging (275). Hieruit wordt duidelijk, dat volgens Goode ten aanzien van beroepscodes een expliciet onderscheid moet worden gemaakt tussen een geheel van informele gedragsregels en een set van officieel voorgeschreven, formele en schriftelijke gedragsregels. Dit onderscheid blijft bij alle hier beschreven auteurs enigszins verhuld. Ook bij Goode staat het slechts tussen de regels geschreven en wordt het pas duidelijk uit de context.

Een ander aspect dat Goode naar voren brengt betreft de beroepsgroepen die een ontwikkeling doormaken naar een hogere status en autonomie als (semi-)professie. Veel van deze beroepsgroepen bezitten weliswaar een code, maar missen nog voldoende cohesie of, erger, zijn versplinterd (gesegmenteerd) in vele sub-groepen. De feitelijk werkzame (informele) code is dan niet veel meer dan een 'ethic of science', hoewel de officiële 'pa- 
pieren' code getrouw de formulering en inhoud van de gebruikelijke beroepscodes kan volgen (293). In dit verband kan dus worden gewezen op een mogelijk groot en onoverbrugbaar verschil tussen ideaal en werkelijkheid (verwerkelijking) van officiële, formele beroepscodes, met name bij semi- en 'would-be'-professies.

Freidson (1970) is evenmin erg optimistisch over de werkelijkheidswaarde van beroepscodes, zelfs in gevestigde professies als de geneeskunde. Refererend aan Parsons rekent Freidson beroepscodes tot het normatieve segment van de formele organisatie van professies, waarin verwachtingen worden geformuleerd ten aanzien van het gedrag van beroepsbeoefenaren. Deze verwachtingen -en dus ook de achterliggende beroepscodes- "... are quite distinct, analytically and empirically, from the actual norms of individual professionals. (...) they are formal claims and officially held expectations, perhaps ideals, but not necessarily the operative norms of performance" (160).

Deze uitspraak moet worden gezien tegen de achtergrond van Freidsons nadruk op autonomie als belangrijkste constituerend element in het werk van professionals in casu van geneeskundigen. Deze autonomie en het door de aard van het werk aangemoedigde individualisme van artsen bemoeilijken de onderwerping en deelname aan regulatieve processen ter verzekering van hoge morele en wetenschappelijke maatstaven van gedrag. Als gevolg hiervan is er sprake van grote permissiviteit ten aanzien van deviant gedrag, beperkte persoonlijke verantwoordelijkheid en weinig nadruk op een algemene of gemeenschappelijke verantwoordelijkheid (164 en 184). Zelfregulatie, die immers de toetssteen en rechtvaardiging moet zijn van de juistheid van autonomie-claims (137) komt dán ook onvoldoende van de grond. Functioneren in de medische wereld slechts weinig formele controle-procedures, de zichtbaarheid van het werk is beperkt, en bovendien is de gerealiseerde controle geringer dan de zichbaarheid van het werk zou doen vermoeden (157). Men moet het wel erg bont maken wil men op formeel en officieel niveau als immoreel handelend beroepsbeoefenaar worden ontmaskerd (vergelijk voor Nederland de recente Finkensieper-casus).

Beroepscodes maken in de geneeskunde dus onder andere deel uit van de retoriek van de professie en spelen wellicht feitelijk slechts een ondergeschikte rol in het proces van formele zelfregulering. Aan deze retoriek wordt evenwel een groot belang gehecht in het proces dat moet leiden tot realisatie van de autonomie-claim: "... persuasive rhetoric (is, AA) of greater importance than the objective character of knowledge, training, and work" (79). In het verlengde hiervan wordt de geneeskunde tevens een moreel ondernemerschap ('moral entrepeneur') toegedicht: de medische wetenschap probeert sociale betekenissen van gezondheid en ziekte ingang te doen vinden, waar die betekenissen tevoren niet aanwezig waren (254). Gesteld dat dergelijke betekenisverleningen ook in beroepscodes doorklinken, bezitten beroepscodes dus niet alleen een, zij het geringe, functie in het kader van de zelfregulering van de professie op zowel individueel als groepsniveau, maar in deze context tevens een normatief-ethische functie ten opzichte van buitenstaanders in casu de samenleving. Beroepscodes beogen en/of bevatten dus meer dan uitsluitend retoriek.

Met dit laatste kan worden verwezen naar een andere bedenking van Freidson tegen het verschijnsel beroepscodes. Beroepscodes bestaan in het algemeen voor een belangrijk deel uit morele aanbevelingen, voorschriften of richtlijnen. De daaruit voortkomende oordelen bezitten een slechts beperkt objectief karakter en zijn meestal een kwestie van 
wisie, voorkeur of smaak. Freidson concludeert hieruit, in navolging van Carr-Saunders, dat het onverstandig is om formele codes te ontwerpen, omdat dit zou betekenen dat de mening of theorie van een (beperkte) groep beroepsbeoefenaren boven die van anderen wordt gesteld (162). Freidson verwijst hier dus impliciet naar het mogelijk ongerechtvaardigde repressieve en conformerende karakter van beroepscodes, terwijl weinig plaats wordt ingeruimd voor de mogelijkheid van morele consensus binnen een beroepsgroep. Deze laatste implicatie is begrijpelijk vanuit de eerder vermelde kijk van Freidson op de aard van het werk van artsen.

Wat Freidson naar voren brengt ten aanzien van de geneeskunde geldt naar zijn oordeel nog in sterkere mate voor de semi-professies in de gezondheidszorg (door hem 'paraprofessies' genoemd). Zij trachten hun autonomie-claim kracht bij te zetten door dezelfde instituties in het leven te roepen als die waardoor de gevestigde professies worden gekenmerkt. Dit leidt onder andere tot het ontwerpen van beroepscodes. Wat de betekenis van dit alles is voor de status van een semi-professie en dientengevolge voor haar beroepscode, wordt door Freidson als volgt geschilderd: "... the status of other occupations participating in a medical division of labor can only be subordinate, however much their faces may be smoothed by such cosmetics as a code of ethics (...) and a claim to serve humanity" (185). Plastischer kan de retorische functie van een beroepscode binnen de activiteiten van semi-professies nauwelijks naar voren worden gebracht. Een beroepscode is een uitgelezen devies om het publiek te overtuigen van het moreel onberispelijke gedrag van beroepsbeoefenaren, maar dit garandeert nog niet dat het publiek er ook werkelijk in gelooft. Evenmin biedt hij enige waarborg dat beroepsbeoefenaren zich in hun gedrag daadwerkelijk aan de normen en waarden in een code conformeren (186-187). De beroepscode vertegenwoordigt dus bij semi-professies, nog meer dan bij professies, een overwegend strategisch belang.

De lijvigheid en doorwrochtheid van de studie van Larson (1979) staan in schril contrast tot het aantal verwijzingen daarin naar het verschijnsel beroepscode. In feite betreft het slechts drie korte passages.

Beroepscodes zijn volgens Larson onder andere een poging tot standaardisering van gedrag van professionals. In de situatie van de geneeskunde in de Verenigde Staten had deze poging bovendien expliciet tot doel competitieve elementen op de 'medische markt' de kop in te drukken (131). Daarnaast en in het verlengde van dit laatste was onderschrijving van de beroepscode van de American Medical Association reeds in 1855 een voorwaarde om als lid van deze beroepsorganisatie te worden toegelaten (130). (In tegenstelling tot Goode hierboven erkent Larson dus wél het bestaan van formele beroepscodes vó6r 1900).

Beroepscodes vervulden dus ook volgens Larson een bepaalde functie in het streven naar zelfregulering van een professie en naar controle over het gedrag van beroepsbeoefenaren. Die functie mag echter naar zijn mening niet worden overschat; in ieder geval niet met betrekking tot het proces van socialisatie en interne cohesie: "From the point of view of socialisation into the profession and professional 'cohesion', control over members is (...) a matter of structure much more than a matter of obedience to an association's code of ethics" (72). 
De bundel van Blair en Rubin (1980) over zelfregulering van (semi-) professies bevat, gezien de centrale thematiek, uiteraard weer meer uitspraken over beroepscodes. Van de desbetreffende auteurs worden hier alleen de belangrijkste aangehaald:

In de inleiding op de bundel plaatsen de redacteuren maatstaven van gedrag van beroepsbeoefenaren, inclusief beroepscodes ('code of ethics'), binnen de context van regulerende organen en raden als een algemeen kenmerk van bescherming van de beroepsuitoefening door de overheid. Deze raden hebben onder andere de exclusieve opdracht dergelijke beroepscodes te formuleren. Deze codes dienen zelfs gedetailleerd te zijn. De desbetreffende raden bestaan meestal uitsluitend uit leden van de eigen beroepsgroep (VII). Hoewel maatschappelijk gesanctioneerd, is controle op en regulering van het gedrag van beroepsbeoefenaren via beroepscodes dus in hoofdzaak een beroeps-interne aangelegenheid.

De beroepscode ('code of conduct') is een van de zes elementen die telkens terugkomen in de zogenaamde 'professional licensing laws' in de Verenigde Staten. Hoewel het in codes overwegend draait om kwesties van etiquette en om abstracte ethische normen is de implementatie ervan niettemin een zeer serieuze en soms keiharde aangelegenheid. Ten aanzien van rechtspraak en advocatuur stelt Rubin (1980) bijvoorbeeld dat toepassing van een beroepscode slechts plaats kan vinden als wordt voldaan aan het vereiste van "... a formal disciplinary mechanism, including powers of investigation, prosecution, adjudication, and punishment" (37). Het element van repressie, zoals ook reeds genoemd door Freidson, is hier in al zijn hoedanigheden aanwezig.

Daarmee zijn beroepscodes echter niet meteen gediskwalificeerd of in diskrediet gebracht. Een dergelijke aanpak had volgens Rubin voor de beroepsgroep ook duidelijke voordelen. Hij somt een groot aantal regels en normen op die, gezien vanuit een historisch perspectief, alle mede tot gevolg hadden dat een absolute barrière werd opgeworpen tegen allerlei vormen van concurrentie en competitie onder beroepsbeoefenaren. Dit hield de beloning voor de dienstverlening op een hoog peil. Pas in 1975 kwam hier een einde aan. Toen werden de beroepscodes van de genoemde raden en van beroepsorganisaties in het algemeen in toenemende mate onderworpen aan een vernietigende kritiek met betrekking tot de mate waarin ze monopolies van beroepsbeoefenaren beschermden en hun handelingsvrijheid beknotten (37). Of deze monopolies en vrijheidsbeknotting ook de kwaliteit van de dienstverlening en de mate van onzekerheid bij het publiek positief dan wel negatief hebben beïnvloed, laat Rubin in het midden.

Vanuit sociaal-economisch perspectief zijn elementen als kwaliteitsbewaking en onzekerheidsbeheersing echter volgens Horowitz (1980) de belangrijkste motieven achter de verschillende beroepscodes ('professional ethics codes'). Beroepscodes dragen bij aan een marktgerichte oplossing voor publieke onzekerheid en dienstverleningskwaliteit. $\mathrm{Zij}$ doen dit onder andere in de vorm van tarifering en prijsbeheersing, terwijl tegelijkertijd de dienstverlening wordt gewaarborgd aan personen die er anders van verstoken zouden blijven. Een overblijvend nadeel is dan wellicht de instandhouding van een mogelijke misvatting onder consumenten, dat een hogere prijs gepaard gaat met een kwalitatief betere dienstverlening (15):

Zoals zovelen hierboven ziet ook de sociologe Haug (1980) codes ('ethical codes') als de belichaming van het dienstbaarheidsideaal van beroepen: de belangen van de beroepsbeoefenaar worden ondergeschikt geacht aan die van de cliënt. Daarmee wordt een rechtvaardiging geboden van het publieke vertrouwen in het beroep (63). Socialisa- 
tieprocessen binnen (de opleiding tot) het beroep bieden echter onvoldoende waarborgen dat de individuele beroepsbeoefenaar zich ook daadwerkelijk door een beroepscode laat leiden. 'Peer review' is een noodzakelijke aanvulling. Deze wordt vanuit het perspectief van de beroepsbeoefenaar gezien als een vorm van externe controle, naast de interne controle die een beroepscode biedt. Beide zijn onderdeel van het deels informele zelfreguleringssysteem van een beroepsgroep, dat volstrekt los staat van en vijandig is gezind tegenover de duidelijk formelere vormen van (externe) controle via bijvoorbeeld wettelijke of bureaucratische interventies (64). Dat een beroepscode zou behoren tot het uitsluitend informele zelfreguleringssysteem van âlle beroepsgroepen wordt echter door Haug zelf tegengesproken: "Law differs from medicine most dramatically in terms of the formal external controls governing the legal profession, as codified in the Bar Association's canon of ethics..." (71).

Carson (1980) zou aan beroepscodes het liefst in het geheel geen aandacht schenken, ware het niet dat er in een professionele context toch vaak naar wordt verwezen. Naar zijn mening zijn beroepscodes meestal te typeren als handleidingen voor etiquette of als verklaringen van verheven idealen en niet als richtlijnen voor het handelen (97).

In zijn beschrijving van de voornaamste tot dan toe ontwikkelde theorieën en modellen met betrekking tot professie en professionalisering refereert Van der Krogt (1981, 36-90) relatief vaak aan het verschijnsel beroepscode. Over het karakter en de functie ervan zegt hij onder andere het volgende:

- een beroepscode voorkomt misbruik van de autoriteitspositie door beroepsbeoefenaren (naar aanleiding van Greenwoods kenmerkenbenadering);

- ontwikkeling van een beroepscode is én van de stadia op de weg van een beroep naar de status van professie (naar aanleiding van Caplows ontwikkelingsbenadering);

- beroepscodes kunnen gevoeglijk worden gerangschikt onder de 'vrome voornemens' van beroepsgroepen, anders zouden zij tot dat doel wel onderzoeksgelden vrijmaken (naar aanleiding van Daniels' kritiek op de kenmerkenbenadering);

- er lijkt een grote mate van overeenkomst aanwezig tussen de 'kern-elementen' van professies en de preambules en inhoud van beroepscodes; de beroepscode heeft een belangrijke functie in de handhaving van de door de beroepsgroep opgestelde roldefinitie (naar aanleiding van Johnsons theorie van geïnstitutionaliseerde beroepscontrole);

- het is voorbarig de beroepscode als een 'sociologische wet' te beschouwen, daar de toepassing ervan in de samenleving voor alle groepen uniform zou moeten zijn, hetgeen niet het geval is (naar aanleiding van Rueschemeyers onderzoek naar de status van professie-theorieën).

In het door Van der Krogt zelf ontwikkelde model speelt de beroepscode een duidelijk ondergeschikte rol. Beroepscodes zijn een weerspiegeling van de mate waarin binnen het beroep consensus over waarden is bereikt (indien ze althans niet het resultaat zijn van het overwicht van een professionele elite; vergelijk Freidson hierboven). Bovendien kunnen ze worden beschouwd als een poging om te ontkomen aan externe controle of patronage. Verwijzingen ernaar kunnen worden gerangschikt onder de morele legitimeringsargumenten, die overigens van veel minder belang zijn dan de kennisargumenten (127-131). Beroepscodes zijn van nog minder betekenis "... wanneer de legitimering ervan niet door de overheid wordt aanvaard." Wordt deze daarentegen wél aanvaard, dan 


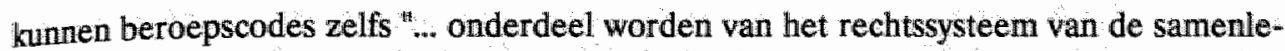
ving." (124). Een beroepscode zou dus een belangrijke rol kunnen spelen in de door Van der Krogt ontwikkelde professionaliseringsstrategieën (134 wv.). Deze komt echter nergens expliciet aan de orde, noch bij de beschrijving van de strategieën noch in de uitgebreide case-studies.

In de bundel van Dingwall en Lewis (1983) treffen we, behalve een verwijzing naar boven vermelde opvatting van Ruesehemeyer, het verschijnsel beroepscode alleen aan in de bijdrage van de socioloog Mungham en de jurist Thomas. Zij onderzochten de beroepsgroep van juristen in casu advocaten in Groot Brittannië en besteedden daarbij aandacht aan hun beroepscode.

Het doel van de beroepscode is ".... to protect the public from the vagaries of caveat emptor." (135). Uitgangspunt is het principe van altruilsme (131). Het altruïstisch model vormt de basis van de 'charismatic authority' van de beroepsgroep. De bescherming ervan voorziet in een rechtvaardiging voor de claim op macht ter bepaling van de eigen arbeidscondities en voor de claim op het privilege van overheidsprotectie (137). Nader onderzoek in de interne politiek van de beroepsgroep leert echter dat het altruistisch model vooral van retorische aard is en in dienst staat van het eigenbelang (132 en 149).

\subsubsection{Beroepscodes als vindplaats van waarden}

Uit bovenstaande beschrijvingen en opvattingen ten aanzien van beroepscodes blijkt allereerst een conceptueel verschil. Het begrip beroepscode wordt enerzijds toegepast op het geïnternaliseerde geheel van waarden en normen bij de leden van een beroepsgroep. Anderzijds wordt het begrip gereserveerd voor het geheel van op schrift gestelde gedragsregels dat door de organisatie van beroepsbeoefenaren in een officiële verklaring aan de leden wordt voorgehouden. Sommige auteurs houden ook expliciet rekening met dit conceptueel verschil bij hun beschrijving en waardering van het verschijnsel beroepscode. Zo maakt Goode een onderscheid tussen informele gedragsregels enerzijds en officiële, formele gedragsregels anderzijds. De empirische bron is in het eerste geval het gedrag van beroepsbeoefenaren, in het tweede geval de tekst van officiële verklaringen van de beroepsgroep. Het onderzoek richt zich dan primair op feitelijke gedragingen respectievelijk wenselijke gedragingen.

Het is bij een aantal van de genoemde auteurs niet geheel duidelijk van welke empirische bron men uitgaat. Echter, er wordt opvallend weinig geschreven over de precieze inhoud van beroepscodes. In dit opzicht is veelzeggend dat analyses van het gedrag van beroepsbeoefenaren en beroepsgroepen vooral gaan over hun autonomie, daarentegen sporadisch in verband worden gebracht met officiële beroepscodes en dat integrale weergave van de tekst ervan bij alle auteurs ontbreekt. Over de inhoud wordt slechts gezegd, dat deze bestaat uit etiquetteregels en abstracte morele normen (bijvoorbeeld door Rubin en Larson), uit morele aanbevelingen, voorschriften en richtlijnen (bijvoorbeeld door Freidson), en dat deze vooral een verwoording is van de dienstbaarheidsoriëntatie van een beroepsgroep (door nagenoeg alle auteurs in enigerlei vorm naar voren gebracht).

Niettemin worden veel uitspraken aangetroffen met betrekking tot de algemene doeleinden en beoogde functies van beroepscodes. Daarnaast treffen we uitspraken aan met betrekking tot de rol die beroepscodes (kunnen) vervullen in de interactie tussen be- 
roepsgroep en beroepsbeoefenaar enerzijds en tussen beroepsgroep en samenleving anderzijds. In deze uitspraken komt het normatieve karakter van beroepscodes in vele toonaarden naar voren. Door Freidson bijvoorbeeld wordt de beroepscode expliciet beschouwd als onderdeel van het "normatieve segment van de formele organisatie van professies'. Evenals Mungham en Thomas rekent hij beroepscodes tot de professionele retoriek. Beroepscades worden derhalve beschouwd als een middel tot betekeniswerlening aan individuele en sociale verschijnselen en processen. Anderen komen dicht bij deze laatste opvatting in de buurt. Ze schrijven aan beroepscodes een rol en/of functie toe bij de normering en interne regulering van het handelen van (kandidaat-)beroepsbeoefenaten en bij het wekken van specifieke verwachtingen ten aanzien van dat handelen binnen de samenleving door het collectivum van de beroepsgroep. Op deze wijze wordt misbruik van een eventuele autoriteitspositie voorkomen en wordt de roldefinitie van de beroepsgroep gehandhaafd (zie Greenwood respectievelijk Johnson).

Over het reële effect van een beroepscode door beroepsgroepen divergeren de meningen. Een code kan weliswaar onmisbaar worden geacht als verwoording van de dienstbaarheidsoriëntatie (bijvoorbeeld bij Toren). Daarnaast kan een code een belangrijke rol worden toegedicht bij de standaardisering van gedrag van beroepsbeoefenaren (bijvoorbeeld bij Larson). En ook het 'commitment' tot de code kan bij de (klassieke) professies als erg groot worden beschouwd (bijvoorbeeld bij Toren). Toch blijkt een grote kloof te bestaan tussen de in de beroepscode geformuleerde wensen en idealen en de in het handelen van beroepsbeoefenaren gepraktiseerde werkelijkheid. De dienstbaarheidsoriëntatie staat mogelijk te zeer op gespannen voet met de eigen doeleinden, autonomiewensen en strategische belangen van de beroepsgroep (zie Goode, Freidson, Blair/Rubin, Johnson). Het in dienstbaarheid vertaalde altruïsme slaat gemakkelijk om in een het eigenbelang dienend egoïsme (vergelijk Mungham/Thomas). Met name het autonomiestreven zou contraproductief werken ten aanzien van de omzetting van de in een beroepscode ten behoeve van cliënten omschreven wensen en idealen in 'operationele normen van gedrag' (Freidson). Volgens Freidson en anderen kan dat ook nauwelijks anders, omdat deze wensen en idealen vanuit hun aard als morele aanbevelingen puur een kwestie van persoonlijke voorkeur en smaak zijn. Daarom zijn ze per definitie niet gebaseerd op een morele consensus onder beroepsbeoefenaren, maar op de opvattingen van een professionele elite. Derhalve bezitten ze tevens een repressief en conformerend karakter (zie ook Blair/Rubin en Greenwood). Beroepscodes zijn dan ook alleen maar toepasbaar met behulp van 'formele disciplinaire mechanismen' en krijgen slechts een officieel gewicht via de formele regulering van gedrag, bijvoorbeeld in de 'professional licensing laws' in de Verenigde Staten van Amerika (Rubin). Beroepscodes zijn dan ook juist voor de overheid van belang als instrument tot regulering van het gedrag van beroepsbeoefenaren. Gebruik van dit instrument levert bovendien bescherming van de beroepsuitoefening op in het belang van de samenleving als collectivum van consumenten (Rubin).

In tegenstelling tot de mening van Freidson weerspiegelen beroepscodes volgens Van der Krogt wel degelijk een bepaalde consensus over waarden binnen een beroepsgroep. Omdat zij echter vooral morele argumenten bevatten ter legitimering van de positie van de beroepsgroep, worden beroepscodes van minder belang geacht dan instrumenten gebaseerd op argumenten ontleend aan het kennisdomein. Freidson daarentegen acht ze juist van groter belang dan kennisargumenten, omdat ze vanuit ideëel perspectief een be- 
langrijke bijdrage kunnen leveren aan de realisering van autonomie-aanspraken. Deze mening staat los van de constatering, dat het feitelijk gedrag van beroepsbeoefenaren nauwelijks door een code wordt beînvloed.

Het onderzoek naar (opvattingen over) beroepscodes in de professionaliseringsliteratuur leidt tot de voorlopige conclusie, dat beroepscodes ondubbelzinnig kunnen worden gerekend tot het normatieve kader van het functioneren van beroepsgroepen. Er bestaat weliswaar verschil van mening over het effect van beroepscodes op het concrete gedrag van beroepsbeoefenaren. En ook is niet altijd geheel duidelijk welke conceptuele status aan het begrip wordt verleend. Daarentegen worden beroepscodes ontegenzeglijk beschouwd als expliciete of impliciete dragers van de waarden, normen en doeleinden, die door een beroepsgroep worden nagestreefd (en daarmee van hun ideologie). Ze helpen de sociale werkelijkheid mede vormgeven en ze vormen een instrument ter evaluatie en beoordeling van die werkelijkheid.

Met name als officiële en formele neerslag van de opvattingen van een beroepsgroep levert een beroepscode een belangrijke bijdrage aan de verduidelijking van haar positie. Deze bijdrage -en daarmee de aard van de vormgeving en evaluatie van de sociale werkelijkheid-wordt uitgewerkt in twee richtingen: extern in de richting van de samenleving, intern met het oog op het gedrag van beroepsbeoefenaren. In het eerste geval worden beroepscodes beschouwd als de verwoording van beroepseigen werkelijkheidsverklaringen en zingevingskaders, beroepsidentiteit en dergelijke. Deze sluiten zodanig aan bij behoeftem in de samenleving, dat ze als kader van collectieve interpretaties kunnen worden aanvaard. Hierbij gaat het dus om acceptatie van de ideologie van de beroepsgroep door de samenleving. In het tweede geval worden beroepscodes beschouwd als een geschikt (en soms onmisbaar) instrument tot normatieve integratie van beroepsbeoefenaren en ter regulering van hun bandelen. Dit betreft derhalve de processen van collectivisering en standaardisering binnen de beroepsgroep zelf.

Uit het bovenstaande volgt een aantal verdere conclusies. Ten eerste blijken beroepscodes een geschikt fenomeen om normatieve aspecten van het functioneren van beroepsgroepen te analyseren op het waarnemingsniveau van de beroepsgroep. Er moet weliswaar rekening worden gehouden met de mogelijkheid, dat beroepscodes de waarden en doeleinden weerspiegelen van een slechts beperkte elite binnen de beroepsgroep. Niettemin mogen zij tevens worden beschouwd als instrument van en gericht op het collectivum van beroepsbeoefenaren. Dit laatste verdient ook wel enige nadruk vanuit een institutionaliseringsperspectief. Het introduceert een aspect van eenheid binnen de beroepsgroep: de beroepscode is gebaseerd op de verwachting; dat lang niet alle leden zich zullen houden aan algemeen geaccepteerde normen van betamelijk gedrag, terwijl men dat op deze wijze juist tracht te voorkomen.

Op de tweede plaats blijkt het mogelijk de in beroepscodes geïmpliceerde normatieve aspecten te differentièren naar hun interne en externe functie, dat wil zeggen: naar normatieve aspecten die van belang zijn voor het functioneren van respectievelijk beroepsbeoefenaar en samenleving. In de analyse van het functioneren van beroepsgroepen door middel van het verschijnsel beroepscode zijn dan ook de waarnemingsniveaus wan beroepsbeoefenaar en samenleving tot op zekere hoogte in het niveau van de beroepsgroep opgenomen. Aan dit laatste niveau kan derhalve een binnen- en een buitenperspectief worden onderscheiden. 
Ten derde, de aan (de inhoud van) beroepscodes toegeschreven doeleinden en functies komen naar hun aard in belangrijke mate overeen met de waarden die wij ten aanzien van het professionaliseringsproces van beroepsgroepen theoretisch zouden kunnen onderscheiden (vergelijk ook 3.3). De uitwerking van deze constatering volgt later. $\mathrm{Ze}$ wordt hier alvast op 'face value' gepresenteerd. Voorlopig is 'dienstbaarheid" het centrale inhoudelijke aspect, dat ons in de eerste plaats zal bezighouden. Hoewel op grond van de onderzochte professionaliseringstheorieën een zekere rol van beroepscodes bij professionaliseringsprocessen mocht worden verondersteld, lijkt deze vanwege de overeenkomstige waarden en doeleinden nader te kunnen worden bevestigd en uitgewerkt. Hiermee zijn beroepscodes opnieuw, maar langs een andere weg, geplaatst in het streven van beroepsgroepen naar institutionalisering, legitimering en het bezit van een collectieve machtspositie; kortom in het perspectief van de realisering van de centrale waarde 'geprofessionaliseerd-zijn'.

Ten aanzien wan de aan beroepscodes toegeschreven doeleinden en functies wordt sterk het accent gelegd op de realisering van én specifieke waarde, namelijk 'dienstbaarheid'. Deze waarde speelt dus een belangrijke rol zowel in professionaliseringsprocessen als in beroepscodes en kan als het verbindend element tussen beide worden beschouwd. Promotie en verwerkelijking van deze waarde bezitten een sterke instrumentele kracht ter versterking van de ruil- en gebruikswaarde van professioneel verrichte arbeid en ter legitimering van de machtspositie van een beroepsgroep. Voorzover beroepscodes inderdaad een vertaling van deze waarde zijn en voorzover dienstbaarheid in de beroepspraktijk als operationele norm van gedrag werkzaam is, kunnen beroepscodes derhalve een belangrijke bijdrage leveren aan de realisering van de centrale waarde 'geprofessionaliseerdzijn'.

Voorzover het kennisdomein in de waarde 'dienstbaarheid' is verdisconteerd (zoals Freidson veronderstelde) vertegenwoordigt zij of is zij de samenvatting van alle of tenminste een groot deel van de te onderscheiden actor-gerelateerde waarden op de diverse waarnemingsniveaus en gezien vanuit zowel een binnen- als een buitenperspectief. Dienstbaarheid behoort tot de expressieve oriëntatie van beroepsbeoefenaren op hun werk en is veelal de vertaling van de intrinsieke waarde van arbeid in het algemeen (dit in tegenstelling tot een instrumentele oriëntatie op arbeid). Tevens is dienstbaarheid een belangrijke factor met betrekking tot de gebruikswaarde van professioneel verrichte arbeid (vergelijk figuur 2.1). In aansluiting hierop is dienstbaarheid van professionals voor de samenleving van belang ter beheersing van allerlei behoeften en onzekerheidsbronnen en derhalve voor haar voortbestaan. Ook in dit opzicht mag van beroepscodes -als belichaming en vertaling van de waarde 'dienstbaarheid' bij uitstek- een voorname rol en functie worden verwacht in het beleid en de activiteiten van beroepsgroepen binnen een samenleving.

\subsubsection{Naar een vraagstelling voor verder onderzoek: beroepscodes in mo-}

\section{reel perspectief}

Dit onderzoek gaat over het geheel van waarden en normen, doeleinden en voorschriften, deugden en plichten van beroepsgroepen en hun leden, met name in relatie tot professionaliseringsprocessen en hun rol in de samenleving. Genoemd geheel beïnvloedt de sociale werkelijkheid en context van beroepsmatig verrichte arbeid. Aan de hand 
daarvan wordt die sociale werkelijkheid tevens beoordeeld in termen van feitelijkheid en wenselijkheid.

Redenerend en analyserend vanuit professionaliseringstheorieën hebben we geconstateerd, dat beroepscodes een relevant verschijnsel vormen met behulp waarvan de normatieve aspecten van professionalisering kunnen worden beschreven. Dit werd toegelicht aan de hand van de functie en inhoud van beroepscodes, zoals beschreven door professionaliseringstheoretici.

De aandacht zal nu meer in detail op dit verschijnsel beroepscode en zijn normatieve betekenis worden gericht. Een beroepscode werd eerder reeds omschreven als een verzameling richtlijnen en/of aanbevelingen, opgesteld door een beroepsgroep om het gedrag van beroepsbeoefenaren te reguleren. Inmiddels is duidelijk geworden, dat een beroepscode een aantal, zowel interne als externe functies vervult. Daarbij is gedragsregulering van beroepsbeoefenaren slechts één van de doeleinden waarmee een beroepsgroep met behulp van een beroepscode de sociale werkelijkheid tracht te beinvloeden. Een beroepscode vervult tenminste ook een bepaalde ideologische functie. Hij kan als instrument fungeren ten behoeve van (wijziging van) betekenisverlening door de samenleving aan de door beroepsgroepen en beroepsbeoefenaren vervulde activiteiten.

In samenhang met het gestelde in het onderhavige hoofdstuk lenen zich direct twee onderzoekslijnen voor verdere uitwerking. De normatieve aspecten van professionalisering en de functies van beroepscodes zijn in het voorafgaande beschreven vanuit een sociologisch perspectief. Dat wil zeggen: vanuit het gezichtspunt van sociologen die zich met de verschijnselen beroep en professie/professionalisering hebben beziggehouden. Echter, vanuit dit perspectief werden de normatieve aspecten van professionalisering slechts zeer globaal en bijna uitsluitend vanuit een conceptueel en theoretisch kader met beroepscodes in verband gebracht. Het verdient dan ook aanbeveling de onderzoeksaandacht in eerste instantie te richten op een nadere uitwerking van dit verband en wel in empirische zin. Meer in het bijzonder zou dan een vraagstelling kunnen worden ontwikkeld waarbij de concepten en theoretische relaties met betrekking tot (de normatieve aspecten van) professionalisering en beroepscodes worden vertaald en onderzocht naar hun empirische samenhang. Het gaat dan om het (maatschappelijk) gedrag van beroepsgroepen en professionals in vergelijking tot de inhoud van beroepscodes.

Ondanks het belang van een dergelijke onderzoekslijn wordt in de onderhavige studie gekozen voor een tweede onderzoekslijn, namelijk de wijsgerig-ethische. De normatieve aspecten van professionalisering zijn niet alleen vanuit een sociologisch perspectief, maar ook vanuit een moreel perspectief te bestuderen. Dan doet zich de vraag voor welke waarden naar voren komen uit een analyse van de functies en inhoud van beroepscodes als belichaming van de normatieve aspecten van professionalisering en van welke ard deze waarden zijn. Het antwoord op deze vraag bleek in 3.2.2 reeds van belang om vanuit normatief-ethisch perspectief waarden als morele waarden te kunnen identificeren. Vastgesteld werd, dat dit het geval is wanneer waarden een motief, bedoeling, daad of karaktereigenschap van mensen betreffen en op grond van de beginselen uit het ethisch gezichtspunt, dus op morele gronden, kunnen worden aanbevolen.

In zekere zin wordt met deze onderzoekslijn het empirisch-sociologisch onderzoek enigszins tussen haakjes gezet. Vanuit moreel perspectief is niet alleen de vraag van belang naar een preciese bepaling van de feitelijke plaats, inhoud en functie van waarden in professionaliseringsprocessen en beroepscodes. Ook moet op grond van rationele over- 
wegingen worden gepoogd aan te geven in hoeverre het nastreven van dergelijke waarden bijdraagt aan een realisering van de goede mens en de goede samenleving. Dit betekent enerzijds dat aanbevelingen kunnen worden gedlaan met betrekking tot een moreel juist verloop van professionaliseringsprocessen en een moreel juiste invulling en formulering van beroepscodes. Anderzijds kan ook een normatief-ethische benadering het niet stellen zonder kennis van en inzicht in de sociale werkelijkheid, zodat onze theoretischinterpretatieve studie voor een deel gehandicapt zal zijn door het ontbreken van voldoende empirische gegevens. We hebben gezien, dat gegevens ten aanzien wan beroepscodes in hun relatie tot professionaliseringsprocessen en het gedrag van beroepsbeoefenaren schaars zijn.

Dit ontbreken van gegevens levert echter geen doorslaggevend argument op om van de voorgestelde studie af te zien. Normatief-ethische oordelen en de identificatie, rechtvaardiging en toepassing van criteria voor hetgeen moreel juist of onjuist is, komen in de ethiek niet tot stand op grond van empirische bewijsvoering (dit zou namelijk een naturalistische drogreden impliceren). Veeleer wordt de weg bewandeld van rationele argumentatie door middel van explicitering van morele vooronderstellingen en posities (vergelijk 3.2.2). Bovendien zal in deze studie worden getracht het probleem, dat met het gebrek aan gegevens dreigt te ontstaan, gedeeltelijk te ondervangen. De beschouwing zal namelijk uitsluitend worden betrokken op beroepscodes die een schriftelijke neerslag hebben gekregen in een door de beroepsgroep of beroepsorganisatie erkend officieel document. Er zijn allerlei schriftelijke uitingen van beroepsgroepen en beroepsbeoefenaren, maar van een dergelijk document mag worden verwacht dat het de weergave is van de waarden en normen die men aanhangt, proclameert en wenst te verwezenlijken in het belang van de groep en in de context van overheersende opvattingen binnen de samenleving.

Aldus komt de normatief-ethische waardering van een beroepscode niet in het luchtledige te hangen, maar kan worden gerelateerd aan bestaande posities binnen een beroepsgroep en in relatie tot de samenleving. Dit laatste is van belang om de resultaten van het onderzoek uiteindelijk ook te laten uitmonden in een normatief-ethische waardering van een door een beroepsgroep ondernomen professionaliseringsproces. Dergelijke processen vormen immers meestal -zoals eerder naar voren gebracht- de context van een beroepscode. De vanuit een analyse van beroepscodes geschetste en gewaardeerde morele posities kunnen dan worden geconfronteerd met de morele posities zoals naar voren komend in bijvoorbeeld de machtsbenadering. 'Positie' wordt hier overigens gebruikt in de betekenis van 'opvatting', 'stellingname'. In 5.3.1 zal aan de term een iets andere betekenis worden gehecht, namelijk een die nauw aansluit bij het sociologisch vocabularium. Uit de vorige alinea blijkt, dat het onderhavige onderzoek tevens sociaal-ethische belangen dient. Vanuit een beschrijving en waardering van de morele dimensie van beroepscodes zal worden getracht de functie van morele beginselen te schetsen bij de waardering en sturing van professionaliseringsprocessen. Verwacht mag worden dat hiermee ook een bijdrage kan worden geleverd aan beroepsethische noties, als speciaal gebied van de normatieve ethiek.

Gezien deze doelstellingen en perspectieven dienen keuzes te worden gemaakt. Een eerste beperking is gegeven met het uitgangspunt, vooral aandacht te schenken aan beroepscodes die binnen ons eigen cultureel erfgoed zijn ontstaan, dat wil zeggen: vanuit de westerse culturele traditie, zoals aan te treffen in de Westeuropese en Angelsaksische 
(inclusief Noordamerikaanse) samenlevingen. Een tweede beperking ligt in de keuze voor een specifieke sector van het maatschappelijk leven, namelijk de gezondheidszorg. Andere beperkingen zijn reeds in het inleidende hoofdstuk aangegeven, met name ons voorstel de analyse te beperken tot beroepscodes voor verpleegkundigen.

Het voorgaande samenvattend kan als de centrale vraagstelling voor het verdere verloop van deze studie worden geformuleerd:

Welke morele posities zijn te onderscheiden in de door beroepsgroep(en) en beroepsarganisaties op het terrein van de verpleegkunde in de westerse samenleving gepubliceerde beroepscodes; hoe verhouden deze morele posities zich tot het professionaliseringsproces van de beroepsgroep in het bijzonder en tot maatschappelijke processen in het algemeen; en hoe dienen deze vanuit een normatief-ethisch perspectief te worden gewaardeerd?

Het onderzoek tracht inzicht te verschaffen in de morele status van beroepscodes in relatie tot die van professionaliseringsprocessen en tot morele noties van algemeen maatschappelijke en wijsgerige aard.

In samenhang met deze vraagstelling dringt zich een aantal subvragen op:

1. In hoeverre kunnen beroepscodes als moreel verschijnsel worden geduid? Hierbij is met name aan de orde of een beroepscode bestaat uit etiquetteregels dan wel uit morele voorschriften, aanbevelingen, regels en/of adviezen. Kortom, vertegenwoordigt een beroepscode een bepaalde moraal, een specifiek ethos? Alleen in dit geval, overigens, zijn de volgende subvragen relevant. Deze zijn immers gebaseerd op de vooronderstelling, dat de inhoud van beroepscodes van morele aard is en met behulp van het begrippenapparaat en instrumentarium van de wijsgerige ethiek kan worden bestudeerd.

2. Van welke aard is een beroepscode als moreel verschijnsel? Hierbij gaat het bijvoorbeeld om de vraag of een beroepscode moet worden opgevat als een verzameling handelingsregels, als een geheel van na te streven handelingsdoeleinden of als een beschrijving van een aantal disposities. In samenhang hiermee dient te worden nagegaan of de bepalingen in beroepscodes bestaan uit morele plichten die aan beroepsbeoefenaren worden voorgehouden dan wel uit een rechtstreekse weergave van de door een beroepsgroep aangehangen morele waarden. Dit vergt een nauwkeurige analyse van de tekst van beroepscodes.

3. Op welke wijze worden de in de toelichting bij de vorige subvraag genoemde plichten en/of waarden gerechtvaardigd? Voor een antwoord op deze vraag dient te worden onderzocht welke criteria voor een dergelijke rechtvaardiging kunnen worden aangewend en van welke aard een eventueel achterliggende sociaal-normatieve of normatief-ethische theorie is of kan zijn. In sociaal-normatieve zin kan bijvoorbeeld sprake zijn van een plichttheorie, waardetheorie of evaluatieve theorie. In normatief-ethische zin kan sprake zijn van een teleologische, deontologische dan wel deugd-ethiek. Dit deel van het onderzoek richt zich met name op de preambules van, de toelichtingen op en de discussies in beroepskringen rondom een beroepscode. 
4. In hoeverre is er sprake van hiërarchisering van plichten eniof waarden in beroepscodes en hoe moet deze moreel worden gewaardeerd? Kan een bepaalde rangordening worden herkend en/of aangebracht, waarbij één of meer plichten/waarden centraal staan en andere als perifeer kunnen worden gekwalificeerd? Hierbij kan worden herinnerd aan hetgeen professionaliseringstheoretici als de centrale waarde binnen beroepscodes formuleerden, namelijk dienstbaarheid. Een normatief-ethische waardering van een eventueel aanwezige rangordening zall vooral zijn gericht op de vraag in hoeverre daarmee de goede mens en de goede samenleving worden bevorderd. In het onderzoek zal naast een zorgvuldige analyse van de inhoud van beroepscodes uitdrukkelijk aandacht moeten worden besteed aan de functie(s) van beroepscodes om de adequaatheid van het middel (code) aan het doel (functie) in normatief-ethisch opzicht te kunnen beoordelen.

5. Hoe verhouden de resultaten uit de beantwoording van de voorgaande subvragen zich tot de dominante normatief-ethische posities respectievelijk plichten en waarden zoals naar woren komend in professionaliseringsprocessen op grond van de machtsbenadering en in de samenleving als geheel? Deze vraag voorziet in een terugkoppeling van onderzoeksgegevens natr beschouwingen in het onderhavige hoofdstuk ten aanzien van de normatieve aspecten van professionalisering, mede met betrekking tot de samenleving. Daarbij gaat het primair om het analyseren van overeenkomsten en verschillen in morele posities ten aanzien van beroepscodes, professionaliserings- processen en samenleving. Secundair zal worden getracht hieraan conclusies te verbinden met betrekking tot de morele kwaliteit van professionaliseringsprocessen als maatschappelijk fenomeen en met betrekking tot de verhouding tussen algemeen ethische noties en de morele uitgangspunten en randvoorwaarden in de beroepsethiek.

In het bovenstaande werden professionaliseringsprocessen in hoofdzaak geïnterpreteerd vanuit de machtsbenadering. Ten aanzien van het gebruik van de term beroepscode werd reeds nadruk gelegd op de verpleegkundige beroepscode. In de navolgende beschouwingen zal dit in nog sterkere mate het geval zijn, tenzij uit de context anders blijkt.

De beantwoording van de centrale vraagstelling vormt het sluitstuk van de nu volgende hoofdstukken. Daarbij fungeren de subvragen als leidraad. Zij komen als eerste aan de orde.

In lhet cerstwolgende hoofdstuk windt een nadere analyse plaats van de inhoud van een viertal beroepscodes, gepubliceerd door de beroepsgroep van verpleegkundigen. Het bevat een belangrijk deel van de antwoorden op de subvragen 1, 2 en 4.

Het daarop volgende hoofdstuk (5) is hoofdzakelijk gericht op de normatief-ethische anallyse en waardering van de basisgegevens uit hoofdstuk 4. Hierin zullen woorzover nodig ten behoeve van interpretatie- tevens een aantal meta-ethische noties worden verduidelijkt en uitgewerkt. Het geheel moet leiden tot antwoorden op de subvragen 3 en 4.

In de laatste paragraaf van dit hoofdstuk komt subvraag 5 aan de orde. De centrale vraagstelling, tenslotte, zal kort worden beantwoord in de slotconclusies van hoofdstuk 6 . 


\section{BEROEPSCODES VOOR}

\section{VERPLEEGKUNDIGEN}

\subsection{Inleiding}

In de voorafgaande hoofdstukken werd op basis van een beroepensociologisch kader alsmede op geleide van algemene noties uit de praktische wijsbegeerte toegewerkt naar een vraagstelling voor verder onderzoek. De primaire interesse ging daarbij uit naar het identificeren van de normatieve aspecten van professionalisering. Betoogd werd, dat het verschijnsel beroepscode zich ertoe leent de genoemde normatieve aspecten meer in extenso aan het daglicht te brengen. In de vraagstelling die op grond hiervan is uitgewerkt werd vervolgens het belang benadrukt van een wijsgerig-ethische analyse en evaluatie van dat verschijnsel.

Zoals aangekondigd, vangt deze analyse aan met de inhoudelijke beschrijving van een aantal beroepscodes. Daarbij wordt het focus gericht op de beroepsgroep van verpleegkund"̈gen. In de paragrafen 4.3 zal uitvoerig worden ingegaan op de inhoud en context van de beroepscodes, gepubliceerd door de International Council of Nurses (ICN), de American Nurses' Association (ANA), de United Kingdom Council of Nurses, Midwives and Health Visitors (UKCC) en de Nederlandse Maatschappij voor Verpleegkunde (NMV, nu Nieuwe Unie '91 geheten).

Deze beroepscodes zullen in de paragrafen 4.4 worden geanalyseerd op het (impliciet of expliciet) aanwezige patroon van waarden en normen. In een semiotische analyse hiervan zal vervolgens blijken dat er sprake kan zijn van meervoudige betekenissen en van functieverschuivingen. In ieder geval zal ook aandacht worden besteed aan het feitelijk functioneren van de codes, mede in het licht van een aantal factoren die dit functioneren beïnvloeden. In dat verband zal een onderscheid worden gemaakt tussen hun morele functie en hun ideologische functie. Met name de laatste krijgt in dit hoofdstuk veel aandacht.

De analyse wordt in de paragrafen 4.2 voorafgegaan door enige kanttekeningen van terminologische en historische aard. Met betrekking tot de historische aspecten zal onder andere worden ingegaan op de beroepscodes die in de loop van de geschiedenis op het terrein van de geneeskunde tot stand werden gebracht. Zij gelden ten dele als voorbeeld voor de beroepscodes die in de twintigste eeuw zijn ontstaan binnen andere beroepsgroepen. 


\subsection{Terminologische en historische context}

\subsubsection{De term 'code"}

Volgens de Grote Winkler Prins Encyclopedie $(1980 / 6,338)$ wordt de term 'code' in twee betekenissen gebruikt. In een eerste, algemene betekenis duidt de term op een afspraak die aan een reeks symbolen, tekens of signalen een betekenis toekent. Voorbeelden hiervan zijn de morsecode en de binaire code. Hiermee correspondeert de verwante term 'codetheorie': Dit is het deelgebied van de wiskunde waarin men zich bezighoudt met het ontwerpen, decoderen en analyseren van codes voor informatietransport. Ten tweede heeft code de betekenis van wetboek. Deze tweede betekenis is ontleend aan het Frans en heeft wereldwijd bekendheid gekregen in de Code Napoléon of Code Civil, het Franse burgerlijk wetboek. In de Franse taal worden echter niet alleen wetboeken met de term code aangeduid, maar ook andere (verzamelingen van) voorschriften en regels (Maas 1963, 63).

Het woord 'code', zoals op deze wijze gespeld in vele talen, is afgeleid van het Latijnse 'codex' (of het Oudllatijnse 'caudex'). In het antieke Rome was het de benaming van het houten tafeltje, dat met was werd bestreken om erop te kunnen schrijven, ofwel van een aantal van dergelijke tafeltjes tezamen, ofwel van een 'boek' van gevouwen en bijeengebonden bladen papyrus of perkament. Als begrip is de 'codex' vooral bekend geworden in het recht. Daar is het de oude benaming voor een verzameling wetten of voor een wetboek als geheel. Verder was het in gebruik in de ruimere betekenis van iedere geautoriseerde verzameling voorschriften. Bekende verzamelingen van rechtsregels zijn de Codex Hammoerabi (ca. 1700 vór Christus), die lange tijd gold als de vroegste, op schrift gestelde, systematische verzameling rechtsregels; de Codex Theodosianus (435-437 na Christus), de eerste officiële verzameling constituties van Romeinse keizers; en de Codex Juris Canonici (oorsprong: 1582), die vanaf 1918 het officiële kerkelijke recht van de Rooms-Katholieke Kerk vertegenwoordigt. Interessant is verder dat het verkleinwoord van 'codex' -codicillus (codicil)- momenteel vaak in publieke discussies en de media opduikt. In het Romeinse recht was het de aanduiding van een bijzondere vorm van uiterste wilsbeschikking, waarin geen erfstelling voorkwam (dus geen erfgenaam werd aangewezen). Ook in het huidige Nederlandse recht is deze betekenis nog in gebruik (Grote Winkler Prins 1980/6, 338-341).

De oorsprong van de term 'code' in het Latijnse 'codex" en het veelvuldig gebruik van 'codex' als aanduiding van wetboeken en andere verzamelingen van rechtsregels zou ons ertoe kunnen verleiden ook beroepscodes primair als een dergelijke verzameling te beschouwen. Hiertegen pleiten echter de betekenis die hedentendage aan de term wordt verleend zoals beschreven in het worige hoofdstuk en de boven reeds gememoreerde ruimere betekenis van het oorspronkelijke begrip 'codex'.

Hoewel in veel encyclopedieën en dictionnaires nadruk wordt gelegd op de juridische betekenis en context van de begrippen 'code' en 'codex' (onder andere in de Grote Winkler Prins Encyclopedie 1980/6, en in de Brockhaus Enzyclopädie 1968/4), wordt in andere juist deze bredere betekenis voorop geplaatst. Zo omschrijft de Concise Oxford 
Dictionary $(1982,180)$ 'code" onder andere als de "...prevalent morality of a society or class" en als een "...person's standard of moral behaviour". De New Encyclopaedia Brittannica (in Micropaedia 1974/2, 1034) vermeldt als betekenis van 'code": "... more or less systematic and comprehensive written statement of rules on a given subject. The rules may or may not be authoritatively promulgated, and the subject may be broad or narrow and range in importance from school dress codes to the elaborated civil-law codes of France, Germany and Switzerland". 'Codex' wordt in dit werk omschreven als de "...earliest type of manuscript in modern book form (...) which replaced the earlier rolls of papyrus and wax tablets". Vermeldenswaard is, dat in vergelijking met andere standaardwerken de oudste betekenis van 'codex' (het met was bestreken schrijftafeltje) van de omschrijving of definitie wordt uitgesloten.

Gezien de herkomst, gebruik en omschrijvingen van het begrip 'code' is het derhalve niet verwonderlijk, dat het nu eens in zijn 'enge' betekenis als verzameling rechtsregels wordt gehanteerd, dan weer in een wat ruimere betekenis van de latst gegeven omschrijving in de vorige alinea. Vooralsnog sluiten wij ons bij deze laatste aan. Dit betekent, dat eerder gegeven omschrijvingen onder de definitie vallen. Een code is dan: een systematisch geheel van waarden, normen, regels en voorschriften op enigerlei terrein. Een beroepscode is dan: een systematisch geheel van waarden, normen, regels en voorschriften met betrekking tot (de uitoefening van) een beroep. Zo beschouwd, kan elke systematische reeks van regels en voorschriften, geldend binnen een beroepsgroep, als een beroepscode worden opgevat. In deze studie wordt de aandacht echter vooral gericht op de op schrift gestelde en officieel gepubliceerde waarden, normen, regels en voorschriften van morele aard. Beroepscodes met betrekking tot waarden, normen, regels en voorschriften op gebieden als kleding, omgangsvormen en de technische uitvoering van taken en functies blijven dus grotendeels buiten beschouwing.

Deze omschrijving van 'beroepscode' wijkt af van de door de Nationale Raad woor de Volksgezondheid (NRV) voorgestelde ornschrijving. Deze luidt: "Een "beroepscode" kan worden omschreven als de codificatie van ethische en praktische normen en beginselen omtrent hetgeen in de uitoefening van een beroep behoort te worden gedaan en te worden nagelaten jegens collega-beroepsbeoefenaren, de patiënt of cliënt en anderen." (NRV 1988, 10). Tegen deze omschrijving zijn vanuit het perspectief van de onderhavige studie, de volgende bezwaren aan te voeren:

1. Het definiens brengt een te sterke beperking aan in het definiendum. Dat wil zeggen: de termen en kenmerken waarmee het begrip 'beroepscode' wordt omschreven, geven de volledige betekenis onvoldoende weer. Niet alle codes zijn "gecodificeerd". Ze kunnen meer bevatten dan "ethische en praktische normen en beginselen". Ze kunnen op meer betrekking hebben dan psychomotorische aspecten van het handelen (bijvoorbeeld ook cognitieve aspecten, naast doen en nalaten). En ze kunnen jegens meer zijn gericht dan uitsluitend personen (bijvoorbeeld ook jegens andere delen van de levende natur en jegens zaken en goederen; indien althans met "praktische" iets anders wordt bedoeld dan het nevengeschikte "ethische");

2. De omschrijving vervult een zowel descriptieve als persuasieve functie. Dat wil zeggen: de omschrijving is ontwikkeld op grond van de analyse van (een beperkt aantal) officieel gepubliceerde beroepscodes en wordt op basis hiervan aanbevolen als omvattende omschrijving van nog te ontwerpen beroepscodes. Daarentegen pleiten wij voor 
een nominale omschrijving. Hierin is slechts sprake van voorlopige afspraken met betrekking tot de betekenis van het begrip met het oog op de nog volgende analyse.

De keuze voor een ruime omschrijving van het begrip 'beroepscode' en onze inperking ervan tot het gebied van morele waarden, normen, regels en voorschriften impliceren geenszins een afsluiting ten opzichte van het juridische domein. Verderop in deze studie zal blijken, dat een beperking tot het gebied van morele waarden, normen, regels en voorschriften weliswaar zinvol is, maar dat het gebruik van beroepscodes in een maatschappelijke context soms dermate juridisch is verankerd, dat aan de exlusief morele status ervan moet worden getwijfeld. Hiermee is alvast de noodzaak aangegeven om beroepscodes tenminste ook naar hun juridische implicaties en context te bezien. Tevens nodigt dit uit tot een nadere beschouwing van de verhouding tussen recht en ethiek vanuit het perspectief wan de waarden, normen, regels en voorschriften ten aanzien van de uitoefening van een beroep. We komen hier in 5.3.5 op terug.

\subsubsection{Beroepscodes in historisch perspectief}

De in deze studie gepresenteerde en te analyseren beroepscodes staan niet op zichzelf. Enerzijds kunnen ze worden gezien als een vanuit een streven naar professionalisering logisch voortvloeiend verschijnsel. Anderzijds staan ze in de context van een historisch proces, waarin zeer lang reeds beroepsgroepen, die een bepaalde organisatiegraad hadden bereikt, het gedrag van hun leden aan zekere maatstaven wilden binden en ons daartoe documenten nalieten. Beroepscodes zijn derhalve als het ware al zo oud als onze beschaving.

Het doel van onze beschouwing hier is niet een volledig overzicht te bieden van de historische ontwikkelingen met betrekking tot het verschijnsel beroepscode. Slechts enkele hoogtepunten worden belicht. De nadruk zal daarbij liggen op codes uit de sfeer van de gezondheidszorg. Een en ander betekent, dat hoofdzakelijk gebruik wordt gemaakt van secundaire literatuur en geen onderzoek aan oorspronkelijke bronnen plaatsvindt.

De Codex Hammoerabi (circa 1700 vóór Christus) geldt, zoals eerder vermeld, als één van de oudste systematische verzamelingen rechtsregels. De Codex bevat een aantal regels en voorschriften met betrekking tot het gedrag en de tarieven van 'chirurgen'. De betekenis en impact van deze regels en voorschriften zijn echter niet geheel duidelijk (Kepler 1981, 15).

Van veel groter betekenis is geweest de zogenaamde 'Eed van Hippocrates'. Hoewel we op grond van de naamgeving hier ogenschijnlijk niet van een code mogen spreken, wordt de Eed door gezaghebbende auteurs als Edelstein $(1943,6)$ en May $(1975,29)$ wel als zodanig aangeduid. De Eed biedt bij nadere beschouwing inderdaad een geheel van algemene en bijzondere (morele) regels en voorschriften en well met betrekking tot de uitoefening van het beroep van geneeskundige (vergelijk hiertoe de oorspronkelijk Griekse en de internationaal aanvaarde Engelse tekst in Edelstein 1943, 3).

De Griekse cultuur -en meer in het bijzonder het Corpus Hippocraticum- heeft vele eeuwen model gestaan voor een geneeskunde, waarin een wetenschappelijke aanpak en humaan handelen als één geheell werden gezien (uitvoerige studies hierover treft men aan 
in Flashar, 1971). Het Griekse 'humanisme' werd echter langzamerhand overwoekerd door de Joods-Christelijke imperatieven van naastenliefde en goed rentmeesterschap (Kepler 1981, 22).

De geneeskunde diende steeds opnieuw haar positie te bepalen ten opzichte van vigerende godsdienstige beginselen. Het bezit van bepaalde, moreel positief te waarderen karaktereigenschappen en/of deugden moest de gezondheidswerker helpen bij de realisering van moreel onbesproken gedrag. Als voorbeeld hiervan is ons de 'Eed van Maimonides' bewaard gebleven (hier weergegeven in de Engelse versie):

\begin{abstract}
"May neither avarice nor miserliness, nor thirst for glory, nor for great reputation engage my mind; for the enemies of truth and philantropy could easily deceive me and take me forgetful of my lofty aim of doing good to my patients. May I newer see in a patient anything but a fellow creature of pain ..." (Purtilo/Cassel 1981, 37).
\end{abstract}

Maimonides was een Joods filosoof uit de dertiende eeuw, die veel geschriften naliet over de verhouding van geneeskundige thema's tot de Joodse wet.

Percivals "Code of Ethics" uit 1803 wordt gezien als een van de eerste verzamelingen morele regels en voorschriften, waarin medisch-ethische tradities uit de Antieken en Middeleeuwen werden verbonden met de kenmerken van de beroepsbeoefenaar in de moderne tijd (Kepler 1981, 23; voor een reprint van het desbetreffende werk van Percival, zie Reiser et al 1977, 18-25). De Code van Percival (1740-1804; ziekenhuisarts te Manchester) stond model voor de "Code of Medical Ethics", aangenomen tijdens de nationale conventie van de American Medical Association in 1847. Tot 1957 zou deze code geen fundamentele wijzigingen ondergaan (May 1975, 31). Ook de Engelse medisch-ethische code is gebaseerd op Percivals werk (Lindeboom 1960, 12).

In 1948 werd tijdens de Algemene Vergadering van de World Medical Association te Genève de zogenaamde "Declaration of Geneva" aangenomen. Deze verklaring is feitelijk een artsen-eed en vertoont veel overeenkomsten met de structuur van de 'Eed van Hippocrates' (Lindeboom 1960, 41-42). De tekst werd in 1968 te Sydney geamendeerd en herbevestigd:

\footnotetext{
"At the time of being admitted as a member of the medical profession:

I solemnly pledge myself to consecrate my life to the service of humanity;

II will give to my teachers the respect and gratitude which is their due;

I will practice my profession with conscience and dignity, the health of my patient will be my first consideration;

I will maintain by all the means in my power, the honor and the noble traditions of the medical profession; my colleagues will be my brothers;

I will not permit considerations of religion, nationality, race, party politics or social standing to intervene between my duty and my patient;

I will maintain the utmosit respect for human life from the time of conception, even under threat, I will not use my medical knowledge contrary to the laws of humanity;

I make these promises solemnly, freely and upon my honor." (Beauchamp/Childress $1979{ }_{n} 281$ 282).
}

In dezelfde periode begon men ook codes te ontwerpen op deelterreinen van de geneeskunde. De meest geruchtmakende betreft uiteraard de 'Code van Neurenberg" uit 1947. Deze kwam tot stand naar aanleiding van de berechting van oorlogsmisdadigers die zich schuldig hadden gemaakt aan onaanvaardbare medisch-wetenschappelijk experimenten op proefpersonen (voor de tekst zie Beauchamp/Childress 1979, 289-293). 
Vanaf de jaren vijftig van deze eeuw is een grote toename te constateren van het aantal codes. Door diverse beroepsgroepen binnen en buiten de gezondheidszorg worden op zowel nationaal als internationaal niveau vele codes officieel aan de openbaarheid prijsgegeven (een dwarsdoorsnede van teksten, in gebruk in de Verenigde Staten van Amerika en in internationale organisaties, biedt Gorlin 1990; op het terrein van de bescherming van de rechten van de mens, zie Amnesty International 1984, 1-36; een opsomming van bronnen in Nederland biedt NRV 1988,8).

Het gebied is nauwelijks meer in kaart te brengen en is waarschijnlijk ook voor individuele beroepsbeoefenaren moeilijk te overzien. De reden van dit laatste is niet alleen gelegen in het aantal codes binnen het eigen vakgebied. Op grond van de vele samenwerkingsverbanden waarin de moderne professional functioneert, ziet deze zich tevens voor de noodzaak geplaatst inzicht te hebben in de codes van aanverwante beroepsgroepen. Bovendien zijn veel codes uitgevaardigd door vakorganisaties en -verenigingen, waardoor ze in principe alleen van toepassing zijn op de beroepsbeoefenaren die zich bij een dergelijke organisatie of vereniging hebben aangesloten. Op dit probleem komen overigens later nog terug (zie 4.5).

In Nederland werd reeds in 1845 de zogenaamde "Artseneed" opgesteld. Deze werd in 1865 geregeld in de Wet op de uitoefening der geneeskunst, overigens zonder dat aan de eed zelf de bevoegdheid werd ontleend. De eed wordt afgelegd bij het behalen van het artsdiploma en luidt als volgt:

\footnotetext{
"Tk zweer (beloof), dat ik de genees-, heel- en verloskunst volgens de daarop wettelijk wastgestelde bepalingen naar mijn beste weten en vermogen zal uitoefenen en dat ik aan niemand zal openbaren wat in die uitoefening, als geheim mij is toevertrouwd of ter mijner kennis is gekomen, tenzij mijne verklaring, als getuige of deskundige in regten gevorderd of ik anderszins tot het geven van mededeeling door de wet verpligt worde. Zo waarlijk helpe mij God almachtig. (dat beloof ik)." (Lindeboom 1960, 42)
}

De tekst van de Artseneed is tot op heden nagenoeg ongewijzigd gebleven (vergelijk Vroom-Kastelein 1985, 8).

Naalst de Artseneed werden reeds in een vroeg stadium uitgebreidere adviezen en aanwijzingen voor een moreel verantwoorde beroepsuitoefening geformuleerd (KNMG 1936; KNMG 1959; KNMG 1978).

Andere beroepsgroepen ontwikkellden hun eigen code. Vanaf de jaren vijftig kwamen er vele tot stand. Binnen de gezondheidszorg werd deze tendens in de jaren tachtig nog versterkt door de discussies en adviezen inzake het voorstel van Wet beroepsuitoefening in de individuele gezondheidszorg (Wet BIG). Het voorontwerp van deze wet werd in 1981 aan de Tweede Kamer der Staten Generaal aangeboden. Anno 1992 is zij nog steeds niet in werking getreden. Het voorontwerp bevat een groot aantal bepalingen teneinde de kwaliteit van de beroepsultoefening in de gezondheidszorg te bevorderen. Een van die bepalingen betreft het instellen van een Raad voor de Beroepen in de Individuele Gezondheidszorg die zich zal bezighouden met het formuleren van "aanbevelingen omtrent gedragsregels voor beroepsbeoefenaren" (NRV 1988, 7). Voor de NRV vormde dit de aanleiding om in 1988 zijn "Nota bouwstenen voor "beroepscodes" en "gedragsregels"' als advies aan de Minister aan te bieden. Deze gebeurtenissen zijn tekenend voor de maatschappelijke relevantie van de onderhavige studie. 
Inmiddels zijn de beroepsgroepen, op wie de Wet BIG zal worden toegepast, echter niet stil blijven zitten. De een na de andere beroepsorganisatie publiceerde een beroepscode waaraan zich de eigen leden geacht werden te houden. De discussies hierover waren meestal ook reeds aan het roerige eind van de jaren zestig op gang gekomen (interessant in dit verband is het gegeven, dat het voorontwerp BIG tot stand is gekomen op basis van het rapport wan de in 1967 ingestelde Staatscommissie Medische Beroepsuitoefening; zie Van der Mijn 1989, 236-237; Nys 1982, 269). De toenemende kritiek op de geneeskunde, de democratiseringsbeweging en een benadrukking van de rechten van de patiënt/cliënt brachten vele beroepsgroepen ertoe zich nader te bezinnen op de morele aspecten van hun beroepsuitoefening. Beroepsgroepen die reeds een code bezaten, brachten een herziene versie uit (onder andere artsen, tandartsen, apothekers en verloskundigen). Beroepsgroepen die nog geen code publiceerden, gingen daar nu toe over (onder andere fysiotherapeuten, diverse categorieèn oefentherapeuten, diëtisten, logopedisten, psychotherapeuten, gedragstherapeuten en ambulance-personeel) (NRV 1988, 8 en Bijlage II). De Nederlandse Maatschappij voor Verpleegkunde volgde in 1990.

Ook door aan de gezondheidszorg gelieerde beroepsgroepen en -organisaties werden codes naar voren gebracht. Bekend zijn die van de psychologen en maatschappelijk werkenden. Daarnaast zijn in de dienstverlenende sector al langer bekend de beroepscodes van bijvoorbeeld notarissen en makelaars.

Met het bovenstaande is de historische -en in zekere zin maatschappelijke- context geschilderd, tegen de achtergrond waarvan de beroepscodes op het terrein van de verpleegkunde zijn en worden ontwikkeld. Duidelijk is, dat deze codes niet op zichzeif staan. Ze zijn ingebed in meeromvattende processen, waaraan zij ook deels hun betekenis ontlenen. De invloed van professionaliseringspogingen en -processen is reeds in het voorgaande hoofdstuk vermeld. In deze paragraaf is vooral gewezen op de continuilteit en expansie in het denken over en vastleggen van de morele aspecten van de uitoefening van een beroep in de gezondheidszorg. In de paragrafen hierna wordt meer in detail ingegaan op beroepscodes voor verpleegkundigen.

\subsection{Beroepscodes voor verpleegkundigen}

Geneeskunde en verpleegkunde hangen nauw met elkaar samen. Er is sprake van een zekere interdependentie, ondanks het feit dat hun relatie een nogal asymmetrisch karakter heeft ten voordele van de geneeskunde (zie 2.4.2). Ook de geschiedenis van beide beroepen laat een dergelijke asymmetrie zien. Tussen de geneeskunde en verpleegkunde werd telkens een bepaalde verdeling gemaakt tussen aandacht voor de ziekte respectievelijk aandacht voor de zieke. Het verloop van de geschiedenis bracht echter met zich mee, dat nu eens de ziekte, dan weer de zieke meer aandacht kreeg (Dane 1985, 8). De asymmetrie is in dit opzicht dus niet altijd in het voordeel van de geneeskunde geweest. Tijdens de Middeleeuwen bijvoorbeeld bleek de geneeskunde onmachtig tegenover een groot aantal epidemische ziekten. Dezelfde tijd wordt gekenmerkt door een niet aflatende zorg en aandacht van kloosters, kloosterorden, ridderlijke en burgerlijke verplegersorden voor zieken, armen en gebrekkigen (Dane 1985, 28-29). Sinds de negentiende eeuw gaat de meeste aandacht echter weer uit naar de beheersing en behandeling van allerlei ziektes. 
Gezien deze interdependentie van geneeskunde en verpleegkunde is het niet verwonderlijk, dat we in het bovenstaanide enige aandacht schonken aan beroepscodes op het terrein van de geneeskunde. De geneeskunde is de belangrijkste partner van de verpleegkunde en heeft van beide ook de rijkste traditie met betrekking tot het ontwikkelen van codes. Bovendien menen sommige auteurs, dat later ontwikkelde beroepscodes op het terrein van de verpleegkunde veel elementen bewatten die ook aanwezig zijn in literatuur en codes van medische oorsprong (onder andere Carroll/Humphrey 1979, 15-16). Met het eerder vermelde standpunt is dan ook niet bedoeld, dat het de verpleging volledig aan codes ontbrak, zeker niet als we uitgaan van een ruim begrip van beroepscodes. In de kloosterorden en verplegersorden was men veelal strikt gebonden aan expliciete gedragsregels. Deze vonden hun oorsprong echter in allerlei decreten en tradities van godsdienstige en religieuze aard en werden, voorzover bekend, nimmer specifiek met betrekking tot het gedrag van hen, die de verpleging beoefenden, vastgelegd (Davis/Aroskar 1978, 12; zie ook 4.2.2). Hierin kwam pas verandering op het moment dat de verpleging een zekere verzelfstandiging onderging en niet meer uitsluitend als onderdeel van christelijke armenzorg werd gezien. Het werk van Theodor Fliedner (1800-1864) en vooral Florence Nightingale (1820-1910) kan als een grondgegeven worden beschouwd van de latere ontwikkelingen, ook op het terrein van de verpleegkundige beroepscodes.

\subsubsection{Voorgeschiedenis en afbakening}

Zoals we in hoofdstuk 2 hebben gezien is verzelfstandiging van een beroep volgens professionaliseringstheoretici een belangrijke indicator voor het formuleren van allerlei eisen met betrekking tot de uitoefening van dat beroep door de beoefenaars ervan (overigens geldt dit ook omgekeerd: eisen en praktijken als indicator voor verzelfstandiging). De ontwikkeling van een beroepscode sluit hier naadloos bij aan.

Eén van die eisen betreft een opleiding, gecontroleerd door de beroepsgroep. Via zo'n opleiding kunnen de kwaliteit en continuilteit van de beroepsuitoefening worden bevorderd en uitgebouwd. Het is dit terrein waarop de grote verdiensten van zowel Fliedner als Nightingale liggen. Zij paarden hun activiteiten ten behoeve van een gedegen opleiding voor verpleegkundigen overigens aan een tomeloze inzet en groot organisatietalent, die mede aan hun succes hebben bijgedragen.

Fliedner geldt als de stichter van het negentiende-eeuwse diaconessenwerk. In zijn tijd vond een opbloei plaats van het geestelijk leven, als reactie op het rationalisme. Tevens bestond er veel sociale nood. Fliedner had hier aandacht voor en zag verpleging als éen van de werken van barmhartigheid. Daartoe stichtte hij in 1836 te Kaiserswerth (bij Düsseldorf) een ziekenhuisje. Jonge, ongetrouwde vrouwen schakelde hij bij dit werk in. Zij vonden bescherming in het zogenaamde diaconessenhuis en kregen een bescheiden zakgeld. Onder leiding van Fliedners echtgenote ontvingen ze in die tijd als eersten een opleiding die op hun specifieke taak was toegesneden. Het diaconessenwerk breidde zich vanaf 1844 ook over ons land uit (Dane 1985, 78-82). De verpleging in Nederland stond in die tijd in grote mate onder Duitse invloed (Van Lieburg 1980, 119).

Nightingale bezocht in 1850 gedurende enige weken het ziekenhuis van Fliedner in Kaiserswerth en werd gegrepen door het daar verrichte werk. Tegen de zin van haar rijke en aristocratische ouders koos ze voor de verpleging van zieken (en tégen het huwelijk). Hun huisvriend, de Engelse minister van oorlog, nodigde Nightingale bij het begin van de 
Krim-oorlog tussen Turkije en Rusland uit de verpleging te leiden in de militaire hospitalen van de te hulp geschoten Engelsen. Van 1854 tot 1856 buitte zij daar haar organisatietalent volledig uit door, ondanks alle tegenwerking, te zorgen dat het de zieke en gewonde soldaten aan niets ontbrak. Zij zorgde onder andere voor medicijnen en dekens, dieetkeukens en schoonmakmiddelen. De sterfte onder de soldaten werd in korte tijd teruggebracht van $40 \%$ naar $2 \%$. Teruggekomen beloonde het Engelse volk haar met een groot fonds. Met het geld hiervan stichtte Nightingale een verpleegstersschool en een vroedvrouwenschool (Dane 1985, 83-86). Haar geboortedag, 12 mei, geldt internationaal als de jaarlijkse "Dag van de verpleging". Haar verpleegstersschool stond model voor een groot aantal verpleegstersopleidingen in Europa en Amerika. Naast haar inzet voor de opleiding van verpleegsters is zij de eerste die voor het werk van verpleegsters een salaris opeiste (Dane 1985, 90). Zij wilde dus niet toegeven aan het exclusieve imago van verpleging als een vorm van liefhebberij of liefdewerk. Dit laatste was in de opvattingen van Fliedner nog duidelijk aanwezig. Toch kan ook Nightingale een zekere religieuze inspiratie niet worden ontzegd (Van der Peet 1983, 533-535). Dit belette haar echter niet het verplegen te zien als een beroep dat als zodanig moet worden gesalarieerd.

Florence Nightingale wordt niet alleen gezien als de drijvende kracht achter de ontwikkeling van de verpleging tot een modern beroep vanwege haar organisatievermogen en het creëren van opleidingsmogelijkheden. In dit verband werd door haar ook nogal wat gepubliceerd. Het meest bekend is geworden "Notes on nursing: what it is and what it is not" (1859). Hierin presenteert zij een gezondheidsleer, die niet alleen van belang is vanwege haar (theologisch-filosofische) mensvisie met betrekking tot de verpleging (Van der Peet 1983, 535), maar ook in een grote behoefte voorzag bij vrouwen en gezinnen in een bredere context. Binnen én maand werden er 15.000 exemplaren van verkocht (Dane 1985, 89). In Nederland kende haar boekje overigens een veel geringere populariteit, hetgeen deels veroorzaakt lijkt door de kwaliteit van de vertaling (Van Lieburg 1980, 102-103).

Rond 1875 verscheen een geschrift dat voor ons historisch van belang is. Het bevat de zogenaamde "Florence Nightingale Pledge", dat voorzover bekend de eerste op schrift gestelde beroepscode is op het terrein van de verpleegkunde. De tekst hiervan luidt als volgt:

"I solemnly pledge myself before God and in the presence of this assembly to pass my life in purity and to practice my profession faithfully.

I will abstain from thatever is deleterious or mischievous and will not take or knowingly administer any harmful drug.

I will do all in my power to elevate the standard of my profession, and will hold in confidence all personal matters committed to my keeping and all family affairs coming to my knowledge in the practice of my calling.

With loyalty will I endeavor to aid the physician in his work and devote myself to the welfare of those committed to my care." (Nightingale 1915, 23; Purrtilo/Cassel 1981, 37; voor de Nederlandse vertaling, zie Tate 1980,72 )

De Pledge bestaat uit ellementen die impliciet deels refereren aan de Eed van Hippocrates, deels aan de Eed van Maimonides. Ze verplichten verpleegkundigen tot de ontwikkeling van moreel hoogstaande karaktereigenschappen (zoals in de Eed van Maimonides). Bovendien eisen ze van verpleegkundigen een afzien van het gebruik of de toediening van schadelijke geneesmiddelen en inachtneming van het beroepsgeheim (zoals in de Eed van Hippocrates) (vergelijk Purtilo/Cassel 1981, 38). 
Hiermee is eens te meer de interdependentie aangegeven tussen geneeskunde en verpleegkunde. De Florence Nightingalle Pledge continueert het morele appèl dat via genoemde eden aan geneeskundigen wordt voorgehouden en conformeert zich daar in belangrijke mate aan. In moreel opzicht wordt in zekere zin één lijn getrokken.

Tegen deze achtergrond vertoont de zogenaamde "Verpleegkundige Belofte", die tegenwoordig in Nederland bij het behalen van het diploma wordt uitgesproken, een nogal smalle basis. De tekst hiervan luidt als volgt:

"Ik beloof dal ik geheim zal houden al hetgeen mij bij de uitoefening van mijn beroep als verpleegkundige als geheim is toevertrouwd, of wat daarbij als gebeim te mijner kennis is gekomen, of waarvan ik het vertrouwelijk karakter moet begrijpen." (tekst toegevoegd aan het desbetreffende diploma)

In feite komt in deze Belofte alleen het beroepsgeheim aan de orde. In vergelijking daarmee bezitten bijvoorbeeld de Nederlandse Artseneed en de internationale Declaration of Geneva voor artsen een veel rijkere inhoud (vergelijk 4.2.2).

Intussen hadden de beroepsorganisaties voor verpleegkundigen zich well al mee laten voeren met de stroom der ontwikkelingen na de Tweede Wereldoorlog op internationaal niveau. Evenals de World Medical Association beraadde zich de International Council of Nurses (ICN) op de ontstane situatie na de gruweldaden van nazi-artsen in de Duitse concentratiekampen. De discussies op dit niveau leidden uiteindelijk tot de aanvaarding van een beroepscode die wereldwijd het morele gedrag van verpleegkundigen zou moeten gaan sturen. De respectievelijke beroepsorganisaties van verpleegkundigen in Nederland hebben zich als lid van de ICN steeds aan deze beroepscode geconformeerd.

Met het vermelden van deze code is tegelijk éen van de codes genoemd die in dit hoofdstuk aan een nadere analyse zullen worden onderworpen. Gekozen is voor een viertal codes: die van de

1. International Council of Nurses (ICN).

2. American Nurses" Association (ANA).

3. United Kingdom Central Council of Nurses, Midwives and Health Visitors (UKCC).

4. Nederlandse Maatschappij voor Verpleegkunde (NMV).

De redenen voor deze keuze liggen enigszins voor de hand:

1. De ICN is de belangrijkste internationale organisatie van verpleegkundigen en spreekbuis voor deze beroepsgroep naar derden. Beroepsorganisaties van nagenoeg alle landen over de gehele wereld zijn bij de ICN aangesloten. Haar beroepscode is voor de meeste van deze organisaties de enige schriftelijke leidraad ten aanzien van het morele gedrag van de bij hen aangesloten leden.

2. De ANA geldt als de eerste nationale beroepsorganisatie van verpleegkundigen die zich met het vastleggen van een beroepscode heeft beziggehouden. Tegelijkertijd is zij de nationale organisatie die, mondiaal gezien, het grootste aantal verpleegkundigen bindt (op dit moment meer dan 150.000 leden; ter vergelijking: de NMV haalt nauwelijks 15.000 leden). Haar beroepscode heeft dus een traditie en werkingsgebied welke die van andere nationale organisaties verre overtreft.

3. Voor de UKCC geldt, zij het in mindere mate, hetzelfde als voor de ANA, indien we ons althans beperken tot Europa en de landen van het voormalige Oost-blok buiten beschouwing laten (Polen heeft immers al sinds 1973 een code voor verpleegkundi- 
gen; zie Sawyer 1989, 145). Daarnaast vervalt de code van de UKCC in gezondheidsrechtelijk opzicht een functie die uniek mag worden genoend.

4. De beroepscode van de NMV kan, ook internationaal; worden beschouwd als eén van de meest recente codes. Verwacht mag worden, dat bij de formulering ervan rekening is gehouden met de specifieke situatie van verpleegkundigen in Nederland en met de ervaringen die elders in de wereld met beroepscodes zijn opgedaan.

De genoemde beroepscodes worden hierna afzonderlijk gepresenteerd. Daarbij zal tevens worden ingegaan op hun ontstaansgeschiedenis en de specifieke problemen die daarmee gepaard gingen.

\subsubsection{De ICN-code}

De ICN, opgericht in 1899, publiceerde de eerste versie van haar code in 1953. Hij was het resultaat van discussies naar aanleiding van de Geneefse Conventies uit 1949 met betrekking tot de rechten van de mens. De code werd aangenomen tijdens het vier-jaarlijkse congres van de ICN in Sao Paulo, Braziliè. Een revisie volgde in 1965 (ICN 1973, 12 en 154-155; voor de tekst van de code uit 1953, zie Callahan 1988, 452-453; voor de Nederlandse versie, zie Tate 1980, 73-74).

Op verzoek van de leden (nationale beroepsorganisaties) werd in 1969 begonnen met een grondige herziening van de code. Hiermee werd een commissie belast onder voorzitterschap van Ingrid Hämelin en verder bestaand uit Rebecca Bergman en Margery Westbrook. De commissie zond in 1971 een eerste concept voor herziening ter advisering aan de leden. Op basis van de reacties werd een definitief voorstel geformuleerd en voorgelegd aan de Council of National Representatives. Deze stemde met het voorstel in tijdens het ICN-congres te Mexico-Stad in mei 1973. De tekst werd opgenomen in de 'proceedings' van het congres. De beroepscode kreeg de volgende titel mee: "Code for nurses - ethical concepts applied to nursing" (ICN 1973, 154; voor de Nederlandse tekst, zie Van der Peet 1990, 297).

De code van 1973 heeft ten opzichte van die uit 1953 een aantal wijzigingen ondergaan, deels van fundamenteel-inhoudelijke aard:

1. De oorspronkelijke veertien statements zijn in vijf aparte paragrafen ondergebracht, die een weerspiegeling worden geacht van de belangrijkste verantwoordelijkheidsgebieden van verpleegkundigen.

2. De inleiding (preambule) werd sterk ingekort. Statements uit de inleiding werden onder de genoemde vijf paragrafen geplaatst.

3. Diverse formuleringen werden aangepast aan het inmiddels gewijzigde taalgebruik en sociale verkeer.

4. Van fundamentele aard is de gewijzigde nadruk op de eigen verantwoordelijkheid van de verpleegkundige ten aanzien van de patiënt, het eigen vakgebied, en de arts. "Service to mankind is the primary function of nurses" (preambule, 1953) werd bijvoorbeeld gewijzigd in "The nurse's primary responsibility is to those people who require nursing care" ("nurses and people", 1973). Ten aanzien van de arts verdween bijwoorbeeld een zinsnede als "The nurse is under an obligation to carry out the physician's orders intelligently and loyally" (art. 7, 1953). Daarvoor in de plaats kwam "... a cooperative relationship with co-workers in nursing and other fields" ("nurses and society", 1973). Ten aanzien van het eigen vakgebied valt bijvoorbeeld op, dat de vijfde 
paragraaf in de 1973-wersie ("nurses and the profession") geheel nieuw is en geen equivalent bezit in de versie van 1953 . Van de verpleegkundige wordt verwacht eigen kwaliteitsmaatstaven vast te stellen en toe te passen, een eigen kennisgebied te ontwikkelen, en via de beroepsorganisatie te werken aan sociaal en economisch aanvaardbare arbeidswoorwalarden.

Figuur 4.1: De Code van de ICN (1973)

\section{Code for Nurses, Ethical Concepts Applied to Nursing}

The fundamental responsibility of the nurse is fourfold: to promote health, to prevent illness, to restore bealth and to alleviate suffering.

The need for nursing is universall. Inherent in nursing is respect for life, dignity, and the rights of man. It is unrestricted by considerations of nationality, race, creed, colour, age, sex, politics or social status.

Nurses render health services to the individual, the family and the community and coordinate their services with those of related groups.

\section{Nurses and people}

The nurse"s primary responsibility is to those people who require nursing care

The nurse, in providing care, promotes an environment in which the values, customs and spiritual beliefs of the individual are respected.

The nurse holds in confidence personal information and uses judgement in sharing this information.

\section{Nurses and Practice}

The nurse carries personal responsibility for nursing practice and for maintaining competence by continual learning.

The nurse maintains the highest standards of nursing care possible within the reality of a specific situation.

The nurse uses judgement in relation to individual competence when accepting and delegating responsibilities.

The nurse when acting in a professional capacity should at all times maintain standards of personal conduct which reflect credit upon the profession.

\section{Nurses and Society}

The nurse shares with other citizens the responsibility for initiating and supporting action to meet the health and social needs of the public.

\section{Nurses and Co-Workers}

The nurse sustains a cooperative relationship with co-workers in nursing and other fields.

The nurse takes appropriate action to safeguard the individual when his care is endangered by a co-worker or any other person.

\section{Nurses and the Profiession}

The nurse plays the major role in determining and implementing desirable standards of nursing practice and nursing education.

The nurse is active in developing a core of professional knowledge.

The nurse, acting through the professional organization, participates in establishing and maintaining equitable social and economic working conditions in nursing. 
5. Nog andere opvallende aspecten zijn te melden, niet omdat ze in de 1973-versie werden gewijzigd, maar daaruit zelfs geheel verdwenen. Deze bestaan onder andere uit de volgende zinsneden: "Nurses do not permit their names to be used in connection with the advertisement of products ..." (art. 10, 1953); "The nurse in private life adheres to standards of professional ethics ..." (art. 12, 1953); en "In personal conduct nurses should not knowingly disregard the accepted patterns of behaviour of the community ..." (art. 13, 1953). Dat het eerste statement uit de 1973-versie werd gelaten is opmerkelijk, omdat het in praktisch alle codes van latere datum in enigerlei worm aan verpleegkundigen wordt voorgehouden (zie de hierna gepresenteerde codes). Het verdwijnen van de laatste twee statements duidt op een algemene tendens om morele eisen meer uitdrukkelijk te verbinden aan de beroepsuitoefening en om verpleegkundigen daarbuiten, in hun privé-leven, zo weinig mogelijk in de weg te leggen.

De ICN-code staat model voor talloze codes die door nationale beroepsorganisaties voor verpleegkundigen zijn en worden ontwikkeld (Sawyer 1989, 146 en 148). De maatschappelijke impact wordt groot geacht wanneer wordt gesteld, dat de ICN-code "... can function as the international ethical standard to which nurses can refer when faced with unethical government policies, for example, torture. The code can be used by international bodies to protect individual nurses." (Sawyer 1989, 148). "... can" is hier veelzeggend. In het kader van de onderhavige studie werden bij literatuuronderzoek geen verwijzingen gevonden die er op duiden dat de vermelde maatschappelijke impact inderdaad gerealiseerd is/wordt. De vraag is vervolgens of dit ook reëel mag worden verwacht. We komen daar nog op terug.

\subsubsection{De ANA-code}

De voorgeschiedenis van de ANA-code is aanmerkelijk langer dan die van de ICN-code (deze staat onder andere beschreven in Carroll/Humphrey 1979, 15-27; Sward 1978; Viens 1989). Reeds in 1897 werd in de allereerste constitutie van de ANA de behoefte aan een dergelijke code vastgelegd (Viens 1989,45 ). Het zou echter nog tot de jaren twintig duren vooraleer actie werd ondernomen om tot de formulering van een beroepscode te komen. Dit gebeurde op initiatief van de National League of Nursing Education. Een eerste concept werd gepresenteerd tijdens de nationale conventie van 1926. Sindsdien vonden veel herzieningen plaats. De doelstelling bleef echter steeds dezelfde, namelijk "... to formulate general principles which (...) create the individual habit of forming conscious and critical judgments resulting in action in specific situations." (Carroll/ Humphrey 1979, 16).

Het concept werd echter niet aanvaard. Pas in 1940 werd (opnieuw) "A tentative code" gepresenteerd, nu in de American Journal of Nursing. Ten opzichte van de 1926-versie werden verdergaande statements voorgesteld met betrekking tot de verhouding tot de werkgever en tot de verantwoordelijkheden van de verpleegkundige tegenover zichzelf. Statements met betrekking tot de verhouding van de verpleegkundige tot aanverwante beroepsgroepen werden uitgebreid met de verhouding van de verpleegkundige tot familie en bekenden van de patiënt en tot anderen (Sward 1978, 3).

Een laatste poging om toch nog een code aanvaard te krijgen binnen de ANA zelf werd ondernomen in 1949. Om sterk te staan deed een speciale commissie nader onderzoek en zond een checklist aan lokale en regionale beroepsorganisaties, opleidingen, werknemers 
en enkele aanverwante beroepsgroepen. De op grond hiervan geformuleerde code werd in 1950 door de House of Delegates van de ANA aangenomen. De code bevatte 17 statements. De inhoud kwam in grote lijnen overeen met eerdere concepten (Sward 1978, 3). Met de aanvaarding van de code bleef de ANA dus nog juist de ICN een aantal jaren voór (vergelijk 4,3,2).

Carroll en Humphrey $(1979,16-17)$ noemen een tweetal mogelijke redenen voor het feit, dat het meer dan vijftig jaar moest duren voordat de ANA de reeds in 1897 aangekondigde code inderdaad bezat:

1. Verpleegkundigen werden lange tijj geacht geen belangrijke rol te spelen bij besluitvormingsprocessen inzake patiëntezorg. Er werd eenvoudig verwacht, dat zij de opdrachten wan de arts uitvoeren. Zelfs in 1950 was dit nog de dominante attitude binnen de ANA.

2. Binnen de opleidingen werd weinig aandacht geschonken aan het verwerven van inzicht in de morele aspecten van het verpleegkundig handelen. Hetzelfde geldt voor de geneeskundige opleidingen, maar was daar wellicht minder urgent, omdat verpleegkundigen in het algemeen een frequenter en intensiever contact met patiënten onderhouden en gemakkelijker een schatting van hum belangen kunnen maken (zie ook Viens 1989, 46).

In 1956 werd een aantal kleine wijzigingen in de code aangebracht. In 1960 volgde een uitgebreider herziening. Er werden nieuwe statements geintroduceerd met betrekking tot de verantwoordelijkheid van verpleegkundigen ten aanzien van de arbeidsvoorwaarden en ten aanzien van het delegeren van handelingen. In 1968 werd de code opnieuw herzien. Het aantal statements werd teruggebracht van 17 naar 10 , de preambule verviel en de verwijzingen naar de rol van persoonlijke morele opvattingen van verpleegkundigen werden geschrapt. Voor het overige veranderde er inhoudelijk nilet veel (Sward 1978, 4).

Een fundamenteler herziening van de code vond plaats in 1976. Alle statements ondergingen wijzigingen. Sexistisch taalgebruik en de term "patient" werden verwijderd (Viens $1989,47)$. Een nieuw statement werd toegevoegd. De code werd opnieuw voorzien van een preambule en nu ook van een inleiding. De toelichting bij eerdere versies werd volledig vernieuwd en ingrijpend uitgebreid (voor een volledig overzicht van aangebrachte wijzigingen, zie Sward 1978, 5-7; voor de tekst, inclusief toelichting, zie ANA 1976; Jameton 1984, 300-309; woor de Nederlandse vertaling, zie Tate 1980, 78-96).

Bij aanvaarding van de herziene code installeerde de House of Delegates tevens een permanente Committee on Ethics. Deze zou toekomstige herzieningen moeten begeleiden en toezien op een adequate toepassing. Haar eerste activiteit en publikatie betrof inderdaad een handleiding voor de toepassing van de code (zie ANA 1980).

De 1976-versie werd van dermate groot belang geacht dat tijdens de desbetreffende Conventie van de ANA (in Atlantic City, New Jersey) een groot aantal beschouwingen vanuit verschillend perspectief aan het onderwerp werd gewijd. Er werd tevens een afzonderlijke publikatie over uitgegeven (zie ANA 1978). Daarnaast is toepassing van de code onderdeel van een gericht streven binnen de ANA naar kwaliteitsverbetering van de verpleegkundige zorg door middel van het ontwikkelen van harde maatstaven voor de beroepsuitoefening (ANA 1982, 2).

In 1985 vond de laatste herziening plaats. Deze wordt echter van marginale betekenis geacht. Behoudens een enkele tekstcorrectie blewen de 11 artikelen in de code dezelfde. 
Preamble

A code of ethics makes explicit the primary goals and values of the profession. When individuals become nurses, they make a moral commitment to uphold the values and speciall moral obligations expressed in their code. The Code for Nurses is based on a belief about the nature of individuals, nursing, health, and society. Nursing encompasses the protection, promotion and restoration of health; the prevention of illness; and the alleviation of suffering in the care of clients, including individualls, families, groups and communities. In the context of these functions, nursing is defined as the diagnosis and treatment of human responses to actual or potential health problemis.

Since clients themselves are the primary decision makers in matters concerning their own health, treatment, and well-being, the goal of nursing actions is to support and enhance the client's responsibility and self-determination to the greatest extent possible. In this context, health is not necessarily an end in itself, but rather a means to a life that is meaningful from the client's perspective.

When making clinical judgments, nurses base their decisions on consideration of consequences and of universal moral principles, both of which prescribe and justify nursing actions. The most fundamental of these principles is respect for persons. Other principles stemming from this basic principle are autonomy (self-determination), beneficence (doing good), nonmaleficence (avoulding harm), veracity (truth-telling), confidentiallity (respecting privileged information), fidelity (keeping promises), and justice (treating people fairly).

In brief, then, the statements of the code and their interpretation provide guidance for conduct and relationships in carrying out nursing responsibilities consistent with the ethical obligations " of the profession and with high quality in nursing care.

\section{Code for nurses}

1. The nurse provides services with respect for human dignity and the uniqueness of the client, unrestricted by considerations of social or economic status, personal attributes, or the nature of health problems.

2. The nurse safeguards the client"s right to privacy by judiciously protecting information of a confidential nature.

3. The nurse acts to safeguard the client and the public when health care and safety are affected by the incompetent, unethical ${ }_{\text {, }}$ of illegal practice of any person.

4. The nurse assumes responstbility and accountability for individual nursing judgments and actions.

5. The nurse maintains competence in mursing.

6. The nurse exercises informed judgment and uses individual competence aund qualifications as criteria in seeking consultation, accepting responsibilities, and delegating nursing activities to others.

7. The nurse participates in activities that contribute to the ongoing development of the profession's body of knowledge.

8. The nurse participates in the profession's efforts to implement and improve standards of nursing.

9. The nurse participates in the profession's efforts to establish and maintain conditions of employment conducive to high quality nursing care.

10.The nurse participates in the profession's effort to protect the public from misinformation and misrepresentation and to maintain the integrity of nursing.

11.The nurse collaborates with members of the health professions and other citizens in promoting community and national efforts to meet the health needs of the public. 
De preambule werd uitgebreild met:

1. Nadere uitspraken met betrekking tot de doelstelling en aard van het beroep van verpleegkundige.

2. Verdere benadrukking van het recht op zelfbeschikking van de patiënt, die overigens gezondheid niet als hoogste waarde hoeft te beschouwen.

3. Vermelding van de twee belangrijkste methoden van klinische oordeelsvorming en van de morele principes die daarbij in het geding kunnen zijn.

Uiteraard werd tevens de toelichting bij de code aangepast aan de eisen des tijds. Maar ook hier was slechts sprake van marginale wijzigingen. Sommige recente handboeken op beroepsethisch terrein vermelden dan ook nog steeds de -iets kortere-1976-versie (bijvoorbeeld Callahan 1988, 451-452). Voor de analyse in deze studie zullen we gebruik maken van de meest recente 1985 -versie. De preambule en artikelen zijn opgenomen in figuur 4.2 (voor de toelichting, zie ANA 1985; voor een verkorte toelichting, zie Gorlin 1990, 259-266).

Volgens Viens $(1989,49)$ vertoont de ANA-code vanuit historisch perspectief een grote mate van continuiteit. Zes statements uit de 1985-versie zijn direct herkenbaar in de allereerste proeve wan 1926. De vijf andere artikelen stammen uit de grootscheepse herziening in 1960.

\subsubsection{De UKCC-code}

De totstandkoming van de UKCC-code heeft slechts weinig tijd gekost in vergelijking tot die van de ANA. Het onderwerp heeft vór 1976 ook nooit de aandacht gehad, die het in sommige landen en/of beroepsgroepen kreeg. Dit betrof overigens in Groot-Brittannië niet alleen verpleegkundigen, maar ook de geneeskundige beroepsgroep (Melia 1984, 20).

In de jaren zeventig kwamen in Groot-Brittannië nieuwe wettelijke regelingen tot stand met betrekking tot de beroepsuitoefening, de bewaking van de kwaliteit daarvan en de wijze waarop de belangen van beroepsbeoefenaren konden worden behartigd. De aankondiging van deze maatregelen dwong de Royal College of Nursing (RCN) tot een heroriëntatie op haar positie als vertegenwoordigend orgaan van de beroepsgroep van verpleegkundigen. De RCN moest zich sterker dan voorheen profileren als vakbond, omdat dit de enige mogelijkheid was om nog als gesprekspartner te worden erkend door bijvoorbeeld de overheid (vergelijk ook 2.4 .5 ).

De interne discussies over de kwesties resulteerden in 1976 in twee belangrijke publikaties:" "What the Rcn stands for", het meest doorwrochte beleidsstandpunt dat de RCN ooit nar buiten bracht, en "The Ren code of professional conduct: a discussion document" (voor de volledige tekst inclusief toelichting, zie ook Royal College ... 1977, 115119; voor de Nederlandse vertaling hiervan, zie Tate 1980, 98-109). Zoals de titel al aangeeft, betreft de laatste publikatie een beroepscode voor verpleegkundigen. In zekere zin is dit dan ook de eerste nationale beroepscode voor verpleegkundigen in Groot-Brittannië. Mar zoals de titel eveneens aangeeft is het 'slechts' een discussiestuk. Het zou deze status ook nimmer ontgroeien.

Beide publikaties zijn elkaars verlengde. In elk wordt het beroep van verpleegkundige uitdrukkelijk geponeerd als een professie, naast andere professies, met een duidelijk e:gen competentie en praktijkveld en met de RCN als spreekbwis en vertegenwoordiger. 
Het beleidsdocument bevat daarnaast impliciet een grote hoeveelheid, nauwelijks verholen kritiek op de National Health Service. De code werd echter niet gepresenteerd met als doelstelling tuchtrechtelijke maatregelen uit te lokken, maar als een richtlijn voor discussies, met name in de opleidingen (Professional code 1976, 1504-1505).

De gewenste discussies bleven niet uit. In de vakpers werd veel aandacht aan de code besteed (zie onder andere Professional code 1976; Jarvis 1977). Ook de wetenschappelijke tijdschriften lieten zich niet onbetuigd (zie Ethical codes ... 1977; Dawson 1977; Altschul 1977; Sampson 1977; McCall Smith 1977). Kritiek was er vooral in verband met de realiteitswaarde van de code. Hij werd meer als politiek dan als moreel document gewaardeerd.

Een en ander kan niet los worden gezien van de ontwikkelingen die volgden. Onder andere een krachtige politieke lobby leidde in 1979 tot de aanvaarding van de "Nurses, Midwives and Health Visitors Act" door het Britse parlement. In deze wet werd voorzien in de oprichting van de UKCC en vier National Boards. De belangrijkste taak die de UKCC meekreeg, was het vaststellen en verbeteren van de maatstaven voor opleiding en professioneel gedrag van verpleegkundigen. $\mathrm{Zij}$ diende verpleegkundigen hierin tevens te adviseren. De National Boards kregen een intermediaire rol toebedeeld en moesten de UKCC assisteren bij de uitvoering van haar taak (Pyne 1987).

De UKCC kreeg vergaande bevoegdheden, onder andere de mogelijkheid om disciplinaire maatregelen tegen verpleegkundigen te nemen en hen uit te sluiten van verdere beroepsuitoefening (dus uit het nationaal register van verpleegkundigen te schrappen). Het duurde dan ook niet lang vooraleer de UKCC normen formuleerde om een zorgvuldige besluitvorming in dergelijke tuchtrechtelijke procedures te waarborgen. In 1983 publiceerde zij haar "Code of professional conduct for nurses, midwives and health visitors (based on ethical concepts)" (voor de Nederlandse vertaling, zie Van der Arend 1985, 235).

De reactie vanuit de beroepsgroep bleef niet uit. De RCN had haar mening reeds geventileerd ten aanzien van de conceptversie. Zoals op grond van het bovenstaande mocht worden verwacht, vreesde zij vooral de thchtrechtelijke aspecten van de code. Zij was voorstander van een beleid van "protection rather than punishment" ten aanzien van in moeilijkheden geraakte verpleegkundigen. Daarnast plaatste zij grote vraagtekens bij de faciliteiten voor begeleiding van deze verpleegkundigen. In dat verband werd gepleit voor de instelling van een Health Committee voor de opvang van verpleegkundigen die om gezondheidsredenen laakbaar gedrag vertonen, alvorens ze te onderwerpen aan disciplinaire procedures en maatregelen (Protection ... 1982, 8). Na publikatie van de code werden binnen één jaar meer dan vierduizend commentaren geproduceerd door individuen en groepen: "For the first time nurses realised that they had a registration body which wanted communication with them and was open to their influence." (Pyne 1987, 30).

Op basis van de commentaren werd een tweede versie van de code gepubliceerd (UKCC 1984) die nog steeds actueel is. De preambule en artikelen zijn weergegeven in figuur 4.3 . Ten opzichte van de 1983-versie vonden de volgende wijzigingen plaats (zie ook Melia 1984):

1. De zinsnede "based on ethical principles" werd uit de titel geschrapt.

2. De toonzetting veranderde. De eerste editie ademde nog teveel een sfeer van eigenbelang in plaats van altruisme. 
3. Artikel 12 uit de eerste editie werd positiever geformuleerd in artikel 14 van de 1984 versie. Artikel 9 uit de eerste editie werd vereenvoudigd in artikel 11 van de 1984-versie.

4. De artikelen 4 en 5 uit de 1984-versie zijn nieuw toegevoegd. Ze bevatten uitspraken over de grenzen van de eigen competentie en het vervullen van gedelegeerde taken, respectievelijk over de samenwerking met andere beroepsbeoefenaren en de erkenning van elkaars deskundigheid.

Melia $(1984,8)$ uit als belangrijkste punt van kritiek, dat de opstellers van de nieuwe code teveel zijn uitgegaan van denkbeelden met betrekking tot de disciplinaire procedures en te weinig van de waarden die een professionele beroepsuitoefening onderscheiden van andere activiteiten. De aanvankelijke kritiek van de RCN op de eerste versie wordt door haar dus overgenomen met betrekking tot de tweede versie.

Deze kritiek heeft de UKCC zich aangetrokken. In de verpleegkundige vakpers werden de procedures en casus van de UKCC Professional Conduct Committee bij herhaling uitvoerig toegelicht en van commentaar voorzien (zie onder andere Pyne 1987; Vousden 1987a; Vousden 1987c; Morrison 1987). Vanaf 1987 verschenen bovendien in de Nursing Times Mirror (voortzetting van de tijdschriften Nursing Times en Nursing Mirror) lange series casusbesprekingen ten aanzien van de morele aspecten van het verpleegkundig handelen. Deze series werden verzorgd door de ethici Kath Melia en Irene Heywood Jones, die zich beide inzetten voor de ontwikkeling en professioneler aanpak van de verpleegkundige ethiek. Daarnaast werd vanuit juridisch gezichtspunt aangegeven, dat er een duidelijk verschil bestaat tussen de disciplinaire procedures van de UKCC en het Britse strafrecht, ten gunste overigens van de eerste (zie Scrivenger 1987).

Uit deze publikaties blijkt dat de zorg van de RCN voor een deel ongegrond is. Er zijn diverse vangnetconstructies gecreëerd om het aantal casus dat daadwerkelijk door de Conduct Committee wordt besproken en tot een disciplinaire maatregel leidt, zoveel mogelijk te beperken:

1. De Health Committee: deze begeleidt en adviseert verpleegkundigen, die vanwege gezondheidsklachten (onder andere alcohol- en drugsgebruik) het gevaar lopen een fout te maken die een disciplinaire straf zou uitlokken (Mitchell/Morton 1983, 11).

2. De National Boards: deze fungeren als meldpunt voor laakbaar gedrag en als tussenstation voor de UKCC Professional Conduct Committee. De Boards kijken naar de feiten en beoordelen een voorgelegde casus op laakbaarheid/verwijtbaarheid in het licht van de code. Bij constatering van laakbaar gedrag worden de details doorgespeeld naar de Conduct Committee (Vousden 1987c, 29).

3. De Nurses' Welfare Service: deze heeft onder andere tot taak verpleegkundigen, die zich vanwege begane fouten in de beroepsuitoefening aanmelden of worden aangemeld, te begeleiden tijdens de procedure voor de Conduct Committee. Deze taak omvat enerzijds emotionele en juridische ondersteuning, en anderzijds gerichte hulp tot herintreding in de verpleegkundige praktijk (Vousden, 1987c; Morrison 1987, 32).

Verder leiden zeker niet alle casus die aan de Conduct Committee worden voorgelegd, tot een disciplinaire straf. Van de 126 casus die tot 1987 werden behandeld en waarin sprake was van laakbaar gedrag, leidde $45 \%$ niet tot enigerlei maatregel. Een belangrijk deel hiervan betrof situaties waarin het laakbare gedrag werd toegeschreven aan ongunstige arbeidsomstandigheden, onder andere veroorzaakt door optreden van het management (Vousden 1987a, 34). 


\section{Code of Professional Conduct for the Nurse, Midwife and Health Visitor}

Each registered nurse, midwife and health visitor shall act, at all times, in such a manner as to justify public trust and confidence, to uphold and entance the good standing and reputation of the profession, to serve the interests of society, and above all to safeguard the interests of individual patients and clients.

Each registered nurse, midwife and bealth visitor is accountable for his or her practice, and, in the exercise of professional accountability shall:

1. Act always in such a way as to promote and safeguard the well being and interests of patients/clients.

2. Ensure that no action or omission on his/her part or within his/her sphere of influence is detrimental to the condition or safety of patients/clients.

3. Take every reasonable opportunity to maintain and improve professional knowledge and competence.

4. Acknowledge any limitations of competence and refuse in such cases to accept deleggated functions without first having received instruction in regard to those functions and having been assessed as competent.

5. Work in a collaborative and co-operative manner with other health care professionals and recognise and respect their particular contributions within the health care team.

6. Take account of the customs, values and spiritual beliefs of patients/clients.

7. Make known to an appropriate person or authority any conscientious objection which may be relevant to professional practice.

8. Avoid any abuse of the privileged relationship which exists with patients/clients and of the privileged access allowed to their property, residence or workplace.

9. Respect confidential information obtained in the course of professional practice and refrain from disclosing such information without the consent of the patient/client, or a person entitled to act on his/her behalf, except where disclosure is required by law or by the order of a court or is necessary in the public interest.

10. Have regard to the environment of care and its physical, psychological and social effects on patients/clients, and also to the adequacy of resources, and make known to appropriate persons or authorities any circurnstances which could place patients/clients in jeopardy or which militate against safe standards of practice.

11. Have regard to the workload of and the pressures on professional colleagues and subordinates and take appropriate action if these are seen to be such as to constitute abuse on the individual practitioner and/or to jeopardise safe standards of practice.

12.In the context of the individual's own knowledge, experience, and sphere of authority, assist peers and subordinates to develop professional competence in accordance with their needs.

13.Refuse to accept any gift, favour or hospitality which might be interpreted as seeking to exert undue influence to obtain preferential consideration.

14.Avoid the use of professional qualifications in the promotion of commercial products in order not to compromise the independence of professional judgement on which patients/clients rely. 
Men zou mogen veronderstellen, dat -vanwege de consequenties van deze code- de Britse verpleegkundigen hem goed kennen. In 1987 had echter meer dan $10 \%$ van de verpleegkundigen die in Manchester een groot congres bezochten, nog nooit een letter van de code gezien. Een veel groter percentage was nauwelijks in staat enig artikel uit de code te reproduceren (Vousden 1987b, 27). Deze situatie zal wellicht intussen een hoopgevende wending hebben gekregen. Sinds de introductie van de code in 1983 zijin diverse handboeken op het terrein van de ethiek in verband met de verpleegkunde gepubliceerd, waarin ruime aandacht aan de code is geschonken (Rumbold 1986; Tschudin 1986; Burnard/Chapman 1988; Fitzpatrick 1988). Burnard en Chapman (1988) hebben hun boek zelfs volledig opgezet conform de respectievelijke artikelen uit de UKCC-code en aan elk daarvan een conceptuele analyse en nadere uitleg verbonden.

\subsubsection{De NMV-code}

De NMV-code is internationaal gezien één van de jongste beroepscodes voor verpleegkundigen. Hij is tevens de eerste nationale beroepscode voor verpleegkundigen in $\mathrm{Ne}$ derland (en niet één van de eerste nationale codes in mondiaal perspectief, zoals sommigen ons graag doen geloven; zie onder andere Van Rooijen 1990, 1). In vergelijking tot de eerder in deze paragrafen besproken beroepscodes kan dus nog moeilijk worden gesproken van een zekere traditie van elkaar opvolgende disputen en herziene versies (de in figuur 4.4 gepresenteerde tekst is dan ook de eerste en enige versie). Behoudens enkele verspreide berichten in de media is de publikatie van de NMV zelfs vrij geruisloos voorbijgegaan en waarschijnlijk aan de aandacht van veel verpleegkundigen ontsnapt. Hetzelfde kan worden gezegd van de voorgeschiedenis van deze code. Wie handboeken op het terrein van de verpleegkunde van vóór 1980 raadpleegt, komt daarin weliswaar werwijzingen tegen naar de morele aspecten van het verpleegkundig handelen, maar van een beroepscode wordt nauwelijks gewag gemaakt. De ICN-code uit 1953 of 1973 is door ons bijwoorbeeld niet aangetroffen.

De bij de ICN aangesloten NMV vergaat het niet veel beter. In haar uitgebreide beleidsvisie ten tijde van de fusie tussen de Katholieke Unie van Verpleegkundigen en Verzorgenden en de Landelijke Beroepsorganisatie van Werkers in de Gezondheidszorg, komen we slechts eén verwijzing tegen (de NMV heette toen overigens nog Het Beterschap en ontstond uit genoemde fusie; inmiddels is de naam NMV al weer gewijzigd in Nieuwe Unie '91). Daarin wordt een beroepscode anbevolen ter aanvulling van het rechtspositiereglement van verpleegkundigen om hun arbeldssituatie voldoende te kunnen beoordelen (Medemens ... 1978, 28). Maar enkele jaren later is in een voorlichtingsbrochure over haar uitgangspunten, taken en werkzaamheden geen spoor van genoemde beleidsoptie terug te vinden (Jouw belang ... 1983).

Intussen had de Beroepsgroep Verpleegkundigen en Verzorgenden (CFO, CNV-bond voor ambtenaren en trendvolgers) de formulering van een beroepscode voor verpleegkundigen al wel expliciet als doelstelling van beleid aangegeven (Van der Arend 1985, 234). $\mathrm{Zij}$ bracht deze doelstelling ten uitvoer in de formulering van een concept-code voor verpleegkundigen en verzorgenden. Deze werd echter volgens onze informatie nimmer gepubliceerd. Daarnaast werd ook in een uitvoerig themanummer van Metamedica over professionalisering in de verpleegkunde het onderwerp beroepscode volledig onaangeroerd gelaten (zie onder andere Wellen 1978; Janssen van den Doornmalen 1978) 
en had Nys ten aanzien van de medische beroepscode in 1982 nog gewaarschuwd voor "... een proces van afkalvende invloed van gecodificeerde regels." (Nys 1982, 272).

Het tij leek dus ongunstig om een discussie ten aanzien van de wenselijkheid en formulering van een beroepscode aan te gaan. Toch werd deze in de vakpers door ons aangezwengeld. Naar aanleiding van de publikatie van de UKCC-code werden de voor-en nadelen van een dergelijke code besproken. Vooralsnog werden overigens de nadelen groter geacht dan de voordelen (zie Van der Arend 1985; zie ook Van der Arend 1983; Van der Arend 1986).

Daarnaast kan worden herinnerd aan de stimulerende werking die uitging van het voorontwerp BIG in 1981 en de onder invloed hiervan tot stand gekomen advisering van de NRV inzake beroepscodes en gedragsregels (zie 4.2.2). In dezelfde periode, waarin de discussies met het oog op deze advisering een aanvang namen, bracht de NMV -als gesprekspartner binnen de NRV- ook intern een proces op gang om te komen tot de formulering van een beroepscode voor verpleegkundigen. Een Projektgroep Beroepskode toog in 1986 aan het werk. Ze ontwikkelde een concept-tekst, legde deze voor aan externe deskundigen voor nader commentaar en besloot een herziene versie ter goedkeuring an te bieden aan de Algemene Ledenvergadering van de NMV. Door ingrijpen van het bestuur van de NMV tijdens deze vergadering kon worden voorkomen, dat de fundamentele en algemene kritiek op het voorstel uitmondde in een totale afwijzing. Het voorstel werd terugverwezen naar de Projektgroep. Een deskundige werd aan de Projektgroep toegevoegd en de nogmaals herziene tekst werd apart nog eens voorgelegd aan een Ledenraadpleging. Op basis van alle commentaren werd een definitief voorstel opnieuw gepresenteerd aan de Algemene Ledenvergadering, die het op 28 april 1990 met algemene stemmen aanvaardde.

De indeling van de NMV-code (zie figuur 4.4) volgt het vermelde advies in deze van de NRV. Verder wordt de code een nadere toespitsing genoemd van de ICN-code op de Nederlandse situatie (zie de Toelichting bij de Beroepskode ... 1990, 2-3; Schaart 1989, 14). Deze toespitsing heeft tevens een nadere detaillering met zich meegebracht, hetgeen tot uitdrukking komt in de omvang. De NMV-code is aanzienlijk langer dan de ICNcode. Hij gaat bovendien gepaard met een toelichting. Deze ontbreekt bij de ICN-code.

\section{Figuur 4.4: De Code van de NMV (1990)}

\section{Beroepskode voor hen die beroepsmatig werkzaam zijn op het terrein van de Verpleging}

1. Fundamentele uitgangspunten met betrekking tot de beroepsuitoefening

1.1 De verpleegkundige benadert de patiënt zonder onderscheid des persoons.

1.2 De verpleegkundige respekteert de rechten van de patiënt en informeert hem over de betekenis daarvan.

1.3 De verpleegkundige respelkteert de opvattingen van de patiênt ten aanzien van leven, lijden, ziekte, sterven en dood.

1.4 De verpleegkundige is persoonlijk verantwoordelijk voor de manier waarop zij haar taak vervult. 
1.5 De verpleegkundige houdt de kennis en vaardigheden bij die nodig zijn voor een adequate beroepsuitoefening.

1.6 De verpleegkundige houdt ennstig rekening met de grenzen van het eigen deskundigheidsgebied.

1.7. De verpleegkundige ontplooit initiatieven en ondersteunt alkiviteiten ter bevordering van de ontwikkeling van het beroep.

1.8 De verpleegkundige toetst de zorgverlening aan de waarden en normen uit deze beroepskode.

\section{De verplecegkundige in relatie tot de patiēnt}

2.1. De verpleegkundige stelt in de zorgverlening de belangen van de patiënt op de eerste plaats.

2.2. De verpleegkundige stimuleert de patient tot het nemen van veranitwoordelijkheid voor zijn eigen gezondheid.

2.3 De verpleegkundige stimuleert de patiënt om aktief deel te nemen aan de zorg die hem verleend wordt.

2.4 De verpleegkundige schept een situatic waarin de patiênt zich overeenkomstig zijn levensbeschouwing en gewoonten, waarden en normen kan gedragen.

2.5 De verpleegkundige ziet er op toe dat de bijdragen van alle beroepsbeoefenaren die bij de zorg voor de patiënt betrokken zijn, op elkaar aansluiten.

2.6 De verpleegkundige die zich tegenover een patiënt anders heeft gedragen dan in deze beroepskode wordt voorgesteld legt aan bem bierover verantwoording af.

2.7 De verpleegkundige onthoudt zich van elke vorm van machtsmisbruik tegenover de patiènt.

2.8 De verpleegkundige informeert de patiënt op begrijpelijke wijze over alles wat met de zorg te maken heeft.

2.9 De verpleegkundige bemiddelt tussen de patiënt en een andere beroepsbeoefenaar wanneer zijzelf gewenste informatie niel mag of kan geven.

2.10 De verpleegkundige gaat tot zorgverlening over indien de patiënt daarmee ingestemd heeft.

2.11. De verpleegkundige verzamelt alleen de gegevens die voor de zorgverlening noodzakelijk raju.

2.12. De verpleegkundige brengt de patiënt ervan op de hoogte dat er een clossier van hem aangelegd wordi en dat hij dat desgewenst ter inzage kan krijgen.

2.13 De verpleegkundige ziet er op toe dat met het dossier op verantwoorde wijze wordt omgegaan. Wanneer daarvoor onvoldoende garanties aanwezig zijn, neemt zij het initiatief daarin verbetering aan te brengen.

2.14 De verpleegkundige houdt geheim wat de pătiènt haar in vertrouwen heeft verteld of waarvan zij het vertrouwelijk karakter begrijpt.

2.15 De verpleegkundige wijst in woorkomende gevallen de patient op de mogelijkheid van het indienen van een klacht en ondersteunt hem zonodig hierbij.

2.16 De verpleegkundige accepteert voor zichzelf geen geschenken van de patiënt. 
2.17 De verpleegkundige die er op basis van haar levensovertuiging bezwaar tegen heeft mee te werken aan bepaalde handelingen ten aanzien van de patient draagt de zorgverlening over aan een kollega mits de konditie van de patiënt dat toelaat.

2.18 De verpleegkundige helpt ieder persoon die acuut behoefte heeft aan zorgwerlening.

3 De verpleegkundige in relatie tot kollega's en anderen

3.1. De verpleegkundige werkt samen met kollega's en anderen ten behoeve van een goede zorgverlening.

3.2 De werpleegkundige respekteert de opwatting en deskundigheid van kollega"s en anderen die bij de patiëntenzorg betrokken zijn.

3.3 De verpleegkundige staat open voor en pleegt overleg met kollega's en anderen.

3.4 De verpleegkundige betrekt de naasten van een wilsonbekwame patiënt bij het nemen van beslissingen.

3.5 De verpleegkundige is bereid om voor een kollega tijdelijk werkzaamheden over te nemen.

3.6 De werpleegkundige die op principiële gronden geen medewerking aan een bepaalde handeling wil werlenen, zorgt in overleg met kollega's voor verwanging.

3.7 De verpleegkundige die bij kollega's of andere beroepsbeofenaren gedrag bemerkt waarmee zij de patiënt schade zouden kunnen toebrengen, neemt maatregelen ter bescherming van de patiënt.

3.8 De verpleegkundige steunt kollega's en anderen die nadelige gevolgen ondervinden doordat zij zich overeenkomstig hun beroepskode gedragen.

3.9 De verpleegkundige integreert de bijdragen van anderen uit de samenleving in het totaal van de patiëntenzorg.

4 De verpleegkundige in relatie tot de samenleving

4.1 De verpleegkundige ondersteunt de aktiviteiten van de beroepsgroep om voorwaarden te scheppen woor de beroepsuitoefening.

4.2 De verpleegkundige stelt zich aktief op in het signaleren en opheffen wan gezondheidbedreigende faktoren.

4.3 De verpleegkondige draagt ertoe bij dat de ter beschikking staande middelen op verantwoorde wijze gebruikt worden.

4.4 De verpleegkundige zet zich in voor arbeidsvoorwaarden die in overeenstemming zijn met de waarde van het beroep.

4.5 De verpleegkundige blijft bij stiptheidsakties en stakingen altijd die zorg verlenen die nodig is om blijvende schade te voorkomen.

4.6 De verpleegkundige draagt bij tot de ontwikkeling wan nieuwe inzichten ter verbetering van de volksgezondheid.

4.7 De verpleegkundige maakt tijdig resultaten van verpleegkundig, onderzoek bekend.

4.8 De verpleegkundige onthoudt zich van het maken van reklame.

4.9 De verpleegkundige die namens de beroepsgroep aan enig overleg betreffende de volksgezondheid deelneemt, zorgt ervoor dat recht wordt gedaan aan de bepalingen in deze beroepskode. 
Als men het ontwikkelingsproces van de NMV-code volgt, ontkomt men niet aan de indruk, dat niet zozeer de genoemde discussies en publikaties in de vakpers dit proces hebben bevorderd. Grotere stimulansen gingen uit van de presentatie van het voorontwerp BIG en de daarmee in verband te brengen discussies en adviezen met betrekking tot de kwaliteit van de hulpverlening in het algemeen en het tuchtrecht in het bijzonder. Dat blijkt ook uit publikaties en reacties uit de periode van verschijnen van de NMV-code. Hoewel wij hiertegen al in 1985 een waarschuwing lieten horen en onze bezwaren formuleerden (Van der Arend 1985, 241-242), wordt de code in verreweg de meeste commentaren in een juridisch kader geplaatst en veelal verbonden aan de BIG (zie onder andere Rijlaarsdam 1990, 40-41; Van Rooijen 1990, 1; Vos 1990; Boer 1990; Tuchtrecht ... 1990, 357 en 360; Pool 1991, 39).

\subsection{Waardenoriëntaties in de beroepscodes}

In de ontstaansgeschiedenis wan de codes van de ICN, ANA, UKCC en NMV zijn diverse momenten aan te wijzen, waarop koerswijzigingen in het beleid van de beroepsgroep, in de verhoudingen tussen diverse beroepsgroepen en in de cultuur aanleiding hebben gegeven tot aanpassing van de formulering en inhoud van de codes. De gepresenteerde codes moeten dan ook als een momentopname worden gezien van een proces dat nog steeds voortduurt.

Dat hoeft ons er niet van te weerhouden hun inhoud nauwkeurig te bestuderen en aan een nader onderzoek te onderwerpen. Deze analyse wordt in onderstaande paragrafen aangevangen met een studie naar de waardenoriëntaties in de beroepscodes. Allereerst komt daarin aan de orde of de codes een moreel document kunnen worden genoemd. Daarnaast wordt ingegaan op de vaak geuite kritiek als zouden beroepscodes puur uit etiquetteregels bestaan en hun morele achtergrond achter dergelijke regels verhullen. Het belangrijkste onderdeel volgt daarna: een inhouds-analyse van de beroepscodes, waarin de uitgangspunten, (morele) principes, waarden en normen worden geïdentificeerd die in de beroepscodes aanwezig zijn. Afgesloten wordt met een verhandeling over het ideologische karakter van de beroepscodes. Op basis van bovengenoemde gegevens zullen in 4.5 de functies van de beroepscodes worden gereconstrueerd.

\subsubsection{Het morele karakter van de beroepscodes}

De vier beschreven codes bezitten ongetwijfeld een moreel karakter. In het voorafgaande is daar reeds stilzwijgend van uitgegaan. Op de eerste plaats is er het gegeven, dat de desbetreffende documenten uitdrukkelijk als code worden gepresenteerd. Gezien de eerder vermelde brede betekenis van het begrip code, is de morele bedoeling ervan impliciet aanwezig. Bij de $\mathrm{ICN}$-code komt deze bedoeling zelfs uitdrukkelijk in de titel tot uiting. Bij de ANA-code is iets dergelijks te destilleren uit de preambule.

Naast deze meer vormelijke kenschets van hun moreel karakter kunnen de codes ook inhoudelijk als van morele strekking worden gekwalificeerd. Dit wordt toegelicht door toepassing van de criteria van het zogenaamde 'ethisch gezichtspunt' (vergelijk 3.2.2.).

Indien de codes voldoen aan de criteria van het ethisch gezichtspunt, dienen zij op de eerste plaats normatieve uitspraken te bevatten over handelingen, verlangens, disposities, 
bedoelingen, motieven, karaktereigenschappen en/of personen. De uitspraken in de diverse beroepscodes zijn echter veelal in pseudo-descriptieve vorm aan te treffen (vergelijk de aantonende wijs in de werkwoordsvormen). Als voorbeeld geven we hier de volgende uitspraak weer: "De verpleegkundige houdt de kennis en vaardigheden bij die nodig zijn voor een adequate beroepsuitoefening" (NMV-code, art. 1.5.). Dergelijke uitspraken bezitten niettemin een duidelijk normatieve strekking. Immers de uitspraak impliceert, dat degene die de vermelde kennis en vaardigheden miet bijhoud, zich geen verpleegkundige mag noemen.

Een tweede criterium betreft de algemene geldigheid van de uitspraken. Degene, die een normatieve uitspraak doet, moet ook bereid zijn deze algemeen te laten gelden. Dit criterium staat bekend als het universaliseringsprincipe. Het wordt toegepast indien de normatieve uitspraken voor iedereen gelden en uitzonderingen daarop pas worden toegelaten als deze voor ieder gelden die in dezelfde situatie en omstandigheden verkeert. Uit de tekst van de codes en hun toelichting alsmede uit de intenties die met het publiceren van de codes zijn meegegeven, blijkt duidelijk, dat toepassing van dit universaliseringsprincipe tenminste wordt beoogd. Het meest expliciet hierin is de UKCC-code, waarin de 14 imperatieven worden voorgehouden aan "Each registered nurse ...". De ANA volgt een iets andere benadering door in de toelichting haar code te omschrijven als "... more a collective expression of nursing conscience and philosophy than a set of external rules imposed upon an individual practitioner". Bovendien wordt gesteld, dat "Personal and professional integrity can be assured only (cusivering AA) if an individual is committed to the profession's code ..." (ANA-code, toelichting, iii). Ook de toelichting buj de NMV-code bevat dergelijke uitspraken (zie bijvoorbeeld p. 3). Met 'de verpleegkundige' en 'the nurse' wordt in alle codes dus bedoeld: 'alle verpleegkundigen' en 'all nurses' of 'elke verpleegkundige' en 'each nurse'. Uitzonderingssituaties worden hiermee impliciet eveneens conform het universaliseringsprincipe behandeld. Ze gelden voor alle verpleegkundigen die zich in dezelfde situatie en omstandigheden bevinden. Tot dergelijke situaties wordt andere gerekend wanneer toepassing van de normen leidt tot overtreding van enigerlei wettelijke maatregel (zie bijvoorbeeld ANA-code, toelichting iv; UKCC-code, art. 9; NMV-code, toelichting, 5 en 7) of tot een conflict met het geweten van individuele verpleegkundigen (zie bijvoorbeeld ANA-code, toelichting, 3-4; UKCC. code, art. 7; NMV-code, toelichting, 3 en art. 2.17).

Op de derde plaats moeten de normatieve uitspraken betrekking hebben op de feitelijke bevordering en verdeling van nonmoreel goed en kwaad ten gunste van hen op wie de uitspraken betrekking hebben of ten gunste wan hen die erdoor worden beinvloed indien het ons eigen handelen betreft. Een voorbeeld van zo'n nonmoreel goed, dat in alle codes vóórkomt, betreft de competentie van verpleegkundigen. De verpleegkundige wordt geacht deze op peil te houden met het oog op het eigen functioneren ten behoeve van een optimale patiëntenzorg. Bovendien wordt soms van de verpleegkundige verwacht, dat ook collega's hierin worden ondersteund (vergelijk ICN-code, "Nurses and practice"; ANA-code, art. 5 en 6; UKCC-code, art. 3 en 12; NMV-code, art. 1.5). Het probleem met dit criterium schuilt in het bijvoeglijk naamwoord "feitelijke". Strikt genomen, kan het criterium hierdoor alleen worden toegepast in retrospectief-evaluatieve zin. Immers, of een goed 'feitelijk' is bevorderd en verdeeld, kan pas achteraf met enige mate van zekerheid worden beoordeeld. Het criterium wordt echter ook in prospectieve zin gebruikt. Beslissend is dan of er een reejele verwachting bestaat dat het nonmorele goed daadwer- 
kelijk zal worden bevorderd en verdeeld. Ten aanzien van de vermelde codes is dit niet rechtstreeks te bepalen, Of bevordering en verdeling van het nonmorele goed reëel mogen worden verwacht, hangt in grote mate samen met het realiteitsgehalte en de realiseerbaarheid van de voorgehouden normen. Maar ook deze zijn moeilijk te beoordelen, gezien de algemene termen waarin de codes voor het grootste deel zijn gesteld en vanwege de afwezigheid van nadere criteria en indicatoren ter precisering van de voorgehouden normen. Vooralsnog gaan we er echter van uit dat de opstellers van de codes de situatie van verpleegkundigen en hun mogelijkheden tot realisering van de voorgestelde normen realistisch hebben geschat. Dat er niettemin enig voorbehoud moet worden gemaakt kan op grond van het gestelde in 2.4.4 (zie met name 2.4.1. en 2.4.7.) gemakkelijk worden toegelicht. We komen hier nog op terug (zie vooral 5.3.1).

In ieder geval moge duidelijk zijn, dat het bij de toepassing van het derde criterium niet uitsluitend gaat om goede bedoelingen (hoewel deze wel een voorwaarde zijn). Het gaat tenminste ook om een reëele verwachting omtrent de uiteindelijke effecten van de realisering van voorgestelde normen. Een definitief oordeel kan tenslotte pas worden geveld indien de effecten als feiten aantoonbaar zijn.

Teverns moge duidelijk zijn dat apert onrealistische verwachtingen ten aanzien van de bevordering en verdeling van nonmoreel goed op grond van bepaalde voorgestelde normen, als zodanig buiten het morele gezichtspunt kunnen gaan vallen. Morele uitspraken worden dan illusoire of ideologische uitspraken of missen eenvoudigweg elke werkelijke grond (hetgeen ze overigens al verdacht maakt om redenen van.logica). Een dergelijke conclusie wordt echter zelden getrokken. Een probleem is waar de grens tussen realistische en onrealistische verwachtingen moet worden getrokken. Omdat dit probleem waarschijnlijk slechts met behulp van inhoudelijke argumenten kan worden opgelost, komt men tevens gemakkelijk van een categoriaal in een normatief onderscheid terecht, met alle verdere problemen van dien. We hoeven hier slechts te verwijzen naar het vraagstuk van het moreel relativisme alsmede de plaats van individuele morele preferenties (zie verder bij Musschenga 1984; Frankena 1973, 109-110). De bedoeling van deze paragraaf is ook slechts beroepscodes in categoriale zin als moreel te kwalificeren. Indien we hierin zijn geslaagd, impliceert dit tevens, dat een gedeelte van de eerste subvraag van onze vraagstelling is beantwoord (zie 3.4.3).

\subsubsection{Beroepscodes als etiquette?}

Nu de beroepscodes van de ICN, ANA, UKCC en NMV tenminste voor een belangrijk gedeelte aan de criteria van het morele gezichtspunt voldoen, kunnen ze in algemene zin als een moreel verschijnsel worden getypeerd. Met opzet wordt hier vermeld "in algemene zin", omdat een gedetailleerder analyse nog moet volgen. Echter, op basis van deze voorlopige conclusie kan in ieder geval worden afgerekend met een potentieel vooroordeel als zouden de beroepscodes uit louter etiquetteregels bestaan. Dit vooroordeel is niet denkbeeldig, omdat overeenkomstige kwalificaties meermaals vanuit een sociologische invalshoek zijn toegeschreven aan beroepscodes uit andere sectoren van de gezondheidszorg, met name de geneeskunde (zie onder andere Rubin en Carson in 3.4.1.). Commentatoren vanuit het vakgebied ethiek stellen zich daarentegen behoudender op. Vanuit het door velen aanvaarde standpunt, dat elke beslissing of aanwijzing tot 
niet-handelen een morele beslissing of aanwijzing is, worden normen in beroepscodes minder snel gedegradeerd tot etiquetteregels.

Overigens zijn de genoemde kwalificaties en commentaren historisch wel enigszins verklaarbaar. Binnen de geneeskunde bijvoorbeeld werden v6or de Tweede Wereldoorlog etiquette en ethiek nauwelijks onderscheiden. Het bekende 'blawwe boekje' gold als 'de ethiek van de geneeskunde', terwijl we mu zouden zeggen, dat het voor het grootste deel uit pure etiquetteregels bestaat. Ze werden ook voornamelijk gebruikt als middel tot sociale controle (vergelijk Dupuis 1988, 24). Toen echter meer nadruk ontstond op de individuele beleving en invulling van de rol van arts en het arts-patient-contact, bleek het blauwe boekje zijn functie in belangrijke mate te hebben verloren en werden in latere uitgaven de etiquetteregels vervangen door normen van meer morele aard. Dat dit met de nodige spraakverwarring en conceptuele misverstanden -ook buiten het gebied der geneeskunde- gepaard ging, blijkt wanneer de juriste Rood-De Boer nog in 1969 in een analyse van toenmaals bekende beroepscodes concludeert: "De hoofdinhoud van de meeste codes (...) bestaat uit, soms minitieus uitgewerkte, gedragsregels. Slechts verpakt treft men ethische principes aan" (Rood-De Boer 1969, 154). Etiquette wordt hier weliswaar (in het gebruik van de term 'gedragsregels') reeds onderscheiden van ethiek, maar hun specifieke relatie is nog geenszins duidelijk (zie onderstaande omschrijving).

Een etiquette bestaat globaal uit een geheel van geschreven en ongeschreven fatsoensnormen en beleefdheidsvormen. De Concise Oxford Dictionary omschrijft etiquette als de "conventional rules of personal behaviour in polite society". Bij etiquette ligt de nadruk op vormelijke aspecten van gedrag, fatsoensregels en overtreding ervan roept schaamte op. Bij ethiek daarentegen ligt de nadruk op de inhoudelijke aspecten van gedrag en het gedrag zelf, op morele regels en overtreding ervan roept schuld op. Bijvoorbeeld, een baby in het openbaar de borst geven kan indruisen tegen de etiquette. Niet het voeden op zichzelf staat hierbij open voor kritiek, maar de wijze waarop: het feit dat het plaatsvindt in een openbare gelegenheid en onbloting van intierne delen van de persoon noodzakelijk maakt. Afkeurende opmerkingen van omstanders kunnen leiden tot een schaamtegevoel bij de desbetreffende vrouw. Hetzelfde gedrag kan vanuit een moreel perspectief juist worden toegejuicht. Met het feit van het voeden zelf wordt een belangrijke waarde gediend, namelijk het welzijn van de baby. De in het kader van etiquette relevante plaats en omstandigheden hebben in de morele beoordeling en waardenafweging bovendien een lagere prioriteit.

Toch kan de grens tussen het morele en het etiquettekarakter van een regel niet altijd zo scherp worden getrokken. Een regel als "The nurse sustains a cooperative relationship with co-workers in nursing and other fields" (ICN-code, "nurses and co-workers") is hierin op zichzelf genomen onduidelijk. Gaat het hier om samenwerking als betamelijke arbeidsvorm en manier van omgaan met elkaar (etiquette) of om samenwerking met het oog op de realisering van een belangrijke (morele) verantwoordelijkheid? We kiezen uiteindelijk voor het laatste, gezien de inhoud van de preambule en de coherentie met andere regels.

De grens tussen het morele en etiquettekarakter van een regel kan dus onder andere worden bepaald door te vragen naar de reden, de rechtvaardiging van de desbetreffende regel. Naar onze mening is dit ook het beslissende criterium. In dit verband is bet bijvoeglijk naamwoord "conventional" in bovengenoemde omschrijving van etiquette veelbetekenend. Etiquetteregels worden namelijk gerechtvaardigd op grond van conventie en 
zijn instrument woor sociale controle. De argumentatie neemt daarbij de structuur aan van: "dat doe je nu eenmaal zo!" Etiquetteregels worden hiermee buiten het morele gezichtspunt geplaatst (vergelijk 4.4.1.).

Morele regels doorbreken de vanzelfsprekendheden van een dergelijke, op conventies gebaseerde moraal, omdat ze het resultaat zijn van overwegingen met betrekking tot de geldigheid van die moraal. Ze zijn instrument woor morele beoordeling. Ze zijn het resultaat van de vraag "waarom zou ik of mijn groep die conventionele moraal moeten aanvaarden?" In het antwoord en de argumentatie ten aanzien van die vraag wordt duidelijk op welke onderdelen men wil afwijken van de conventionele moraal en welke (afwijkende) prioriteiten men wil stellen met betrekking tot de realisering van morele principes; waarden en normen. Zo wordt in de onderhavige codes hoge prioriteit gegeven aan de bevordering van gezondheid en het verlichten van pijn en lijden. Daarnaast worden in dit licht vele morele principes genoemd, waaraan verpleegkundigen uitdrukkelijk worden geacht zich te houden (zie bijvoorbeeld de opsomming in de preambule van de ANAcode). De beroepsgroep distantieert zich hiermee duidelijk van een conventionele moraal, waarin bijvoorbeeld persoonlijk economisch gewin en de 'etiquette van de blauwe blazer' de boventoon voeren. Weliswaar ontbreekt hiertoe in de codes een uitvoerige argumentatie, maar zij is tussen de regels herkenbaar en kan worden afgeleid uit hun ontstaansgeschiedenis.

\subsubsection{De waarde dienstbaarheid in de beroepscodes}

Met de behandeling van bovenstaande categoriale onderscheidingen is het belangrijkste nog niet verteld. Een minstens zo relevant probleem betreft de vraag wat beroepscodes nu concreet hebben te bieden, welke de inhoud van de voorgehouden normen is en hoe die normen zich tot elkaar verhouden en kunnen worden geclassificeerd. Interessant is met name de vraag welke inhoud via de codes wordt gegeven aan de eerder gesignaleerde (morele) waarde/plicht "dienstbaarheid", als centraal en primair uitgangspunt van het handelen van professionals op basis van een beroepscode (zie 3.4.2). In dit verband stelt zich echter vervolgens nog een andere vraag, namelijk die naar het functioneren van deze waarde/plicht in de concrete doelstellingen en activiteiten van de beroepsgroep van verpleegkundigen en haar plaats in het maatschappelijk proces.

Wie de codes leest en bestudeert ontkomt inderdaad niet aan de indruk, dat de belangrijkste opgave van verpleegkundigen is zich dienstbaar op te stellen: In praktisch alle normen is sprake van een morele verplichting of van morele waarden die aan verpleegkundigen worden voorgehouden ter realisering jegens anderen. In slechts enkele gevallen is expliciet sprake van morele verplichtingen of morele waarden, die tevens een moreel recht van de verpleegkundige zelf uitdrukken. Bijvoorbeeld, de verplichting tot het bijstaan van collega's in het ontwikkelen van hun competentie of het handelen volgens de beroepscode (UKCC-code, art. 12, respectievelijk NMV-code, art. 3.8) is, zo gesteld, tevens een recht dat de verpleegkundige zelf bezit ten opzichte van collega's. Een zelfde redenering geldt voor het (tijdelijk) overnemen van werkzaamheden (NMV-code, art. 3.5; ANAcode, art. 6; UKCC-code, art. 11) en het streven naar optimale werkomstandigheden en arbeidsvoorwaarden (ICN-code, laatste artikel; NMV-code, art. 4.1 en 4.4).

Uit deze voorbeelden blijkt al, dat in en tussen de regels van de aanbevolen morele verplichtingen en waarden tal van claims aanwezig kunnen zijn, die op verhulde wijze be- 
paalde rechten voor verpleegkundigen en hun beroepsgroep opeisen. $Z_{0}$ is een streven naar optimale arbeidsvoorwaarden weliswaar van voordeel voor de verpleegkundige zelf, maar impliciet wordt een plaats en stem geclaimd in de desbetreffende adviserende en besluitvormende (overheids)organen. Anderzijds is het steunen van verplegingswetenschappelijk onderzoek en het bekendmaken van de resultaten daarvan niet direct profijtelijk voor de verpleegkundige, maar indirect worden mogelijkheden en middelen geclaimd om metterdaad onderzoek te verrichten en te rapporteren. De dienstbaarheidsverplichting, hoe duidelijk ook aanwezig, kan dus een sociale en/of morele claim verhullen en doet dit blijkens de voorbeelden ook. Dit duidt op een ideologische functie van de beroepscodes die in het onderstaande nog nader zal worden onderzocht. Vooralsnog ligt deze echter in thet verlengde van de voorlopige conclusies uit 3.4.1 en 3.4.2.

Bij ons voornemen tot een nadere inhoudelijke analyse van de gepresenteerde beroepscodes dienen op grond van het bovenstaande twee accenten te worden gelegd casu quo twee hypotheses te worden onderzocht:

1. De dienstbaarheidsverplichting kan gelden als samenvatting van de in de beroepscodes onderscheiden en geformuleerde normen; zij is hiërarchisch geordend boven de afzonderlijk genoemde normen; zij bepaalt het kader en karakter van de morele doelstellingen van de verpleegkundige en diens beroepsgroep en beroepsorganisatie.

2. De dienstbaarheidsverplichting kan gelden als de samenvatting van een in de beroepscodes veelal impliciet aanwezig kenmerk, namelijk de verhulde ideologie van de beroepsgroep en haar organisaties; zij bepaalt het kader en karakter van de sociale doelstellingen daarvan.

De laatste hypothese komt in de volgende paragraaf aan de orde. In de onderhavige houden we ons bezig met de eerste hypothese.

De ethicus Kultgen is onzes inziens de enige filosoof die in meer dan globale en conceptuele zin het verschijnsel beroepscode heeft onderzocht (zie met name Kultgen 1983, 225-264; 1988a, 209-251; 1988b, 411-421). Hij heeft vooral onderzoek verricht naar de functies en inhoud van beroepscodes in de zakensector en de vrije beroepen, in mindere mate in de gezondheidszorg. We maken gebruik van zijn analyseschema en interpretatiemodel, zij het met enige modificaties. Deze hebben minder betrekking op het methodologische aspect dan wel op een aantal inhoudelijke categorieën ter structurering van de informatie.

Zo steunt figuur 4.5 in belangrijke mate op het werk van Kultgen (1988a, 241), maar zijn de genoemde thema's in categorieën onderverdeeld en is in de tabel gewerkt met aantallen uitspraken in plaats van met een singuliere aanduiding van het vórkomen van een thema alleen. De tabel geeft aan welke en hoe vaak bepaalde thema's in de normstelling van de vermelde beroepscodes voor verpleegkundigen aan de orde komen. De thema's zijn daarnaast onderscheiden naar een viertal categorieën: (1) thema's met betrekking tot algemene aspecten; (2) thema's met betrekking tot de relatie van verpleegkundigen met patiënten/cliënten, (3) met collega's/anderen, en (4) met de samenleving en het beroep. De eerste categorie bevat thema's die hoofdzakelijk stammen uit de preambule van een code (zoals bij de ICN-, ANA- en UKCC-code) of uit een verzameling normen die de uitgangspunten en doelstellingen van de code of de verpleegkunde als onderwerp hebben. De overige categorieën spreken voor zich, waarbij wordt aangetekend, dat discussie 
mogelijk is over de preciese categorisering van een aantal (onderdelen van) thema"s. Met name de laatste categorie bevat thema's, die wellicht ook onder de eerste categorie kunnen worden geplaatst. De categorisering volgt globaal de indeling die ook door de NRV $(1988,32)$ is voorgesteld en in de NMV-code wordt gehanteerd (vergelijk figuur 4.4). Bij de rangschikking van normen onder bepaalde thema's is uitgegaan van de letterlijke tekst en is geen rekening gehouden met eventuele toelichtingen.

Dat er discussie mogelijk is over de rangschikking van thema's onder bepalalde categorieên geeft reeds aan, dat een relativerende opmerking met betrekking tot de betrouwbaarheid van de scores op zijn plaats is. Zij zijn niet voorgelegd aan een panel noch is aan anderen een verzoek gedaan tot rangschikking en categorisering opdat vergelijking en optimalisatie van scores konden plaatsvinden. Het is derhalve mogelijk, dat anderen tot scores komen, die van de hier gepresenteerde afwijken.

Figuur 4.5: Inhoudsanalyse van normen in de beroepscodes voor verpleegkundigen (de cijfers in de tabel verwijzen naar het aantal witspraken per thema)

\begin{tabular}{|c|cccc|c|}
\hline Thema's & ICN & ANA & UKCC & NMV & Totaal \\
\hline $\mathbf{1}$ & 1 & 1 & 0 & 1 & 3 \\
$\mathbf{2}$ & 4 & 2 & 0 & 1 & 7 \\
$\mathbf{3}$ & 1 & 2 & 0 & 1 & 4 \\
$\mathbf{4}$ & 4 & 3 & 1 & 1 & 9 \\
$\mathbf{5}$ & 2 & 2 & 2 & 1 & 7 \\
$\mathbf{6}$ & $0(12)$ & $1(11)$ & $1(4)$ & $0(5)$ & $2(32)$ \\
\hline $\mathbf{7}$ & 2 & 2 & 4 & 3 & 11 \\
$\mathbf{8}$ & 2 & 1 & 1 & 3 & 7 \\
$\mathbf{9}$ & 0 & 1 & 1 & 7 & 9 \\
$\mathbf{1 0}$ & 1 & 0 & 1 & 0 & 2 \\
$\mathbf{1 1}$ & $0(4)$ & $0(4)$ & $2(9)$ & $2(15)$ & $4(33)$ \\
\hline $\mathbf{1 2}$ & 3 & 1 & 2 & 11 & 17 \\
$\mathbf{1 3}$ & $1(4)$ & $1(2)$ & $4(6)$ & $4(15)$ & $10(27)$ \\
\hline $\mathbf{1 4}$ & 1 & 1 & 4 & 2 & 8 \\
$\mathbf{1 5}$ & 3 & 3 & 0 & 0 & 6 \\
$\mathbf{1 6}$ & 1 & 1 & 2 & 3 & 7 \\
$\mathbf{1 7}$ & 1 & 3 & 0 & 3 & 7 \\
$\mathbf{1 8}$ & 1 & 1 & 0 & 1 & 3 \\
\hline Totaal & $27(7)$ & $26(9)$ & $25(6)$ & $44(9)$ & $123(31)$ \\
\hline
\end{tabular}

\section{Verklaring van thema's (maarden en normen met betrekking tot):}

Aligemeen:

1. Uitgangspunten/belang/functie/toetsingskarakter van de codle; (prioriteiten in) belangrijkste morele principes/waarden/normen; criteria morele keuzes

2. Doelstelling/taken/functies/reikwijdte van verpleegkunde

3. Respect voor leven/uniciteit en waardigheid van de mens/mensenrechten

4. Persoonlijik karakter van verantwoordelijkheid; belang/gebruik van eigen oordeelsvermogen/handelingsmaatstaven 
5. (Adequate schatting en bijhouden van eigen) competentie; permanente scholing

6. Mogeliikherden/grenzen van wettelijke maatregelem.

Relatie met de patiènt/cliën:

7. Belangen van patiênt/cliënt primair" respect voor automomie/privacy

8. Respect voor aard/herkomst/status/waarden/gewoonten/overtügingen van patiënt/cliènt en zijn vertegenwoordiger

9. Bevordering van eigen oordeelsvermogen/verantwoordelijkheid/keuzes van patiënt/cliënt

10. Omgevingsfactoren $m . b . t$. patiènt/cliènt/hulpwerlening

11. Vermijden misbruik van positie/relatie met patiënt/privileges/giften

Relatie met collega's/anderen:

12. Samenwerking met collega's/anderen; respect voor competentiegrenzen; overnemen/delegeren/integreren van werantwoordelijkheden/taken

13. Ondersteuning bij nakomen code; voorkomen/melden van misstanden/fouten/onwetmatigheden; belastbaarheid collega's; melding (gewetens) bezwaren

Relatie met samenlewing/beroep:

14. Bescherming reputatie van bet beroep; bescherming van/dienstbaarheid aan belangen wan het publiek/samenleving

15. Bepaling/handhaving/toepassing van maatstaven/kwaliteit van zorg/onderwijs

16. Bevordering professionele kennis/kunde/wetenschappelijk onderzoek; openbaring van onderzoeksresultaten

17. Deelname aan activiteiten van beroepsorganisatie/beroepsgroep; bevordering van optimale arbeidsomstandigheden/-voorwaarden/verdeling van middelen

18. Bijdragen aan gezondheids-/welzijnsbevorderende maatschappelijke activiteiten

In totaal werden 123 uitspraken gescoord. Hierin heeft de NMV een relatief groot aandeel, gezien het grote aantal artikelen in vergelijking tot de andere codes. Na rangschikking onder de 4 vermelde categorieën blijkt een redelijke spreiding over de categorieën aanwezig, zonder dat daar op voorhand rekening mee werd gehouden. Deze spreiding is echter aanzienlijk minder evenwichtig wanneer naar de codes afzonderlijk wordt gekeken. Zo bevatten de ICN- en de ANA-code relatief veel uitspraken die hebben te maken met de uitgangspunten van de code en/of het beroep en met algemene aspecten van de verantwoordelijkheid van verpleegkundigen. Daarnaast bevat de ANA-code relatief veel uitspraken met betrekking tot de relatie van de verpleegkundige tot de samenleving en/of het beroep. De UKCC-en NMV-code bevatten daarentegen relatief weel uitspraken met betrekking tot de relatie van verpleegkundigen met patiënten/cliënten en de NMV-code bovendien met betrekking tot de relatie van verpleegkundigen met collega"s en anderen. Deze verschillen tekenen de accenten die in de verschillende codes aanwezig zijn. Ze zijn minder begrijpelijk vamuit de ontstaansgeschiedenis van de codes (vergelijk de paragrafen 4.3) dan wel vanuit de wens van de opstellers bepaalde aspecten van het handelen van verpleegkundigen explicieter en gedetailleerder naar voren te brengen dan andere aspecten. Hun culturele achtergrond en/of waardensysteem hebben ongetwijfeld aan de genoemde verschillen en accenten bijgedragen. Dit beeld verandert overigens niet wanneer twijfels ten aanzien van de categorisering van bepaalde uitspraken onder de vierde dan wel eerste categorie tot een andere score en rangschikking zouden hebben geleid.

Argumenten om dienstbaarheid als de centrale morele verplichting en/of waarde van verpleegkundigen te beschouwen, zullen uiteraard primair moeten worden ontleend atan uitspraken met betrekking tot de uitgangspunten van de codes en/of de beroepsuitoefening* 
dus de eerste categorie. In deze uitspraken wordt een aantal warden benoemd. Hieruit volgt dat de centraliteit van dienstbaarheid mede dient voort te vloeien uit een discussie en confrontatie met deze waarden.

Zoals wermeld, leveren ons de ICN-en ANA-code hiertoe de meeste aanwijzingen. In de preambule van beide codes wordt gewag gemaakt van de fundamentele verantwoordelijkheid van de verpleegkundige. Deze wordt omschreven als dienstverlening aan individuen, groepen en de gemeenschap op het terrein van de bevordering van gezondheld, het voorkomen van ziekte en het verlichten van pijn en lijden. De toedeling van verantwoordelijkheid en het verlenen van diensten aan personen impliceren, dat hier sprake is van een morele waarde. De nadruk op het dienstverlenende aspect van de verantwoordelijkheid lat toe, dat deze morele waarde wordt aangeduid met 'dienstbaarheid'. Het fundamentele karakter ervan doet haar bestempelen als de centrale morele waarde in de desbetreffende codes. In de ANA-code wordt (tussen de regels) bovendien nog eens aangegeven, dat deze morele waarde en de code als geheel consistent zijn met de doeleinden en waarden van het beroep van werpleegkundige als zodanig.

In de UKCC-code staat dienstbaarheid minder exclusief un functie van een omschrijving van de fundamentele verantwoordelijkheid van de verpleegkundige voor het welzijn en de gezondheid van individuen en groepen. Toch kan zij als centrale morele waarde naar voren worden geschoven. In de preambule is sprake van dienstbaarheid aan de belangen van de samenleving en bewaking van de belangen van patiënten/cliënten. Hiermee wordt in meer algemene termen dan het gevall was bij de ICN- en de ANA-code het belang van dienstbaarheid als centrale morele waarde aangegeven. Bovendien wordt als fundamenteel aspect aangevoerd, dat deze dienstbaarheid zich uitstrekt tot loyaliteit aan de goede reputatie van het beroep. Deze vorm van dienstbaarheid wordt door ons echter meer als een afgeleide norm beschouwd; we hebben haar in figuur 4.5 onder de vierde categorie uitspraken geplaatst. De vraag is zelfs of we hier met een morele waarde of verplichting hebben te maken. In het onderstaande zal nog worden aangetoond, dat er naast morele overwegingen tenminste ook prudentiële argumenten een rol spelen bij de proclamatie van een dergelijke norm. Het morele karakter en de centraliteit van dienstbaarheid kunnen dus met grotere waarschijnlijkheid worden afgeleid uit de uitspraken met betrekking tot de belangen van de samenleving en van patiënten of cliênten. Het primaat (en dus het centrale karakter) van dienstbaarheid als morele waarde wordt dan ook in deze zin bevestigd door artikel 1 van de UKCC-code: "Act always in such a way as to promote and safeguard the well being and interests of patients/clients". Alle andere belangen, die in de preambule in algemene termen en in de overige artikelen in specifieker vorm worden genoemd, dienen op dit bijzondere belang te worden georiënteerd.

Een soortgelijk artikel als het zojuist genoemde uit de UKCC-code treffen we aan in de NMV-code: "De verpleegkundige stelt in de zorgverlening de belangen van de patiënt op de eerste plaats" (art. 2.1). In de code ontbreken echter aanduidingen van het perspectief waarin deze belangen moeten worden geplaatst; ook de "fundamentele uitgangspunten" helpen ons niet verder. Bovendien wordt de strekking van het artikel beperkt door de conditionele term "in de zorgverlening". "Tot het morele karakter en de centraliteit van dienstbaarheid in de NMV-code kan slechts worden besloten op grond van een reconstructie van de normatieve strekking van de code als geheel.

Het laatste argument is niet alleen van toepassing op de NMV-code, maar ook op de andere codes. Dit doet de vraag rijzen of een dergelijke reconstructie geen andere waarden 
aan het licht kan brengen die kandidaat kunnen staan voor de kwalificatie 'centrale morele waarde?.

Wanneer wij deze vraag proberen te beantwoorden vanuit de inhoud van de codes zelf, dan valt direct een aantal waarden af, omdat het predikaat 'moreel' er niet op van toepassing is. Dat geldt bijvoorbeeld voor de waarde 'competentie', zoals in 4.4.1 reeds werd betoogd. Competentie is een nonmoreel goed. $\mathrm{Zij}$ is geen persoon of motief, maar een ervaring. De bevordering ervan kan weliswaar op morele gronden worden aanbevolen, maar op zichzelf genomen vertegenwoordigt zij geen morele waarde. Op dezelfde wijze kunnen ook waarden als 'verpleging', 'gezondheidszorg', 'oordeelsvermogen', 'rechts" handhaving', 'coördinatie' en 'kwaliteit van zorg' niet als serieuze kandidaten worden beschouwd om de plaats van 'dienstbaarheid' als centrale morele waarde in te nemen.

Daarnaast worden in alle codes echter waarden genoemd waarvan het morele karakter direct kan worden ingezien. In de ANA-code bijvoorbeeld wordt 'respect voor mensen' het meest fundamentele morele beginsel genoemd voor een rechtvaardiging van verpleegkundig handelen. In verband hiermee worden nog andere waarden vermeld, die ieder voor zich als morele waarde kunnen worden gekwalificeerd: 'goed-doen', 'zelfbeschikking', 'eerlijkheid", 'trouw', 'betrouwbaarheid' en 'rechtvaardigheid'. Al deze waarden komen ook in de andere codes op enigerlei wijze aan de orde. Het betreft hier echter morele waarden met een algemene strekking. Anders gezegd: ze zouden ieder mens sieren, ongeacht zijn rol in het maatschappelijk verkeer, en drukken onvoldoende uit vanuit welk perspectief ze worden aanbevolen. Hiertoe wordt bovendien een nadere legitimering vermeden of overbodig geacht. Ook dienstbaarheid siert de mens weliswaar, maar zij bevat daarnaast een duidelijke verwijzing naar hetgeen in de codes met de functie van de verpleegkunde in de samenleving expliciet wordt bedoeld, namelijk het verlenen van diensten. De realisering van de eerder genoemde waarden moet in de context van de uitoefening van het beroep steeds vanuit dit dienstverleningsperspectief worden bekeken. Op grond hiervan staat dienstbaarheid centraal en kan vervolgens de vraag worden gesteld naar haar morele legitimering. Voor dit laatste verwijzen we echter naar 5.2.3.

De centraliteit van dienstbaarheid komt niet zomaar uit de lucht vallen. Dienstbaarheid wordt weliswaar niet als zodanig in de beroepscodes genoemd, de centraliteit ervan kan evenwel worden afgeleid uit de combinatie van verschillende overwegingen:

1. Dienstbaarheid is een belangrijk expressief element in de oriëntatie van beroepsbeoefenaren op hun werk.

2. Dienstbaarheid is een handelingsmaatstaf die uitstekend past bij het dienstverleningsperspectief op de taak van het beroep in de samenleving.

3. Het is vanuit het oogpunt van consistentie en geloofwaardigheid aannemelijk dat de sub 1 en sub 2 genoemde oriëntaties en perspectieven door een beroepsgroep worden verwerkt of geïmpliceerd in geschriften, juist wanneer deze een verduidelijking of normstelling beogen van de verhouding tot derden.

4. Toepassing van de criteria van het morele gezichtspunt leidt tot aanvaarding van dienstbaarheid als morele waarde.

5. Dienstbaarheid is de morele waarde waardoor zowel de morele en niet-morele waarden als de algemene en bijzondere waarden in de beroepscodes in een zeker verband kunnen worden geplaatst, terwijl hun morele samenhang anderszins veel moeilijker aantoonbaar is. 
Juist de combinatie van deze overwegingen ondersteunt in belangrijke mate de kandidatuur van dienstbaarheid als centrale morele waarde.

'Dienstbaarheid' bepaalt in de codes dus het kader en karakter van de morele doelstellingen van de verpleegkundige en diens beroepsgroep. Hiermee is de eerste bypothese, die wij in deze paragraaf zouden uitwerken, bevestigd. Voor onze vraagstelling is dit antwoord echter nog niet voldoende (zie subvraag 2 in 3.4.3). We zullen ook nauwkeuriger moeten aangeven welke principes, waarden en normen in de dienstbaarheidsverplichting geïmpliceerd zijn en wat de aard is van de daarin gehanteerde concepten. Het gaat er dus om de inhoud van de dienstbaarheidsverplichting nader te beschrijven en de vorm waarin dat gebeurt aan een zorgvuldig oordeel te onderwerpen.

De inhoud van de dienstbaarheidsverplichting kan worden afgeleid uit de in figuur 4.5 vermelde (onderdelen van) thema's. De daarbij behorende tabel laat verschillen zien tussen de vier geanalyseerde codes, maar deze laten we hier buiten beschouwing. Mede met het oog op de beschouwingen in het nog volgende hoofdstuk zijn we vooral geïnteresseerd in het totaalbeeld. We zullen dat nuanceren door verwijzingen te vermelden naar codes met de meest geprononceerde of kernachtige uitspraken op de diverse onderdelen. Met dit in gedachten laat de dienstbaarheidsverplichting zich als volgt beschrijven:

verpleegkundigen stemmen hun handelen af op de gezondheidsbelangen van mensen en conformeren zich in dat kader aan:

\section{Algemene normen met betrekking tot:}

a. het wolgen van de code (ANA);

b. het gebruik van eigen oordeelsvermogen (ICN, ANA);

c. het rekening houden met de gevolgen van keuzes en handelen (ANA)

d. het op zich nemen van persoonlijke verantwoordelijkheid (UKCC, NMV);

e. de universelle behoefte aan werpleging (ICN);

f. de realisering van de doeleinden en waarden van het beroep (ANA);

g. het bijhouden van eigen competentie (ANA, NMV);

h. het respecteren wan de rechten van de mens (ICN, ANA);

i. het volgen van belangrijke morele principes als respect voor personen, (waarvan afgeleid) zelfbeschikking, goed-doen, schade-vermijding, waarheidslievendheid, betrouwbaarheid, eerlijkheid en rechtvaardigheid (ANA);

$j$. het rekening houden met de wettelijke context (UKCC).

2. Nomen ten aanzien wan de relatie met patiënten/cliënten met betrekking tot:

a. het op de eerste plaats stellen van hun belangen (ICN, UKCC, NMV);

b. het respecteren van huin eigen aard, gewoonten en overtuigingen (ICN, UKCC, NMV); c. het respecteren en bevorderen van hun vermogen tot beslissen en verantwoordelijkheid over
de eigen zorg (ANA, NMV);

d. het informeren van hen inzake de zorgverlening, klachten en eigen (gewetens)bezwaren (NMV);

e. het zorgdragen voor hun persoonlijke levenssfeer (privacy) (UKCC);

f. het rekening houden met en beinvloeden van omgevingsfactoren die hen raken (UKCC);

g. bet vermijden en rapporteren aan derden van fouten, ongevallen en misständen (ANA,
UKCC, NMV);

h. het weigeren van geschenken (UKCC, NMV);

3. Nomen ten aanzien van de relatie met collega's/anderen met betrekking tot:

a. het bevorderen van de samenwerking met collega's en anderen (ICN, NMV); 
b. het coördineren en integreren van de diverse bijdragen aan de zorgverlening ( $\left(\mathrm{CN}_{\mathrm{a}} \mathrm{UKCC}\right.$, NMV);

c. het respecteren van de grenzen van de diverse vakgebieden (UKCC, NMV);

d. het owernemen en delegeren yan verantwoirdelijkheden (ANA, NMV);

e. het ondersteunen van minder bekwamen en ondergeschikten in de zorgverlening (UKCC);

f. het ondersteunen van collega"s bij het nakomen van de code (NMV);

g. het melden van (gewetens) bezwaren (UKCC, NMV);

h. het voorkomen en rapporteren van fouten, ongevallen en misstanden (ICN, ANA, UKCC, NMV);

i. het rekening houden met de belasting en/of belastbaarheid van collega's (UKCC);

4. Normen ten aanzien van de relatie met de samenleving en de plaats van het beroep daarit, met betrekking tot:

a. het respecteren en bevorderen van het algemeen gemeenschapsbelang (ANA);

b. het bijdragen aan gezondheidsbevorderende maatschappelijke activiteiten (NMV);

c. het deelnemen aan de activiteiten van de beroeps- en/of vakorganisatie (ANA, NMV);

d. het bevorderen van optimale arbeidsomstandigheden en/of -voorwaarden (ICN, NMV);

e. het bijdragen aan een adequaat gebruik en rechtwaardige verdeling van middelen (UKCC, NMV);

f. het bepalen en handhaven van een hoge kwaliteit wan zorg (ICN, ANA);

g. het bepalen en handhaven van hoge opleidingseisen ( $\mathrm{ICN}$ );

b. het bevorderen van of bijdragen aan ontwikkeling van verpleegkundige kennis en kunde, onder andere via wetenschappelijk onderzoek (ANA, NMV);

i. het zorg dragen voor openbaarmaking en verspreiding van onderzoeksresultaten (NMV);

j. het vermijden van commerciële activiteiten en/of het maken van reclame (UKCC);

k. het hoog houden van de naam en faam (reputatie) van het beroep (ICN, ANA);

j. het beschermen van het publiek tegen valse informatie (ANA);

m.het zorgdragen voor een goede vertegenwoordiging van het beroep in de samenleving (ANA, NMV);

n. het handhaven van een minimale veiligheid voor het publiek bij stakingen en/of stiptheidsalkies (NMV).

Al deze normen vervullen op een of andere wijze een rol in de dienstbaarheidsverplichting van de verpleegkundige. We hebben deze niet weergegeven met de bedoeling een voorstel te formuleren voor een nieuwe of ideale code. Dit was immers de doelstelling van de NRV bij haar analyse van een aantal beroepscodes in Nederland (NRV 1988). Onze opzet is slechts een beschrijving te geven van normen als de grootste gemene deler van wat we in de respectievelijke codes van de ICN, ANA, UKCC en NMV aantreffen. Er gaat geen normatieve pretentie van uit.

Wel is nu een bepaalde hiërarchie aan te geven in de aldus gepresenteerdle normen. De dienstbaarheidsverplichting geldt daarbij kennelijk als de alomvattende norm. Alle andere normen zijn in zekere zin daaraan ondergeschikt. Ze moeten worden gezien in functie van de alomvattende norm. We noemen ze daarom 'instrumentele normen'. "In zekere zin" is van belang, omdat een aantal van deze instrumentele normen basale morele principes en/of intrinsieke waarden herbergt, die ieder voor zich als primaire verplichting of verantwoordelijkheid in enig debat of bepaalde praktijken dienst zouden kunnen doen.

Bijvoorbeeld de normen genoemd onder $1 \mathrm{~h}$, $1 \mathrm{i}$ en $4 \mathrm{a}$ vertegenwoordigen principes die in meer algemene zin dan exclusief in het kader van de uitoefening van een beroep van belang worden geacht. Ons sociale verkeer laat er zich in hoge mate door normeren en zonder deze kan men zich nauwelijks een goede of rechtvaardige samenleving voorstellen. $\mathrm{Zij}$ kunnen dus op ieder moment de dienstbaarheidsverplichting van verpleegkundigen overvleugelen, zonder aan deze verplichting als zodanig afbreuk te doen. $\mathrm{Zij}$ bepalen ook 
de randwoorwaarden, waaronder andere normen, zoals genoemd in de codes, kunnen worden gerealiseerd. Dientengevolge staan ze in de codes hiërarchisch onmiddellijk onder de dienstbaarheidsverplichting gerangschikt.

Andere normen vertegenwoordigen niet zozeer een moreel principe of centrale waarde maar zijn preliminair ten aanzien van de realisering ervan, zelfs ten aanzien van hun kwalificatie als moreel. Dat zijn onder andere de normen met betrekking tot het eigen en andermans oordeelsvermogen ( $1 \mathrm{~b}$ en $2 \mathrm{c}$ ), de gevolgen van keuzes en handelingen (1c), en het persoonlijk verantwoordelijk zijn voor keuzes, beslissingen en handelingen (Id en 1c). Zonder oordeelsvermogen, het betrekken van de gevolgen van handelingen in de keuzes die men doet en het persoonlijk instaan voor die keuzes, kan er slechts in zeer beperkte zin sprake zijn van moreel gedrag (maar ook van immoreel gedrag).

Zoals preliminaire normen voorafgaan aan de dienstbaarheidswerplichting kunnen andere normen er direct of indirect uit worden afgeleid. "Indirect" wanneer zij een uitvloeisel zijn van de met de dienstbaarheidsverplichting samenhangende basale morele principes en waarden. "Direct" wanneer zij moeten worden beschouwd als een nadere uitwerking of instrumentele functie van de uitoefening van het beroep van verpleegkundige als zodanig. De indirect afgeleide normen dienen vanuit moreel perspectief hiërarchisch te worden geordend boven de direct afgeleide omdat zij een uitwerking zijn van algemene principes en waarden met betrekking tot menselijk handelen, in tegenstelling tot de bijzondere principes en waarden met betrekking tot het beroepsmatige handelen in de direct afgeleide normen. Tot de indirect afgeleide normen behoren $1 \mathrm{i}, 2 \mathrm{a}, 2 \mathrm{~b}, 2 \mathrm{~d}, 2 \mathrm{e}, 2 \mathrm{~h}, 3 \mathrm{e}, 3 \mathrm{f}, 3 \mathrm{i}$, $4 \mathrm{e}, 4 \mathrm{i}, 4 \mathrm{l}, 4 \mathrm{n}$. Tot de direct afgeleide normen behoren 1e, 1f, $2 \mathrm{f}, 2 \mathrm{~g}, 3 \mathrm{a}, 3 \mathrm{~b}, 3 \mathrm{c}, 3 \mathrm{~d}, 3 \mathrm{~g}, 3 \mathrm{~h}$, $4 \mathrm{~b}, 4 \mathrm{c}, 4 \mathrm{~d}, 4 \mathrm{f}, 4 \mathrm{~g}, 4 \mathrm{~h}, 4 \mathrm{j}, 4 \mathrm{k}, 4 \mathrm{~m}$.

Aldus ontstaat de volgende hiërarchische ordening van normen in de beroepscodes, met als criterium het centrale karakter van de desbetreffende normen in een moreel perspectief:

1. Preliminaire normen.

2. Dienstbaarheidsverplichting.

3. Basale morele principes, waarden en normen.

4. Indirect afgeleide normen.

5. Direct afgeleide normen.

(1) tot en met (3) zijn vooral te vinden in de preambules en uitgangspunten van de codes, maar ze kunnen ook worden aangetroffen in categorieën die specifiek ingaan op de rellatie van verpleegkundigen met patiënten, collega's en de samenleving als geheel. (4) en (5) bevinden zich verspreid over de hele code.

Tot nu toe is steeds melding gemaakt van verplichtingen en normen. Bovendien zijn ethische principes steeds genoemd in samenhang met waarden, zonder in specifieke gevallen te beslissen voor de ene dan wel andere term. Voor een bepaling van de aard en inhoud van een handelen gebaseerd op een code, is het echter van belang tussen genoemde termen te differentiëren. Dit zal dan moeten gebeuren overeenkomstig de in 3.2(.3) voorgestelde nomenclatuur.

Eerder in dit hoofdstuk hebben we gezien, dat vanuit de primaire doelstelling waarmee de codes zijn gepubliceerd, alle ogenschijnlijk empirische uitspraken als een imperativum moeten worden opgevat. Verder kunnen we ervan uitgaan, dat in alle imperativa door de 
beroepsgroep een uitspraak wordt gedaan over wat zij als goed, juist en derhalve nastrevenswaardig acht. Met andere woorden, elke uitspraak bevat een waarde. Door deze in een imperativum te verwerken worden verwachtingen uitgesproken voor vanzelfsprekend gedrag. De uitspraken voldoen dan aan de definitie van 'norm" (verwachting ten aanzien van uit een waarde begrijpelijke regel voor vanzelfsprekend gedrag). Omdat deze norm in een code is geformaliseerd, kunnen we tevens spreken van een "voorschrift'.

Deze norm of dit voorschrift staat hier echter in de context van de realisering van een bepaald doel of goed, namelijk dienstbaarheid in ruime zin en optimale verpleging en verzorging in het kader van de gezondheidszorg in engere zin. De norm of het voorschrift moet dan ook worden opgevat als een plicht (een in een norm of voorschrift tot uitdrukking gebracht(e) handelingskenmerk of handelingsregel met het oog op de realisering van een bepaald doel of goed).

Wat echter te zeggen van het morele karakter van de in de beroepscodes te onderscheiden plichten? Hierop is een tweeledig antwoord mogelijk. Op de eerste plaats is er de oriëntatie van de code op dienstbaarheid als centrale, te realiseren waarde. De plichten die verpleegkundigen in de codes worden opgelegd, moeten dan ook in dit perspectief worden bekeken. Derhalve bezitten alle in de plichten verwoorde handelingskenmerken en -regels een zekere morele importantie. Immers, zij spelen een rol in het antwoord op de vraag of een specifiek verpleegkundig handelen in voldoende mate overeenstemt met de dienstbaarheidsverplichting (zoals het een verpleegkundige betaamt) en in die zin moreel verantwoord is.

Ten tweede is het mogelijk om alle plichten analytisch te onderscheiden en ieder afzonderlijk op hun morele merites te beoordelen. Dan ontstaat een ander beeld dan het bovenstaande. We zullen dit verduidelijken met een voorbeeld. De plicht tot samenwerken met collega's en andere beroepsbeoefenaren kan -vanwege haar verwijzing naar de solidariteit en collegialiteit met de gemeenschap van beroepsbeoefenaren- weliswaar van morele betekenis zijn voor een vervulling van de dienstbaarheidsverplichting, maar het blijft een middel, een instrumentele waarde, waarvan het morele karakter apart kan en ook moet worden bekeken. Als zodanig voldoet 'samenwerking' niet aan onze omschrijving van morele waarde. Het is geen intrinsieke waarde die op zichzelf genomen volgens de criteria van het ethisch gezichtspunt kan worden aanbevolen. Dan zou samenwerking moeten kunnen worden gekozen als doel op zichzelf. En dat lijkt een nogal triviale bezigheid bij ons streven naar de goede mens en een goede samenleving, zeker in aen gezondheidszorg waarin het individuele contact tussen hulpverlener en hulpvrager uitgangspunt is van het behandelings- en verzorgingsproces. De plicht tot samenwerking moet dan ook worden beschouwd als een nonmorele plicht. Andere voorbeelden van een dergelijke nonmorele plicht zijn verwoord in $2 \mathrm{f}, 2 \mathrm{~h}, 3 \mathrm{~b}, 3 \mathrm{c}, 3 \mathrm{~h}, 3 \mathrm{i}, 4 \mathrm{~b}, 4 \mathrm{c}, 4 \mathrm{~d}, 4 \mathrm{f}, 4 \mathrm{~g}, 4 \mathrm{~h}, 4 \mathrm{i}$, $4 \mathrm{j}, 4 \mathrm{k}, 4 \mathrm{~m}, 4 \mathrm{n}$. Het betreft hier dus in hoofdzaak direct afgeleide normen.

De in de codes verwoorde plichten kunnen echter nog op een andere wijze worden geinterpreteerd, namelijk als een plicht tot het dragen van verantwoordelijkheid voor .... Elke plicht impliceert dan een moreel waarde-oordeel. Immers, het waarde-oordeel geldt het handelen van verpleegkundigen.

Bovendien is in sommige plichten, met name in de basale en indirect afgeleide normen, sprake van principes waarvan het morele karakter onmiddellijk valt in te zien (bijvoorbeeld 1i). Een aantal plichten stoelt dan ook niet alleen op een aretaïsch oordeel (moreel 
walarde-oordeel), maar kan ook een deontisch oordeel (oordeel van morele verplichting) als uitgangspunt hebben.

Hiermee is aangegeven, dat een conclusie ten aanzien van het morele karakter van de normen in de codes niet eenduidig is te geven. Onder de aanname dat we in alle gevallen te maken hebben met een imperativum kunnen alle normen als plicht worden beschouwd. Het morele karakter van de inhoud van die plichten is echter afhankelijk van interpretatie, waarbij enerzijds een keuze moet worden gemaakt tussen de normen sec en de context waarin zij staan en anderzijds tussen normen als toegedeelde verantwoordelijkheid en normen als verwoording van aretaissche dan wel deontische oordelen. En dan laten we nog buiten beschouwing dat zelfs een interpretatie in categorieën van (morele) deugden tot de mogelijkheden behoort.

\subsubsection{Beroepscodes als ideologie}

Uit het bovenstaande is gebleken, dat de beroepscodes op het terrein van de verpleging in thet algemeen kunnen worden beschouwd als een verzameling van plichten met een overwegend moreel karakter, die alle tot doel hebben vorm te geven aan de dienstbaarheid van het beroep en de beoefenaars ervan aan de samenleving in het algemeen en de patiëntenzorg in het bijzonder. We hebben ons daarbij nog niet uitgelaten over de realiseerbaarheid van de plichten, hoewel deze een duidelijke rol dient te spelen bij de beoordeling van het morele karakter van de codes als zodanig (vergelijk 4.4.1). Over het realisme van de codes komen we echter nog in een volgend hoofdstuk te spreken (zie de paragrafen 5.2). We laten de discussie daarover voorafgaan door de bespreking van een ander aspect van codes, dat in zekere zin de voortzetting is van onze verhandeling in de vorige paragraaf en een antwoord moet bieden op de tweede hypothese die daar is geformuleerd.

Het stellen van normen, het geven van voorschriften en het formuleren van plichten kan een belangrijk hulpmiddel zijn voor de beoefenaars van een beroep wanneer zij op zoek zijn naar morele maatstaven of standaarden voor de specifieke problematiek die zij in hun werk ontmoeten. Met name vanuit een sociologische optiek is echter meermaals gesteld, dat zij ook een belangrijk hulpmiddel kunnen zijn -en zelfs als zodanig functioneren- bij de realisering van een aantal maatschappelijke pretenties: wekken van vertrouwen bij het publiek, doen aanvaarden van de eigen doelstellingen en praktijken, opkrikken van de eigen status, enzovoort. In de paragrafen 2.3 .7 en 3.4.1 hebben we met deze pretenties nader kunnen kennismaken. $\mathrm{Zij}$ werden daar samengevat en aangeduid als de ideologie van de beroepsgroep en/of de ideologische functie van beroepscodes.

De vraag is nu of een dergelijke functie in de onderhavige codes kan worden onderkend. Daarachter ligt de vraag of aan de dienstbaarheidsverplichting niet alleen een moreel maar ook een opsierend karakter kan worden toegeschreven. Hierbij wordt in het midden gelaten of deze functie een bedoeld of onbedoeld kenmerk van de desbetreffende codes is.

Eerder (in 4.4.3) is het ideologisch karakter van beroepscodes al in verband gebracht met de sociale en/of morele claims die in en achter de gestelde verplichtingen schuil kunnen gaan met betrekking tot de eigen belangen van de beroepsgroep casu quo de opstellers van de codes. Nu moeten we dit verband nauwkeuriger gaan formuleren. Voorzover het ideologisch karakter namelijk betrekking heeft op de realisering van het eigenbelang 
zonder daarin het belang van anderen of groepen anderen te verdisconteren kan er slechts sprake zijn van een sociale claim en geen morele claim. In dat geval worden geen morele rechtvaardigingen geboden, maar puur prudentiële overwegingen. Statusverhoging is een dergelijke prudentiële overweging. De reputatie van het beroep is dat ook (zie bijvoorbeeld de preambule van de UKCC-code).

Andere claims kunnen naast het eigenbelang ook gericht zijn op de realisering van in het algemeen belangrijk geachte sociale waarden. $Z o$ is de bescherming van de privacy van patiënten dienstbaar aan een algemeen vrijheidsrecht en komt het voorkómen en melden van misstanden in de hulpverlening tegemoet aan de implicaties van het sociale grondrecht op een optimale en tenminste veilige gezondheidszorg. Beide kunnen in dat perspectief ook als morele claims worden beschouwd. Ondanks hun gerichtheid op het algemeen belang kunnen ze 'onderhuids' echter een ideologisch karakter bezitten. Ten eerste omdat beide in dienst kunnen staan van de met het eigenbelang samenhangende reputatie van het beroep. Ten tweede, omdat beide claims op zichzelf genomen niet exclusief hoeven worden gekoppeld aan de uitoefening van een beroep in de gezondheidszorg en bovendien onhaalbare idealen kunnen blijken die telkens door de praktijk van alledag worden ingehaald.

Zowel prudentiële als morele claims kunnen dus deel uitmaken van de ideologie achter beroepscodes. Beslissend is of ze exclusief het eigenbelang dienen respectievelijk een sociale en/of morele waarde vertegenwoordigen die het algemeen belang op het oog heeft maar niet tot de specifieke praktijk van het beroep behoort. Voorzover het hier gaat om morele waarden of principes spreken we in dit opzicht liever van morele idealen.

Dat een ideologie wordt gekenmerkt door een oriëntatie op het eigenbelang, komt duidelijk tot uiting in de definitie die De Jager en Mok van het verschijnsel geven: "systeem van opvattingen, dat een uitdrukkelijke rechtvaardiging van de positie van de betreffende groepering inhoudt" $(1983,309)$. Kultgen daarentegen spreekt in eerste instantie niet van een eigenbelang, maar van sociale doeleinden: "ideology is a set of ideas promulgated in order to promote a social objective" $(1988 \mathrm{a}, 211)$. Deze omschrijving laat in het midden of een ideologie wordt gerechtvaardigd met behulp van prudentiële overwegingen of door middel van sociale en morele argumenten. Dat wordt anders wanneer hij het begrip in verband brengt met beroepen en professies: "... professional ideology consists of ideas about professions, professionals and professionalism to which an occupational group appeals to mobilize its members and appeals to those in positions of power, in order to gain or retain the control over the market for their services and the social standing which recognized professions enjoy" (1988b, 413). Deze omschrijving van ideologie staat duidelijk meer in lijn met die van De Jager en Mok. Prudentiële overwegingen overheersen en voorzover er sprake is van sociale doeleinden worden zij door deze overvleugeld (dit was ook reeds de opvatting van Mannheim, die hiermee ideologie onderscheidde van utopie; zie Spranger in Lieber 1976, 150). Hiermee wordt min of meer uitgesloten, dat morele overwegingen het 'Leitmotiv' achter een ideologie kunnen vormen, hetgeen wij boven overigens hebben tegengesproken. (Wie uitvoerig ingelicht wil worden over het ideologiebegrip en zijn historische wortels en wetenschapssociologische connotaties wordt verwezen naar Lieber 1976 en Zizek 1989).

Het verschijnsel ideologie wordt derhalve door Kultgen geheel binnen de prudentiële en sociale sfeer en buiten de morele gehouden, welke sferen in een soort geforceerde tegenstelling tot elkaar worden gebracht. In zijn eerder genoemde analyse van beroepscodes in 
de private en bedrijfssector worden ideologieên geplaatst in het kader van de sociale functie(s) van beroep(sgroep)en en morele overwegingen in het kader van hun humane functies. In deze analyse hanteert hij een zogenaamde 'consequentialistische strategie', die in de context van de sociale functies van een beroep inhoudt, dat de actuele effecten worden bestudeerd die een verklaring bieden voor her bestaan van regels, praktijken en instituties (1988a, 210-211).

Zoals wij ten aanzien van de codes van de ICN, ANA, UKCC en NMV reeds constateerden is ook Kultgen van mening, dat beroepscodes een duidelijk moreel stempel hebben. Sociale functies die hiermee in tegenspraak zijn, kunnen slechts onder de oppervlakte en schijnwereld van de 'morele retoriek' worden herkend (1988a, 211). Hiervoor is nodig dat een 'hermeneutic hurdle' wordt genomen (218). Een geschikt instrument om deze horde te overwinnen biedt de semiotiek. De codes dienen volgens hem dan te worden geanalyseerd op de volgende drie aspecten:

1. De semantische kenmerken van de tekst (helderheid, nauwkeurigheid en eenduidigheid van afzonderlijke woorden en zinnen).

2. De logische structuur van de tekst (consistentie van bepalingen, sterkte van hun onderlinge verhoudingen, aanwezigheid van prioriteiten, noodzaak van additionele postulaten, helderheid van structuur).

3. De context van vooronderstellingen die de interpretatie van de tekst sturen (waarden en overtuigingen waaraan door lezers een bepaald belang wordt gehecht) (219).

Beroepscodes die beantwoorden aan deze semiotische vereisten, bezitten een duidelijke morele én sociale functie. De sociale functie is dan niet verscholen achter morele retoriek. Zo wordt ook de ideologie duidelijk voor het voetlicht gebracht.

Hoe zit dat met de codes van de ICN, ANA, UKCC en NMV? Vooraf moet worden gesteld, dat de aanpak van Kultgen geschikt is om deze vraag te beantwoorden. Immers, zij is gebaseerd op een analyse van de inhoud van de codes zelf en niet op het feitelijk functioneren ervan binnen de beroepsgroep en samenleving. Ten aanzien van dit laatste hebben wij, zoais meermalen naar voren gebracht, weinig gegevens (zie echter het slot van deze paragraaf en paragraaf 4.5).

Wanneer we dan de genoemde semiotische aspecten in chronologische volgorde behandelen, dan kunnen duidelijk vraagtekens worden gezet bij de semantische kenmerken van de teksten. Er is in hoge mate sprake van abstracte terminologie die tot vaagheid in begripsvorming aanleiding geeft. Centrale begrippen als 'ethiek', 'waardigheid', 'mensenrechten', 'verpleegkundige' en 'patiënt' worden niet expliciet gedefinieerd. Vanuit principieel-positivistisch oogpunt bezien ligt in een hoog abstractieniveau weliswaar hum kracht, maar de afwezigheid van definities stelt ons niettemin voor problemen ten aanzien van hun betekenis. Bij de afwezigheid van expliciete definities kan dan hoogstens worden nagegaan in hoeverre zij uit de bepalingen van de codes zelf kunnen worden afgeleid, dus in hoeverre er contextuele definities kunnen worden opgesteld. Zelf hebben we bijwoorbeeld een dergelijke operatie uitgevoerd ten aanzien van het begrip 'dienstbaarheid' (zie 4.4.3).

Contextuele definities zijn in de praktijk moeilijk hanteerbaar, want zij berusten op interpretatie. En het voorkómen van interpretatieverschillen is nu juist weer een belangrijke functie van expliciete (formele en operationele) definities. Interpretatieverschillen leiden tot 'een verschillend begrip bij degenen tot wie de code is gericht en derhalve tot een gro- 
te diversiteit in potentiele handelingsaanwijzingen. Bijvoorbeeld 'respect voor leven' laat interpretaties open als 'respect voor leven als zodanig' en 'respect voor een bepaalde kwaliteit van leven'. Deze leiden naar hun aard tot geheel verschillende handelingsaanwijzingen: een verbod op euthanasie respectievelijk een plicht in sommige gevallen op een verzoek tot euthanasie van een patiënt in te gaan. In een contextuele definitie van het begrip zou weliswaar kunnen worden opgenomen, dat het hier vooral gaat om een levensbegrip volgens de eigen opvatting van patiënten, maar dan blijft weer impliciet waar aan deze opvattingen een grens mag of moet worden gesteld vanuit de eisen van het vakgebied of de opvattingen van haar beoefenaars. Met het aanbieden van mogelijkheden tot het uiten en effectueren van gewetensbezwaren (zie NMV-code) is men er niet uit, want wat is een gewetensbezwaar en welke maatstaven legt men dan aan (zie ook 5.3.4)? Met dit ene voorbeeld is geschetst hoe het gebruik van sommige begrippen op grond van hun abstractieniveau tot een bepaalde vorm van onduidelijkheid en vaagheid aanleiding kan geven. Vergelijkbare begrippen komen in de onderhavige codes veelvuldig voor, zonder te worden begeleid door een nauwkeurige omschrijving of afbakening. We kunnen geen uitspraak doen over de vraag of deze onduidelijkheid en vaagheid welbewrust in de codes zijn aangebracht. Overigens zou Toren $(1969,144)$ hierop waarschijnlijk bevestigend antwoorden. In ieder geval dienen ze wél een ideologisch nut. Juist door hun hoog abstractieniveau kunnen ze door het overgrote deel van een (verdeelde) beroepsgroep en samenleving worden geaccepteerd en wordt de illusie van eenheid bewaard. Echter, dit abstractieniveau versterkt de prudentiële aspecten van codes: de lezer kan op deze wijze worden overtuigd van de hoge morele standaard van het beroep en de beoefenaars ervan, zonder hen al te duidelijke verplichtingen op te leggen.

Een dergelijk effect kan nog worden versterkt door onvolkomenheden in de logische structuur van teksten, welke het tweede semiotische aspect was. Ten aanzien van dit aspect lijken de codes op het eerste gezicht redelijk te voldoen. In alle codes is een preambule of eerste sectie aanwezig waarin de grote lijnen van de code worden uitgezet en prioriteiten in te hanteren waarden en normen worden voorgehouden. Bovendien zijn de afzonderlijke bepalingen of plichten in sommige codes ook nog eens geclassificeerd in bepaalde categorieën, zodat duidelijk moet zijn ten opzichte van wie de desbetreffende plichten gelden. Welke samenhang tussen prioriteiten en afzonderlijke plichten en tussen categorieën en afzonderlijke plichten onderling bestaat, is echter veel minder duidelijk. Deze kan hoogstens worden ontleend aan de toelichting bij sommige codes, maar ook deze scheppen meestal meer verwarring dan duidelijkheid en zullen bovendien slechts in tweede instantie door een geïnteresseerde worden gelezen.

De problemen in de logische structuur van de codes zijn van velerlei aard:

1. De categorisering van bepalingen en plichten in de ICN-en NMV-code hangt grotendeels in het luchtledige, omdat zij niet rechtstreeks voortvloeit uit de preambule of uitgangspunten van de code. In de ANA- en UKCC-code is aan de mogelijkheid van categorisering zelfs geheel voorbijgegaan. Bovendien is niet inzichtelijk gemaakt waarom bepaalde plichten onder de ene categorie zijn geplaatst, terwijl ze evident ook in een andere categorie passen (bijvoorbeeld het merendeel van de plichten in de categorie 'samenleving' in de NMV-code kan zonder bezwaar in de categorie 'patiënt' worden geplaatst).

2. De prioritering van basale noties en uitgangspunten blijft impliciet of is inconsistent. $\mathrm{Zo}$ is onduidelijk welke de relatie precies is tussen het bevorderen van gezondheid en 
het eerbiedigen van mensenrechten (zie bijvoorbeeld de ICN-code; een uitzondering hierop vormt de ANA-code). En het benaderen van een patiënt zonder onderscheid des persoons kan gemakkelijk in conflict komen met het respect voor diens opvattingen over leven, lijden, ziekte en dood, indien althans de grens tussen beide niet wordt verhelderd (zie bijwoorbeeld de NMV-code). Deze constateringen doen vermoeden, dat de beroepscodes een intern waardenconflict bevatten. Het opvolgen van de ene norm zal in sommige gevallen het afzwakken, negeren of zelfs overtreden van een andere norm impliceren. Hoewel dit gedeeltelijk samenhangt met de interpretatie van die normen (zie bijvoorbeeld het beslissingsprobleem dat in 5.2.1 wordt uitgewerkt), kan toch in het algemeen worden gesteld, dat door een verpleegkundige onmogelijk aan alle normen tegelijk kan worden tegemoetgekomen. Dat hier sprake is van een intern waardenconflict lijkt verder te worden bevestigd door de onduidelijkheden die hierna sub 4 en sub 5 worden beschreven.

3. De sequuentie van (categorieën) bepalingen en plichten is onlogisch. De volgorde van de categorieẽn is nogal willekeurig en vindt geen grond in de gestelde of impliciete prioriteiten (zie vooral de ICN-code). Duidelijk is slechts dat op grond van deze Jaatste de bepalingen en plichten ten opzichte van patiënten en cliënten voorop dienen te staan en dat daar ook rekening mee is gehouden. Maar dat bijvoorbeeld de bevordering van professionele competentie voorafgaat aan het respect voor de gewoonten, waarden en overtuigingen van patiënten (zie de UKCC-code), doet in dit verband wat vreemd aan.

4. Er is een belangrijk dekkingsprobleem aanwezig. Het respecteren van mensenrechten en het bevorderen van gezondheid laten onverlet, dat ook verpleegkundigen bepaalde rechten hebben, waaronder het behoud van gezondheid. Nergens in de codes wordt echter expliciet een grens gesteld aan de opofferingen en loyaliteit waartoe verpleegkundigen ten opzichte van patiënten zijn gehouden. Het mogen uiten en effectueren van gewetensbezwaren en het rekening houden met de beperkingen van de eigen competentie staan meestal in een andere context en vermogen het dekkingsprobleem slechts via een omweg en marginaal op te lossen. Een ander dekkingsprobleem betreft het feit, dat verpleegkundige activiteiten veelal in een institutionele context plaatsvinden. Plichten (en rechten) ten aanzien van instellingen en werkgevers worden echter slechts zelden en minimaal aan de orde gesteld.

5. De relatie tussen verschillende concepten en plichten blijft impliciet. Ten aanzien van de relatie tussen de morele plichten en de wettelijke verplichtingen van een verpleegkundige wordt nergens duidelijk hoe hun onderlinge verhouding precies moet worden gezien. Deze constatering is onderdeel van een groter probleem, namelijk welk standpunt moet worden ingenomen ten aanzien van de relatie tussen morele en nonmorele principes, waarden en verplichtingen. Ook dit komt vrijwel nergens ter sprake (alleen de ANA-code lijkt een prioriteit aan te geven voor het morele). Een zelfde probleem doemt op wanneer we de codes onderzoeken op de aanwezigheid van een ordeningsprincipe voor morele oordeelsvorming. Er lijkt een mengeling aanwezig van zowel deontologische als teleologische principes, zonder dat een keuze voor één van beide typen wordt geẻxpliciteerd (ook hierop vormt de ANA-code een uitzondering; zie ook 4.4.3). 
De beroepscodes voor verpleegkundigen bezitten dus in het algemeen een zwakke logische structuur die voeding geeft aan een imago van abstractheid en vaagheid, waardoor de ideologische functie van de codes wordt versterkt.

Ook de vooronderstellingen achter en geïmpliceerd in de codes -het derde semiotische aspect- geven aanleiding tot enige opmerkingen. Deze hangen nauw samen met de semantische kenmerken van de codes. Op de eerste plaats moet worden geconstateerd, dat de beroepscodes een quasi-beschrijving leveren van de verpleegkundige werkelijkheid van alledag. In het hanteren van een op vakjargon gebaseerde terminologie wordt gesproken van 'professioneel gedrag' en 'professionele verantwoordelijkheden', alsof dit voor iedereen direct inzichtelijke begrippen zijn.

Hiermee stemt een tweede opmerking overeen, namelijk dat 'professie' geen ongedeeld begrip is. De beroepscodes wekken de indruk dat de verpleegkundige professie éen groot, geïntegreerd geheel is en ze versterken deze indruk door te spreken in het singuliere 'de verpleegkundige', 'nursing', en dergelijke. Door deze voorstelling van zaken wordt het publiek op het verkeerde been gezet. Het verwacht te maken te hebben met een krachtige groep die goed in staat is zijn eigen boontjes te doppen en de eigen leden in het gareel te houden en kan derhalve aan deze groep met een gerust hart een grote mate van autonomie verlenen en vertrouwen schenken. De werkelijkheid is anders. Een 'professie' als verpleegkunde is de dekmantel voor een bonte verzameling beroepsbeoefenaren met velerlei aspiraties en velerlei beroepsbeelden en vaak begiftigd met weinig macht en een wankele opleidingssituatie (zie de paragrafen 2.4). Zodoende is tevens de in de codes gewekte vooronderstelling, dat er binnen de beroepsgroep consensus zou bestaan over de aard van het beroep en zijn verplichtingen ten opzichte van patiënt en publiek, volledig op drijfzand gebouwd (codes kunnen overigens tot zo'n consensus wel een bijdrage leveren). Bovendien geldt voor sommige codes, dat zij alleen onderschreven en/of voorgeschreven zijn ten aanzien van een (zeer) beperkt deel van de beroepsgroep, namelijk zij die lid zijn van de (vak)organisatie die de code naar buiten bracht (dit geldt onder andere voor de NMV-code).

Onder de vlag van 'dienstbaarheid' gaan vele zaken schuil die verwijzen naar een ideologisch gehalte van de beroepscodes. Er zijn vele uitgangspunten en verplichtingen in de codes aan te wijzen die het eigenbelang en onrealistische doeleinden van de beroepsgroep (kunnen) dienen, maar met morele retoriek zijn omgeven (vergelijk ook Freidson 1970, 79 en 185; Mungham/Thomas 1983, 132 en 149). Aldus wordt bijgedragen aan de opbouw en instandhouding van bepaalde mythes. Het zijn een soort verdichtsels of ficties die, als ze maar vaak genoeg naar voren worden gebracht, de overlevering en traditie van een samenleving zodanig gaan beïnvloeden dat ze als een deel van de werkelijkheid worden beschouwd.

Kultgen heeft op basis van gegevens uit vele empirische studies een aantal van deze mythes ontmaskerd. Het concept 'mythe' wordt door hem gebruikt "... in its dictionary sense of an ostensibly historical narrative of obscure origin that explains practices, beliefs and institutions. The term carries over from its theological use the notion that a myth supports mores of a group and reinforces communal life" (Kultgen 1988b, 120). Het concept is aldus nauw verwant aan zijn begrip van 'ideologie'. Zowel mythes als ideologieën zijn idealisaties gericht op groepscohesie. Om ze niettemin van elkaar te onderscheiden zouden ze kunnen worden aangeduid als reconstructies respectievelijk constructies van 
warheid en werkellijkheid. Als typen van dergelijke ideele reconstructies bij beroepen noemt Kulitgen (1988b, 417-418):

1. De mythe van onafhankelijkheid.

2. De mythe van altruisme.

3. De mythe van zelfregulering.

4. De mythe van deskundigheid.

Op grond van onze eigen analyse kunnen daaraan nog worden toegevoegd:

5. De mythe van eenheid.

6. De mythe van alles tegelijk?.

7. De mythe van morele omnivalentie.

Aan al deze mythes wordt voedsel gegeven doot de beroepscodes van de ICN, ANA, UKCC en NMV.

Met betrekking tot de mythe van onafhankelijkheid hebben wij zelf reeds elders een realiteit van afhankelijkheid aangetoond, ook ten aanzien van morele besluitvorming (Van der Arend 1988; vergelijk ook de paragrafen 2.4). Veel artikelen in de codes postuleren een mate wan zelfstandige besluitvorming door verpleegkundigen, die zij in het geheel niet bezitten. Verpleegkundigen zijn in het algemeen in dienstverband werkzaam en verkeren in een positie waarbij veel beslissingen van bovenaf in de hiërarchie of geheel buiten hen om worden genomen (vergelijk Davis/Aroskar 1978, 35-42). Rechten en privileges van verpleegkundigen maken dan ook deel uit van de mythevorming.

De mythe van altruisme is in de codes overduidelijk aanwezig in het primaat van dienstbaarheid aan de belangen van patiënten/cliënten en de samenleving. Verpleegkundigen zijn echter in de regel doodgewone mensen, weliswaar misschilen begiftigd met hoge idlealen van medemenselijkheid, maar niettemin mensen die werken om te voorzien in hun middelen van bestaan. Het is zeer onwaarschijnlijk dat verpleegkundigen werkelijk voortdurend aan de belangen van patiënten en het publiek denken. De intrinsieke waarde van hun werk is geen garantie voor voortdurende persoonlijke dienstbaarheid aan het gemeenschapsbelang (vergelijk ook Mungham/Thomas 1983, 132 en 149). Opwaartse mobiliteit en carrières komen ook bij verpleegkundigen niet tot stand door uitdrukkelijk het belang van de patiënt te dienen of de reputatie van het beroep hoog te houden, maar vereisen soms ordinair ellebogenwerk en meer in het algemeen een zich verwijderen van het ziekbed waarin het belang van de patiënt het meest duidelijk aanwezig is en kan worden gediend. Bedacht moet worden, dat ook verpleegkundigen niet altijd hoogstaande en verheven activiteiten verrichten, maar dat ze gewone taken en functies vervullen als vaak positief te duiden uitvloeisel van bureaucratiserings- en institutionaliseringsprocessen.

De mythe van zelfregulering wordt krachtig gevoed door verpleegkundigen aan te sporen fouten, ongevallen en misstanden te melden die door collega's of anderszins zijn veroorzaakt. Verder dienen zij collega's te steunen bij het voldoen aan de codeverplichtingen, onder andere ten aanzien van het bijhouden en verbeteren van hun deskundigheid. Verpleegkundigen worden in het algemeen ook gezien als degenen die het best in staat zijn te beoordelen of verpleegkundige taken naar behoren zijn uitgevoerd. Voor dergelijke vormen van zelfregulering is echter nodig, dat verpleegkundigen in hoge mate en nauwkeurig zijn geïnformeerd. In vele rollen en functies mag dat echter een illusie worden genoemd. Bovendien is er een belangrijk sociaal-psychologisch mechanisme werkzaam ('collegialiteit'), dat ervoor zorgt, dat verpleegkundigen niet zo snel aan de bel zullen trekken of advocaat van de duivel gaan spelen, als zij althans hun werk nog met veel 
vreugde en ongehinderd door persoonlijke conflicten willen blijven doen. Bekend is bijvoorbeeld het geringe aantal meldingen van fouten, ongevallen en bijna-ongevallen dat de daartoe in het leven geroepen instellingscommissies bereikt (Van de Elzen 1985, 111). Men mag veronderstellen dat het werkelijke aantal fouten en ongevallen vele malen hoger ligt. Dit zou betekenen dat men alleen iets meldt wanneer men er letterlijk niet meer omheen kan: wanneer men iets ziet gebeuren of wanneer men zelf gezien wordt. De rest wordt vergeten.

De mythes van deskundigheid en eenheid worden hoog gehouden door in de codes niet te differentiëren naar sectoren, rollen en functies waarin verpleegkundigen werkzaam zijn. De verpleegkundige met een zeer specialistische opleiding en werkzaam op de intensive care unit bezit een geheel anderssoortige deskundigheid dan de verpleegkundige die jarenlang de kwaliteit en criteria bewaakt waaraan de bedden en andere hulpmiddelen in een ziekenhuis moeten voldoen. $\mathrm{Zij}$ voldoen al lang niet meer aan een breed en algemeen geformuleerd criterium van deskundigheid en eenheid. De mythe van eenheid die in de codes zo duidelijk aanwezig is (zie boven), wordt met andere woorden weersproken door de verregaande mate van segmentering waaraan ook het beroep van verpleegkundige onderhevig is. Voortgaande arbeidsverdeling (specialisaties), grote verschillen in de mate van autonome beroepsuitoefening (vergelijk de verpleging in ziekenhuizen met wijkverpleging en ambulanceverpleging), diversiteit in afnemersgroepen (cardiochirurgische verpleging versus moederschapszorg voor allochtonen), een richtingenstrijd ten aanzien van theoretische en praktische domeinafbakeningen en zeer uiteenlopende opleidingsniveaus bepalen de gang van zaken en leiden tot een grote variatie in belangengroeperingen (vergelijk Goode 1969, 293; Hammenga 1990, 442-443).

De mythe van 'alles tegelijk' verwijst naar het eerder geschetste interne waardenconflict dat een handelen volgens de beroepscodes kan blootleggen. Men gaat er vanuit, dat een beroepsbeoefenaar op elk moment en ten aanzien van al diens handelen de bepalingen uit een code kan volgen. Bovendien wordt dit van toepassing geacht op alle beroepsbeoefenaars. Een dergelijke opvatting is echter evident bezijden de waarheid. Argumenten daarvoor kunnen deels worden ontleend aan hetgeen boven werd gesteld ten aanzien van de mythe van eenheid. Een verpleegkundige 'aan het bed', zonder verdere scholing, is eenvoudig niet in de positie om bijvoorbeeld te voldoen aan de bepaling in de NMVcode (art. 4.5 en 4.6) dat moet worden bijgedragen aan de ontwikkeling van nieuwe inzichten ter verbetering van de volksgezondheid en dat de resultaten van verpleegkundig onderzoek tijdig bekend moeten worden gemaakt. En verkeert men wél in die positie, dan is de vraag of met het nakomen van genoemde bepalingen het belang van de patiënt met een actuele verpleegbehoefte is gediend (art. 2.1).

De mythe van morele omnivalentie, tenslotte, is een verwoording van de impliciete verwachting, dat iedere verpleegkundige de code(s) kent en zich altijd en overal met de ethische aspecten van de beroepsuitoefening bezighoudt. Dit laatste is uiterst dubieus, alleen al op grond van hetgeen boven werd gesteld ten aanzien van de mythe van altruïsme. Bovendien kan het als een nogal triviale bezigheid worden beschouwd wanneer men een bed opmaakt, een patiënt helpt bij het eten of het nachtrapport opmaakt. Ook de bekendheid met een beroepscode is onder verpleegkundigen, althans in Nederland (maar ook in Groot Brittannië; zie 4.3.4), bijzonder laag (Van den Hurk 1991, 18 en 27).

De kracht van mythevorming kan zijn, dat zij idealen voorhoudt waaraan men zich in zijn gedrag kan oriënteren. Als zodanig kan een mythe de groepsbinding bevorderen en de 
idee van eenheid in verscheidenheid helpen realiseren. Een mythe is dan ook niet alleen richtinggevend voor het individuele gedrag van beroepsbeoefenaars, maar speelt tevens een rol op groepsniveau. Voorzover de aspiraties van beroepsgroepen op dit niveau als sociaal goed zijn gelegitimeerd zal er echter minder sprake zijn van de proclamatie van mythes. Voor een beoordeling daarvan moeten beide niveaus dan ook duidelijk worden onderscheiden. Want pas in het individuele gedrag van beroepsbeoefenaars openbaart zich de realiteitswaarde van groepsgerichte claims en doelstellingen. Naargelang van deze realiteitswaarde kunnen we besluiten tot het mythische karakter van deze claims en doelstellingen, zoals boven duidelijk naar voren kwam bij onze beschrijving van bijvoorbeeld de mythes van eenheid en alles tegelijk.

\subsection{Functies van de codes}

Voorgaande anialyses kunnen nu een reconstructie opleveren van de functies van de beroepscodes. We zouden deze kunnen samenvatten onder de noemer 'dienstbaarheidsfuncties van beroepscodes'. In figuur 4.6 zijn deze functies genoemd en naar een aantal formele aspecten onderscheiden.

Figuur 4.6: Functies en aspecten van 'dienstbaarheid'

\begin{tabular}{|c|c|c|}
\hline aard & moreel & ideologisch \\
\hline beoogde groep & vooral intern gericht & vooral extern gericht \\
\hline doel & verpleegkundigen & $\begin{array}{c}\text { niet-verpleegkundigen } \\
\text { (samenleving, } \\
\text { beroepsgroepen, recruten) }\end{array}$ \\
\hline middel & $\begin{array}{c}\text { morele besluitvorming en } \\
\text { praktijk van } \\
\text { verpleegkundigen (t.b.v. } \\
\text { algemeen belang) }\end{array}$ & $\begin{array}{c}\text { sociale acceptatie, } \\
\text { waardering, status, } \\
\text { privileges (t.b.v. het } \\
\text { eigenbelang) }\end{array}$ \\
\hline & $\begin{array}{c}\text { morele principes, waarden, } \\
\text { normen (morele raadgeving } \\
\text { en toetsing) }\end{array}$ & $\begin{array}{c}\text { idealen, mythen, } \\
\text { beeldvorming, manipulatie) }\end{array}$ \\
\hline
\end{tabular}

De primaire functie van beroepscodes is van morele aard. De ideologische functie is daar min of meer van afgeleid. Nauwkeuriger geformuleerd: naarmate de semiotische kenmerken van beroepscodes en de daarin vervatte uitgangspunten, doeleinden en morele principes, waarden en normen wijzen op abstracties en/of vaagheden, inconsistenties en/of vooronderstellingen die een interpretatie in termen van eigenbelang en zelfbescherming mogelijk maken, naar die mate kunnen (zullen) beroepscodes een ideologische functie vervullen.

De morele functie is vooral gericht op de eigen leden van de beroepsgroep. Het betreft dus een interne functie. Door middel van schriftelijke uitgangspunten, morele principes, waarden en normen wordt verpleegkundigen een spiegel voorgehouden met betrekking 
tot het eigen en moreel ideaaltypisch handelen, opdat vorm wordt gegeven aan adequate morele besluitvorming en een moreel verantwoorde praktijkvoering.

De ideologische functie is vooral extern gericht en wel op diverse groepen niet-verpleegkundigen in de samenleving: het publiek in het algemeen (waaronder patienten), aanverwante beroepsgroepen en zij die overwegen verpleegkundige te worden. Door het bewust of onbewust presenteren van idealen, mythen en vanzelfsprekendheden met betrekking tot de rol van verpleegkundigen binnen het beroep en van het beroep zelf in de samenleving, worden sociale acceptatie, waardering, status en privileges geoogst die in overeenstemming zijn met het belang van de beroepsgroep. Patiënten worden op hun gemak gesteld door te verwijzen naar het primaat van hun belangen. Aan de samenleving wordt lippendienst bewezen door belangrijke sociale waarden te bekrachtigen. Beroepsgroepen en -beoefenaren waarmee de verpleegkundige relaties onderhoudt wordt een 'worst' van samenwerking en deskundigheid voorgehouden. En degenen die overwegen de verpleging als hun arbeidsterrein te kiezen zullen verheugd zijn hun ideaalbeeld van medemenselijkheid en dienstbaarheid in de codes zo krachtig te zien bevestigd.

De mate waarin de beroepscodes deze functies inderdaad vervullen hangt van diverse factoren af. We noemen er hier enkelle. Op de eerste plaats hangt zij uiteraard af van de bekendheid van verpleegkundigen en niet-verpleegkundigen met de inhoud van beroepscodes. Hiermee lijkt het droevig te zijn gesteld (zie boven). Hoe weinig is er dan te verwachten van de bekendheid bij het publiek, patiënten en verwante beroepsgroepen! Als tweede factor moet worden genoemd de mate van realisme, gedetailleerdheid, volledigheid, helderheid en consistentie van de codes, hetgeen ook al uit onze analyse in 4.4 .3 en 4.4.4 naar voren kwam. Dergelijke vereisten vergen qua omvang zeer uitgebreide codes die niet voor meer dan één interpretatie vatbaar zijn, waarin professionele normen duidelijk worden onderscheiden van morele normen en de rechten en belangen van patiënten duidelijk worden afgebakend ten opzichte van die van de samenleving en van de verpleegkundige (zie ook Blair/Rubin 1980, VII). Wordt aan deze vereisten niet voldaan dan zal de morele functie van een code verkeren in het tegendeel, zijn ideologische functie. Beide functies kunnen aan de onderhavige codes worden onderkend en maken deel uit van de beroepscultuur.

Ten derde is van belang in hoeverre instanties of verpleegkundigen zelf de interpretatie van de code sturen en controle uitoefenen op de naleving ervan. Volgens Toren (1969, 171) vormt dit element een uiterst zwakke schakel in het gebruik wan beroepscodes. Ook Freidson (1970, 157 en 185) noemt een aantal bedenkingen. Controle op naleving is overigens wél in sommige codes onderschreven als een belangrijke plicht van verpleegkundigen. Een belangrijke vraag is hierbij echter in hoeverre de naleving van bepalingen uit een code kan worden afgedwongen. Rubin $(1980,37)$ stelt dit zelfs als eis. In het algemeen kunnen morele normen echter niet worden afgedwongen, tenzij zij onderwerp zijn van geldend recht. Controle op de naleving van codes is dan ook hoofdzakelijk georganiseerd in een of andere vorm van tuchtrecht (of vormen van socialisatie of sociale druk), zoals het geval is met de UKCC-code, maar bijwoorbeeld (nog) niet met de NMV-code. Op grond van dit tuchtrecht zou men ook voor een semi-wettelijke functie van beroepscodes kunnen pleiten. Overigens is Haug $(1980,64)$ hier fel op tegen, terwijl Van der Krogt $(1981,124)$ hiervan juist weer een voorstander lijkt te zijn. Op deze wettelijke functie van beroepscodes komen we in het volgende hoofdstuk nog uitgebreid terug (zie 5.3.5). 
Een laatste factor die we hier willen noemen betreft het geldingsgebied van de beroepscodes. De code van de UKCC is als onderdeel van het tuchtrecht voor verpleegkundigen in Groot Brittannië onder de algemene werking van de wet gebracht en geldt daarmee voor alle (van overheidswege geregistreerde) verpleegkundigen. In Nederland kennen we een dergelijke constitutieve registratie (nog) niet. De NMV-code is daarnaast een verenigingsdocument. Hij kan dus hoogstens onderwerp van verenigingsrecht zijn. Alleen leden van de NMV zijn gehouden aan de in de code geformuleerde plichten. Het aantal leden is slechts een fractie van de totale populatie verpleegkundigen in Nederland. De code maakt dat echter op geen enkele wijze duidelijk. Dit feit op zichzelf geeft een extra dimensie aan de ideologische functie van de NMV-code, terwijl de morele functie van de UKCC-code juist wordt overschaduwd door zijn wettelijke functie. 


\section{PROFESSIONALISERING}

\subsection{Inleiding}

In dit hoofdstuk zal worden getracht een antwoord te formuleren op de subvragen 3 en 5 en op het laatste gedeelte van subvraag 4 van onze vraagstelling, zoals naar voren gebracht aan het slot van hoofdstuk 3. Daarin werd de vraag gesteld naar de rechtvaardiging van de in beroepscodes aanbevolen normen en naar de aanvaardbaarheid van een in samenhang hiermee aangebrachte hiërarchisering van die normen, zoals in hoofdstuk 4 naar voren gebracht. De behandeling van deze vraag biedt tevens mogelijkheden tot het plaatsen van morele kanttekeningen bij processen van professionalisering of aspiraties daartoe.

Voor onze beschouwing over de rechtvaardiging van de normen uit beroepscodes wordt geput uit de sociologische en morele posities die werden beschreven in 3.2. Zij bieden het kader voor een theoretische en normatieve plaatsbepaling van beroepscodes in het algemeen en beroepsgebonden normen in het bijzonder. Bij de invulling van dit kader wordt aangesloten bij de waardetheorie van Vos (1989), die vanuit een meta-ethische combinatie van cognitivistische en noncognitivistische posities een pluralistisch normatief-ethisch kader opbouwt waarin noties van algemene morele verplichting ten diepste worden gelegitimeerd door hun correspondentie met en uitdrukking van morele waarden (vergelijk ons terminologisch kader in figuur 3.1).

De resultaten van onze beschouwing zullen bovendien licht werpen op de formele en inhoudelijke mogelijkheden tot het centraal stellen van specifieke waarden en normen en tot hierrarchisering van waarden en normen überhaupt. In 4.4.3 hebben we reeds kennis gemaakt met een dergelijke hiërarchisering op grond van onze anallyse van de beroepscodes van de ICN, ANA, UKCC en NMV. De vraag is nu of de daarin geïdentificeerde centrale waarde dienstbaarheid terecht als primair na te volgen waarde aan verpleegkundigen wordt voorgehouden. Daartoe zal echter worden geconcludeerd, dat dienstbaarheid uitdrukkelijk in de context moet worden gezien van centrale maatschappelijke en morele waarden.

Het voorgaande is onderwerp van bespreking in de paragrafen 5.2. Zij monden uit in een beschouwing van de morele status van beroepscodes en in de formulering van een aantal problemen die vanuit sociaal-ethisch perspectief met de proclamatie en toepassing van beroepscodes zijn gegeven. Deze problemen vormen onderwerp van bespreking in de paragrafen 5.3. Daarin zal blijken, dat het juist deze problemen zijn, die beroepscodes een lage morele status bezorgen. Uiteraard concentreren we ons daarbij voornamelijk op de in hoofdstuk 4 geanalyseerde codes voor verpleegkundigen, maar waar mogelijk zullen de bevindingen en conclusies worden doorgetrokken naar andere terreinen van beroepsmatig verrichte arbeid.

De morele consequenties van een en ander voor professionaliseringsprocessen zullen aan de orde komen in paragraaf 5.4. Het focus wordt daarbij gericht op de machtsbenadering 
wit hoofdstuk 2. Onze kritiek zal in hoofdzaak bestaan wit een morele diskwalificatie van impliciete instrumentalistische en prudentiele opvattingen als gevolg wan de machtsbenadering, de potentiele neiging tot een amoraliseringsstrategie en de veronachtzaming van het inherente morele karakter van beroepsuitoefening en beroepsbeoefenaren.

\subsection{Ethiek, beroepsethiek en beroepscodes}

Zoals reeds wele malen naar voren is gebracht, vervullen beroepscodes en de daarin vervatte principes, waarden en normen een bepaalde morele functie. Deze functie krijgt gestalte op geleide van de interpretatie die wordt gehecht aan enerzijds de rol van beroepscodes binnen de activiteiten van beroepsgroepen in een maatschappelijke context en anderzijds de afzonderlijke bepalingen in beroepscodes en de prioriteiten die daarbinnen kunnen worden aangegeven. Dat deze interpretatie van belang is en tot uiteenlopende opvattingen aanleiding kan geven, is in 4.4.3 uitvoerig toegelicht aan de hand van een semiotische analyse van de beroepscodes van de ICN, ANA, UKCC en NMV.

Beide aspecten, zowel als morele interpretaties in het algemeen, hangen ten nauwste samen met meta-ethische en normatief-ethische inzichten en posities. Zo zal een naturalistische teleologisch-ethische zienswijze tot geheel andere conclusies leiden ten aanzien van de betekenis van een beroepscode en zijn normen dan een noncognitivistische deontologisch-ethische zienswijze (vergelijk 3.2.2). In het laatste geval zullen de code en zijn normen bijvoorbeeld worden opgevat en beoordeeld als rationeel verdedigbaar geheel van preferentiële morele verplichtingen van een beroepsgroep en haar leden. In een naturalistische teleologisch-ethische zienswijze daarentegen zullen de code en zijn normen worden opgevat en beoordeeld naar de mate waarin zij verwijzen naar en voldoen aan in de empirie aanwijsbare doelstellingen en waarden.

De morele functie van beroepscodes en hun normen kan dus niet los worden gezien van het soort rechtvaardiging en het type argumenten dat kan worden aangevoerd voor hun bestaan. Deze verlenen beroepscodes een bepaalde morele status, waarvan hun functie als het ware een afgeleide is (of beter: behoort te zijn). Het is deze morele status waarom het ons in de paragrafen 5.2 te doen is. Voor alle duidelijkheid: hier wordt niet het in de sociologie gebruikte begrip bedoeld. Het gaat ons veeleer om de 'ontologische status' van beroepscodes en zijn 'gevolgen voor de praktijk' (deze betekenis wordt ontleend aan Kuitert 1990, 106). Met andere woorden: we willen weten wat de zijnswaarde van beroepscodes is en of deze van dien aard is dat bepaalde morele gedragsregels in acht moeten worden genomen. Aan het bezit van een bepaalde status zijn dan morele consequenties verbonden die de beroepsgroep als geheel en beroepsbeoefenaren in het bijzonder binden aan bijzondere vormen van verantwoordelijkheid en bejegening.

De morele status van beroepscodes zal in het onderstaande worden toegelicht aan de hand wan een analyse van de status van beroepsethische principes, waarden en normen in het geheel van maatschappelijk aanvaarde en moreel te verdedigen stellingnames. Deze laatste vormen onderwerp van bespreking in de eerste, nu volgendle paragraaf. Daarin zal een schets worden geboden van het meta-ethische en normatief-ethische kader waarbinnen speciale morele noties, zoals in een beroepsethisch perspectief meestal worden geboden, hun plaats krijgen. We hopen aan te tonen, dat een waarden-theoretisch perspectief een adequaat referentiekader biedt voor een nadere bepaling van de morele status 
van beroepsethische opvattingen in het algemeen en van die van beroepscodes en hun normen in het bijzonder. Vooruitlopend op de conclusies uit deze beschouwing, wordt mu reeds gesteld, dat de door beroepsgroepen en anderen veronderstelde en door Barnsley geïdentificeerde (zie 3.2.1) superioriteit en legitimiteit van beroepsgebonden morele claims onvoldoende rechtvaardiging vinden in theoretisch-praktische noties met betrekking tot een moreel adequaat functioneren van mens en samenleving en dat derhalve de morele status van beroepsethische opvatingen en beroepscodes gering is.

\subsubsection{Meta-ethisch en normatief-ethisch kader}

Dienstbaarheid is in het kader van onze bespreking van professionaliseringstheorieën in hoofdstuk 2 geïdentificeerd als éen van de belangrijkste elementen van de expressieve oriëntatie van professionals op hun werk (zie figuur 2.1). In hoofdstuk 3 werd daarnaast gesteld, dat dienstbaarheid als de meest centrale waarde kan worden benoemd die uit een analyse van beroepscodes voor verpleegkundigen naar voren komt. De collectiéve opvattingen over de taak van de verpleegkundige in de samenleving en beroepsuitoefening zijn dus congruent aan (het merendeel van) de individuele motieven van verpleegkundigen dienaangaande. Er is in zekere zin sprake van een morele cultivering van individuele preferenties, uitmondend in een algemene verplichting tot dienstbaarheid. Dienstbaarheid geldt dan als 'het hoogste goed' in morele praktijken van verpleegkundigen en als een nadere articulatie van 'het goede' in mens en samenleving (zoals ook rechtvaardigheid, vrijheid en naastenliefde articulaties van 'het goede' zijn). Hoe moeten deze uitspraken echter meta-ethisch en normatief-ethisch worden gewaardeerd?

Voor een antwoord op deze vraag staan ons het instrumentarium en theoretisch raamwerk uit 3.2.2 ter beschikking. Maar vooraleer een dergelijke formele duiding van morele concepten en relaties kan plaatsvinden, dienen deze eerst inhoudelijk te worden beschrewen. Immers, een nadere kwalificatie van dienstbaarheid als notie van algemene morele verplichting ("verpleegkundigen behoren zich dienstbaar op te stellen") of als uiting van een algemeen waarde-oordeel ("een goede verpleegkundige stelt zich dienstbaar op") zegt op zichzelf nog niet zoveel. Een dergelijk onderscheid is wellicht voor ethici theoretisch interessant en relevant, maar levert nog geen inzicht op in een actuele morele praktijk. Bovendien is het deze morele praktijk waaruit de indicaties oplichten voor welke theoretische bespiegeling en systematisering dan ook. Wij stellen ons dus op het standpunt, dat de voorwaarden voor deze bespiegeling en systematisering niet uitsluitend gelegen zijn in het bestaan van theoretische concepten en noties als zodanig, maar tevens en fundamenteel gegeven zijn met de eigen aard en kenmerken van de praktijk van het morele leven zelf.

Hoe ziet dan deze morele praktijk van verpleegkundigen er global uit? Het gevaar voor lief nemend eclectisch te werk te gaan, lichten wij dit toe aan de hand van een voorbeeld uit de dagelijkse praktijk van de beroepsuitoefening van verpleegkundigen. Hierin wordt vele malen per dag een beroep gedaan op eerlijkheid. Verpleegkundigen hebben er in het algemeen weinig moeite mee om hieraan te voldoen, omdat het in de regel gaat om vragen inzake informatie, die voor geen van de betrokkenen bedreigend is. Maar hoe te handelen als dit wél het geval is? Bijwoorbeeld wanneer een patiënte met een mammacarcinoom, in een vergevorderd stadium met uitzaaiingen in longen, wervelkolom en hoofd en onwetend van de reële ernst van de situatie, vraagt naar haar toekomstperspec. 
tief met betrekking tot de aandoening. $\mathrm{Zij}$ heeft het gevoel dat liedereen in haar omgeving, zowel partner, kinderen als artsen, iets voor haar verzwijgt en ontwijkende antwoorden geeft. Het maakt haar tegelijk verdrietig en wanhopig; zonder dat aan haar omgeving duidelijk te kunnen maken. De verpleegkundige moet dit nu maar eens recht zetten en volledige openheid van zaken geven.

Op een dergelijk verzoek zijn diverse reactiewijzen mogelijk. We noemen hier enkele alternatieven:

1. De verpleegkundige doet mededeling van alle informatie die haar omtrent de aandoening en het (infauste) toekomstperspectief van deze patiënte ter beschikking staat.

2. De verpleegkundige reageert als alle anderen in de omgeving van de patiënte en omzeilt de vraag ofwel doet alsof er niets aan de hand is ofwel verwijst naar een collega.

3. De verpleegkundige wijst de patiënte erop dat haar vraag van medische aard is, dus door de behandelend arts moet worden beantwoord en schakelt deze vervolgens in of verwijst de patiënte ernaar.

Elk alternatief kan worden verdedigd met een beroep op dienstbaarheid van de kant van de verpleegkundige. En elk wan deze beroepen op dienstbaarheid kunnen hun grond vinden in gebruikelijke praktijken enerzijds en normatieve concepties anderzijds.

In het eerste alternatief kan dienstbaarheid worden uitgelegd als een primaire plicht tot het in handen geven van alle informatie aan een patiënte die van belang kan zijn voor nadere keuzes met betrekking tot haar toekomstige levensloop, ook in het kader van de behandeling van haar aandoening. Dienstbaarheid krijgt hier, met andere woorden, een nadere invulling in toepassing van het respect voor de autonomie of het zelfbeschikkingsrecht van de patiënte. Deze autonomie of zelfbeschikking worden klaarblijkelijk ook gesteld boven de ogenschijnlijk tegengestelde opvattingen van anderen in haar omgeving daaromtrent.

Ook het tweede alternatief kan worden opgevat als een uiting van dienstbaarheid. Wanneer wij dienstbaar willen zijn aan anderen zullen we in het algemeen voorkómen dat deze anderen door ons optreden schade wordt berokkend, hetzij door de kwalijke eigenschappen of gebreken die nu eenmaal ieder van ons bezit, hetzij door wat wij anderen actief aandoen met onze daden. Deze opstelling staat bekend als het principe van 'primum non nocere'. De verpleegkundige in ons voorbeeld realiseert de dienstbaarheidsverplichting met een beroep op dit principe, wanneer deze verwacht dat de patiënte bij het vernemen van de infauste prognose dermate in de war en geschokt zal zijn, dat ernstige nadelige gevolgen optreden voor haarzelf en haar behandeling en verpleging. Daarnaast kan het argument gelden, dat het meedelen van een infauste prognose aan een patiënte ook voor de verpleegkundige ernstige consequenties kan hebben. Er kan bijvoorbeeld sprake zijn van het doorbreken van een uniform beleid, dat de verpleegkundige in conflict kan brengen met collega's, behandelend arts en familie, hetgeen ongetwijfeld nadelige gevolgen zal hebben voor een adequate verpleegkundige zorg aan déze patiënte. Ten tweede zet de waarheidsmededeling bij de patiënte aan tot een verwerkingsproces met vooral in het begin waarschijnlijk zeer heftige emotionelle uitbarstingen, waar de verpleegkundige in lang niet alle gevallen adequaat op zal reageren. Een verpleegkundige die dit van zichzelf weet, bewijst de patiënte een dienst door een dergelijke mededeling aan een ander over te laten en daartoe stappen te ondernemen.

Het laatste argument kan ook van toepassing zijn op het derde alternatief, zij het dat hier sprake is van competentiegremzen van professionele aard en niet van persoonlijke aard. 
In het algemeen behoren vragen met betrekking tot aard, kenmerken en prognose van een aandoening te worden beantwoord door de meest deskundige terzake, in casu de behandelend arts. De verpleegkundige getuigt van een dienstbare opstelling (hier zowel ten opzichte van de patiënte als ten opzichte van collega's en artsen), wanneer steeds de grootst mogelijke deskundigheid met betrekking tot vragen van patiënten aan hun bed wordt verzameld en wanneer wordt teruggetreden indien strikt genomen de vragen van niet-verpleegkundige aard zijn.

Bij de keuze voor één van de alternatieven hoeft niet uitsluitend het persoonlijk en professioneel inzicht van de individuele verpleegkundige een rol te spelen. In tal van situaties heeft de verpleegkundige bovendien te maken met zogenaamde teamafspraken, met strakke behandelregimes, met een professioneel statuut, met het instellingsbeleid. Ook deze worden meestal onder de noemer gebracht van dienstbaarheid (aan het belang van de patiënt). $\mathrm{Zij}$ vormen een mengeling van (ethisch-)normatieve concepties en ervaringsgegevens. Een team dat, mede op basis van onderzoeksgegevens, de stellige indruk heeft dat bekendheid van patiënten met de infauste prognose van hun aandoening in het algemeen leidt tot een sterke ondermijning van hun gezondheidstoestand en tot aanzienlijke verkorting van het leven, zal een dergelijke prognose niet snel meedelen en teamleden aan zo'n beleid trachten te binden. Een instelling die er van uitgaat, dat in dit soort situaties aan patiënten nooit hoop mag worden ontnomen, zal eveneens dergelijke maatregelen treffen. Verpleegkundigen die in zo'n geval voor het eerste alternatief kiezen, zullen ter verantwoording worden geroepen, ongeacht het feit dat zij persoonlijk of professioneel en ten opzichte van déze patiënte de enig juiste benadering kunnen hebben gekozen. Hetzelfde kan eventueel gebeuren met verpleegkundigen die kiezen voor het tweede of derde alternatief in situaties waarin het beleid in dergelijke gevallen is gericht op onmiddellijke en volledige openheid van zaken aan patiënten.

Zowel openheid als geslotenheid vallen dus blijkbaar onder de noemer dienstbaarheid, zij het dat gebruik wordt gemaakt van verschillende argumenten. In dit geval wordt voornamelijk gebruik gemaakt van de principes 'primum non nocere' of 'autonomie' of 'competentie'. In hun uitwerking kunnen deze blijkbaar leiden tot tegengestelde gedragsalternatieven, die alle onder de toepassing van de dienstbaarheidsverplichting vallen. Verder blijkt, dat de mate waarin een bepaald alternatief voorkeur geniet afhankelijk is van een combinatie van persoonlijke en professionele inzichten van de individuele verpleeg* kundige en van feitelijke omstandigheden, opties en noties in diens omgeving en arbeidscontext.

Vanwaar nu deze uitweiding? We hebben getracht aan de hand van een voorbeeld uit het verpleegkundige-patiënt-contact de morele praktijk van verpleegkundigen uitvoerig woor het voetlicht te brengen. De keuzes die wij de verpleegkundige in dit geval lieten doen, zijn behandeld en geanalyseerd als een aspect van en argumentatie pro dienstbaarheid. Eventuele psychologische aspecten noemden we slechts 'en passant'. Wij zijn er daarbij stilzwijgend van uitgegaan dat een realistische schets is geboden van situaties die zich in werkelijkheid op dezelfde wijze (kunnen) voordoen. Het is onze overtuiging dat dit inderdaad zo is. Primair was het echter onze bedoeling een aanzet te geven tot een metaethische en normatief-ethische waardering van de algemene verplichting tot dienstbaarheid, zoals die aan verpleegkundigen wordt voorgehouden. 
Welnu, om bij het begin te beginnen, verpleegkundigen worden geacht 'goed' te doen, "het goede' te verwezenlijken. Met deze uitspraak wordt op formele wijze aan verpleegkundigen een algemene morele verplichting opgelegd waarmee meta-ethisch een "moeten' of 'behoren' tot uitdrukking wordt gebracht dat op zichzelf weer verbonden is met een positief gevoel van goedkeuring. Een verpleegkundige zall echter vreemd opkijken als hem of haar wordt gezegd 'het goede' te doen, alsof hiermee moreel de zaak is beklonken. Dezelfde verbazing zal optreden, wanneer een nadere explicatie volgt van het feit, dat hier een 'behoren' wordt bedoeld en dat de oproep moet worden gezien als een voorschrift of voorkeur waarbij goedkeuring zijn of haar deel zal worden.

Het wordt de verpleegkundige al iets duidelijker wanneer erbij wordt gezegd dat 'het goede' in de context van de beroepsuitoefening primair betekent dat men dienstbaarheid moet betonen. De verpleegkundige gaat helemáal een licht op indien wordt uitgelegd waarin die dienstbaarheid zoal kan bestaan. Er gaan dan kwalificaties over tafel als "ondersteunen van autonomie van patiënten", "respecteren van de competentie van collega's", "primum non nocere", enzovoort. Met andere woorden, voor moreel verantwoord handelen is het niet voldoende dat verpleegkundigen in formele zin weten dat iets goed is om te doen, maar dat zij tevens een inzicht hebben in hetgeen materieel met 'het goede' wordt bedoeld, dus dat hen een normatief-ethisch perspectief wordt geboden. Metaethiek en normatieve ethiek zijn op elkaar betrokken. Morele uitspraken brengen niet alleen een gevoel van goedkeuring over, maar ze verwijzen ook ergens naar: "het is goed zich dienstbaar op te stellen". En dat, waar ze naar verwijzen, is dan blijkbaar een morele waarde, lets dat op zichzelf goed is om naar te streven.

Dit gezegd zijnde komen we ten aanzien van ons voorbeeld en de beschreven gedragsalternatieven ogenschijnlijk in de problemen. De waarde of het begrip dienstbaarheid blijkt vele verschillende connotaties te bezitten en afhankelijk van individuele opvattingen en contextuele factoren tot uiteenlopende, ja zelfs tegengestelde handelwijzen aanleiding te geven. Dat nu is niet direct bevorderlijk voor een eenduidige begripsvorming, die immers als voorwaarde moet worden gesteld aan de opbouw van een systematisch meta-ethisch en normatief-ethisch kader.

We moeten derhalve een stap terugdoen en nog eens meer in detail de morele praktijk van dienstbaarheid aan een onderzoek onderwerpen. Laten we daarbij aannemen dat een verpleegkundige het primaire gezag van de dienstbaarheidsverplichting kent, erkent en in de uitoefening van het beroep tot uitdrukking wil brengen; dus ook ten aanzien van de beslissing of mededeling moet worden gedaan van een infauste prognose aan een patiênte met mamma-carcinoom in een gevorderd stadium. Hoe komt de verpleegkundige nu aan haar notie van dienstbaarheid, uit welke elementen is deze opgebouwd en hoe ziet de daarop gebaseerde beslissing ten aanzien van de 'waarheidsmededeling' er uiteindelijk uit?

Een verpleegkundige betreedt het arbeidsveld nimmer als een soort 'tabula rasa'. Wanneer dienstbaarheid aan mens en samenleving een min of meer belangrijk intredemotief vormt, is de kennismaking met deze waarde van veel vroegere datum (anders zou ze immers geen intredemotief kunnen zijn). Reeds tijdens de opvoeding en gedurende de periode van scholing en vorming vormt zich een bepaald begrip van dienstbaarheid. Gedragingen van mensen worden door opvoeders en opleiders als dienstbaar aangewezen, op de verpleegkundige in spe overgedragen en door deze vervolgens als zodanig herkend. 
Dergelijke gedragingen wordt in de regel tevens een positieve kwaliteit verleend. De verpleegkundige in spe wordt geleerd aan deze gedragingen gevoelens van goedkeuring te hechten.

Dit besef van dienstbaarheid is dan onderdeel van de persoonlijkheid of persoonlijke identiteit van de verpleegkundige in spe geworden. Het bepaalt de eigen wijze waarop de verpleegkundige in de wereld staat en gedragingen van zichzelf en anderen als dienstbaar interpreteert. Onder invloed van opvoeding en scholing kunnen deze interpretaties dus onderling aanzienlijke verschillen vertonen. Er is een meerduidig begrip van dienstbaarheid aanwezig, waardoor uiteenlopende gedragingen in de werkelijkheid als dienstbaar worden herkend, benoemd en goedgekeurd en dienstbaarheidsmotieven tot uiteenlopende handelingspraktijken aanleiding kunnen geven.

Niettemin kan het individuele begrip van dienstbaarheid zich drastisch wijzigen onder invloed van gewijzigde omstandigheden. De intrede in een beroep is zo'n omstandigheid. Sterker nog, in het geval van de verpleegkundige doet zich een situatie voor waarin de notie dienstbaarheid zich met veel vlagvertoon aan hem of haar opdringt. $\mathrm{Zij}$ wordt verwoord in beroepscodes, in professionele statuten, in instellingsdoelstellingen, in afdelings- of teambeleid, in hulpverleningsargumenten en in de min of meer dwingende eisen van collegialiteit. Ook hierin zal sprake zijn van een meerduidig begrip van dienstbaarheid, omdat nu eenmaal telkens weer andere personen met ieder hun eigen achtergrond, opvoeding, scholing en arbeidscontext aan de formulering ervan hebben bijgedragen. Evenzo zullen zij dus uiteenlopende gedragingen onder de noemer dienstbaarheid brengen en in hun gedrag telkens weer een andere interpretatie van dienstbaarheid als zodanig verwezenlijken. De oorspronkelijke opvatting over dienstbaarheid van verpleegkundigen in spe kan dus danig op de kop worden gezet. Er wordt kennis gemaakt met interpretaties en handelingspraktijken van dienstbaarheid die sterk kunnen verschillen van het aanvankelijke besef van deze waarde en waarvan wordt verwacht dat men ze incorporeert in het eigen gedrag.

De mate waarin dit laatste plaatsvindt is sterk persoonlijk bepaald en wederom afhankelijk van opvoeding, scholing en vorming. De normatieve werking van socialisatie- en enculturatieprocessen enerzijds en het behoud van eigen identiteit anderzijds strijden daarbij om de macht. Duidelijk is echter dat uiteindelijk een veelkleurig palet tot stand komt van, soms ver uiteenlopende interpretaties en gedragingen die alle de waarde dienstbaarheid belichamen, maar telkens vertegenwoordigd in een andere persoon. Elke verpleegkundige stelt uit het geheel van de articulaties van dienstbaarheid die hem of haar uit op" voeding, scholing, hulpverleningsdoeleinden en -normen en uit als dienstbaar betitelde handelingspraktijken tegemoet treden, een eigen mix van dienstbaarheidsnoties en -gedragingen samen. Deze leidt tot een unieke identiteit, waarin beslissingen ten aanzien van morele vraagstukken vanuit het perspectief van dienstbaarheid voor iedere verpleegkundige anders kunnen uitvallen en tot andere prioritering van afgeleide of constituerende waarden aanleiding kunnen geven. Vandear dat ten aanzien van ons voorbeeld tenminste drie alternatieven konden worden geboden, die ieder voor zich voor een verpleegkundige vanuit het perspectief van dienstbaarheid moreel verdedigbaar zijn.

Het voorgaande is van belang voor ons meta-ethisch en normatief-ethisch kader (zie voor het volgende ook figur 3.1 in 3.2.2). De morele uitspraak van een verpleegkundige in het vraagstuk van de waarheidsmededeling aan de patiënte met mamma-carcinoom, kan 
meta-ethisch niet worden afgedaan met een exclusief beroep op hetzij de persoonlijke voorkeur van de verpleegkundige of een eenduidige betekenis van dienstbaarheid (noncognitivistisch standpunt), hetzij een aantoonbare eigenschap van de werkelijkheid (cognitivistisch standpunt), hetzij het zelf-evidente karakter van dienstbaarheid (intuitionistisch standpunt). De uitspraak is gebaseerd op een afweging van eigen gevestigde noties van dienstbaarheid, de positieve attitude daartegenover en van opvattingen en realisaties van dienstbaarheid die in de omgeving kunnen worden waargenomen. Er is dus sprake van een combinatie van noncognitivistische en cognitivistische elementen.

Normatief-ethisch gezien is een centrale rol toebedeeld aan waarden (in casu de waarde dienstbaarheid). Er wordt van uitgegaan, dat een oproep "het goede te doen" materieelinhoudelijk weinig zinvol is zonder nadere aanduiding waaruit dit goede bestaat. Vervolgens blijkt dat een antwoord op zo'n vraag niet om specifieke waardebegrippen heen kan. Een nadere explicatie van een verplichting door middel van een verwijzing naar de verplichting zelf zou immers een tautologische uitspraak opleveren, die hoogstens op consistentie en noncontradictie kan worden beoordeeld.

Het gebruik van waardebegrippen in een normatief-ethisch perspectief is echter niet onproblematisch. In de ethische theorievorming wordt er in het algemeen vanuitgegaan dat begrippen met een meerduidige betekenis zich slecht lenen voor opname in een model. Aan het voorbeeld wan de waarde dienstbaarheid zouden we dan ook kunnen illustreren dat, willen we waarden toch incorporeren in onze theoretische morele stelsels, dit op zijn minst tot een crisis in de theorievorming leidt. Immers, juist de laatste decennia is door ethici veel energie gestoken in een zuivere begripsmatige afbakening van het morele ten opzichte van het nonmorele. Men trok zich daarbij steeds meer terug op formele en wijsgerig-analytische stellingen, dus op meta-ethische posities. Kentheoretische en logische criteria kregen een centrale plaats in de ethiek. Materieel-inhoudelijke noties, zoals die behoren bij waardebegrippen, zouden door hun meerzinnigheid en vaagheid de voortgang van het denkproces verstoren.

Intussen is ons echter duidelijk geworden dat het morele leven zonder waardebegrippen ondenkbaar is. Dat waardebegrippen meestal niet eenduidig zijn hoeft ons in deze niet te verontrusten. Wat wél tot nadenken stemt is de bovengeschetste stand van zaken met betrekking tot de ethische theorievorming, die zich ogenschijnlijk van het concrete morele leven verwijdert, zelfs zich daarvan distantieert (voor de medische ethiek werd dit treffend beschreven door bijvoorbeeld Ten Have 1990). Hierin wensen wij niet mee te gaan. Dit noodzaakt ons tot kritiek op genoemde stand van zaken. Het ligt voor de hand daarbij een ontwerp aan te bieden van of aansluiting te zoeken bij een ethische theorie, waarin waardebegrippen belangrijke morele concepten vertegenwoordigen. Een dergelijke theorie moet dus kunnen worden beschouwd als een axiologische of waardetheorie.

Zo'n theorie menen wij aan te treffen bij Vos (1989). Deze Leidse filosoof ziet waardebegrippen als de "...operationele categorieën bij uitstek van alle moraal en ethiek. Hiermee wordt bedoeld dat waardebegrippen (...) ons de voorstellingen verschaffen van datgene waarin het moreel goede leven bestaat of zou kunnen bestaan; dat we zonder deze voorstellingen absoluut niet weten wat we uit naam van 'het goede' of onze 'plicht' behoren te doen en te laten" (3). Niettemin is hij zich, evenals wij, bewust van de meerzinnigheid van waardebegrippen. Mensen streven met een beroep op eén en dezelfde waarde zeer uiteenlopende dingen na (hij vermeldt als voorbeeld het gebruik van de waarde rechtvaardigheid door respectievelijk juristen, liberalen, socialisten, christenen en mo- 
hammedanen). Daarnaast legt hij nadruk op de onderlinge afhankelijkheid van waardebegrippen. Zo is bijvoorbeeld solidariteit ondenkbaar zonder authenticiteit en integriteit (3). Tot soortgelijke conclusies waren wij reeds gekomen met betrekking tot de waarde dienstbaarheid.

Begrippen hebben, volgens Vos, twee belangrijke functies: ze kunnen naar iets verwijzen en ze kunnen uitdrukking geven aan gevoelens. In de eerste betekenis zijn begrippen beschrijvend, referentieel of zakelijk (voorbeelden zijn 'boek', 'deur' en 'tafel'). In de tweede betekenis zijn ze voorschrijvend, preferentieel of emotief (voorbeelden hier zijn 'goed', 'plicht' en 'behoren'). Termen van Hare gebruikend, benoemt Vos de genoemde functies als de phrastische (aantonende) respectievelijk neustische (toestemmende) component van begrippen (17). Beide adjectieven zijn ontleend aan het Grieks. Wanneer we beide adjectieven vergelijken met het begrippenkader uit 3.2.1 dan blijkt de phrastische component nauw aan te sluiten bij het door Philipsen onderscheiden denotatieve denken en de neustische component bij het connotatieve denken. We geven echter de voorkeur aan de begrippen phrasticiteit en neusticiteit, daar zij meeromvattend zijn.

Waardebegrippen bezitten in het algemeen zowel een phrastische als neustische component, hetgeen ze superieur maakt aan algemene verplichtingsnoties, die immers alleen een neustische component hebben, zoals boven is getoond. Een waarde als dienstbaarheid bevat niet alleen een positieve aansporing tot bepaald gedrag (neustisch), maar ook een betekenis als "ieder naar zijn of haar behoeften" (phrastisch). Bij een morele uitspraak of waardeoordeel waarin waardebegrippen worden gehanteerd, wordt dus min of meer uitgegaan van de normatieve werking van gevoelens én feiten. Vanwege het netelige karakter van een dergelijk uitgangspunt in de ethiek, wordt door Vos veel aandacht besteed aan een verduidelijking hiervan (zie Vos 1989, 25-41).

Waardebegrippen hebben volgens Vos (76-81) de volgende kenmerken:

1. De neustische en phrastische component, zoals boven geschetst, en het evenwicht daartussen. Hierdoor onderscheiden waardebegrippen zich enerzijds van algemene verplichtingsnoties, die het neustische 'hypertrofiëren', en anderzijds van morele soorttermen als 'overspel', 'terreur' en 'abortus: moord', omdat hier de ondubbelzinnigheid van de phrastische component de neustische component overwoekert (zie ook Vos, 35-36).

2. De vele phrastische betekenissen. Boven is al gewezen op de vele betekenissen die kunnen worden verleend aan het waardebegrip 'dienstbaarheid". Hetzelfde geldt voor de vaak gehanteerde begrippen 'vrijheid' en 'rechtvaardigheid'. De veronderstelling dat een waardeoordeel slechts eén betekenis heeft, zoals in het noncognitivisme wordt beweerd, is dus aanvechtbaar. Fenomenologisch zijn meta-ethische opties te beschouwen als gelijkwaardige beschrijvende modellen voor de verschillende pretenties die mensen met hun waarde-oordelen voeren en voor het verschillende gewicht en de verschillende consequenties die zij daaraan verbinden (zie ook Vos, 31). Daarnaast kan worden gewezen op de reeds eerder vermelde cognitieve component van waardebegrippen, die de gevoelsfactor verzwakt. Immers, inzicht in de goedheid van dienstbaarheid en de slechtheid van bijvoorbeeld egoïsme vooronderstelt een zekere vertrouwdheid met maatschappelijk leven en sociale interacties, hun achtergronden en uitwerkingen (zie ook Vos, 33).

3. De onderlinge relatie van waardebegrippen. Een waardebegrip als 'dienstbaarheid' leidt geen geïsoleerd bestaan, maar onderhoudt een bepaalde relatie met andere 
waardebegrippen. Dienstbaarheid in de gezondheidszorg vereist bijvoorbeeld van ons een zekere saamhorigheid met andere mensen, zowel in altruïstische zin (als "dienstbaarheid aan patiënten') als in prudentiële zin (als 'collegialiteit'). Bovendien kan zij niet worden gerealiseerd zonder dat wij onszelf trouw blijven en een zekere authenticiteit en integriteit tentoonspreiden.

4. De structuur van het axiologische veld. Als uitvloeisel van het bovenstaande kan worden gewezen op een tweetal verbanden: (a) tussen de verschillende betekenissen van eenzelfde waardebegrip; (b) tusen de verschillende waarden onderling; en (c) als logische implicatie van (a) en (b), tussen de verschillende betekenissen van verschillende waarden.

5. Eenheidstichtende methoden. De waardebegrippen zelf maken deel uit van opvattingen, methoden of theorieên die ons de criteria verschaffen om uit de vele betekenissen van waarden ondubbelzinnige handelingsindicaties af te leiden (zie hieronder voor een werdere explicatie).

6. De variabiliteit van de neustische component. Deze is reeds gegeven met de opmerkingen sub 1, 2 en 3. Het verwervingsproces van een waarde als 'dienstbaarheid' door verpleegkundigen gaat gepaard met ontkenning van oude betekenissen en toekenning van nieuwe betekenissen, bepaling van een nieuw relatief gewicht van deze waarde, een nieuw toepassingsgebied en een ander realisatieniveau. Dit alles maakt de neustische component veranderlijk. Naar (de verklaring van) een zuiver neustisch idee van 'het behoren' in de waarde dienstbaarheid zal vergeefs worden gezocht. Naar het morele ideaal van dienstbaarheid kan echter vruchtbaar sociologisch en wijsgerig onderzoek worden gedaan, variwege de vereniging van het phrastische en het neustische in de verschillende betekenissen van deze waarde.

7. De betekenis van omstandigheden. De omstandigheden waaronder morele beslissingen worden genomen zijn telkens anders en vormen dus een extra complicatie voor de keuze voor een of meer waarden of voor een of meer betekenissen van een specifieke waarde. Een poging om uit deze problematiek te geraken is wel ondernomen in de zogenaamde 'situatie-ethiek'. Het probleem van de situatie-ethiek is echter, dat de feitelijke kenmerken van een stand van zaken op zichzelf genomen geen handelingsnorm. opleveren. Feiten, maar ook gevoelens kunnen zichzelf immers niet legitimeren, maar behoeven daarvoor de waardebegrippen. Om dezelfde reden dienen de deterministische (causaliteits)these en de esthetische these te worden afgewezen, daar zij een te vergaande emancipatie vooronderstellen van feiten respectievelijk gevoelens ten opzichte van morele idealen (zie ook Vos, 43-47).

Gegeven deze kenmerken, laat zich de vraag stellen of er sprake kan zijn van ideale waardebegrippen, bijvoorbeeld dienstbaarheid in de context van de uitoefening van een beroep als dat van verpleegkundigen. In dat geval zou dienstbaarheid moeten voldoen aan phrastische ondubbelzinnigheid, interne consistentie en zou zij een volledig beeld moeten geven van te verwerkelijken verpleegkundige idealen. Volgens Vos (69-70) is dit onmogelijk en wel om twee redenen:

1. Het nominalisme, dat zich in de phrastische component van dienstbaarheid nestelt (maar aan waardebegrippen geen objectieve geldigheid toekent) en dat zich laat verdedigen door het idiosyncratische karakter van onze waardenbeleving. 
2. Het voluntarisme, dat het belangrijkste kenmerk van de neustische component van dienstbaarheid is en op grond waarvan wij kiezen voor bepáalde aan dienstbaarheid gerelateerde waardebegrippen en hun phrastische betekenis en niet voor andere.

Er is dus geen eenduidig en uitputtend ideaalbeeld van dienstbaarheid te construeren dat beantwoordt aan een morele praktijk en beleving van werpleegkundigen. Bovendien is dit ook niet nodig om een moreel goed leven te leiden casu quo moreel verantwoorde verpleegkundige zorg te verlenen. De tijd van de 'heiligenlevens' ligt reeds ver achter ons.

Daarnaast wordt ons inzicht in de beleving en praktijk van waarden en de problemen die daarmee gepaard gaan, door sommige verschijnselen nogal negatief beïnvloed. Vos (9193) noemt drie uit elkaar voortvloeiende verschijnselen en plaatst ze in een chronologie die tevens een toenemende zwaarte impliceert:

1. Moralisme. Hiermee worden morele opvattingen of meningen ten aanzien van warden gediskwalificeerd als té ondubbelzinnig, tê belangrijk en té perfectionistisch. Er is dus sprake van 'verenging' en 'verkramping', meestal ten gevolge van overbenadrukking van één waarde en/of éen betekenis.

2. Ideologie. Hiervan is sprake als men zich permanent onderwerpt aan een beperkte waarde-optiek, waardoor het morele leven wordt losgemaakt van het veranderlijke karakter van situaties, hun ontwikkeling en de gevolgen van het handelen.

3. Tirannie. Moralisme en ideologie monden uiteindelijk uit in een situatie van tirannie, waarin men meent over slechts één waarde te beschikken waarop het handelen van mensen moet worden beoordeeld en geconcentreerd.

Moralisme, ideologie en tirannie zijn voorbeelden van opvattingen, waarin de status van waardebegrippen sterk afwijkt van een nominalistisch-voluntaristische en die thuishoren in de zogenaamde "massieve axiologie": "... in een massieve waardebeleving wordt (...) ontkend dat 'waarden' begrippen zijn waarvan de phrastische en neustische betekenis afhankelijk zijn van traditie en conventie; dat dergelijke begrippen, oorspronkelijk, worden voortgebracht door menselijke schepping (...) en uitvinding (...); dat waarden bijgevolg een mentaal, (inter)subjectief, betrekkelijk veranderlijk en tamelijk vluchtig bestaán leiden; dat de autoriteit van waarden primair is gelegen in het feit dat zij gelden" (Vos 1989, 96). 'Massief' staat in deze axiologie derhalve voor 'statisch', 'onwrikbaar', 'ahistorisch', 'niet-cultureel/niet-sociaal bepaald'.

Naast de genoemde 'extra-mentale' massieve waardebeleving onderscheidt Vos een 'intra-mentale', waarbij hij doelt op het inneïsme van Chomsky (107-112). Bij deze vorm van massieve axiologie worden waarden opgevat als aangeboren ideeën. In deze ontkenning van het sociale karakter van waarden ligt het belangrijkste aangrijpingspunt voor een afwijzing van een naturalistische benadering van warden.

Wat betekent dit alles nu voor ons meta-ethisch en normatief-ethisch kader?

In de ethiek heeft de normatieve ethiek een centrale functie, omdat men zich daarin bezighoudt met de materieel-inhoudelijke formulering van 'het goede' en in dat perspectief met de rechtvaardiging van het morele gedrag van mensen. Deze activiteit levert een aantal handelingscriteria op die de voorwaarden scheppen tot moreel verantwoord handelen. Deze verantwoordelijkheid moet primair normatief worden verstaan, zodat ook de handelingscriteria zelf normatief moeten zijn of tot normatieve criteria moeten kunnen worden herleid. Kentheoretische en logische criteria komen onvoldoende aan deze eis tegemoet, zodat daaraan in de ethiek geen centrale rol kan worden toebedeeld. Het te- 
gendeel is het geval met criteria, ontleend aan waardebegrippen. Deze begrippen nemen in de ethiek dan ook een centrale positie in.

Onze ethische theorie moet derhalve axiologisch worden geduid. Wij volgen Vos (1989, 133-134) wanneer hij stelt, dat we ons daarmee tegelijk verwijderen van gangbare, soms ook dominant geachte theorieën als die van Kant, Hare en Rawls. Deze hebben welliswaar objectiviteit en onpartijdigheid als fundamentele waardebegrippen geïdentificeerd, maar vanwwege hun claims op universaliteit, logische beginselen en waarheid kregen concrete waardebegrippen slechts een afgeleide betekenis. Op grond van deze theorieën bestaat er hedentendage grote nadruk op rationaliteit, terwijl 'plicht' daarvan als een afgeleide wordt beschouwd. Hiermee komt de eigen aard van moraal en ethiek in het gedrang (zie ook Vos, 140-141).

Als universaliteit en rationaliteit niet die vooraanstaande plaats in de ethiek kan worden toegekend waarvan velen uitgaan, hoe moet het morele waarde-oordeel dan worden gekarakteriseerd? Onze voorkeur voor een axiologische duiding van de ethiek en voor het primaat van waardebegrippen als materieel-inhoudelijke articulaties van verplichtingsnoties leidt hier als het ware vanzelf tot een benadrukking van de phrastische betekenis van waardebegrippen (als tegenwicht voor het neustische karakter van algemene verplichtingsnoties). Deze phrastische betekenis blijft van belang, zelfs wanneer aan de desbetreffende waardebegrippen een werschillend neustisch gezag wordt toegekend.

Dit betekent volgens Vos $(1989,143)$ dat phrasticiteit en deliberatie de plaats innemen van noncognitivisme, prescriptivisme, universalisme en dergelijke. Bij phrasticiteit denkt hij dan aan "... beelden en voorstellingen die, verschillend als zij zijn, hun zin en bestaan danken aan het feit dat we ermee tot uitdrukking kunnen brengen dat iets concreets moet worden gedaan of gelaten. In het geding is hier in de eerste plaats ons voorstellingsvermogen, onze inventiviteit en creativiteit" (143-144). Phrasticiteit beschouwt hij uitdrukkelijk als hét antwoord op het (meta-ethisch) noncognitivisme. Deliberatie is het antwoord op het prescriptivisme (met name door Hare vertegenwoordigd). Het staat voor een "... afweging (...) van de verschillende morele idealen in een concrete situatie" (144), waarbij de overwegingen en argumenten niet de hardheid bezitten van die in logica en empirie. Het morele streven is eerder gericht op instemming en overeenstemming dan op universaliteit. Onderhandelen en het sluiten van compromissen maken hiervan een wezenlijk onderdeel uit.

Bij de bepaling van een normatief-ethische invulling van 'het goede', het rechtvaardigbaarheidscriterium van ons morele gedrag, wordt vervolgens wederom uitgegaan van de beschreven morele praktijk met waardebegrippen. Uiteindelijk komt Vos (147) dan uit bij 'loyaliteit' als centraal waardebegrip en meest omvattende (maar nog steeds onvolledige) articulatie van 'het goede'. De reden hiervoor is simpel: waardebegrippen zijn aangeleerde en overgenomen conventies, waaraan we trouw (loyaal) blijven, totdat de nutteloosheid of contraproductiviteit ervan is gebleken. Zolang die trouw ten opzichte van onszelf én anderen bestaat, kan zij in waardebegrippen worden geconcretiseerd. Is zij afwezig, dan kan geen enkel concreet waardebegrip doordringen tot de kern van ons morele leven.

Een dergelijke verklaring lijkt ons plausibel. De axiologische theorie waarop zij steunt zullen wij daarom in het vervolg van ons betoog benoemen als de 'loyaliteitstheorie van Vos' (voorzover ons bekend, heeft zijn waardentheorie nog geen algemeen aanwaarde ti- 
tel of etiket meegekregen). Deze theorie bepaalt in hoge mate het meta-ethisch en normatief-ethisch kader voor de nog volgende beschouwingen.

Het belang van de loyaliteitstheorie van Vos voor onze vraagstelling is met het voorgaande min of meer rechtstreeks gegeven. Op de eerste plaats staat de theorie ons toe beroepscodes formeel te duiden als een verzameling waardeoordelen met waardebegrippen als criteria. Dan is niet meer de vraag aan de orde of verschil moet worden gemaakt tussen verschillende soorten normatief-ethische uitspraken (als uitdrukking van morele principes, waarden, normen of plichten). Morele uitspraken worden integendeel beoordeeld naar de mate waarin een waarde phrastisch-neustisch wordt beschreven als uitdrukking van 'goed gedrag' van een beroepsbeoefenaar. Daarbij is de vraag of deze uitspraken verpakt zijn in teleologische dan well deontologische formuleringen van secundair belang. Wel is hiermee het verschil van mening tussen Barnsley en Philipsen ten aanzien van de approbationistische these in 3.2.1. in het voordeel van laatstgenoemde beslecht. In deze these werd gesteld: normen zijn de vanuit waarden begrijpelijke regels van vanzelfsprekend gedrag.

Ten tweede biedt de theorie hulp bij een nadere plaatsbepaling en interpretatie van de waarde 'dienstbaarheid', die wij als centrale waarde in beroepscodes voor verpleegkundigen hebben geïdentificeerd. De theorie biedt, zoals we hebben gezien, onder andere een verklaring voor het feit dat aan de waarde dienstbaarheid in morele praktijken van beroepsuitoefening uiteenlopende interpretaties en dienovereenkomstige handelingsindicaties kunnen (en mogen) worden gehecht, zonder dat dit onmiddellijk leidt tot morele of conceptuele diskwalificatie van de waarde als zodanig. Een vraag die nog openstaat is echter of dienstbaarheid vanuit normatief-ethisch (lees: loyaliteitstheoretisch) perspectief inderdaad als centrale waarde naar voren kan worden geschoven. In het verlengde hiervan stelt zich de kwestie in hoeverre dienstbaarheid als een exclusieve domeinwaarde door een bepaalde (beroeps)groep kan worden geclaimd. Verwacht mag worden dat het antwoord schuilt in een verduidelijking van de relatie tussen de waarden dienstbaarheid en loyaliteit. Het antwoord op deze vraag is van belang bij de bepaling van de morele status van beroepscodes, zoals we nog zullen zien.

\subsubsection{Superioriteit van beroepsgebonden morele claims}

Dienstbaarheid claimen als het exclusieve domein van het morele gedrag van beroepsbeoefenaren lijkt vragen om moeilijkheden. Immers, iedere burger kan zich dienstbaar opstellen jegens anderen en dit ook als zodanig benoemen. In feite is het zelfs een motief tot intrede in een beroep in de gezondheidszorg, voordat überhaupt kennis is gemaakt met de morele praktijken en normen van beroepsbeoefenaren (vergelijk 2.3.7). Hoeveel recht van spreken heeft men dan, wanneer een dergelijke waarde nog eens extra wordt benadrukt? Het lijkt op het overschreeuwen van een reeds bestaande morele praktijk. met bekende termen en formuleringen.

Hoe anders lijkt het gesteld te zijn met de niet-morele praktijk van beroepsbeoefenaren! Daar is het heel gebruikelijk en geaccepteerd als men zich opwerpt als deskundige op een speciaal terrein en dit gebied beschermt tegen onbevoegden en indringers (in het geval van een geslaagde domeininstitutionalisering; vergelijk 2.3.7). Hierin zou een analogie of reden kunnen worden gevonden om ook de op dat gebied betrekking hebbende 
morele praktijk uitzonderlijk te verklaren. Hoewel een dergelijk afsluitingsproces ten opzichte van de omgeving onwalarschijnlijk is en afscherming van deskundigheid meestall zal berusten op overstemming ten alanzien van (ook morele) doelstellingen, berust een dergelijke redenering echter op een categorie-fout. Argumenten wit het niet-morele domein mogen niet zonder meer worden overgeplant naar het morele domein zonder toevoeging van overwegingen die aan dat morele domein zelf zijn ontleend. Anders maakt men zich schuldigin aan een naturalistische drogreden.

Desondanks kan men zich afvragen, zoals boven reeds gesuggereerd, of in morele praktijken van beroepsbeoefenaren geen argumenten kumnen worden gevonden om hun domein af te zonderen van dat van andere groepen en de samenleving als geheel. Waarom zouden diverse beroepsgroepen, in samenwerking met ethici, zich anders zoveel moeite getroosten om een specifieke, op hun beroepspraktijk toegesneden toegepaste ethiek te ontwikkelen? Een dergelijke tendens is op vele terreinen van beroepsuitoefening bespeurbaar. Om enkele voorbeelden te noemen: het recht (zie met name Davis/Elliston 1986); maatschappelijk werk (zie met name Watson 1985); sociale vernieuwing (zie met name Bermant e.a. 1978); management (zie met name Behrman 1988); de zakenwereld (zie met name Beauchamp/Bowie 1983; De George/Pichler 1978); wetenschappelijk onderzoek (zie bijwoorbeeld Berg/Tranфy 1983; Burgess 1989). Ook op de terreinen van geneeskunde en verpleegkunde is een dergelijke ontwikkeling reeds lang aanwezig. Het aantal lijvige boekwerken ower de morele aspecten van beiderlei beroepspraktijk en de bijzonderheden daarin omvat tientallen titels.

We betreden hier het terrein van de beroepsethiek en haar verhouding tot noties van algemeen-ethische aard. Deze beroepsethiek hebben wij eerder omschreven als "... een wijsgerige bezinning op het door de beroepsbeofenaren van een bepaalde professie gemeenschappelijk aanvaard complex van waarden en normen, bepaald en beinvloed door de waarden en door de waarderingen van gedrag die in de samenleving gangbaar zijn" (Van der Arend 1990, 292). Een beroepscode en de daarin vervatte uitgangspunten en verplichtingen hebben wij leren kennen als een door de beofenaren van een bepaald beroep gemeenschappelijk aanvaard complex van waarden en normen. Deze beroepscode valt dus onder de definitie en wordt beschouwd als onderdeel van de beroepsethiek in verband met een beroepsgroep. Hetgeen echter in de onderhavige paragraaf wordt geproblematiseerd betreft de additionele voorwaarde in thet tweede deel van de definitie van beroepsethiek: in hoeverre en in welke mate dient een door een beroepsgroep algemeen aanvaard complex van waarden en normen, dus ook de inhoud van een desbetreffende beroepscode, bepaald en beïnloed te zijn door de waarden en waarderingen van gedrag die in de samenleving gangbaar zijn? Of anders geformuleerd: in hoeverre mag door een beroepsgroep een zekere superioriteit worden geclaimd voor specifieke morele waarden ten opzichte van de houding tegenover diezelfde en andere waarden in de samenleving als geheel? Hiermee is onze vraag naar de superioriteit van de centrale waarde "dienstbaarheid" in beroepscodes voor verpleegkundigen getransformeerd naar een algemener niveau, namelijk dat van de verhouding tussen beroepsethiek en algemene ethiek:

'Superioriteit' werd in 3.2.1. door Barnsley uiteengelegd in de autonomie enerzijds en de prioriteit anderzijds van morele waarden. Hun autonomie bestaat erin dat verdere rechtvaardiging ervan niet noodzakelijk wordt geacht, alls ze eenmaal aanvaard zijn. Hun prioriteit betreft de voorrang op andere (morele en niet-morele) aspecten van het gedrag. 
Deze autonomie en prioriteit worden nu dus betrokken op de verhouding tussen beroepsethiek en algemene ethiek.

Onder de vele ethici die zich op enigerlei wijze met beroepsethische noties hebben beziggehouden zijn er slechts enkele die zich expliciet hebben gericht op grondslagenonderzoek vam het fenomeen beroepsethiek als zodanig. Wij noemen hier met name Bayles (1981) en Goldman (1980). Beide zullen we in deze en de volgende paragraaf veelvuldig tegenkomen (zie ook onze beschouwing over beide auteurs in Van der Arend 1985). Eerstgenoemde geldt als een bekend verdediger van het standpunt, dat beroepsethische waarden en normen niets anders zijn dan algemene, maatschappelijk aanvaarde waarden en normen in een ander jasje. Goldman is tot een soortgelijke conclusie gekomen op grond van een vergelijkende analyse van het functioneren van specifieke waarden en normen in de context van de samenleving en in die van de uitoefening van diverse beroepen. Bayles (1981, 16-17) onderscheidt vier mogelijkheden om de verhouding tussen beroepsethische waarden en normen en algemeen-ethische waarden en normen te beschrijven: beroepsethische waarden en normen zijn

1. identiek aan,

2. specificaties van,

3. functioneel verbonden met, of

4. onafhankelijk van algemene waarden en normen.

Beroepsethische waarden en normen in de eerste betekenis hebben naar de mening van Bayles weinig zin. Ze vervullen dan hoogstens een herinneringsfunctie. Omwille hiervan en volledigheidshalve zouden ze dan pro forma in een beroepscode kunnen worden opgenomen. Dit zou bijvoorbeeld kunnen gelden voor onderdelen van de beroepscode van de NMV (maar ook die van organisaties in andere landen) die insisteren op de plicht tot geheimhouding. Deze plicht heeft in het Nederlands rechtstelsel reeds lang een wettelijke verankering gekregen (zeer lezenswaard is in dit verband De Brauw 1988, met name 34-36 en 43-46). Een desbetreffend artikel in een beroepscode voor verpleegkundigen kan dan ook in principe achterwege blijven. Indien beroepscodes in hun geheel uit dergelijke waarden en normen bestaan, geldt voor hen hetzelfde.

Dat beroepsethische waarden en normen nauwelijks een pendant zouden vinden in algemene waarden en normen moet direct al op 'face value" worden afgewezen. We komen dan terecht in een volstrekt ethisch relativisme. Ieder redelijk denkend mens zal zich een dergelijke situatie alleen met de grootste moeite kunnen voorstellen. Bovendien, in termen van de loyaliteitstheorie van Vos zouden we dan in een massieve waardebeleving terechtkomen die gemakkelijk leidt tot een of andere vorm van morele tirannie. Dan zou er van een samenleving, zoals wij die kennen, geen sprake kunnen zijn.

Ten aanzien van de twee resterende mogelijkheden -de betekenissen sub 2 en 3-komt Bayles' theorie, kort samengevat, op het volgende neer: morele waarden en normen die worden gekoppeld aan de vervulling van een rol als beroepsbeoefenaar kunnen alleen worden gerechtwaardigd door hun bevorderende dan wel conserverende werking ten aanzien van de waarden en normen die in een samenleving als geheel voor nastrevenswaard worden gehouden en als zodanig gerechtvaardigd zijn. Steeds moet dus worden bekeken in hoeverre en op welke wijze beroepsethische waarden en normen invloed uitoefenen op de realisatie van algemene waarden en normen door beroepsbeoefenaren, cliënten en samenleving. Voor een rechtvaardiging van beroepsethische waarden en normen is derhalve noodzakelijk dat de specifieke rol van het beroep in de samenleving wordt of is ge- 
rechtwaardigd. Pas daarna kan de rol wan beroepsethische waarden en normen in ogenschouw worden genomen ten aanzien wan de rechtvaardiging en inhoudelijke vormgeving wan andere (aanvullende of specificerende) waarden en normen. Dit geldt ipso facto voor beroepscodes.

Uit het bovenstaande wolgt, dat een beroepscode vanuit ethisch perspectief zijn laatste grond en legtimering niet vindt in een strewen naar professionalisering, maar in de morele zienswijze( $n$ ) van de samenleving. Een beroepscode dient uiteindelijk te berusten op de maatschappelijke aanvaarding van de rollen en functies die met de uitoefening wan het beroep worden beoogd en op de mate waarin men hiertoe nadere specificatie van algemene normen noodzakelijk acht. In termen van het eerder vermelde voorbeeld: in principe is het niet nodig, dat in een beroepscode woor verpleegkundigen expliciet aandacht wordt besteed aan de geheimhoudingsplicht van de verpleegkundige. Het kan echter noodzakelijk worden in dit verband aanvullende normen te stellen ten aanzien van het opslaan van verpleegkundige gegevens in omvangrijke gecomputeriseerde databestanden, bijwoorbeeld wanneer deze ook voor derden toegankelijk zijn. Dit is echter alleen geĩndiceerd wanneer de rol van de verpleegkundige met betrekking tot automatische verwerking van gegevens ten dienste van patiëntenzorg en onderzoek maatschappelijk is erkend en er op dit terrein nog geen regelgeving tot stand is gekomen (hetgeen deels al wel het geval is met betrekking tot persoonsregistraties).

Hoewel de conclusies van Goldman sterk op die van Bayles lijken, kiest hij woor een geheel andere aanpak van het probleem. Hij gaat niet uit van een gedetailleerde beschrijving van alle alternatieven ten aanzien van de verhouding tussen beroepsethische en algemene waarden en normen. Ook komt hij niet uit bij de rechtvaardiging van de rol van een beroepsgroep in de samenleving ter bepaling van die verhouding. Daarentegen probeert hij zo sterk mogelijke argumenten te vinden voor de posities en noties die hij onder kritiek wil stellen in casu het apartstellen van beroepsgebonden morele claims ten opzichte van de waarden en normen die in de samenleving als geheel gelden. Dit laatste plaatst hij in het kader van de bestaande professionele ideologieën, die hij hiermee impliciet afwijst en die hij wenst te vervangen door een op morele rechten gebaseerde normatieve ethiek van algemene strekking. Hoewel deze ethiek het zwakste onderdeel van zijn beschouwingen vormt (zie hiervoor Luban 1981, 38-40), levert hij overtuigende argumenten ter onderbouwing van zijn afwijzing van de suprematie van beroepsethische waarden en normen.

Zijn uitgangspunt is het concept 'rol-differentiatie', en wel de meest sterke vorm ervan: "We may define a professionall role as strongly differentiated if it requires unique principles, or if it requires its norms to be weighted more heavily than they would be against other principles in other contexts. (...) it must be the case that the occupant of the position be permitted or required to ignore or weigh less heavily what would otherwise be morally overriding considerations in the relations into which he enters as a professional: (Goldman 1980, 2-3). Buiten de professies acht hij 'sterke rol-differentiatie' op minstens eén situatie direct vän toepassing, namelijk die van het gezin. De intrinsieke waarde van de relaties daarbinnen zorgt ervoor, dat de waarden en normen binnen het gezin in veel opzichten een geprivilegieerde vorm aannemen, die daarbuiten ondenkbaar is (ouders hebben bijvoorbeeld vele verplichtingen ten opzichte van hun kinderen die ze niet hebben ten opzichte van andere kinderen). 
Vervolgens evalueert Goldman de argumenten die in verschillende beroepsgroepen zouden pleiten voor een sterke roldifferentiatie en dus voor een bijzondere positie van de daarmee corresponderende waarden en normen in concurrentie met algemeen geldende waarden en normen. Zo ook in de geneeskunde (de verpleegkunde komt niet of nauwelijks aan de orde). Het belangrijke Hippokratische principe 'primum non nocere' zou een sterke stimulans inhouden voor medisch paternalisme, terwijl paternalisme in andere situaties op hevige bezwaren stuit. De aard van het medisch beroep brengt dan met zich mee dat het als sterk rolgedifferentieerd moet worden beschouwd en een afwijkende set waarden en normen bezit. Het is interessant om hier nader op in te gaan, omdat een analogie met het verpleegkundig beroep voor de hand ligt casu quo dezelfde redenering en argumenten oplevert.

Goldman $(1980,179)$ vat de argumenten die gewoonlijk ten faveure van medisch paternalisme worden gegeven, als volgt samen:

1. Volledige openheid van zaken ten opzichte van patiënten maakt soms het optreden van depressies en een achteruitgang in lichamelijke conditie waarschijnlijk of leidt tot medisch niet-optimale keuzes voor een behandeling.

2. Volledige openheid is derhalve soms schadelijk voor de gezondheid van een patiënt en kan zelfs leiden tot verkorting van het leven.

3. Gezondheid en levensverlenging kunnen worden beschouwd als prioriteit onder de preferentiële waarden van degenen die zich onder doktersbehandeling stellen.

4. Aantasting van de gezondheid of versnelling van de dood kunnen daarom worden beschouwd als tegengesteld aan het eigen waardenpatroon van patiënten.

5. Dus is paternalisme gerechtvaardigd: artsen mogen soms voorbijgaan aan het prima facie recht van patiënten op informatie over risico's en behandelingen of over hun eigen situatie, ter voorkoming van schade aan hun gezondheid.

De fundamentele denkfout die hier volgens Goldman (en onszelf) wordt gemaakt ligt in de vooronderstelling dat gezondheid en een lang leven absolute prioriteit genieten in de waardencataloog van patiënten. Patiènten kunnen immers ook kiezen voor de vervulling van een onvoltooide levenstaak, ook al schaalt deze hun gezondheid. Daarnaast is de vraag of artsen voldoende in staat en toegerust zijn om een adequaat beeld te krijgen van die waardencataloog, adequaat althans met het oog op beslissingen die een morele keuze voor patiënten impliceren. Goldman (1980,174-178) vermeldt diverse empirische studies waaruit het tegendeel blijkt. Alles overziende komt hij dan ook tot de conclusie, dat er ten aanzien van de geneeskunde geen sprake is van een zó sterke rol-differentiatie dat een concurrerende set van waarden en normen ten opzichte van die van de samenleving in het algemeen gerechtvaardigd is, zelfs niet als eén van de belangrijkste als typisch medisch beschouwde handelingsprincipes in stelling wordt gebracht.

Op grond van de analyses van Bayles en Goldman moet een beroep op de superioriteit van beroepsgebonden morele claims worden afgewezen of op zijn minst in twijfel worden getrokken. De autonomie van beroepsethische waarden en normen geldt alleen wanneer deze autonomie voor diezelfde waarden en normen reeds in algemene zin is vastgesteld. Prioritering van waarden en normen vanuit de positie van een beroepsgroep is alleen aanvaardbaar overeenkomstig de maatschappelijke erkenning van de rol die een dergelijke beroepsgroep in de samenleving verult. Zowel autonomie als prioriteit van beroepsgebonden morele claims zijn dus extern bepaald en van retorische of tautologische aard. 
Wanneer we de warden in beroepscodes in ogenschouw nemen is deze conclusie nog op andere wijze toe te lichten. De centrale waarde 'dienstbaarheid' bijvoorbeeld heeft als belangrijkste afgeleide waarde het vooropstellen van de belangen van patiënten/cliënten. De centrale watrde zelf kan dus alleen maar een zekere autonomie en prioriteit worden verleend indien deze constellatie door patiënten/cliênten als een belang wordt ingezien en aanvaard. Dit betekent wederom dat de atumomie en prioriteit van een waarde -in dit geval 'dienstbaarheid'- door een aan de beroepsgroep externe instantie worden bepaalid, namelijk de als vertegenwoordiger van de samenleving te beschouwen groep patienten/clëmten. In dit geval dient dus alleenal om redenen van logica de superioriteit van beroepsgebonden morele claims te worden afgewezen (vergelijk ook Goldman 1980 , 24).

Verder kan deze conclusie phrastisch-neustisch worden geduid in termen van de loyaliteitstheorie van Vos. Daaraan zijn argumenten te ontlenen die pleiten voor een zekere autonomie en prioritering van beroepsethische waarden en normen ten opzichte van algemene walarden en normen. Dat is althans de eerste indruk die men krijgt op grond van de vele phrastische betekenissen van bijwoorbeeld een waarde als 'dienstbaarheid' en de daarmee corresponderende neustische componenten. Het is immers voorstelbaar dat een beroepsgroep en beroepsbeoefenaren gezamenlij $k$ besluiten uit de vele betekenissen er ến dominant te verklaren en de neustische component ervan in één rỉchting te definiëren.

Een dergelijke witleg moet op grond van de theorie zẻlf worden afgewezen. Ten eerste, omdat onvoldoende rekening wordt gehouden met de praktijk van het morele leven. De betekenis voor de individuele verpleegkundige van een waarde als dienstbaarheid is de resultante van overlevering, traditie, opvoeding, scholing en arbeidscontext. Buiten het beroep gelegen factoren kunnen dus mede de uiteindelijke inhoud van zo'n waarde bepalen. Om dezelfde reden kan die inhoud voor elke verpleegkundige weer anders zijn. We hebben al gezien dat dit tot uiteenlopende en zelfs tegengestelde handelingspraktijken aanleiding kan geven. Het dominant verklaren van éen bepaalde betekenis kan weliswaar leiden tot een zeker uniformering van deze handelingspraktijken, maar is in strijd met de gebruikelijke ontwikkeling in phrasticiteit van waarden. Ook dreigt het gevaar van een hypertrofiëring van de neustische component. Bovendien is het de vraag welke betekenis uiteindelijk de voorkeur moet krijgen (zie ook hieronder). Op de keper beschouwd komen hiervoor alleen maar betekenissen in aanmerking die reeds in het morele leven buiten de beroepsethische sfeer besloten liggen. Anders worden ze niet herkend en gekend. Een tweede reden volgt uit het principe van deliberatie. Een afweging van de morele idealen in een concrete situatie vindt altijd plaats op grond van de behoeften, belangen en verlangens van de betrokkenen. De cliènt en via deze de samenleving vormen een storende factor indien men hieruit zou willen besluiten tot de autonomie en prioriteit van beroepsethische waarden. Deze factor blijft zijn invloed op een dergelijk beshitvormingsproces behouden, ook wanneer dit op een centralal niveau als dat van de beroepsgiroep als geheel plaatsvindt en min of meer van de concrete (hulpverlenings)situatie wordt geabstraheerd (en dus het gevaar dreigt van bovenvermelde strijdigheid met de praktijk van phrasticiteit). Bovendien moet dan in het geval van beroepscodes worden gewezen op een ander gevaar. Het principe van deliberatie wordt geweld aangedaan indien we mogen accepteren, dat beroepscodes in veel gevallen het werk zijn en de morele idealen weerspiegelen van een professionele elite (vergelijk 3.4.1.). 
Een laatste reden tenslotte vat de voorgaande min of meer samen in een kritiek op de wooronderstellingen achter de vermeende superioriteit van beroepsethische claims. Gezien de eisen van phrasticiteit en deliberatie alsmede de kenmerken van waardebegrippen heeft een dergelijke optie alleen kans van slagen wanneer het veld van beroepsmatig verrichte arbeid wordt opgevat als een gesloten systeem van activiteiten zonder directe beinvloeding van buiten. Dit nu moet als een onhoudbare situatie worden beschouwd, die op den duur ook niet verdedigbaar is. In de gezondheidszorg zou een dergelijk systeem alleen kunnen functioneren wanneer men patiënten en cliënten (en dus de samenleving) buiten de deur houdt. Maar daarmee houdt het op gezondheids-zorg te zijn, nog afgezien van andere factoren die zo'n opstelling in de weg staan (bijvoorbeeld werkgelegenheid). Waar het gesloten systeem toch wordt hooggehouden komt men onherroepelijk terecht in een massieve waardenbeleving, waarbij de kenmerken van het systeem van toepassing worden verklaard op de totale werkelijkheid. Alleen dan kan er sprake zijn van een superioriteit van beroepsgebonden morele claims. Dat dit uiteindelijk leidt tot vormen van moralisme, ideologisering en morelle tirannie is inmiddels bekend, maar moet tevens worden gezien als een vervelende uitwas van bedrijfsblindheid op grond van verkeerd gekozen vooronderstellingen.

\subsubsection{Legitimiteit van beroepsgebonden morele claims}

De superioriteit van beroepsethische waarden moet nu weliswaar worden ontkend, het blifift echter de vraag hoe vanuit ons meta-ethisch en normatief-ethisch perspectief tegen die waarden zelf moet worden aangekeken. Is bijvoorbeeld 'dienstbaarheid' wel een geschikte waarde om als centraal en samenvattend begrip voor de beroepsethiek van verpleegkundigen dienst te doen? Welke samenhang bestaat er met andere als centraal gekarakteriseerde waarden? Dergelijke vragen insisteren op een verheldering van het fundament van deze waarden en een beschrijving van hun onderlinge relaties. Een min of meer formele duiding van hun aard en positie volstaat dan niet meer. Werd in de voorgaande paragraaf de superiorieit van beroepsgebonden morele claims beoordeeld vanuit een beschrijving en analyse van de verhouding tussen beroepsethiek en algemene ethiek, het gaat er nu om de daarbij aan de orde zijnde waarden materieel-inhoudelijk te waatderen. Uiteindelijk betreft dit de vraag naar de legitimatie van beroepsethische waarden. Vanuit loyaliteitstheoretisch perspectief wordt de legitimiteit van (beroeps)ethische waarden ten diepste bepaald door hun phrastisch-neustisch karakter. Wenselijk daarbij is een weerspiegeling van de vele betekenissen die aan menselijke activiteiten en gebeurtenissen worden verleend en van de positieve houding daartegenover. De legitimiteit van walarden wordt derhalve groter of sterker naarmate zij meer betekenissen en/of (sub)waarden insluiten en naarmate de genoemde positieve houding door meer mensen wordt gedeeld.

Een dergelijke uitwerking van de legitimiteit van (beroeps)ethische waarden ligt in het verlengde van de aspecten die Barnsley in 3.2.1. aan het legitimiteitsvraagstuk onderscheidde. Volgens hem wordt de legitimiteit van waarden bepaald door hun realiteit-gebondenheid, intersubjectiviteit en rechtvaardigbaarheid. Met 'realiteit-gebondenheid" bedoelt hij dat waarden een zekere band onderhouden met de ware aard der dingen, dat zij een substraat in de werkelijkheid van alledag bezitten. Dezelfde eis geldt ten aanzien van de phrastische bijdrage aan de legitimiteit van waarden. 'Intersubjectiviteit' slaat op 
het vereiste dat een waarde bindend moet zijn voor meer dan ến persoon, niet alleen mijzelf, maar ook anderen. Dit vereiste duidt op een zekere belangeloosheid en generaliseerbaarheid in het morele karakter van waarden. Een dergelijke binding ontstaat alleen wanneer een aantal personen een positieve houding inneemt ten opzichte van waarden, hetgeen ook geimpliceerd is in de neustische bijdrage aan de legitimiteit van waarden. Met "rechtwaardigbaarheid" verwijst Barnsley naar de gegrondheid van een waarde, waarmee hij zelfs de mogelijkheild van een zekere bewijsvoering niet wil uitsluiten. Zo omschreven valt dit aspect min of meer samen met of kan als het resultaat worden beschouwd van de twee eerder genoemde aspecten. Met cen evenwichtige verhouding tussen realiteit-gebondenheid en intersubjectieve waardering oftewel tussen phrastische en neustische componenten van waarden is hun rechtvaardigbaarheid en legitimiteit in zekere zin gegeven.

Wat nu te zeggen wan de legitimiteit van 'dienstbaarheid" als centrale waarde binnen de uitoefening van het beroep van verpleegkundige? Aan deze vraag kunnen twee verdere wragen worden onderscheiden, namelijk die naar de interne en die naar de externe legitimiteit van dienstbaarheid. De interne legitimiteit verwijst naar de rechtvaardigbaarheid van dienstbaarheid als constituerende, meest fundamentele morele waarde die met het morele karakter van de uitoefening van het beroep van verpleegkundige is verbonden en dit morele karakter nader specificeert. De externe legitimiteit betreft de rechtvaardigbaarheid van dienstbaarheid binnen de context van waarden die in gezondheidszorg en samenleving van fundamenteel belang worden geacht. Gezien onze conclusie uit de vorige paragraaf kan de interne legitimiteit worden beschouwd als een functie van de externe legitimiteit. Niettemin zullen we eerst enige alinea's besteden aan eerstgenoemde vorm. Onderzoek naar de motieven en belangen van beroepsbeoefenaren bij de vervulling van hun arbeidstaken heeft een inzicht opgeleverd in hun dominante waardenoriëntatie. In paragraaf 2.3.7. zijn daarbij de volgende waarden onderscheiden (zie ook figuur 2.1): dienstbaarheid, zelfontplooiing, inkomen/prestige, en onafhankelijkheid/autonomie. De eerste twee waarden zijn van expressieve aard, de laatste twee van instrumentele aard. Vanuit een moreel perspectief dienen de laatste drie een prudentieel belang en alleen de eerste, 'dienstbaarheid', een sociaal belang. Zo beschouwd komt dus alleen de waarde 'dienstbaarheid' in aanmerking om als centrale waarde voor beroepsbeoefenaren moreel te worden gelegitimeerd. Indien 'dienstbaarheid' empirisch een socialle waarde is, dan bezit deze warde een hoge mate van realiteit-gebondenheid en mogen we aannemen dat veel verpleegkundigen er positief tegenover staan. In dat geval is er ook een zeker evenwicht aanwezig tussen de phrastische en neustische component van dienstbaarheid. In zoverre is dienstbaarheid dus phrastisch-neustisch intern gelegitimeerd als centrale morele waarde bij de uitoefening van het beroep van verpleegkundige.

De toevoeging "in zoverre" wordt hier echter met nadruk naar voren gebracht. Het genoemde evenwicht blijkt immers nogal wankel. Ons eigen onderzoek heeft tot nu toe opgeleverd dat de realiteit-gebondenheid wan dienstbaarheid zich manifesteert in vele phrastische betekenissen, die niet alle even hoog als moreel kunnen worden gewaardeerd. Sommige betekenissen moeten zelfs moreel worden gediskwalificeerd. Bij dit laatste hoeven we slechts te verwijzen naar het naar voren schuiven van dienstbaarheid als 'window-dressing", dus als centraal object van een massieve waardenbeleving waarin het neustische het phrastische heeft overwoekerd (vergelijk 5.2.1 en 4.4.4). 
Maar ook bij de betekenissen waarin schijnbaar een evenwicht is bereikt tussen het phrastische en het neustische kan sprake zijn van een verschillend moreel gewicht. Deze verschillen hebben onder andere te maken met de mate waarin dienstbaarheid een betekenis krijgt die overeenkomt met overlevering, traditie en conventie en aldus sociaal-culturele continuïteit vertoont (de mate waarin fundamenteel geachte maatschappelijke waarden worden gerepresenteerd komt hierna aan de orde). Dienstbaarheid als morele waarde heeft in dit opzicht primair betekenis in het sociale verkeer en de interactie tussen mensen. Iemand is dienstbaar wanneer hij iemand van nut is, zijn belang bevordert. Een dienstbare opstelling wordt in belangrijke mate gekenmerkt door belangeloosheid en partijdigheid: veronachtzaming van het eigenbelang en partijdigheid voor het belang wan de ander. Om deze reden moet dienstbaarheid als 'window-dressing' moreel worden gediskwalificeerd. Daarentegen dienen handelingen die het belang van de ander op het oog hebben moreel positief te worden gewaardeerd, zeker indien met dit belang belangrijke persoonlijke en maatschappelijke waarden zijn gemoeid.

Welnu, het belang waar het in het kader van de verpleegkundige beroepsuitoefening om gaat is nauw verbonden met de bestaansgrond van het beroep als zodanig, namelijk de gezondheid en het welzijn van mensen alsmede de bevordering daarvan. Alle handelingen die daarop zijn gericht en tevens zijn geïmpliceerd in de waarde dienstbaarheid, verdienen moreel het primaat. Daarmee zijn zowel die handelingen als de waarde dienstbaarheid zelf phrastisch-neustisch gelegitimeerd.

Met het bovenstaande kan nu ook phrastisch-neustisch een zekere prioriteit worden aangegeven in de morele connotaties bij de waarde dienstbaarheid zoals gerealiseerd of te realiseren door verpleegkundigen. Deze waarde is primair gericht op het belang van de patiënt/cliënt, zoals dat door deze zelf (op maatschappelijk aanvaarde wijze) wordt waargenomen. Pas secundair wordt de aandacht gericht op factoren die (direct of indirect) met dit belang in verbinding staan, maar niettemin een eigenbelang vertegenwoordigen, zoals het rekening houden met de eigen competentie, ontwikkeling van het vakgebied, samenwerking met collega's en het volgen van instellingsbeleid. Dezelfde rangordening of hiërarchisering troffen wij aan in de onderzochte beroepscodes voor verpleegkundigen, zodat die rangorde kennelijk legitiem wordt geacht.

Vervolgens de externe legitimiteit van dienstbaarheid. Om deze phrastisch-neustisch te kunnen duiden is nodig dat wij de waarde 'dienstbaarheid' in relatie brengen tot de waarde 'loyaliteit' die Vos als de meest fundamentele morele waarde identificeerde op grond van zijn axiologische theorie (zie 5.2.1). Daarnaast dienen we aan te geven hoe dienstbaarheid en loyaliteit samenhangen met andere, als maatschappelijk relevant geachte waarden.

Voor dit laatste doen we een beroep op een door Philipsen (1988, 138-148) beschreven en vervolmaakte taxonomie van fundamentele waarden die in ons huidige (westerse) tijdsgewricht in de samenleving worden aangetroffen (zie figuur 5.1). Deze taxonomie is vertikaal geordend volgens de vier fundamentele problemen waardoor, naar een inzicht van Parsons, elk sociaal systeem wordt gekenmerkt, namelijk die van aanpassing, doelverwezenlijking, integratie en patroonhandhaving (de engelstalige termen leveren de beginletters op voor wat ook wel bekend staat als het AGIL-schema). Horizontaal zijn de waarden geordend naar de mate waarin ze vooral instrumenteel dan wel expressief van aard zijn (merk op dat we een dergelijk onderscheid ook aantroffen bij de waar- 
denoriêntatie van beroepsbeoefenaren). De waarden zelf zijn ontleend aan recente beschouwingen van Nagel en van Mooy waarbij "hun' waarde 'kennis en inzicht' werd gesplitst in 'functionele rationaliteit' en 'substantiële rationaliteit'. In deze laatste waarden herkent men overigens de invloed van Weber en Habermas op de beschouwingen van Philipsen.

Figuur 5.1: Taxanomie van fundamentele maatschappelijke waarden (Bron: Philipsen, 1988, p. 147)

\begin{tabular}{|c|c|c|}
\hline & instrumenteel & expressief \\
\hline aanpassing & efficiency & continuïteit \\
\hline doelverwezenlijking & perfectie & welzijn en geluk \\
\hline integratie & rechtvaardigheid & solidariteit \\
\hline patroonhandhaving & functionele rationaliteit & substantiële rationaliteit \\
\hline
\end{tabular}

De kracht van deze taxonomie ligt in het vermogen tot ordening en in de schijnbare eenvoud ervan. Maar schijn bedriegt. De werkelijkheid is complexer, het palet van waarden oneindig groot en het geheel tamelijk weerbartig met het oog op ordening. Bovendien is deze taxonomie gebaseerd op een sociologische interpretatie van de werkelijkheid. Zoals onder nog zal blijken, staat zij op gespannen voet met een morele interpretatie van die werkelijkheid.

Phrastisch-neustisch is op deze taxonomie dan ook wel het een en ander af te dingen. Op de eerste plaats vertegenwoordigen de categorieèn uit het AGIL-schema zelf bepaalde waarden die nominalistisch-voluntaristisch nader moeten/kunnen worden geduid. Hetzelfde geldt voor de waarden 'instrumentaliteit' en 'expressiviteit'. Ten tweede blijkt alleen al ten aanzien van de classificatie van de waarde 'rechtvaardigheid' als instrumenteel-integratief dat we hier van doen hebben met een specifieke en wat ons betreft geen alledaagse betekenis van rechtvaardigheid. De waarde kan volgens een andere betekenis ook worden beschouwd als een vorm van expressieve doelverwezenlijking. Uit het voorgaande kan worden afgeleid dat het weliswaar muttig kan zijn een taxonomie op te stellen, maar dat de betekenis van het aldus geclassificeerde aan veranderingen onderhevig is; veranderingen die onder andere te maken hebben met de context waarbinnen de taxonomie wordt gebruikt. In ons geval betreft deze het morele perspectief en bijvoorbeeld niet een sociaal-economisch perspectief. Het gaat ons dan ook niet zozeer om een kritische beschouwing van de taxonomie als zodanig, maar om een doordenking ervan vanuit het morele in het licht van de loyaliteitsthese van Vos en de plaats daarin van de waarde 'dienstbaarheid".

Zoals we hebben gezien ten aanzien van de arbeidsmotieven bij de bespreking van de interne legitimiteit van dienstbaarheid, zal ook haar externe legitimiteit vooral moeten worden gezocht in de expressief-georiënteerde waarden. Instrumentele waarden (hier bekeken vanuit ethisch perspectief) doen immers altijd dienst als vehikel voor het bereiken van 'hogere' waarden. Instrumentele waarden worden door deze gelegitimeerd en begrensd. Ze zijn dan ook geen eindwaarden in de betekenis die Philipsen daaraan 
hechtte en ze bezitten een 'middellijk' karakter, hetgeen eveneens niet in overeenstemming is met de opvatting van deze auteur (vergelijk 3.2.1).

Expressieve waarden daarentegen zijn vaak de articulatie van "het goede" in normatiefethische zin en verwoorden een moreel ideaal waaraan andere (bijvoorbeeld instrumentele) waarden ondergeschikt zijn.

Daarnaast hebben we ten aanzien van de toen genoemde arbeidsmotieven geconstateerd dat lang niet alle expressieve waarden de morele toets kunnen doorstaan. Expressieve waarden die gericht staan op het eigenbelang (bijvoorbeeld "zelfontplooiing") moeten noodzakelijkerwijs buiten beschouwing blijven bij de omschrijving van 'het goede". Hetzelfde geldt voor waarden die betrekking hebben op de voorwaarden voor het functioneren van waardebegrippen en derhalve voor een omschrijving van 'het goede' tout court. Voor dit laatste kan worden verwezen naar de door Vos in meta-ethisch perspectief onderscheiden fundamentele begrippen 'phrasticiteit' en 'deliberatie' (zie 5.2.1). Het gaat ook op voor waarden als 'moed' en 'integriteit'. In beide gevallen is sprake van een zogemaamde "... executieve deugd, d.w.z. een waardebegrip waarmee een voorwaarde wordt aangeduid voor het handelen in het algemeen. Of we met een dergelijk gedrag werkelijk lets goeds nastreven hangt af van de meer untrinsieke waardebegrippen als rechtvaardigheid en vrijheid" (Vos 1989, 150). Overigens blijkt uit dit citaat dat ook Vos aan 'rechtvaardigheid' een meer intrinsieke respectievelijk expressieve betekenis hecht dan een extrinsieke respectievelijk instrumentele betekenis.

Dit onderscheid tussen executieve deugden en 'het goede' definiërende waarden maakt het ons mogelijk te differentièren naar het morele karakter van de expressieve waarden in de taxonomie van Philipsen. 'Substantiële rationaliteit' blijkt dan veel verwantschap te vertonen met 'deliberatie', ook wanneer belde begrippen unhoudelijk worden ontleed. 'Continuitteit' vervult dezelfde functie als bovenvermelde 'integriteit' en dient dus als executieve deugd te worden gekwalifficeerd. Noch 'substantiele rationaliteit' noch 'continuiteit' zijn een geschikt waardebegrip voor een nadere bepaling van 'het goede'. Vanuit moreel perspectief zouden zij onder de instrumentele waarden zijn gerangschikt.

Blijven over 'welzijn en geluk' en 'solidariteit'. De eerste waarde wordt in diverse varianten van een eudaimonistisch-hedonistisch gefundeerde teleologische normatieve ethiek gereserveerd voor een omschrijving wan niet alleen "het goede", maar zelfs van het 'hoog ste goed' (een situatie derhalve die volgens Vos nimmer ten volle wordt bereikt). In de taxonomie van Philipsen wordt dezelfde waarde geidentificeerd als een systeembehoefte, waaraan bijvoorbeeld de zorg voor de volksgezondheid in hoge mate tegemoet lijkt te komen en veelal zelfs met het resultaat daarvan wordt gelijkgesteld. In de bevrediging van deze behoefte toont zich echter het individualistische karakter ervan, waardoor kan worden gewezen op een zeker verband met het eigenbelang. Dit maakt deze waarde minder geschikt als criterium voor moreel gedrag.

Ook volgens Vos kunnen 'welzijn en geluk' niet de centrale noemer zijn waarop de functie van morele oordelen kan worden verklaard, omdat zij de mogelijkheid impliceren van. het zogenaamde 'amorele goede leven', terwijl zij ook te maken hebben met de wijze waarop wij door anderen worden bejegend. Ook keert bij zich tegen een speltheoretische opvatting als zouden gedragsoriëntatie en -coördinatie de belangrijkste functies van moraal en ethiek zijn, vanwege de impliciete concurrentie tussen waarden onderling (Vos 1989, 146-147). 'Loyaliteit" heeft deze nadelen niet. Zij heeft geen concurrentie te duch ten van contradictoire waarden zonder het morele zelf aan te tasten. Een moreel leven 
zonder loyaliteiten (zowel ten aanzien van bijwoorbeeld eigen afkomst en geluk, als die van anderen) is ondenkbaar. 'Loyaliteit' fungeert dus zowel meta-ethisch als normatiefethisch als centraal principe. Zij verklaart niet alleen het morele gedrag, maar is tevens als het ware de materieel-inhoudelijke verwoording van wat gedrag uiteindelijk tot moreel gedrag maakt.

De door Philipsen onderscheiden waarde 'solidariteit' kan met deze 'loyaliteit' van Vos inhoudelijk op één lijn worden gesteld en vertegenwoordigt dus een waarde die wél een moreel goedkeuringsstempel kan krijgen, mits ontdaan van moralistisch-ideologische verengingen. Een dergelijke verenging treedt op wanneer wij 'solidariteit' (of 'loyaliteit') bijvoorbeeld de betekenis zouden meegeven van de meer op het eigenbelang gerichte 'klassesolidariteit', zoals nogal eens wordt benadrukt in de verhouding van beroepsbeoefenaar tot beroepsgroep, of 'collegialiteit', een waarde die kenmerkend kan worden geacht voor de relaties tussen beroepsbeoefenaren onderling (vergelijk Vos 1989, 79). Moralistisch-ideologische verengingen lijken in veel mindere mate aanwezig in een betekenis als 'solidariteit met de onderdrukten' of 'loyaliteit aan de behoeftigen'. Maar ook hier moeten we steeds de vraag stellen uit wiens naam solidariteit en loyaliteit worden betoond. Wordt een actie van solidariteit of loyaliteit ondernomen vanwege het belang van de ander, in altruilstische zin, of zijn onze handelingen gericht op het (bijvoorbeeld economische) voordeel dat onze solidariteit met of loyaliteit aan de onderdrukten ons kan opleveren, dus in egoïstische zin? Vanuit moreel perspectief bezien wordt uiteraard de voorkeur gegeven aan de altruïstische betekenis. Neustisch is dit ook de betekenis die in onze samenleving de grootste waardering geniet. $\mathrm{Zij}$ wordt gebezigd in ons politieke spreken over ontwikkelingssamenwerking; maar ook in ons sociaal-economisch spreken over een herziening van het stelsel van ziektekostenverzekeringen. Maar nogmaals, wij mogen daarbij nimmer de beperkingen uit het oog verliezen, die ons door recht, moraal en gewoonte zijn gesteld (vergelijk Vos 1989, 92).

Deze stellingname is, strikt genomen, niet zonder betekenis voor een belangrijke kwestie in samenhang met onze centrale vraagstelling, namelijk met betrekking tot het morele karakter van het professionaliseringsstreven van verpleegkundigen. We zouden dit streven vanuit het gezichtspunt van patiënt en samenleving als contra-altruïstisch kunnen interpreteren en daarmee moreel diskwalificeren. In de solidariteit met en loyaliteit aan de patiënt zou geen plaats kunnen worden ingeruimd voor een oriëntatie op het eigen beroep. Echter, 'solidariteit' en 'loyaliteit' worden ook hier gespecificeerd door situatie en omstandigheden, met name door de gezondheidszorg- en hulpverleningstaak van de verpleegkundige. Men staat niet als mens tegenover mens, maar primair als beroepsbeoefenaar tegenover cliënt. Met/aan de laatste kan alleen solidariteit respectievelijk loyaliteit worden betoond indien men zijn vak verstaat, anders moet men zijn contacten beperken tot het bezoekuur of de vrijetijdsclub. Een zekere gerichtheid op het vak en de ontwikkeling daarvan in groepsverband kan dan ook worden beschouwd als 'executieve deugd', als voorwaarde voor het betonen van solidariteit met en loyaliteit aan de patiënt. Men kan hetzelfde ook verwoorden in termen van de taxonomie van Philipsen: om de expressieve waarde solidariteit in hulpverleningsprocessen te realiseren, is nodig dat instrumentele waarden als efficiency, perfectie en functionele rationaliteit met het oog op de beroepsuitoefening zelf een zekere plaats toebedeeld krijgen. In acute situaties kunnen deze zelfs van levensbelang zijn. 
Met het bovenstaande is betoogd dat 'solidariteit' en 'loyaliteit' kunnen worden beschouwd als centrale morele waarden, zo niet als "het hoogste goed' articulerende waarden binnen de samenleving en de verhoudingen tussen mensen. Bovendien hebben we gezien dat deze waarden in de concrete hulpverleningssituatie nader worden gespecificeerd, mede in de context van andere relevante waarden. De meest positieve morele connotatie wordt echter geboden bij die betekenissen waarin het minst sprake is van een gerichtheid op het eigenbelang. Altruïsme, belangeloosheid en onpartijdigheid zijn de nadere structurerende waarden ter bepaling van de morele kwaliteit van het handelen.

Ligt het dan niet voor de hand 'loyaliteit' en 'solidariteit' als centrale waardebegrippen te vervangen door 'altruïsme', 'belangeloosheid' en 'onpartijdigheid'? Naar onze mening vormen deze begrippen in meta-ethisch perspectief niet meer dan een redelijk alternatief. $\mathrm{Zij}$ verklaren het morele gedrag van mensen niet beter dan reeds is gebeurd door invoering van het loyaliteits- en solidariteitsprincipe.

Wanneer wij dan 'loyaliteit' als centraal waardebegrip willen blijven beschouwen, doen wij dat vooral om redenen van theoretische en phrastisch-neustische plausibiliteit en wel als verklaring voor de functie van morele oordelen in het kader van de meta-ethiek. 'Solidariteit' handhaven we als centraal waardebegrip in normatief-ethische zin, in haar primaire morele duiding als 'solidariteit met de hulpbehoevenden'. Hiermee worden andere belangrijke morele waarden (bijvoorbeeld 'vrijheid' en 'rechtvaardigheid') weliswaar voorlopig even tussen haakjes gezet, maar uit het voorgaande moge duidelijk geworden zijn dat 'solidariteit' veel verbindingen heeft met andere waardebegrippen en dat haar phrastisch-neustische oriëntatie in belangrijke mate met behulp van diezelfde waardebegrippen wordt bepaald. Daarnaast speelt op de achtergrond mee dat onze verhandeling in hoofdzaak betrekking heeft op sociale verschijnselen als professionallisering, beroepscodes en gezondheidszorg en minder op het persoonlijke morele leven van mensen. In het laatste geval zullen wellicht andere waarden centraal moeten worden gesteld (bijwoorbeeld wederom 'vrijheid'). Ten aanzien van verschijnselen die niet direct appelleren aan het persoonlijke morele leven van mensen, maar voornamelijk sociaal-ethisch of macro-ethisch van aard zijn, voldoet een waarde als 'solidariteit' in hoge mate aan actualiteits- en relevantiecriteria, gezien haar rol in het moderne politiekmaatschappelijke debat over diverse aspecten van de inrichting van onze samenleving. Met andere woorden: 'solidariteit' voldoet aan hoge eisen van phrasticiteit en deliberatie, de twee voornaamste bepalende factoren voor het karakter van waardebegrippen.

Tenslotte de relatie tussen de waardebegrippen 'solidariteit' en 'dienstbaarheid'. Hiervan zegt Philipsen het volgende: ".... solidariteit kent twee varianten. De eerste en oorspronkelijke betekenis is particularistisch van aard: de naasten worden gedefinieerd als de eigen mensen. De tweede betekenis is universalistisch en wellicht de belangrijkste bijdrage van het christelijk denken aan de huidige wereld: de eigen mensen is gelijk aan alle mensen. Bij solidariteit wordt gewoonlijk geacht een cluster van handelingswaarden te behoren die men kan aanduiden met de term dienstbaarheid" (Philipsen 1988, 48). Voorts zijn wij het in dezelfde context eens met zijn constatering dat de grondgedachte van 'solidariteit" bestaat in de verantwoordelijkheid voor de naaste in nood.

Meer nog dan deze gelijkenis in de primaire morele betekenis van solidariteit in de opvatting van Philipsen vergeleken met die van onszelf, valt de directe relatie op die hij legt met het waardebegrip 'dienstbaarheid'. Het is precies deze relatie die wij op het oog hebben bij het vraagstuk van de externe legitimatie van beroepsgebonden morele claims. Dit 
wordt eens te meer duidelijk wanneer dit waardencomplex kenmerkend voor de gezondheidszorg wordt genoemd (Philipsen 1988, 47), dus ook voor verpleegkundige hulpverlening.

Voor een nadere duiding van genoemde relatie is nodig dat wij ons het door Philipsen gehanteerde verschil tussen eindwaarden en handelingswaarden in herinnering roepen (zie 3.2.1). Eindwaarden zijn (gewenste) eindtoestanden en kunnen worden vergeleken met waarden zoals we in het normale spraakgebruik hanteren of, specifieker, met expressieve waarden zoals we die boven reeds tegenkwamen. Handelingswaarden vormen differentiaties in bejegeningsstijlen, te vergelijken met deugden en instrumentele waarden en, gezien deze laatste vergelijking, meer specifiek met executieve deugden. Wanneer nu 'dienstbaarheid" moet worden beschouwd als de samenvatting van een complex handelingswaarden ter realisatie of ondersteuning van de eindwaarde 'solidariteit', dan is niet alleen beider relatie beschreven, maar dient 'dienstbaarheid' nadrukkelijk in approbationistische zin te worden beschouwd als een afgeleide norm, deugd of plicht (wergelijk 3.2.1. Dit betekent dat er een rechtstreeks verband kan worden gelegd tussen een beroepsgebonden morele claim ('dienstbaarheid') en een centrale maatschappelijke waarde ('solidariteit'), waarbij de eerste functioneel verbonden is met of een specificatie vormt van de laatste. Met andere woorden: 'dienstbaarheid' wordt extern gelegitimeerd door 'solidariteit' en kan dus geen prioriteit krijgen anders dan in een nadere phrastisch-neustische duiding van diezelfde 'solidariteit'. Deze conclusie volgt geheel de lijn en argumentatie die wij eerder aantroffen in de opvattingen van Bayles, Goldman en Vos (vergelijk 5.2.1 en 5.2.2).

\subsubsection{Morele status van beroepscodes}

Wanneer 'dienstbaarheid' kan worden beschouwd als de centrale en samenvattende morele waarde van de waarden en verplichtingen die zijn opgenomen in de onderzochte beroepscodes voor verpleegkundigen, dan heeft het bovenstaande vergaande implicaties voor de morele status van deze beroepscodes. Zoals eerder vermeld, is deze morele status verbonden met het soort rechtvaardiging en het type argumenten die kunnen worden aangevoerd voor hun bestaan. Deze verlenen beroepscodes een bepaalde zijnswaarde, waarbij vervolgens de vraag aan de orde is of deze van dien aard is dat specifieke morele gedragsregels in acht moeten worden genomen door en ten opzichte van degenen op wie de beroepscodes betrekking hebben.

We merken op dat we hier niet ingaan op het statusbegrip, zoals dat functioneert en wordt omschreven binnen de sociologie (bijvoorbeeld zijn relatie met begrippen als sociaal prestige, beroepscode als statussymbool). In het morele debat verwijst 'status' naar eigenschappen die moreel relevant zijn en tot bepaalde handelingsindicaties aanleiding geven. Deze eigenschappen kunnen zijn gelegen in zowel personen als zaken, zodat aan beide morele status kan worden toegewezen. Dit blijkt ook wel uit binnen de ethiek gevoerde discussies over de proportionaliteit van middelen aan morele doeleinden. Toegepast op de gezondheidszorg: het gebruik van een dikke botte naald bij het injecteren van medicijnen wijst (bij de beschikbaarheid van dunne, scherpe naalden) op een disproportionaliteit van middelen. De naald bezit een bepaalde morele status, tot uiting komend in zijn geschiktheid bij de realisatie van een moreel doel (bijvoorbeeld pijnbestrijding). 
Een gevolgtrekking ten aanzien van de morele status van beroepscodes kan nu reeds zijn, dat deze vooral moet worden gezocht in hun 'middellijk' karakter, in hun morele geschiktheid als middel tot een moreel doel. Dit betreft echter beroepscodes als 'zaak'. De conclusie dient te worden gemuanceerd in het licht van de hen constituerende waarde(n). Ten aanzien van de beroepscodes voor verpleegkundigen gaat het dan om 'dienstbaarheid'. Hun zijnswaarde is er nauw mee verbonden.

'Dienstbaarheid' werd in 5.2 .3 intern gelegitimeerd als de centrale morele waarde bij de uitoefening van het beroep van verpleegkundige. Deze legitimatie kwam voort uit de verbondenheid van een specifieke phrastisch-neustische duiding van 'dienstbaarheid' met de bestaansgrond van het beroep -namelijk de gezondheid en het welzijn van mensen- en met de expressieve waardenoriëntatie van beroepsbeoefenaren. Bovendien bleek het hierdoor mogelijk prioriteit aan te geven in verschillende phrastisch-neustische interpretaties van 'dienstbaarheid' in haar samenhang met andere waarden. Zowel ten aanzien van de primaire morele betekenis van 'dienstbaarheid' als met betrekking tot genoemde prioritering werden sterke overeenkomsten gevonden met de structuur en inhoud van de beroepscodes, waardoor ook deze laatste intern gelegitimeerd werden ten aanzien van hun morele functie.

Extern werd 'dienstbaarheid' moreel gelegitimeerd vanwege haar deelname aan een andere, overkoepelende waarde. Op grond van een ethische analyse van fundamentele maatschappelijke waarden en dominante waardenoriëntaties in samenleving en gezondheidszorg werd een dergelijke positie toegekend aan een specifieke phrastisch-neustische interpretatie van de waarde 'sollidariteit'. Bovendien werd, juist in het kader van de gezondheidszorg, een sterke samenhang gevonden tussen deze 'solidariteit' en 'dienstbaarheid' in die zin, dat de laatste functioneel is verbonden met de eerste en deze nader specificeert in hulpverleningssituaties. $\mathrm{Er}$ is dus weliswaar sprake van een externe morele legitimatie van 'dienstbaarheid', echter niet als centrale (eind)waarde, maar als afgeleide (handelings)waarde of executieve deugd ten opzichte van 'solidariteit' (vergelijk het eerder vermelde 'middellijke' karakter van beroepscodes). Met dit laatste is tevens aangegeven dat ten aanzien van 'dienstbaarheid' als centraal moreel model en handelingskader voor de uitoefening van het beroep van verpleegkundige in maatschappelijk opzicht geen superioriteit kan worden geclaimd in vergelijking tot andere morele waarden. Met het oog op meer zekerheid en onderbouwing van deze conclusie zijn in 5.2 .2 beroepsethische waarden vergeleken met waarden van algemeen-ethische strekking.

Hiermee staan de morele status van 'dienstbaarheid' en die van beroepscodes, die daarvan de neerslag vormen, in belangrijke mate vast. Deze kunnen worden getypeerd als een 'middellijk' kader voor morele handelingsindicaties op geleide van sociaal- of algemeenethisch gelegitimeerde maatschappelijke waarden casu quo 'solidariteit', in een specifieke interpretatie daarvan. Deze interpretatie gaat uit van een phrastisch-neustische duiding van de moreel meest acceptabele betekenis van 'solidariteit". In deze omschrijving van haar status wordt de interne legitimiteit van 'dienstbaarheid' als een functie beschouwd van haar externe legitimiteit, conform een inzicht uit het begin van deze paragraaf. Deze interpretatie benadrukt een altruïstisch omgaan met de belangen van de onderdrukte, zwakke of behoeftige medemens en stelt zich teweer tegen al te grote aandacht voor het egoïstisch geinterpreteerde eigenbelang. Daarentegen is er wel ruimte voor het zogenaamde "welbegrepen" eigenbelang, voorzover dit wordt gedefinieerd vanuit de altruistische interpretatie. Dit strookt met de diversiteit in phrasticiteit die ten aan- 
zien van de waarde 'dienstbaarheid' kan worden onderscheiden en die in de structuur en inhoud van beroepscodes duidelijk naar voren komt. Beroepscodes bewijzen dus in zekere zin hun nut om dergelijke interpretaties op het spoor te komen. En wanneer deze interpretaties extern en intern kumnen worden gelegitimeerd, draagt dit bij tot een zekere morele status.

Nu rest ons echter nog een belangrijk probleem, dat niet onder tafel mag verdwijnen. Ook een morele status is een toegewezen status, juist als in een sociologische duiding van de term. Deze toewijzing heeft in het bovenstaande plaatsgevonden op grond van loyaliteitstheoretische en sociaal-ethische overwegingen, dus vanuit de positie van de ethicus. Deze op zichzelf juiste gang van zaken bij de behandeling van een dergelijk vraagstuk gat niettemin voorbij aan de beroepsbeoefenaren op wie de handelingsindicaties waar het hier om draait betrekking hebben. Zij dragen impliciet bij aan het proces van statustoewijzing door in hun gedrag de phrasticiteit van bepaalde waarden in haar volle omvang, maar met name in hun primaire morele betekenis, naar voren te brengen. Niet-aanwezige betekenissen worden na werloop van tijd niet meer gekend, leiden tot verarming van het waardebegrip en tenslotte mogelijk tot ontmemen van morele status en/of ontaarding in een massieve waardebeleving. De mogelijkheden tot toepassing van beroepscodes en de daarin vervatte morele waarden hebben derhalve belangrijke repercussies voor de morele status ervan. Dit is een exclusief gevolg van onze keuze voor een loyallteitstheoretisch perspectief op moraal en ethiek en het belang daarin van phrasticiteit en deliberatie. Het volgt ook uit een letterlijke interpretatie van het realiteitsgebondenheidscriterium bij de vaststelling wan de legitimiteit van morele waarden.

Typerend voor de verpleegkunde is, dat de introductie van een beroepscode gepaard gaat met allerlei toepassingsproblemen van uiteenlopende aard. Dit behoeft geen verwondering te wekken na hetgeen in de paragrafen 2.4 is gezegd ten aanzien van de professionalisering van het beroep en met betrekking tot de rol en positie van zijn beoefenaren. Deze toepassingsproblemen zullen in de volgende paragrafen nog nader worden uiteengezet. Het is echter van belang op voorhand reeds rekening te houden met de conclusies daaruit. Deze wijzen in de richting van forse praktisch-theoretische belemmeringen om een beroepscode in zelfs maar een beperkte omvang van zijn betekenis(sen) te realiseren. Daarop voortbordurend kunnen wij geen andere gevolgtrekking maken dan dat de status van beroepscodes voor verpleegkundigen gering is en dat zij vooral is gebaseerd op een morele legitimatie op grond van (loyaliteits)theoretische overwegingen.

\subsection{Toepassingsproblemen bij beroepscodes}

De vervulling van morele vereisten, ontleend aan een beroepscode, speelt zich niet af in een vacuüm. In elke situatie die zich voor toepassing leent (en in principe is dat elke hulpverleningssituatie) is de verpleegkundige onderhevig aan invloeden die deze kunnen afleiden van het oorspronkelijke, moreel gedefinieerde doel. Op elk niveau van beroepsuitoefening ontmoeten verpleegkundligen behoeften, belangen en waardenoriëntaties van henzelf, patiěnten of derden die een tegemoetkomen aan een specifieke verplichting vanwege de beroepscode in de weg kumnen staan of kunnen afleiden van het oorspronkelijke doel van die verplichting. 
Toepassingsproblemen bij beroepscodes hebben, zoals boven reeds aangeduid, dan ook alles te maken met de rol en positie van verpleegkundigen in gezondheidszorg en samenleving. Wij spreken in dit verband van de 'morele positie' van verpleegkundigen en bedoelen daarmee: de plaats die verpleegkundigen innemen in hun netwerken van relaties met anderen met het oog op de realisering van morele verplichtingen vanwege de beroepscode. We zullen trachten allereerst deze morele positie te verduidelijken alvorens in het onderstaande expliciet in te gaan op een aantal toepassingsproblemen bij beroepscodes voor verpleegkundigen. Deze toepassingsproblemen zelf zijn geaggregeerd naar een viertal centrale processen, namelijk die van rationalisering, uniformering, individualisering en sanctionering. Aan elk van deze processen is een antal concrete en minder concrete problemen verbonden die verpleegkundigen kunnen afleiden van het met de beroepscode beoogde morele doel.

\subsubsection{Morele positie van verpleegkundigen}

De morele positie van verpleegkundigen dient te worden gezien tegen de achtergrond van hetgeen in de paragrafen 2.4 in het kader van de professionalisering van het beroep naar voren werd gebracht aangaande de verhouding tussen verpleegkunde en geneeskunde, de verpleging als typisch vrouwenberoep en de rol en positie van verpleegkundigen binnen organisaties voor gezondheidszorg. Daarnaast is de morele positie van verpleegkundigen expliciet voorwerp van studie geweest in met name op de situatie in de Verenigde Staten gericht onderzoek. De conclusies hieruit hebben wij eerder besproken en aangevuld met gegevens die van toepassing zijn op de situatie in Nederland (zie Van der Arend 1988, 278-280). Bij wijze van samenvatting kan hieruit het volgende worden afgeleid (een overzicht van Amerikaans onderzoek wordt geboden in Davis/Aroskar 1978, 3542):

1. De verpleegkundige en de geneeskundige vervullen scherp contrasterende taken. Voor de geneeskundige zijn daaraan posities verbonden die deze verzekeren van een hoge status en relatief veel vrijheid van controle door een organisatie. De verpleegkundige daarentegen is vanuit diens taakstelling en rol in de gezondheidszorg en hulpverlening veelal behept met de plicht te zorgen voor continuiteit in tijd en plaats van patiëntenzorg. Aldus wordt een positie opgedrongen waarin met tact het coördinatorschap twssen medisch en bureacratisch systeem moet worden waargemaakt.

2. Binnen een multi-professionele organisatie worden verpleegkundigen vaak geconfronteerd met een situatie van beperkte wederzijdse communicatie en psychologisch isolement. Er is sprake van een grote neerwaartse stroom van orders, regels en procedure-voorschriften door bovengeschikten (meestal niet-verpleegkundigen), terwijl er mauwelijks of althans inadequaat functionerende kanalen aanwezig zijn woor de overdracht van plannen, suggesties en klachten uit lagere hierarchische niveaus als die van de verpleegkundige. Initiatief wordt derhatve gedoofd en een situatie van afhankelijkheid, gevoelens van inferioriteit, en ontevredenheid wordt bevorderd.

3. Verpleegkundigen ondersteunen de wetenschappelijke activiteiten van geneeskundigen en helpen onvolkomenheden voorkomen in de wetenschappelijke aanpak van de praktische geneeskunde. De verpleeglkundige zorgt er aldus mede voor dat kennis over ambivalenties, onzekerheden en vergissingen ver van de patiènt blijft en wordt geacht moreel passief te blijven met betrekking tot het gebeuren in een organisatie. De verpleegkundige fungeert als een soort buffer in het systeem, zonder daarover op voet van gelijkheid met geneeskundigen en anderen te kunnen onderhandelen.

4. Verpleegkundigen bezitten geen sterke groepsbinding met collega's en ziem de eigen beroepsgroep slechts in beperkte mate als bron van normen voor het eigen handelen. In sa- 
menhang hiermes zijn zij eerder bereid om een bovengeschikte in een organisatie als cen dergelijke bron te beschouwen.

5. Hoewell een ontwikkeling in tegengestelde richting gaande is (zeker voor wat betreft Neder lland), wordt de werpleegkunde vooral beoefend door vrouwen. Gezien een aantal sociaalculturele factoren laten wrowwen echter in het algemeen gemakkelijker dan mannen controle toe vanuit de organisatie, hebben een geringer status-bewustzijn en zijn in dit verband dan ook onderdaniger.

6. De aard van het beroep trekt vooral yrouwen aan. $\mathrm{Zij}$ zjn meer gericht op traditionele levensdoeleinden dan op een carrièreperspectief. Aan de ontwikkeling van het beroep worden slechts schoorvoetend concessies gedaan.

7. Arbeidsverhoudlingen worden in belangrijke mate bepaald door het verschil in status dat aan mannen en vrouwen, juist als mannen en vrouwen; wordt toegekend. In een zelfde rol en functie wordt mannen meestal een grotere deskundigheid toegeschreven (illustratief is de bekende dissertatie van Ott 1985 ). Meer mannen in de rol van verpleegkundige kan dus een gunstige invloed hebben op de positie van verpleegkundigen. Zij zijn echter nog steeds (sterk) in de minderheid. Daarnaast kan hun verschijning worden beschouwd als een bevestiging van genoemd statusverschil, want zij stromen meestal snel door naar leidinggevende functies (vergelijk Spijker 1979, 122-123).

8. Verpleegkundigen worden in de moderne bedrijfsachtige cultuur binnen ziekenhuizen steeds nadrukkelijker als werknemer gezien in plaats van als professional met een bepaalde opdracht. Een functionele instelling wordt belangrijker geacht dan een moreel aanvaardbare houding. Systematiek en methodiek vervangen de onbevraagde vanzelf́sprekendheid van routine, klinische blik en intuitie. Genoemde opdracht en morele instelling blijven echter hardnekkig voortleven in praktisch ongewijzigde waarden, rolopvattingen en aanwijzingen woor concreet gedrag (zie hiervoor Spijker 1979). Deze ambivalentie zorgt voor talrijke rolconflicten.

9. "Zorg" vertegenwoordigt een belangrijk maatschappelijk ideaal en scoort hoog in de politieke ideologie en in overheidsstrategieen. Concrete zorg wordt daarentegen laag gewaardeerd en gehonoreerd en bezorgt de verpleegkundige in dit (sociaal-economisch) verband een slecht imago. Men kan zich hieraan op twee manieren ontworstelen: alledaagse zorg afstoten aan anderen of de zorg ongewoon verklaren. Beide strategieen worden gehanteerd, hoewel ze met elkaar in tegenspraak lijken (zie Van Gemert/Spijker 1982, 163-164). Ook hierin is de positie van de verpleegkundige nogal ambivalent.

Op grond van deze kenschets dient de morele positie van verpleegkundigen te worden beschouwd als in hoge mate heteronoom en ambigue. $\mathrm{Er}$ is niet alleen sprake van een grote afhankelijkheid van de waardenoriëntaties van andere personen en instanties, maar tevens van bellemmeringen in de eigen houding om zich die waardenoriëntaties eigen te maken of er zich kritisch tegenover op te stellen. De verpleegkundige is als het ware gevangen in een web van referentiekaders, waarin aan de ene kant vanuit een professioneel beroepsperspectief zelfstandig optreden en autonome oordeelsvorming worden gevraagd, maar anderzijds deze vaak de expliciete goedkeuring en medewerking van derden vereisen. Daartussen bevindt zich dan de verpleegkundige met diens eigen complex van waarden en normen en arbeidsmotivatie. Deze referentiekaders bevatten deels strijdige elementen die tot contradictoire morele handelingsindicaties aanleiding (kunnen) geven. In 5.2.1 is hiervan een voorbeeld gegeven door in te gaan op de uiteenlopende betekenissen en dienovereenkomstige morele gedragsalternatieven die bij nader inzien reeds ten aanzien van éên waarde, 'dienstbaarheid', kunnen worden onderscheiden. Verwacht mag worden dat het aantal betekenissen respectievelijk alternatieven nog aanzienlijk zal toenemen indien we meer waarden in onze beschouwingen betrekken.

Heteronomie en ambiguitteit ten aanzien van de morele positie van verpleegkundigen dienen nadrukkelijk in elkaars verlengde te worden gezien. Heteronomie zonder ambi- 
guiteit laat toe dat verpleegkundigen zich (passief) aanpassen aan overheersende morele oriëntaties en directieven die van buiten op hen afkomen. Heteronomie met ambiguiteit impliceert een keuze uit orièntaties en directieven (inclusief die van verpleegkundigen zelf) en geeft uitdrukking aan de rolconflicten en morele dilemma's waarvoor verpleeg. kundigen zich veelvuldig zien gesteld wanneer zij desondanks een keuze móten maken (voor voorbeelden van dergelijke dilemma's zie Van der Arend 1990, 293-294).

Dit samengaan van heteronomie en ambiguïteit in de morele positie van verpleegkundigen kan bovendien worden geplaatst in het perspectief van de in 2.4 .7 beschreven machteloosheid van verpleegkundigen en hun beroepsgroep tot het varen van een eigen koers in professionele aangelegenheden. De confrontatie met tegengestelde belangen en waardenoriëntaties leidt bij machteloosheid tot een continue reeks van deels uitgestelde, deels willekeurige keuzes, omdat deze niet met de eigen doelstellingen in overeenstemming kunnen worden gebracht. En waar deze overeenstemming well wordt gevonden, is de keuze meestal niet ingegeven door professionele maatstaven (deze zijn immers veelal door anderen ontwikkeld en voor verpleegkundigen weinig toegankelijk), maar door een persoonlijke intuïtie ten aanzien van het morele evenwicht tussen opgedrongen en eigen waardenoriëntatie. Dit werkt willekeur in de hand en betekent impliciet een versterking van het heteronome uitgangspunt, hoewel heel eventjes de schijn van autonomie heeft kunnen dóórbreken. Uiteindeli.jk belanden we dan in een situatie van anomie waarin het heteronome niet meer als zodanig wordt herkend en ambiguïteit in moreel optreden stilzwijgend als norm is geaccepteerd.

Voor dit laatste menen wij argumenten te kunnen ontlenen aan een onderzoek van Self (1987) onder 1107 verpleegkundigen en leerling-verpleegkundigen in de Verenigde Staten, nota bene het land met de hoogste graad van professionalisering onder verpleegkundigen ter wereld. Uit haar onderzoek komt naar voren dat verpleegkundigen een tamelijk sterke subjectivistische opvatting huldigen ten aanzien van de functie van waarden en. normen in theorie en praktijk. Zij beschouwen waarde-oordelen veel meer als een zuiver persoonlijke uitdrukking van iemands eigen mening of innerlijke gevoelens dan als rationeel verdedigbare en te rechtvaardigen aanspraken. Waarde-oordelen kunnen in deze zin geen uitdrukking zijn van morele verplichtingen en normatieve vereisten voortkomend wit een extern kader van morele waarden en normen of uitdrukking van een bepaalde morele orde in de samenleving. Daarnaast constateerde Self dat er weinig consistentie aanwezig is in de grondslagen of rechtvaardiging van de morele keuzes en beslissingen van verpleegkundigen. Hieruit kan worden afgeleid dat verpleegkundigen telkens een andere gedragslijn vertonen in de wijze waarop morele vraagstukken worden herkend en opgelost en dat daaraan geen (rationeel-)objectief gegeven ten grondslag ligt. Het onderzoek van Self bevat aldus duidelijke indicaties voor morele ambiguiteit onder verpleegkundigen. Over de achtergrond hiervan doet zij geen uitspraken. Op grond van het eerder gestelde kunnen we hier echter een zekere werkzaamheid van het heteronomie-principe vermoeden.

Vanuit het perspectief van de beroepscodes voor verpleegkundigen zijn de problemen die met een heteronome en ambigue morele positie van verpleegkundigen gaan gepaard vooral daar te vinden waar een realisering van de waarde dienstbaarheid (met het focus op het belang van de patiënt) botst met de belangen van henzelf, van geneeskundigen en van de organisaties waar ze deel van uitmaken. Naar hun aard kunnen deze problemen samenhangen met culturele factoren, factoren in verband met de functie(s) van beroeps- 
codes zelf en met factoren die een combinatie van beide vormen. Ze kunnen nader worden geduid als systeemproblemen waaraan de volgende vier aspecten met betrekking tot de toepassing van beroepscodes zijn te onderscheïden:

1. Rationalisering: bij beroepsvormingsprocessen krijgt de ontwikkeling van kennis en kunde veel aandacht. Deze kan leiden tot een specifieke stijl van denken en doen. Ook aan de toepassing van beroepscodes is een dergelijke specifieke stijl verbonden. Beide stijlen kunnen in een concurrentieverhouding tot elkaar staan in bepaalde rationaliseringsprocessen die in samenleving, gezondheidszorg en beroepsuitoefening kunnen worden onderscheiden.

2. Uniformering: beroepsbeoefenaren kunnen een eigen stijl van denken en doen ontwikkelen die een bedreiging vormt voor de belangen van hulpvragenden enerzijds en de beroepsgroep anderzijds. Deze laatste tracht daar greep op te houden door het vaststellen en vastleggen van collectieve morele handelingsaanwijzingen in een beroepscode. De vraag is echter in hoeverre zich dat verdraagt met de beroepspraktijk en in hoeverre de beroepsgroep inderdaad in staat is overeenstemming in moreel gedrag van haar leden te handhaven.

3. Individualisering: aan het individu en zijn rechten wordt in tal van maatschappelijke ontwikkelingen veel aandacht besteed, zo ook in de gezondheidszorg. Dit kan op gespannen voet staan met een morele regulering van de intermenselijke verhoudingen vanuit de algemene en op een collectiviteit gerichte normen waaruit een beroepscode bestaat.

4. Sanctionering: mochten beroepsbeoefenaren zich onvoldoende houden aan de in groepsverband overeengekomen normen voor betamelijk gedrag, zoals verwoord in een beroepscode, dan zou de beroepsgroep (en/of samenleving) graag mogelijkheden hebben overtredingen te corrigeren en normen af te dwingen. In dat verband ziet men zich voor de kwestie gesteld of dat wel mogelijk is.

Genoemde vier processen worden hier gepresenteerd als systeemproblemen. Ze beschrijven de belangrijkste aspecten waarmee beroepsbeoefenaren worden geconfronteerd wanneer de toepassing van beroepscodes in een maatschappelijk perspectief wordt geplaatst. Als zodanig zijn ze te beschouwen als een verwoording van de instrumentele en/of expressieve oriëntaties die in onze samenleving aan de toepassing van codes een bepaalde kleur geven. Uit het oogpunt van consistentie ware het wellicht aan te bevelen ons dan te conformeren aan de eerder gegeven taxonomie van fundamentele maatschappelijke waarden (zie figuur 5.1). Als systeemproblemen zouden dan zijn benoemd: aanpassing, doelverwezenlijking, integratie en patroonhandhaving. We hebben hier echter om de volgende redenen van afgezien: genoemde taxonomie is slechts in beperkte mate geschikt als ordening van morele en niet-morele interpretaties van de werkelijkheid (zie 5.2.3); in deze taxonomie bezitten de systeemproblemen een vooral formeel karakter, terwijl onze voorkeur hier uitgaat naar een inhoudelijke typering; de door ons benoemde systeemproblemen bevatten een nauwkeuriger beschrijving van de specifieke processen en problemen die de toepassing van beroepscodes beïnvloeden en waarmee verpleegkundigen weliswaar als burger, maar tevens primair als beroepsbeoefenaar worden geconfronteerd. Rationalisering, uniformering, individualisering en sanctionering zijn de trefwoorden waaronder deze processen en problemen zijn samengevat. Onze verantwoording daarvan sluit evenwel niet uit dat ze in termen van de eerder genoemde taxo- 
nomie worden geherformuleerd. Waar mogelijk en gewenst zal dat in de onderstaande analyse ook gebeuren.

\subsubsection{Het probleem van de rationalisering}

Het eerste probleem dat wij hier bespreken, is voornamelijk van culturele aard en vatten we samen onder de noemer 'rationalisering'. 'Rationaliteit' is te beschouwen als een bepaalde stijl van denken en handelen. Beroepsbeoefenaren vertonen een zekere rationaliteit, wanneer in de manier waarop ze hun beroep uitoefenen, daarop reflecteren en deze reflectie vertalen in activiteiten, een bepaalde systematiek kan worden onderkend en leidende principes zichtbaar worden. 'Rationalisering' is dan het proces via welk deze systematiek en principes steeds sterker in de beroepsuitoefening worden verankerd en tot uitdrukking worden gebracht.

Zo beschouwd kunnen er vele vormen en soorten van rationaliteit worden onderscheiden. De bureaucraat houdt er nu eenmaal een andere stijl van denken en doen op na dan de professional, terwijl beide stijlen kunnen worden teruggevoerd op en verklaard uit een specifieke (en soms tegengestelde) taakopvatting en kijk op de werkelijkheid (vergelijk 2.3.9). Aldus is voorstelbaar dat het hanteren en toepassen van een beroepscode past bij een bepaalde vorm van rationalisering.

In 3.2.1 maakten we kennis met twee (ideaal-typische) vormen van rationaliteit, die als elkaars tegenpolen kunnen worden beschouwd en de uitersten vertegenwoordigen van een continuüm voor een nadere plaatsbepaling van beroepscodes. We refereren hier aan twee stijlen die door Barnsley werden omschreven als intrinsiek moreel rechtvaardigend respectievelijk extrinsiek moreel rechtvaardigend. Deze sluiten aan bij het door Philipsen aangebrachte onderscheid tussen substantiële respectievelijk functionele rationaliteit. De eerste wordt gekenmerkt door connoterend denken, de laatste door denoterend denken. Extrinsieke morele rechtvaardigingen en denoterend denken werden beschouwd als de dominante vorm van rationalisering in samenleving respectievelijk gezondheidszorg. Zij kenschetsen een wijze van redeneren en handelen waarbij de doeleinden zijn voorgegeven en het er alleen maar om gaat de meest geschikte middelen en procedures te bepalen en aan te wenden. Een dergelijke stijl wordt kenmerkend genoemd voor een samenleving waarin economische groei de voornaamste drijfveer voor de bepaling van de onderlinge verhoudingen van burgers is respectievelijk voor een gezondheidszorg waarin alle inspanningen zijn gericht op de (projectmatige) behandeling van ziektes en niet op een correcte bejegening van zieken. Hieruit volgt dat het belang van de patiënt wordt gedefinieerd vanuit (de objectieve kenmerken van) zijn ziekte en niet zoals deze dat zelf waarneemt vanuit (het subjectieve karakter van) zijn waardenoriëntatie.

Dit vastgesteld zijnde ontmoeten we een probleem. Er van uitgaande dat we te maken hebben met een min of meer stabiele samenleving en gezondheidszorg (op grond van "patroonhandhaving", vergelijk figuur 5.1), zal rationalisering een verdere versterking impliceren van extrinsieke en denoterende wijzen van denken en handelen, als behorend bij de stijl die momenteel dominant is (in casu 'functionele rationaliteit', vergelijk figuur 5.1). Betekenissen die een patiënt wenst te hechten aan een andere stijl in het kader van zijn levensloop en -perspectief, verdwijnen steeds meer uit het gezichtsveld. Daarentegen leggen beroepscodes voor verpleegkundigen juist nadruk op die door een patiënt zelf verleende betekenissen als uitvloeisel van de primaire morele invulling die gegeven is 
aan de waarde 'dienstbaarheid' (het belang van de patiênt staat steeds voorop). Het focus is hier dus gericht op een nadere formulering van doeleinden, op intrinsieke morele rechtvaardigingen en op connoterend denken (in casu 'substantiele rationaliteit', vergelijk figuur 5.1). Er is dus sprake van een breuk tussen de stijl van denken en doen van beroepsbeoefenaren in de gezondheidszorg en de eisen die aan verpleegkundigen worden gesteld op grond van de bepalingen in hun beroepscodes.

Met opzet is in de laatste zin gesproken van 'beroepsbeoefenaren'. Hoewel onwaarschijnlijk, mag immers niet worden uitgesloten dat verpleegkundigen zich aan de genoemde dominante stijl van denken en doen onttrekken en een eigen 'rationaliteit' ontwikkelen die beter past bij een handelingskader op grond van hun beroepscodes. Sterker nog, het 'zorgimago' van de verpleegkunde en de dominante gerichtheid op traditionele waarden van de vrouw (zie 5.3.1) lijken goed te incorporeren in een stijl die wordt gekenmerkt door intrinsieke morele rechtvaardigingen, connoterend denken, kortom substantiële rationaliteit.

Een dergelijke stijl kan inderdaad de grondhouding, primaire waardenbeleving en arbeidsmotivatie van verpleegkundigen tekenen, des te zwaarder is echter de 'reality shock', wanneer zij worden geconfronteerd met een stijl die daar welhaast lijnrecht tegenover staat (zie Kramer 1974). Deze stijl wordt belichaamd door het functioneren van de formele organisaties waarbinnen verpleegkundigen in grote meerderheid werkzaam zijn. Daarvan is tevens bekend, dat zij minder zijn gericht op het welzijn van de werknemers en cliènten dan op hun eigen voortbestaan en dat zij dit laatste onder andere langs bureaucratische weg trachten veilig te stellen door het uitvaardigen van reglementen, procedures, voorschriften en gestandaardiseerde vaardigheden (Philipsen 1988, 25; zie ook 3.2.9): Bovendien zijn van alle organisaties waarin professionals zijn georganiseerd die van geneeskundigen de meest machtige. Deze formele organisaties, met name die van geneeskundigen, zijn bepalende factoren in de handhaving van een stijl van functionele rationaliteit in de gezondheidszorg. Het lijkt nauwelijks voorstelbaar dat verpleegkundigen zich aan al deze invloeden kunnen onttrekken en er een eigen stijl van denken en doen op na kunnen houden die er diametraal tegenover staat (met uitzondering wellicht van segmenten waarin deze invloeden minder sterk aanwezig zijn zoals in de extramurale gezondheidszorg). Dat zou ook in tegenspraak zijn met de in 5.3.1 geïdentificeerde heteronome en ambigue morele positie van verpleegkundigen en hun machteloosheid om de loop der dingen naar hun hand te zetten. Daarom zijn de formele organisaties waarin en vanwaaruit uitdrukkelijk rekening wordt gehouden met de belangen en aspiraties van verpleegkundigen, zoals in hun beroepsverenigingen en belangenorganisaties, van overwegend marginale betekenis (vergelijk ook 2.4.5).

Daarnaast is er een ander argument tegen de veronderstelling, dat een stijl van substantiële rationaliteit die van functionele rationaliteit zou gaan overheersen of tenminste daaraan een tegenwicht biedt. Dit argument wordt geleverd door de toenemende verwetenschappelijking van de verpleegkunde. In de wetenschap wordt een wereldbeeld gecreëerd waarin de werkelijkheid wordt geobjectiveerd en primair wordt gezien als ketens van oorzaak en gevolg die door waarneming, theorie en methodiek (steeds beter) worden gekend (Philipsen 1988, 19). Ook hier richt men zich dus primair op de middelen en laat de doeleinden van het handelen ongemoeid. Verwetenschappelijking van de verpleegkunde impliceert dus een toename in functionele rationaliteit ten koste van substantiële 
rationaliteit. Het gaat er niet om waarom en in wiens belang een verpleegprobleem wordt opgelost, maar dát het wordt opgelost.

Beroepscodes lijken dus nog slechts hanteerbaar en uitvoerbaar voorzover deze een functioneel-rationele stijl van denken en doen in de gezondheidszorg en verpleegkunde niet in de weg staan. Dit impliceert bijvoorbeeld dat competentie (als geheel van kennis en kunde benodigd voor de uitoefening van een beroep) een vooraanstaande plaats inneemt in de waardencataloog van de verpleegkundige. Competentie wordt dan als het ware verzelfstandigd tot een intrinsieke waarde, waarvan de verwezenlijking omwille van zichzelf wordt gezocht en die bijdraagt aan een opvatting waarin superioriteit wordt geclaimd voor beroepsgebonden morele claims en dus aan een massieve wardenbeleving (vergelijk 5.2.2). Vanuit het perspectief van de beroepscodes voor verpleegkundigen betekent dit bovendien dat zij moreel noch intern noch extern langer zijn gelegitimeerd vanuit (prioriteiten in) fundamenteel geachte morele waarden als dienstbaarheid respectievelijk solidariteit, althans in hun primaire morele betekenis.

Het gevar is derhalve groot dat de beroepscodes voor verpleegkundigen

1. terzijde worden geschoven als onrealistisch, want niet aansluitend bij de dominante stijl van denken en doen of als onuitvoerbaar met het oog op de prioritering van een morele waarde als 'dienstbaarheid' boven 'competentie' (zie de studies beschreven in Davis/Aroskar 1978, 34-43); ofwel

2. een exclusieve rol gaan vervullen in de ideologie van de beroepsgroep, niet beantwoordend aan enige realiteitszin, maar integendeel leidend tot een massieve waardenbeleving als enig redmiddel om de idee van samenhang tussen doeleinden en middelen en het evenwicht tussen functionele en substantiële rationaliteit overeind te houden (een dergelijke tendens ligt besloten in sommige beroepensociologische opvattingen en studies beschreven in 3.4.1); ofwel

3. worden geïncorporeerd in de dominante stijl van rationalisering en aldus deel gaan uitmaken van de 'instrumentele ceremoniële orde' (Philipsen 1988, 15 en 17), daarbij voor lief nemend dat secundaire (morele of niet-morele) waarden de primaire morele waarden ('dienstbaarheid' en 'solidariteit') vervangen (zie wederom bij Davis/Aroskar $1978,34-43)$.

Aan deze dreiging kan naar onze mening alleen een positieve wending worden gegeven indien een externe instantie, bijvoorbeeld de patient, zich eigenaar verklaart en/of tot beheerder wordt benoemd van het proces van rationalisering. Alleen wanneer de patient (mede)verantwoordelijk is gesteld voor de doeleinden van hulpverlening en voor de stijl door middel waarvan deze worden gerealiseerd, kan iets worden teruggewonnen van de substantièle rationaliteit die met 'dienstbaarheid' en het primaire belang van de patient in beroepscodes wordt bedoeld of is geimpliceerd. Het is vervolgens aan de patient om te bepalen of genoemde stijl vooral van functioneel-rationele of van andere aard moet zijn.

We zijn ons ervan bewust dat we hiermee opnieuw het paard achter de wagen dreigen te spannen. Immers, gezien de dominantie van een functionele rationaliseringsstijl, niet alleen in de gezondheidszorg maar in de samenleving als geheel, vormt deze stijl als het ware automatisch de eerste voorkeur wan de patiënt. Voegen we daarbij de versterking van dit proces door medicalisering en sociale latrogenese enerzijds en de principiële afhankelijkheid van patiënten anderzijds, dan behoeft de uitslag nog nauwelijks discussie. Overigens heeft het kritisch bewustzijn in de samenleving een tegenbeweging op gang gebracht die tenminste op politiek en juridisch niveau de machteloosheid van patiênten 
wenst op te heffen. Het recht op lichamelijke en psychisch-geestelijke integriteit bijvoorbeeld is inmiddels hecht in de Nederlandse Grondwet verankerd, waardoor patiënten, waarbij die integriteit vaak juist zo fundamenteel is geschonden, expliciet naar hun belang moet worden gevraagd. Bovendien zijn in het verlengde daarvan diverse rechten geformuleerd die de bescherming van die integriteit helpen realiseren en min of meer afdwingen. De American Hospital Association heeft deze in 1972 reeds als een soort beroepscode vastgelegd in 'A Patient's Bill of Rights' (zie bijvoorbeeld Davis/Aroskar 1978, 52-54; Beauchamp/Childress 1979, 285-287). Tenslotte kan nog worden gewezen op de recente spectaculaire groei en inwloed van patiëntenorganisaties. Zij zijn in Nederland bijvoorbeeld al meermalen betrokken geweest bij consensusbijeenkomsten. Een zelfde tendens is voorstelbaar ten aanzien van typisch morele aangelegenheden.

Niet alleen laatstgenoemde code, maar ook de beroepscodes voor verpleegkundigen en anderen, bezitten in principe voldoende kritische massa om een tegenwicht te bieden aan een al te grote opdringerigheid en assimilatieve kracht van functioneel-rationele stijlen, mits men ze niet laat afglijden tot ideologische mythen, mits ze voldoende concrete handelingsindicaties opleveren en mits er op de werkvloer materieel-inhoudelijk ruimte wordt gecreëerd voor hun geïmpliceerde, primaire morele waarden en betekenissen. Beroepscodes behoeven daartoe derhalve de steun van een voldoende grote groep kritische en substantieel-rationalistisch denkende beroepsbeoefenaren en daarenboven van algemene bekendheid bij het publiek.

\subsubsection{Het probleem van de uniformering}

Uniformering is een probleem dat niet zozeer van culturele aard is maar nauw samenhangt met de functie(s) van beroepscodes zelf. Met 'uniformering' wordt bedoeld: de sturing van (moreel) gedrag naar één model van bejegening, namelijk het model dat ten grondslag ligt aan een beroepscode en tot uiting komt in zijn opzet, structuur en waardebegrippen. Deze uniformering stelt beroepsgroepen voor een praktisch probleem omdat enerzijds onvoldoende rekening wordt gehouden met de complexiteit en veranderlijkheid (dynamiek) van de uitoefening van een beroep in de gezondheidszorg. Anderzijds laten beroepscodes noodzakelijkerwijs teveel ruimte voor interpretatie. Omdat zij moeten kunnen worden toegepast in uiteenlopende rollen en functies en liefst in alle segmenten van de verpleegkundige beroepsuitoefening, moet worden volstaan met algemene termen, begrippen, waarden en handelingsindicaties. Hierdoor blinken beroepscodes vaak uit in abstracties en gemeenplaatsen. Slechts dan is het mogelijk én model van bejegening te ontwerpen en deze als beroepscode naar voren te schuiven.

Echter, wanneer we het laatste op zijn merites beoordelen, kan blijken dat we met een schijnprobleem te maken hebben. Immers, abstracties en algemeenheden kunnen het gevolg zijn van een doelbewuste poging de mythevorming te bevorderen die wij in 4.4 .4 hebben ontmaskerd als behorend bij de ideologische functie van beroepscodes. Indien deze ideologische functie is voorgegeven kunnen we alleen maar concluderen dat het middel (beroepscode) adequaat is aan het doel (het beroep zo positief mogelijk aan het publiek te presenteren).

Hier wordt echter uitgegaan van de morele functie van beroepscodes en dan vormt uniformering wél een probleem. Deze morele functie kan weliswaar een deel van het visitekaartje van de beroepsgroep ten opzichte van de samenleving zijn, maar dient niettemin 
herkenbaar te zijn in het gedrag van beroepsbeoefenaren. De vraag is dan welk gedrag beantwoordt aan de waardebegrippen en algemene handelingsindicaties uit de beroepscode. Omgekeerd stelt zich de kwestie welke waardebegrippen en handelingsindicaties van toepassing zijn op een bepaald gedrag. Bovendien zal men verlangen uit het oogpunt van consistentie en non-contradictie, dat de antwoorden op de gestelde problemen en dientengevolge de samenhang tussen handelingsindicaties en concreet gedrag een zekere eenheid vertonen. Het zou immers getuigen van wankelmoedigheid of willekeur indien aan een zelfde gedrag in een zelfde situatie een verschillend moreel kaartje wordt gehangen. Welnu, een dergelijke uniformiteit in labeling van het morele gedrag van beroepsbeoefenaren moet op grond van de abstracties in beroepscodes en de variabiliteit in professioneel gedrag als een fictie worden beschouwd. Dit zal nu verder worden uitgewerkt.

Een kenmerk van abstracties is, dat een veelvormige werkelijkheid onder één noemer wordt gebracht. Zo is in de term 'ethiek' een breed scala van normatief-ethische en metaethische opvattingen begrepen die elkaar gedeeltelijk zelfs uitsluiten (vergelijk 3.2.2). Iets dergelijks doet zich voor bij termen in de beroepscodes voor verpleegkundigen, zoals onze semiotische analyse in 4.4 .4 heeft laten zien. Expliciete definities ontbreken meestal en contextuele definities leunen teveel op de interpretatie(verschillen) van toevallige lezers.

Om nog een voorbeeld aan te halen: artikel 1.6 van de NMV-code stelt, dat de verpleegkundige ernstig rekening dient te houden met de grenzen van het eigen deskundigheidsgebied. Dienen deze grenzen te worden geïnterpreteerd in samenhang met de bekwaamheden van de individuele verpleegkundige of die van het vakgebied als zodanig? Blijkens de toelichting op de code zijn beide interpretaties mogelijk, maar worden handelingsindicaties mogelijk beperkt tot het terrein waarop een verpleegkundige formeel bevoegd is. Daarnaast wordt een opening geboden voor overschrijding van die grenzen, maar dan moet dit wel ter discussie worden gesteld. Deze toelichting geeft dus reeds op twee niveaus aanleiding tot (tegengestelde) interpretatieverschillen: individu versus groep en formele bevoegdheid versus overschrijding daarvan. Het abstractieniveau van artikel 1.6 leidt derhalve tot handelingsindicaties die elkaar min of meer uitsluiten. Een intensivecare-verpleegkundige die wordt geconfronteerd met een patiënt met acute ademnood, kan -bij afwezigheid van een arts- intuberen indien hij of zij zich tot deze medische handeling bekwaam acht. Maar de verpleegkundige staat op grond van de code evengoed in diens recht, wanneer de komst van een in allerijl opgeroepen arts gewoon wordt afgewacht, ook wanneer dit de toestand van de patiënt nadelig beïnvloedt of zelfs leidt tot diens dood. In de eerste situatie kan de verpleegkundige nog enige steun ervaren in artikel 2.18, dat stelt dat de verpleegkundige iedere persoon helpt die acuut behoefte heeft aan zorgverlening. Maar wordt hier medische of verpleegkundige zorgverlening bedoeld? In de toelichting blijkt het dan te gaan om het naleven van de wettelijke plicht het leven van een ander te redden. Men moet echter een uitgebreide kennis van de code bezitten, wil deze interpretatie reeds op voorhand aan artikel 2.18 worden gehecht. Er is dus niet alleen sprake van tegengestelde handelingsindicaties op grond van de mogelijke interpretaties van één artikel, maar ook op grond van de interpretatie en toepassing van meer artikelen op één geval. In het verlengde hiervan kan (nogmaals, zie 5.2.1) worden geconstateerd dat beroepscodes weinig houvast bieden voor de oplossing van concrete morele problemen in de praktijk van alledag. 
Ook de variabiliteit in professioneel gedrag staat de uniformering wan morele handelingsindicaties in de weg. Deze variabiliteit is gegeven met de segmentering van het beroep. Verpleegkundigen zijn te vinden in talloze rollen en functies: als ambulancebegeleider, als unitleider in de zwakzinnigenzorg, in de medische dienst van bedrijven, als wetenschappelijk onderzoeker, in dialyse-centra, op consultatiebureaus, in ziekenhuizen, verpleeghuizen, instellingen voor ambulante zorg, wijkverpleging en dienstencentra. In het verlengde hiervan kan worden gesproken van een uitermate grote diversiteit in zorgbehoeften en derhalve in belangen van patiënten en cliènten. Ten aanzien van de uniformiteit in moreel gedrag levert deze situatie twee problemen op:

1. Hoe kan een zelfde gedrag in een zo verschillende context onder één noemer casu quo onder éen waardebegrip of handelingsindicatie worden gebracht?

2. Hoe kunnen zoveel verschillende gedragingen in zoveel verschillende contexten zodanig in een beroepscode worden verwerkt dat zijn waardebegrippen en handelingsindicaties voor al die gedragingen en contexten een morele richtlijn of handreiking bieden?

De vraag stellen is hem ogenschijnlijk beantwoorden. Maar wellicht moeten we hier niet naar het 'hoe' vragen, evenwel naar de voorwaarden van een dergelijke onderneming. Het 'hoe' leidt ons namelijk onvermijdelijk in de armen van de abstracties die reeds in het voorgaande werden gekritiseerd. Vragen naar de voorwaarden noodzaakt ons daarentegen meer expliciet naar de variabiliteit in het verpleegkundig handelen zelf te kijken. We lichten dit wederom toe aan de hand van een voorbeeld. Pijnverlichting en -bestrijding kan als een belangrijke tak van verpleegkundigen worden beschouwd. Naast de vooral medicamenteuze behandeling van bijvoorbeeld hoofdpijn door een geneeskundige staan de verpleegkundige daartoe vele wegen open. Het toepassen van warmte en koude (compressen) en angstreductie zijn slechts enkele methoden. Ook het voorschrijven en toedienen van eenvoudige middelen als acetylsalicylzuur en paracetamol wordt soms aan verpleegkundigen overgelaten. Hoewel pijnbestrijding te rangschikken zou zijn onder de morele norm van 'goed-doen' of 'schade-vermijding' (vergelijk 'beneficence' en 'non-maleficence' in de ANA-code) kan zij in deze vorm toch niet als specificerende of functionele morele norm van goed-doen of schade-vermijding in een beroepscode worden opgenomen. Dat komt door de vele omstandigheden waaronder hoofdpijn van een patient of cliënt zich aan een verpleegkundige kan presenteren. In de ene situatie is directe pijnbestrijding geindiceerd (bijvoorbeeld in de zwakzinnigenzorg of tijdens het verbinden van een pijnlijke wond in de thuiszorg). In een andere situatie zal directe pijnbestrijding als een artefact worden beschouwd (bijwoorbeeld omdat de observatie van pijn deel uitmaakt van een nog te stellen medische diagnose, zoals tijdens ambulancevervoer na een ongeval of bij verdenking van somatisering wan psychiatrische klachten). Hier is dus sprake van verschillende situaties die aanleiding geven tot tegengestelde handelingsindicaties en derhalve niet onder eén algemene norm, tenzij een zeer abstracte norm, zijn te vangen. Toespitsing van een dergelijke norm op de meest voorkomende handelingssituaties loopt onherroepelijk vast op de praktische en theoretische onmogelijkheid om al deze situaties in én model van (morele) bejegening te vangen. Bovendien zouden beroepscodes dan verre de omvang overtreffen die ze nu (inclusief eventueel aanwezige toelichtingen) bezitten.

In zekere zin loopt de gewenste uniformiteit in moreel gedrag van verpleegkundigen dus vast in de noodzaak van interpretatie: interpretatie van abstracte waardebegrippen en 
handelingsindicaties en interpretatie van de variabiliteit van het verpleegkundig handelen. In beide gevallen komen we uit op tegenstellingen die niet in éen model kunnen worden verzoend tenzij ernstig afbreuk wordt gedaan aan het realiteitsgehalte van aldus geformuleerde normen.

Nu kan men hiertegenover twee houdingen innemen. Bij een minimalistische interpretatie gaat men uit van de primaire (morele) betekenis van de in beroepscodes geïmpliceerde waardebegrippen, conform de principes en criteria die wij vermeldden onder de interne en externe legitimiteit van beroepsgebonden morele claims (zie 5.2.3). Dan blijft slechts een beperkt aantal gedragsalternatieven open voor discussie en zal men moeten erkennen dat ten aanzien van concrete gedragingen hetzij vele of wellicht alle normen niet van toepassing zijn, hetzij dat vele van deze gedragingen buiten de reikwijdte van de beroepscode vallen. Bij een ruime interpretatie gaat men ervan uit dat in principe alle gedragingen van verpleegkundigen onder de invloedssfeer van de beroepscode vallen en dat de daarin aanwezige waardebegrippen en handelingsindicaties moeten worden opgevat in de meest brede zin van hun betekenis(sen). Dit leidt echter tot een grote mate van permissiviteit, omdat elk gedragsalternatief op een of andere wijze vanuit de beroepscode te verantwoorden en te rechtvaardigen is. Dan vormt een beroepscode geen morele leidraad meer, maar vervult een alibi-functie.

Tegen beide interpretaties bestaan dus bezwaren. Deze kunnen nog enigszins worden verzacht door beroepscodes sterk te detailleren of door aan beroepscodes uitgebreide toelichtingen te verbinden, maar veel soelaas biedt dit niet, zoals we hebben gezien. Een andere oplossing meent men wel te hebben gevonden in het belasten van een commissie met de moeilijke taak van interpretatie. Een dergelijke werkwijze wordt bijvoorbeeld gevolgd door de UKCC (zie 4.3.4). Zij wordt meestal gekoppeld aan een systeem van (intern) tuchtrecht. Dit levert op zichzelf reeds voldoende stof voor discussie op (zie 5.3.5). In het kader van het probleem van uniformering is hier echter een ander aspect minstens zo interessant en problematisch, namelijk dat een beroepscode instrument wordt voor conformisme en anti-emancipatoire tendenzen.

Als een dergelijk bevoegd orgaan zijn werk serieus opvat, dan zal elke interpretatie van de beroepscode worden getoetst aan criteria van externe en interne legitimiteit, dat wil zeggen in belangrijke mate aan fundamentele maatschappelijke waarden. Bovendien zal worden getracht zoveel mogelijk gedragingen van verpleegkundigen onder de werking van de beroepscode te brengen. We zien hier een samengaan van elementen wit een minimalistische en een ruime interpretatie. De eerste zal echter prioriteit krijgen, omdat het gedrag zelf geen criterium kan zijn voor de toetsing ervan (want is tautologisch). Dit impliceert, dat uiteindelijk een groot aantal gedragingen zal worden beschouwd als in strijd met de beroepscode. Indien dit gedrag negatief wordt gesanctioneerd zal het bovendien minder frequent gaan vóórkomen. Een kritische opstelling binnen het beroep krijgt hierdoor steeds minder ruimte en zal worden omgevormd tot maatschappelijk aangepast gedrag. De beoogde uniformering van moreel gedrag leidt hier dan ook tot conformisme en tot apathie ten aanzien van emancipatieve doelstellingen, ook wanneer het zo gekoesterde belang van de patiënt een andere opstelling vraagt.

Moeten dan alle pogingen tot het formuleren van beroepscodes en het doen naleven van de bepalingen daarin maar worden gestaakt? Vanuit de loyaliteitstheorie is hierop een genuanceerd antwoord mogelijk. De geschetste problematiek ontstaat vooral daar waar uniformering wan het morele gedrag van beroepsbeoefenaren wordt gewenst op het ni- 
veau van de beroepsgroep en toegepast op een sterk gesegmenteerd arbeidsveld. Op dit niveau zijn zowel aan een minimalistische als aan een ruime interpretatie van de code (morele) problemen verbonden die samenhangen met de (on)mogelijkheden tot oordeelsvorming op het niveau van de individuele beroepsbeoefenaar. Bij een minimalistische interpretatie zijn er te beperkte mogelijkheden, vanwege de massieve waardenbeleving die van een dergelijke interpretatie uitgaat. Bij een ruime interpretatie ondervinden beroepsbeoefenaren te weinig sturing in de richting van een in moreel opzicht meest wenselijk gedrag. Bij beide interpretaties zijn beroepsbeoefenaren echter afhankelijk van het beleid van de beroepsgroep. Deze afhankelijkheid wordt slechts doorbroken wanneer morele keuzes en beslissingen naar het niveau worden gebracht waarop ze thuishoren. En volgens de loyaliteitstheorie is dat het niveau van de concrete waardenbeleving, dus dat van de praktijk van beroepsbeoefenaren. Slechts op dit niveau kan worden beoordeeld welke betekenissen aan waarden (moeten) worden gehecht, welke handelingsindicaties deze opleveren en welk gedrag dientengevolge moreel het meest wenselijk is. Dit betekent dat beroepsbeoefenaren weliswaar via een beroepscode waarden aangereikt kunnen krijgen ter navolging, maar dat de morele consequenties daaruit door henzelf moeten worden getrokken. Verder impliceert dit op het niveau van de beroepsgroep het opgeven van de pretentie het morele gedrag van beroepsbeoefenaren in verregaande mate te (kunnen) uniformeren.

\subsubsection{Het probleem van de individualisering}

Het volgende probleem hangt nauw met het vorige samen. Met beroepscodes wordt enerzijds een poging ondernomen het morele gedrag van verpleegkundigen te uniformeren. Anderzijds worden diezelfde verpleegkundigen vastgepind op hun persoonlijke verantwoordelijkheid. In de NMV-code bijvoorbeeld wordt dit als één van de fundamentele uitgangspunten van de beroepsuitoefening beschouwd (vergelijk artikel 1.4). Met hetzelfde oogmerk is in de laatste versie van de UKCC-code de algemene aanduiding 'nursing' vervangen door het particuliere 'each registered nurse', als primaire drager van verantwoordelijkheid (zie 4.3.4). Men heeft hiermee willen aangeven dat, ondanks het bestaan van een voorgeschreven moreel en op uniformering van gedrag gericht kader, het de individuele verpleegkundige is die dit kader in de beroepsuitoefening realiseert en over de wijze waarop dit gebeurt verantwoording aflegt.

Dit veronderstelt het bestaan van een ongeschreven code, strekkend tot phrastisch-neustische betekenisverlening aan waarden die in de beroepsuitoefening aanwezig zijn. Het is echter welhaast een platitude om aan te nemen dat een dergelijke individuele code niet aanwezig zou zijn. Morele keuzes ten aanzien van het handelen zijn ook in de gezondheidszorg in belangrijke mate het resultaat van persoonlijke afwegingen, ongeacht het feit dat men daarin het advies van anderen laat meewegen (zie ook het slot van de vorige paragraaf). Opvallend daarentegen is, dat dit in beroepscodes voor verpleegkundigen zo nadrukkelijk wordt verwoord. Is dit gedaan om te voorkómen dat verpleegkundigen zich verschuilen achter de morele keuzes van anderen? Daar zit iets in, als we ons de zwakke morele positie van verpleegkundigen uit 5.3.1 in herinnering roepen. Maar betekent dit niet tegelijk een ondermijning van het gezag van diezelfde beroepscodes? Ook daar zit iets in. Echter, het ondermijnende karakter van de nadruk op persoonlijke 
verantwoordelijkheid is deel van een veel groter probleem dat het gezag van beroepscodes aantast. Wij vatten dit samen onder de noemer 'individualisering'.

'Individualisering' is te beschouwen als een van de belangrijkste dimensies of kenmerken van de dominante waardenoriëntatie in westerse samenlevingen. Het kan worden omschreven als "... de mate waarin een samenleving het individuele belang en de individuele mening laat gelden boven het collectieve belang en collectieve oordelen" (Philipsen 1988, 77). Binnen het individualisme worden een utilitaire en een expressieve vorm onderscheiden. In de utilitaire vorm wordt het menselijk leven gezien als een streven naar maximalisatie van het eigenbelang ten aanzien van primaire behoeften. Deze vorm past bij uitingen van consumentisme, denoterend denken en het hanteren van instrumentele waarden. In het expressief individualisme wordt het menselijk leven vooral gezien als zelfontplooiing, als ontvouwing en ontwikkeling van individuele mogelijkheden. Deze vorm komt onder andere naar voren in de humanistische psychologie en past bij connoterend denken en het hanteren van expressieve waarden (Philipsen 1988, 84-85).

Hoewel het individualisme als geheel immorele trekken vertoont inzoverre een exclusieve concentratie op het eigenbelang plaatsvindt, kan het tevens als achtergrond dienen voor de verklaring van een toenemende nadruk op het hanteren van een individuele morele code, zelfs als dit ten koste zou gaan van collectieve opvattingen over hetgeen goed en derhalve nastrevenswaard is. Beroepscodes voor verpleegkundigen waarin deze nadruk expliciet wordt uitgesproken, zijn dus kinderen van hun tijd, maar zij ontkrachten daarmee tegelijkertijd hun collectieve functie als vindplaats van waarden die in de beroepsuitoefening zouden moeten worden gerealiseerd.

Ook verpleegkundigen en patiënten/cliënten zijn kinderen van hun tijd en derhalve kunmen/zullen ook bij hen individualistisch gekleurde waardenoriëntaties de overhand krijgen bij de bepaling van een gedragslijn in morele aangelegenheden. Alleen al de arbeidsomstandigheden van professionals werken een hoge mate van individualisme in de hand (vergelijk Larson 1979, 236). Vanuit een expressief-individualistisch perspectief verdienen dan twee moreel relevante verschijnselen nadere aandacht: het beroep op gewetensbezwaren respectievelijk de nadruk op zelfbeschikking. Zowel gewetensbezwaren van verpleegkundigen als de zelfbeschikking van patiënten/cliënten worden in verreweg de meeste beroepscodes woor verpleegkundigen (zij het soms impliciet) erkend en benadrukt. Ofschoon op hun betekenis wel het een en ander valt af te dingen (zie onder) zijn beide verschijnselen bovendien echter tekenend voor de paradoxale situatie waarin beroepscodes in de gezondheidszorg uiteindelijk belanden.

Een beroep op gewetensbezwaardheid kan worden beschouwd als een uiterste individuele poging van verpleegkundigen om te ontsnappen aan de externe druk van waardenoriëntaties en morele keuzes die niet de hunne zijn. Deze druk kan zowel afkomstig zijn van patiënten/cliënten, andere hulpverleners, richtlijnen vanuit de organisatie, als van de eigen beroepscode. Gewetensdwang wordt in onze samenleving als een ernstige aantasting beschouwd van de persoonlijke vrijheid en integriteit. Gewetensbezwaren worden dan ook in de Collectieve Arbeidsovereenkomst waaronder verpleegkundigen vallen, genoemd en erkend als grondslag voor het niet hoeven uitvoeren van handelingen die worden ervaren als indruisend tegen voor hen fundamentele waarden en morele beginselen (CAO voor verpleegkundigen, artikel 6 , lid 1). Het geweten kan derhalve worden gezien als het cumulatiepunt van een op expressief-individualistische leest geschoeide ethiek voor verpleegkundigen. 
Een expliciete en fundamentele keuze tégen een door anderen (patiënt en/of collega's) gepercipieerd moreel belang en derhalve een beroep op het eigen geweten is echter niet onproblematisch. Niet zozeer vanwege een vermeende obstructie tegen de bepalingen van een beroepscode, want deze zou nog kunnen worden begrepen als uitvloeisel van een al te rigide interpretatie van deze code ten aanzien van een zeer variabele (gesegmenteerde) beroepspraktijk (vergelijk 5:3.3). Het probleem is meer gelegen in het individualistische karakter ervan. Het persoonlijk geweten is een dermate subjectief te duiden verschijnsel, dat het uiterst moeilijk door middel van een extern, min of meer objectief criterium is te toetsen. Een verband met de centrale warde(n) uit een beroepscode zal dus sowieso moeilijk zijn aan te geven. We hebben weliswaar 'solidariteit' respectievelijk 'dienstbaarheid' geìdentificeerd als centrale waarden en moreel handelingskader voor verpleegkundigen, maar moesten daarbij tevens erkennen dat zij phrastisch pluriform zijn en voor hun realisering executieve deugden als moed en trouw behoeven.

We kunnen er dus nooit zeker van zijn dat we het juiste criterium hanteren voor de morele toetsing van iemands geweten. Derhalve kan elke beslissing of handeling van een verpleegkundige in principe worden opgevat als een gewetensdaad en op grond daarvan moreel aanvaardbaar worden geacht, mits geen gewetensdwang ontstaat voor anderen of fundamentele vrijheden worden geschaad. Het geweten is dus enerzijds een eindeloos rekbaar begrip, anderzijds is het, afhankelijk van het gekozen toetsingscriterium, door middel van negatieve uitsluiting bijna volledig te beperken. Een beroep op het geweten kan voor de persoon zelf een uiterste keuze bevatten en tegelijkertijd voor anderen volkomen inhoudsloos zijn en slechts een alibi-functie vervullen. Daarnaast kan men zich afvragen of een verpleegkundige wel geneigd zal zijn een dergelijk beroep te claimen en of dit wel effectief en voordelig voor die verpleegkundige is. In een positie van heteronomie, ambiguitteit en machteloosheid moet dit immers sterk worden betwijfeld. Onze indruk is ook, dat een beroep op gewetensbezwaren door verpleegkundigen zeer zelden plaatsvindt.

Een beroep op het geweten door een verpleegkundige wordt verder gecompliceerd door diens belofte -verwoord in alle beroepscodes- de belangen van patiënten/cliënten te allen tijde te laten prevaleren boven de eigen belangen. Hoewel eerst moet worden gewezen op de tegenstrijdigheid in deze ordening van belangen, gaan wij hieraan nu nog voorbij en merken op dat we hiermee zijn beland bij het tweede thema dat we in expressief-individualistisch perspectief aan de orde willen stellen, namelijk zelfbeschikking van patiënten/cliënten. Het is de waarde waarin tegenwoordig gewoonlijk al hetgeen wordt samengevat dat samenvalt met het belang van de patiënt/cliënt. Diens hoogste belang bestaat erin het beheer over het eigen leven en de eigen levensloop zoveel mogelijk in eigen hand te nemen en te houden. Vele gezondheidsethische en gezondheidsrechtelijke beschouwingen en handboeken zijn op dit uitgangspunt gebaseerd (als wij ons beperken tot de meest recente Nederlandstalige compilatiewerken, zie De Beaufort/Dupuis 1988, respectievelijk Gevers/Hubben 1990). Individualisering van zorg, als algemeen kenmerk van de huidige gezondheidszorg, is ook vooral in dit perspectief te bezien.

De rol die zelfbeschikking speelt in actuele discussies over taken, plichten en bevoegdheden van hulpverleners ten opzichte van patiënten/cliënten is door Ten Have en Kimsma $(1987,82)$ wel gekenschetst als autonomiedogmatisme. Met deze uitdrukking wordt weergegeven wat wij zouden willen opvatten als een massieve waardenbeleving waarin zelfbeschikking van patiënten/cliënten als het ware tot een bovenwerkelijk gegeven 
wordt opgetild en een ideologische paraplu vormt om het hulpverlener-hulpvragendecontact moreel en juridisch af te dekken. Immers, dit contact blijft fundamenteel gekenmerkt door een afhankelijkheidsrelatie: de patiënt/cliënt vraagt om iets dat alleen de hulpverlener in de vorm van kennis en kunde bezit en hij/zij moet maar afwachten of het wordt verkregen. Bovendien, voorzover de patiënt/cliënt dat 'iets" al kan verwoorden, dan nog is diens denken en spreken daarover reeds voorgevormd door de categorieën van de moderne hulpverlening, met name de geneeskunde, door middel van processen als medicalisering en sociale iatrogenese. Men kan zich derhalve afvragen of een door de patiënt/cliënt ingezien en aanvaard belang niet al te zeer door heteronome factoren wordt bepaald.

Hoewel dus zowel bij het beroep op gewetensbezwaren door verpleegkundigen als bij de nadruk op zelfbeschikking van patiënten duidelijk vraagtekens kunnen worden geplaatst, corrumperen zij in zekere mate de gelding en toepasbaarheid van beroepscodes. In beide gevallen kan de beroepscode (tijdelijk) buiten werking worden gesteld. Het paradoxale is, dat deze situatie door de meeste beroerpscodes zelf wordt opgeroepen en gesanctioneerd. Verder wordt min of meer impliciet aanvaard dat tussen de belangen van verpleegkundigen en die van patiënten/cliënten een fundamentele breuk kan bestaan. Deze wordt niet overbrugd door het belang van patiënten/cliënten te laten prevaleren, zoals in de beroepscodes wordt voorgeschreven, want hiermee zou een maatschappelijk onacceptabele vorm van gewetensdwang op verpleegkundigen kunnen ontstaan.

Nu zou het in de praktijk met genoemde breuk zeer wel mee kunnen vallen. Het is zelfs voorstelbaar dat verpleegkundigen en patiënten/cliënten een soort bondgenootschap aangaan. Immers, beiden staan voor de opgave hun leven in eigen beheer te houden (hoewel vanuit een verschillende rol) en beiden worden daarin belemmerd door feitelijk bestaande afhankelijkheidsrelaties met hun omgeving. Een bepaald element verbindt hen daarin. Om dit te verduidelijken grijpen we terug op wat in 5.3.2 werd benoemd als de dominantie van instrumentele waardenoriëntaties en functionele rationaliteit in de gezondheidszorg.

Zoals toen werd uiteengezet vormt zij een probleem voor de realisering van expressieve waardenoriëntaties en substantiële rationaliteit; waardoor beroepscodes vooral worden gekenmerkt. Diezelfde expressieve waardenoriëntatie en substantiële rationaliteit treffen we evenwel aan in de primaire (morele) arbeidsmotivatie van verpleegkundigen ('dienstbaarheid') en in het zich bezighouden met zinvragen door patiënten (het toèkomstperspectief). $\mathrm{Zij}$ vormen dus als het ware een kritische massa ten opzichte van genoemde dominantie die bij voldoende volume licht kan ontploffen, daartoe min of meer gesanctioneerd door de beroepscodes voor verpleegkundigen.

Voorzover het expressief-individualisme voldoende 'incentives' biedt en toelaat voor een integratie van substantieel-rationele en morele motieven van verpleegkundigen én patiënten/cliënten, kan het proces van toenemende individualisering aldus de toepasbaarheid van beroepscodes vergroten. Het is zelfs mogelijk dat een zeker conformisme ten aanzien van de primaire morele waarden en handelingsindicaties uit beroepscodes, hetgeen wij in de vorige paragraaf nog kritiseerden, in dit verband moet worden aanbevolen. Conformisme aan de uitgangspunten van beroepscodes impliceert hier immers kritiek op de dominantie van instrumentele waarden en functionele rationaliteit. Het kan zich gemakkelijk verbinden met de kritische massa van morele arbeildsmotivaties en zinvragen 
en vervult daarmee een emancipatieve functie in de richting van grotere aandacht voor fundamentele maatschappelijke en morele waarden, zoals 'solidariteit'.

Een dergelijk proces is tevens van belang voor de rol, functie en status van de beroepscodes zelf. Zonder substraat in de verpleegkundige werkelijkheid vervullen zij een puwr ideologische functie en is hun morele status gering. Dat een dergelijk gevaar duidelijk aanwezig is, hebben we intussen voldoende aangetoond. Wanneer beroepscodes echter worden ingezet als emancipatief instrument tegen een exclusieve dominantie en all te rigide vormen van instrumentele waardenoriêntaties en functionele rationaliteit in de hulpverlening, kan deze dreiging worden gekeerd. Een zekere mate van (moreel gedefinieerd) collectief conformisme en expressief-individualistische moed is hier well voor nodig.

\subsubsection{Het probleem van de sanctionering}

Aan de proclamatie van een beroepscode kan een langdurig proces vooraf zijn gegaan van wikken en wegen, zoeken naar juiste begrippen, opzetten van een adequate ordening, schrijven en herschrijven van conceptversies, raadpleging van deskundigen en betrokkenen. Dit proces heeft bijvoorbeeld bij de eerste ANA-code bijna een halve eeuw geduurd (zie 4.3.3). Als hij dan afgerond en aanvaard is, wil men hem uiteraard ook graag toegepast zien, tenzij de code als puur vlagvertoon wordt beschouwd in het kader van de professionaliseringsaspiraties en ideologie van de eigen beroepsgroep en/of -organisatie.

Nu kan die toepassing van normen uit een beroepscode vanuit verschillende perspectieven worden bekeken, die mede samenhangen met hun ontstaansgeschiedenis. Volgens één daarvan kunnen de normen uit een beroepscode worden opgevat als moreel ideaal, dat nog niet overal toepassing vindt maar waartoe reële mogelijkheden bestaan en/of worden gezocht. Men zal in dat geval trachten zich serieus te bemoeien met het gedrag van beroepsbeoefenaren en de omgeving waarin het wordt gerealiseerd. Van de norm afwijkend gedrag zal men trachten te corrigeren en een de norm tegenwerkende situatie zal men willen aanpassen.

Onze beschouwing in de onderhavige paragrafen heeft vooral betrekking op bovengenoemd perspectief. In dat kader is tot nu toe een aantal problemen besproken die in meer of mindere mate samenhangen met de aard en kenmerken van de situatie of context waarin een beroepscode voor verpleegkundigen wordt toegepast, mede met het oog op de aard en functie van beroepscodes zelf. In deze paragraaf concentreren we ons op de mogelijkheden tot correctie van het gedrag van beroepsbeoefenaren. We vatten deze samen onder het probleem van de sanctionering. Hiermee wordt verwezen naar een centraal probleem bij elke ethische normstelling, namelijk haar mate van afdwingbaarheid.

Afdwingbaarheid van normen is niet alleen een problematisch gegeven in de ethiek. Het recht heeft er evenzeer mee te maken, in die zin dat in principe elke rechtsregel afdwingbaar moet zijn wil deze als zinvol wettelijk instrument worden beschouwd. Er worden dan ook sancties gezet op het niet naleven ervan en er wordt een uitgebreid rechtsapparaat opgebouwd om dit te bewaken. Wie de rechtsnorm overtreedt kan in staat van beschuldiging worden gesteld.

Morele normen zijn in principe niet afdwingbaar zoals rechtsnormen. De phrastischneustische pluriformiteit van morele waardebegrippen impliceert dat voortdurend twijfel moet worden geuit aan de juistheid van ingenomen morele standpunten. $\mathrm{Er}$ kunnen zo 
vele standpunten naast elkaar bestaan zonder dat kan worden uitgemaakt welk het ideaal van 'het goede" het dichtst benadert. Men kan het weliswalar eens worden over een zekere prioriteit, maar anderen zullen een andere volgorde hanteren. Overtreding van een morele norm zal daarom door de ene persoon nauwelijkss worden opgemerkt, terwijl een ander de overtreder hoogstens kan overladen met verwijten en een gevoel van schaamte kan bezorgen. De reacties van geneeskundigen ten opzichte van elkaar bestaan dan bijvoorbeeld voornamelijk uit boycot en contact-vermijding (Freidson 1970, 183).

Sanctionering van gedrag is derhalve in de ethiek van andere aard dan in het recht. In het recht heeft zij een hoofdzakelijk negatief karakter; hangt in belangrijke mate samen met de afdwingbaarheid van normen en bestaat voor een belangrijk deel wit het ontnemen van vrijheden of van middelen om deze uit te oefenen (bijvoorbeeld onder-curatelestelling respectievelijk geldboete). In de ethiek heeft sanctionering een zowel positief als negatief karakter, maar reikt niet verder dan uitingen van goedkeuring respectievelijk afkeuring. Bijvoorbeeld, negatieve sanctionering van (im)moreel gedrag van verpleegkundigen kan deze weliswaar belemmeren in de uitoefening van het beroep, zeker wanneer deze is gebaseerd op hechte samenwerking, maar zal er in Nederland niet toe leiden dat hem of haar het recht daartoe wordt ontnomen.

Dit verschil in sanctionering heeft als achtergrond een verschil in de primaire taak van het recht respectievelijk de ethiek in de samenleving (we volgen hier in grote lijnen Meuwissen 1982, 198-206). De taak wan de ethiek is die van morele opvoeding, indien men althans niet blijft steken in meta-ethische posities en de normatieve ethiek serieus neemt. De ethiek appelleert derhalve aan de vrije wil van mensen het goede te doen en het kwade te laten. Daarbij is de richting waarin het moreel goede wordt gezocht een zogenaamde vrije kwestie en afhankelijk van normatieve concepties met betrekking tot de aard van en de relaties tussen mens en wereld (met andere woorden: levensbeschouwing en kosmologie). Elke waarheidsclaim is dus in absolute zin weerloos, omdat zij voortdurend kan worden gesteld tegenover een aantal andere morele idealen, waarvan de legitimiteit casu quo rechtvaardigbaarheid evenzo op rationeel verdedigbare gronden kan berusten.

De allereerste taak van het recht is evenwel niet morele opvoeding, maar meer de bescherming en de bevordering van het algemeen belang. We hebben het dan uiteraard over het positieve recht waarmee we iedere dag te maken hebben en waaraan we allen zijn gebonden. Het recht behoeft daarbij niet primair een beroep te doen op de vrije wil van mensen, maar heeft allereerst te maken met hun feitelijke handelingen en de mate waarin deze overeenstemmen met geldende rechtsnormen en pas daarnaast met de intenties van mensen. Deze rechtsnormen zijn geen vrije kwestie, omdat zij maatschappelijke conventies belichamen van wat minimaal vereist is voor een goed functioneren van mens en samenleving op basis van beginselen van vrijheid en rechtvaardigheid. Om deze minimale vereisten te realiseren zijn in veel gevallen sancties nodig. Deze sancties zijn mogelijk, omdat in beginsel geen verschil van inzicht hoeft te bestaan over hun grondslag en reikwijdte, indien althans met betrekking tot de toepassing van de desbetreffende rechtsnormen jurisprudentie bestaat. In de ethiek staan deze grondslag en reikwijdte steeds ter discussie, waardoor sancties een meerzinnig karakter hebben en dientengevolge in principe achterwege zouden moeten blijven.

Omdat rechtsnormen maatschappelijke conventies zijn met betrekking tot beginselen van onder meer vrijheid en rechtvaardigheid en omdat diezelfde beginselen aan de basis staan van de meeste normatief-ethische theorieën, is als het ware de ethiek bepalend 
voor de grenzen die het recht en zijn normen niet mogen overschrijden. Met betrekking tot een groot deel van het recht zijn rechtsnormen dan ook het minimaal noodzakelijk geachte bestanddeel van wat als grootste gemene deler wit normatief-ethische opvatingen in cen samenleving is af te leiden (dit geldt niet voor bijvoorbeeld het administratief recht, omdat dit ethisch weinig interessant en relevant kan worden geacht). Het recht en zijn normen kumen in deze zin derhalve worden opgevat als een minimalistische conventie-ethiek die de volheid van al hetgeen, dat in een samenleving voor moreel geindiceerd en daarom nastrevenswaard wordt gehouden, nooit kan bevatten. Immers, in een moreel pluriforme samenleving als de onze zou dan steeds met twee of meer maten worden gemeten, hetgeen het recht zelf in zijn diepste wortels zou aantasten. Daartegenover is uiteraard ook een andere opvatting mogelijk. Ten opzichte van normatief-ethische stelsels die neustisch bezien berusten op een te massieve waardenbeleving, kan het recht ook een verruimende functie vervallen. Dit gebeurt bijvoorbeeld wel bij het tijdelijk uit de ouderlijke macht zetten van Jehovah-ouders wier kind een levensreddende bloedtransfusie nodig heeft:

Niettemin heeft het bovenstaande belangrijke consequenties woor de toepassing van beroepscodes voor verpleegkundigen. Daarbij kan nu een onderscheid worden gemaakt tussen hun toepassing als morele leidraad en hun toepassing als juridisch relewant document. In het eerste geval zijn de normen uit een beroepscode in beginsel niet afdwing* baar. Vergroting van de mogelijkheden om het volgen van de normen door middel van sancties alsnog af te dwingen impliceert een fundamenteel conflict met het morele karakter ervan en dient om die reden te worden afgewezen. Proclamatie van een beroepscode als morele leidraad voor het handelen van verpleegkundigen houdt impliciet een erkenning in dat ook andere morele normen, bijwoorbeeld op grond van een andere beroepscode of een individuele code, kunnen gelden en als juist kunnen worden beoordeeld. Het is dus mogelijk dat aan verpleegkundigen een aantal beroepscodes met verschillende morele normstellingen wordt aangeboden, waaruit diezelfde verpleegkundigen vrijelijk een keuze kunnen maken, terwijl aan een daarvan afwijkende keuze geen sancties zijn verbonden. Dat geldit bijvoorbeeld voor leden van de NMV. Deze organisatie heeft zich gecommitteerd aan de ICN-code, maar heeft ook zelf een code ontworpen. De leden worden derhalve geacht beide codes als morele leidraad voor hun handelen te aanvaarden, maar afwijken daarvan heeft vooralsnog geen invloed op het lidmaatschap van de NMV. Deze situatie wordt als problematisch ervaren, omdat men vanuit het perspectief van een (beroeps)organisatie of segment van de beroepsgroep die het morele gedrag van haar leden serieus neemt, daarin graag de normen uit de beroepscode gerealiseerd ziet. Het is ook iets waartoe men zich als het ware heeft verplicht uit het oogpunt van zelfregulering in het kader van een streven naar professionalisering. Men kan dit echter alleen afdwingen wanneer men de normen beschouwt als of omvormt tot rechtsnormen, dus door de beroepscode toe te passen als een document met juridische betekenis. Bovendien vereist dit de opbouw van een uitgebreid apparaat om de handhaving ervan te garanderen. Hoewel dit laatste al voldoende problemen kan opleveren (zie Leenen 1979, 106-113; 1981, 125-128), is met deze constellatie als zodanig een aantal principiëler kwesties verbonden, die we in het volgende aan een nadere beschouwing willen onderwerpen. Zij thangen samen met en worden nader gekarakteriseerd alls de verschijnselen van juridisering, instrumentalisering en minimalisering van morele waarden en normen. 
De toepassing van beroepscodes als juridisch relevant document haakt in op een zekere maatschappelijke tendens tot juridisering van het morele. $\mathrm{Er}$ is een neiging bij allerlei groeperingen en overheden om de morele opvattingen, waarden en normen die zij voorstaan in aparte regelgeving onder te brengen en zo mogelijk kracht van wet te geven. Op deze wijze worden relaties nader gedefinieerd en wordt tegemoet gekomen aan de alleszins menselijke behoefte aan overzicht en zekerheid. Een dergelijk proces is ook gaande ten aanzien van de gezondheidszorg. Het wordt bevorderd door een toenemend spreken in termen van rechten van patiënten, zelfbeschikking of autonomie en het daarmee verbonden proces van individualisering (vergelijk 5.3.4).

Volgens Ten Have en Kimsma $(1987,86)$ wordt hiermee een verwarring ingebouwd tussen rechten die mensen bezitten krachtens een moreel beginsel en rechten die zij hebben op grond van een vigerend rechtsstelsel. Als consequentie hiervan wordt een tendens in de hand gewerkt waarbij moeilijk bediscussieerbare morele zienswijzen worden beslecht door de vorming van een op rechtsnormen gebaseerde minimale consensus. Een ander gevolg van deze tendens is volgens hen, dat afspraken en het volgen van procedures de inhoud van die afspraken en van hetgeen waarover die procedures gaan, naar het tweede plan verwijzen en tot een soort procedurele ethiek aanleiding geven (vergelijk ook Kultgen 1988,248 ).

Het gebruik van beroepscodes als juridisch relevant document draagt dus bij aan een verwarring van hun moreel karakter met hetgeen wettelijk is toegestaan, terwijl wij beide functies juist uiteen wensen te halen. Bovendien kan er dan sprake zijn van ofwel een hypertrofiëring ofwel een atrofiëring van de eigen morele opvattingen en verantwoordelijkheid van een beroepsgroep, waardoor het beoogde morele evenwicht in de beroepsuitoefening geweld wordt aangedaan. Hypertrofiëring kan naar voren komen in het feit dat een bestaande beroepscode als juridisch relevant document wordt geacht de (zij het minimale) consensus te bevatten van al hetgeen aan morele opties in een beroepsgroep aanwezig is. Dit lijkt ons zowel in het licht van het bovenstaande als op grond van ons eigen meta-ethisch en normatief-ethisch kader een massieve pretentie. Het atrofische kan schuilen in het gegeven dat noodzakelijkerwijs in een op te stellen beroepscode alleen nog maar datgene kan worden vastgelegd dat verwijst naar de grootste gemene deler van alle mogelijk aanwezige opties, dus ontdaan van alle nuancering en alleen nog bestaand in een nauwelijks gevuld omhulsel.

De instrumentalisering van morele waarden en normen hangt hier naw mee samen, maar moet mede in de context worden bezien van de formalisering van de verhoudingen tussen mensen in organisaties en hetgeen dat betekent voor de positie van morele opvattingen. Ten aanzien van de gezondheidszorg is reeds gesteld dat in haar organisaties het gedrag van beroepsbeoefenaren in zekere mate wordt geleid door bureaucratische principes in de vorm van protocollen, procedures en voorschriften (zie 2.3.9). Door Philipsen werd geconstateerd dat de relatie tussen bijvoorbeeld hulpverlener en hulpvragende wordt gedomineerd door instrumentele waarden en functionele rationaliteit (als kenmerken van het 'project' hulpverlening) en niet door expressieve waarden en substantiële rationaliteit (als kenmerken van onderlinge 'bejegening') (zie 3.2.1; vergelijk ook 5.3.2). Formele voorschriften van instrumentele aard lijken de toepassing van morele normen te verdringen. Deze laatste dreigen hun relevantie en zeggingskracht te verliezen.

Het is dan ook niet verwonderlijk als beroepscodes weinig toepassing vinden in de verpleegkundige praktijk van alledag. Naar sommigen menen, zou hun toepasbaarheid ech- 
ter kunnen worden verhoogd door ze te plaatsen in de dominante werkwijze en oriëntatie, dat wil zeggen door ze te formaliseren en op te nemen in het geheel van procedures en voorschriften. Immers, wil men morele normen afdwingen, dan moet men ze formuleren als rechtsnormen. Pas dan bezitten ze formele en onontkoombare geldingskracht. Bovendien, iets dergelijks lijkt inmiddels aanvaard ten aanzien van de besluitvorming inzake een euthanasieverzoek of ten aanzien van het informed consent van proefpersonen bij medisch wetenschappelijk onderzoek!

Morele normen gaan dan deel uitmaken van de 'instrumentele ceremoniële orde', zoals we reeds enkele malen naar een uitspraak van Philipsen naar voren brachten. Ze worden dan echter grotendeels ontdaan van hun morele karakter (vergelijk Ten Have en Kimsma hierboven). Ze worden vooral opgevolgd en geacht het handelen te leiden omdat ze bestaan, minder om wat ze materieel-inhoudelijk uitdrukken en dus eventueel aan keuzealternatieven bieden. Ze gaan derhalve deel uitmaken van de dominante oriëntatie waar ze in beginsel een alternatief of tegenwicht voor moesten bieden. Beroepscodes zijn hier in het algemeen niet voor bedoeld en verkeren aldus in hun tegendeel.

Ten slotte de minimalisering van morele waarden en normen. Wellicht kan hier beter worden gesproken van een beperking van hun morele functie. Bedoeld worden in elk geval alle processen die boven reeds werden vermeld en die leiden tot een minimalistische opvatting van ethiek. Zowel juridisering als instrumentalisering geven aanleiding tot een dergelijke opvatting. Zij heeft tot consequentie, dat het morele debat verschraalt tot hetgeen reeds in voorschriften en procedures vastligt en geen nieuwe gezichtspunten meer opent. Het verliest daarmee haar kritische functie, niet in het minst juist ten opzichte van diezelfde voorschriften en procedures en met betrekking tot de dominantie van waardenoriëntaties waaruit ze voortvloeien. Daarmee wordt een zeker conformisme geëist ten aanzien van vigerende regels, dat wij ook in 5.3.3 reeds in een dergelijke negatieve rol tegenkwamen. Eigenlijk is zij ook geen ethiek meer te noemen, maar een apart soort ethos: een feitelijk bestaande leefwijze waarvoor men weliswaar kan kiezen maar die met morele overwegingen en de discussie daarover weinig meer van doen heeft. Via instrumentalisering van morele waarden en normen zoekt men hun sanctionering, daarbij uit het oog verliezend dat men aan hen dan het morele karakter grotendeels ontneemt.

Er is op grond van het bovenstaande veel voor te zeggen het probleem van de sanctionering in het algemeen en het gebrek aan afdwingbaarheid in het bijzonder als een schijnprobleem te beschouwen, wanneer het althans om morele waarden en normen gaat. Vanwaar immers die behoefte aan afdwingen? Er zijn talloze sectoren, ook in het recht, waarin van het afdwingen van normen nauwelijks sprake kan zijn. Starr $(1983,99)$ bijvoorbeeld trekt hierin een parallel met het internationale recht. Zelfs als er aantoonbaar grove schendingen van dit recht plaatsvinden, dan nog blijft de afdwingbaarheid en de bekrachtiging ervan een probleem. Toch zullen maar weinig juristen en ethici hieraan de conclusie willen verbinden dat internationaal recht weinig zin heeft. Het doet dienst als het geweten van politici en ambtenaren, ook al zijn er weinig middelen voorhanden om het af te dwingen (uitgezonderd die van revanche en boycot).

Hetzelfde nu kan gelden ten aanzien van de betekenis van beroepscodes voor het morele klimaat waarin een beroep wordt uitgeoefend. Zij houden een morele maatstaf voor waartoe men zich kan bekennen. Zij dragen daardoor bij aan een zekere stabiliteit en consistentie in de besluitvorming ten aanzien van gevoelige morele vraagstukken, zonder 
dat dit leidt tot rigiditeit of een massieve moraal. Daarmee behouden ze de opvoedende functie waartoe alle ethiek oorspronkelijk is ontworpen.

De eerder gencemde kwesties komen samen in het gebruik van beroepscodes in het kader van een tuchtrecht voor verpleegkundigen. Hoewel deze problematiek hier niet in extenso kan worden behandeld, laten we niet na er enige opmerkingen over te maken.

Het tuchtrecht kan worden beschouwd als een bijzondere vorm van juridisering, instrumentalisering en minimalisering van morele waarden en normen. Het regelt primair de onderlinge verhoudingen van beroepsbeoefenaren, maar het vervult daarenboven een ideologische functie inzoverre het een bescherming biedt voor de goede naam en faam van het beroep. Het tuchtrecht kan een dergelijke rol vervullen door negatieve sanctionering van laakbaar gedrag. Vooral dit laatste is bepalend voor het juridische karakter ervan en voor de wijze waarop het functioneert, zij het dat het bij het tuchtrecht niet zozeer gaat om schuld, schadevergoeding en straf maar meer om een correctie van het handelen met het oog op vigerende normen. Er worden geen strafrechtelijke sancties opgelegd maar disciplinaire maatregelen getroffen. Extern tuchtrecht wordt via de wet publiekrechtelijk geregeld (bijvoorbeeld de Medische Tuchtwet van 1928). Bij intern tuchtrecht wordt de naleving van normen en regels door beroepsbeoefenaren zelf getoetst en bewaakt (Leenen 1981, 122-124). Volgens de Wet BIG zal een aantal beroepen in de gezondheidszorg, waaronder dat van verpleegkundigen, direct of indirect worden gebonden aan een of andere vorm van extern tuchtrecht:

Uiteraard kunnen voor de toepassing van het tuchtrecht normen worden ontleend aan beroepscodes. Maar dan gelden dezelfde bezwaren als die boven reeds werden behandeld met betrekking tot een verlies van hun moreel karakter onder invloed van juridisering, instrumentalisering en minimalisering. Beroepscodes die voor een dergelijke toepassing zijn ontworpen zouden niet meer als ethische codes mogen worden gepropageerd. Dit geldt duidelijk voor de UKCC-code (zie 4.3.4) en -afhankelijk van wat de toekomst ons zal leren- waarschijnlijk ook voor de NMV-code (zie 4.3.5). Zij dienen dan als normen en criteria om het feitelijk handelen te beoordelen, via de jurisprudentie die ten aanzien daarvan ontstaat. Morele overwegingen doen dan minder terzake. Deze worden geacht in de norm of het criterium verdisconteerd te zijn.

Wellicht is het dan aan te bevelen een soort schaduwcode van de oorspronkelijke ethische code te ontwerpen waarin de aanwezige normen en handelingen volgens juridische maatstaven zijn geoperationaliseerd. Dat dit zeer uitvoerige en gedetailleerde documenten oplevert bewijst een aantal beroepscodes in de Verenigde Staten (bijvoorbeeld die van de American Bar Association en de National Society of Professional Engineers; zie Callahan 1988, 439-451 en 460-464). Het verschijnsel juridisering is daar dan ook reeds ver voortgeschreden.

Naast deze behoefte aan detaillering en de reeds eerder gesignaleerde bezwaren zijn er nog andere problemen verbonden aan het gebruik van beroepscodes in het kader van het tuchtrecht; deze houden vooral verband met de specificatie ervan in het intern tuchtrecht:

1. Intern tuchtrecht speelt zich af binnen de beslotenheid van de eigen (beroeps)organisatie en kan in dat verband aanleiding geven tot fricties. De maatschappelijke controle op deze vorm van tuchtrecht is aanzienlijk kleiner dan bij extern tuchtrecht, omdat het 
laatste expliciet en voortdurend wordt getoetst aan algemene beginselen van het positieve recht.

2. In samenhang hiermee dreigt een situatie te ontstaan waarin sprake is van een staat in de staat. Door het thanteren van een intern tuchtrecht spreekt men als het ware uit, dat het uitoefenen van een beroep in de visie van de desbetreffende organisatie aan bijzondere, van de algemene norm afwijkende beginselen is gebonden of dient te zijn. Hierdoor wordt geknabbeld aan de externe legitimiteit van de intern geformuleerde normen, hetgeen we voor beroepscodes als een ongewenst en niet moreel te rechtvaardigen verschijnsel hebben gekwalificeerd (zie 5.2.3).

3. Intern tuchtrecht introduceert een zekere rechtsongelijkheid omdat het alleen van toepassing is op de eigen leden van een organisatie: In het algemeen mag men er niet van uitgaan dat werkelijk alle leden van een beroepsgroep tevens lid zijn van één beroepsorganisatie. Dat geldt in ieder geval voor verpleegkundigen in Nederland (zie 2.4.5). Bovendien hanteert alleen de NMV (nog geen 20.000 leden) een eigen beroepscode en de andere beroepsorganisaties voor verpleegkundigen niet. Hierdoor kan de situatie ontstaan dat in een team van verpleegkundigen de ene verpleegkundige zich gebonden weet aan een code en een andere verpleegkundige niet of aan een andere code. Bij toepassing van intern tuchtrecht op basis van een beroepscode die slechts voor een beperkt aantal verpleegkundigen geldt, kan derhalve eenzelfde handeling voor verschillende verpleegkundigen verschillende formele consequenties hebben. Dit leidt tot een zekere rechtsongelijkheid en daardoor waarschijnlijk tot verschillen in benadering en handelingen ten aanzien van de beroepsuitoefening, afhankelijk van het lidmaatschap van een bepaalde beroepsorganisatie.

Uiteraard schuilt in dit lidmaatschap een element van keuze: men onderwerpt zich vrijwillig aan de uitgangspunten van de organisatie. In de praktijk van alledag maakt deze constellatie de situatie er voor patiënten/cliënten en de beoefenaren van andere beroepen echter niet doorzichtiger op. Met name voor patiënten/cliënten kan dit een bron van frustratie opleveren. Zij zijn immers gebaat bij een zekere voorspelbaarheid van het gedrag van verpleegkundigen. Castles $(1980,12)$ beschouwt dit zelfs als de belangrijkste functie van beroepscodes. Afwijken van een door een beroepscode voorgeschreven praktijk zou een element van onzekerheid introduceren, indien ineens blijkt dat sommige of veel verpleegkundigen zich in het geheel niet aan die beroepscode (hoeven) storen. Anderzijds kunnen we ons afvragen in hoeverre dit als een negatief verschijnsel of gevolg moet worden geïnterpreteerd. Voorspelbaarheid van verpleegkundig gedrag zou ertoe kunnen leiden dat bepaalde (morele) vragen door patiënten/cliënten niet meer worden gesteld (bijvoorbeeld met betrekking tot stervensbegeleiding, indien een beroepscode medewerking aan een verzoek om euthanasie expliciet zou verbieden). Ook op deze wijze zou het hanteren van een beroepscode dus indirect mee kunnen werken aan een bevordering van de instrumentele ceremoniële orde.

Tenslotte nog een algemeen bezwaar dat zowel tegen het strafrecht als tegen het tuchtrecht kan worden ingebracht en dat juist betrekking heeft op bovenvermelde inbreng van patiënten/cliënten. De suggestie wordt wel eens gedaan dat het bestaan van een beroepscode mogelijkheden schept voor een meer onafhankelijk oordeel van een rechtsprekend orgaan in een geval van vermeend laakbaar handelen van beroepsbeoefenaren. Onder 
andere McCall Smith $(1977,122)$ heeft zich in deze zin uitgelaten. Ten aanzien van de gebruikelijke rechtspraktijk wijst hij op een merkwaardige cirkelredenering die ook voor de Nederlandse situatie geldt. Het is de taak van genoemd orgaan om de verwijtbaarheid van een eventueel gemaakte beroepsfout te definiëren. Dit baseert het echter onder andere op verklaringen van deskundigen die uit dezelfde beroepsgroep afkomstig zijn. Aldus bepaalt de beroepsgroep als het ware zelf het sanctiebeleid tegen haar leden. Welnu, dit wordt moeilijker wanneer een beroepscode beschikbaar is, zeker als deze gedetailleerd is en concrete gedragingen voorschrijft. Hierdoor kan op onafhankelijker wijze worden geoordeeld over het handelen van beroepsbeoefenaren. In deze zin worden door juristen ook wel aanbevelingen gedaan ten aanzien van de inhoud van codes.

Op deze wijze lijken aan patiênten/cliënten betere garanties te kunnen worden geboden voor de bescherming van hun belangen. De maatschappelijke controle op het handelen van beroepsbeoefenaren wordt immers vergroot. Wij wagen dat echter in twijfel te trekken en wel om de volgende redenen:

1. Ook die beroepscodes zijn door de desbetreffende beroepsgroep zélf opgesteld en vertegenwoordigen dus een bepaald eigenbelang dat sterker zal worden benadrukt naarmate maatschappelijke controle en externe invloed op de beroepsuitoefening niet worden gewenst.

2. Bij de beoordeling van gedrag is medebepalend onder welke omstandigheden dit zich heeft voorgedaan. Hierop kan te allen tijde worden gewezen en aldus kunnen de bepalingen in een code onwerkzaam, onuitvoerbaar of niet terzake worden verklaard (bijvoorbeeld bij een code die een puur ideologische functie vervult).

3. Naast deze praktische bezwaren gelden uiteraard ook de theoretisch-praktische bezwaren die wij boven vanuit het perspectief van de verhouding tussen recht en ethiek formuleerden inzake het hanteren van een beroepscode als juridisch relevant document.

Deze bezwaren tegen het vermeende belang van beroepscodes voor de bescherming van patiënten/cliënten convergeren met twijfels ten aanzien van elke wettelijke regeling met betrekking tot het handelen van beroepsbeoefenaren. Leenen $(1979,109)$ vat deze als volgt samen:

1. Het beroepsmatig handelen is zo veelvormig en omvangrijk dat het feitelijk niet mogelijk is tot een sluitende of redelijk hanteerbare regeling te komen.

2. Beroepsbeoefenaren hebben nu eenmaal een grotere deskundigheid ten aanzien van hun professioneel handelen dan bijvoorbeeld de overheid heeft.

3. Regeling van hulpverlening heeft de neiging wetenschappelijke ontwikkelingen met betrekking tot de desbetreffende vakgebieden te verstarren.

4. Het vertrouwen van het publiek in de onafhankelijkheid van de hulpverlener en de vertrouwelijkheid van de relatie hulpverlener-hulpvragende kan worden verminderd.

5. Bij hulpwerleners kan de neiging ontstaan om zich strikt aan de regelingen te gaan houden, waardoor een conservatieve wijze van hulpverlening en verambtelijking kan ontstaan.

6. De wetgever is nimmer in staat garanties te bieden voor de individuele hulpverlening.

Al deze bezwaren en/of gevolgen zijn in enigerlei vorm reeds naar voren gebracht en betrokken op het gebruik van beroepscodes als juridisch relevant document. Zij bieden dan ook een goede samenvatting van wat wij als het probleem van sanctionering hebben beschreven bij de toepassing van beroepscodes. 


\subsubsection{Nogmaals: de morele status van beroepscodes}

In 5.2.4 werd de morele status van beroepscodes voorlopig getypeerd als een 'middellijk' kader voor morele handelingsindicaties voor beroepsbeoefenaren op geleide van sociaalof algemeen-ethisch gelegitimeerde maatschappelijke waarden, in casu 'solidariteit', in een specifieke, primair moreel phrastisch-neustische interpretatie daarvan. Deze status werd ontleend aan een beschouwing ower de superioriteit en legitimiteit van beroepsgebonden morele claims in het licht van fundamentele maatschappelijke waarden. Erkend werd dat 'dienstbaarheid', als specificatie van en in haar functionele verbondenheid met dergelijke waarden alsmede als centrale morele waarde in beroepscodes voor verpleegkundigen en als articulatie van de bestaansgrond van het beroep en van de expressieve werkoriëntatie van de beoefenaren ervan, in belangrijke mate bijdraagt aan de morele status van die codes.

Daarnaast werd er echter van uitgegaan dat deze morele status niet alleen op waardentheoretische gronden kan worden verleend, maar ook afhangt van de toepassingsmogelijkheden van beroepscodes. Dit uitgangspunt hangt samen met het criterium van realiteit-gebondenheid dat bij het legitimiteitsvraagstuk een specifieke rol speelt. Wij hebben dit criterium trachten te operationaliseren in de morele rol en positie van verpleegkundigen in de context van hulpverlening, gezondheidszorg en maatschappelijke factoren. Daarbij werd geconstateerd dat deze rol en positie worden gekenmerkt door heteronomie en ambiguitteit. Deze interfereren met de context waarbinnen beroepscodes worden toegepast. Ten aanzien hiervan werden de volgende problemen geïdentificeerd: die van rationalisering, uniformering, individualisering en sanctionering. Kort samengevat komen deze op het volgende neer:

1. Functionele rationalisering is een kenmerk van onze huidige cultuur. Extrinsieke en instrumentele rechtvaardigingen van gedrag zijn daarin dominant aanwezig, zo ook in de gezondheidszorg. De toepassing van beroepscodes dreigt hieraan te worden aangepast, daardoor deel te gaan uitmaken van de instrumentele ceremoniële orde en aldus hun kenmerken als morele leidraad voor het handelen te verliezen.

2. Uniformering is een factor op het niveau van de beroepsgroep die met de functie van beroepscodes zelf samenhangt, omdat in de noodzakelijke materieel-inhoudelijke abstracties de opvatting schuilgaat van een ongedeelde beroepsgroep. Deze opvatting moet als een fictie worden beschouwd vanuit de aantoonbare variabiliteit van het professionele handelen. $\mathrm{Zij}$ bevordert daarmee een puur ideologisch functieoneren van beroepscodes. De genoemde abstracties noodzaken tot interpretatie, die in haar minimalistische vorm leidt tot een te beperkte reikwijdte van de beroepscodes. Daarentegen staat een ruime interpretatie een te grote permissiviteit toe en een gebruik van beroepscodes als alibi. Vermeende oplossingen in de richting van commissies van toezicht en tuchtrecht leiden onherroepelijk tot een minimalistische interpretatie en tot conformisme. Alleen het loslaten van de pretentie van uniformering zelf biedt soelaas.

3. Individualisering is zowel een cultureel verschijnsel als een gegeven dat in de beroepscodes zelf tot uitdrukking is gebracht in de erkenning van gewetensbezwaren van verpleegkundigen en het primaat van zelfbeschikking voor patiënten/cliënten. Hierdoor kunnen tegenstellingen optreden tussen verschillende waarden en normen in één code en tussen (gerechtvaardigde) opvattingen van verpleegkundigen en patiënten/cliënten 
ten aanzien van de implementatie van een beroepscode. Derhalve wordt zo' $n$ beroepscode ontkracht als morele leidraad voor het handelen. Een kritische massa van moreel gemotiveerde verpleegkundigen en patiënten/cliënten biedt nauwelijks een oplossing vanwege belemmerende factoren die samenhangen met andere beschreven toepassingsproblemen (met name rationalisering).

4. Sanctionering is eigen aan een cultuur van volgzaamheid ten aanzien van voorschriften en procedures en een marginale implementatie van morele waarden en normen. Deze cultuur is dominant in samenleving en gezondheidszorg en noodzaakt als het ware tot een juridisering, instrumentalisering en minimalisering van morele waarden en normen indien toepassing daarvan (dwingend) wordt gewenst. Ook hierdoor wordt het morele karakter van beroepscodes gemarginaliseerd en vervullen deze alleen nog een rol als juridisch relevant document. De opvoedende rol van de ethiek wordt overgenomen door de controlerende (sanctionerende) rol van het recht. Dit komt met name naar voren bij het gebruik van beroepscodes in het kader van straf- en tuchtrecht. Bovendien leidt dit tot het reeds genoemde conformisme op basis van een minimalistische interpretatie van beroepscodes.

De realiteit gebiedt ons te erkennen, dat de toepassing van beroepscodes op zodanig grote en fundamentele problemen stuit dat we ons ernstig moeten afvragen of

1. het morele karakter van een beroepscode als zodanig wordt herkend,

2. (indien 1 positief) verpleegkundigen in een positie verkeren waarin voldoende waarborgen aanwezig zijn om een beroepscode toe te passen en

3. (indien 1 en 2 positief) de context van cultuur, samenleving en gezondheidszorg waarin een beroepscode wordt toegepast niet zodanig verstorend werkt, dat implementatie van de morele waarden en normen eruit voortdurend wordt gefrustreerd en uiteindelijk in haar tegendeel verkeert.

Deze vragen zijn, gezien het bovenstaande, uiteraard van retorische aard. Dit leidt tot de situatie dat geen of allerlei tegengestelde of zelfs valse betekenissen kunnen worden verleend aan een beroepscode en zijn waarden en normen. Er zijn dus slechts beperkte condities aanwezig voor de toepassing van beroepscodes volgens hun primair morele betekenis.

In een loyaliteitstheoretisch perspectief op de functie van beroepscodes kan dit niet zonder gevolgen blijven voor hun morele status. Zoals gezegd, hangt deze in belangrijke mate samen met de legitimering van beroepsgebonden morele claims in het kader van de centrale waardenoriëntaties in gezondheidszorg en samenleving. Waardentheoretisch gezien leidt dit tot een hoge morele status van beroepscodes. Moreel-praktisch gezien staan we nu echter voor het probleem van hun beperkte toepasbaarheid. Praktijken in de gezondheidszorg bieden weinig referenties naar een vanuit beroepscodes geïndiceerd moreel gedrag en pogingen om deze situatie te keren stranden op de weerbarstigheid van diezelfde praktijken of op een verlies van het morele karakter van die codes. Als gevolg van dit alles zijn er weinig mogelijkheden voor verpleegkundigen tot effectieve betekenisverlening van hun beroepsuitoefening in de richting van morele kaders zoals geboden in hun beroepscodes. De individuele beroepsuitoefening wordt aldus gekenmerkt door een geringe phrasticiteit van morele waarden, waardoor deze codes slecht voldoen aan het realiteitscriterium. Vanuit dit perspectief moet de morele status vant de beroepscodes voor verpleegkundigen dan ook laag worden geschat. 


\subsection{Morele kanttekeningen bij professionalisering}

Onze beschouwingen over de toepassingsproblemen en status van beroepscodes voor verpleegkundigen in het perspectief van de in 5.2 geschetste morele kaders laten toe, dat nu ook enige morele kanttekeningen worden geplaatst bij professionalisering, in het bijzonder die van de verpleegkundige. Hiermee pogen we een antwoord te geven op de in 3.4.3. gestelde subvraag 5 en keren we terug tot de kern van hoofdstuk 2 waarmee we deze studie aanvingen.

Een opmerking vooraf geldt de beperkte reikwijdte van onderstaande beschouwingen. De pretentie van volledigheid is op geen enkele wijze waar te maken. In het focus van ons onderzoek stond een analyse van beroepscodes voor verpleegkundigen als (ethisch-)normatief aspect van de professionalisering van een specifieke beroepsgroep. Generalisering van de resultaten naar het verschijnsel professionalisering als zodanig kan slechts met de grootste omzichtigheid geschieden en is dan ook louter tentatief. Een verdere beperking betreft het conceptuele uitgangspunt dat in 2.3.7. ten aanzien van de bestaande professionaliseringstheorieën werd gekozen en dat wij hier wensen door te zetten, namelijk dat wan de machtsbenadering.

We herhalen hier nog eens de omschrijving die Van der Krogt, als exponent van de machtsbenadering, van het verschijinsel professionalisering gaf: "... een proces waarbij leden van een beroepsgroep op collectieve wijze, vooral gebruik makend van kennismacht, trachten een collectieve machtspositie te verwerven en/of te verdedigen, met het doel de gebruiks- en ruilwaarde van het beroep te beheersen." (1981, 94; zie ook figuur 2.2 in 2.3.7.). Aan de basis van dit collectieve gedrag staan de behoeften en belangen van de individuele beroepsbeoefenaar en diens machtspositie. In deze benadering wordt het machtsstreven van de beroepsgroep verklaard vanuit de belangen van de groepsleden en worden structuren als een belemmerende factor gezien om deze te realiseren.

Wat direct opvalt aan deze omschrijving van professionalisering is de term 'macht'. Hieraan wordt wel een pejoratieve betekenis toegekend. Daarachter schuilt een waarde-oordeel over wat door bezit van macht aan immoreels tot stand kan worden gebracht. Vooralsnog kunnen wij dit waarde-oordeel hier niet volgen, omdat niet direct kan worden ingezien waartoe macht wordt aangewend en wat het morele karakter daarvan is. Het gebruik van macht wordt vooral moreel gekwalificeerd door hetgeen ermee wordt bewerkt. Het laatste kan voor sommigen aanleiding zijn thet machtsstreven als zodanig moreel neutraal te verklaren of zelfs als alternatief aan te bieden voor een door morele ge- en verboden beheerst gedrag. Macht wordt dan bijvoorbeeld beschouwd als een vorm van strategisch handelen dat vele verschijnselen in de samenleving legitimeert vanwege het aan macht verbonden succes (vergelijk Vos 1989, 82). Beroepsgroepen zullen een dergelijke amoraliseringsstrategie verkiezen wanneer het erom gaat hun professionaliseringsstreven te legitimeren. Het doel van hun handelen ligt immers meestal vast (bijvoorbeeld de gezondheid van mensen bevorderen). Bij professionalisering gaat het er vervolgens alleen maar om -zo zou men kunnen redeneren- dit doel in de samenleving meer bekend te maken en te verankeren en hun eigen activiteiten daartoe beter te organiseren en met het oog daarop te verklaren. Dat achter een dergelijk proces van institutionaliseren en legitimeren van beroepsactiviteiten een zekere mate van machtsuitoefening 
schuilgaat zou kunnen worden beschouwd als een secundair fenomeen dat gezien het doel moreel niet van belang is. Er zijn daarnaast nog minstens drie andere factoren te noemen die pleiten voor een amoraliseringsstrategie. Op de eerste plaats de aard en context van professionele arbeid; ten tweede de aard van tussengeschakelde doeleinden; en ten derde het karakter van de benutte middelen.

Wat dit laatste betreft wordt er in de machtsbenadering van uitgegaan dat machtsuitoefening primair plaatsvindt vanuit het bezit van kennis en kunde ook hiervan wordt wel gesteld dat zij op zichzelf moreel neutraal zijn. Zij komen pas in een morele constellatie terecht wanneer zij worden aangewend voor bepaalde doeleinden, die moreel gekwalificeerd zijn (bijvoorbeeld het gebruik van epidemiologische kennis en kunde ten behoeve van een rechtvaardige verdeling van gezondheidszorgvoorzieningen). Morele neutraliteit van kennis en kunde voorkómt waarde-oordelen daaromtrent en past derhalve uitstekend in een amoraliseringsstrategie.

Een amoraliseringsstrategie wordt verder ingegeven door tussengeschakelde doeleinden van professionalisering. Bij professionalisering gaat het niet zozeer om de bijdrage van een beroepsgroep aan een maatschappelijk goed, maar ten naaste bij om de beheersing van de gebruiks- en ruilwaarde van het beroep. De term 'beheersing' is hier cruciaal. Professionaliseringsactiviteiten zijn niet gericht op de leniging van matschappelijke behoeften, maar op het belang van de beroepsgroep daartoe. Met professionalisering is dus ten diepste een prudentieel belang gediend, geen moreel belang. Dit prudentieel belang kan met behulp van een amoraliseringsstrategie uitstekend worden gemaskeerd.

De laatste factor betreft de aard en context van professionele arbeid. Deze wordt veelal verricht in het verband van organisaties. In paragraaf 3.2.1 en eerder in dit hoofdstuk hebben we gezien dat daarbinnen een denk- en handelingsstijl heersen die worden gedomineerd door denoterend denken en functionele rationaliteit. Kennisontwikkeling en kennistoepassing overheersen het doel, kader en degenen ten aanzien waarvan de professionele arbeid wordt verricht. Bovendien heeft men in dit verband veelal te maken met een gebureaucratiseerde werkomgeving. Protocollen; werkprocedures, regels en standaarden vormen het belangrijkste oriëntatiepunt voor de beroepsbeoefenaar bij het vervullen van zijn taken en functie. In paragraaf 2.3 .9 werd dan ook gesteld dat een grote toename van kennisontwikkeling en gebureaucratiseerde kennistoepassing op zich reeds een teken is van een geslaagd professionaliseringsproces. Wederom komt hilerbij de vraag "waartoe dit alles..?" niet aan de orde. En opnieuw lijkt het voor beroepsgroepen dus verstandig te opteren voor een amoraliseringsstrategie bij de legitimering van professionalisering(ssuccessen).

Wat zien we echter gebeuren? Veel beroepsgroepen -en ook die in de gezondheidszorgkiezen met het proclameren van beroepscodes in zekere zin voor een anti-amoraliseringsstrategie. Terwijl veel groepen en individuen in de samenleving zich trachten te ontworstelen aan de als knellend ervaren houdgreep van morele kaders (bijwoorbeeld de morele positie achter de euthanasie-wetgeving), kiezen beroepsgroepen er juist voor om de banden met het morele leven strakker aan te halen. Een dergelijke strategie is ook herkenbaar bijwoorbeeld bij vakbonden: men tracht verschillende beroepsgroepen op eén lijn en bij elkaar te houden door hun keuzes moreel in te kleden. Zo wordt voor verpleegkundigen geen extra salarisverhoging geclaimd in het $\mathrm{CAO}$-overleg omdat dit de solidariteit met andere beroepsgroepen zou ondermijnen. (Dit voorbeeld is overigens 
slechts gedeeltelijk van toepassing omdat 'solidariteit' hier gebruikt wordt in de moreel beperkte betekenis van 'klasse-solidariteit').

Men tracht dus een voor de hand liggende functionele of instrumentele legitimerings- en argumentatiestructuur te vermijden door op zijn minst naar de buitenwereld toe de indruk te wekken dat men zich terdege bewust is van de morele doeleinden van het professionele handelen. Met betrekking tot het professionaliseringsmodel op grond van de machtsbenadering worden we dan geconfronteerd met een probleem waarop uiteenlopende visies mogelijk zijn:

1. Men houdt er onvoldoende rekening mee, dat ten behoeve van professionalisering naast kennismacht feitelijk ook (ethisch)normatieve macht wordt opgeëist. Een dergelijke visie lijkt verdisconteerd te zijn in de opvattingen van Van der Krogt (zie 2.3.7) maar werd niet verankerd in zijn omschrijving van professionalisering.

2. De wijze waarop beroepsgroepen hun normatieve macht in beroepscodes verwoorden, verwijst naar een functioneel of instrumenteel gebruik en omgaan met morele doeleinden ten behoeve van de eigen status en machtspositie. In 4.4.4 is al gewezen op de ideologische functie van beroepscodes. En uit de paragrafen $5.3 \mathrm{kan}$ een dergelijk instrumenteel gebruik van beroepscodes worden afgeleid uit hun toepassingsproblemen. Het morele domein wordt niet als zodanig herkend of erkend en men kan het op deze wijze gemakkelijk incorporeren in een instrumentalistische opvatting van professionalisering.

3. Er is sprake van een paradoxale aanpak van de professionaliseringsopties die in conceptuele modellen onvoldoende tot zijn recht komt. Aan de ene kant wordt prioriteit gegeven aan functioneel opgevatte en toegepaste kennis, anderzijds aan de morele kwaliteit van professionele activiteiten met het oog op te vervullen doeleinden. Deze paradox lijkt op de werkvloer echter te worden opgelost ten faveure van de eerste prioriteit; waarmee men zich aanpast aan bureaucratiserende invloeden. Beroepscodes blijken bijvoorbeeld op de werkvloer nauwelijks bekendheid te genieten (zie bijvoorbeeld 4.3.4). Ook hun toepassingsproblemen versterken de indrak dat de morele normen uit beroepscodes nauwelijks als operationele normen kunnen worden beschouwd.

4. Het morele domein dat beroepscodes beschrijven is eigenlijk een wezensvreemd element in het proces van professionalisering. Het hoort er niet echt bij. Het kan daartoe zelfs een belemmering zijn (vergelijk ook 5.3 .3 en 5.3.4). Het ligt dan ook voor de hand dat het in sociologische modellen wordt gemarginaliseerd en er verder weinig aandacht aan wordt geschonken (vergelijk ook 3.4.1).

Met name de laatste drie opties bieden een ondersteuning van de veronderstelde amoraliseringsstrategie van beroepsgroepen met het oog op hun professionalisering. Deze wordt door ons echter niet houdbaar geacht en wel om drie redenen:

1. De morele relevantie van machtsuitoefening en professionalisering. De pretentie dat macht -en vanuit de machtsbenadering dus ook professionalisering- een amoreel karakter zou bezitten, kan nauwelijks worden waargemaakt. Macht staat in de directe invloedssfeer van morele waardebegrippen. Bijvoorbeeld, macht die verworven is zonder de schending van vrijheid, rechtvaardigheid en solidariteit is absoluut moreel te prefereren boven macht waarvan de verwerving wél met een dergelijke schending gepaard is gegaan. Vos formuleert het aldus: "De zogenaamde amorele goederen van rijkdom, roem en macht worden terecht amoreel genoemd, wanneer daarmee wordt 
bedoeld dat zij de legitimerende functie van waardebegrippen niet kunnen overnemen; maar daar wij ons bij de verwerving en het beheer van deze goederen niet kunnen onttrekken aan de invloedssfeer van moraal en ethiek, zouden we ze ten onrechte amoreel noemen wanneer wij daarmee bedoelen dat moraal en ethiek er niet of nauwelijks toe doen" $(1989,84)$. Er is dus een duidelijk verband tussen macht en (morele) waarden en deze relatie is bovendien onomkeerbaar. Het bezit van macht kan worden gelegitimeerd door morele waarden, maar morele waarden worden nooit gelegitimeerd door het bezit van macht (zie ook Kunneman, 1983, 126). Hetzelfde kan worden geconstateerd ten aanzien van hetgeen waarop machtsuitoefening is gericht, namelijk de beheersing van de gebruiks- en ruilwaarde van het beroep. Deze vormen nooit een legitimering voor de sociaal-morele doeleinden waarmee de beroepsuitoefening is verbonden. Evenzo wordt het prudentieel belang gelegitimeerd door het morele belang en niet omgekeerd.

2. Macht en professionalisering zijn nauw verbonden met intrinsieke waardenoriëntaties in de samenleving. Professionalisering en de daarop gerichte machtsuitoefening zijn geen op zichzelf staande fenomenen, maar ingebed in het maatschappelijk gebeuren. In dit kader verrichte activiteiten zijn derhalve te beschouwen als een bepaalde vorm van maatschappelijk handelen. Daarmee worden ze vatbaar voor sociaal-morele kritiek en verliest een amoraliseringsstrategie haar grond.

Professionalisering en machtsuitoefening gaan ergens over, ze worden ondernomen in de context van bepaalde maatschappelijke doelstellingen, ook al laten ze deze doelstellingen zelf ongemoeid. In ons geval betreft dat de als essentieel ervaren maatschappelijke behoefte aan gezondheidszorg en bescherming van de waarde gezondheid. Professionalisering en machtsuitoefening beïnvloeden, ook al is het slechts indirect, de wijze waarop en de mate waarin het belang van deze behoefte wordt ingezien, geformuleerd en geëffectueerd. De daarmee verbonden waarde gezondheid staat echter in de context van andere als belangrijk geachte waarden (bijvoorbeeld vrede en veiligheid). De morele kritiek nu richt zich op de mate waarin deze verhouding als concurrerend wordt gezien en niet als complementair. Omdat professionalisering en machtsuitoefening steeds zijn verbonden met specifieke institutionaliserings- en legitimeringsprocessen van een specifieke beroepsgroep zal genoemde verhouding vooral concurrerend zijn. Deze verhouding is een impliciet gevolg van professionalisering en leidt tot eenzijdige nadruk op bepaalde waarden, zelfs als men niet de bedoeling heeft de relatieve positie van deze waarden tussen andere maatschappelijke waarden te wijzigen. Dit laatste komt bijvoorbeeld naar voren in een overwegend instrumentalistische en functionele opvatting van de eigen taak: het doel (moreel of niet) is voorgegeven en om de relatie met andere gewichtige doeleinden bestaat geen bekommernis, tenzij als randfenomeen (bijvoorbeeld medische polemologie).

Een dergelijke instrumentalistische zienswijze kan overigens wel contraproductief werken: boven een bepaald niveau van realisatie en aspiratie kan men zijn doel voorbijschieten. In de ethiek staat dit bekend als de 'hedonistische paradox' (zie Vos 1989, 86-87). In de overbenadrukking van activiteiten gericht op bijvoorbeeld gezondheid schuilt een overwaardering van wat we niet zijn en niet bezitten en een onderwaardering van wat we wél zijn en bezitten. Daarbij kan uit het oog worden verloren dat gezondheid voor een belangrijk deel een bijproduct is van iets anders (bijvoorbeeld 
vrede, veiligheid, voedsel en sociale zekerheid). Zich professionaliserende beroepsgroepen kunnen gemakkelijk in een dergelijke hedonistische paradox verzeild raken en zich daarmee moreel diskwalificeren, omdat bij de concentratie op de gebruikswaarde van het beroep onvoldoende rekenschap is gegeven van haar inbedding in het geheel van intrinsieke en morele waarden in de samenleving (zie ook Larson 1979, XIII; Purtilo/Cassel 1981, 152; Toren 1969, 148). Ook de dreiging van deze paradox pleit derhalve tegen een amoraliseringsstrategie met betrekking tot (de rechtvaardiging wan) professionalisering.

3. Een volgend bezwaar daartegen gaat uit van het feit (dat ook in de machtsbenadering wordt erkend) dat aan de basis van elke machtsuitoefening in verband met professionalisering steeds de activiteiten van individuele leden van een beroepsgroep staan. Hun moreel-expressieve waardenoriëntatie van dienstbaarheid, zoals meermalen naar voren gebracht, verdraagt zich slecht met een instrumentalistische, functionele en prudentiele opvatting van de taak van het beroep in de samenleving, zoals naar voren komend in de machtsbenadering (vergelijk 2.7 en 3.4.2). Feitelijk vindt er zelfs een verschuiving plaats ten gunste van instrumentalistische opvattingen (Stevens 1987, 161). Hier vertoont zich een zekere spanning in de relatie tussen professionalisering als collectief project en beroepsuitoefening als individuele bejegening. In de paragrafen 5.3 hebben we laten zien dat deze spanning met betrekking tot verpleegkundigen tot veel problemen aanleiding kan geven. Ook het gebruik van macht als zodanig lost hier niets op (vergelijk ook Toren 1969, 166). Verpleegkundigen zien zich gesteld voor onverenigbare grootheden, die wellicht een belangrijke bijdrage leveren aan het verschijnsel van 'burn-out'. Toegelicht aan de functie(s) van beroepscodes: vanuit de professionaliseringsidee bereikt hen een dubbele boodschap. Ideologisch wordt dienstbaarheid ten tonele gevoerd ter verkrijging van de medewerking van patiënten/cliënten met het oog op prudentiële onzekerheidsbeheersing (vergelijk ook Van der Krogt 1981, 44). Moreel wordt dienstbaarheid opgevat als solidariteit met patiënten/cliënten met het oog op morele onzekerheidsbeheersing. Tussen beide boodschappen bestaat een zekere discrepantie. De ideologische interpretatie en functie van dienstbaarheid verdraagt zich slechts zeer ten dele met de morele interpretatie en functie ervati, omdat prudentiële motieven mu eenmaal moeilijk te verenigen zijn met morele motieven. In de onderzochte beroepscodes zijn deze ook nauwelijks of onvoldoende onderschieden. Dit creëert onduidelijkheid en verwarring onder beroepsbeoefenaren, die immers (aanvankelijk) vooral moreel zijn gemotiveerd. Bezien vanuit het oogpunt van professionalisering worden de codes dan ook gekenmerkt door een gebrek aan realisme. Vanuit dit perspectief openbaart zich in de proclamatie van dergelijke beroepscodes dus zoiets als een professionaliseringsparadox.

Wanneer we het bovenstaande samenvatten komen we tot de volgende morele kritiek ten aanzien van professionalisering, zoals geïmpliceerd in de machtsbenadering:

1. Bij dle beoordeling van macht als amoreel wordt onvoldoende zijn noodzakelijke verbondenheid tot uitdrukking gebracht met de (sociaal-)morele functie van de uitoefening van een beroep in de samenleving (legitimeringsprobleem).

2. Machtsuitoefening en professionalisering zijn gebaseerd op een overwegend prudentieel en overtrokken oordeel over het belang van de waarde die het beroep vertegenwoordigt (hedonistische paradox). 
3. Macht en professionalisering berusten op een instrumentalistische opvatting van de werkelijkheid waarin het morele karakter van de beroepsuitoefening en van beroepsbeoefenaren onvoldoende aan bod komt (professionaliseringsparadox).

Tenslotte: deze kritiek richt zich dus niet op professionalisering als organisatieprincipe of -model van beroepsmatig verrichte arbeid, maar in hoofdzaak op wat Davis en Elliston $(1986,109)$ ook wel noemen: de zweem van morele neutraliteit die ervan uitgaat. Onze analyse en kritiek laten onverlet dat professionalisering een belangrijke factor kan zijn voor de oplossing van complexe maatschappelijke vraagstukken. Men is zich echter onvoldoende bewust van de (ethisch-)normatieve aspecten daarvan. In dat kader dient men zich te onthouden van een amoraliseringsstrategie, zoals boven geschetst. De ontwikkeling van specifieke kennis en kunde heeft altijd invloed op de maatschappelijke waarden en normen waarin deze kennis en kunde worden toegepast. Kiest men vanuit dat perspectief daarentegen voor een anti-amoraliseringsstrategie, bijvoorbeeld door de introductie van beroepscodes, dan dient de prudentieel-ideologische functie daarvan duidelijk te worden onderscheiden van hun morele functie. Daarnaast zal men erop bedacht moeten zijn dat deze anti-amoraliseringsstrategie zich slecht verdraagt met het type rationaliseringsprocessen dat zich momenteel onder andere in de gezondheidszorg voordoet. 



\subsection{Vraagstelling}

Deze studie beschrijft enkele facetten van de ontwikkeling van het beroep van verpleegkundige. Deze betreffen met name het proces van professionalisering en in verband daarmee gepubliceerde beroepscodes. Daartoe wordt gebruik gemaakt van in de sociologie ontwikkelde modellen. De nadruk ligt echter op een ethische reflectie. Als doelstelling voor het onderzoek werd geformuleerd: het verwerven van een inzicht in de relatie tussen ethische en sociale aspecten van de professionalisering van het beroep van verpleegkundige. Daarbij werd aangenomen dat een ethische analyse van beroepscodes voor verpleegkundigen een geschikt instrument is tot het bereiken van dit inzicht. Dit leidde tot de volgende vraagstelling: welke morele posities zijn te onderscheiden in door beroepsgroep(en) en beroepsorganisaties op het terrein van de verpleegkunde in de westerse samenleving gepubliceerde beroepscodes; hoe verhouden deze morele posities zich tot het professionaliseringsproces van de beroepsgroep in het bijzonder en tot maatschappelijke processen in het algemeen; en hoe dienen deze vanuit een normatief-ethisch perspectief te worden gewaardeerd? 'Beroepscode' wordt hier omschreven als: een samenhangend geheel van (morele) principes en regels met betrekking tot de doeleinden en waarden van een beroep en de houding en het gedrag hiervoor vereist; de beroepscode dient ter ondersteuning van de positie en het handelen van beroepsbeoefenaren. Het onderzoek sluit aan bij actuele discussies onder verpleegkundigen en onder ethici (hoofdstuk 1).

\subsection{Professionalisering}

Vanuit de sociologie (meer in het bijzonder de beroepensociologie) zijn modellen en theorieën van professionalisering ontwikkeld waarmee de rol, positie en status van een beroep en zijn beoefenaars worden beschreven. Deze modellen en theorieën worden in hoofdstuk 2 kort beschreven, waarna één ervan nader wordt uitgewerkt ter evaluatie van de rol, positie en status van het beroep van verpleegkundige. 'Beroep' wordt hier opgevat als: een bepaald deel van de maatschappelijke arbeidsverdeling dat een aantal mensen tegenover anderen beschouwt als het domein dat bij uitstek van hen is en waarop zij een claim leggen (par. 2.2.1).

Het moderne beroep heeft zich na de industriële revolutie sterk kunnen ontwikkelen als gevolg van een nauwe aansluiting bij gevestigde belangen en behoeften, processen van collectivisering en bureaucratisering binnen beroepsgroepen en door een sterke differentiatie en specialisatie van arbeidstaken. Centrale processen in dit geheel zijn institutionalisering en legitimering, hetgeen wil zeggen: het doen ontstaan van een sociaal kader voor een min of meer vast patroon van bepaalde activiteiten respectievelijk het doen aanvaarden van de eigen verklaring en zingeving van de werkelijkheid door relevante ande- 
ren (par. 2.2.2-2.3.3). Beroepsgroepen die hier het best in slaagden worden professies genoemd.

Ten aanzien van het onderzoek hiernaar worden in deze studie drie benaderingen beschreven: de kenmerkenbenadering, de functionalistische benadering en de procesbenadering. De laatste is een verzamelnaam voor een groot aantal modellen en theorieën die deels als reactie en kritiek op de eerste twee benaderingen zijn ontstaan. Uit deze verzameling wordt de zogenaamde 'machtsbenadering' van Van der Krogt (1981) nader uitgewerkt (par. 2.3.7). Deze auteur beschrijft bowendien uitwoerig een groot aantal andere benaderingen die onder de noemer procesbenadering schuilgaan. 'Professionalisering' ziet hij als een proces waarbij leden van een beroepsgroep op collectieve wijze, vooral gebruik makend van kennismacht, trachten een collectieve machtspositie te verwerven en/of te verdedigen met het doell de gebruiks- en ruilwaarde van het beroep te beheersen. Aan de basis hiervan staat echter het individuele gedrag van beroepsbeoefenaars. Bij deze worden een expressieve en een instrumentele beroepsoriëntatie onderscheiden. Onder de eerste vormt dienstbaarheid één van de kernmotieven. Ontwikkeling van kennis en kunde is de primaite bron op grond waarvan het beroep kan worden geinstitutionaliseerd en gelegitimeerd en waarlangs een machtspositie kan worden opgebouwd. Daarnaast wordt gebruik gemaakt van normatieve macht, hetgeen wil zeggen: beinvloeding van het gepercipieerde belang van de doeleinden die worden gediend: Hiermee hangt samen het gebruik van beroepscodes.

In een evaluatie van de stand van zaken in de beroepensociologie worden de conclusies overgenomen en toegelicht van Dingwall (1983) dat: beroepen in een breder (onder andere historisch) perspectief moeten worden bestudeerd; de factor kennis nog onvoldoende is uitgewerkt; en vergelijkend empirisch onderzoek in een grote behoefte voorziet (par. 2.3.8). Ten aanzien van de eerste twee conclusies is in deze studie de relatie tussen professionalisering en bureaucratisering beschreven. Dit blijken twee elkaar versterkende processen te zijn. Een geslaagd professionaliseringsproces geeft een hoge mate van kennisontwikkeling te zien die gepaard gaat met een hoge mate van gebureaucratiseerde kennistoepassing (par. 2.3.9).

\subsection{Het beroep van verpleegkundige}

Het beroep van verpleegkundige behoort tot de zogenaamde semi-professies. Het is onderdeel van een gezondheidszorgsysteem waarin de geneeskunde dominant aanwezig is. Kennis en kunde omtrent de verpleging hebben zich onvoldoende ontwikkeld om hier een tegenwicht tegen te bieden. Het beroepsvormingsproces is derhalve nog volop gaande. Dit wordt toegelicht aan de hand van een beschrijving van de verhouding tussen verpleegkunde en geneeskunde, de verpleegkunde als typisch vrouwenberoep, de rol en positie van de verpleegkundige binnen organisaties, de rol van beroepsorganisaties van verpleegkundigen en de socialisatie van verpleegkundigen in het beroep (par. 2.4.22.4.6).

Met behulp van andere interpretatoren van het model van Van der Krogt wordt het beroep vervolgens bekeken in het licht van de machtsbenadering (par. 2.4.7). Geconstateerd wordt, dat de institutionalisering en legitimering van het beroep weinig problemen kende zolang het onder de vleugels van de geneeskunde verkeerde. Echter, het huidige 
tijdsgewricht wordt gekenmerkt door verdere verzelfstandiging van beroepsgroepen in de gezondheidszorg, mede onder invloed van een heroriëntatie op de rol van de geneeskunde. Op grond hiervan dienen verpleegkundigen nieuwe legitimeringsargumenten te vinden voor de opbouw van een autonomer positie, met andere woorden: een collectieve machtspositie. Dit proces wordt echter door diverse factoren belemmerd: verpleegkundigen zijn vooral werkzaam in de onderste regionen van de lijnstructuur van bureaucratisch opererende organisaties; hun werkzaamheden worden in belangrijke mate gedefinieerd en bepaald door derden; het beroep is sterk gesegmenteerd; functie-eisen overheersen de beroepseisen; de ontwikkeling van wetenschappelijke kennis en kunde staat nog in de kinderschoenen; de organisatiegraad is laag, waardoor onvoldoende gebruik wordt gemaakt van de aantalsmacht. Aldus dreigt het gevaar van de-professionalisering. Aanbevolen wordt dit proces te keren door (hernieuwde) aansluiting bij en sponsoring door arbeidsorganisaties en/of artsenorganisaties.

\subsection{Sociologie en ethiek}

Hoofdstuk 3 begint met een vergelijkende beschrijving van de systematiek en methodologie in sociologie en ethiek ten aanzien van het onderzoek naar de normatieve aspecten van verschijnselen in de werkelijkheid. Hun normatieve lading reikt verder dan het gebied der voorschriften en beoordelingscriteria ten aanzien van het handelen. Zij is tevens geïmpliceerd in de keuze voor specifieke (wetenschappelijke) modellen, theorieën en begrippen.

Het sociologische perspectief op de normatieve dimensie krijgt onder andere vorm in het waardenonderzoek en wordt hier gebaseerd op het werk van Barnsley (1972) en van Philipsen (1988). Bij Barnsley fungeert het begrip 'moral code' als de centrale analytische term ter beschrijving van individuele en groepsgebonden opvattingen en gedragsmaatstaven van goed en kwaad, wenselijkheden en onwenselijkheden. De morele voorschriften en waarden die hiermee samenhangen, worden formeel gedefinieerd in termen van de superioriteit en legitimiteit die ervoor worden geclaimd. In de discussies daarover wordt onderscheiden tussen extrinsieke en intrinsieke argumentaties, hetgeen overeenstemt met het wijsgerig-ethische onderscheid tussen teleologische respectievelijk deontologische theorieèn.

Bij Philipsen wordt het normatieve opgevat als een aspect van de cultuur en samengevat met de term 'waardenoriëntatie', nader aangeduid als opvattingen inzake waarden en normen. In de uitwerking van deze begrippen openbaart zich een tegenstelling met Barnsley op het terrein van waarden als primair object van onderzoek. Ten aanzien van de functie van waarden en normen in de gezondheidszorg maakt hij een onderscheid tussen denoterende en connoterende denk- en gedragswijzen. De eerste is dominant en wordt gekenmerkt door instrumentele rationaliteit. Connoterend denken is verbonden met substantiële rationaliteit en omvat het omgaan met zinvragen (par. 3.2.1).

In de ethiek wordt van gegevens uit bovengenoemd onderzoek gebruik gemaakt om ethische verschijnselen te beschrijven in de zogenaamde descriptieve ethiek. Zij poogt daaraan in de normatieve ethiek echter tevens een reflectie te verbinden met betrekking tot de wenselijkheid van die verschijnselen in termen van morele goed- en afkeuring. Ten aanzien van het karakter van de criteria daarvoor kunnen teleologische en deontologi- 
sche theorieën worden onderscheiden. In onze studie wordt daarin een parallellie gevonden met waardetheorieến respectievelijk plichttheorieën in de sociale filosofie. Hetzelfde geldt voor het soort theorieën dat gebruikt wordt voor de bepaling van de aard van het morele en de rechtvaardiging van waarde-oordelen. In zowel de (meta-)ethiek als de sociale filosofie worden in verband daarmee zowel naturalistische (cognitivistische) als intuitionistische en noncognitivistische standpunten verdedigd. Beslissingen ten aanzien van het morele karakter van waarde-oordelen komen echter hoofdzakelijk tot stand op basis van toepassing van de criteria van het zogenaamde 'ethisch gezichtspunt' (par. 3.2.2).

Verschillen tussen sociologie en ethiek bewegen zich voornamelijk op het terrein van de methodologie en de omschrijving en plaats van het normatieve. In de confrontatie van beide perspectieven werd vervolgens het begrippenkader voor het vervolg van onze studie vastgesteld. Waarden spelen daarin een centrale rol (par. 3.2.3).

\subsection{Normatieve aspecten van professionalisering}

Met behulp van het ontwikkelde begrippenkader wordt de normatieve dimensie onderzocht van de eerder beschreven professionaliseringstheorieën. Deze blijkt vooral beïnvloed door de aard van de gekozen concepten, de context waarin zij functioneren en de effecten ervan in termen van geboden strategieën (par. 3.3).

Wanneer deze theorieën zelf worden onderzocht naar de wijze waarop de normatieve dimensie wordt benoemd, dan blijken 'beroepscodes' een centrale categorie die in praktisch alle studies wordt genoemd. Derhalve werden beroepscodes als geschikt instrument beschouwd voor onze verdere analyse. In de professionaliseringstheorieën en de beschrijvingen van concrete professionaliseringsprocessen worden beroepscodes algemeen geduid als de samenvatting van de waarden en normen via welke beroepsgroepen zich wensen te presenteren aan de 'buitenwereld' en waaraan men het gedrag van de eigen leden wil binden. Beroepscodes worden onder andere geïdentificeerd als een verwoording van het dienstbaarheidsideaal van een beroep of professie (par. 3.4.1).

Op grond hiervan werd een vraagstelling ontwikkeld voor verder onderzoek, waarin beroepscodes als object worden gekozen om de normatieve aspecten van het professionaliseringsproces van verpleegkundigen aan te illustreren (par. 3.4.3). Daarbij werd het focus geconcentreerd op een viertal gepubliceerde beroepscodes voor verpleegkundigen en een ethische analyse daarvan.

\subsection{Beroepscodes voor verpleegkundigen}

Uit een etymologische beschouwing van de term 'code' komt naar voren dat deze meer dan én betekenis heeft (gehad). De stam is overigens van het Latijnse 'codex' (oorspronkelijke betekenis: blok, boek, lijst). Wij gebruiken de term in de betekenis van een verzameling voorschriften en richtlijnen, meer in het bijzonder een systematisch geheel van op schrift gestelde waarden, regels en voorschriften van morele aard (par. 4.2.1).

Beroepscodes blijken een reeds lang bestaand verschijnsel. De Codex Hammoerabi (circa 1700 vóór Christus) wordt algemeen als de vroegste beschouwd. Binnen de genees- 
kunde kennen we verder onder meer de Eed van Hippokrates, de Eed van Maimonides, Percivals "Code of Ethics" en de "Declaration of Geneva". Ten onzent kunnen daaraan worden toegevoegd de "Artseneed" en diverse, door de KNMG opgestelde richtlijnen en regels (par. 4.2.2).

De beroepscodes voor verpleegkundigen vertonen enige overeenkomsten met die voor geneeskundigen. De eerste dateert van ongeveer 1875 en is bekend uit een geschrift van Florence Nightingale. Vandaar de naam "Florence Nightingale Pledge".

Voor onze analyse van beroepscodes voor verpleegkundigen maakten we gebruik van de codes van de International Council of Nurses, de American Nurses" Association, de United Kingdom Central Council of Nurses, Midwives and Health Visitors en de Nederlandse Maatschappij voor Verpleegkunde (nu Nieuwe Unie '91 geheten). Hiervan werden de teksten weergegeven en de ontstaansgeschiedenis en globale inhoud beschreven (par. 4.3.2-4.3.5).

Toepassing van de criteria van het 'ethisch gezichtspunt' toont aan dat de genoemde beroepscodes ontegenzeglijk een moreel karakter bezitten. Op grond hiervan wordt een opvatting als zouden beroepscodes louter uit etiquetteregels bestaan, afgewezen: Morele regels doorbreken de vanzelfsprekendheden van een op conventies gebaseerde moraal waaruit etiquetteregels bestaan (par. 4.4.2).

In de beroepscodes kunnen twee soorten plichten worden onderscheiden: plichten die een moreel recht van anderen (in het bijzonder patiënten en cliënten) impliceren en plichten die een moreel recht van de verpleegkundige of diens beroepsgroep garanderen. Dit doet vermoeden dat beroepscodes naast een morele functie jegens derden tevens een ideologische functie in verband met een prudentieel belang van de eigen groep bezitten. Om dit te toetsen werden twee hypotheses opgesteld om het morele respectievelijk ideologische karakter te onderzoeken van de in de professionaliseringsliteratuur als centraal aangemerkte waarde 'dienstbaarheid'.

Daartoe werden eerst de in de beroepscodes voorkomende waarden, normen en verplichtingen thematisch geïdentificeerd en gerangschikt volgens een analyse-schema en interpretatiemodel van Kultgen (1988a). Dit op grond van de letterlijke code-teksten, exclusief toelichtingen. Op grond van de omschrijvingen van de fundamentele verantwoordelijkheden van verpleegkundigen wordt dienstbaarheid inderdaad als de centrale morele waarde aangemerkt. De ICN-en ANA-code zijn hierin het meest expliciet. Andere waarden zijn minder geschikt als centrale waarde ófwel omdat zij een puur instrumenteel karakter hebben ofwel omdat zij van een te algemene strekking zijn in relatie tot de rol en functie van de verpleegkundige. Om deze redenen ook kunnen de waarden in codes hiërarchisch worden geordend. Nadere beschouwing van de desbetreffende statements in de codes bracht tevens aan het licht dat uitspraken over het teleologische dan wel deontologische karakter van de codes berusten op interpretatie van die statements (par. 4.4.3). De ideologische functie van de beroepscodes gaat schuil achter de morele retoriek ervan en kan volgens. Kultgen (1988a) worden achterhaald met behulp van onderzoek naar hun semantische kenmerken, logische structuur en context van vooronderstellingen. Onze eigen analyse in dat verband laat zien, dat er in de codes vele uitgangspunten en doeleinden verhuld aanwezig kunnen zijn die bijdragen aan de instandhouding van een zevental mythes: de mythes van onafhankelijkheid, altruisme, zelfregulering, deskundigheid, eenheid, 'alles tegelijk' en morele omnivalentie. Al deze mythes kunnen worden ontmaskerd 
als bijdragend aan een ideologisch gebruik van beroepscodes in het kader van de eigen prudentiële belangen en doelstellingen van de beroepsgroep (par. 4.4.4).

\subsection{Ethisch kader en status van beroepsethische noties}

De morele functie van beroepscodes en hun normen kunnen niet los worden gezien van het soort rechtvaardiging en het type argumenten die kunnen worden aangevoerd voor hun bestaan. Hiertoe werd in hoofdstuk 5 een meta-ethisch en normatief-ethisch kader ontwikkeld op basis van een beschrijving van een actuele morele praktijk van verpleegkundigen met betrekking tot de dienstbaarheidsverplichting. Uit een analyse van keuzealternatieven blijkt dan, dat het voor verpleegkundigen niet alleen van belang is om in formele zin te weten dat iets goed is om te doen, maar dat minstens ook inzicht wordt geboden in hetgeen met het goede materieel wordt bedoeld. Ten aanzien van dit laatste worden we dan vervolgens geconfronteerd met diverse (uiteenlopende) interpretaties en handelingsindicaties, die bovendien te maken hebben met de eigenschappen van verpleegkundigen en de context waarin zij hun werk verrichten. Daarnaast blijkt, dat de hieruit voortvloeiende morele verplichtingen steeds in termen van specifieke waardebegrippen worden gesteld.

Een theorie die hierop aansluit menen wij te hebben gevonden in de zogenaamde loyaliteitstheorie van Vos (1989). Deze ziet waardebegrippen als de operationele categorieën bij uitstek van alle moraal en ethiek. Ze bevatten twee componenten: een aantonende, denoterende component, die wij met Vos als phrastisch betitelen; en een toestemmende, connoterende component; die neustisch wordt genoemd. Door middel van deze twee componenten wordt in de loyaliteitstheorie de dichotomie tussen feiten en gevoelens opnieuw beschreven en gedeeltelijk geslecht: in morele praktijken zijn ze steeds op elkaar betrokken en, afhankelijk van betekenissen van waarden, in een nieuw en veranderlijk evenwicht gebracht. Dit evenwicht wordt verstoord bij verschijnselen als moralisme, ideologie en morele tirannie. Deze leiden tot een statische, zogenaamd massieve axiologie. Bovendien impliceert de theorie een kritiek op eenzijdige naturalistische en noncognitivistische standpunten in de meta-ethiek. Ook aan kentheoretische en logische criteria en aan universaliteit en rationaliteit kan niet langer een exclusieve en centrale rol worden toegekend bij de rechtvaardiging van moreel gedrag. Hieruit voortvloeiende algemene verplichtingsnoties bezitten een te nadrukkelijk neustisch karakter, dat dient te worden gecompenseerd en aangevuld door een groter accent op phrastische betekenissen van waarden en de deliberatie daarover. Waardebegrippen zijn aangeleerde en overgenomen conventies, waaraan we trouw blijven totdat de nutteloosheid of contraproductiviteit ervan is gebleken. Deze trouw laat zich vertalen in loyaliteiten. 'Loyaliteit' is dan ook de centrale morele waarde waardoor we ons in het morele leven laten leiden (par. 5.2.1).

\subsection{Superioriteit en legitimiteit van beroepsgebonden waarden}

Beroepscodes maken deel uit van de beroepsethiek van beroepsgroepen. De rechtvaardiging van dienstbaarheid als centrale morele waarde is dan ook onderdeel van de vraag naar de rechtvaardiging van beroepsethische waarden in het kader van noties van alge- 
meen-ethische aard. Aan deze rechtvaardiging werd door ons een beschouwing gewijd in termen van de superioriteit en legitimiteit van beroepsgebonden waarden, hetgeen wil zeggen: hun autonomie en prioriteit enerzijds en hun realiteit-gebondenheid, intersubjectiviteit en rechtvaardigbaarheid anderzijds (vergelijk 6.4).

Op geleide van de opvattingen van Bayles (1981) en Goldman (1980) dienen beroepsgebonden morele waarden uiteindelijk te berusten op de maatschappelijke aanvaarding van de rollen en functies die met de uitoefening van een beroep worden beoogd en op de mate waarin hiertoe nadere specificatie van algemene waarden en normen noodzakelijk wordt geacht. Derhalve moet een superioriteit van beroepsgebonden waarden (in casu dienstbaarheid) worden uitgesloten. $\mathrm{Zij}$ is alleen mogelijk in geval beroepsarbeid wordt opgevat als een gesloten systeem, hetgeen illusoir is (par. 5.2.2).

De legitimiteit van dienstbaarheid kan op-basis van een phrastisch-neustische interpretatie weliswaar intern worden erkend, maar extern dient zij in de context te worden geplaatst van de centrale waarde 'loyaliteit'. Deze waarde vertoont een opvallende parallellie met de centrale morele waarde 'solidariteit' die kan worden gedestilleerd uit een taxonomie van Philipsen (1988) met betrekking tot fundamentele waarden in de huidige westerse samenleving (par. 5.2.3). Vanuit deze taxonomie kan een rechtstreeks verband worden gelegd tussen 'dienstbaarheid' als beroepsgebonden morele waarde en 'solidariteit', als centrale maatschappelijke waarde, waarbij de eerste functioneel verbonden is met of een specificatie vormt van de laatste. 'Dienstbaarheid' (en daarmee een beroepscode die deze als centrale morele waarde impliceert) wordt dus extern gelegitimeerd door 'solidariteit' en/of "loyaliteit" (par. 5.2.4).

\subsection{Toepassingsproblemen van codes}

Realiteit-gebondenheid is in phrastisch-neustisch opzicht een belangrijk criterium bij het vaststellen van de legitimiteit van 'dienstbaarheid' en haar verwoording in beroepscodes. Dit criterium staat in functie van de mogelijkheden tot toepassing van beroepscodes in de concrete beroepspraktijk en via deze tot de morele positie van verpleegkundigen. Met deze morele positie bedoelen we: de plaats die verpleegkundigen innemen in hun netwerken van relaties met anderen met het oog op de realisering van morele verplichtingen vanwege de beroepscode.

Deze positie werd op basis van literatuur-en onderzoeksgegevens beschreven alls in hoge mate heteronoom en ambigue en is een bevestiging van onze conclusies in 6.3 (par. 5.3.1). Vanuit het perspectief van de beroepscodes voor verpleegkundigen en hun functies worden vervolgens vier probleemvelden geïdentificeerd en beschreven die genoemde toepassing belemmeren, namelijk die van rationalisering, uniformering, individualisering en sanctionering. Hieruit komt naar voren dat het morele karakter van een beroepscode waarschijnlijk onvoldoende als zodanig wordt herkend; dat verpleegkundigen in een positie verkeren, waarin onvoldoende waarborgen aanwezig zijn om een beroepscode toe te passen; en dat de context van cultuur, samenleving en gezondheidszorg zodanig verstorend werkt, dat implementatie van waarden en normen uit beroepscodes voortdurend wordt gefrustreerd en zelfs een averechts effect kan sorteren (par. 5.3.25.3.5). 


\subsection{Morele status van de codes}

Bovenstaande conclusies uit 6.8 en 6.9 bevatten een indicatie voor de morele status van beroepscodes voor verpleegkunidigen. Morele status verwijst hier naar eigenschappen die moreel relevant zijn en tot bepaalde handelingsindicaties aanleiding geven. Phrastischneustisch gezien betreft deze niet alleen het soort rechtvaardiging en type argumenten die kunnen worden aangevoerd voor het bestaan van beroepscodes in casu dienstbaarheid, maar tevens de mogelijkheden tot betekenisverlening ervan in de concrete morele praktijk van verpleegkundigen. Dit laatste is een nadere specificatie van het criterium van realiteit-gebondenheid bij het legitimiteitsvraagstuk.

Vanuit het gestelde ten aanzien van het rechtvaardigbaarheidscriterium werd naar voren gebracht dat aan beroepsgebonden waarden en normen in casu dienstbaarheid weliswaar geen superioriteit kan worden toegekend, maar dat er zeker sprake is van een forse interne legitimiteit alsmede van een externe legitimiteit in het perspectief van centrale maatschappelijke waarden in casu solidariteit en loyaliteit. Dit doet een hoge morele status van beroepscodes vermoeden (par. 5.2.4).

Dit vermoeden werd echter ontkracht door toepassing van het criterium van realiteit-gebondenheid. Hieruit komt naar voren dat er in de concrete beroepspraktijk van verpleegkundigen onvoldoende ruimte is voor de verwezeniijking van in de beroepscodes geimpliceerde waarden in casu dienstbaarheid volgens hun primaire morele betekenis. Loyaliteitstheoretisch gezien is er sprake van phrastisch-neustische betekenisverleningen die tenminste het morele karakter van beroepscodes ondermijnen, maar bovendien een verarming inhouden van hun oorspronkelijke conceptualisaties als sturingsmechanisme voor het morele gedrag van beroepsbeoefenaren. Om deze reden achten wij de morele status van beroepscodes gering (par. 5.3.6).

\subsection{Morele aspecten van professionalisering}

Vanuit het bovenstaande bleken enige kanttekeningen te kunnen worden geplaatst bij professionaliseringsprocessen. Deze werden toegespitst op opvattingen in het licht van de machtsbenadering (vergelijk 6.2). De omschrijving van de daarin gehanteerde concepten en begrippen kan aanleiding zijn tot een amoraliseringsstrategie met betrekking tot de processen van professionalisering en machtsuitoefening. $\mathrm{Zij}$ volgt tevens uit het prudentiële belang dat aan professionaliseringsprocessen veelal is verbonden en waaruit bijvoorbeeld ook de ideologische functie van beroepscodes kan worden verklaard. Een amoraliseringsstrategie kan dit belang en deze functie maskeren, bijvoorbeeld door extra benadrukking van de ontwikkeling van kennis en kunde als zijnde puur instrumentele waarden die de maatschappelijke doelstellingen van beroepsuitoefening ongemoeid laten.

Niettemin kiezen momenteel veel beroepsgroepen in de gezondheidszorg voor een antiamoraliseringsstrategie door middel van het uitgeven van beroepscodes en benadrukking van het morele karakter ervan. Deze paradox lijkt in de professionaliseringstheorieën, 
waaronder de machtsbenadering, niet te worden onderkend of tenminste in het voordeel van de amoraliseringsstrategie te worden beslecht.

Deze wordt door ons echter onhoudbaar geacht. Dit werd toegelicht aan de hand van een beschrijving van: de morele relevantie van professionalisering in casu machtsuitoefening; de verbondenheid van deze laatste met intrinsieke waardenorientaties in de samenleving; en een onvoldoende rekening houden met moreel-expressieve waardenoriëntaties van beroepsbeoefenarem. In het verlengde hiervan lieten zich vanuit moreel perspectief drie problemen identificeren: een legitimeringsprobleem, een hedonistische paradox en een professionalliseringsparadox.

Professionalisering helpt weliswaar complexe maatschappelijke vraagstukken op te lossen, maar voltrekt zich meestal zonder voldoende bezinning op de morele aspecten van de beroepsuitoefening. Dit blijkt onder meer uit de onvoldoende doordachte formulering en het gebrek aan implementatie van beroepscodes (par. 5.4).

\subsection{Perspectief en aanbevelingen}

Bovenstaande beschrijvingen, analyses en conclusies bieden een bepaald perspectief op de centrale vraagstelling en subvragen die aan het slot van hoofdstuk 3 werden geformuleerd. Aan de basis hiervan staat een analyse van 4 beroepscodes voor verpleegkundigen. Deze beroepscodes werden geduid als moreel verschijnsel en vanuit een normatief-ethisch kader van commentaar voorzien. De benaderingen van Barnsley (1972) en Philipsen (1988), de analyse-schema's van Kultgen (1988) en de loyaliteitstheorie van Vos (1989) bleken hiertoe geschikte instrumenten.

'Dienstbaarheid" bleek de centrale waarde vanwaaruit morele posities in de beroepscodes kunnen worden beschreven. Nagenoeg alle in de codes aangegeven (morele en nietmorele) verplichtingen zijn op deze waarde te betrekken. Nadere beschouwing van deze waarde en van beroepscodes in het algemeen leerde echter, dat daaraan naast een morele functie tevens een ideologische functie moet worden onderscheiden. Dit is zowel vanuit een ethische als een sociologische invalshoek beargumenteerd.

Beide invalshoeken zijn gehanteerd om de morele status van beroepscodes te beschrijven. Deze status wordt theoretisch bevestigd door de legitimatie van dienstbaarheid op grond van dominante sociaal-morele waarden die vanuit ethisch en sociologisch perspectief kunnen worden onderscheiden, respectievelijkk loyaliteit en solidariteit Hun morele status wordt echter ondermijnd door toepassingsproblemen die verpleegkundigen ontmoeten via de processen wan rationalisering, uniformering, individualisering en sanctionering. Deze, in oorsprong sociaal-maatschappelijke processen bezitten vanuit loyaliteitstheoretisch perspectief een zekere morele relevantie, in die zin dat zij tijdens de beroepsuitoefening het zicht op authentieke morele betekenisverleningen van dienstbaarheid, loyaliteit en solidariteit in sterke mate kumnen verduisteren dan wel ondergeschikt maken aan de functionele verbanden waarin zij tot uitdrukking komen. In samenhang hiermee is tevens gewezen op amoraliseringsstrategieèn die op grond van de nadruk op kennis en kunde achter professionaliseringsprocessen kunnen schuilgaan en in dat gevall beroepscodes tot een wezensvreemd element maken.

De relevantie van het hier gepresenteerde onderzoek betreft niet alleen de analyse en beschouwing van de morele en sociale functie van beroepscodes voor verpleegkundigen, 
mede als normatief aspect van professionaliseringsprocessen. Minstens even belangrijk is het perspectief dat wordt geboden op vraagstellingen voor verder onderzoek. Ook hier laten zich een sociologische en een ethische invalshoek onderscheiden, die evenwel op een aantal punten convergeren.

Nader onderzoek naar het concept dienstbaarheid kan nieuwe stimulansen geven aan het enigszins in de versukkeling geraakte waardenonderzoek in de (beroepen)sociologie en waardevolle bijdragen leveren aan beroepsethische beschouwingen in het kader van gezondheidsethiek en sociale ethiek. Onze kennismaking met professionaliseringstheorieën levert de conclusie en aanbeveling op dat intensiever studie dient te worden verricht naar de dienstbaarheidsorièntatie van professionals. Vanuit de sociologie is tot op heden vooral aandacht geschonken aan beroepsvormingsprocessen en aan het aspect kennis en kunde. In dat kader is dienstbaarheid weliswaar aangeduid als een belangrijk arbeidsmotief van professionals, maar te weinig duidelijk is hoe zich dit verhoudt tot feitelijke praktijken.

Dergelijke gegevens zijn ook van belang voor het ethisch onderzoek. Het waardenonderzoek is decennia lang op kentheoretische gronden veronachtzaamd. Ook ons eigen onderzoek heeft niet meer dan een globaal inzicht gegeven in het concept dienstbaarheid, omdat het focus daar niet direct op was gericht. Met de loyaliteitstheorie van Vos is echter een aanzet gegeven tot herformulering van de positie van waardebegrippen in kentheorie, (sociale) ethiek en morele praktijken en is het belang aangetoond van concepten als dienstbaarheid en solidariteit om praktijken als die van professionals in normatief-ethische zin te analyseren en te evalueren. Vanuit wijsgerig-ethisch perspectief verdienen dergelijke aanzetten en conceptualisaties nadere uitwerking.

Dit laatste is des te meer van belang nu sprake lijkt te zijn van een zogenaamde 'empirische wending' in de gezondheidsethiek, een tak van onderzoek die in het bijzonder is gericht op morele praktijken van professionals in de gezondheidszorg. Tot voor kort hield deze zich vrijwel uitsluitend bezig met toepassing van algemene principes op bijzondere gevallen. Haar werd verweten zich hiermee steeds verder van het concrete morele leven te verwijderen. Een van de eerste aanzetten in Nederland om dergelijke bezwaren te ondervangen werd verwoord door Ten Have (1990) in zijn pleidooi voor de introductie van hermeneutische methoden in de gezondheidsethiek. De nadruk moet niet liggen op toepassing van algemene beginselen op concrete gevallen, maar op het blootleggen van structuren en ervaringen waarin het morele zich in de gezondheidszorgpraktijk voordoet. Een parallel met de loyaliteitstheorie van Vos ligt hier voor de hand, waar deze veel nadruk legt op de phrasticiteit van waardebegrippen. Een onderzoek naar de wijsgerig-ethische implicaties en de mogelijkheid tot vervlechting van beide benaderingen in nieuwe conceptualisaties van (gezondheids)ethiek lijkt ons de belangrijkste aanbeveling die vanuit het onderhavige onderzoek ten aanzien van het vakgebied der ethiek kan worden gedaan. 


\section{SUMMARY}

In this study some aspects of the development of the nursing occupation are described as related to the process of professionalization and to the publication of professional codes. For that purpose the availability of sociological models and theories was of great help. However, emphasis has been laid on ethical reflection of the phenomena mentioned. The objective of this study was to get an insight into the relation between the ethical and social aspects of professionalization in nursing. During our research it became clear that the ethical analysis of professional codes for nurses is an appropriate instrument to develop such insight. Therefore, the central question to be answered in this study was formulated as follows: what moral positions can be distinguished in professional codes published by occupational groups and organizations in the field of mursing in western society; what relation exists between these moral positions and social processes in general and the process of professionalization in nursing in particular; and how can these moral positions be evaluated from a normative-ethical perspective? In this study, 'professional code' was defined as a coherent collection of (moral) principles and rules concerning the ends and values of an occupation and the attitudes and behaviour, as required for supporting the position and activities of professionals.

In the sociology of occupations several models and theories have been developed to describe the role, position and status of occupations and professionals. 'Occupation" was defined as a certain part of the social division of labour that certain people consider and claim as their special domain. After the industrial revolution modern occupations became characterized by collectivization and bureaucratization of occupational groups and by strong differentiation and specialization of labour tasks. To these developments, institutionalization and legitimation are central processes, $e_{\text {. }}$ the creation of a social framework for a certain pattern of activities respectively the gain of acceptance by relevant others of the groups interpretation of reality. Occupational groups with the greatest success in these processes are called professions.

Among sociological theories of professionalization three main streams can be discerned: the trait-approaches, the functionalistic approaches, and the process approaches. From the last group, we decided to elaborate the power approach of Van der Krogt (1981) to describe professionalization in nursing. In this approach, professionalization is seen as a process in which members of an occupational group collectively aim at obtaining and defending a power position to control the utility value and exchange value of the occupation. Towards this aim, especially knowledge power is applied. Nevertheless, the process is based on the individual behaviour of professionals which is characterized by an expressive and an instrumental orientation. Servitude is one of the key motives in an expressive vocational orientation (see also below). Beside knowledge power, to obtain its goal, an occupational group uses normative power by stearing the social ends in the 
direction of its own interests. Towards exercising normative power, professional codes are an important instrument.

Nursing belongs to the so-called semi-professions. In its role, position and status, it is dominated by the medical profession. Specific knowledge is being developed but cannot yet neutralize medical dominance. Therefore, nurses are still engaged in a process of occupation building and professionalization. This has been illustrated here in more detail by descriptions of the relationship between nursing and medicine, of nursing as a typically feminine occupation, of the role and position of nurses within organizations, of the role of professional organizations for nurses, and of the socialization of nurses into their occupation. From the perspective of power, professionalization in nursing is obstructed by several factors. Most nurses are doing their work in the lowest echelons of the bureaucraticaly operating health organizations. Their activities are strongly defined by others and their occupational area is strongly segmented. Moreover, functional demands dominate occupational demands, and scientific knowledge and skills have not yet matured. Finally, their numerousness is poorly used as a source of power. For all this reasons professionalization is weak and there is even a danger of deprofessionalization.

In order to gain more insight into the sociological perspective on the normative dimension of professionalization, we referred to the value oriented studies of Barnsley (1972) and Philipsen (1988). To Barnsley, moral code is the central analytical concept to describe individual and collective ideas of right and wrong and related standards of behaviour. He analyzes the related moral prescriptions and values in terms of claims to their superiority and legitimacy. These claims are discussed in extrinsic and intrinsic argumentations, conform the usual distinction between teleological and deontological ethics:

To Philipsen the normative dimension is an aspect of culture and is summarized by the term value orientation, i.e. conceptions about values and norms. The function of values and norms in health care can be denotative and/or connotative. The former is the dominant way of reasoning, especially in modern medicine, and is characterized by instrumental rationality. But values and norms are also connected with substantial rationality and are also associated with questions of affection and meaning.

These sociological perspectives have been confronted with an ethical perspective on the normative dimension of reality in order to formulate the conceptual framework for the analysis and moral evaluation of professional codes. Both perspectives mainly differ in methodology and in the description and place of the normative. The sociological perspective is included in descriptive ethics. Normative ethics exceeds both in a reflection on the desirability of phenomena in terms of moral approval and disapproval, using teleological and deontological criteria. The nature of the moral dimension and the justification of value judgements are decided in meta-ethics in which naturalistic, intuitionistic and noncognitivistic theories can be distinguished. Decisions in this field, however, are most often based on the criteria of the so-called moral point of view.

The normative dimension of theories on professionalization consists in the nature of their concepts, the context of their functioning, and their effects in terms of strategies. The normative dimension of theories on professionalization is articulated by professional codes. These, therefore, seem an appropriate instrument for our further analysis. They 
are seen as the summary of values and norms with which occupational groups present themselves to the outside world and regulate the behaviour of their members. Among other qualifications, codes are identified as a written formulation of the occupational or professional ideal of servitude.

Our further analysis has been focused on four professional codes for nurses and on an ethical evaluation of these.

The analysis starts with an etymological and brief historical review of professional codes. 'Code' has been defined as a collection of prescriptions and directives, especially as a systematic whole of written moral values, rules and prescriptions. The first professional code for nurses was formulated about 1875 and is known from a writing of Florence Nightingale: the Florence Nightingale Pledge. In this study we have analysed the codes of the International Council of Nurses, the American Nurses' Association, the United Kingdom Central Counsil of Nurses, Midwives and Health Visitors, and The Netherlands Society for Nursing. They undoubtedly have their moral nature in common. This has been shown by applying the criteria for the moral point of view and by confronting the codes with the principles of etiquette. Moreover, the codes consist of two categories of duties: duties implicating a moral right of others (particularly patients) and duties warianting a moral right of nurses or their occupational group.

In this connection, the question was raised whether the codes do not only have a moral function, but also an ideological one - i.e. serving the interests of an occupational group. This was tested by studying the moral and/or ideological nature of the value of servitude which has been considered central in the normative dimension of professionalization. Following Kultgen (1988), a content analysis was made of the values, norms, prescriptions and duties mentioned in the codes. On a basis of ordering, ranking and interpretation, servitude indeed was identified as the central moral value in the codes. Other values turned out to be too instrumental or too general, relative to the role and function of nurses. Another result of this analysis was that the values, norms, prescriptions and duties could be set in a hierarchical order of moral importance.

The question raised above was answered positively. The ideological function of the codes is hidden behind their moral retoric and could be identified by questioning their semantic features, logical structure and context of presuppositions. Moreover, their hidden claims : and objectives contribute to the preservation of seven myths: independance, altruism, selfregulation, competence, unity, 'all in one", and moral omnivalence.

The moral function of codes is related to their justification and to the inherent structure and type of arguments used to this end. From a description and analysis of actual moral practices of nurses, focusing on the duty of servitude, we concluded that moral obligations are mainly formulated in terms of concepts of value. This conclusion led us to Vos' moral theory of loyalty (1989) in which concepts of value are characterized as the operational categories of all morals and ethics. They consist of a 'phrastic' (demonstrating, denotating) component and a 'neustic' (approving, connotating) component. Application of these on moral practices can partly neutralize the dichotomy between facts and feelings and clarify their ever changing balance which is dependent on the meanings of values. This balance is disturbed in cases as moralism, ideology, and moral tyranny (with their so-called massive axiology). Moreover, the theory criticizes the 
one-sidednesses of naturalism and non-cognitivism in meta-ethics and the central role of knowledge-theoretical and logical criteria and the concepts of universality and rationality in justifying moral behaviour. Concepts of value are conventions to which we are loyal until their uselessness or contraproductivity become evident. Therefore, loyality is the central value in moral life.

Based on this theory we studied the problem of justification of ocupation-bound moral values using Barnsley's criteria of superiority (autonomy and priority) and legitimacy (reality-boundedness, intersubjectivity and justifiability). It has been shown that superiority of occupation-bound moral values (i.c. servitude) should be denied, except if occupational work should be regarded as a closed system, which is an illusion. It is true that from a 'phrastic-neustic' perspective the legitimacy of servitude can be acknowledged internally, but externally it has to be situated and legitimated in the context of the central value of loyalty:

Reality-boundedness - as an important criterion in both a theory of loyalty and the problem of legitimacy - is a function of the possibilities for applicating professional codes in occupational practice and refers to the moral position of nurses, i.e: the place of nurses in their networks of relations with others, in consideration of realizing the moral obligations required by their code. This position, however, has shown to be highly heteronomous and ambiguous. Therefore, nurses have great difficulties in applying their codes. This has been illustrated by identifying and describing four main fields of problems which interfere with that application: rationality, uniformity, individualism and sanctioning. Summarizing the results, we concluded that the morality of a code might be recognized insufficiently, that nurses are lacking the means and possibilities to applicate a code, and that the context of culture, society and health care permanently frustrates the implementation of values and norms from a code and even can stimulate the opposite. From this perspective professional codes for nurses were characterized as having a low moral status.

The last question to be answered in this study concerns the moral aspects of professionalization, especially in view of the power approach. This approach, as we have shown, uncovers the amoralizing strategy in processes of professionalization and the pursuit of power. (The term 'amoralizing' indicates the process of moral neutralization). Moreover, such a strategy fits the prudential interests often involved in processes of professionalization and served by the ideological function of professional codes. A strategy of amoralizing can be detected, for instance, in the emphasis on the development of knowledge and skills as purely instrumental values which supposedly do not prejudice the social objectives of the occupation.

Nevertheless, many occupational groups in health care have opted for a strategy of antiamoralizing by publishing a professional code and emphasizing its moral nature. This moral claim is, however, unjustified, as indicated above. On the other hand, the strategy of amoralizing is also untenable. We have explained this by describing the moral relevance and qualities of professionalization and of the pursuit of power and the connection of the latter to intrinsic value orientations in society, as well as the invalidation of moral-expressive value orientations of the professionals. In line with that and from a moral perspective three problems were identified: a problem of legitimacy, a hedonistic paradox and a paradox of professionalization. 
It is true that professionalization may contribute to the solution of complex social problems, but it most often developes with insufficient reflection on the moral aspects of occupational life. The premature formulation of professional codes and their lack of implementation is a negative example of that phenomenon.

Besides its analysis and evaluation of the moral and social function of professional codes for nurses, this study also offers a perspective for further sociological and ethical research. For example, studying the concept of servitude in more detail may open new opportunities for value research as a probably underestimated branch in sociology (i.e. sociology of occupations). Moreover, it may contribute to new insights in professional ethics (i.e. health care ethics) and social ethics. Our analysis of actual approaches in theories of professionalization suggest that servitude-orientations in professionalls should be studied more intensively. Until now, sociology has mainly analysed processes of occupation building which center on the development of knowledge and skills. Admittedly, servitude has been identified as an important motive in expressive value orientations of professionals, but its presence, relevance, and operationalization in actual practices is still questioned.

Such research is of great interest for ethics too. Value-related studies in ethics have long been rare. Ethical inquiries were dominated by knowledge-theoretical criteria. Our description and application of the theory of loyalty may give rise to a reorientation on the position of concepts of value in the theory of knowledge, (social) ethics and moral practice. For example, we have shown the importance of the value of servitude for analyzing and evaluating professional practices in a normative-ethical way. These conceptualizations have to be broadened to the field of moral philosophy as a whole.

The latter is of even more interest when we relate our suggestions to the so-called empirical turn in health care ethics. Until very recently this branch of ethics was mainly focused on the application of general principles on particular cases (health care ethics as applied ethics). As noticed by many commentators, health care ethics, by sticking to this strategy, has weakened its relationship with and its relevance for concrete moral life. In The Netherlands, Ten Have (1990) is one of the first health care ethicists who tried to change this trend. He suggested the systematic introduction in health care ethics of hermeneutical methods, aimed at the disclosure of moral structures and experiences instead of the application of general principles to particular cases. In this connection we may point to some similarity with the theory of loyalty in which the importance of concrete moral life is presupposed and is actualized and explicated in the 'phrasticity' of concepts of value. Therefore, we suggest that further reasearch be attempted on the moral-philosophical implications of the hermeneutical method and the theory of loyalty and their interrelationships. Such research may lead to new conceptualizations of (health care) ethics in which actual moral life is explicitly taken into account. 


\section{LIJST VAN AFKORTINGEN EN FIGUREN}

\section{Afkortingen}

ANA $=$ American Nurses ${ }^{*}$ Association

BIG = Wet beroepsuitoefening in de individuele gezondheidszorg

ICN = International Counsil of Nurses

KNMG = Koninklijke Nederlandse Maatschappij tot bevordering der Geneeskunst

NMV = Nederlandse Maatschappij voor Verpleegkunde

NRV = Nationale Raad voor de Volksgezondheid

$\mathrm{RCN}$ = Royal College of Nursing

UKCC = United Kingdom Central Counsil of Nurses, Midwives and Health Visitors

\section{Figuren}

Figuur 1.1: Opbouw van deze studie en belangrijkste aangehaalde auteurs

Figuur 2.1: Oriëntatie op het beroep: motieven en belangen

Figuur 2.2: Basisschema van professionalisering

Figuur 3.1: Samenhang van theorieën in de praktische filosofie

Figuur 4.1: De Code van de ICN (1973)

Figuur 4.2: De Code van de ANA (1985)

Figuur 4.3: De Code van de UKCC (1984)

Figuur 4.4: De Code van de NMV (1990)

Figuur 4.5: Inhoudsanalyse van normen in de beroepscodes voor verpleegkundigen

Figuur 4.6: Functies en aspecten van dienstbaarheid

Figuur 5.1: Taxonomie van fundamentele maatschappelijke waarden 


\section{LITERATUURLIJST}

Abel-Smith, B.: A history of the nursing profession; William Heinemann, London 1960.

Abrams, N. and Buckner, M. (edls.): Medical ethics", The MTT Press, Cambridge/London 1983.

Akties hebben zin. Het Beterschap 9, 1987, 10, 24.

Albert, H.: Theorie en kritiek - opstellen ower theoniewoming hemenewtiek en waardewnijheid in de sociale welenschappen; Boom, Meppel 1976.

Altschul, A.T.: On whose authority (commentary). Joumal of Medical Eohics 3, 1977, 3, 120-121.

American Nurses' Association: Code for murses with interpretive staternents; American Nurses Association, Inc., Kansas City (Missouri) 1976.

American Nurses" Assaciation: Perspectives on the code for nurses; American Nurses Association, Inc., Kansas City (Missouri) 1978.

American Nurses' Association: Guidelines for implementing the code for nurses; American Nurses Association, Inc., Kansas City (Missouri) 1980.

American Nurses" Association: A fore for the nation's health; American Nurses Association, Inc, Kansas City (Missouri) 1982.

American Nurses' Association: Code for murses with interpretive statements; American Nurses Association, Inc., Kansas City (Missouri) 1985.

Amnesty International: Codes of professional ethics; Amnesty International Publications, London 1984.

Arend, A. van der: Ethiek, beroepsethiek en beroepscode. In: Peet, R. wan der (red.): Inleiding in de verpleegkande; De Tijdstroom, Lochem 1990 (2e), 282-301.

Arend, A. van der: Verpleegkundige identiteit en verpleegkundige beroepsuitoefening. Tijdschrift voor Ziekenverpleging 36, 1983, 17, 524-529.

Arend, A. van der: Gedragsregels voor verpleegkundigen - over de wenselijkheid en mogelijkheid van een beroepscode. Tijdschrift voor Ziekenverpleging 38, 1985, 8, 234-243.

Arend, A. van der: Ontwikkelingen in verpleegkundig-ethische codes. In: Aller, H.B. van et al: Eshiek, recht \& zorg - dilemma's bij euthanasie, AIDS, begin van leven, en grenzen van zorg; Stichting Sympoz, Amstelveen 1986, 15-18.

Arend, A. van der: Verpleegkundigen. In: Beaufort, 1. de/Duputs, H.M. (red.): Handboek gezondheidsethiek; Van Gorcum, Assen/Maastricht 1988, 275-285.

Asperen, G. van: De goede maatschappij - inleiding in de sociale filosofie; Van Gorcum, Assen 1978 (Serie Terreinverkenningen in de. Filosofie 6).

Atkinson, P.: The reproduction of the professional community. In: Dingwall, $\mathrm{R}$. and Lewis, Ph.: The sociology of the professions - lawyers, doctors and others; The Macmillan Press Lid, London/Basingstoke 1983, 224241.

Austin, R.: Professionalism and the nature of nursing reward. Joumal of Advanced Nursing 3, 1978, $1,9-23$.

Bakker-Van der Kooy, C.: De zoekende zusters. Tijdschrift voor Ziekenverpleging 36, 1983, 9, 275-278.

Bakker, J.H./Grand-Van den Boogaard, M.J.M. le: Verpleegkandig beroepsprofiel; Nationale Raad voor de Volksgezondheid, Zoetermeer 1988.

Barnsley, J.H.: The social reality of ethics - the comparative analysis of moral codes; Routledge \& Kegan Paul, London/Boston 1972.

Bayles, M.D.: Professional ethics; Wadsworth Publ. Company, Belmont (Calif.) 1981.

Beauchamp, T.L.Bowie, N.E. (eds.): Ethical theory and business; Prentice-Hall, Inc., Englewood Cliffs (New Jersey) 1983 (2e).

Beauchamp, T.L./Childress, J.: Principles of biomedical ethics; Oxford University Press 1979. 
Beaufon, L de/Dupuis, H.M. (red.): Handboek gezondheidsethieky Van Gorcum, Assen/Maastricht 1988.

Behrman, J.N.: Essays on ethics in business and the professions; Prentice Hall, Englewood Cliffs (New Jersey) 1988.

Bellaby, P. and Oribabor, P.: Determinants of the accupational strategies adopted by British hospital nurses. International Joumal of Health Services 10, 1980, 2, 291-309.

Berg K.Tranoy, K.E. (eds.): Research ethics, Alan R. Liss, Inc., New York 1983 (= Progress in Clinical and Biological Research, Vol. 128).

Bergh-Braam, A.H.M. van den: w. van goeden will, maar wlleugellam ... - overwegingen na een onderzoek. Tijdschrift voor Ziekenwerpleging 35, 1982, 10, 322-326.

Bergh-Braam, A. van den: Professionals en semi-professionals - mannen- en vrouwenzaak. Tijdschrift voor Ziekenverpleging 38, 1985, 7, 204-208.

Bermant, G.fKelman, H.C.Warwick, D.P. (eds.): The ethics of social intervention; Hemisphere Publishing Corporation, Washington/London 1978.

Beroepskode woor hen die beroepsmatig weikzciam zijn op het terrein van de verpleging (inclusief Toelichting); Nederlandse Maatschappij voor Verpleegkunde/De Tijdstroom, Lachem 1990.

Beroepsprofiel - de basis voor verplegen en professionaliseren (symposiumverslag); 'De Zuysel', Deventer 1982 (Bijdragen van J. Koehoorn, J. de Jong. J. Ples-Van der Hoeven, T. Korsten-Koremromp).

Binneveld, J.M.W.: Ziekte en gezondheid in historisch perspektief. Tijdschrift voor Sociale Geschiedenis 8 , $1982,94-111$.

Blair, R.D. and Rubin, St. (ed.): Regulating the professions; D.C. Heath and Comp, Lexington (Mass.)/Toronto 1980.

Boer, G.: Reaktie. NMV visie 12, 1990, 23-24, 2.

Boer, Thi de, Köbben, AJ.F. (red.): Waarden en wetenschap - polemische opstellen over de plaats van het waardeoordeel in de sociale wetenschappen; Amboboeken, Bilthoven 1974.

Boyle, K.: Power in nursing - a collaborative approach. Nursing Outlook 32, 1984, 3, 164-167.

Brandt, R.B.: Parallel between epistemology and ethics. In: Edwards, P. (ed.): The encyclopedia of philosophy, Volume 3; Macmillan Publishing Co., Inc. \& The Free Press, New York/Collier Macmillan Publishers, London 1967, 6-8.

Brauw, P. de (red.): Medisch beroepsgeheim; Ambo, Baarn 1988.

Brockhaus Enzyklopaddie (Band 4); F.A. Brockhaus, Wiesbaden 1968.

Brown, S. and Claus, L.M.: Unionization and professionalization: a cross-cultural analysis. Gezondheid en Samenleving 4, 1983, 3, 189-198.

Bullough, B. and Bullough, V. (eds.): New directions for nurses; Springer Publ. Co., New York 1971.

Bullough, V. and Bullough, B.: The care of the sick - the emergence of modem nursing, Croom Helm, London 1979.

Burgess, R.G. (ed.): The ethics of educational research; The Falmer Press, New York/Philadelphia/London 1989 ( = Social Research and Educational Studies Series, Vol. 8).

Burnard, Ph./Chapman, C.M.: Professional and ethical issuer in nursing - the Code of Professional Conduct; John Willey \& Sons, Chichester 1988.

Callahan, J.C. (ed.): Ethical issues in professional life; Oxford University Press, New York/Oxford 1988.

Callebaut, W. en Mostert, P. (red): Congnesbundel Filosofiedag Moastricht 1987 - lezingen gehouden op de negende filosofiedag aan de Rijksuniversiteit Limbung; Eburon, Delft 1988 ( = Filosofische Reeks, 23).

Campbell, T.: Seven theories of human society; Clarendion Press, Oxford/Oxford University Press, New York 1981 .

Carroll, M.A./Humphirey, R.A.: Moral problems in nursing - case studies; University of America Press, Washington D.C. 1979.

Carson, R.A.: Ethical aspirations and the regulation of the professions. In: Blair, R.D. and Rubin, St. (eds.): Regulating the professions; D.C. Heath and Comp., Lexington (Mass.)/Toronto 1980, 97-104.

Castles, M.R.: Professional codes and personal values - some implications of incongruence. Today's Operating Room Nurse 2, 1980, 3, 11-16.

Chapman, C.M.: Concepts of professionalism. Joumal of Advanced Nursing 2, 1977, 1, 51-55. 
Chaska, N.L. (ed.): The nursing profession - views through the mist; McGraw-Hill Book Company, New York 1978.

Coser, LA.: Greedy institutions - pattems of indinudual commitment; The Free Press, New York/Collier Macmillan Publishers, London 1974.

Dane, C.: Geschiedenis wan de ziekenverpleging; De Tijdstroom, Lochem 1985 (1e 1966)...

Dassen, T.: Verplegen in het psychiatrisch centrum - een onderzoek naar taken wan psychiatrisch werpleegkandigen (Proefschrift Rijkksuniwersiteit Limburg); T.W.N. Dassen, z.pll. (Maastricht), z.j. (1989).

Davies, C.: Professionals in bureaucracies - the conflict thesis rewisited. In: Dingwall, R. and Lewis Ph. (eds.): The sociology of the professions - lawyers, doctors and others; The Macmillan Press Ltd., London/Basingstoke 1983, 177-194.

Davis, A.J./Aroskar, M.A.: Ethical dilemmas and nursing practice; Appleton-Century-Crofts, New York 1978.

Davis, F. (ed.): The mursing profession - five sociological essays; John Wiley \& Sons, New York/London/Sydney 1966.

Davis, M./Elliston, F.A. (eds.): Ethics and the legal profession; Prometheus Books, New York 1986.

Dawson, J.D.: Origins of ethical codes (commentary). Joumal of Medical Ethics 3, 1977, 3, 119-120.

Dean, D.J.: The development of professional and political awareness in nursing. Joumal of Advanced Nursing $8,1983,6,535-539$.

De George, R.T./Pichler, J.A. (eds.): Ethics, free enterprise, and public policy - original essays on moral isswes in business; Oxford University Press, New York 1978.

Dickinson, S.: The nursing power and the professional status of nursing. Nursing Times 1982, June 2/8 (Occasional Papers), $61-64$.

Dingwall, R.: Introduction. In: Dingwall, R. and Lewis, Ph. (eds.): The sociology of the professions - lawyers, doctors and others; The Macmillan Press Ltd., London/Basingstoke 1983, 1-13.

Dingwall, $\mathrm{R}$, and Lewis, Ph. (eds.): The saciology of the professions - Lawyers, doctors and others;, The Macmillan Press Ltd., London/Basingstoke 1983.

Dupuis, H.M.: Ontwikkelingen in de medische ethiek - van artsencode naar ethiek van de gezondheídszorg. In: Beaufort; In de/Dupuis, H.M. (red.): Hondboek gezondheidsethiek; Van Gorcum, Assen/Maastricht $1988,21-27$.

Edelstein, L.: The Hippocratic oath - text, translation and interpretation; The Johns Hopkins Press, Baltimore 1943 ( $=$ Supplements to the Bulletin of the History of Medicine, ed. H.E. Sigerist, 1).

Elzen, H. van de: Verpleegkundigen en Fonak - ervaringen in een ziekenhuiis. In: Bironneberg, $\mathrm{C}_{\mathrm{a}}$ el al: Nieuwe wetenschappers woor de gezondheidszorg, Rijksuniversiteit Limburg, Maastricht 1985, 111-112.

Ethical codes (Editorial. Joumal of Medical Ethics 3, 1977, 3, 105-106.

Etzioni, A. (ed.): The semi-professions and their organization - Leachers, nurses, social workers; The Free Press, New York 1969.

Fitzpatrick, F.J.: Ethics in nursing practice - basic principles and their application; The Linacre Center for the Study of the Ethics of Health Care, London 1988.

Flashar, H. (Hrsgb.): Antike Medizin; Wissenschaftliche Buchgesellsschaft, Darmstadt $1971(=$ Wege dler Forschung, Band $\mathrm{CCXXI}$ ).

Fowler, M.D.M/Levine-Ariff, J. (eds.): Ethics at the bedside - a source book for the critical care nurse; American Association of Critical Care Nurses/J.B. Lippincott Company, Philadelphia 1987.

Frankena, W.K.: Value and valuation. In: Edwards, P. (ed.): The encyclopedia of philosophy, Volume 8; Macmillan Publishing Co., Inc: \& The Free Press, New York/Collier Macmillan Publishers, London 1967, 229-232.

Frankena, W.K.: Ethics; Prentice-Hall, Inc, Englewood Cliffs (New Jersey) 1973 (1e 1963),

Freildson, E.: Profession of medicine - a study of the sociology of applied knowledge; Harper \& Row, New York 1970.

Freidson, E.: The theory of professions - state of the art. In: Dingwall, R. and Lewris, Ph. (eds.): The socilology) of the professions - lowyers, dociors and others; The Macmillan Press Lid., Londom/Basingstoke 1983, 19. 37.

Freidson, E.: The formall characteristics of a profession. In: Abrams, N. and Buckner, M. (eds.): Medical ethics; 'The MIT Press, Cambridge/London 1983, 46-52. 


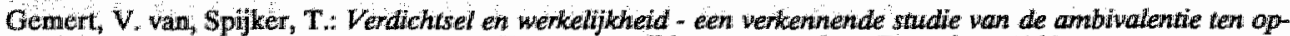
ztchte van zongen en verwangen in de verpleging; De Tijdstroom, Lochem/Poperinge 1982.

Gemert, V. van, Spijker, $T$.: Ambrvalente ten aanzien van zong en zorgverlening in onze samenleving - een wan de bellemmeringen ten aanzien van de professionalisering van verpleegkundigen. Tijdschrift voor Zhekenverpleging $36,1983,4,92,97$.

Gevers, JKM./Hubben, JH, (red) Grenzen con de zong zongen aan de grens - Liber Amiconum voor prof dr. H.J. Leenen, Samson H.D. Tjeenk Wilink, Alphen aan den Rijn 1990.

Gewirth, A Ethics In The new encyclopaedia Brittonnica, Macropaedia Volume 6; Encyclopaedia Briltannica, Ine, William Benton, 1943-1973/Helen Hemingway Berton, Clificago 1974, 976-998.

Glaser, W.A. Nursing leadership and policy - some cross-national comparisons. In: Davis, $F$. (ed.): The nursing profession - five sociological essays; John Wiley \& Sons, Inc., New York/London/Sydiney 1966, 1-59.

Goldman, A.H.: The moral foundations of professional ethics; Rowman and Littlefield, Totowa (New Jersey) 1980 .

Goode, W. J. The theoretical limits of professionalization. In: Etzioni, A. The semi-professions and their organization-teachers, nurses, social worken; The Free Press, London 1969, 266-313.

Gorlin, R.A. (ed.)" Codes of professional responsibility; The Bureav of National Affairs, Inc, Washington D.C. 1990 (1e 1986).

Corman, S. and Clark, N.: Power and effective nursing practice. Nursing Outlook 34, 1986, 3, 129 -134.

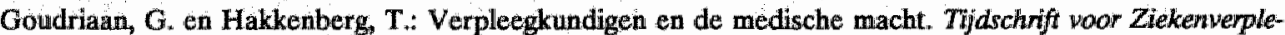
ging $35,1982,19,617-620$ (1)/35, 1982, 20, 652-658 (II).

Greenwood, E: Attributes of a profession. Social Work $2,1957,45-55$.

Grote Winkler Prins: Encyclopedie (Deel 6); Elsevier, Amsterdam/Brussel 1980.

Gruending, D.L.:Nursing theory - a vehicle of professionalization? Joumal of Advanced Nusing 10, 1985, 6 , $553-558$

Gunkel, M.H.: De B.1.G. - het voonontwerp wet op de beroepen in de individuele gezondheidszorg. Tijdschrift woor Ziekenverpleging $35,1982,11,346-350$.

Hadders, L.: De beroepsopleiding tot verpleegkundige. In: Peet $\mathbf{R}$, van der (red.): Inleiding in de vepleegkunde; De Tijdstroom, Lochem 1990, 265-281.

Hall, C.M. Who controls the nursing profession - role of the professional association. In: International Council of Nurses: Nurses and nursing - proceedings of the 15th quadrennial congress, 13-18 May 1973, Mexico City; Mexico City 1973, 27-34.

Hall, $D_{n}:$ The mature of nursing and the education of the nurse. Joumal of Advanced Nursing 5, $1980,149-159$.

Hall, R.H.: The professions, employed professionall, and the professiomal association. In: Professionatism and the empowemnent of nursing a papens presented at the 53rd convention, Washington D.C., June 25-Juby $l_{\text {, }}$ 1982; American Nurses Association, Kansas City (Missouri) 1982, 1-15.

Hall, R.H.: Theoretical trends in the sociology of occupations. Sociological Quarterly 24, 1983, 1, 5-23.

Hammenga, H.: Arbeidsverdeling en beroepsmatige zorg. In: Peet, R. van der (red.): Inleiding in de verpleegkunde; De Tijdstroom, Lochem 1990, 345-366.

Hammenga, H.: Professionalisering - en proces. In: Peet, R. van der (red.): Inleiding in de verpleegkunde; De Tijdstroom, Lochem $1990,428-448$.

Hammenga, H. Professionaliseringsistrategieën. In: Peet, R. van der (red.): Inleiding in de verpleegkande; De Tijdstroom, Lochem 1990, 449-460.

Hammenga, H./Smits, S.: Professie en professionalisering. In: Peet, R. van der (red.): Inleiding in de verpleeg kunde; De Tijidstroom, Lochem 1990, $411-427$.

Haug, M.: "The sociological approach to self-regulations. In: Blair, R.D. and Rubin, St. (eds.): Regulating the professions; D.C. Heath and Comp., Lexington (Mass.)/Toronto 1980, 61-80.

Have, H. ten: Ethiek tussen alliantie en dissidentie; Inaugurele rede Rijksuniversiteit Limburg, Maastricht 1990.

Have, H. ten/Kimsma, G: Geneeskwnde hussen droom en drama - voortplanting ethiek en voonitgang; Kok Agora, Kampen 1987.

Henderson, R.D.: A basis of normativity. In: Callebaut, W., Mostert, P. (red.): Congresbundel Fulosofiedag Maastricht 1987 - lexingen gehouden op de negende filosofiedag aan de Rijksuniversiteit Limburg; Eburon, Delft 1988, 20-24 ( = Filosofische Reels, 23). 
Horowitz, L.: The economic foundations of self-regulation in the professions. In: Blair, R.D. and Rubin, St. (eds.): Regulating the professions; D.C. Heath and Comp., Lexington (Mass.)/Toronto 1980, 3-28.

Hurk, C.H.M. van den: De ontwikkeling van een meetinstrument voor de bepaling van aard, oorzaken en gevolgen van morele problemen van verpleegkundigen (Doktoraalscriptie Rijskuniversiteit Limburg); Geldrop 1991 .

Hutchinson, S.A.: Four perspectives on physicians, nurses, power and games. Floridä Nurse 30 "1982, 9, 9-12.

Ilich, I.: Medical nemesis - the expropriation of health; Marion Boyars Publishers, London/New York 1975.

Illich, I.: Disabling professions. In: Ilich, I. et al: Disabling professions; Marion Boyars Publishers, London/New York 1987, 11-39.

Illich, I. et al: Disabling professions; Marion Boyars Publishers, London/New York 1987.

International Council of Nurses: Nurses and nursing - proceedings of the 15th quadrennial congress, $13-18$ May 1973, Mexico City; Mexico City 1973.

Jacobs, D.: De toekomst van de verpleegkunde - professionalisering, profanatie, profetie. Tijdschrift woor Ziekenverpleging 21, 1968, 19, 778-782.

Jacox, A.: Professional socialization of nurses. In: Chaska, N.L. (ed.): The nursing profession - views through the mist; McGraw-Hill Book Company, New York 1978, 10-20.

Jager, H. de, en Mok, A.: Grondbeginselen der sociologie - gezichtspunten en begrippen; Stenfert Kroese, Leiden $1983(8 \mathrm{e})$.

Jameton, A.: Nursing practice - the ethical issues; Prentice-Hall Inc., Englewood Cliffs (New Jersey) 1984.

Janssen van den Doornmalen, G.L.M.: Professionalisering in de verpleegkunde - kanttekeningen bij het artikel van J. Wellen. Metamedica 57, 1978, 179-183.

Jarvis, P.: Some comments on the Rcn code of professional conduct. Nursing Mirror 21, 1977, 24 Now., $27-28$.

Jong, J. de: Beroepsprofiel - uitgangspunt woor verplegen en professionaliseren. In: "Beroepsprofiel", de, basis voor verplegen en professionaliseren (symposiumverslag); 'De Zuysel', Deventer 1982, 11-35.

Jouw belang is onze zong; Het Beterschap, Utrecht 1983.

Katz, F.E.: Nurses. In: Etzioni, A (ed.): The semi-professions and their organization - teachers, murses, social workers; The Free Press, New York 1969; 54-81.

Kepler, M.O.: Medical stewardship - fulfilling the Hippocratic legacy; Greenwood Press, Westport (Connecticut) 1981 .

Ketefian, S.: Professional and bureaucratic role conceptions and moral behavior among nurses. Nursing Research 34, 1985, 4, 248-253.

Klinkert, J.J.: Th.P.W.M. van der Krogt: Professionalisering en collectieve macht - een conceptueel kader (boekbespreking). Gezondheid en Samenleving 3, 1982, 2, 113-114.

Koninklijke Nederlandsche Maatschappij tot bewordering der Geneeskunst: Medische ethiek; Utrecht 1936 .

Koninklijke Nederlandsche Maatschappij tot bevordering der Geneeskunst: Medische ethiek en gedrogsiev, Utrecht 1959.

Koninklijke. Nederlandsche Maatschappij tot bevordering der Geneeskunst: Gedragsregels voor antsen; Utrecht 1978.

Korthals, M.: Kritiek wan de maatschappijkritische rede - de struchuur wan de maatschappijkritiek wan de Frankfunter Schule; Dick Coutinho, Muiderberg 1986.

Kramer, M.: Reality shock - why nurses leave nursing; Mosby, St. Louis 1974.

Kramer, M. and Baker, C.: Exodus - can nursing afford it? Joumal of Nursing Administration 1, 1971, 1., 15 30 .

Krantzler, M.J.: Media images of physicians and nurses in the United States. Social Science \& Medicine 22, $1986,9,933-952$.

Krogt, Th. van der: Professionalisering en collectieve macht - een conceptueel kader; Vuga-Uitgewerij, 's-Gravenhage 1981.

Kuitert, H.M.: De morelle status van het embryo - de pauselijke instructie Donum Vitae. In: Gewers, J.K.M./Hubben, J.H. (red.): Grenzen aan de zong zongert aan de grens - Liber Amiconum voor profi. dr. HJJ. Leenen; Samson H.D. Tjeenk Willink, Alphen aan den Rijn 1990, 101-119. 
Kultgen, I: Evahuating codes of professional ethics. In: Robison, W.L.Pritchard, MSS Ellin, J. (eds.) Profits and professions - essays in business and professional ethics; Humana Press, Cliftorn (New Jersey) 1983, $225-264$

Kultgen, I: Ehics and professionatsm; University of Pennsylvania Press, Philadelphia 1988.

Kultgen, $J_{\text {. }}$ The ideological use of professional codes. In: Callahan, J, (ed.): Ethical issues in professional hfe; Oxford University Press, New York/Oxford 1988, 411-421.

Kunneman, H, Habemas' theorie van het communicatieve hondelen - een samenvating; Boom, Meppel/Amsterdani 1983.

Lammers, C.J.: Uïterlikke samenhang en bindüngskacht wan de onganisatue (oratie); Van Grorcum, Assen 1964.

Lammers, $C_{\text {J }}$ : Het ziekenbuis alls kastemaatichappij. Sociologische Gids $14,1967,2 ; 67-85$.

Larson, M,S. The rise of professionalism - a sociologicai approach; The University of Callifornia Press, Berkeley 1979.

Leenen, HJ I. Struchut en functioneren van de gezondheidszong; Samson Uitgeverij, Alphen aan den Rijn 1979 ( $=$ Sociale en Culturele Reeks).

Leenen, HIJ.: Gezondheidsrecht voor opleidingen in de gezordheidszorg; Samson Uitgeverìj, Alphen aan den Rijn 1981 ( Sociale en Culturele Reeks).

Lieber, H.J. (Hrsgb): Ldealogie - Wissenschaft - Gesellschaft - neuere Beutrage zur Digkussion; Wissenschaftiche Buchgesellschaft, Darmstadt 1976 ( $=$ Wege der Forschung, Band CCCXI.II $)$.

Lieburg; M. van: De verpleegkundige literatuur in Nederland in de $19 \mathrm{e}$ eeuw. Tijdschrift woor de Geschiedemis van de Geneeskunde, Natuw wetenschappen, Wiskunde en Techniek 3, 1980, 3,97-122.

Lindeboom, G.A.: Opstellen over medische ethiek; J.H. Kok N.V., Kampen 1960.

Lubam, D.: Professional ethics in a world without trumps. The Hastings Center Repont 11, 1981, June, 38-40.

Lurie, Ex: Nurse practitioners - issues in professional socialization. Joumal of Healh and Social Behavior $22,1981,1,31-48$.

Mass, P.M.: Frans-Nederlands; Het Spectrum, Utrecht/Antwerpen 1963 (8e).

Manenschijn; G.: Morele argumentatie. In: Musschemga, A. W. (red.): Ondenwijs in de matuunetenschappen en morele vorming - opstellen over wetenschapsfilosofie, theologie, antropologie en ethiek voor het natuwnetenschappelijk ondenwijs; Ten Have, Baarn 1984, 160-184.

May, W.F.: Code, covenant, contract, or philantropy. The Hastings Center Report 5, 1975, Dec., 29-38.

MoCall Smith, A.x Cessation of treatment, autonomy and consent (commentary). Joumal of Medical Ethics 3 , $1977,3,122-123$.

McCloskey, J.C.: The professionalization of nursing - United States and England Intemational Nursing Review $28,1981,2,40-47$.

Medemens van beroep - visie wan het Beterschap; Het Beterschap, Utrecht 1978.

Malia, K.: Cracking the new code. Nursing Twmes $80,1984,43,20$.

Meuwissen, D.H.M.: Recht en wrijheid - inleiding in de rechtsfilosofie; Het Spectrum, Utrecht/Antwerpen 1982 ( = Aula Paperback 83).

Mok, An L: Verpleegkunde als profiessie. Tijdschrift voor Ziekenverpleging 21, 1968, 19, 771-777.

Mok, A.L.: Beroepen in aktie; Boom, Meppel 1973.

Mok, A.L. Professionalisering als maatschappelijk verschijnsel. Mens en Ondememing 31, 1977, 4, $219-231$.

Mok, A.: Commentaar op Brown en Claus. Gezondheid en Samenleving 4, 1983, 3, 197-198.

Morrison, I.: $_{\text {. }}$ Reviewing the evidence. Nursing Times $83,1987,25$ Feb., 31-33.

Mungham, G. and Thomas, Ph. A.: Solicitors and clients - altruism or self-interest? In: Dingwall, R. and Lewis, Pl. (eds.): The sociology of the professions - lawyers, doctors and others; The Macmillan Press. Lid., London/Basingstoke 1983, 131-151.

Mutphy, J.F.: Toward a philosophy of nursing. In: Chaska, N.L. (ed.): The nursing profession - views through the mist; McGraw-Hill Book Company, New York 1978, 3-9.

Murray, $T$, Dingwall, R., Eekelaar, J : Professionals in bureaucracies - solicitors in private practice and local government. In: Dingwall, $\mathbf{R}$. and Lewis, $\mathrm{Ph}_{\mathrm{i}}(\mathrm{eds}$ ): The sociology of the professions - lawyers, doctors and others; The Macmillan Press Ltd. London/Basingstoke 1983, 195-220. 
Musschenga, A.W.: Relativisme, pluralisme en het gevaar van indoctrinatie. In: Musschenga, A. W. (red)

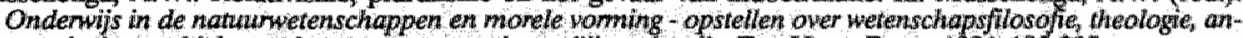
tropologie en ethiek voor het notuumetenschappelik ondenwijs, Ten Have, Baarn 1984, $185-205$.

Nationale Raad voor de Volksgezondheid: Adwes inzake de profielschets wan eer benoepsbeofonaar die zich professioneel bezighoudt muet het veplegen; Zoetermeer 1984.

Nationale Raad voor de Volksgezondheid: Nota bouwstenen voor "beroepscodes" en "gedragsregels" Zoetermeer 1988 ( $=$ Publikatie 22/88)

Nauta, L.W.: Agumenten woor een kritische ethiek; Van Gennep, Amsterdam 1975.

Nightingale, F.: Notes on nursing - what it is and what it is not; Harrison \& Sons, London 1859. (Nederlandse vertaling: Ower ziekenverpleging - wat men om de herstelling te bevorderen, te doen en te vermijden heeft; K.H. Schadd; Amsterdam 1960.

Nightingale, F, Florence Nightingale to her nurses, Macmullan and Company, Ltd., Londion 1915.

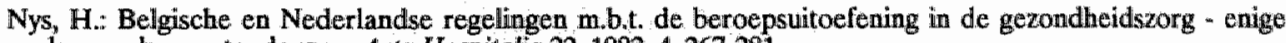
kenmerkem en tendenzen. Acta Hospitalia 22, 1982, 4, 267-281.

Oakley, A.: The importance of being a nurse - what price professionalism? Nursing Times $80,1984,43,24-27$.

Ommen, M. van: Tussen professionele autonomie en wederzijdse aanpassing - een ondenoek naar mwitidiscipli. naire behandelfeams in een psychiatrisch centrum: hum ontstaan en ontwikkeling in relatie tot de weranderende organisatiestnuktuur sinds 1841 en hun funktioneren anno 1984 (Proefschrift Rijksuniversiteit Groningen); Van Denderen, Groningen 1988.

O'Reilly, D.P.: Toward autonomy of the nursing profession Nursing Leadership $5,1982,3,18-22$.

Ott, M.: Assepoesters en kroonprinsen - een onderaok naar de minderheidspositie van agentes en werplegers; Proefschrift Universiteilt van Amsterdam, Amsterdam 1985.

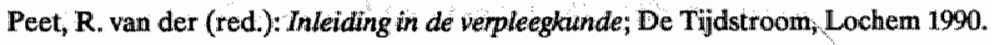

Peet, R. van der: Florence Nightingale en haar visie op verplegen - in relatie tot het leven en werk van Charles Darwin. Tijdschrift woor Zlekenverpleging 36, 1983, 17,530-536.

Philipsen, H.: Gezondheidszorg als project en bejegaring - waarden ten aanzien van ziekte, gezondheid en sa-

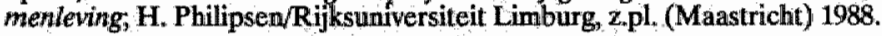

Phillips, D.L.. Normative theorizing in the social sciences - a defense. Kennis en Methode 7, 1983, 3,170-189.

Pool, A.: Een beroepscode; vrijwillig of verplicht? Verpleegkande 6, 1991/1992, 1, 38-39.

Pool, JJ.: Verpleegkunde is niet professioneel. Het Ziekenhuis 8, 1978, 22, 556-561

Pool, J.J.: De verpleegkundige als buffer tussen arts en patient. Metamedica 61, 1982, 6, 233-239.

Prince, J.: Education for a prolession - some lessons from history. Intemational Joumal of Nunsing Studies 21 , $1984,3,153-163$.

Professional code. Nursing Times 72, 1976, 30 Sept., 1504-1505.

Protection rather tham punishment - Ren response to professional conduct paper. Ron Nursing Sitandard $1982,255,8$.

Purtilo, R.B./Cassel, C.K.: Ethucal dimensions in the health professions; W.B. Saunders Company, Philadel. phita 1981 .

Pyne, R: A professional duty to shout: Nursing Times $83,1987,42,30431$.

Querido, A.: Godshuizen en gasthwizen - en geschiedenis wan de ziekenverpleging in West-Europa; Weten. schappelijke Uitgeverij, Amsterdami 1967.

Reiser, SJ.Dyck, AJJ/Curran, WJ. (eds.) Ethics in medicine - historical perspectives and contemporary concems; The Massachusetts Institute of Technology Press, Cambridge (Massachusetts)/London 1977.

Rijlaarsdam, J.: Tuchtrecht of onrecht voor verpleegkundigen? Tijdschrift voor Ziekenverpleging 100, 1990, 2 , 40-43.

Roberts, K.L.: Nursing - profession or pretender? Australian Nurses Joumal 9, 1980, 10, 33-35.

Rood-De Boer, M.: Het aerwoud wan de erecodes Advocatenblad 1969, 146-161.

Rooujen, M. van: Beroepskode NMV biedt kader voor werpleging. NMV visie 12, 1990, 2, 1-2.

Royal College of Nursing. The Rcm code of professional conduct - a discussion document; Royal College of Nursing, London, 1976 . 
Royal College of Nursing: What the Ren stands for, Royal College of Nursing, London, 1976.

Royal College of Nursing (Ren) code of professional conduct - a discussion document. Joumal of Medical Ethics 3, 1977, 3, 115-123.

Rubiin, St.: The legal web of professional regulation. In: Blair, R.D, and Rubin, St. (eds.); Regulating the professions; D.C. Heath and Comp ., Lexington (Mass.).Toronto 1980, $29-60$.

Rueschemeyer, D. Professional autonomy and the social control of expertise. In: Dingwall, R and Lewis, $\mathrm{Ph}$ (eds.): The sociology of the professions - lawyers, doctors and others; The Macmillan Press Ltd., London/Basingstoke 1983, 38-58.

Rumbold, $\mathrm{G}_{\text {.: }}$ Ethics in nursing practice ${ }_{*}$ Bailliere Tindall, London 1986.

Sampson, C.i Some student's contributions (commentary). Joumal of Medical Ethics 3, 1977, 3, 121-122.

Sawyer, L.M.: Nursing code of ethiics - an international comparison. Intemational Nursing Review 36, 1989, 5, $145-148$.

Schaart, J.: ICN-kode aangepast aan Nederlandse praktijk. NMV wisïe 11, 1989, 5, 14-16.

Scott, W.R.: Managing professional work - three models of control for health organizations. Health Services Research 17, 1982, 3, 213-240.

Scrivenger, M.: Ethics, etiquette and the law. Nursing Times 83, 1987, 42, 28-29.

Self, D.J.: A study of the foundations of ethical decision-making. Theoretical Medicine 8, 1987, 2, 85-95.

Simpson, R.L. and Simpson, I.H.: Women and bureaucracy in the semi-professions. In: Etzioni, A. (ed.): The semi-professions and their organization - teachers, nurses, social workers; The Free Press, New York/London 1969, 196-265.

Singleton, E.K. and Nail, F.C.: Autonomy in nursing. Nursing Forum 21, 1984, 3, 123-130.

Spijker, $T$.: Mooi en beschaafd verplegen - een historische anahse van een vrouwenberoep; De Tijdstroom, Lochem 1979.

Spreeuwenberg, C. et al: Experimenten met embryo's? Medisch Contact 44, 1989, 14, 451-472.

Starr, P.. The social transfonnation of American medicine; Basic Bioolks, New York 1982.

Starr, W.C.: Codes of ethics - towards a rule-utilitarian justification. Joumal of Business Ethics 2, 1983, 99 106.

Stein, L.I.: The doctor-nurse game. In: Bullough, B. and Bullough, V. (eds.); New directions for nurses; Springer Publ. Co., New York 1971, 129-137.

Stevens, F.C.J.: De bureaucratisening van het medisch specialistisch ambacht - een vergelijkend onderzoek naar bureaucratie en professie in twintig ziekenhuisafdelingen (proefschrift Rijksuniversiteit Limburg); Van Gorcum, Assen/Maastricht 1987.

Stevens, F.C.J. en Philipsen, H. De bureaucratisering van het medisch specialistisch ambacht. $M \& O T$ Tjjschifft woor Organisatiekunde en Sociaal Beleid 42, 1988, 3, 168-179.

Storch, J. et al: The Nursing Profession Act - an achievement for Alberta nurses. The Camadian Nurse 80, $1984,10,49-55$.

Strauss, A.: The structure and idleology of American nursing - an interpretation. Im: Davis, F. (ed): The numsing profession - five sociological essays; John Wiley \& Sons, Inc., New York/London/Sydney 1966, 60-108.

Sward, K.M.: The code for nurses - an historical perspective. In: American Nurses' Association: Perspectives on the code for nutrses; American Nurses' Association, Inc., Kansas City (Missouri) 1978, 1-9.

Sykes, J.B. (ed.): The concise Oxford dictionary of current English; Oxford University Press, Oxford 1982 (7e).

Tate, B.L. (red.): Verpleegkundige dilemma's - ethische kanttekeningen bij het verpleegkundig beroep; De Tijdstroom, Lochem/Poperinge 1980.

Tate, B.L. (cd.): The nurse's dilemma; International Council of Nurses, Geneva 1977.

Tiffany, R.: Nursing - industry or profession. Australian Nurses Joumal 11, 1982, 4, 43-45.

Toren $_{1}$ N.: Semi-professionalism ans social work: a theoretical perspective. In: Etzioni, A. (ed.): The semiprofessions and their organization - teachers, nurses, social workers; The Free Press, New York/London $1969,141-195$.

Tschudin, V.: Ethics in nursing - the caring relationship ${ }^{i}$ Heinemanm, London 1986.

Tuchtrecht of onrecht voor verpleegkundigen - reacties. Tijdschrift voor Ziekenverpleging 100, 1990, 11, 357360. 


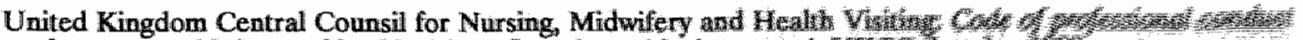

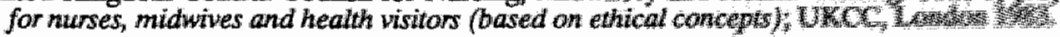

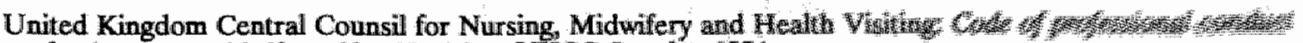
for the nurse, midwife and health visitor, UKCC, London 1984.

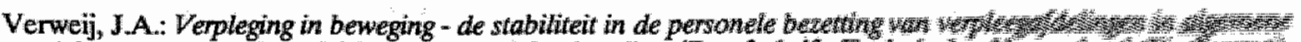

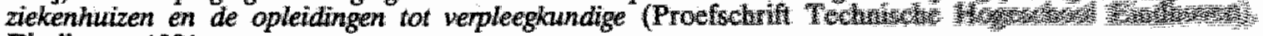
Eindhoven 1981.

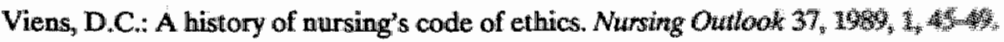

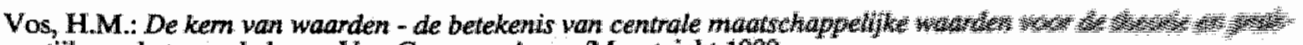
tijk vas het morele leven; Van Gorcum, Assen/Maastricht 1989.

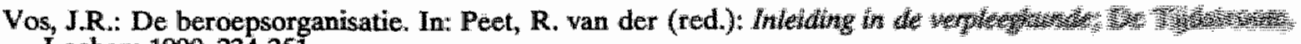
Lochem 1990, 234-25i.

Vos, R.: Beroepskode (brief). NMV visie 12, 1990, 23-24, 2.

Vousden, M.: Conduct unbecoming. Nursing Times $83,1987,25$. Feb, $33-34$.

Vousden, M.: Top secret code? Nursing Times $83,1987,42,25-27$.

Vousden, M.: When nightmare becomes reality. Nussing Times $83,1987,25, F, 2,24$,

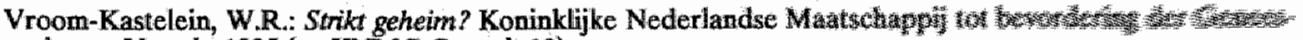
kunst, Utrecht 1985 (= KNMG Consult 10)

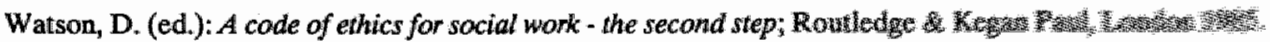

Watson, J.: Professional identity crisis - is nursing finally growing upt Amenicon Low 8, 1488-1490.

Weinrich, $\mathbf{R}$ : Bedeutung und Stellenwert der Krankenpflege in unserer Gesellsc $1,2-3$.

Weiss, S.J.: Role differentiation between nurse and physician - implications for wux $1983,3,133-139$.

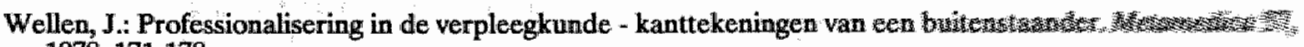
1978, 171-178.

Wirsing, R.: Die Stellung des amerikanischen Krankenpflegeberufs und seine Prow kenpflegezeitschrift 32, 1979, 1, 1-11.

Yeager, S.J. and Kline, M.: Professional association membership of nurses - factory and the decision to join an association. Research in Nursing \& Healih $6,1983,2,45-52$.

Zizek, S.: The sublime object of ideology; Verso, London/New York 1989. 


\section{INDEX}

\section{Actor $35,74,81,94$}

Act-theorie (zie Ethische theorie)

Affectieve neutraliteit 30

Altruisme $91-92,142,156,170-171,173$

American Nurses" Association 16, 51, 99, 108, 111-114

Amoraliseringsstrategie $200-205$

Approbationisme $63,65,77,159,172$

Arbeidsbeschikbaarheid 37,55

Arbeidstaken, differentiatie en specialisatie van $22-24$

Artseneed 104, 108

Attitude 19,27

Autonomie

van beroepsbeoefenaren/beroepsgroepen 24 , $27,29,36,44,88$

van professionele organisaties $42-43$

van verpleegkundige (zie Verpleegkundige)

Axiollogie 68-69, 83-84, 154, 158

Begrippen, functie van 155

Bieroep(en),

autonomie van 24

beeldvorming t.a.v. 15,22

corporatieve aspecten van 22

gebruiks- en ruilwaarde van $36-37,55,201$

geschiedenis van 12, 40 (zie ook Verpleging)

hièrarchie van $28,81,83$

'hogere'/'gevestigde' $21,86-87$

ideaal-type van 25,27

idleologie van $24,26,82,136-137,165$

institutionalisering en legitimering van 25-26,

$57,200-201,203$

omschrijuing van 14, 19-20,25

ontstatum en ontwikkeling van $12,14,21$-23

opleiding tot een 20 (zie ook

Verpleegkundige)

professies to.v. 20,25

samenleving en 14-15, 17, 20, 23, 29, 32, 40, $131,165,201,204$

segmentering binnen 23,32 (zie ook

Verpleging)

status van 20,26

toekomst van 14

wettelijke bescherming van 47

(zie ook Professie)

Beroepensociologie 12, 14, 19, 40-41, 44, 81-83

Beroepsbeoefenaren,

belangen/claims van $24,36-37,200$ gedrag van $19,36,91,183-184$

ideologie van 24,82

machtspositie van $36,38,200$

motieven van $36-37$ (zie ook

Waardenoriëntatie)

persoonlijk opvattingen van 19,21

socialisatie van 85

waärdenconflict bij 82,180 :

Beroepscode

als juridisch relevant document $89,91-92$,

" $100-102,115,122,183,192-195,197$

als kenmer'k van professie $27,86,88$

als middel tot controle/regulering 86-92, 142, 192-197

bij semi-professies 86,88

en autonomie $87-88,91-93,142$

en beroepsorganisatie $91,96,195-96$

en tuchtrecht $16,185,195-197$

in geneeskunde $102-105,125$

in professionaliseringsliteratuur $\mathbf{8 5 - 9 3}$

van de A.N.A. 16,99, 111-114

van de I.C.N. 16, 99, 109-111, 118-119

van de N.M.V. 16, 99, 118-122, 192, 195-196

van de U.K.C.C. 16, 99, 114-118, 119, 195

Beroepscode,

analysemodel van $127-128$

'commitment' tot $86,92,118,141,143,145,202$

dienstbaarheid in $91-92,94,98,127,129-135$,

$144,164,165-172,180,204$

effect van $92-93,183,185,192$

en etiquette $90,91,97,124-126$

ethische waardering van $87,95,97-98,122$,

$127,130,134,162,183,185-186,193-195,199$

hièrarchie van normen in 133-134

historische aspecten van 100,102-108

inhoudsanalyse van $127-136$

kenmerken vain $85,87,91,182$

kennis en kunde i.v.m. 92-93, 123-124, 131,

$142-143,167,183$

legitimering en 26,32

(morele/ideologische/sociale) functie van 17, $62,86-90,91-94,11,136-137,144-146,148$, $181-182,185,194-195,199,204-205$

(morele) status van 93, 147-148, 172-174,

198-199

omschrijving van $11,62,84-85,91,100-102$

proffessionalisering en $59,90-91,94,95,162$

semiotische anallyse van 138-141, 144 
teksten van $103-104,107-108,110,113,117$, 119-121

toepassing(sproblemen) van $86,92-93,104$, 174, 178-197, 199

waarden in $90,92-95,123,126-135,159,164$

wrenselijkbeid wan $17,86,118-119,185-186$

Beroepsethiek,

beroepscode en $148-149,160,165-172$

omschrijuing van 96,160

(zic ook Ethiek)

Beroepsgroep,

belangen van 19, 32, 201

collectivisering binnen $22-23$

maatschappelijk rol van $24,32,131,197$,

200-201

macht van $34-35,197,200$

oriëntatie op maatschappelijk waarden door $32,84,131$

Beroepsorganisatie(s),

beroepscode van (zie Beroepscode)

collectivisering binnen 23

ontwikkeling en functie van 22, 52

overheid en 24, 195-196

verpleegkundige (zie Verpleging)

Beroepsorientatie 36-37, 149

Beroepsvorming,

domeininstitutionalisering en 26

sociologisch begrip van 24

structurele contekst van $22,40,176$

B.I.G.,

tuchtrecht in 16,195

voorontwerp 104-105, 119, 122

Bureaucratisering,

beroepsorganisaties en 22

model van 22

omschrijving van 42

professionalisering en $14,33,42-44,50$, 201-202

'Burn-out' 53, 204

'Care' en 'cure' 47

Carrière 22, 50

Code (zie Beroepscode)

Code of Ethics (Parcival) 103

Codex 100-102

Cognitivisme (zie Ethiek, meta-)

Collectivisering

binnen bercepsgroep 22-23, 93

en sociale institutionalisering 26

(zie ook Verpleging)

Collegialiteit $135,142,153,156,170$

Competentie (zie Kennis en kunde)

Connoterend en denoterend denken 66, 155 , $179-180,201$

Continuumbenadering (zie Professionalisering)

Declaration of Geneva 103,108

Deliberatie 158, 164, 169, 171

Deontologie (zie Ethische theorie)
De-professionalisering $44,57,82$

Descriptieve ethiek (zie Ethiek)

Deugd 65, 74, 169

Deugdethiek (zie Ethische theorie)

Dienstbaarheid $13,28,36,48,57,85-86,89,94$, $147,149-159,165,168,171,173-174,204$ (zie ook Beroepscode)

Eed van Hippocrates 102, 107

Eed van Maimonides 103, 107

Eenheid

beinvloeden van $24,26,93,139$

beroepsgroep als 23

mythe vain 142

Eigenbelang 137, 167, 169-171, 173, 187, 197

Elite $22-23,55,92-93,164$

Emancipatie 13, 185, 190

Empirisch onderzoek, gegevens van $12,40,79,91,96$ noodzaak wan $40-41$

Ethiek, argumentatiewijzen in 63,158

beroepsethiek t.o.v. 160-163

descriptieve 67-68

geneeskundige $17,102-105,125,154,163$

meta- $69-72,147,152,155,157-159$

normatieve $12,68-69,76,152,157-159$

recht en 102 161, 190-192, 197

situatie - 156

sociale 67,147

sociologie en $15,75-78$

verpleegkundige 16-17, 149-152

waardetheorie in $68,147,154-159$

wijsgerige 67-75

Ethische

code (zie Beroepscode)

'gezichtspunt' 72, 95, 122-124, 131, 135

theorie $12,17,63-64,67-75,76,147 \cdot 148$, $154-155,157-159,164,169,171$

Ethos (zie Morele verschijnstel)

Etiquette (zie Beroepsoode)

Feitelijkheid en wensellijkheid $73,77,82,155-156$

Fenomenologic 41,155

Filosofie, praktische $67-75$

sociale $67-69$

systematiek in 67,71

Fliedner, The odor 13, 106-107

Florence Nightingale Pledge 107-108

Functionalistische benadering (zue Professionalisering)

Functionele specificiteit 29,33

Gedragsregels (zie Beroepscode)

Geneeskunde, als gevestigde professie $28-29,81$ beroepscodes in (zie Beroepscode)

kenmerken van 47

uniwersiteit en 21,29 
verpleegkunde en (zie Verpleegkunde)

Geschiedenis

van beroepen 40

van thet ziekenhuis 12

van verpleging (zie Verpleging)

Gewetensbezwaren 187-18

Gezondheidszorg,

professionalisering en 16, 201,204

stamenleving en 16, 179

waarden en normen in 65-66, 179

Hedonisme (zie Ethische theorie)

Hedonistische paradox 203-204

Heteronomie van professies 29

van morele positic (zie Positie, morele)

\section{Huisarts 38-39}

Ideaal-type $25,27,33$

Identiteil $13,26,93,153$

Ideologie

en mythe 141

van beroepsgroepen 26, 31 (zie ook Beroep,

Beroepscode)

van gelijkheid 50

Ideologie, omschrijving wan 137,157

Individualisme/individualisering $87,169,186-190$, 193,198

Industrièle revolutie 21-23

Institutionalisering,

belang van 26,38

domein- $25,38-39$

omschrijwing van 25,200

sociale 25

'Instrumentele ceremoniële orde' 66, 181, 194, 196

International Council of Nurses 16,99, 108-111

Intuitionisme (zie Ethiek, meta-)

Kenmerkenbenadering (zie Professionalisering)

Kenmis en kunde

als kenmerk van professie $27.31,40$

en arbeidsbeschikbaarheid 37

en sociale controle 41

in beroepscode (zie Beroepscode)

in professionele organisatie 44

in verpleging (zie Verpleging)

Kwakzalverij 22

Legitimering,

belang van 26,38

domein - 38-39

machts - 26

omschrijving van 25,200

Legitimeringsargumenten en -gronden 26

Loyaliteit,

morelle status van 167-172

omschrijving van 158

ongedeelde 19

Loyaliteitstheorie (zie Ethische theorie)

Maatschappelijke

arbeidsverdeling $20-22,25,34,40$ behoeften 14,32

'Maatschappelijk midden' 24,82

Macht,

amoraliseringsstrategie m.b.t. 200-205

institutionalisering en legitimering van 38 ,

201-205

kennis - 36,201

normatieve 38,94

omschrijving vam 200-202

onderzoek m.b.t. 41,79

rol van 15,200

Machts-

- benadering (zie Professionalisering)

- bronnen 37-38

- positie $26,38,94,200,202$

Markicapaciteit 37, 55

Massieve waardebeleving/axiologie 157, 161, $165-166,174,180,186,188,192-193$

Medische ethiek (zie Ethiek)

Moraal (zie Morele verschijnsel)

Moralisme 157, 165

Morele

ervaring 12,164

gedraging 134, 149-152, 178, 184

omnivalentie 142-143

status 172

verschijnsel $68,77,97,124$

waarden (zie Waarden)

Mythes 141-144, 145, 182

Nationale Raad voor de Volksgezondheid 16, $101,104,119,133$

Naturalisme (zie Ethiek, meta-)

Naturalistische drogreden $76,96,160$

Nederlandse Maatschappij woor Verpleegkundle $16,51,99,105,109,118-122,192$

Neusticiteit (zie Waarden)

Nieuwe Unie '91 (zie Nederlandse Maatschappij voor Verpleegkunde)

Nightingale, Florence 13, 106-107

Nominalisme 156,168

Noncognitivisme (zie Ethiek, meta-)

Normatieve integratie 33,93

Normativiteit

van professionaliseringstheorieën (zie

Proffessionalisering)

van theorieën/concepten $60-61,80-81$

Normativiteit, contextafhankelijkheid van $60-61,82$

ethische opvatting van $67-68,75-78$

omschrijuing van $15,60-61,75-77$

sociologische opvatting van $61-67,75-78$

Normen, omschrijving van $64-65,77-78,135$

sociologisch begrip van $62-67$

Ontwikkelingsbenadering (zie

Professionalisering)

Onzekerheidsbeheersing 37-38, 56, 94, 196, 204 
Opleiding

tot een beroep 20

tot verplegende (zie Verpleegkundige)

Opzet van deze studie 18

Overheid,

(on)macht van 24,83

Patiëntea/cliënten,

bejegening van $66,105,150-151,163,170,179$

184,204

rol(model) van 30, 165

belangen van $86,130,150-151,163,167,181$, $188-189,197$

wensen van 19, 196

Phrasticiteit (zie Waarden)

Plicht 74, 78, 135, 147, 152, 158

Plichtethiek/Plichttheorie (zie Ethische theorie)

Positie

van artsen 13

van verplegenden 11,13

Positie,

maatschappelijke 14

morele $11,96,97-98,175,176-177,188$ (zie

ook Verpleegkundige)

normatieve 17

Prescriptivisme 158

'Primum non nocere' 150-151, 163

Procesbenadering (zie Professionalisering)

Professie,

binding aan 27

cognitieve, normatieve en evaluatieve dimensie van 28

kenmerken van 27-29

omschrijying wan 14,31

retoriek van (zie Beroepscode, functie van)

(zie ook Beroep)

Professionalisering,

basisschiema wan 38-39

bureaucratisering en $1.4,20,33,42-44,50$

continumbenadering van 28

functionalistische benadering van $20,29-33,81$

geneeskunde en 25

gezondheidszorg en 16,165

kenmerkenbenadering van $20,27.29,31-33$,

81-82

kritiek op theorieên/modellen van $\mathbf{3 1 - 3 3}, \mathbf{3 5}$,

40-41, 81-83

machtsbenadering wan $20,35-39,5457,81-83$,

98, 200-205

morele waardering van $17,97-98,170,201-205$

(zie ook Beroepscode, Ethiek)

normatieve aspecten van theorieën m.b.t.

79-84, 200-205

ontwikkelingsbenadering van 28

procesbenadering van $20,33-35,82-83$

sociale controle en (zie Sociale controlle)

strategieën van 38-39, 83, 200 symbolisch-interactionistische benadering vam

34- 35,81

theorieèn/modellen van $19-20,27-39,81-83$

werpleging en (zie Verpleging)

Professionaliseringsparadox $202,204-205$

Profiessionals,

oriëntaties van $30,49,149$

rol van 24

(zie ook Beroepsbeoefenaren)

Professionele organisatie, autonome en heteronome $42-43$

Psychotherapie 39

Rationalisering, 178-182

Rationaliteit,

cognitieve 33

functionele $22,168,170,179-182,189,193$;

198,201

instrumentelle 66

professioneel ideaal-type en 29

substantièle $168,179-182,189,193$

'Reality shock' 180

Recht en ethiek (zie Ethiek)

Rechtwaardigheid 74, 149, 154-155, 168-169, 171, 191, 202

Rechtvaardigingstheorieèn (zie Ethische theorie)

Regeltheorie (zie Ethische theorie)

Roepingsideaal 13,27

Rol-

-afwijking 30; 87

- differentiatie 162-163

- model $19,21,30$

Royal College of Nursing 51, 114-116

Ruiltheorie 34, 81

Samenleving (zie Beroep, Gezondheidszorg)

Samenwerking 135, 167

Sanctionering

als machtsbron 38

van beroepsmatig handelen $19,178,190-197$, 199

Segmentering

binnen de verpleging (zie Verpleging)

van beroepen $23,26,44,86$

Semi-professie(s), kenmerken van 28-29

'Sociaal feit' 33, 35

Socialle

controle $24,30,41,178$

stratificatie 21-23

Socialisatie

van professionals $30,52,89-90$

van verplegenden (zie Verpleegkundige)

Sociologische

Franse school 35

modellen 34,202

s.chool van Chicago 34

Solidariteit 135, 155, 168-174, 202, 204

Succes 30 
Symbolisch-interactionistische benadering (zie Professionalisering)

Teleologie (xie Ethische theorie)

Theorieetn, kenmerken wan $80-81$ normativiteil wan (zie Normativiteit) contextafhankelijkbieid van $80-83$

Tirannie 157, 165

Tuchtrecht, medisch 19,145

verpleegkundig 115-116, 146, $195-197$ (zie ook B.I,G)

Uniciteit (zie Eenheid)

Uniformering 164, 178, 182-186, 198

United Kingdom Central Counsil of Nurses; Midwives and Health Visitors $16,99,108$, $114-118,146$

Universaliseerbaarheidsprincipe $73-74,123,158$

Unuversalisme $29-30,33$

Vakbondsworming 22

Valkorganisatie (zie Beroepsorganisatie)

'Verlengde arm' 47-48

Verpleegkunde als vrouwenberoep $48-49,53$, 175-176, 180

Verpleegkundige

Belofte 108

en geneeskundige $20,25,46-48,49,53,56-57$, $105-108,150-151,175,183$

en patięnt 46, 149-151, 183-184

registratie 146

Verpleegkundige,

arbeidssatisfactie van $48,175-176$

autonomie van $45-46,47,49,142,175-177$

beroep van $11,45-57$

beroepsoriëntatie van 49,149, 152-153,

$176-177,180,189$

kenmerken van $47-48,54,56,82,175-176$

(morcle) positie van $175 \div 177,180$

opleiding tot $11,13,49-50,52-54,106-107$

rolconflict van/belemmeringen woor $49,53,82$,

177

socialisatie van 52-54, 153

verantwoordelijkheid van 186

Verpleging,

beeldworming t.a.w. 13, 46, 48,54, 180

beroepscodes in (zie Beroepscode)

beroepsorganisaties van $\mathbf{5 1 - 5 2 , 1 8 0}$

collectivisering in $55-56$

ethiek i.v.m. 16, 149-153, 165-167, 187, 199

extramurale $45,55,180$

functionalistische beschrijving van 13,45

gelijkheidsideologie in 50

historische aspecten van 12-14, 45, 105-108 juridische aspecten t.a.v. 47, 53, 115-116, 161 , 183, 195-197

kennis en kunde in $46-50,55,123,150-151$, $167,176,180-181$

maatschappelijke positie van $14,45-46,48,56$ macht van $54-57,20_{n} 177,188$

management in 50

ontwikkeling van $12,51,176$

organisatiegraad in 56,175

overheid en 52,53

profiessionalisering van $44-57,175$

roepingsideaal in 13,56

rol in organisaties van $49,55-56,175-176,180$

segmentering in $45,50-51,56,184$

specialisaties in 13,50

status van $13,20,45-46,48-50,53,141,143$

structurele aspecten van $13,45-54,175-176$

Verzorgingsstaat $20,23-24$

Voorschriften, omschrijying van 65,78

Voluntarisme 157,168

Vraagstelling $11,15,97-98$

Waarden,

conflict van 82,143

culturele/maatschappelijke context van 64,79 , $155,157,161-162,167-168,187,203$

ethische 72, 134-136, 147, 168-169, 173, 194

hiërarchie van 98, 133-134, 147, 164, 167

institutionalisering van $65,76,78,155-156$

instrumentele $135,168-170,193$

internalisatie van $78,86,91$

intrinsieke $70,135,169,181$

omsehrijving van $64,69-70,77,154-156,158$, 168,183

phrastisch-neustische interpretatie van 155 ,

$164,165,169,171-172$

rechtwaardiging wan $70-72,76,97,149,158$,

161-162, 165-172, 204

superioriteit en legitimiteit van $62-63,154$,

$160-174,181,199$

typen/taxonomie van $63,70-72,83,132-134$,

$167-170,178$

wetenschap en 80

Waardenonderzoek 62-66, 67

Waardenoriëntatie 64-66, 168, 187

van beroepsbeoefenaren $30,49,84,94,131$, $149,152-153,163,166,168-169,176-177$

Waardetheorie (zie Ethiek)

Waarheidsmededeling 150, 152

Welzijn en geluk 168-170

"Would-be'-professie 28,81

Zelfbeschikking 187-189, 193 


\section{CURRICULUM VITAE}

Arie van der Arend werd geboren op 27 oktober 1950 te Monster. Na het Gymnasium B studeerde hij theologische ethiek in Nijmegen waar hij in 1979 zijn doctoraaldiploma behaalde. Daarvoor behaalde hij in 1976 het diploma van de Hogere Beroepsopleiding voor Verpleegkundigen te Nijmegen.

In 1977 was hij werkzaam als assistent studiesecretaris in de Theologische Faculteit te Nijmegen. Yanaf 1978 is hij werkzaam als Universitair Docent bij de Vakgroep Gezondheidsethiek en Wijsbegeerte van de Faculteit der Gezondheidswetenschappen in de Rijksuniversiteit Limburg te Maastricht.

Hij publiceerde boeken, boekbijdragen en in verschillende tijdschriften op het terrein van de ethiek en de verpleegkunde en is lid van diverse adviesorganen op deze gebieden. Hij was vaste medewerker voor het Vlaams-Nederlands tijdschrift Verpleegkunde en is sinds 1982 rubrieksredacteur van het Pijn-Informatorium, uitgegeven door Stafleu Bohn Van Loghum te Houten. 